\title{
Modernistički pokret mladih u hrvatskoj kulturi i politici na prijelomu 19. i 20. stoljeća
}

\section{Tomašegović, Nikola}

Doctoral thesis / Disertacija

2022

Degree Grantor / Ustanova koja je dodijelila akademski / stručni stupanj: University of Zagreb, Faculty of Humanities and Social Sciences / Sveučilište u Zagrebu, Filozofski fakultet

https://doi.org/10.17234/diss.2022.8940

Permanent link / Trajna poveznica: https://urn.nsk.hr/urn:nbn:hr:131:516297

Rights / Prava: In copyright/Zaštićeno autorskim pravom.

Download date / Datum preuzimanja: 2023-04-26

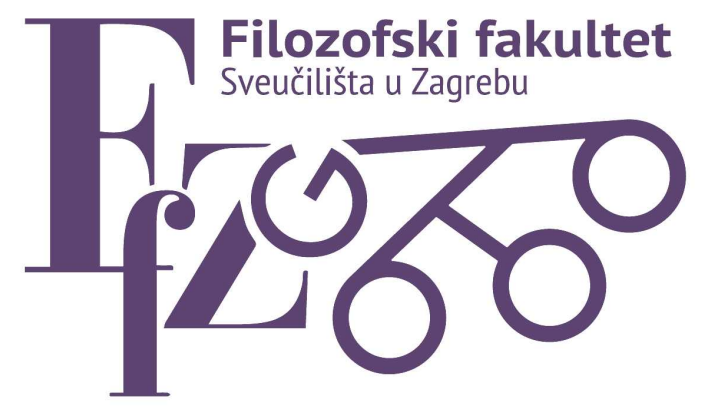

Repository / Repozitorij:

ODRAZ - open repository of the University of Zagreb Faculty of Humanities and Social Sciences
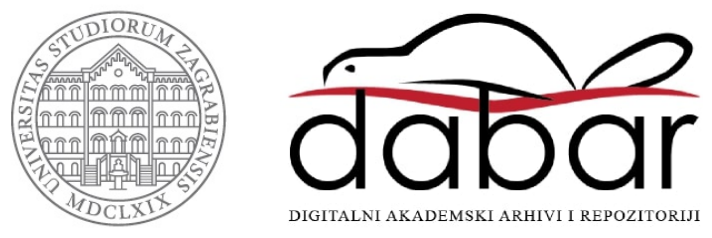


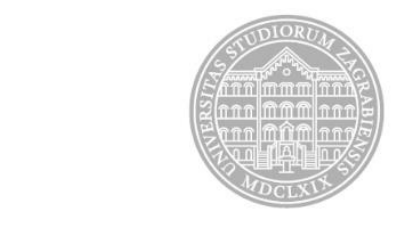

Sveučilište u Zagrebu

Sveučilište u Zagrebu

Filozofski fakultet

Nikola Tomašegović

\section{MODERNISTIČKI POKRET MLADIHU HRVATSKOJ KULTURI I POLITICI NA PRIJELOMU 19. I 20. STOLJEĆA}

DOKTORSKI RAD

Zagreb, 2022. 


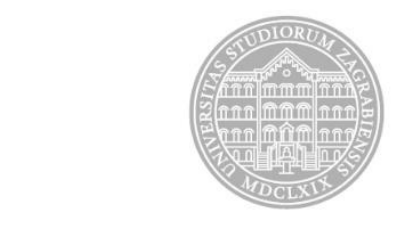

Sveučilište u Zagrebu

Sveučilište u Zagrebu

Filozofski fakultet

Nikola Tomašegović

\title{
MODERNISTIČKI POKRET MLADIH U HRVATSKOJ KULTURI I POLITICI NA PRIJELOMU 19. I 20. STOLJEĆA
}

\section{DOKTORSKI RAD}

\author{
Mentorica: \\ prof. dr. sc. Iskra Iveljić
}

Zagreb, 2022. 


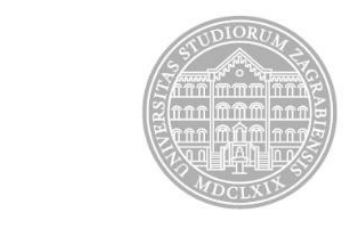

Sveučilište u Zagrebu

University of Zagreb
Faculty of Humanities and Social Sciences

Nikola Tomašegović

\title{
THE MODERNIST MOVEMENT OF THE YOUTH IN CROATIAN CULTURE AND POLITICS AT THE TURN OF THE 20th CENTURY
}

DOCTORAL THESIS

\author{
Supervisor: \\ prof. dr. sc. Iskra Iveljić
}

Zagreb, 2022. 


\section{Bilješka o mentoru}

prof. dr. sc. Iskra Iveljić

Iskra Iveljić rođena je 1959. u Frankfurtu na Majni. Maturirala je na Klasičnoj gimnaziji te diplomirala povijest i engleski jezik i književnost na Filozofskom fakultetu Sveučilišta u Zagrebu. Od 1987.-1990. radila je u Arhivu Hrvatske (danas Hrvatski državni arhiv) kao mlađi arhivist, a od 1990.-1993. u Institutu za suvremenu povijest kao istraživač-suradnik. Od 1993. godine zaposlena je na Odsjeku za povijest kao asistent, od 1999. u nastavnonastavnom zvanju docenta, od 2004. izvanrednog, 2010. redovitog profesora te 2016. redovitog profesora u trajnom zvanju. Magistrirala je 1992. godine radom „Pokušaji modernizacije Banskog vijeća (1848.-1850.)“ i doktorirala 1998. disertacijom naslovljenom „Uloga zagrebačke privredne elite u modernizaciji Hrvatske (1860.-1883.)“ pod mentorstvom prof. dr. sc. Mirjane Gross. Na Odsjeku za povijest predaje hrvatsku povijest u 19. stoljeću. Voditeljica je doktorskog studija Hrvatske moderne i suvremene povijesti u europskom i svjetskom kontekstu Od 2008./9. do 2010./11. obnašala je dužnost pročelnice Odsjeka za povijest i predstojnice Zavoda za hrvatsku povijest, a od 2014. do 2016. predstojnice Katedre za hrvatsku povijest Odsjeka za povijest. Istraživački se bavi hrvatskom poviješću 19. stoljeća, poglavito modernizacijskim procesima, stasanjem moderne građanske elite, svakodnevnim životom na prijelomu 19. i 20 stoljeća, plemstvom Hrvatske i Slavonije, hrvatskim studentima i elitom u Beču te tranzicijom hrvatskih elita iz Habsburške Monarhije u jugoslavensku državu. Sudjelovala je u više domaćih i inozemnih projekata, a od 2017. do 2020. bila je voditeljica projekta Hrvatske zaklade za znanost „Tranzicija hrvatskih elita iz Habsburške Monarhije u jugoslavensku državu“. Autorica je tri, a urednica pet znanstvenih monografija te niza znanstvenih radova u domaćim i stranim publikacijama. 


\title{
MODERNISTIČKI POKRET MLADIH U HRVATSKOJ KULTURI I POLITICI NA \\ PRIJELOMU 19. I 20. STOLJEĆA
}

\begin{abstract}
Sažetak
Predmet je istraživanja ovoga rada modernistički pokret mladih kao hrvatski slučaj šireg fenomena fin de siècle modernizma. Kako su dosadašnja istraživanja uglavnom bila disciplinarno profilirana te su se fokusirala na određeni aspekt djelatnosti pokreta, u ovome se radu fenomenu želi pristupiti cjelovito, razmatrajući modernistički pokret jednako u domeni politike i kulture. Kronološki je fokus na razdoblju između 1895. i 1903. godine, što se obično smatra vremenskim određenjem trajanja samoga pokreta. U dijakronijskoj perspektivi postavlja se osnovna istraživačka teza da pokret mladih predstavlja mehanizam smjene generacija u okviru hrvatske građanske političke i kulturne elite. $\mathrm{S}$ obzirom na to da se modernistički pokret u Hrvatskoj razvija kroz proces aproprijacija i prilagodbi stranih kretanja, prvenstveno srednjoeuropskim posredovanjem, spacijalni je fokus analize na isprepletenom imperijalnom prostoru Zagreba, Beča i Praga. U tom se smislu postavlja druga temeljna teza o načinima aproprijacija suvremenih intelektualnih strujanja koji obuhvaćaju direktnu imitaciju izvora, ali i prilagodbe uvjetovane specifičnim hrvatskim kontekstom. U teorijsko-metodološkom smislu rad se oslanja na intelektualnu historiju kao historijsku subdisciplinu, posebice na njezine kontekstualističke pristupe, uz snažne poticaje transnacionalnih pristupa i interdisciplinarnosti, napose kada je riječ o povijesti književnosti. Rad se prvenstveno temelji na interpretaciji tekstova modernističke provenijencije objavljenih $\mathrm{u}$ brojnim časopisima mladih. Kako se ne bi izgubila dimenzija personalnih odnosa, idiosinkrazija i divergentnih strujanja unutar samoga pokreta, osim javno objavljenih tekstova analizira se korespondencija i privatni zapisi iz osobnih arhivskih fondova. Sve to bi, uz rekonstrukciju specifičnog hrvatskog kulturnog i političkog konteksta, trebalo rezultirati stvaranjem cjelovite slike o modernističkim strujanjima u Hrvatskoj na prijelomu 19. i 20. stoljeća.
\end{abstract}

Ključne riječi: mladi; moderna; fin de siècle; aproprijacije; elita; intelektualna historija 


\title{
THE MODERNIST MOVEMENT OF THE YOUTH IN CROATIAN CULTURE AND POLITICS AT THE TURN OF THE 20th CENTURY
}

\begin{abstract}
The topic of this $\mathrm{PhD}$ dissertation is the Croatian modernist Movement of the Youth as a local iteration of the global and transnational phenomenon of fin de siècle modernism. Although chronologically located at around 1900, this movement is often cited as playing a pivotal role for the development of Croatian culture and politics in the whole first half of the 20th century. Because of this, the research is focused on the intellectual formation of a generation that is going to have a profound influence on Croatian cultural and political development, including the transition to the Yugoslav state. The research is conceptually framed on two axes. The first is diachronic in nature and deals with the question of continuities and discontinuities with established political and cultural notions and practices dominant in Croatian public, cultural and political life at the time. The second is synchronic and investigates the ways in which historical actors - adherents and activists of the Croatian modernist movement - transferred and appropriated ideas and practices stemming from other European modernist movements of the time, especially in Vienna and Prague. This aspect of the research owes primarily to the theoretical and methodological impetuses put forward by transnational and entangled history, thus enriching and expanding the more nationally-oriented perspective inherent to the first, diachronic axis. Other than that, the main theoretical and methodological framework is that of intellectual history, especially the contextualist and externalist apporaches that focus on the usages of ideas and concepts by the historical actors in specific contexts and situations.
\end{abstract}

The public demonstration of the Croatian students during the visit of the Emperor Franz Joseph on October 16th 1895, in which they burned the Hungarian flag in sign of protest against ban Khuen's regime and Croatia's subdualistic arrangement within the Monarchy is often cited in the historiographical literature as the beginning of the Movement of the Youth. In reality, though, the students who carried out this demonstration made up a very heterogeneous group and had no intention of making it a public announcement of a new political project or party. Only what followed triggered the events that would lead to the emergence of the full-fledged Movement of the Youth. As a consequence of the government reprisals, the expelled Croatian students continued their studies at Cisleithenian universities, 
mostly in Vienna and Prague, where they came into contact with new, modernist ideas. Yet, at the same time, the relationship between the Movement to its more famous counterparts - the Viennese modernist movement and the Prague progressivist and realist movement - remains ambiguous. Although it is clear that the student activists of the Movement of the Youth were clearly under the impression of their respective milieus, they were nevertheless primarily engaged with the Croatian public, its politics and culture. This raises the central question of the modalities of the Croatian modernist movement's entanglement with other Austrian and broader European modernisms. The Croatian modernist movement was not purely an imitation of broader modernist currents, so a more nuanced model which takes into account different contexts needs to be employed in order to fully examine the complex interactions between various actors, ideas and practices.

The universities in Prague and Vienna had already been established as popular destinations for students from all over Croatia. The difference with the student emigration that started to arrive at these universities in 1896 is that they carried with themselves a symbolic capital in the eyes of the public and were already invested in politics. By reading their letters, we can see that they were consciously building a movement that should carry out the mission of changing Croatian culture, society and politics. This movement, comprised of student and youth groups in Prague, Vienna, Zagreb, Osijek, Split and Karlovac came to be known as the Movement of the Youth (mladi) or the Progressive Youth Movement (napredna omladina). In historiographical literature we can find heuristic divisions of the Movement in the so-called Prague and Vienna groups, and sometimes the separate Zagreb and high-school groups. The Prague and Zagreb groups were supposedly more invested in politics and social questions, the latter also focusing more on the question of nationhood and Serbo-Croat relations, while the Vienna group concentrated on literature and art, drawing heavy influences from fin de siècle Viennese cultural developments. This division can, however, somewhat obscure the reality of the interconnected functioning of these groups as part of the Movement of the Youth in general. This was mirrored in existing research on the topic, which was disciplinary focused and therefore fragmented. Historiography was mostly interested in the Prague group and the politics of the Movement, while art history and history of literature examined mostly the artistic aspects of the Movement. One of the main goals of this $\mathrm{PhD}$ dissertation is to offer a comprehensive survery of the topic, surpassing the narrow disciplinary focus. In order to do that, we have to focus on the Movement in its entirety when examining its distinctive 
ideological and political positions and practice, which presuposses employing an interdisciplinary perspective, especially with regards to history of literature and art history.

Even though the centers of the formation of the Movement were abroad, it had to ideologically position itself according to the current political and cultural situation in Croatia. The students in Prague were impressed with the successes of Czech national politics and were ardent admirers of Tomáš Garrigue Masaryk's thought, proclaiming themselves "political realists". Yet at the same time they were very well aware that Croatia was not as near as developed as the Czech lands and that they would have to adapt the ideas they appropriated to the current needs and situation of their homeland. The mladi saw themselves as the true successors of the Illyrian project and as rejuvenators of Croatian politics and Yugoslav ideology in the form of Serbo-Croat national unity. Yet this rejuvenation was not a simple imitation. The very problem they identified with Croatian culture and politics is that it was not up to date with current developments in modern Europe. Therefore, there could be no return to old forms. The forces of tradition had to be brought into conjunction with the present needs and practices. The mladi primarily demanded the transformation or development of a new national intelligentsia based on modern, positivist knowledge of the people and their needs, as well as on the strong individual character that had to be shaped through education. The goal was to make existing national politics more effective in new, mass politics circumstances. The real subject of politics were still not the people, but their representatives embodied in bourgeois intelligentsia. This was actually a reformulation of the role of the preporoditelj (national reformer/revivalist), its (re)appropriation and adaptation to new political circumstances and needs. One of the main theses of this $\mathrm{PhD}$ dissertation is that the Movement of the Youth largely played a part in the generational change within the Croatian political and cultural élite of the time. Although their criticism might have sounded radical, in practice it was an inner critique aimed at reforming, and not destroying the existing national political and cultural traditions. The appropriations of modernist ideas were thus used by the mladi to reform bourgeois Croatian culture and politics, to bring it up to date with current developments and to establish themselves as part of the national élite in the process.

We can trace the same notions in culture as in politics. Croatian literature at that time was dominated by a romanticist-realist stylistic nexus which was heavily burdened by earlier, founding traditions, political considerations and, most of all, the particular interests of the national élites that had control over the most important cultural institutions. The result, 
especially in the eyes of the mladi, was isolation from the broader European cultural currents and stagnation behind closed provincial walls. The beginning of the Croatian modernist movement in literature can be attributed to the before mentioned Vienna group of the Modernist Movement which published their ideas and texts in three successive journals titled Youth, The Croatian Salon and Life. Joining the Viennese and Prague Secession and Modernism, they called for complete artistic freedom, criticized the political instrumentalization of art and proclaimed the need for the incorporation of Croatian literature into modern European artistic trends. Not all of the Movement agreed, though. Especially those members that were close to the Prague group emphasized that art should continue to play a national role and that the turn to Europe should not mean a blind imitation, but an inspiration to create literature rooted in national traditions. The question of national literature, its role and function, as well as its preferred stylistic orientation and content, became crucial in the ensuing polemic between the stari and mladi which raged most intensely in the cultural sphere. Yet focusing only on the national context of the debate will surely obscure the ways in which both sides drew from the broader, European reservoir of ideas and practices to reinforce their own position. These transfers came in many forms: borrowing, translation, imitation, emulation and appropriation. Sometimes writers and artists imitated European modernist role models to fashion themselves as 'modern', increasing their social capital in fin de siècle café society. This opens the question of the limitations of modernist appropriations which is one of the main themes of the research. The comparison with other neighbouring movements and a transnational perspective of their interaction brings forth a thesis that the specific character of the Croatian modernist movement at the turn of the 20th century consisted in the domination of the political over the cultural and artistic aspects, in conjunction with the focus on the question of the national intelligentsia, which was the result of the implementation of contemporary modernist concepts in a specific Croatian cultural and political context.

Keywords: the Youth; modernism; fin de siècle; appropriations; élites; intellectual history 


\section{SADR}

I. UVOD..............................................................................

I. 1. Definicija istraživanja i pregled historiografije ...................................

I. 2. Istraživački cilj, teze i teorijsko-metodološki okvir............................... 12

II. GENEZA POKRETA...........................................................24

II. 1. Studentska demonstracija 1895. i njezine posljedice...............................24

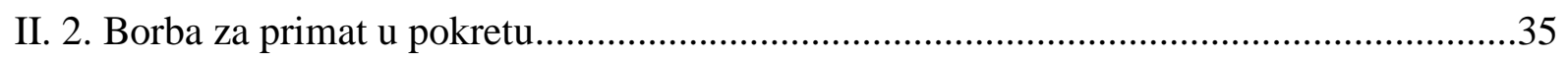

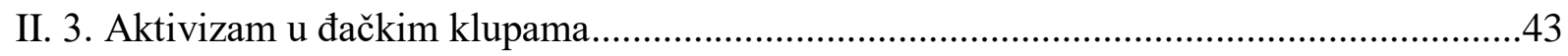

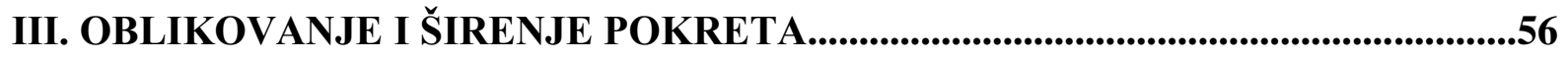

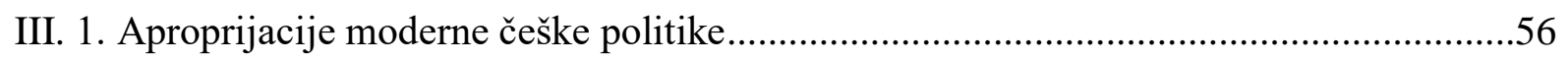

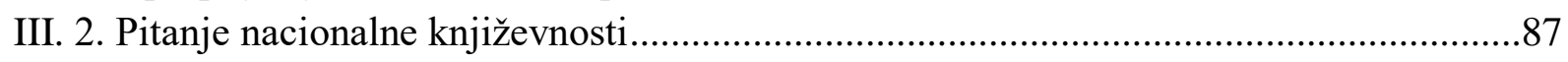

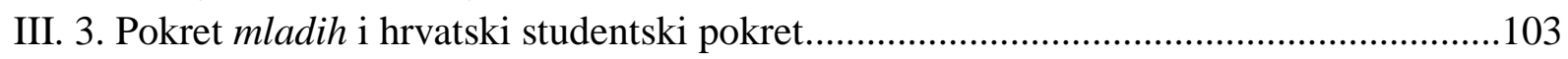

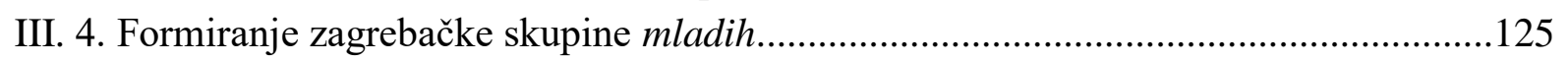

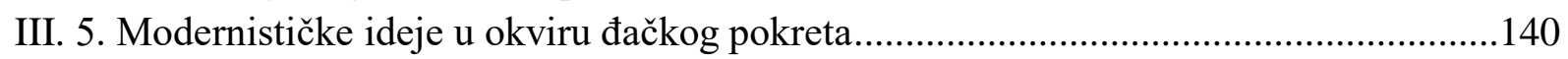

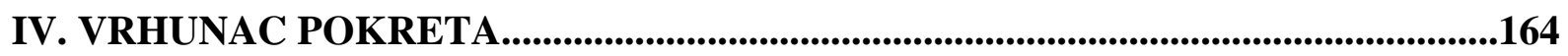

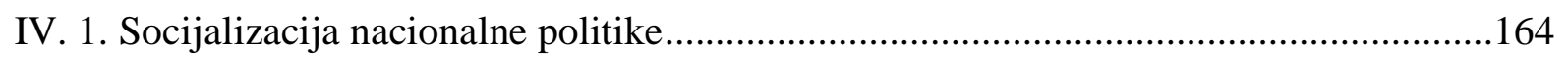

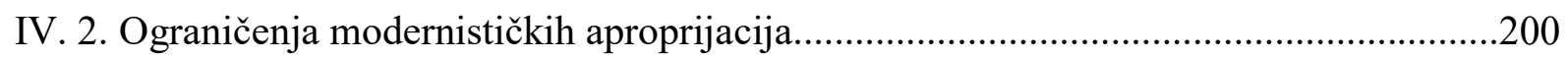

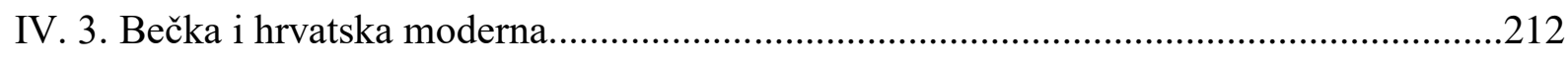

IV. 4. Secesija i mladi: udruživanje književnika i likovnih umjetnika................................229

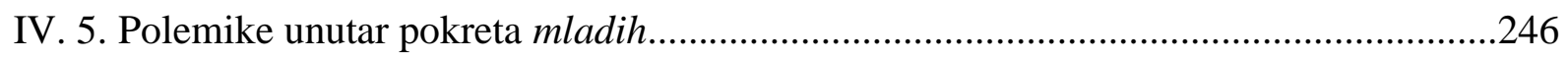

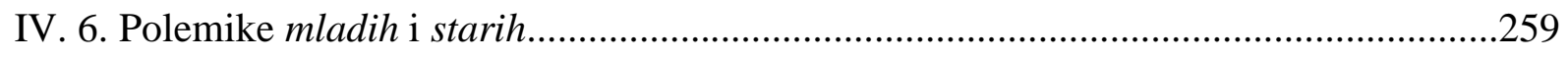

V. JENJAVANJE I TRANSFORMACIJA POKRETA ............................................283

V. 1. Od pokreta mladih do Hrvatske napredne omladine...................................................283

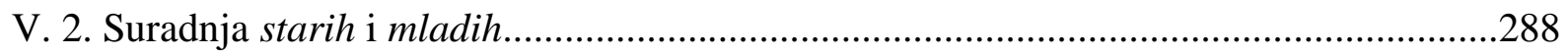

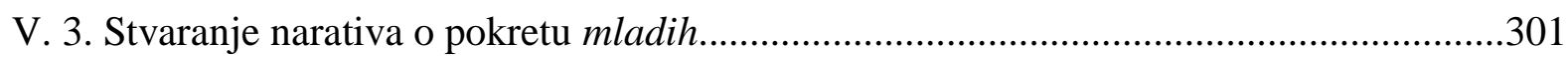

V. 4. Pokret mladih u transnacionalnoj i dijakronijskoj perspektivi.....................................305

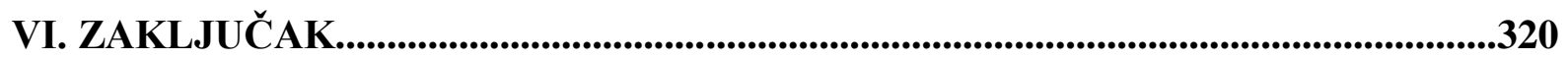

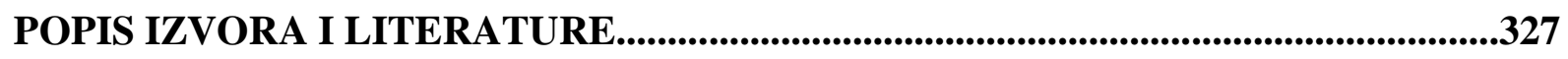

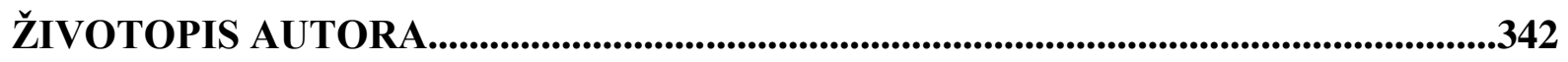




\section{UVOD}

\section{1. Definicija istraživanja i pregled historiografije}

Iako bi se prema naslovu rada moglo činiti sasvim drugačije, jedan od najvećih izazova prilikom konceptualiziranja ovog istraživanja bio je definirati sam njegov predmet. ${ }^{1}$ Problem definicije modernističkog pokreta mladih $^{2}$ nije samo problem preciznosti određenja. On se javlja već na razini razumijevanja same naravi predmeta. Temeljno je pitanje sljedeće: u kojem smislu koristimo pojam pokreta kada je riječ o modernističkom pokretu mladih na prijelomu 19. i 20. stoljeća? Je li on bio formaliziran, strukturiran i jedinstven pokret ili neformalno, heterogeno strujanje različitih ideja i grupacija? Drugo je pak pitanje, neovisno o odgovoru na prvo: je li modernistički pokret mladih u bitnome smislu bio vezan uz određeno područje djelovanja, npr. kulturno-umjetničko ili političko, ili je riječ o sveobuhvatnu fenomenu koji u jednakoj mjeri inkorporira različita područja djelovanja?

Povjesničari koji su se u svojim istraživanjima dotaknuli fenomena pokreta mladih na prijelomu stoljeća nisu se podrobno bavili ovim problemima. Ipak, može se iščitati kako je implicitni pristup većine njih taj da modernistički pokret mladih prvenstveno vide kao sveobuhvatni - društveni, politički i kulturni - pokret. Rene Lovrenčić u svojoj knjizi Geneza politike „,novog kursa“ ovoj problematici posvećuje pažnju u okviru poglavlja naslovljena „Mlada generacija buržoaske opozicije“. ${ }^{3}$ Međutim, iako ova knjiga predstavlja možda najbolju historiografsku razradu razdoblja i fenomena u pitanju, njegov je predmet istraživanja zapravo širi te se on na fenomen modernističkog pokreta oslanja u genetičkom, pa čak u određenoj mjeri i u teleološkom smislu. Tražeći u modernističkim gibanjima mlade generacije izvorište za koncepcije i prakse politike „novog kursa“, Lovrenčić nužno sužava svoj pogled na tzv. prašku grupu modernističkog pokreta te pritom gubi iz vida šira društvena i kulturna obilježja i ciljeve tog pokreta. Međutim, važno je istaknuti da on razumijeva pokret mladih kao generacijski pokret, iako ga ne razmatra u komparativnoj perspektivi s drugim srodnim i istodobnim europskim modernističkim strujanjima. U jednom od najranijih stručnopublicističkih obrada ove problematike Mate Ujević isto je tako modernistički pokret mladih

\footnotetext{
${ }^{1}$ Dijelovi ovoga potpoglavlja u ponešto izmijenjenu obliku objavljeni su u radu Nikola Tomašegović, „Prema intelektualnoj historiji hrvatskog modernističkog pokreta na prijelomu 19. i 20. stoljeća: stanje istraživanja i istraživački problemi“, Radovi Zavoda za hrvatsku povijest 51, 2, 2019, 217-232.

${ }^{2}$ Kurziv se koristi kako bi se naznačilo da se pojam odnosi na konkretan pokret u pitanju, a ne na mlade kao takve. U literaturi se još koriste oblici „mladi“ i Mladi.

${ }^{3}$ Rene Lovrenčić, Geneza politike „,novog kursa“, Zagreb, 1972, 39-53.
} 
koncipirao kao generacijski pokret koji nije imao čvrstu organizacijsku i ideološku strukturu, nego je predstavljao omladinska strujanja čiji je cilj bio unijeti nove, modernističke ideje u hrvatski javni život, politiku i kulturu. ${ }^{4} \mathrm{Na}$ jednak će način problemu pristupiti i sam sudionik pokreta, Milan Marjanović, koji u svojoj kasnoj antologiji kritike iz perioda hrvatske moderne pokret ne opisuje kao jedinstven i organiziran, nego kao vrenje novih ideja i „prirodnu“ smjenu generacija. ${ }^{5}$

Definiciji modernističkog pokreta mladih više su pažnje posvetili povjesničari književnosti. U svojoj knjizi Časopisi hrvatskog modernističkog pokreta, Vida Flaker predložila je pojmovno razlikovanje između hrvatske moderne kao pokreta, nazivajući ga još i hrvatskim modernističkim pokretom, te hrvatske moderne kao stilskog razdoblja koje kronološki smješta između 1890. i 1914. godine. ${ }^{6}$ Takvu je distinkciju prihvatio i u svojoj knjizi Književnost moderne proveo Miroslav Šicel, pomičući pritom kronološke odrednice stilskog razdoblja moderne na period između 1892. i 1916. godine, dok je pokret hrvatske moderne konceptualizirao kao prvu fazu ovog stilskog razdoblja u trajanju od 1897. do 1903. godine. ${ }^{7}$ Krešimir Nemec i Marijan Bobinac također su ponudili svoje kronološke odrednice, shvaćajući modernu kao „razdoblje novije hrvatske književnosti koje karakterizira ubrzano smjenjivanje stilskih pravaca i poetičkih opredjeljenja te njihova sinkronijska brojnost" $u$ trajanju od 1895. do 1914. godine, pritom također zadržavajući, makar implicitno, distinkciju spram hrvatskog modernističkog pokreta. ${ }^{8}$ Zanimljivo je, međutim, da iako oni moderni pristupaju prvenstveno kao književnom fenomenu, njezine su kronološke granice omeđili društvenim i političkim događajima, naime studentskom demonstracijom 1895. godine i izbijanjem Velikog rata 1914. godine. ${ }^{9}$ Očekivano, za razliku od povjesničara, koji su se uglavnom fokusirali na političke teme, književni su povjesničari problem modernističkog pokreta mladih primarno obrađivali kao književno-kulturni fenomen, iako su bili svjesni njegovih društvenih i političkih aspiracija u mnogo većoj mjeri nego što su povjesničari pridavali pažnju kulturnim aspektima pokreta. Na sličan način povjesničari umjetnosti uglavnom su se fokusirali na likovnu secesiju u Hrvatskoj. U središtu njihova interesa nalazi

\footnotetext{
${ }^{4}$ Mate Ujević, Prilozi za povijest pokreta hrvatske omladine koncem XIX i početkom XX stoljeća, s osobitim osvrtom na borbu starih i mladih, Zagreb, 2015, 7.

${ }^{5}$ Milan Marjanović, Hrvatska moderna: Izbor književne kritike, knj. I, Zagreb, 1951, 5.

${ }^{6}$ Vida Flaker, Časopisi hrvatskoga modernističkog pokreta, Zagreb, 1977, 9.

${ }^{7}$ Miroslav Šicel, Književnost moderne, Povijest hrvatske književnosti, knj. 5, Zagreb, 1978, 8-12.

${ }^{8}$ Krešimir Nemec i Marijan Bobinac, „Bečka i hrvatska moderna: poticaji i paralele“, u: Damir Barbarić (ur.), Fin de siecle Zagreb-Beč, Zagreb, 1997, 84.

${ }^{9}$ Aleksandar Flaker u tom smislu iz književno-povijesne perspektive ističe važnost periodizacije M. Šicela jer je odustao od „periodizacije koja se temeljila na datumima političke povijesti“, označivši početak perioda „značajnim književnim tekstom.“ Aleksandar Flaker, „Proučavanje početaka moderne u hrvatskoj, srpskoj i slovenskoj književnosti (1970-1989)“, Wiener Slavistisches Jahrbuch 39, 1993, 8.
} 
se analiza samih umjetničkih djela te biografije umjetnika, dok je politička i društvena pozadina umjetnosti donekle zapostavljena. U tom je smislu mnogo zastupljeniji pristup secesiji kao umjetničko-stilskom razdoblju, nego kao društvenom fenomenu. U slučaju povijesti književnosti i povijesti umjetnosti postoji stoga tendencija da se društveno-politički kontekst promatra više kao ilustracija prilika u kojima nastaju pojedina umjetnička djela i nova umjetnička strujanja, nego kao sredstvo u funkciji interpretacije cjeline modernističkog pokreta mladih.

Istraživanja su dakle tendirala tome da modernistički pokret mladih shvate kao sveobuhvatni - kulturni, politički i socijalni - generacijski pokret, koji pak treba razlikovati od razdoblja moderne u hrvatskoj kulturi i umjetnosti, koje se proteže od 90-ih godina 19. stoljeća pa sve do početka ili kraja Prvog svjetskog rata. ${ }^{10}$ Pojmovi koji se pritom koriste ipak nisu posve jasno određeni. Prije svega je riječ o tome da odnos pojma moderne spram drugih srodnih pojmova, kao što su fin de siècle, secesija ili modernizam nije u potpunosti razjašnjen. Ako govorimo o moderni kao o razdoblju, koji je odnos ovog pojma i u čemu je njegova razlika spram koncepta fin de siècle? Ili ako govorimo o modernističkom pokretu isključivo u domeni kulture, koja je njegova razlika spram secesije kao umjetničkog pokreta, osim što se potonja poglavito veže uz likovne umjetnosti? Ne treba zaboraviti da je i modernistički pokret mladih predstavljao svojevrsnu secesiju od starih, da je prisvajao metode i vizualne identitete bečke secesije (Klub hrvatskih književnika, Hrvatski salon), kao i da je tijesno surađivao s hrvatskim likovnim secesionistima (Mladost, Hrvatski salon, Život). Naposljetku, koji je pak odnos pojma hrvatske moderne spram pojma modernizma, ako uzmemo u obzir da je ona predstavljala stilski vrlo heterogen fenomen koji je uključivao i neke elemente koji bi se u drugim europskim kontekstima smatrali upravo suprotstavljenima moderni (npr. naturalizam) $?^{11}$

\footnotetext{
${ }^{10}$ Prema Hrvatskoj enciklopediji, na primjer, razdoblje hrvatske moderne završava objavljivanjem antologije Hrvatska mlada lirika i Matoševom smrću 1914., ili 1917. kada svojim programom nastupaju ekspresionisti. V. natuknicu „moderna“, Hrvatska enciklopedija, URL: https://enciklopedija.hr/natuknica.aspx?ID=41458 (pristup 3. 9. 2021.)

11 Nikola Batušić, Zoran Kravar i Viktor Žmegač rade daljnju distinkciju između moderne, modernizma i moderniteta. Prema njima, „bečki pojam moderne“ odnosi se na književna kretanja oko godine 1900., dok se općenitiji pojam moderne definira u opreci s pojmom postmoderne. Modernizam pak kao pojam može se koristiti kao tipološka ili kao periodizacijska kategorija (npr. za razdoblja mlađa od moderne), dok je pojam moderniteta isključivo tipološka kategorija koja označava „svojstva književnih djela pripadnih ovako ili onako shvaćenoj moderni.“ Doista, možemo se složiti s autorima da „tko danas govori o 'moderni', ne može pretpostavljati da će biti posve jasno što je njegov predmet.“ Nikola Batušić, Zoran Kravar, Viktor Žmegač, Književni protusvjetovi: Poglavlja iz hrvatske moderne, Zagreb, 2001, 7-8. Rezerve prilikom korištenja pojma moderne spominje i Pavao Pavličić, ističući da se on u posljednje vrijeme često zamjenjuje opisnim pojmovima kao što je „književnost na mijeni stoljeća“. Pavao Pavličić, „Što je danas hrvatska moderna?“, Dani Hvarskoga kazališta 28, 1, 2002, 5 .
} 
Kako modernistički pokret mladih u najvećem dijelu svojeg trajanja nije bio formaliziran i homogeno strukturiran pokret, ne postoji terminološka konzistentnost prilikom njegova imenovanja kako u literaturi, tako i u izvorima. U ovome će se radu najčešće upotrebljavati naziv „,modernistički pokret $m l a d i h^{\prime}$ ili skraćeno „pokret $m l a d i h^{\prime}$. Osim što je naziv mladi najzastupljeniji u tekstovima samih aktera pokreta, time se također želi pridonijeti jedinstvenom i sveobuhvatnom pogledu na ovaj fenomen. U historiografiji, koja se najviše bavila političkim dimenzijama pokreta, ustalio se naziv „napredna omladina“, dok su povijest književnosti i povijest umjetnosti sa svojim kulturno-umjetničkim fokusom uglavnom koristili nazive „hrvatska moderna“ i „,secesija“. Naziv „,napredna omladina“ javlja se, međutim, tek u završnoj fazi pokreta kada on poprima sve homogeniju strukturu te se počinje institucionalizirati. Ranije su kao politički termini mnogo zastupljeniji nazivi „novosmjeraši“ i „realisti““. S druge pak strane o pojmovima moderne, modernizma i secesije vodila se velika polemika između mladih i starih, a u brojnim slučajevima upravo su stari bili ti koji su lansirali ove termine u javni prostor, obično sa svojom karakterističnom interpretacijom koju su mladi potom pobijali. U tom smislu naziv koji se ovdje koristi i zastupa, osim što ima svoje utemeljenje u izvorima, pomaže nadilaženju disciplinarnih podjela prilikom istraživanja ovog fenomena, a opet jasno naglašava dvije njegove ključne sastavnice: fin de siècle modernizam i generacijsku napetost (mladi vs. stari).

U definiciji predmeta istraživanja važnu ulogu dakako igra i njegovo kronološko i spacijalno omeđivanje. Međutim, baš zato što u slučaju modernističkog pokreta mladih nije riječ o homogenu i čvrsto strukturiranu pokretu, nego o pojavi novih strujanja, prodoru novih pogleda i praksi te u krajnju ruku o nastupu nove generacije čiji su nositelji, ovisno o situaciji, djelovali na različite načine (kao jedinstveni pokret, kao specifične grupacije i kao pojedinci), vrlo je teško govoriti o njegovim jasno utvrđenim vremenskim i prostornim odrednicama. Kao što se moglo vidjeti iz ranije navedenih pokušaja vremenskog određenja pokreta mladih, vrlo se često kao ishodišna točka pojavljuje 1895. godina. Riječ je naravno o studentskoj demonstraciji spaljivanja mađarske zastave prilikom posjeta cara Franje Josipa Zagrebu, događaju koji je u okviru hrvatske političke historije kasnije okarakteriziran kao bitna prijelomnica. ${ }^{12}$ Kao gornja kronološka odrednica najčešće se pak ističe 1903. godina i narodni

\footnotetext{
${ }^{12}$ Kako je ovaj događaj gotovo odmah zadobio važan status u hrvatskoj javnosti, literatura o njemu doista je brojna i seže u razdoblje neposredno nakon demonstracije. Kao svojevrsna prijelomnica tematiziran je u gotovo svim sintetskim pregledima hrvatske (političke) povijesti. U novije vrijeme, međutim, nastaju radovi koji su primarno fokusirani na studentsku demostraciju, njezin kontekst, uzroke, povode i posljedice. Među njima svakako treba istaknuti radove Ljerke Racko, „Spaljivanje mađarske zastave 1895. god. u Zagrebu“, Radovi Zavoda za hrvatsku povijest Filozofskog fakulteta u Zagrebu XXIII, 1990, 233-245 i Bosiljke Janjatović, „Sudski proces zagrebačkim studentima u studenome 1895.“, Historijski zbornik 50, 1997, 91-108. Važnu interpretaciju
} 
pokret koji se tada razvija. U tom smislu pokret mladih omeđuju dvije demonstracije, odnosno dva slučaja društvenih nemira. Međutim, kao što ćemo vidjeti, ovakva interpretacija dijelom je proizašla iz samoga pokreta, odnosno iz njegovih najranijih prikaza koje su pisali sami akteri pokreta.

Kako god bilo, sama narav predmeta istraživanja, naime njegova heterogenost i fluidnost, osujećuje pokušaje stroga određivanja njegova početka i kraja. Korijeni su modernističkog pokreta mladih višestruki te se moraju tražiti kako u domaćim intelektualnim, kulturnim i političkim tradicijama i okolnostima, tako i u formativnim iskustvima njegovih aktera u imperijalnim centrima te u njihovim aproprijacijama širih europskih kretanja. Mladi nisu istupili samo jednom, nego su to činili mnogo puta, svaki puta pokušavajući se probiti do sve šire publike. Učinili su to 1895. spaljivanjem zastave, učinili su to u istupima na suđenju koje je uslijedilo, nadalje prilikom objave svakog od svojih brojnih novih časopisa te kroz nebrojene tekstove i javne polemike. Sve to upućuje na nužnost višeslojnog vremenskog razumijevanja geneze i razvoja modernističkog pokreta mladih koje se ne ograničava čvrstim i fiksiranim vremenskim okvirima.

S prostornim je određenjem situacija mnogo jasnija. Posve je izvjesno da je nužno nadići formalne državne ili nacionalne okvire te da je potrebno pratiti kretanja samih povijesnih aktera. Najvažniji prostori za proučavanje modernističkog pokreta mladih svakako su Zagreb, Beč i Prag. Međutim, ono što je važno naglasiti jest da oni nisu tri odvojene prostorne točke ili monade, nego gradovi u interakciji, dijelovi većeg imperijalnog prostora, čije su međusobne „silnice“ bitno utjecale na definiranje kulturnih, političkih i društvenih uvjeta i obzorja, a jednako su tako važna i šira europska kretanja.

Uobičajeno heurističko sredstvo u istraživanjima modernističkog pokreta mladih jest podjela na određene grupacije kojima se potom pripisuju različita obilježja, ideološki naglasci te područja djelovanja. Najčešća je podjela ona na „bečku grupu“ i na „prašku“ ili „praškozagrebačku grupu“. ${ }^{13}$ Pritom se prvu opisuje kao artističku, esteticističku i kozmopolitsku, a drugu kao socijalno-političku, nacionalističku i realističku. Područje djelovanja prve ograničava se na književnost, književnu kritiku i eventualno likovnu umjetnost, a druge na politiku i socijalna pitanja. Prva je pod snažnim utjecajem bečke moderne i secesije, prije

događaja donosi Sarah Kent, ,State Ritual and Ritual Parody: Croatian Student Protest and the Limits of Loyalty at the End of the Nineteenth Century“, u: Laurence Cole i Daniel Unowsky (ur.), The Limits of Loyalty: Imperial Symbolism, Popular Allegiances, and State Patriotism in the Late Habsburg Monarchy“, 2009, 162-177, u kojemu tematizira odnos simboličkih ritualnih praksi iskazivanja nezadovoljstva, patriotizma i imperijalne lojalnosti. Svakako treba istaknuti i monografiju Filipa Šimetina Šegvića, Patriotizam i bunt: Franjo Josip I. $u$ Zagrebu 1895. godine, Zagreb, 2014, u kojoj je ovaj važan kraljev posjet Zagrebu po prvi puta obrađen cjelovito. ${ }^{13}$ Tako npr. Nemec i Bobinac, nav. dj., 84, a i M. Šicel te V. Flaker barataju istom distinkcijom, iako manje eksplicitno. 
svega kruga oko Hermanna Bahra i časopisa Ver Sacrum, a druga je pod utjecajem Tomáša Garriguea Masaryka i čeških naprednjaka. Neki su autori pak razlikovali više skupina. Mate Ujević tako dijeli pokret na „realiste“ (praški krug oko Hrvatske misli, Novog doba i Glasa), „naprednjake“ (karlovačko-zagrebački krug oko Nade, Nove nade i drugih manjih časopisa), „moderniste“ (bečki krug oko Mladosti, Hrvatskog salona i Života) te „nacionaliste“ (krug oko Narodne misli). ${ }^{14}$ Ujević „,realistima“ obilježava onu grupaciju (,,prašku skupinu“) koja je bila pod najsnažnijim utjecajem Tomáša G. Masaryka, a čiji je spiritus movens u ovom razdoblju bio Stjepan Radić. Oni su u prvi plan stavljali socijalna i ekonomska pitanja, zalagali se za kršćanski moralizam, odbacivali su larpurlartizam te su zagovarali individualizam u službi izgradnje čvrstog narodnog karaktera. ${ }^{15}$ „Naprednjaci“ su, prema Ujeviću, predstavljali mlađu generaciju okupljenu oko listova Nada, Nova nada i drugih manjih publikacija. Oni su bili pod snažnim utjecajem praške skupine realista, ali su također modificirali njihove ideje te su u pokret unijeli i neke svoje. Njihov je naglasak tako bio na obrazovanju pojedinca, organizacijskim pitanjima pokreta te individualizmu. Zalagali su se za utilitarni pristup književnosti, ali su ujedno bili pristaše moderne i kriticizma. ${ }^{16}$ Iako su isprva bili pod snažnim utjecajem praških realista, kasnije su razvili distinktivne političke i kulturne poglede koji su u mnogo čemu bili u opreci s onima realista, ali i bečkih modernista. Upravo su ovi potonji prema Ujeviću najuže vezani uz europska kulturna strujanja koja se označavaju pojmom moderne. Predvođeni Milivojem Dežmanom, oni su se zalagali za subjektivizam i individualizam, za otvorenost prema europskim strujanjima, za slobodu misli i izražavanja te za umjetničku originalnost. ${ }^{17}$ Naposljetku, Ujević „nacionalistima“ označava krug oko zagrebačke Narodne misli koji je naglašavao objektivno narodno jedinstvo Srba i Hrvata. Oni su se od svih navedenih skupina prema starima odnosili najblaže i politički agitativno. ${ }^{18}$ Ovakav se Ujevićev pristup koji odstupa od uobičajene binarne dihotomije čini plodnim, pogotovo ako se uspiju pokazati brojne sličnosti između tih grupacija, njihova dijeljena ideološka, kulturna i politička stajališta te česte interakcije i (pokušaje) zajedničkih poduhvata.

Modernistički pokret mladih doista je bio heterogen i nestrukturiran pokret koji je funkcionirao na temelju grupacija koje su se najčešće okupljale oko poduhvata izdavanja časopisa i prigodnih publikacija. Međutim, potreban je oprez kako se te grupacije ne bi

\footnotetext{
${ }^{14}$ Ujević, nav. dj., 69-70.

${ }^{15}$ Isto, 88.

${ }^{16}$ Isto, $110-111$.

17 Isto, 120.

${ }^{18}$ Isto, 140.
} 
shvatile odviše kruto. Takav bi pristup potencijalno vodio u smjeru toga da se sa svakom od tih skupina poveže određena vrsta historijskog istraživanja, npr. političko-historijskog s praškom grupom ili književno-historijskog s bečkom grupom te da se tako iz vida izgubi cjelina pokreta, kao i unutrašnja dinamika te interakcija njegovih aktera. Umjesto toga, potrebno je pratiti grupnu dinamiku i dinamiku široke mreže pokreta, zadržavajući pritom svijest o njegovoj heterogenosti i fluidnosti. ${ }^{19}$

Od najranijih prikaza modernističkog pokreta mladih ključni izvor za rekonstrukciju ideologije i intelektualnih strujanja pokreta bili su njegovi časopisi. ${ }^{20}$ Časopisi su doista bili centralni za pokret mladih. Oni su predstavljali njegov glavni medij te mjesto formiranja stajališta, za što su posebice bili važni tekstovi manifestnog karaktera. Za hrvatsku modernu općenito je karakteristična važnost književne kritike, čak i u većoj mjeri nego sama književna produkcija. ${ }^{21}$ Kroz proglase, polemičke tekstove, eseje, studije autora te književne kritike, mladi su predstavnici moderne izgrađivali nove nazore na književnost, politiku i društvo općenito, unoseći u hrvatsku javnost šira europska strujanja, koja su pritom modificirali prema lokalnim uvjetima i potrebama. Oni stoga predstavljaju temeljni izvor za intelektualnu historiju modernističkog pokreta mladih.

Tek se u suglasju s drugim izvorima, međutim, može steći relevantna slika o cjelini intelektualnih razvojnih puteva, ideoloških konstrukcija, političkih angažmana, osobnih veza i uloga aktera modernističkog pokreta mladih. U tom pogledu komplementarnu ulogu ključnim tekstovima ima građa osobnih ostavština samih povijesnih aktera, prije svega njihova korespondencija. ${ }^{22}$ Osim toga, važni su i zapisnici i drugi dokumenti formalnih i neformalnih tijela i društava koja su služila kao organizacijska osnovica za djelatnost modernističkog pokreta, što obuhvaća razna uredništva časopisa, đačka i studentska društva itd. Za evaluaciju važnosti i značenja pokreta bitnu ulogu ima i memoaristika te kasnija publicistika njegovih aktera.

\footnotetext{
${ }^{19}$ Dobar je primjer takvog pristupa, iako posve sintetski i općenit, onaj u poglavlju „Napredna omladina i njene ideje“ u knjizi Jaroslav Šidak et al., Povijest hrvatskog naroda g. 1860-1914., Zagreb, 1968, 152-155.

${ }^{20}$ Tako npr. Ujević, nav. dj.; Marjanović, nav. dj.; Flaker, nav. dj.; Stanislav Marijanović, Fin de siècle hrvatske moderne (Generacije ,,mladih“ i časopis „Mladost“), Osijek, 1990.

${ }^{21}$ Marjanović, nav. dj., 7.

22 Određeni izvori već su objavljeni. Vidi: Bogdan Krizman, Korespondencija Stjepana Radića, 1885.-1918., Zagreb, 1972; Damir Agičić, Dragi Franta! Hrvatska korespondencija Františeka Hlaváčeka (1896.-1904.), Zagreb, 2003; Iskra Iveljić, „Od uza Sudbenog stola do turneje po Rusiji, Nepoznata pisma Josipa Henneberga iz 1894.-1897.“, Časopis za suvremenu povijest XL, br. 2, 2008, str. 587-623; Vida Flaker, "Deset neobjavljenih pisama Stjepana Radića”, Kronika Zavoda za književnost i teatrologiju JAZU I, br. 2, 1975, str. 95-97; Stjepan Matković, „Ivo Pilar: Pisma Dušanu Plavšiću (1897.-1898.)“, u: Srećko Lipovčan, Zlatko Matijević, Prinosi za proučavanje života i djela dra Ive Pilara, sv. 2, Zagreb, 2002, str. 159-167; Stjepan Matković, „Iz rane Pilarove korespondencije: pisma Milivoju Dežmanu“, Pilar: časopis za društvene i humanističke studije X, br. 19-20, 2015, str. 161-175; Tomislav Sabljak (ur.), Korespondencija hrvatskih pisaca, Zagreb, 2002.
} 
Naravno da se ne smije zapostaviti niti sama književna produkcija. Ona ima dvojaku interpretativnu funkciju. Kroz analizu književnih djela moderne može se pokazati kako su predstavnici moderne zamišljali ulogu književnosti, koje su bile njihove estetske norme i na koje su se uzore oslanjali te na koji su se način odnosili spram domaće književne tradicije. S druge strane, ona također može ukazivati na korištenje književnosti kao sredstva za propagiranje određenih političkih stavova, napose onih koji se odnose na kritiku postojećih društvenih odnosa. U tom je smislu prije svega kroz kontekstualno čitanje književnih djela moguće rekonstruirati njihove političke ili šire društvene uloge, čak i u slučaju onih, napose esteticističkih djela čija je intencionalna funkcija deklaratorno larpurlartistička.

$\mathrm{S}$ obzirom na njegovu važnost kao fenomena $\mathrm{u}$ okviru hrvatske povijesti, modernistički pokret mladih relativno se često pojavljivao i spominjao u radovima $\mathrm{i}$ istraživanjima povjesničara te povjesničara književnosti. Međutim, ono što je zanimljivo jest to da do sada on nije bio predmet zasebne cjelovite historiografske obrade. Istraživanjima su uglavnom dominirale partikularne disciplinarne perspektive s većim ili manjim pokušajima osvrta na cjelinu problematike. Prije nego što se izlože ciljevi, pristup i teorijsko-metodološki okvir ovoga rada, usmjerena upravo na cjeloviti prikaz razvoja i važnosti modernističkog pokreta mladih na prijelomu 19. i 20. stoljeća, potrebno je ukratko se osvrnuti na dosadašnja istraživanja ovoga fenomena.

Najraniji prikazi modernističkog pokreta mladih dolaze iz pera samih njegovih aktera, kako u formi novinskih članaka, tako i kao zasebne monografije publicističkog karaktera. Među njima, najvažniji su tekstovi Milana Marjanovića, prije svega knjižice Hrvatski pokret objavljene u dva sveska 1903. i 1904. godine te knjiga Iza Šenoe: četvrt vijeka hrvatske književnosti objavljena 1906. godine u Zadru. ${ }^{23}$ Sažet prikaz pokreta mladih daje se i u knjizi Savremena Hrvatska iz 1913. godine. ${ }^{24}$ Ovi tekstovi danas, međutim, više funkcioniraju kao izvori te i sami zahtijevaju kritičku obradu i interpretaciju.

Pokret mladih postaje predmet znanstvenih istraživanja $\mathrm{u}$ punom smislu riječi $\mathrm{u}$ razdoblju nakon Drugog svjetskog rata. Prije toga, a posebice u međuraću, o pojedinim njegovim aspektima raspravljalo se u okviru tadašnje publicistike, uglavnom u kraćim tekstovima i novinskim člancima. Među njima treba istaknuti članak Dragutina Prohaske, „Utjecaj T. G. Masaryka na modernu jugoslavensku kulturu“, u kojemu poseban naglasak

\footnotetext{
${ }^{23}$ Milan Marjanović, Hrvatski pokret: opažanja i misli na pragu narodnoga preporoda g 1903, 2 sv., Dubrovnik, 1903. i 1904; Milan Marjanović, Iza Šenoe: četvrt vijeka hrvatske književnosti, Zadar, 1906.

${ }^{24}$ Milan Marjanović, Savremena Hrvatska, Beograd, 1913.
} 
stavlja na važnost ovog češkog mislioca i političara za hrvatske studente u Pragu. ${ }^{25}$ Zanimljiv je i kritički nastrojen članak Josipa Bognera koji pokret mladih vidi kao konglomerat tendencija pun opreka koji nije uspio povezati proklamirane ideale i praktične zahtjeve, rasplinuvši se naposljetku u konkretnoj praksi. ${ }^{26} \mathrm{U}$ spomen knjizi Obzora iz 1936. godine koju je, uostalom, uz Rudolfa Maixnera uredio i akter pokreta Milivoj Dežman - također je objavljeno nekoliko tekstova koji se dotiču pokreta mladih. Tako Josip Horvat u svojem prilogu iznosi tezu koja će imati prominentno mjesto u njegovoj sintezi hrvatske političke povijesti o pokretu mladih kao mehanizmu smjene generacija u hrvatskoj politici, dok Ivo Hergešić piše o njegovoj ulozi u hrvatskom književnom životu. ${ }^{27}$ Najvažniji monografski prikaz pokreta mladih iz međuratnog razdoblja jest do nedavno neobjavljeni rad Mate Ujevića iz 1933. godine naslovljen Prilozi za povijest pokreta hrvatske omladine koncem XIX $i$ početkom XX stoljeća, s osobitim osvrtom na borbu starih i mladih. Osim toga, u međuratnom se razdoblju pokret mladih počinje pojavljivati u sintetskim prikazima hrvatske povijesti kao važna karika u njezinu političkom razvoju, pri čemu je najreprezentativniji primjer djelo Josipa Horvata, Politička povijest Hrvatske iz 1936. godine. ${ }^{28}$ Možemo spomenuti da pokret mladih dobiva važno mjesto i u sintetskim radovima Ferde Šišića, a o razvoju ideja Stjepana Radića u svojem ranom tekstu iz 1940. godine pisao je Jaroslav Šidak. ${ }^{29}$

Nakon Drugog svjetskog rata interes za znanstveno istraživanje pokreta mladih ponovno je pokrenuo Milan Marjanović, ovoga puta objavljivanjem izbora relevantnih tekstova mladih nastalih u razdoblju trajanja pokreta između 1897. i 1903. godine u dvije knjige Hrvatska moderna: izbor književne kritike, koje je popratio opširnim uvodnim studijama. Prve znanstvene monografije koje obrađuju ovu problematiku izlaze, međutim, u sedamdesetim godinama prošlog stoljeća. ${ }^{30} \mathrm{U}$ okviru akademske historiografije najvažnija je

\footnotetext{
${ }^{25}$ Dragutin Prohaska, „Utjecaj T. G. Masaryka na modernu jugoslavensku kulturu“, u: Prohaska (ur.), T. G. Masarik: zbornik, Beograd i Prag, 1927, 102-168.

${ }^{26}$ Josip Bogner, „Polemika oko hrvatske moderne“, Književnik III, 3, 1930, 114-120, prema: Ivan Krtalić (ur.), Anarhija u hrvatskoj književnosti i umjetnosti, Zagreb, 1983, 7-14.

${ }^{27}$ Ivo Hergešić, „Mladi u hrvatskoj književnosti 1897.-1907.“, u: Milivoj Dežman i Rudolf Maixner, Obzor: spomen knjiga 1860-1935, Zagreb, 1936, 126-130; Josip Horvat, „Izmjena generacija: ideje i ljudi kroz četvrt vijeka hrvatske politike (1895.-1905.)“, u: Isto, 15-27. Zanimljivi su također i osvrti Steve Ostermana kao njegova sudionika na đački nadaški pokret, kao i mnogo kasnije objavljena sjećanja Františeka Hlaváčeka. Vidi Racko, 18-19, 26-27.

${ }^{28}$ Josip Horvat, Politička povijest Hrvatske, dio 1, Zagreb, 1990.

${ }^{29}$ Jaroslav Šidak, „Idejno sazrijevanje Stjepana Radića“, u: Studije iz hrvatske povijesti 19. stoljeća, Zagreb, 1973, 379-389.

${ }^{30}$ Prije toga, ovom se problematikom u nekolicini svojih tekstova posredno bavio Jaroslav Šidak. Oni su okupljeni i objavljeni u knjizi: Jaroslav Šidak, Studije iz hrvatske povijesti 19. stoljeća, Zagreb, 1973. Vidi još i: Dragovan Šepić, „Jugoslavenski pokret i Milan Marjanović 1901 - 1919“, Zbornik Odsjeka za povijesne znanosti Zavoda za povijesne i društvene znanosti Hrvatske akademije znanosti i umjetnosti III, 1960, 531-561; Mirjana Gross, „Nacionalne ideje studentske omladine u Hrvatskoj uoči I svjetskog rata“, Historijski zbornik XXI-XXII, 1968-1969, 75-143.
} 
znanstvena monografija (odnosno objavljena doktorska disertacija) Renea Lovrenčića Geneza politike 'novog kursa'. U njoj autor posvećuje zasebno poglavlje problematici pokreta mladih u hrvatskoj politici krajem 19. stoljeća te ujedno prati njegove aktere i u kasnijim političkim zbivanjima. Značajan sintetski prikaz strujanja, promjena i polemika u hrvatskoj kulturi (a zapravo i politici) na prijelomu stoljeća svakako je rad Branke Pribić „Idejna strujanja u hrvatskoj kulturi od 1895. do 1903.“ jer su u njemu prominentno istaknuti mladi u širem intelektualnom kontekstu. ${ }^{31}$ Ovaj je rad jedan od rijetkih primjera u kojemu se problematici pristupa cjelovito, dakle uključujući i političku i kulturnu dimenziju. Niti u najrecentnijim studijama problematika pokreta mladih najčešće nije obrađena cjelovito i kao zasebna tema. Damir Agičić dodatno je istražio hrvatske studente u Pragu na kraju 19. stoljeća te djelatnost tzv. praške grupe pokreta mladih. ${ }^{32} \mathrm{U}$ svojoj doktorskoj disertaciji o svakodnevici i društvenom životu studenata Sveučilišta u Zagrebu u drugoj polovici 19. i početku 20. stoljeća Tihana Luetić dotakla se političke i kulturne djelatnosti zagrebačkih studenata, što nužno uključuje i problematiku modernističkog pokreta krajem 19. stoljeća. $^{33}$ Pojedina poglavlja zbornika The Entangled Histories of Vienna, Zagreb and Budapest (18th - 20th Century) također se bave problematikom hrvatskih studenata na austrijskim sveučilištima te njihove organizacije i društvene djelatnosti. ${ }^{34}$

Mnogo je veći interes zamjetan na području povijesti književnosti jer je moguće izdvojiti niz djela koja se izravno ili neizravno bave navedenom problematikom. Prva znanstvena monografija čija je primarna tema pokret mladih bila je knjiga Vide Flaker Časopisi hrvatskoga modernističkog pokreta objavljena 1977. godine. Ona se zapravo sastoji od opširnije uvodne studije u kojoj autorica daje pregled djelatnosti pokreta s naglaskom na analizi proglasa grupacija mladih okupljenih oko izdavanja različitih časopisa te od bibliografskog pregleda sadržaja tih časopisa. Jedan od najvažnijih istraživača hrvatske moderne svakako je Miroslav Šicel. Osim već ranije istaknutih sinteza, on je zaslužan za brojne objavljene izvore i antologije, a razdobljem moderne bavio se i u pojedinačnim

\footnotetext{
${ }^{31}$ Branka Pribić, „Idejna strujanja u hrvatskoj kulturi od 1895. do 1903.“, Časopis za suvremenu povijest IV, 1, 1972, 87-127.

${ }^{32}$ Damir Agičić, Hrvatsko-češki odnosi na prijelazu iz XIX. u XX. stoljeće, Zagreb, 2000.

33 Tihana Luetić, Studenti Sveučilišta u Zagrebu 1874.-1914.: svakodnevica $i$ društveni život (doktorska disertacija), Zagreb, 2011.

${ }^{34}$ Iskra Iveljić (ur.), The Entangled Histories of Vienna, Zagreb and Budapest (18th - 20th Century), Zagreb, 2015. Osim navedenih, vidi još: Stjepan Matković, „Naprednjački prijepori o jugoslavenstvu: primjer neodržane sarajevske izložbe“, u: Damir Agičić, Drago Roksandić, Tvrtko Jakovina (ur.), Spomenica Renea Lovrenčića, Zagreb, 2016, 231-243; Silvestar Mileta, „Preteča komunističkog pokreta: socijalna demokracija u Hrvatskoj i Slavoniji 1890.-1914. i njena veza s građanskim opcijama napredne omladine i Hrvatske napredne stranke“, Pro tempore 10/11, 2016, 440-461. Dobar pregled na engleskom jeziku dostupan je u Mark Biondich, Stjepan Radić, the Croat Peasant Party, and the Politics of Mass Mobilization, 1904-1928, Toronto, Buffalo, London, 2000., poglavlje „Stjepan Radić: the Formative Years, 1871-1904“
} 
radovima. ${ }^{35}$ Kao istraživača ovog razdoblja treba spomenuti i Stanislava Marijanovića. Njegov je fokus prvenstveno usmjeren na krug oko Mladosti, s posebnim naglaskom na osječke aktere modernističkog pokreta. Uz to što se intenzivno istraživački bavio ovom problematikom, Marijanović je zaslužan i za objavljivanje do tada nedostupnih arhivskih izvora i materijala vezanih uz krug oko Mladosti. ${ }^{36} \mathrm{O}$ književnosti hrvatske moderne pisao je i Viktor Žmegač. On se, međutim, bavio i bečkom modernom, kao i širim, europskim modernističkim strujanjima, što mu je omogućilo da hrvatsku modernu uključi u europski kontekst i da istraži hrvatske aproprijacije bečkih strujanja. ${ }^{37} \mathrm{U}$ kontekstu problematike odnosa mladih i starih svakako treba spomenuti i istraživanja Zorana Kravara usmjerena na antimodernističke tendencije u hrvatskoj književnosti na kraju 19. i u prvoj polovici 20. stoljeća. ${ }^{38}$

Slično je i s istraživanjima u okviru povijesti umjetnosti. Disciplinarni je fokus u ovom slučaju još izraženiji. Dok se za povjesničare književnosti moglo reći kako uzimaju u obzir društveni i politički kontekst književne produkcije mnogo više nego što su povjesničari uzimali u obzir književnu produkciju pokreta mladih, povjesničari umjetnosti dominantno su se usredotočili na secesiju kao stilsko razdoblje, razmatrajući samo u osnovnim crtama njezin društveno-politički kontekst i poveznicu s političkom i književnom djelatnošću pokreta mladih. Secesija je za povjesničare umjetnosti prvenstveno umjetničko-povijesno, odnosno stilsko razdoblje, stoga ne čudi da nema studija koje bi obrađivale secesiju kao pokret,

${ }_{35}$ Miroslav Šicel, Književnost moderne, Povijest hrvatske književnosti, knj. 5, Zagreb, 1978; Isti, Povijest hrvatske književnosti XIX. stoljeća, knj. III: moderna, Zagreb, 2005; Isti (ur.), Hrvatska moderna: kritika i književna povijest, Zagreb, 1975; Isti, „Programi i manifesti hrvatske moderne“, Croatica XXII, 35/36, 1991, 2133; Isti, Stvaraoci i razdoblja u novijoj hrvatskoj književnosti: analize i sinteze, Zagreb, 1971.

${ }^{36}$ Stanislav Marijanović, Fin de siècle hrvatske moderne; Isti, „Guido Jeny o počecima Ivana Meštrovića“, Croatica XXII, 35/36, 1991, 197-226; Isti, „U fin de siècleu hrvatske moderne: Najmlađi mladi i europska književnost“, Dani Hvarskoga kazališta 27, 1, 2001, 55-66; Isti, „Europska književnost i umjetnost u časopisu Mladost (iz vidokruga »bečkog kruga«)“, Dani Hvarskoga kazališta 28, 1, 2002, 247-257.

37 Viktor Žmegač, Duh impresionizma i secesije: studije o književnosti hrvatske moderne, Zagreb, 1997. Isti, „Europski kontekst hrvatske moderne“, u: Josip Bratulić, Josip Vončina, Antun Dubravko Jelčić, Hrvatska $i$ Europa: kultura, znanost $i$ umjetnost, sv. 4, Zagreb, 2009, 411-416; Isti, Bečka moderna: portret jedne kulture, Zagreb, 2012.

38 Zoran Kravar, Svjetonazorski separei: antimodernističke tendencije u hrvatskoj književnosti ranoga 20. stoljeća, Zagreb, 2005. Moguće je navesti još cijeli niz književnopovijesnih radova posvećenih hrvatskoj moderni, bilo kao pokretu ili kao stilskom razdoblju. Vidi npr. Vida Flaker, „Vladimir Nazor i evropska moderna“, u: Aleksandar Flaker i Krunoslav Pranjić (ur.), Hrvatska književnost u evropskom kontekstu, Zagreb, 1978, 451-459; Vinko Brešić, Časopisi Milana Marjanovića, Zagreb, 1990; Ljiljana Ina Gjurgjan, Mit, nacija i književnost „,kraja stoljeća“: Vladimir Nazor $i$ W. B. Yeats, Zagreb, 1995; Ista, „Estetska načela moderne u djelima Vladimira Nazora“, Mogućnosti 4/6, 2005, 131-148; Nevenka Košutić-Brozović, „Evropski okviri hrvatske Moderne“, u: Flaker i Pranjić (ur.), nav. dj., 345-363; Ista, „Ženski udio u književnom životu hrvatske moderne“, Dani Hvarskoga kazališta 27, 1, 2001, 104-111; Marijan Šabić, Hrvatsko-češke književne veze: XIX. $i$ početak XX. stoljeća, Zagreb, 2013; Marina Protrka Štimec, „Pokret Mladih i paradigme moderniteta“ URL: https://uol.de/f/3/inst/slavistik/Oldenburger_Beitraege zum 16. Internationalen_Slavistenkongress in Belgrad/ Stimec2018_Pokret_Mladih_i_paradigme_moderniteta..pdf; pristup: 26.8.2020; Boris Senker, "Razmjena dramskih tekstova između bečkoga i zagrebačkoga književnog kruga na mijeni stoljeća", u: Barbarić, nav. dj., 146-169. 
istražujući ne samo umjetnička djela, nego i njezinu institucionalnu dinamiku, interakciju aktera, ideologiju i društveno-političku djelatnost. Znanstvenom produkcijom stoga dominiraju sintetski pregledi. Jedan od najreprezentativnijih je onaj Grge Gamulina, Hrvatsko slikarstvo na prijelazu iz XIX. u XX. stoljeće. ${ }^{39}$ Važan je i opsežan zbornik radova sa znanstvenog skupa posvećenog secesiji u Hrvatskoj koji je održan u Osijeku 1997. godine. ${ }^{40}$ Ono što pritom treba istaknuti je izražena interdisciplinarna tendencija ovoga zbornika jer obuhvaća teme vezane uz arhitekturu, slikarstvo, estetiku, književnost i urbanu povijest (napose Osijeka). Važne publikacije o secesiji u Hrvatskoj nastale su kao dio izložbenih projekata, među kojima treba izdvojiti Hrvatski salon, Zagreb 1898. posvećenu stogodišnjici Umjetničkog paviljona, Secesiju u Hrvatskoj koja je popratila istoimenu izložbu u Muzeju za umjetnost i obrt, kao i Izazov moderne: Zagreb i Beč oko 1900 urednica Irene Kraševac i Petre Vugrinec. ${ }^{41}$

Usprkos značajnim pokušajima rekonstrukcije društveno-političkog konteksta u pojedinim slučajevima, studije koje su se bavile problematikom hrvatske moderne i secesije u okviru povijesti književnosti i povijesti umjetnosti ipak su ostale dominantno disciplinarno profilirane. Njihov fokus jasno je stavljen na kulturnu produkciju moderne, i to najčešće cjelini ovog razdoblja. Stoga se mora zaključiti da u okviru znanstvene historiografije nedostaje cjelovita studija pokreta mladih na prijelomu 19. i 20. stoljeća koja bi toj problematici pristupila interdisciplinarno, sintetizirajući rezultate dosadašnjih najvažnijih, disciplinarno profiliranih studija i valorizirajući pokret kao zasebni fenomen u njegovu specifičnom, transnacionalnom kontekstu.

\section{2. Istraživački cilj, teze i teorijsko-metodološki okvir}

S obzirom na osnovni problem koji je uočen kod većine dosadašnjih istraživanja fenomena modernističkog pokreta mladih, naime izražena disciplinarna optika i fokusiranost na određeni aspekt fenomena, cilj je ovoga istraživanja ponuditi cjeloviti prikaz i interpretaciju pokreta mladih u hrvatskoj kulturi i politici na prijelomu 19. i 20. stoljeća.

\footnotetext{
${ }^{39}$ Grgo Gamulin, Hrvatsko slikarstvo XIX. stoljeća, sv. 2: Hrvatsko slikarstvo na prijelazu iz XIX. u XX. stoljeće, Zagreb, 1995.

40 Julijo Martinčić, Dubravka Hackenberger (ur.), Secesija u Hrvatskoj: zbornik radova znanstvenog skupa, Zagreb i Osijek, 1999.

${ }^{41}$ Lea Ukrainčik (ur.), Hrvatski salon, Zagreb 1898.: 100 godina Umjetničkog paviljona, Zagreb, 1999; Anđelka Galić, Miroslav Gašparović (ur.), Secesija u Hrvatskoj, Zagreb, 2003; Irena Kraševac, Petra Vugrinec (ur.), Izazov moderne: Zagreb i Beč oko 1900. Slikarstvo, kiparstvo i arhitektura zagrebačke i bečke secesije, Zagreb, 2017.
} 
U tu svrhu, istraživanje će konceptualno biti oblikovano na dvije temeljne osi: vertikalnoj, odnosno dijakronijskoj i horizontalnoj, odnosno sinkronijskoj. Ključni problem dijakronijske osi istraživanja jest pitanje kontinuiteta i diskontinuiteta pokreta mladih u odnosu na hrvatske političke i kulturne tradicije, dok će u fokusu sinkronijske dimenzije istraživanja biti pitanje njegovih aproprijacija suvremenih europskih strujanja, odnosno načini prilagodbe preuzetih ideja i praksi s obzirom na lokalne društvene, političke i kulturne prilike. Iako same po sebi nužno zahvaćaju i kronološki i spacijalno šire područje, ove dvije osi presijecaju se upravo kroz istraživački fokus na pokret mladih, što težište istraživanja stavlja na već spomenuti imperijalni prostor između Zagreba, Praga i Beča te otprilike u razdoblje između 1895. i 1903. godine.

Glavni metodološki izazov svake dijakronijske analize jest izbjegavanje teleološke perspektive. Kasniji razvoj i događaji od samoga su početka opterećivali i usmjeravali narative o modernističkom pokretu mladih na prijelomu 19. i 20. stoljeća. Tomu je u velikoj mjeri pridonijela i činjenica da su prvi prikazi razvoja pokreta proizašli iz pera njegovih sudionika. Tako je npr. narodni pokret 1903. godine služio kao teleološki fokus za rani Marjanovićev narativ. ${ }^{42}$ Bilo da je riječ o novom kursu ${ }^{43}$, Hrvatsko-srpskoj koaliciji ${ }^{44}$ ili jugoslavenskom ujedinjenju 1918. godine ${ }^{45}$, pokret mladih često je funkcionirao kao ishodišna točka u kojoj su se tražile klice za ono što dolazi kasnije. Na sličan su način kasnijim razvojem opterećena istraživanja pojedinačnih aktera pokreta, posebice onih najistaknutijih (Radić, Pribićević, Dežman). Zbog toga je često patila genetička perspektiva, pa je samim time i u interpretacijama jači naglasak stavljen na diskontinuitete nego na kontinuitete. Jedan od glavnih zadataka ovoga istraživanja jest propitati tu tezu o izraženom diskontinuitetu koji u hrvatsku politiku i kulturu ulazi s pokretom mladih te kroz osnaživanje genetičkog aspekta pridonijeti nijansiranoj interpretaciji pokreta.

Pitanje odnosa pokreta mladih spram tradicije hrvatskog nacionalnog pokreta, kako u politici, tako u kulturi, nije rezultat naknadne historiografske konceptualizacije. Ono se javlja u okviru samoga pokreta mladih. Mladi su od samoga početka i uvijek iznova promišljali o svojem mjestu u liniji kontinuiteta hrvatskog nacionalnog pokreta, tako da je ovaj aspekt problema ujedno formativan i za samu ideologiju pokreta mladih. Međutim, za historiografsku konceptualizaciju ovoga problema možemo se poslužiti modelom etapnog procesa hrvatske nacionalne integracije Mirjane Gross. Riječ je zapravo o primjeni modela

\footnotetext{
${ }^{42}$ Marjanović, Hrvatski pokret.

${ }^{43}$ Lovrenčić, nav. $d j$.

${ }^{44}$ Horvat, nav. dj.

${ }^{45}$ Ferdo Šišić, Pregled povijesti hrvatskoga naroda, Zagreb, 1962, posebno 458-469.
} 
Miroslava Hrocha na hrvatski slučaj, pri čemu je Mirjana Gross model prilagodila lokalnim specifičnostima. ${ }^{46}$ Naime, Hroch razlikuje tri faze u procesu nacionalne integracije: početnu ili A fazu u kojoj pojedinci - intelektualci i pisci - iznose ideje koje će činiti osnovu za stvaranje nacionalne ideologije i nacionalnog pokreta; središnju ili B fazu u kojoj se razvija nacionalni pokret, čiju jezgru čini grupa „patriota“ koji organizirano provode nacionalnu agitaciju, šireći je postepeno na sve društvene slojeve; te naposljetku završnu ili $\mathrm{C}$ fazu koju karakterizira to da je nacionalna svijest raširena u velikoj većini društva, koje se može mobilizirati u borbi za nacionalne interese, te u kojoj se javljaju konkurentske ideologije sukobljene oko definicije nacionalnih interesa. Kada je riječ o hrvatskoj nacionalnoj integraciji, Mirjana Gross modificirala je ovaj model tako da je dodala relativno dugotrajno prijelazno razdoblje između faze B i C. Naime, u hrvatskom slučaju ona primjećuje da završetak preporodnog pokreta koji čini B fazu procesa nacionalne integracije ne slijedi faza omasovljenja nacionalnog pokreta, nego period stagnacije u kojemu se „kulturna i politička dostignuća produbljuju i učvršćuju, ali se protežu samo na inteligenciju i bogatije građanstvo, dok se sitnoburžoaski slojevi znantno polaganije uključuju u proces nacionalne integracije.“47 Prema Mirjani Gross, o fazi C, odnosno o omasovljenju hrvatskog nacionalnog pokreta može se govoriti tek u razdoblju prijeloma 19. i 20. stoljeća, i to prvenstveno u sjevernoj Hrvatskoj. Tada se naime intenziviraju oni procesi koji čine temelj za masovni nacionalni pokret: nacionalno osvješćivanje seljaštva, uspon građanske kulture, širenje obrazovanja, razvoj mogućnosti općehrvatske političke akcije, demokratizacija političkog života i ekonomska suradnja nacionalne buržoazije. ${ }^{48}$ Iz svega navedenog, jasno je da će u tom pogledu važnu ulogu igrati i modernistički pokret mladih, koji se na ovaj ili onaj način dotiče svih ovih točaka. Govoreći o nacionalno-integracijskim ideologijama, Mirjana Gross mlade smješta u kontekst transformacija jugoslavenske ideologije:

„U građanskom je okviru jugoslavenska ideologija doživjela svoju demokratizaciju i laicizaciju s Naprednom omladinom koja je postepeno unosila ideologiju 'Moderne' na sva područja društvenoga života. Napredna se omladina pojavila s novom političkom filozofijom i taktikom koja je išla za odlučnom mobilizacijom širih slojeva u nacionalnoj borbi. Pod utjecajem Masarykove 'realističke' ideologije i pozitivističkih društvenih znanosti nastao je

\footnotetext{
${ }^{46}$ Miroslav Hroch, Društveni preduvjeti nacionalnih preporoda u Europi: Komparativna analiza društvenog sastava patriotrskih grupa malih europskih nacija, Zagreb, 2006; Mirjana Gross, „O integraciji hrvatske nacije“, u: Mirjana Gross (ur.), Društveni razvoj u Hrvatskoj (od 16. stoljeća do početka 20. stoljeća, Zagreb, 1981, 175190.

${ }^{47}$ Gross, nav. dj., 185.

${ }^{48}$ Isto, 187.
} 
građansko-demokratski ideološki sustav naprednjaka kojega je jugoslavenska ideologija bila samo sastavni dio. ${ }^{\text {‘49 }}$

Glavni je zadatak vertikalne, odnosno dijakronijske osi ovoga istraživanja stoga ispitati odnos između modernističkog pokreta mladih i hrvatske građanske politike s jedne strane, odnosno hrvatskog nacionalnog pokreta i općenito procesa nacionalne integracije s druge. Dodatnu dimenziju problemu daje činjenica da su sami povijesni akteri itekako bili svjesni ove problematike, tako da je promišljanje navedenih odnosa činilo srž i ideologije i prakse mladih. Ključno je stoga pitanje intenziteta kontinuiteta i diskontinuiteta koji nastupaju s pojavom mladih, odnosno, još preciznije rečeno, pitanje odnosa između proklamiranih i retoričkih diskontinuiteta i kontinuiteta i stvarnih, odnosno praktičnih promjena. Nijansiraniji pogled na ovu problematiku morao bi uključivati i svijest o tome da radikalnost ideoloških proglasa ponekad ne odgovara konkretnoj političkoj praksi, ili da ideološki iskazi ponekad mogu funkcionirati tako da ostvaruju određeni efekt koji nužno ne odgovara njihovu sadržaju. Osim toga, ne smije se zanemariti niti fluidna i promjenjiva narav ovakvih ideoloških konstrukcija: naglašavanje kontinuiteta i diskontinuiteta također je variralo s obzirom na dane političke i društvene odnose, tako da i sama činjenica fluktuacije u razumijevanju ovih odnosa pregnantno govori o smjeru razvoja pokreta i njegovih aktera.

Ako je ključno obilježje modernističkog pokreta mladih prenošenje suvremenih europskih (i globalnih) ideja i kretanja u hrvatski javni i politički prostor, onda se kao jedno od temeljnih istraživačkih pitanja postavlja ono o načinima aproprijacija i transfera tih ideja i praksi. Upravo je to zadatak horizontalne, odnosno sinkronijske osi ovoga istraživanja. U sadržajnom smislu ono se u tom pogledu oslanja na iznimno plodan i bogat korpus studija fin de siècle-a. ${ }^{50}$ Hrvatski modernistički pokret na prijelomu stoljeća bio je samo jedan u nizu fin de siècle modernističkih pokreta, lokalna iteracija jednog globalnog fenomena. U tom smislu on dijeli brojne značajke s drugim srodnim pokretima te sudjeluje u specifičnoj intelektualnoj kulturi fin de siècle modernizma. Međutim, kao lokalna iteracija globalnog fenomena, hrvatski je modernistički pokret ujedno specifičan jer pokazuje razlikovna obilježja lokalnog konteksta, kako političkog, tako i kulturnog i intelektualnog. Zbog toga ključni izazov u istraživanju nije pokazati kojim se obilježjima modernistički pokret mladih u Hrvatskoj na prijelomu 19. i 20. stoljeća podudara ili kojima odudara od općih obilježja fin de siècle

\footnotetext{
${ }^{49}$ Isto, 297.

50 Ovdje možemo istaknuti samo neke reprezentatitvne studije: Peter Fritzsche, Reading Berlin 1900, Cambridge, London, 1998; Peter Jelavich, Munich and Theatrical Modernism: Politics, Playwriting, and Performance, 1890-1914, Cambridge, London, 1996; John Lukacs, Budapest 1900: A Historical Portrait of a City and Its Culture, New York, 1988; Petr Wittlich, Prague: Fin de Siècle, Pariz, 1992. Za širi pregled vidi: Gail Marshall (ur.), The Cambridge Companion to the Fin de Siècle, Cambridge, 2007.
} 
modernizma i modernističkih pokreta (što je samo po sebi jedan idealni tip), nego objasniti zašto i na koji način nastaju ili ne nastaju specifične razlike koje obilježavaju pokret mladih kao lokalni fenomen isprepleten s istorodnim globalnim fenomenima.

Najvažniji širi kontekst za sinkronijsko istraživanje hrvatskog modernističkog pokreta ipak je onaj austrijskog fin de siècle-a. Ovdje se, dakako, kao dominantna tema nametnula ona fin de siècle Beča koja je u mnogo čemu definirala cjelokupno polje istraživanja. ${ }^{51} \mathrm{U}$ tom pogledu najutjecajnija je bila tzv. Schorskeova paradigma koju je razvio u svojoj utjecajnoj knjizi Fin-de-Siècle Vienna: Politics and Culture iz 1979. godine. Prema njoj, izvor ahistoričnog, esteticističkog modernizma u Beču ležao je u povlačenju „sinova“ austrijskog liberalizma, djece uspješne bečke buržoazije, pod naletom različitih neliberalnih kolektivizama koji su ugrozili klasične liberalne pretpostavke povijesnog i racionalnog napretka, iz političke sfere u kulturnu sferu kojom su dominirala estetska i psihološka razmatranja. $^{52}$ Kombinirajući internalistički i eksternalistički pristup, pod utjecajem intelektualnih kretanja šezdesetih godina 20. stoljeća, Schorske je apostrofirao vezu između političke alijenacije i kulturne inovacije, pri čemu modernizam nije vidio kao hegemonijski kulturni projekt buržoazije, nego kao proizvod njezina političkog neuspjeha i posljedične dezorijentacije. ${ }^{53}$

Jedna od ključnih implikacija Schorskeova pristupa koja se našla na udaru kritičara bio je njegov prevelik naglasak na sam Beč i na njegovu paradigmatičnost za cjelokupno polje studija austrijskog fin de siècle-a. ${ }^{54}$ Paradoksalno, Beč je u okviru Schorskeove paradigme ujedno previše i premalo specifičan. S jedne strane, u kontekstu uspona teze o njemačkom, odnosno srednjoeuropskom Sonderweg-u, zajednička obilježja i dijeljena iskustva fin de siècle modernizma bila su potisnuta u usporedbi $\mathrm{s}$ isticanjem posebnosti kulture i inovativna karaktera fin de siècle Beča kao jednog od specifičnih izvorišta globalnog moderniteta na prijelomu stoljeća. S druge pak strane, u okviru Habsburške Monarhije on je uziman kao svojevrsni pars pro toto, zasjenjujući velike razlike koje su postojale između raznih dijelova Monarhije i namećući Beč kao paradigmu za ostale urbane centre. Upravo je potonje naišlo na

\footnotetext{
${ }^{51}$ Dobar pregled daje Filip Šimetin Šegvić, „Fin de siècle Beč i Beč 1900. kao historiografski problem: pristupi, paradigme, rasprave“, Radovi Zavoda za hrvatsku povijest 52, 2, 2020, 81-128; Za nešto raniji pregled problematike v. Damir Barbarić, „Lišenost i zamuknuće: O filozofijskim osnovama bečkog fin de sièclea“, u: Barbarić, nav. dj., 11-35.

${ }^{52}$ Carl E. Schorske, Beč krajem stoljeća: Politika i kultura, Zagreb, 1997.

${ }^{53}$ Steven Beller (ur.), Rethinking Vienna 1900, New York, Oxford, 2001, 2-3.

${ }^{54} \mathrm{Uz}$ Schorskea, ključne za oblikovanje (zapadne) akademske percepcije fin de siècle Beča su knjige Williama M. Johnstona, The Austrian Mind. An Intellectual and Social History 1848-1938 (1972.) i Wittgenstein's Vienna (1973.) Janika i Toulmina, kao i ranija djela Hermanna Brocha (Hofmannsthal i njegovo doba) i Ilse Bareae (Vienna. Legend and Reality).
} 
žestoke kritike u okviru novijih habsburških studija. Pieter Judson tako ističe da pogled u druge krajeve Monarhije, onkraj Beča, otkriva radikalno drugačije kontekste i iteracije fenomena fin de siècle modernizma: u drugim dijelovima Monarhije on je mogao značiti upravo osnaženje liberalizma, a ne njegov poraz. Najviše od svega, izvan Beča ključan je fenomen nacionalizma te je izražena spona liberalizma i nacionalizma, tako da se fenomen modernističkih pokreta nužno isprepliće i reagira s tom dominantnom „liberalnonacionalističkom sintezom“. 55

U svojoj utjecajnoj knjizi o političkom radikalizmu u Beču krajem 19. stoljeća, John Boyer je kritički nastupio prema onim interpretacijama - uključujući Schorskeovu - koje su u kršćansko-socijalnom pokretu vidjele snažan diskontinuitet s obzirom na tradiciju austrijskog liberalizma, kao i preteču dvadesetostoljetnog fašizma. Prema njemu, bečku su politiku između 1848. i 1914. obilježili kontinuiteti jednako kao radikalne promjene:

„Luegerov bi pokret trebalo mnogo više razumjeti s obzirom na njegove dubinske normativne i društvene korijene u devetnaestom stoljeću nego u odnosu na njegovu navodnu paradigmatsku ulogu za dvadesetostoljetnu politiku radikalne desnice. Austrijski kršćanski socijalizam bio je pokret devetnaestostoljetnog socijalnog buržoaskog protesta, a ne protofašistički križarski rat ili potpuni raskid s devetnaestostoljetnim bečkim političkim vrijednostima i institucijama. Nije bilo apsolutna, precizna razgraničenja između 'racionalističke' i 'iracionalističke' politike u Beču devetnaestoga stoljeća. “56

Boyerovo i Judsonovo upozorenje protiv prenaglašavanja raskida između klasične građanske liberalne tradicije 19. stoljeća i radikalnih političkih pokreta s kraja 19. stoljeća jednako je primjenjivo i na analizu odnosa mladih i starih u hrvatskom kontekstu. Umjesto da ih se čita teleološki kroz perspektivu kasnijeg jugoslavenskog ujedinjenja, pa se u njima traži izvorište onoga što se doći kasnije u podosta različitom kontekstu, pokretu mladih i njihovu odnosu prema hrvatskoj građanskoj političkoj tradiciji potrebno je pristupiti prije svega uzimajući u obzir suvremeni kontekst. Osim toga, potrebno je nadići razinu puke retorike i vidjeti kako određene ideje i koncepti funkcioniraju u konkretnoj političkoj praksi, koja često otkriva mnogo više kontinuiteta i pragmatizma od vatrenih manifesta i programatskih spisa.

Druga osnovna točka kritike Schorskeove paradigme ticala se njezina fokusa na esteticistički modernizam. Nasuprot tome, već su Janik i Toulmin u svojem utjecajnom djelu

\footnotetext{
${ }^{55}$ Pieter Judson, „Rethinking the Liberal Legacy“, u: Beller, nav. dj., 57-79.

56 John W. Boyer, Political Radicalism in Late Imperial Vienna: Origins of the Christian Social Movement, 1848-1897, Chicago, London, 1981, xiii.
} 
o Wittgensteinovu Beču postulirali Beč kao mjesto rođenja „kritičkog modernizma““. 57 Kulturni i intelektualni život u Beču na prijelomu 19. i 20. stoljeća nije se svodio na esteticizam i dekadenciju. On je ujedno bio mjesto znanosti, empirizma i „bečkog prosvjetiteljstva“. ${ }^{58}$ Nijansiraniji pogled koji naglašava raznorodnost fenomena fin de siècle modernizma nije stoga potreban samo između različitih dijelova Monarhije, nego i unutar samih centara razvoja ovog fenomena.

Oslanjajući se na ove dvije ključne točke kritike Schorskeove paradigme možemo stoga definirati i važne odrednice našeg istraživanja o hrvatskom modernističkom pokretu na prijelomu 19. i 20. stoljeća. Fokus na hrvatski slučaj u širem intelektualnom, kulturnom i političkom kontekstu nužno pridonosi popunjavanju slike o modernističkim kretanjima na habsburškom imperijalnom prostoru, a time također i ranije navedenim raspravama oko schorskeovske istraživačke paradigme. Jedan od pristupa koji se nastavljao na Schorskeovu paradigmu bio je onaj postmodernistički. Ono što je Schorske vidio kao izvorište ahistoričnog modernizma, ovi su autori - od kojih su najznačajniji Michael Pollak i Jacques Le Rider identificirali kao prethodnicu postmoderne, s naglaskom na krizu modernog subjektiviteta i identiteta (l'identité blessée). ${ }^{59}$ Međutim, kao što ćemo vidjeti, hrvatski slučaj i u ovome pogledu može služiti kao svojevrsni korektiv protiv generaliziranja bečke moderne. Ako su i postojale aproprijacije ahistoričnog, esteticističkog modernizma, one su u okviru pokreta mladih bile zasjenjene drugim, za hrvatski kontekst mnogo prijemčivijim konceptima. Kada su se pak manifestirale, često su poprimale oblik imitacija čija je prvenstvena uloga bila oblikovati specifični habitus modernog umjetnika, boema ili intelektualca, što je sa sobom nosilo određeni prestiž u okviru nastajuće fin de siècle građanske kulture kavana.

Zagreb se stoga ne može promatrati isključivo kao „mali Beč“, niti se modernistički pokret mladih može istraživati kao puka imitacija bečke moderne. Pogled iz periferije često otkriva više nego pogled iz centra, bilo da je riječ o periferiji, bilo da je riječ o samom centru. Usložnjavanju interpretacija odnosa centra i periferije u slučaju Habsburške Monarhije značajno su pridonijeli autori koji su na analizu ovoga odnosa primijenili konceptualne alate postkolonijalnih studija. Habsburški postkolonijalni pristupi smjerali su nadilaženju dihotomije između nacionalističkih interpretacija s jedne strane i s druge onih nostalgičnih, baziranih na „habsburškom mitu“. Pritom je bila riječ o inovativnoj primjeni koncepata postkolonijalnih studija jer se habsburški slučaj nije uklapao u paradigmatski tip kolonijalne

\footnotetext{
${ }^{57}$ Riječ je prije svega o Le Riderovoj knjizi Modernité viennoise et crisis de l'identité iz 1990. godine. Beller, nav. dj., 2. Za ocjenu vidi Barbarić, „Lišenost i zamuknuće“, 16-17.

${ }^{58}$ Mark Francis (ur.), The Viennese Enlightenment, New York, 1985.

${ }^{59}$ Beller, nav. dj., 5.
} 
sile koji je obilježen unilateralnom dominacijom centra nad kolonijalnom periferijom. Iako prožeti snažnim asimetrijama, odnosi moći između centra i periferije Habsburške Monarhije bili su mnogo manje jednostrani nego što je to bio slučaj kod klasičnih pomorskih kolonijalnih sila. Zbog toga su autori koji su razvijali ovakve istraživačke pristupe posegnuli za onim konceptima koji su usložnjavali odnos centra i periferije, napose u pogledu njihova međusobna djelovanja, a da pritom nisu umanjivali asimetrični karakter odnosa moći. ${ }^{60} \mathrm{U}$ ovome je kontekstu svakako važno spomenuti i koncepte marginocentričnih, odnosno liminalnih gradova koji se odupiru nasilnu utapanju u jednu, nacionalističku paradigmu i perspektivu. ${ }^{61}$ Nasuprot tome, multietnički i multikulturalni gradovi Srednje i Istočne Europe funkcionirali su kao nodalna čvorišta u kojima su se ispreplitale različite kulture i tradicije. Intenzivnom urbanizacijom tijekom druge polovice 19. stoljeća oni su se oblikovali kao mjesta okupljanja, razmjena i modernizacije, ali ujedno i konflikata, otpora promjenama i isključivosti. ${ }^{62}$ Upravo je ovakvo razumijevanje urbanih miljea ključno za razumijevanje dinamike razvoja i razmjena modernističkih pokreta na prijelomu 19. i 20. stoljeća.

Slučaj hrvatskog modernističkog pokreta uklapa se tako u mrežu srodnih pokreta koja obuhvaća velik broj urbanih centara kao njihovih ključnih žarišta, ali i aktera čija djelatnost i kretanje transcendira kasnije utvrđene nacionalne i disciplinarne granice. Osim toga, hrvatski slučaj također osnažuje kritike upućene generaliziranju i ideal-tipiziranju modernističkog pokreta na prijelomu 19. i 20. stoljeća. Baš kao u bečkom slučaju, i modernistički pokret mladih neće karakterizirati samo jedan tip fin de siècle modernizma - onaj esteticistički nego raznorodna modernistička strujanja koja će kroz procese aproprijacija rezultirati specifičnim lokalnim iteracijama modernizma. One će svakako u velikoj mjeri participirati u globalnim kretanjima, dakako posredovanima preko različitih kanala, posuđujući iz šireg, globalnog rezervoara ideja i praksi, ali će ih ujedno prilagođavati specifičnim lokalnim okolnostima i ciljevima. Zbog toga, ključni su element ove sinkronijske, horizontalne osi istraživanja upravo načini aproprijacija - imitacija, emulacija, kritičkih prisvajanja, prevođenja, modifikacija itd. - modernističkih ideja, strujanja i praksi, te njihova uloga i funkcija u specifičnom lokalnom političkom i društvenom kontekstu.

\footnotetext{
60 Jedan od najvažnijih za razvoj habsburških postkolonijalnih pristupa svakako je zbornik: Johannes Feichtinger, Ursula Prutsch i Moritz Csáky (ur.), Habsburg postcolonial: Machstrukturen und kollektives Gedächtnis, Innsbruck, Wien, München, Bozen, 2003. Vidi također i: Marijan Bobinac, „The Habsburg Legacy from a Postcolonial and Postimperial Perspective“" Umjetnost riječi LIX, 3-4, 2015, 239-260.

${ }^{61}$ Marcel Cornis-Pope i John Neubauer (ur.), History of the Literary Cultures of East-Central Europe: Junctures and Disjunctures in the 19th and 20th Centuries, 2. sv., Amsterdam i Philadelphia, 2006.

${ }^{62}$ Moritz Csáky, Das Gedachtnis Der Stadte: Kulturelle Verflechtungen - Wien Und Die Urbanen Milieus in Zentraleuropa, Beč, 2010. Vidi također: Isti, „Die zentraleuropäische Stadt in der Moderne. Eine kulturwissenschaftliche Annäherung“, u: Iveljić, The Entangled Histories, 11-38.
} 
U svrhu fokusiranja istraživanja, kako bi se ono uspješnije provelo kroz ovu konceptualnu shemu koja počiva na dvije istraživačke osi, postavljene su tri osnovne, početne istraživačke teze:

1) Modernistički pokret mladih sastojao se od niza heterogenih grupacija koje su održavale međusobne kontakte i djelovale pod okriljem općih idejnih formulacija i ciljeva, ali čije su ideološke postavke ponekad bile međusobno suprotstavljene, a osobne idiosinkrazije utjecale su na međuljudske odnose, pa posljedično i na opći smjer razvoja pokreta. U tom smislu općenito vrednovanje značenja pokreta moguće je samo u ograničenu dometu i uz svijest o divergentnim kretanjima njegovih konstitutivnih elemenata.

2) Modernistički pokret mladih crpio je raznolike utjecaje od suvremenih pokreta i kretanja slična karaktera, ali zbog specifičnog hrvatskog konteksta ti su utjecaji nužno morali biti prilagođeni konkretnim onodobnim prilikama. Zbog toga se u okviru modernističkog pokreta uz imitaciju suvremenih uzora očituje i originalni sadržaj koji nastaje kroz svjesnu kritičku aproprijaciju.

3) Glavni adresat i mjesto djelatnosti modernističkog pokreta mladih bila je hrvatska kultura i politika, prije svega hrvatska opozicijska politička i kulturna (građanska) elita. Posljedično, novi sadržaj koji mladi žele unijeti u hrvatski kulturni i politički život morao se uklopiti u postojeći kontinuitet hrvatske političke i kulturne prakse, što otvara pitanje stvarne radikalnosti raskida sa starima i postavljanja teze o modernističkom pokretu kao mehanizmu „smjene generacija“ u okviru građanske elite Hrvatske.

Naposljetku, potrebno je ukratko se osvrnuti na (sub)disciplinarni i teorijskometodološki okvir istraživanja. S obzirom na istraživački fokus, kao najprikladniji (sub)disciplinarni i teorijsko-metodološki okvir nameće se onaj intelektualne historije. Prije svega, izvori na koje se ovo istraživanje oslanja prvenstveno su tekstualne naravi i odnose se na intelektualne proizvode modernističkog pokreta mladih (članci, knjige, časopisi, memoari, korespondencija). I po postavljenim početnim tezama, fokus je rada usmjeren na intelektualne veze, aproprijacije, transfere, kontinuitete i diskontinuitete u sinkronijskoj i dijakronijskoj perspektivi. To ne znači, s druge strane, da je metodološki pristup ovog istraživanja internalistički, odnosno tekstualistički. Intelektualna historija kao historijska subdisciplina razvila se kao tematska nastavljačica tradicije historije ideja, ali u metodološkom se smislu 
distancirala od njezina oslonca na idealističku filozofsku tradiciju. ${ }^{63}$ Pristupi koji su se počevši od 60-ih godina etablirali kao glavni nositelji kritike historije ideja bili su socijalnachistorija ideja R. Darntona i ideje u kontekstu, odnosno tzv. kejmbrička škola Q. Skinnera i J. G. A. Pococka, koja je prevagnula u angloameričkoj akademiji te je bila fundamentalna za disciplinarno utemeljenje intelektualne historije, ponajprije u obliku historije političke misli. Kao središnji problem teorijskih rasprava nametnuo se onaj konteksta, odnosno uloge kontekstualizma u okviru intelektualne historije. Za Skinnera je cilj intelektualne historije razumijevanje samih iskaza, koje se postiže kroz proces rekonstrukcije intencija njihovih autora. Pristupi koji stavljaju primat na društveni kontekst zapravo ne vide same iskaze kao predmete intelektualne historije i njihovo razumijevanje kao njezin cilj, nego je to za njih uloga ili funkcija teksta, ideje, misli, intelektualnih sustava ili mentalnih oruđa i svjetova u društvu, pri čemu je cilj intelektualne historije razumjeti ideju kao društveni fakt, što se ne može ni na koji način odvojiti od cilja razumijevanja društva u cjelini. Na tom tragu, u ovome se radu želi naglasiti ključna interpretativna uloga kontekstâ za razumijevanje prije svega funkcije, odnosno uloge intelektualnih proizvoda u danim društvenim i političkim okolnostima. U tom smislu ovo se istraživanje oslanja na kontekstualističke pristupe u okviru intelektualne historije, zalažući se pritom za razumijevanje intelektualne historije kao historijske subdiscipline čiji osnovni cilj nije razumijevanje smisla intelektualnih proizvoda, nego njihova interpretacija u službi razumijevanja društva u cjelini kao ideala totalne historije. $^{64}$

Iako sama tema iziskuje primjenu interdisciplinarnosti, ovaj je rad pisan primarno u okviru historijske znanosti. Intelektualna historija kao (sub)disciplina, međutim, snažno je orijentirana prema interdisciplinarnosti, do te mjere da se vode rasprave o njezinoj disciplinarnoj pripadnosti historijskoj znanosti ili autonomnu disciplinarnom položaju. Kako god bilo, kao „rendezvous disciplina“65 - dovodeći u kontakt historiografiju, povijest književnosti, povijest umjetnosti itd. - ona je i u ovom pogledu prikladna kao teorijskometodološki okvir istraživanja hrvatskog modernističkog pokreta na prijelomu 19. i 20. stoljeća.

\footnotetext{
${ }^{63}$ Donald R. Kelley, The Descent of Ideas: The History of Intellectual History, New York, 2017, 277-280.

${ }^{64}$ Za opširniju raspravu v. Nikola Tomašegović, ,Moderna europska intelektualna historija: teorijski problemi i suvremene tendencije“, Historijski zbornik LXXII, br. 1, 2019, 189-203. Također usp. Richard Whatmore, Brian Young (ur.), Palgrave Advances in Intellectual History, Basingstoke, New York, 2006; Darrin M. McMahon, Samuel Moyn (ur.), Rethinking Modern European Intellectual History, New York, 2014; Richard Whatmore, Brian Young (ur.), A Companion to Intellectual History, Oxford, 2016.

${ }^{65}$ Warren Breckman, „Intellectual History and the Interdisciplinary Ideal“, u: McMahon, Moyn (ur.), nav. $d j$., 286.
} 
Osim što ponovno upućuje na intelektualnu historiju kao teorijsko-metodološki okvir, naglasak na intelektualnim transferima, translacijama i aproprijacijama također podrazumijeva primjenu drugih pristupa koji smjeraju nadilaženju metodološkog nacionalizma. Od 1980-ih oni se razvijaju s ciljem osmišljavanja alternative dominantnim nacionalnim perspektivama: entangled history, connected histories, histoire croisée, transnational history, global history, shared history, Kulturtransferforschung. ${ }^{66}$ Iako divergentni, oni se po svojim osnovnim postavkama mogu supsumirati pod pojam transnacionalnih pristupa. Neki od njih su teorijsko-metodološki razrađeniji od drugih, a njihov je međusobni odnos još uvijek nedovoljno elaboriran. ${ }^{67} \mathrm{~Pa}$ ipak, svi oni dijele interes za „cirkulacije i veze između, iznad i onkraj nacionalnih zajednica. “68 Koncept intelektualnih transfera i translacija oslanja se na tradiciju istraživanja kulturnih transfera. ${ }^{69}$ Međutim, za razliku od klasičnih studija kulturnih transfera koji su se fokusirali na prijenos proizvoda visoke kulture (najčešće književnih djela) iz jednog nacionalnog konteksta u drugi, noviji pristupi pod utjecajem postkolonijalnih studija kritički su se postavili prema mehaničkom razumijevanju procesa transfera. Oni naglašavaju da kulturni transfer ne podrazumijeva tek puki prijenos iz jednog konteksta u drugi, nego da je cijeli proces transfera formativan za objekt prenošenja i njegovo značenje, a transformativan za sve strane uključene u njega. Zbog toga se sve češće koriste pojmovi poput métissage i translacija kako bi se naglasio ovaj kreativni, transformativni karakter procesa transfera. ${ }^{70}$

U kontekstu ovoga rada, transnacionalni pristupi koriste se više kao teorijskometodološka perspektiva nego kao skup metoda u strožem smislu riječi. Iako je ovo

\footnotetext{
${ }^{66}$ Vidi npr. Jeffrey D. Burson, „Entangled History and the Scholarly Concept of Enlightenment“, Contributions to the History of Concepts 8, 2, 2013, 1-24; Idesbald Goddeeris, „The Limits of the Transnational“, Revue belge de philologie et d'histoire 89, 3-4, 2011, 1237-1248; Kiran Klaus Patel, "Transnational History," European History Online (EGO), 2010, URL: http://www.ieg-ego.eu/patelk-2010-en. Pristup: 8. 7. 2020; Sanjay Subrahmanyam, "Connected Histories: Notes towards a Reconfiguration of Early Modern Eurasia", Modern Asian Studies 31, 3, 1997, 735-762; Serge Gruzinski, "Les mondes mêlés de la Monarchie catholique et autres 'connected histories'“, Annales. Histoire, Sciences Sociales 56, 1, 2001, 85-117;

${ }^{67}$ Možda je najrazrađeniji od svih prijedlog Michaela Wernera i Bénédicte Zimmerman za histoire croisée pristup. Vidi: Michael Werner i Bénédicte Zimmerman, „Vergleich, Transfer, Verflechtung. Der Ansatz der Histoire croisée und die Herausforderung des Transnationalen“, Geschichte und Gesellschaft 28, 4, 2002, 607636; Isti, „Penser l'histoire croisée: entre empirie et réflexivite““, Annales. Histoire, Sciences Sociales 58, 1, 2003, 7-36; Isti, „Beyond Comparison: Histoire croisée and the Challenge of Reflexivity“, History and Theory 45, 2006, 30-50.

${ }^{68}$ Akira Iriye i Pierre-Yves Saunier, The Palgrave Dictionary of Transnational History, London, 2009, xviixviii. Za širu raspravu na ovu temu vidi: Nikola Tomašegović, "Transnational Approaches and fin de siècle Modernisms: The Case of the Croatian Modernist Movement", Radovi Zavoda za hrvatsku povijest 52, 1 2020, 173-188.

69 Katharina Scherke, „Kultursoziologie und Kulturtransfer“, u: S. Moebius et al. (ur.), Handbuch Kultursoziologie, Wiesbaden, 2018; Wolfgang Schmale, "Cultural Transfer," European History Online (EGO), 2012, URL: http://www.ieg-ego.eu/schmalew-2012-en. Pristup: 8. 7. 2020.

${ }^{70}$ Scherke, nav. dj., 5. Vidi npr. Stefanie Stockhorst, Cultural Transfer through Translation: The Circulation of Enlightened Thought in Europe by Means of Translation. Amsterdam i New York, 2010.
} 
istraživanje primarno pozicionirano kao studija nacionalne povijesti, transnacionalna perspektiva služi kako bi se osvijestio širi kontekst i isprepletenost povijesnog fenomena koji se istražuje. Ta šira istraživačka perspektiva ipak ima važne metodološke implikacije: ako osnovni teorijsko-metodološki okvir čini kontekstualistički orijentirana intelektualna historija s fokusom na modalitete transnacionalnih intelektualnih transfera, translacija i aproprijacija, onda nadilaženje uske nacionalne perspektive nužno postavlja i pretpostavku novih istraživačkih rezultata, odnosno historijskih interpretacija.

Za razumijevanje dinamike intelektualnih transfera i translacija izrazito je koristan model Gisèle Sapiro koja je upotrijebila Bourdieuovu teoriju polja za analizu strategija (književnih) transfera. Prema ovom bourdieuovskom pristupu, transferirani predmeti - u ovom slučaju ideje i prakse - dovode se u polje koje je već obilježeno postojećim odnosima moći i asimetrijama. Stoga je upravo recipijentno polje konstitutivno za strategije aproprijacija i transfera onih aktera koji se žele što bolje pozicionirati u tom polju. Kada je riječ o književnosti, ova se dinamika očituje u borbi za pozicioniranje što je posebno važno u pogledu analize sukoba mladih i starih kao jedne od ključnih, središnjih epizoda modernističkog pokreta mladih: „Još od romantičarskog zakona originalnosti, avangardistički su se umjetnici (nadrealisti, na primjer) nametali kroz odbacivanje ortodoksije postojećih dominantnih književnih koncepcija. Zauzvrat, stigmatizirani su od strane svojih starijih zbog njihove heterodoksije. ${ }^{\text {“71 }}$ Ovaj se model dakako može poopćiti i primijeniti na strategije transfera i aproprijacija modernističkog pokreta mladih u cjelini.

Modernistički pokreti kao predmeti istraživanja na neki način sami po sebi iziskuju primjenu transnacionalnih pristupa. Zbog svojih međusobnih povezanosti - bilo izravnih, bilo kroz svojevrsne globalne rezervoare ideja i praksi - oni nužno nadilaze zatvaranje povijesnih fenomena u (najčešće anakrone) nacionalne granice. Ipak, nadilaženje metodološkog nacionalizma ne znači ujedno i odbacivanje koncepta nacionalnog kao analitičkog alata. Nacionalna politika, nacionalna kultura i književnost, nacionalna javnost bili su važni okviri u kojima su nužno djelovali modernistički pokreti i s obzirom na koje su se morali pozicionirati. Stoga konkretne modernističke pokrete nije moguće razumjeti ni kroz opće idealne tipove, ni kroz specifične nacionalne okvire, nego kroz dinamičnu interakciju globalnog, odnosno transnacionalnog i nacionalnog, onog zajedničkog i onog posebnog, kao i onog starog i onog novog.

\footnotetext{
${ }^{71}$ Gisèle Sapiro, „Comparativism, Transfers, Entangled History: Sociological Perspectives on Literature“, u: Ali Behdad, Dominic Thomas (ur.), A Companion to Comparative Literature, Blackwell, 2011, 232.
} 


\section{GENEZA POKRETA}

„Kad starci šute, neka mladost govori. Ionako mi smo budućnost.“ - K. Š. Gjalski, Unoći $i^{72}$

\section{1. Studentska demonstracija 1895. i njezine posljedice}

U svojem popularnom publicističkom prikazu hrvatske političke povijesti, Josip Horvat okarakterizirao je studentsku demonstraciju spaljivanja mađarske zastave povodom posjeta cara Franje Josipa Zagrebu 16. listopada 1895. godine kao „prolog velike drame hrvatske politike. ${ }^{673}$ Još prije njega, na sličan je način o tom događaju pisao i Ferdo Šišić. Za njega je pojava mladih bila svojevrsna ishodišna točka teleološkog narativa koji je kulminirao u jugoslavenskom „oslobođenju i ujedinjenju“ 1918. godine. ${ }^{74}$ Važan simbolički status tog događaja zadržao se i u kasnijoj historiografiji. Jaroslav Šidak tako piše kako je „i prije bilo sličnih slučajeva, ali je taj simbolični čin obilježio taj put odlučnu prekretnicu u političkom razvoju Hrvatske. “75

U historiografiji, studentska demonstracija 1895. funkcionirala je dakle kao svojevrsna prijelomnica na dvije razine. Na prvoj razini, u najviše slučajeva ona se uzima kao početna točka upravo onog pokreta mladih o kojem je ovdje riječ. Na drugoj pak razini, u onoj mjeri u kojoj je taj pokret iznjedrio bitne promjene na kulturnom i političkom planu Hrvatske, ona se smatra prijelomnicom u hrvatskoj - napose političkoj - povijesti općenito. Taj događaj predstavlja najavu nečeg doista novog, ,,prolog velike drame“ koja tek treba kulminirati.

Ono što je ovdje potrebno preispitati jest u kolikoj se doista mjeri može o studentskoj demonstraciji 1895. govoriti kao o početnoj točki modernističkog pokreta mladih. Koji elementi demonstracije predstavljaju nešto supstancijalno novo, koji je njen modernistički sadržaj? Ako pobliže pogledamo izvedbu same demonstracije, ali i njene ciljeve, zapravo ćemo teško uočiti nešto što bismo mogli okarakterizirati kao bitan otklon od dotadašnjih shvaćanja hrvatske politike. Odjeveni u svečane odore (gale), opasani sabljama, studenti su pažljivo izrežirali prosvjed kao dramatičan čin pun historijske simbolike. Spaljivanje

\footnotetext{
${ }^{72}$ Ksaver Šandor Gjalski, „U noći“, u: Tihomir Tonković (ur.), Ksaver Šandor Gjalski: sabrana djela, knjiga III, Zagreb, 2016, 136.

${ }^{73}$ Horvat, nav. dj., 223.

74 Šišić, nav. dj., 458-469.

75 Jaroslav Šidak, „Hrvatsko pitanje u Habsburškoj monarhiji“, u: Studije iz hrvatske povijesti 19. stoljeća, Zagreb, 1973, 33.
} 
improvizirane mađarske trobojnice ispred kipa bana Josipa Jelačića trebalo je pokazati nezadovoljstvo hrvatske mladeži - neiskvarene dugogodišnjim Khuenovim režimom hrvatskim državnopravnim statusom, kršenjem odredbi Nagodbe, ali i nagodbenim sustavom kao takvim, te njezinu spremnost na bespoštednu borbu za nacionalnu autonomiju, sve u sigurnom političkom okviru imperijalne lojalnosti. Ništa od ovoga nije bilo supstancijalno novo u pogledu političkog sadržaja. ${ }^{76}$ Ako se kasnije ovaj čin iščitavao kao implicitna kritika pasivnosti i inertnosti tadašnje opozicije Khuenu, on nije uopće bio tako percipiran neposredno nakon što se odvio. Dapače, studenti su u opozicijskoj štampi, a uz značajnu iznimku pravaških krugova oko Frana Folnegovića, što je i uzrokovalo raskol do tada jedinstvene Stranke prava, gotovo jednoglasno bili pozdravljeni kao nacionalni heroji. Upravo je ta činjenica, kao i snažan odjek koji je ovaj događaj proizveo diljem Monarhije, odgovorna za njegov važan simbolički status. Iako se ne može reći da je hrvatski modernistički pokret započeo 16. listopada 1895. na glavnom zagrebačkom trgu, njegovi protagonisti zacijelo su ovime dobili vjetar u leđa i simbolički kapital koji su mogli iskoristiti u svojim naporima da promijene smjer tadašnje hrvatske politike.

Demonstracija paljenja mađarske zastave bio je samo vrhunac u nizu nemira (ali i slavlja) koji su obilježili kraljev posjet Zagrebu. Hrvatsku oporbenu javnost i mladež posebno je provociralo isticanje mađarske zastave, što su smatrali povredom hrvatske autonomije zajamčene Nagodbom. Već je prvi dan kraljeva dočeka Vladimir Frank, sin Josipa Franka, pokušao ukloniti mađarsku zastavu sa slavoluka kod kolodvora, zbog čega su on i brat Ivica idući dan navečer bili napadnuti od mađarskih radnika. Pripremajući svoj prosvjed, studenti su isprva planirali demonstrirati pred glavnim slavolukom na Trgu Franje Josipa, sa zahtjevom da se mađarska zastava kao nezakonito postavljena s njega ukloni. Studentski su nemiri, uključujući i samu demonstraciju, tako bili usmjereni protiv ugarske politike prema Hrvatskoj te nisu imali antidinastičku notu, što je jasno izraženo i u pokliču „Živio hrvatski kralj Franjo Josip I!“, koji su studenti uzviknuli prilikom paljenja mađarske zastave. ${ }^{77}$ Hrvatski su studenti izražavali lojanost hrvatskome, a ne ugarskome kralju, jasno ističući svoje nezadovoljstvo položajem Hrvatske u okviru Monarhije.

Ono što je uslijedilo nakon prosvjeda pokrenulo je lanac događaja koji će dovesti do formiranja modernističkog pokreta mladih. Žrtveni je jarac pronađen u Isidoru Kršnjavome, predstojniku vladina Odjela za bogoštovlje i nastavu, koji je morao otići s funkcije, doduše s

\footnotetext{
76 "Paradoksalno je bilo pri tom to što je kroz jednu bombastičnu demonstraciju starog tipa nastupila skupina koja će unijeti moderni duh u život buržoaske opozicije.“ Lovrenčić, nav. dj., 41.

${ }^{77}$ Racko, ,Spaljivanje mađarske zastave“, 234-235.
} 
odgodom 1896. godine, što je dodatno zakompliciralo njegov odnos s mladima. Nakon suđenja, koje je održano od 11. do 16. studenog 1895. pred Kraljevskim sudbenim stolom u Zagrebu, četrdeset i devet studenata od pedeset i tri koji su bili optuženi za čin spaljivanja mađarske trobojnice proglašeni su krivima i osuđeni na zatvorske kazne od dva do šest mjeseci. ${ }^{78}$ Osuđeni studenti relegirani su sa zagrebačkog sveučilišta, a za vrijeme trajanja sudske rasprave Akademički senat donio je odluku o relegiranju sa sveučilišta i onih studenata koji su sudjelovali u demonstraciji, a nisu bili obuhvaćeni optužnicom. ${ }^{79} \mathrm{U}$ studenome, kada Ivan Lorković izvještava Milivoja Dežmana o stanju stvari, takvih je studenata bilo $80 .{ }^{80} \mathrm{Kao}$ posljedica toga, dakle, veći broj studenata morao je napustiti Zagreb i uputiti se u druga monarhijska sveučilišna središta gdje će nastaviti svoje školovanje.

Tradicionalni centar hrvatske studentske emigracije u 19. st. svakako je bio Beč. Na bečkome sveučilištu studenti iz Hrvatske mogli su se upisivati na studije koji nisu bili dostupni u Zagrebu, kao što je npr. studij medicine, dok su studenti iz Istre i Dalmacije inklinirali austrijskim sveučilištima već iz tog razloga što se diplome stečene na sveučilištima iz ugarskog dijela Monarhije nisu priznavale $\mathrm{u}$ austrijskom dijelu bez dodatnih ispita $\mathrm{i}$ procedura. ${ }^{81}$ Osim toga, studiranje u glavnom gradu imalo je svoje draži te je nosilo sa sobom svojevrsni prestiž, kako u akademskom, tako i u društvenom pogledu. U Beču je postojala razgranata mreža hrvatskih studentskih društava oko kojih se razvijao društveni, zabavni, ali i politički život. Najvažnije od njih svakako je bilo društvo Zvonimir koje je osnovano 1882. godine. Iako je politički rad u studentskim društvima bio formalno zabranjen, on se zapravo odvijao kroz kulturne i društvene manifestacije, kao i unutrašnje rasprave, ali ponekad i otvorene izjave. ${ }^{82}$ Tako je, primjerice, upravo u povodu uhićenja i progona zagrebačkih studentskih demonstranata u zadarskom Narodnom listu 23. listopada 1895. godine objavljena sljedeća izjava „hrvatske akademijske omladine u Beču“:

„Mili drugovi! Tvrdo uvjereni, da Vas je kod demonstracija proti magjarskoj i srbskoj zastavi vodila jedino misao da se oprete nametanju tuđinskih ideja u Hrvatskoj i da suzbijete provokacije vanjskih i domaćih neprijatelja hrvatskoga naroda, manifestirajući tako samo za hrvatsku ideju, jedino za hrvatsko državno i prirodno pravo, s ponosom se pridružujemo tomu rodoljubnom činu Vašem, jer ste zasvjedočili, da je nama sloboda Hrvatske svetinja, za koju

\footnotetext{
${ }^{78}$ Hrvatski djaci pred sudom: stenografski izvještaj o glavnoj razpravi proti hrvatskim sveučilištnim djacima obdržanoj pred kr. sudbenim stolom u Zagrebu dne 11 - 16. studenoga 1895., Zagreb, 1895, 276-280.

${ }^{79}$ Racko, nav. dj., 243.

${ }^{80}$ „Ivan Lorković - Milivoju Dežmanu“, 19. 11. 1895.“, HR-AHAZU-KN-44 Dežman, Milivoj, k.11.

${ }^{81}$ Luetić, Studenti Sveučilišta u Zagrebu, 269.

${ }^{82}$ Božena Vranješ-Šoljan, „Croatian Student Societies in Vienna in the 19th Century“, u: Iveljić (ur.), The Entangled Histories, 361.
} 
ćemo sve žrtvovati, kao što štujemo i slobodu drugih naroda u njihovim državama. Svakom svoje - Hrvatska Hrvatom! Najoštrije osuđujući postupak onih ljudi, koji hoće da zabašure istinu, koja u hrvatskom narodu živi, i koji krne prava hrvatskoga sveučilišta, znamo da će Vas u Vašim patnjama jačati misao, da su s Vama Bog i Hrvati!“‘83

Iz ove je izjave također jasno da je među hrvatskim studentima u Beču bila snažno prisutna pravaška ideologija. Dapače, u ovome je periodu u Zvonimiru bila dominantna pravaška frakcija koja je usto podržavala Josipa Franka. ${ }^{84} \mathrm{~S}$ druge strane, krug oko Stjepana Radića $^{85}$, koji je zapravo organizirao demonstraciju spaljivanja mađarske trobojnice, nije uopće bio sklon Franku i njegovoj politici. ${ }^{86}$ Iako su bili bliži obzorašima, pogotovo nakon što je Frankov utjecaj u Stranci prava ojačao, njihovo je stanovište bilo da mladež ne bi trebala biti puki priljepak stranaka, nego relativno autonoman faktor u politici, dakako ne u izolaciji od službene stranačke politike. ${ }^{87} \mathrm{Za}$ vrijeme trajanja pregovora oko ujedinjenja Stranke prava i Neodvisne narodne stranke u prvoj polovici 1894. godine, oni su u krugovima studentske politike zauzeli upravo takvo stajalište. Stjepan Radić bio je stupio s takvom idejom u kontakt

\footnotetext{
${ }^{83}$ Racko, nav. dj., 238.

${ }^{84}$ Vranješ-Šoljan, nav. dj., 372.

${ }^{85}$ Iako ne treba apsolutizirati Radićevu centralnu poziciju, neupitno je da je njegov utjecaj među zagrebačkim studentima u ovome periodu bio vrlo velik. Milan Krištof mu se tako u pismu 18. 4. 1894. obraća s molbom za savjet kako da se postave u određenom pitanju, pozivajući se na njegov „auctoritet“. I sam Radić kaže nakon demonstracija 1895. da se neposredno prije toga odlučio upisati u Zagrebu kako bi mogao bolje „pratiti razvoj političkih prilika i neposredno djelovati medju sveučilištnom mladežju“ te da se on toj „mladoj četi“ nalazi „na čelu“. Teško je utvrditi koliko je osoba točno sačinjavalo ovu grupaciju, ali učestalo se pojavljuje brojka od 60 studenata koji su podržavali njihove inicijative. Tako je upravo toliko studenata potpisalo njihovu „protuizjavu“ kojom su htjeli kontrirati Frankovoj instrumentalizaciji zagrebačkih studenata u procesu pregovora o ujedinjenju opozicije, a isti toliki broj glasova dobili su na izborima za Zastavu 1894. godine kada su izgubili od pravaških studenata koji su sakupili 110 glasova. Na Sveučilištu su dakle oni bili „opozicija“, ali ne može se reći da su bili homogeni i snažno ideološki profilirani. Kako o tome Stjepko Španić izvještava Radića, ,medju njima nema pravaša, ali ni obzoraša, premda više simpatizuju s 'Obzorom' nego s 'Hrvatskom'.“ „Milan Krištof-Stjepanu Radiću, Zagreb, 18. IV. 1894.“, „“Ivan Lorković (?) - Stjepanu Radiću, Zagreb, 22. IV. 1894.“, „Stjepko Španić - Stjepanu Radiću, Zagreb, 5. XI. 1894.“, „Stjepko Španić - Stjepanu Radiću, Zagreb, 16. XI. 1894.“, „Stjepan Radić - Mariji Dvořákovoj, Zagreb, 3. XI. 1895.“, u: Krizman, Korespondencija I, 119-123, 153, 156.

${ }^{86}$ Mirjana Gross s pravom je ustvrdila kako su nove ideje napredne omladine „djelomično nastale i kao reakcija na frankovačku atmosferu" u okviru studentskog pokreta, odnosno na činjenicu da je Frank u velikoj mjeri uspio pravaški orijentirane studente, služeći se autoritetom ostarjelog Starčevića, učiniti svojim „telićima“ (a ne više „steklišima“ osamdesetih), kako su ih pogrdno nazivali protivnici. Mirjana Gross, „Studentski pokret 1875 1914“, u: Jaroslav Šidak (ur.), Spomenica u povodu proslave 300-godišnjice Sveučilišta u Zagrebu, knj. I, Zagreb, 1969, 457. U instrumentalizaciji studentskog pokreta za svoje ciljeve Frank je imao kao snažnu polugu svoje sinove - Vladimira i Ivicu - koji su i sami bili studenti zagrebačkog sveučilišta. Modus operandi Franka i njegovih sinova plastično opisuje u svojim memoarima Ivan Peršić, i sam pripadnik pravaške mladeži. Ivan Peršić, Kroničarski spisi, Zagreb, 2002, 71-72, o demonstraciji v. 124-131.

${ }^{87}$ Mirjana Gross tako radi sljedeću distinkciju u svojoj periodizaciji studentskog pokreta između 1875. i 1914. godine: od 1875. do 1897. godine razdoblje pravaškog, odnosno od devedesetih frankovačkog studentskog pokreta, čija je karakteristika uska povezanost studentskih aktivnosti s aktivnostima Stranke prava, „sa svrhom da omladina pomogne stranačkoj propagandi“; nakon toga slijedi razdoblje napredne omladine, koje Gross omeđuje godinama 1897. i 1905., a koje obilježava postavljanje temelja studentskom pokretu „,s posebnim položajem unutar političkih stranaka ili izvan političkih stranaka, dok je težište studentskog pokreta bilo u kulturnoj djelatnosti.“ Gross zaključuje kako je „,izuzevši prvi period, osnovna politička dilema studentskog pokreta bila pitanje stava prema političkim strankama.“ Gross, „Studentski pokret“, 451-452.
} 
S raznim opozicijskim prvacima već na prvoj godini studija. ${ }^{88}$ Nakon što je bila dogovorena suradnja pravaša i obzoraša krajem 1892. godine, on je bio na čelu studentskog odbora koji je trebao organizirati veliki komers kao proslavu tog događaja, a koji je održan usprkos zabrani uz pomoć simpatizera hrvatske opozicije iz redova imućnijeg građanstva. ${ }^{89}$ Josip Frank tada je međutim angažirao mrežu pravaške studentske mladeži da agitira i javnim izjavama podupire ideju kako bi ime ujedinjene opozicije trebalo biti Stranka prava, implicirajući tako da je zapravo riječ o ulasku obzoraša u Stranku prava, jačajući time i samoga Franka kao njezina neformalnog vođu. Odazvali su se hrvatski studenti iz Beča, Graza i Innsbrucka, a rasprava se prelila i na zagrebačko sveučilište. Ovdje se tome, međutim, usprotivila upravo Radićeva grupacija (on je tada već bio na studiju u Pragu nakon prvih okršaja s vlastima u Hrvatskoj), inzistirajući na tome da studenti podrže proces ujedinjavanja hrvatske opozicije, ali da ostanu po strani u stranačkim prepucavanjima i nadigravanjima. Milan Krištof u tom smislu piše Radiću: „Ja držim i duboko sam uvjeren da se ti slažeš u tom s nama, jer mi treba, da sačinjavamo javno mnjenje te se nesmijemo staviti u službu ma koje stranke. “90 Razočaranje tadašnjom stranačkom politikom, posebice nakon propasti pregovora o ujedinjenju opozicije i previranja u Stranci prava, bilo je jedan od glavnih motiva za samostalni istup ovog dijela studentske omladine. Na sveučilišnoj skupštini prije dolaska cara u Zagreb, studenti su odlučili „da će kralja pozdravljati samo sa 'Živio hrvatski kralj', za tim, da nijednoga madžarskoga ministra ne valja nikako pozdravljati, a napokon izrazila je skupština svoju ogorčenost nad nedostojnom popustljivošću vlade i nad kukavnom neodlučnošću opozicije.“91 Ili kako je na sudu izjavio jedan od optuženika Živan Bertić: ,[...] ovim činom sveučilišni građani navjestili su borbu starijem svietu, koji drugčije misli $[\ldots]^{692}$

Usprkos tome, opozicijski prvaci aktivno su se uključili kako u sudsku obranu studenata, tako i u kasniju pripomoć oko nastavka studija izvan Hrvatske. Studente su na sudu branili predvodnici i Stranke prava i Neodvisne narodne stranke: Marijan Derenčin, Šime Mazzura, August Harambašić, Franko Potočnjak, Mile Starčević, Ivan Ružić i dr. ${ }^{93}$ U Beču je osnovan „Glavni odbor u pripomoć hrvatskih osuđenih i nastradalih đakah“ koji je imao primarni zadatak sakupiti sredstva za osiguranje daljnjeg školovanja relegiranih studenata. ${ }^{94} \mathrm{U}$ Zagrebu je pak akciju sakupljanja pomoći koordinirao jedan od branitelja studenata i

\footnotetext{
${ }^{88}$ Ivo Perić, Stjepan Radić 1871. - 1928., Zagreb, 2003, 61.

${ }^{89}$ Luetić, nav. dj., 335.

90 „Krištof - Radiću, 18. IV. 1894.“, u: Krizman, nav. dj., 118.

91 „Stjepan Radić - Mariji Dvořákovoj, Zagreb, 3. XI. 1895.“, u: Krizman, nav. dj., 155.

92 Prema Racko, nav. dj., 245.

${ }^{93}$ Djaci pred sudom, 3.

${ }^{94}$ Racko, nav. dj., 243.
} 
obzoraški prvak Šime Mazzura. Kako Ivan Lorković javlja Milivoju Dežmanu u Beč, taj je „građanski“ odbor okupio „sve frakcije opozicije“, iako su prvotno u njemu bili samo obzoraši, kao i brojne članove akademske zajednice. ${ }^{95}$ Po svemu sudeći, odaziv je bio dobar te su sakupljena dostatna sredstva za pokrivanje troškova nastavka studija u inozemstvu onim studentima kojima je to bilo potrebno. ${ }^{96}$ Lorković zaključuje da je hrvatska javnost uvidjela nužnost pomoći studentima jer su na hrvatskom sveučilištu nastradali oni najbolji, a ako se najboljima ne pomogne, u budućnosti prijeti propast cijelom narodu: „Zato, ako hoćemo, da osujetimo namjere Magjara, koji bi od nas htjeli učiniti Slovake, moramo da upremo svu snagu. “97 Usprkos svemu lošemu što se događa, on je u ovim događajima vidio zametak nečega dobroga u budućnosti: „Mi se radujemo, što je ova zgoda, koja će sigurno imati više dobrih nego zlih posljedica, opet pokazala, kako se u hrvat. mladeži sve više i snažnije razvija proces duševnoga ujedinjenja.“98

Još 1893. godine, tijekom svog prvog boravka u Pragu, Stjepan Radić razmišljao je kako bi Prag trebao postati glavna destinacija hrvatskih studenata izvan Zagreba, no te su se godine na češko sveučilište u Pragu upisala samo dva hrvatska studenta. ${ }^{99}$ Za usporedbu, dok je u periodu od 1882. do 1918. godine na češkome sveučilištu u Pragu studiralo 444 studenata iz Hrvatske, Slavonije i Dalmacije, ta se brojka za bečko sveučilište u razdoblju od 1870. do 1916. kretala oko 4685, dakle gotovo deseterostruko više. ${ }^{100}$ Radićeva agitacija i utjecaj uspjeli su, doduše, ponešto promijeniti trendove. Tako je 1895. zabilježeno 6 upisanih hrvatskih studenata u Pragu, 1896. njih 12, 1897. 7, a 1898. čak njih $15 .{ }^{101}$ To uglavnom korespondira s tvrdnjama aktera koji izvještavaju kako je u proljeće 1896. u Pragu bilo otprilike dvadeset hrvatskih studenata. Milan Krištof zadovoljno piše Radiću: „Tvoja se želja dakle ispunila, da nas ide ovamo što više i da se ovdje za uvijek stvori hrvatska kolona.“102

Unatoč predominaciji utjecaja Beča kako u kulturnom životu Zagreba, tako i kao centra hrvatske studentske emigracije, u hrvatskoj je javnosti još od ranije postojala ideja o

\footnotetext{
95 „Lorković - Dežmanu, 18. 11. 1895.“, HR-AHAZU-KN-44 Dežman, Milivoj, k.11. Lorković u tom pismu spominje i brojne druge inicijative: osnivanje „odbora gospodja i gospodjica“, tiskanje rasprave pred sudom u obliku knjige u Dioničkoj tiskari, prihod od čije prodaje bi također bio namijenjen ,relegircima“, kao i prodaja reprodukcije Bukovčeva svečanog zastora u HNK u iste svrhe.

${ }^{96}$ Dakako, veoma je izdašna bila Strossmayerova pomoć. Šegvić, Patriotizam i bunt, 128.

97 „Ivan Lorković - Milivoju Dežmanu, Zagreb, 13. 11. 1895.“, HR-AHAZU-KN-44 Dežman, Milivoj, k.11.

${ }^{98}$ Isto.

99 „Frano Supilo - Stjepanu Radiću, Dubrovnik, 29. IX. 1893.“, u: Krizman, nav. dj., 93; Agičić, Hrvatsko-češki odnosi, 134.

100 Agičić, nav. dj., 131, Iskra Iveljić, „Kroatische Studenten und Professoren in Wien“, u: Iveljić (ur.), The Entangled Histories, 296.

101 Agičić, nav. dj., 134.

102 „Milan Krištof (?) - Stjepanu Radiću, Prag, 22. IV. 1896.“, u: Krizman, nav. dj., 185.
} 
češkome sveučilištu kao glavnome središtu za sve slavenske studente Monarhije. ${ }^{103}$ Osim tradicionalnih veza i percepcija austro-slavističke politike, Stjepan Radić smatrao je da postoje duboke strukturne sličnosti između hrvatske i češke političke, a dijelom i društvene situacije. Te sličnosti omogućavaju da se češka politička i društvena djelatnost temeljito prouči te da se ono što je naučeno potom primijeni u Hrvatskoj: „Prag, dotično Česi bit će još dugo nama Hrvatima učitelji u svem, a ponajpače u politici i državnopravnoj, gdje valja dobro razlikovati cilj od sredstva i u narodnosnoj, gdje se valja kaniti uzrujavanja i 'oduševljenja' i primiti se drobnoga rada na temelju sigurnih statističkih data. “104 To ne znači da Radić nije uočavao bitne razlike između Hrvatske i Češke, posebice u stupnju njihovog razvoja:

„Ali u Hrvatskoj je posvema inače, nego li u Češkoj. U Češkoj, prema zakonu Česi su zapostavljeni kao narod Nijemcima, ali u zbilji, u životu Česi i kao narod ili su ravnopravni, ili imaju prednost (dakako svojom zaslugom), a kao pojedinci, kao ljudi posvema su ravnopravni. Velike ideje francuske revolucije o jednakosti (égalité) i o slobodi (liberté) nisu kroz Češku samo proletjele, one su tamo pustile dubok koren. U Češkoj bijesni narodnosna borba, u njoj je žestokih staleških razmirica i velikih društvenih opreka ali svi su u Češkoj i uopće u t.zv. Austriji kao ljudi (osim u Dalmaciji i u Galiciji) posvema jednaki. To je učinila prosvjeta i gospodarski napredak.“105

S druge strane, u Hrvatskoj postoje „dva naroda: gospoda i puk“, kao da „nisu jedne krvi i jednoga jezika.“ Samo se prvi smatraju punopravnim građanima, dok „nijednomu čovjeku iz puka nije siguran ni imetak, ni osobna čast, ni osobna sloboda.“" ${ }^{106}$ Radić dakle ne vidi razlike samo između austrijskog i ugarskog društveno-političkog konteksta koji definiraju okvire političke borbe, nego i unutar samih društvenih zajednica, odnosno stupnja razvoja nacionalnog pokreta, a koji proizlaze iz općenitog društvenog, tj. gospodarskog i prosvjetnog razvitka. Osim toga, za Radića Češka nije konačna destinacija obrazovanja novih hrvatskih političkih snaga. Oni će također morati „pogledati u veliku gospodarstvenu i socijalnu školu rusku, u parlamenat i upravu englesku ili barem francusku da duboke misli imadu i široki djelokrug [...] $]^{\text {107 }}$ Takva razmišljanja odredila su njegov životni put u godinama koje su slijedile, ali i intelektualne horizonte nastajućeg modernističkog pokreta koji će se manifestirati u njegovim prvim publikacijama.

\footnotetext{
103 „K novoj školskoj godini“, Obzor, 15.IX.1891., prema: Agičić, nav. dj., 136.

104 „Stjepan Radić - Šimi Mazzuri, Bjelovar, 19. II. 1896.“, u: Krizman, nav. dj., 173.

105 „Stjepan Radić - Mariji Dvořákovoj, Martinska ves, 20. XI. 1896.“, u: Krizman, nav. dj., 228.

${ }^{106}$ Isto.

107 „Radić - Mazzuri, Bjelovar, 19. II. 1896.“, u: Krizman, nav. dj., 173.
} 
Studenti su u Pragu upijali dojmove češke politike, intelektualnog i društvenog života, ali su se ujedno i držali zajedno. U određenom pogledu trudili su se oko specifičnih zadataka, osjećajući odgovornost prema misiji koju su si zadali, primjerice da nauče češki jezik, da osnaže veze između češke i hrvatske javnosti te da ostvare kontakte sa češkim studentskim aktivistima, političarima i intelektualcima. S druge pak strane reproducirali su i tipične obrasce studentskog života, što je uključivalo izbjegavanje studijskih obaveza, redovito pohađanje kavana i gostionica te cjelonoćne provode u krčmama. ${ }^{108}$

Brojni su ipak primjeri konstruktivnog djelovanja studenata u Pragu. Neposredno nakon svojeg dolaska, „relegirac“ Živan Bertić, tada još uvijek blizak pravaštvu, počeo je objavljivati svoje dojmove o Pragu i Česima na stranicama Hrvatske domovine, radeći tako na boljem poznavanju čeških prilika u hrvatskoj javnosti. U njima je, između ostalog, reproducirao karakteristične topose (austro)slavističkog diskursa, kao što je inherentna ljubaznost Čeha, njihova „milokrvna“ slavenska ćud i osjećaj slavenske solidarnosti. ${ }^{109}$ Iako je i ranije bio običaj da se hrvatski studenti u Pragu upisuju u češko studentsko društvo Slavija, a ne da osnivaju svoje vlastito, kao npr. hrvatski studenti u Beču, „relegirci“ su svojim pridružvanjem Slaviji htjeli dodatno iskazati svoj interes za dubinsko upoznavanje češkog života i povezivanje s češkim studentima. Bilo je ideja da se osnuje i zasebno hrvatsko akademsko društvo, pogotovo zato što „i Srbi i Bugari imaju i svoje družtvo“, ali ono nije dobilo potrebno odobrenje. ${ }^{110} \mathrm{Tu}$ je činjenicu pozdravio Milan Krištof: „Po mojem mnijenju bilo bi to suvišno; ta nismo se došli ovamo igrati predsjednika, tajn. itd, nego da naučimo češki, da proučimo češke prilike, a zato treba da mnogo družimo sa Česima. [...] Od njih se imamo učit, kako treba tudje uvjerenje poštivati i kako i djaci mogu ozbiljno i bez buke raspravljati o najoprečnijim pitanjima. “111

Krajem svibnja 1896. godine u okviru Slavije osnovan je hrvatsko-slovenski klub koji je trebao služiti kao platforma za razne studentske aktivnosti. Jedna od prvih predstavljala je kontinuitet s činom zbog kojeg su studenti bili relegirani sa zagrebačkog sveučilišta: protest protiv sudjelovanja Hrvatske na milenijskoj izložbi u Budimpešti u obliku prosvjednog skupa i rezolucije. ${ }^{112}$ Osim takvih otvorenih političkih aktivnosti, Hrvatsko-slovenski klub organizirao je i uobičajene kulturne manifestacije, kao što je primjerice koncert povodom

\footnotetext{
${ }^{108} \mathrm{Za}$ ekstreman slučaj potonjega vidi izvještaj Živana Bertića Stjepanu Radiću o ponašanju praškog studenta Ivančića koji je Hrvatima ostavio „gadnu ljagu“. „Živan Bertić - Stjepanu Radiću, Prag, [1896.?].“, u: Krizman, nav. dj., 236-237.

109 Agičić, nav. dj., 138-139.

110 „Svetimir Korporić - Stjepanu Radiću, Prag, 16. IV. 1896.“, u: Krizman, nav. dj., 185.

111 „Stjepan Radić - Mariji Dvořákovoj, Bjelovar, 22. IV. 1896.“, u: Krizman, nav. dj., 185.

112 Agičić, nav. dj., 140.
} 
stote obljetnice rođenja Antuna Mihanovića u lipnju 1896. godine. Na njemu je ipak, suprotno proklamiranim idealima ozbiljnog političkog rada bez prevelike buke, bilo „tom sgodom liepih zdravica, vatrenih rieči i prizora - to se razumije.“113 Osim toga, Hrvatsko-slovenski klub također je radio na stvaranju hrvatsko-čeških veza, pa su tako na njegovim događanjima prisustvovali i važni ljudi češkog političkog i intelektualnog života. ${ }^{114}$ Naposljetku, praški su studenti preko Slavije agitirali u Hrvatskoj s ciljem da što više hrvatskih maturanata nastavi školovanje u Pragu. ${ }^{115}$

$\mathrm{Na}$ ljeto 1896. godine u Osijeku se trebao održati drugi sveopći sastanak hrvatskih „akademičkih građana“. ${ }^{116}$ On je trebao biti nastavak sastanka koji se održao godinu dana ranije (15. i 16. srpnja) u Zagrebu u koordinaciji studentskih društava Zastava iz Zagreba, Zvonimir iz Beča, Hrvatska iz Graza te Velebit iz Innsbrucka. Cilj te inicijative trebao je biti ujedinjenje hrvatske studentske omladine, a na zagrebačkom se sastanku prvi puta pojavila ideja o izdavanju zajedničkog studentskog lista koji bi imao političko značenje. ${ }^{117}$ Međutim, kako je sam sastanak protekao pod naglašenom policijskom paskom, studenti su zbog mogućih budućih neprilika i teške cenzure odustali od izdavanja časopisa u Zagrebu. Ipak, ideja nije odbačena te će se realizirati s praškom Hrvatskom misli manje od dvije godine kasnije. Zagrebački sastanak pokazao je također i duboku razjedinjenost hrvatske omladine, prvenstveno po stranačko-ideološkim linijama. I u ovome slučaju Josip Frank bio je aktivan u pokušajima da instrumentalizira studentski sastanak i poveže ga s političkim aktivnostima Stranke prava. Tome se usprotivila grupa od dvanaest studenata predvođenih Stjepanom Radićem koja je 16. lipnja izdala proglas protiv predviđenog tijeka i datuma sastanka, nakon čega je uslijedila polemika s pripremnim odborom kojim su dominirali pravaši. ${ }^{118}$ Dvanaestorica su se založila za strogi radni karakter sastanka bez različitih banketa, komersa i političkih događaja, za slobodu govora i demokratizaciju sastanka te za općenitu raspravu „o pitanjima općim, socijalnim i kulturnim i političkim“, a ne o stranačkim prepucavanjima koja će studente pretvoriti u stepenice „po kojima će se pojedinci uspinjati do populariteta.“ Treba, dakle, raditi „kao što radi mladež češka, poljska i rusinska.“119 Radićev je krug naposljetku

\footnotetext{
113 „Naši dopisi“, Hrvatska domovina, 1. VII. 1896., prema: Agičić, nav. dj., 140.

114 „Svetimir Korporić - Stjepanu Radiću, Prag, 22. VI. 1896.“, u: Krizman, nav. dj., 200.

115 Agičić, nav. dj., 141.

116 Sastanak je trebao trajati od 15. do 19. srpnja, a lokalni mjesni organizacijski odbor predvidio je brojne popratne aktivnosti i događaje, kao što su nastupi pjevačkog društva „Lipa“ i tamburaškog društva „Vijenac“ te, dakako, neizostavni „,komers“. „Poziv!, Beč, 16. VI. 1896.“ HR-HDA-757 Obitelj Plavšić, k. 53.

${ }^{117}$ Flaker, Časopisi, 12.

${ }^{118}$ Flaker, nav. dj., 13. Potpisnici su: J. Belović, S. Korporić, M. Krištof, I. Lorković, Vl. Marn, L. Mazzura, J. Prosen, S. Radić, M. Sladović, D. Šašel, J. Šikutrić i V. Tomić, dakle već formirana jezgra kasnijeg modernističkog pokreta.

119 „Drugovi!, 2. srpnja 1895.“, prema: Flaker, Časopisi, 13-14.
} 
odbio sudjelovati na zagrebačkom sastanku studenata u srpnju te je pozvao „braću sveučilištarce bez razlike, bili oni kojega mu drago političkog uvjerenja“ na vlastiti planirani sastanak u listopadu iste godine. ${ }^{120}$ Dakako da se taj sastanak zbog događaja u listopadu 1895. godine nije odvio, nego su se posvađani studenti ponovno našli ujedinjeni pred Sudbenim stolom. I planirani osječki sastanak demonstrirao je jasne podjele, odnosno činjenicu „secesije“ tad već oblikovana praškog kruga od središnjica društava preko kojih se vodila hrvatska studentska politika. Iako sastanak na kraju nije održan zbog policijske zabrane, praški su mladi i prije toga odlučili da u njemu neće sudjelovati. Oni su već krenuli svojim putem, mimo glavne struje hrvatske studentske politike pod pravaškim patronatom: „Od sadanjih sveučilišnih djaka ne očekujem mnogo, ako ima pojedinaca dobrih, ti će se sami od sebe, okupiti oko našeg lista. Naše deklamacije na sastanku ne bi djelovale. Možda bi se još opreke zaoštrile [...] “121 Naglasak treba biti na radu s mlađima na koje je još itekako moguće utjecati: „Svu nadu polažem na gimnazije, odavle nam valja započeti, za to ćemo sve sile uložiti, da list u sve gimnazije proturamo. [...] Povest ćemo živu agitaciju, da čim više mladih dobijemo u Prag. “'122

Glavna veza između hrvatskih studenata u Pragu i čeških studentskih, ali i političkih krugova bio je češki studentski aktivist i političar František Hlaváček. „Franta“ je upoznao Stjepana Radića 1894. godine kada je ovaj studirao u Pragu te također bio aktivan u Slaviji. Tada je započelo njihovo intenzivno druženje koje je rezultiralo međusobnim učenjem hrvatskog i češkog jezika te Radićevo upoznavanje s češkim naprednjačkim krugovima. ${ }^{123}$ Hlaváček je tada postao učitelj češkog jezika hrvatskim studentima u Pragu te njihova veza s češkim studentskim i političkim krugovima, napose s Masarykom s kojim je bio u osobnim prijateljskim odnosima.

Vrlo je dobro poznato da je Masaryk ostvario najsnažniji intelektualni utjecaj na praške mlade. Oni su u njemu morali vidjeti sve ono što nisu mogli u hrvatskim opozicijskim prvacima: erudiciju i teorijsku istančanost, ali čvrsto povezane s neumornom političkom praksom, rezolutnost kada je riječ o političkim ciljevima, ali ujedno i realistični i pragmatični pristup političkom radu, upućenost i ukorijenjenost $u$ najsuvremenijim europskim intelektualnim kretanjima, ali i posvećenost nacionalnoj borbi i ideji. Studenti su slušali njegova predavanja, čitali njegova djela, ali i prisustvovali polemikama u kojima je sudjelovao. Tako su slušali predavanje dr. Čuhela o češkom državnom pravu. Na predavanju

\footnotetext{
${ }^{120}$ Isto.

121 „Svetimir Korporić - Stjepanu Radiću, Prag, 22. VI. 1896.“, u: Krizman, nav. dj., 199.

122 Isto, 199-200.

123 Agičić, Dragi Franta!, 9.
} 
je bio prisutan i Masaryk koji je ušao u polemiku s Čuhelom jer ,stoji čisto na historijskom pravu“. Nasuprot tome, Masaryk je branio stav kako se „državno, historički pravo samo u toliko ima upotriebiti, u koliko se da složiti s današnjim stanjem stvari i osvjedočenjem narodnim.“" ${ }^{24} \mathrm{Na}$ studente je utjecao Masarykov demokratizam, antihistorizam i antiklerikalizam te njegove koncepcije političkog realizma i „sitnoga rada“. Osim službenih dodira, studenti su s njim dolazili u kontakt i preko neformalnih susreta. Radić tako piše kako je 5. siječnja 1897. godine, tijekom svojeg posjeta Pragu prije odlaska na studij u Pariz, posjetio Masaryka u njegovu domu s Hlaváčekom i ,još pet Hrvata“ te su proveli tamo tri sata u razgovoru. ${ }^{125}$ Masarykov utjecaj, kao i onaj cjelokupne političke i društvene situacije u Pragu, bit će jasno vidljiv u prvim publikacijama praških mladih.

Ipak, taj utjecaj ne treba precijeniti. Kao što smo vidjeli, određene temljene postavke „,novoga smjera“ - kako su sami studenti nazivali svoje stanovište - sasvim su jasno vidljive još i prije demonstracije 1895. godine. Iako u mnogo čemu nerazvijena, Hrvatska ipak nije bila izolirana od širih monarhijskih i europskih kretanja. U tom smislu nije čudno da nove ideje cirkuliraju i prije svjesne propagatorske djelatnosti „praške skupine“. Ključni je okvir, međutim, zadan lokalnim političkim prilikama, prije svega odnosom prema glavnim hrvatskim političkim strankama. Jasno je da je antagonizam mladih mnogo veći prema Stranci prava, posebice Frankovoj stranci, koja je vrlo aktivna među studentskom populacijom, nego prema obzorašima. Korporić je u tom pogledu vrlo oštar: „Ja najme vjerujem u potpunu nevriednost stranke prava, držim, da je ona za pravo madžaronska stranka, da je nauka Starčevićeva o prosvjetljivanju puka najveća farizejština i da je Starčević silnu krivicu činio Obzorašima, kad je na njih navaljivo, jer je on sa svojom strankom bio u svakom momentu

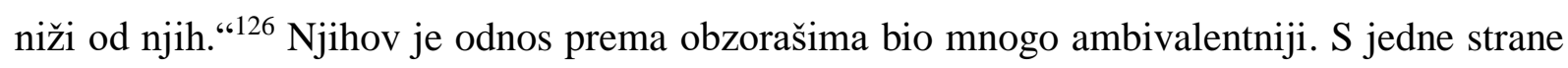
oni su priznavali njihove zasluge i dijelili s njima određene stavove, ali su ih s druge promatrali kao anakronu tvorevinu, analognu staročeškoj stranci. ${ }^{127}$ Već sama činjenica što se Stranka prava - posebice ako imamo u vidu spletke J. Franka i nemilosrdna međusobna razračunavanja nakon raskola 1895. godine - pokazala kao veći krivac za neuspjeh ujedinjenja hrvatske opozicije, a što je bio jedan od glavnih studentskih ideala prije i za vrijeme demonstracije, činila je obzoraše u očima mladih ozbiljnijom političkom opcijom. Osim toga, mladi su s obzorašima imali i bliske osobne veze, primjerice posredstvom Lava Mazzure, sina obzoraškog vođe Šime Mazzure, ili Milivoja Dežmana, koji je također bio sin

\footnotetext{
124 „Svetimir Korporić - Stjepanu Radiću, Prag, 16. IV. 1896،“, u: Krizman, nav. dj., 184

125 „Stjepan Radić - Mariji Dvořákovoj, Prag, 7. I. 1897.“, u: Krizman, nav. dj., 238.

126 „Svetimir Korporić - Stjepanu Radiću, Prag, 13. V. 1896.“, u: Krizman, nav. dj., 189.

${ }^{127}$ Isto.
} 
narodnjačkog političkog prvaka Ivana Dežmana i čiji je mentor u mnogo čemu bio Franjo Rački. ${ }^{128}$ Ranije je istaknuta i financijska pomoć koju su za „relegirce“ organizirali neki obzoraški prvaci. Ideološka srodnost očitovala se u prihvaćanju ideologije jugoslavenstva, tada u obliku hrvatsko-srpskog narodnog jedinstva, šire politike slavenske solidarnosti te ideje primata kulturnog rada. ${ }^{129}$ Ipak, mladi će se pritom postaviti kao revitalizatori tih ideoloških postavki, optužujući „stare“ obzoraše da su one za njih ostale tek mrtvo slovo na papiru. Iz toga će se i razviti ideja o pokretu mladih kao o trećoj fazi hrvatskog narodnog preporoda, o čemu će biti riječi kasnije.

U tom smislu, „novi smjer“ morao bi zapravo nadići obje stranke, ali ne kao puka negacija, nego kao svojevrsna sinteza njihovih pozitivnih tekovina, uz odstranjenje negativnih, odnosno anakronih elemenata koji sputavaju plodonosni politički rad i razvoj. Krištof je to jasno izrazio u proljeće 1896. godine: „Po mojem shvaćanju naš pokret imao bi biti u pitanjima, koja već sada u nas eksistiraju, upravo odstranjenje onoga, što je u strankama zlo jednostavno realnijim shvaćanjem, a jasno je da će se dobro iz obiju stranaka dati ujediniti. U tom se, mislim, i sastoji svagdje napredak."130 Intelektualni instrumentarij apropriran u Pragu trebao im je poslužiti za jasniju konceptualizaciju i formulaciju stajališta, ali i za otvaranje onih pitanja koji ne egzistiraju u hrvatskom javnom prostoru.

\section{2. Borba za primat u pokretu}

Prag nije bio jedino mjesto gdje su među studentima kružile nove ideje. Usprkos snažnom prisustvu pravaštva, i u okviru bečkih studentskih društava javljaju se pojedinci koji prihvaćaju i zastupaju modernističke ideje. S obzirom na modernistička strujanja u fin de siècle Beču, može se reći da je to bilo neizbježno. Ipak, dugotrajne tradicije tamošnjih hrvatskih studentskih društava donekle su sputavale širenje novih ideja, dok je Prag kao svojevrsna tabula rasa u tom pogledu bio povoljnije tlo za eksperimentiranje s novim perspektivama. ${ }^{131}$

\footnotetext{
128 Josip Horvat, Hrvatski panoptikum, Zagreb, 1965, 114-115.

${ }^{129}$ Lovrenčić, nav. dj., 42.

130 „Milan Krištof (?) - Stjepanu Radiću, Prag, 22. IV. 1896.“, u: Krizman, nav. dj., 186.

${ }^{131}$ Iako i bečki studenti sve više skreću prema novim strujanjima, ipak su 1896. Dušan Plavšić i Milivoj Dežman nosili vijenac na sprovod Ante Starčevića, koji je već zadobio svoj status u nacionalnom panteonu čime je u određenoj mjeri nadilazio konkretne stranačke i unutarstranačke prepirke. Ipak, mladi će se kasnije veoma negativno osvrtati na njegov rad i misao. V. „,(K slozi hrv. radništva)“, HR-HDA-757 Obitelj Plavšić, k. 59.
} 
Ključnu ulogu u širenju novih ideja u okviru bečkog hrvatskog akademskog društva Zvonimir imala je tzv. osječko-zagrebačka grupa, u kojoj su svakako najvažniji Dušan Plavšić, Guido Jeny i Milivoj Dežman. Dežmanova će uloga pritom još biti i u tome što je on možda najviše od svih funkcionirao kao integrativni faktor među različitim ,novosmjeraškim“ grupacijama. Upravo će on, doduše na inicijativu Ivana Lorkovića, odigrati vjerojatno ključnu ulogu u organiziranju Glavnog odbora u pripomoć hrvatskih osuđenih i nastradalih đaka $u$ studenom 1895. ${ }^{132}$ Nakon neuspjeha I. Obćeg sastanka hrvatskih akademičkih građana u Zagrebu u srpnju 1895., i drugi je sastanak inicirao Zvonimir, i to upravo navedena osječkozagrebačka pokretačka jezgra. ${ }^{133}$ Već su jasno vidljive temeljne ideje koje distanciraju ovu grupaciju studentskog pokreta od njegove pravaške, odnosno frankovačke faze: povezivanje svih studenata i đaka (odnosno njihovih aktivnih društava) u jedinstveni i od stranaka nezavisni pokret, koji će djelovati samostalno i tako inicirati promjene u hrvatskom društvu, dok se kao početno sredstvo za rad u tom smjeru uzima izdavanje samostalnog omladinskog časopisa. To je razvidno iz predložena dnevnog reda drugog, osječkog sastanka: „1. Izvještaj odbora, 2. Izbor novog odbora, 3. Organizacija hrv. akad. mladeži i djački list, 4. Ćiril i Metod (njegovo djelovanje i naša akcija u tom), 5. Naobrazba naše mladeži na srednjim i visokim školama u Hrvatskoj, 6. Kako ćemo podiči pučku naobrazbu!? (sic!), 7. Odnošaj hrvatskog djačtva naprama svim slavenskim družtvima u monarkiji, 8. Eventualija. “134 Dušan Plavšić, jedan od najaktivnijih organizatora ovog neodržanog sastanka, u konceptu predgovora svojoj nerealiziranoj brošuri „Hrvatski djak, njegov život i odnošaj prema javnosti““ iz 1896. godine možda je najplastičnije izrazio nove tendencije među mladima. On primjećuje da se u novije doba „hrvatska omladina stala malo po malo buditi iz onoga nerada i slijepoga nasljedovanja domaćih stranaka“. To novije doba je „prelazna dob“, odnosno „prelaz 19 u 20 vijek, od kojega čovječanstvo mnogo očekuje“, a koje „,neće samo u kulturnom pogledu uroditi novimi boljimi odnošaji za čitavo ljudstvo, nego i za pojedine narode. “ S obzirom na to da je hrvatski narod vrlo tradicionalan, ,[...] mi [smo] danas očito u razdoru sa modernim svijetom. Naše tradicije trebaju novih sila, novoga oblika da bi nas zadovoljile, i pomogle nam uzdići se novoj dobi, u red kulturnih naroda evropskih.“ Te nove sile, novi oblici i nove ideje moraju se, međutim, dovesti u svojevrsni sklad sa starim, jer se inače može dogoditi da se nove ideje ne prime, da budu odbačene, ili da čak izazovu više štete nego koristi. To je realnost seoskih, još uvijek izrazito tradicionalnih društava, u kojima se

\footnotetext{
132 Marijanović, Fin de siècle, 76.

133 Isto, 64.

134 „Braćo Hrvati!, Beč, 16. VI. 1896.“, HR-HDA-757 Obitelj Plavšić, k. 53.
} 
intelektualac ne može ponašati isto kao u zapadnom velegradu: „, I mi smo danas u stadiju, u kojem se staro bije s novim, i ne bude li buduća generacija, na kojoj je da to izgladi dobro oboružana, mogao bi hrvatski narod poći po zlu.“"135

U konceptu referata naslovljenom „Organizacija hrv. djačtva!“‘, koji je očito pripremao za osječki sastanak, Plavšić se pozabavio općenitim stanjem hrvatskih studenata i njihovih društava, kao i zadacima koji stoje pred njima. Nasuprot „djačke odvažnosti i držanja riječi“, koji bi trebali karakterizirati izgrađeni studentski „značaj“, hrvatski studenti akademsku slobodu stečenu odlaskom na studij u drugi, strani grad, daleko od roditeljske i učiteljske stege, prečesto koriste za uživanje u porocima, od kojih su najgori lijenost, pijanstvo, prostitucija, dužništvo te duševna i materijalna ovisnost od „kojekakvih stranaka i od vlade“. Odavanje svim tim porocima rezultira u potpunoj opreci načelu akademske slobode, temeljene na slobodnom obrazovanju kao osnovi izgradnje karaktera, naime u raznim oblicima materijalne i druge ovisnosti, koja naposljetku producira propale „značajeve“. Takvom degradacijom student „ne naškodi samo sebi nego narodu, jer je ljudski material najvredniji.“ On ne samo da ne ispunjava svoju zadaću prema svojem narodu, nego ga svojim fizičkim i duhovnim truležom čak i „kuži“. U svemu tome odgovornost snose i hrvatska akademska društva. Ona bi zapravo trebala biti korektiv takva ponašanja, osiguravajući okvir za pravilan razvoj studenta, pružajući mu podršku i „sveopću naobrazbu“ koju možda ne može dobiti na svojim studijima. U tim društvima, međutim, vlada strančarstvo i, iznad svega, tromost. Posebno se u tom pogledu okomio na pravnike i filozofe, koji u Hrvatskoj imaju primat u pogledu politike i „,vođenja naroda“, dok je istaknuo da su „tehničari i medicinari jedini koji što rade“. Iako je strančarstvo veliki problem hrvatskih akademskih društava, to ne znači da bi studente trebalo aktivno odvraćati od politike u širem smislu. Posebno je pogrešno ono što radi vlada, a to je „hapšenje“ i ,proganjanje“. Kao budući aktivni građani, studenti bi morali stjecati široko političko obrazovanje, koje uključuje ne samo nauke i „općenitu naobrazbu“, nego i nacionalnu ekonomiju i kulturu, kao i svakodnevno praćenje života koji ih okružuje, što podrazumijeva i redovito čitanje novina, ali ne samo jednih, nego „od Narodnih do Slobode“ i „od Srbobrana do Hrv. Prava“ te pohađanje „sjednica pučkih i političkih.“ Umjesto nekritičkog pristajanja uz jednu stranku, „djak dakle nebi smio da bude čisti ili nečisti pravaš, ili obzoraš ili narodnjak ili socialni demokrata, nego treba da sve te stranke prouči, na svakoj da dobro hvali, a zlo da progleda i kudi, onda će on kasnije kad stupi u život, ući kao slobodan čovjek u onu stranku koja mu se bude najviše svidjela, te neće ni u

135 „Hrvatski djak, njegov život i odnošaj prema javnosti“, Plavšić, Dušan, R7228, II, 4), NSK. 
njoj biti zagriženi strančar, ni politički intolerantan ni fanatičan." ${ }^{136}$ Takvi ljudi onda bi mogli iznutra mijenjati te stranke, te time povoljno djelovati na cjelokupni politički život. Osim toga, đak treba raditi za cijeli narod, a ne samo za jedan njegov dio, pogotovo ne kao instrument osobnog kulta pojedinca. Slično je stanje u pogledu političke svijesti nažalost prisutno i u srednjim školama, gdje također vlada strančarstvo, pa se ironično ističe da je najveći uspjeh hrvatske opozicije što je i među srednjoškolce uspjela prenijeti vlastite svađe. S obzirom da se na taj način ne može razviti „značaj“, da se politička svijest svodi na adoraciju osoba i praćenje svađa između Franka i Folnegovića, ne poznavajući nikakve druge „realnosti“, posebice one u kojoj živi narod, nije čudno da se na kraju upravo takvi gorljivi đaci nakon studija nađu u redovima vladine stranke.

Stanje hrvatskih studenata u Beču još je 1886. godine u svojem za modernistički pokret izrazito utjecajnom romanu U noći kritički opisao Ksaver Šandor Gjalski. Jedan od njegovih likova, Živko Narančić, upravo je antipod stereotipnoj slici hrvatskog studenta u Beču:

„Poradi toga nije dolazio mnogo u đačka društva te je ostao gotovo posve otuđen političkomu gibanju među njima. Ne zato što ga ne bi zanimali javni odnošaji domovine, naprotiv, on je svaki slobodni čas, svaku dokolicu upotrijebio za to; no njegov učenju posvećeni život upravo ga je radi toga odijelio od ostalih hrvatskih mladića. Bijaše mu mrsko ono njihovo ljenčarenje po kavanama, one prazne prepirke o pročitanim novinarskim leaderima, ono njihovo gotovo preziranje knjige i nauke. Ne mogaše ga zanijeti ni ono njihovo plandovanje bez cilja po velegradskim predgrađima, na kojem se uvijek drsko i smjelo psovalo na „glupoga neprijatelja Švabu“, a ipak se uza to uvijek na štetu domaćih odnošaja pravile prispodobe uz besmisleno hvalisanje i slavljenje najkukavnije bečke stvarce." ${ }^{137}$

Slične literarne reprezentacije dobio je život hrvatskih studenata u bečkom velegradu i u djelima mladih protagonista pokreta. Možda je najbolja od njih sadržana u noveli Milutina Cihlara Nehajeva Veliki grad napisanoj 1902. godine. Nehajev, jedan od predvodnika đačkog novonadaškog pokreta, i sam je bio bečki student na prijelomu stoljeća. U ovoj noveli on opisuje polagani proces propadanja perspektivnog hrvatskog đaka Frana Mirkovića nakon dolaska na studij u Beč. Držan pod strogom kontrolom u svojem roditeljskom domu, po dolasku u Beč Mirković otkriva veliko polje slobode koje rasplamsava njegove potisnute

\footnotetext{
136 „Organizacija hrv. djačtva!“, Plavšić, Dušan, R7228, II, 2), NSK.

137 Ksaver Šandor Gjalski, „U noći“, u: Tihomir Tonković (ur.), Ksaver Šandor Gjalski: sabrana djela, knjiga III, Zagreb, 2016, 28.
} 
strasti. Podražaji i primamljivosti velikoga grada potpuno ruše njegovu teško stečenu disciplinu. On postaje i intelektualno i financijski rasipan: umjesto usmjerenog i strukturiranog studija čita sve što mu zagolica maštu, a umjesto nužno potrebne štedljivosti rasipa novac u kavanama i na kartama. Kako godine prolaze, Mirković sve više zapušta studij i sve dublje tone u besmisleni vrtlog besposlene svakodnevice. Situacija kulminira u ljubavnoj aferi s udanom, fatalnom ženom:

„Bili su to i slatki i užasni časovi: cio bi se dan vucario po Beču, kartao se i ubijao vrijeme, čekajući večer i sastanak s njom. Ta ga je ljubav napokon tako okovala da se je s teškom mukom odvažavao na najmanji posao; pa da sâm sebe zavara i dokaže sebi kako ipak nešto radi, bacio se $u$ vrtlog političkih borba među đacima i u beskrajnim sastancima, dogovorima i rezolucijama nastojao da bar donekle nadomjesti svoju posvemašnju lijenost." "138

Nakon kraha te veze, Mirković, tada već ostarjeli student bez ikakve perspektive, razvija zatupljujuću rutinu koja mu omogućava da ignorira svoju situaciju i činjenicu da je zapravo propao: „Jedan je dan kao i drugi - bez nade da će ikad biti bolji, bez straha da bi moglo doći gore [...]“139 Njegovu rutinu pomućuje majčino pismo u kojemu ga ona zove da dođe kući za Božić, jer je to možda posljednja prilika da se vide prije njezine očekivane smrti. Ono ga tjera da ponovno počne propitivati svoj život. Mirković dolazi do zaključka da je za njegovu sudbinu kriv velegrad koji ga je okovao svojim čarima, daleko od rođene grude:

„Jest jest - u tom je odgonetka svega njegova života. Nitko nije kriv njegovoj nesreći nego velegrad. On je došao da ga upozna, da ga savlada, da bude jednak s onima koji mogu da žive u njem. Zašao je u to klupko, no ono ga je zamotalo, stegnulo mu grlo, zatrlo mu dah. Veliki grad - taj blatni i užasni Beč koji mu se tako veličajnim pričinjao i tako vrijednim udivljenja te je od sve duše hleptio da ga upozna što bolje. Htio je da bude velegrađanin, da zna i vidi sve, - a izgubio snagu kraj toga. Nije imao ničega što bi ga vezalo uz rodnu grudu i tako se sav podao velegradu da je taj od njega učinio bogalja i slabića, upokorio ga i slomio mu i mladost i snagu i volju za život.“"140

Beč se kod Nehajeva pojavljuje kao klimtovska Sfinga, u obliku tipične fin de siècle fatalne žene koja je ujedno i privlačna i strašna, čiji vanjski sjaj prikriva njenu inherentnu opasnost:

\footnotetext{
${ }^{138}$ Milutin Cihlar Nehajev, "Veliki grad", u: Krešimir Nemec (ur.), Antologija hrvatske novele, Zagreb, 1997, 245-246.

${ }^{139}$ Isto, 249.

${ }^{140}$ Isto, 250.
} 
„,- Veliki grad - Veliki grad - šaptao je u sebi s gorčinom u kojoj bijaše i smijeha samomu sebi. On ga vidi - tu bestiju, taj ogromni kolos, sfingu i hidru koja ga je smlavila. Jedanaest godina okivao ga je velegrad uza sebe, najprije svojim bogatim razvitkom, šarolikim svojim ulicama i živom masom svojih stanovnika - onda onim egzemplarom prestrasne žene, onda onim predgradskim ljubavima kao što je Ela. Okova ga svojim blatom i svojim sjajem - svojom noćnom kavanom, svojom slobodom svojim grozničavim brzanjem naprijed koje ne zna vjere ni u što, ne zna mira, ne zna sreće, već zna jedino za razorenje, za pokornost i ropstvo svih koji se približe njemu.

- Veliki grad! Veliki grad!

Sada kad ga je upokorio i slomio, kad mu je prenatrpao pamet tako da više ništa nije moglo u nju, kad mu je prenapeo živce tako da već nisu mogli nego drhtati u trzanju ili mirovati u mrtvilu, onda ga je veliki grad okivao još dalje. Okivao ga mehaničkim načinom života, monotonijom kavane, svagdašnjim navikama koje poznaju samo Njegova djeca. Okivao ga svaki dan, svaki korak - učinio ga domaćim da može učiniti potpuno izopaćenim; napravio kozmopolitom da ga može oteti rodnoj kući i majci i svemu što ljudima unosi u život zadovoljstvo.

Veliki grad!‘141

Nehajevljeva je naracija prožeta opisima koji odgovaraju impresionizmu i senzualizmu na tragu Ernsta Macha, kao i tradiciji slikarskog krokija i umjetničkog feljtona. Bečke se mase stapaju s blatnim pločnicima i blještavim svjetlima u „ogromno klupko koje se smotava i razmotava u strostruke niti, opseže sve i valja preko svega.“" ${ }^{142}$ Ova slika neodoljivo podsjeća na Klimtove Vodene zmije ili pak na njegovu Filozofiju, u kojoj jedno takvo klupko čovječanstva besciljno lebdi kozmičkim prostranstvom, dok na njega iz mraka vreba Sfinga. ${ }^{143}$ Mirković, tipični Nehajevljev fragmentirani i nesigurni intelektualac, završava tragično, bacivši se na tračnice električnog tramvaja.

Ovakve literarne reprezentacije ispreplitale su se s osobnim iskustvima studenata tvoreći stereotipnu sliku o životu i stanju hrvatskih studenata u Beču. Ta slika postat će jedan od ključnih toposa modernističkog pokreta mladih na kojemu će zasnivati svoju kritiku stanja i dosadašnje djelatnosti hrvatskih studenata te u opreci s kojom će graditi svoj ideal aktivnog i karakterno čvrstog mladog studentskog aktivista. Kao što smo mogli vidjeti, to je imalo snažnog odjeka u pripremama đačkih sastanaka. Dušan Plavšić bio je također predviđen kao

\footnotetext{
${ }^{141}$ Isto, 256.

142 Isto, 250.

${ }^{143}$ Schorske, Beč krajem stoljeća, 239-240.
} 
„predlagač i prvi obrazlagač“ projekta studentskog lista. ${ }^{144} \mathrm{U}$ tu svrhu pripremio je „Uvod u specialnu debatu“. Iz sačuvanog sinopsisa može se vidjeti kako je Plavšić planirao cjelokupnu osnovu za časopis, uključujući i logističko-organizacijska pitanja. Taj je časopis trebao biti „glasilo svih hrvatskih đaka“ i ,otvoren svima“. S obzirom na ranije izneseno političko stanje među studentima, a koje karakterizira iznimna politička polariziranost i podijeljenost, ovaj časopis, ako želi ostvariti svoju integrativnu svrhu, „ne smije stajati na temelju ni jedne stranke“. Njegov smjer mora dakle biti „list vazda bez smjera.“145 To je dakako bilo uvjetovano mnogo složenijom političkom situacijom koja je vladala među bečkim, pa i zagrebačkim studentima, među kojima je utjecaj političkih stranaka bio mnogo veći nego što je to bio slučaj u Pragu. Za takav list Plavšić je predvidio ime Mladost. Plavšić je planirano ime otkrio u pismu jednom danskom studentskom društvu kojemu je pisao u ime „die kroatische mod.[erne] Jugend“ za vrijeme priprema za opći sastanak, s molbom za slanje literature o danskom studentskom pokretu, višem školstvu i podizanju razine pučkog obrazovanja, jer je danske uspjehe na tom polju vidio kao uzor s obzirom na to da ,ima vrlo mnogo okolnosti koje u nas začuđujuće nalikuju onima u Danskoj. “146 Nije stoga čudno što će Zvonimir nakon propasti pokušaja II. općeg sastanka uz Frana Hrčića povjeriti izdavanje svojeg Almanaha upravo Dušanu Plavšiću. ${ }^{147}$

Ipak, kako je ranije spomenuto, praški studenti bili su odlučili da neće sudjelovati na ovom sastanku, nakon što njihov prijedlog promjene datuma održavanja nije prihvatio Centralni odbor u Beču. Oni su bili predlagali i proširenja dnevnoga reda (agitacija za ustrojenje fonda i izrada plana podizanja osnovnih škola u Međimurju, kritika školskog sustava u Hrvatskoj, od sveučilišta do đačkih društava, pisanje i prevođenje za puk, pučka naobrazba, socijalizam i antiklerikalizam), što je bilo prihvaćeno, ali kako ističe Korporić, ne bez „natezanja za stilizaciju programa“. ${ }^{148}$ Modernistička struja u Zvonimiru još nije bila dovoljno jaka da progura „novosmjeraške“ točke bez značajnijeg otpora pravaša. Međutim, ključni razlog nedolaska praških mladih vjerojatno je bio druge naravi. Naime, oni su već bili odlučili kako će krenuti u izdavanje omladinskog časopisa „u čisto novom duhu“, pa vjerojatno nisu bili spremni na kompromise koji bi bili potrebni ako bi se taj časopis uređivao kroz zajedničku akciju sa Zvonimirom. Za njih deviza „list vazda bez smjera“ nije dolazila u obzir, jer su jasno željeli inaugurirati „novi smjer“ u hrvatskoj politici. Osim toga, to je u neku

\footnotetext{
${ }^{144}$ Marijanović, nav. dj., 77.

145 „Uvod u specialnu debatu“, Plavšić, Dušan, R7228, II, 3), NSK.

${ }^{146}$ Prema Marijanović, nav. dj., 77.

147 Isto, 63.

148 „Svetimir Korporić - Stjepanu Radiću, Prag, 22. VI. 1896.“, u: Krizman, nav. dj., 199-200.
} 
ruku bila i borba za primat u studentskom poketu. Praški su studenti polagali pravo na vodeće mjesto, ne samo kao izvorište novih ideja i novog pokreta, nego kao novo glavno središte hrvatske studentske emigracije, što je nužno vodilo u koliziju sa Zvonimirom i bečkim studentima. Ako su na I. općem sastanku pristaše „novog smjera“ nastupale kao manjina naspram pravaške većine, u pripremama za II. opći sastanak već se primjećuju antagonizmi između praške i bečke grupacije u okviru zajedničkog modernističkog pokreta koji definitivno uzima zamah unutar još uvijek dominantno pravaškog studentskog pokreta.

Iako je sastanak bio zabranjen, u Osijeku se ipak okupilo četrdesetak studenata iz Beča, Graza i Praga te se održao dio planiranog popratnog programa. ${ }^{149}$ Studenti su odlučili da svoje zaključke provedu „dopisivanjem i međusobnim obodrivanjem“. ${ }^{150}$ Nakon toga su krenuli na već poznatu tamburašku turneju po Rusiji. ${ }^{151}$ Nju je organizirao Plavšić, kojega je savjetovao Stjepan Radić, koji je pak tada boravio u Moskvi, a uz jezgru koju je sačinjavao tamburaški zbor Zvonimira sudjelovali su studenti iz društava u Innsbrucku, Grazu, Pragu i Zagrebu. Kako je Plavšić kasnije pisao, ta je turneja trebala biti i svojevrsni ,protest proti magjarskoj Milenijumskoj izložbi u Budimpešti.“"152 Nakon završetka turneje većina studenata je, po običaju, provela ostatak ljetnih praznika kod kuće, što se ponekad znalo odužiti i duboko u jesen. Upravo se tada nastavlja komunikacija između bečkog Zvonimira i praških zagovornika „novog smjera“. Usprkos ranijim neslaganjima, zvonimirovci su poručili pražanima kako su spremni podupirati njihov najavljeni list „i moralno i materijalno“, međutim, prije toga su predlagali razmjenu programa kako bi se ustanovilo da se slažu u ključnim točkama. ${ }^{153}$ Kako je postalo jasno da praški mladi namjeravaju samostalno izdavati omladinski časopis pod svaku cijenu, čini se da su zvonimirovci odlučili promijeniti taktiku i pridružiti se tom projektu, pritom namećući neke njima bitne programske teme. Praški studenti, međutim, nisu bili previše zainteresirani za takav tip suradnje. Fran Poljak, jedan od inicijatora pokretanja Hrvatske misli, odgovorio je Plavšiću kako pražani ne mogu odaslati svoj program jer on kao takav još ne postoji, nego je tek zadaća zamišljenog lista da jedan

\footnotetext{
${ }^{149}$ Marijanović, nav. dj., 79.

150 Isto.

${ }^{151}$ Dojmovi s tog putovanja bili su podijeljeni i ambivalentni. Dok se Plavšić u svojim privatnim zapisima divio velebnoj ruskoj kulturi koja je skrivena od zapadnog pogleda i iskrivljena u njegovim predodžbama te velikom ruskom narodu koji se ne poistovjećuje s carizmom koji koči njegov procvat, drugi tamburaški putnik, Josip Henneberg, unatoč početnom entuzijazmu, bilježi svoje nezadovoljstvo ruskim nepoznavanjem Hrvatske. Vidi: Iskra Iveljić, „Od uza Sudbenog stola do turneje po Rusiji, Nepoznata pisma Josipa Henneberga iz 1894.1897.“, Časopis za suvremenu povijest XL, 2, 2008, 587- 623 i materijale u HR-HDA-757 Obitelj Plavšić, k. 44. 152 „Dušan Plavšić o sebi, Zagreb, 1941.“, HR-HDA-757 Obitelj Plavšić, k. 37.

153 „F. Poljak - D. Plavšiću 1.XI.1896.“, HR-HDA-757 Obitelj Plavšić, k. 42.
} 
takav program iskristalizira. ${ }^{154}$ Poruka je bila jasna: iako je svačija podrška dobrodošla, praški mladi neće dopustiti bilo kakvo remećenje svojeg plana.

\section{3. Aktivizam u đačkim klupama}

Većina aktera studentskog modernističkog pokreta svoja su prva aktivistička iskustva stekli još za vrijeme đačkih dana. Radić je već 1888., sa sedamnaest godina, sudjelovao u svojoj prvoj političkoj demonstraciji kada je u znak protesta protiv Khuenova zatvaranja opere za vrijeme izvedbe trećeg čina Zajčeve opere Nikola Šubić Zrinski izvikivao političke parole protiv bana. ${ }^{155}$ Iduće je godine ponovno kažnjen zbog političkog agitiranja među svojim kolegama u gimnaziji. ${ }^{156}$

U isto vrijeme kada Radić ostvaruje svoje prve političke istupe, Milivoj Dežman radi iskorake na književnom polju. On je kao polaznik Gornjogradske gimnazije u Zagrebu i pitomac Plemićkog konvikta nastupio u književnom almanahu Domovine za 1888.-1889. godinu, koji je izdavalo Čitaoničko društvo konviktorsko, jedno od najstarijih đačkih književnih društava u Hrvatskoj osnovano 1842. godine. ${ }^{157}$ Iako nije bio urednik, Dežman je bio glavni suradnik ove publikacije, pišući za nju predgovor, pjesme, prozu i kritiku. Već u prvoj rečenici predgovora tom tzv. Almanahu osmorice, on iznosi ključnu ideju nužnosti suradnje „starih“ i „mladih“, odnosno neizbježnosti smjene generacija: „Zar ne valja, da na mlagjima počiva nada domovine, da borioci gledaju u mlagje sile, kako bi ih pomogle i zamijenile u radu?“ Kako bi bila spremna za preuzimanje vodeće uloge u javnom i političkom životu, mladež se mora osobito truditi oko svojeg obrazovanja, čak i povrh službeno propisanih očekivanja i kurikula: „Gledali smo da se među sobom podučimo, e da bi se podigli nad obično znanje i indiferentizam.“ Zadaća je mladih aktivista da se agitacijom bore protiv tog indiferentizma i da pokušaju ,uzdrmati onaj drijemež, koji je zavladao većinom naših kolega.“ Ipak, pritom treba biti oprezan. U svojoj pripovijesti iz đačkog života, „Stara pjesan“, Dežman opisuje kako „želja za radom, silovita brza težnja, da pomogne narodu, dolazi u sukob sa polakim, promišljenim svijetom“, pri čemu „glavni junak propada.“ Potreban je dakle strpljiv i dugotrajan rad, prije svega na sebi i na vlastitu obrazovanju kao

\footnotetext{
154 Isto.

${ }^{155}$ Mark Biondich, Stjepan Radić, the Croat Peasant Party, and the Politics of Mass Mobilization, 1904-1928, Toronto, Buffalo, London, 2000, 31.

156 Isto.

157 Marijanović, nav. dj., 30-31. Marijanović pogrešno navodi 1836. kao godinu osnivanja. Tada je naime osnovan Zbor duhovne mladeži, a Konviktorsko čitaoničko društvo osnovano je 1842. godine.
} 
osnovi za sve ostalo. U tom smislu i sam Dežman u ovom almanahu na neki način isprobava i oštri svoju kritičku i esejističku vještinu. Osim što sve radove u almanahu podvrgava svojoj kritici, on također već ovdje iznosi ideje o većoj literarnoj vrijednosti lirske, osjećajne i subjektivističke poezije nad onom patriotskom, koja je „do malih iznimaka“ prolazna. ${ }^{158} \mathrm{~S}$ druge strane, u svojem eseju, književnopovijesnoj „škici“ naslovljenoj „Najnoviji hrvatski romani i novele“, u kojoj daje kritički pregled razvoja domaće proze od Šenoina preuzimanja Vienca 1874. godine do svojega vremena, Dežman čvrsto staje na pozicije realizma i utilitarne zadaće književnosti, snažno pritom odbacujući romantizam koji je u Hrvatsku došao posredstvom njemačke i poljske književnosti:

„Novo doba, doba realizma zavladaće čitavom evropskom književnosti, pa tako i našom. Protivnikom toga smjera mogu reći, neka se ne boje realizma. Romanticizam, a osobito naturalizam ne mogu izobraziti i oplemeniti naroda ni inteligencije. Od njih se dobiva glavobolja. Dočim realizam uči narod, oplemenjuje mu srce, prikazuje njegove socijalne prilike i mane, te ga upućuje, kuda da krene, ako hoće postati prosvjetljen, blagosivljan narod evropski.“159

Dežman ovdje, dakle, stoji u potpunosti na pozicijama Vijenčevih kritičara, posebice Josipa Pasarića, kad je riječ o velikoj polemici o naturalizmu iz 1880-ih godina. On se drži šenoinske linije da je svrha književnosti da podučava te njega smatra pravim i poželjnim ishodištem modernog razvoja hrvatske proze: „Svrha je književnosti, da podučava, oplemenjuje narod. Zar može koja književnost abstraktnim slikama, nemogućim bićima, tajinstvenim prizorima, Ritterima pobugjivati koga na rad, oplemeniti mu srce. ${ }^{\text {“160 }} \mathrm{U}$ tom smislu, Dežman prihvaća i Pasarićevu kritiku Kumičića i iznimno negativnu ocjenu Jakše Čedomila Kovačićeva romana $U$ registraturi, a njega naziva „skrajnim ljevičarem“. ${ }^{161}$ Nasuprot Zoli, Dežman kao poželjni utjecaj europske književnosti ističe rusku realističku književnost, napose Turgenjeva. Zolin pristup književnosti, makar i imao namjere ,žigosati“ ljudske i društvene grijehe, postiže zapravo suprotan efekt ,jer nam ne pokazuje oštrim, odrešitim načinom pošljedice grijeha." ${ }^{162}$ Najbolji primjer sinteze šenoinske realističkoutilitarističke i turgenjevljevske prozne struje on vidi u Gjalskome, čiji roman $U$ noći opisuje kao „najbolji socijalni hrvatski roman“, iako mu zamjera preočitu tendenciju, kao i u nekim

\footnotetext{
158 „Predgovor“, Almanah 1889., HR-AHAZU-KN-44 Dežman, Milivoj, k. 6

${ }^{159}$ Milivoj Dežman, „Najnoviji hrvatski romani i novele (škica)“, Almanah 1889., 64.

${ }^{160}$ Isto, 59.

${ }^{161}$ Isto, 61.

${ }^{162}$ Isto, 60.
} 
ranijim Gjalskijevim pripovijetkama. ${ }^{163} \mathrm{U}$ svojem prvom, đačkom nastupu, Dežman dakle stoji na pozicijama Vijenčeve, šenoinske struje, upravo one koja će kasnije s modernom ući u grčeviti sukob, ističući pritom zahtjev i nužnost suradnje generacija i generacijske smjene, a sve sa ciljem narodnog prosvjetljenja i priključenja tokovima europske kulture.

Ako se uzme u obzir društveni milje iz kojeg je Dežman potekao, ovakva njegova pozicija nije neobična. Za razliku od Stjepana Radića, koji je bio izdanak seljačke obitelji, Milivoj Dežman bio je sin istaknutog i perspektivnog, ali nažalost prerano preminula narodnjačkog prvaka Ivana Dežmana. Budući da je Ivan preminuo kada je Milivoju bilo tek dva mjeseca, njegov skrbnik postao je Franjo Rački, u čijem je krugu upoznao gotovo sve obzoraške prvake i inteligenciju. ${ }^{164}$ On je, dakle, od malih nogu bio uključen u sfere hrvatske visoke politike i kulture, što ga je i stavljalo u poziciju da bude idealni posrednik između starih i mladih. To, međutim, ne znači da u mladosti nije pokazivao buntovnu stranu. Usprkos zagovoru suradnje starih i mladih te prihvaćanju ideja i stavova njegova profesora Josipa Pasarića, Dežman je dolazio u sukob s drugim dijelovima Plemićkog konvikta, napose s njegovim prefektom Stjepanom Korenićem. Zbog toga je i Almanah osmorice zapravo izdan bez odobrenja Konvikta. U tom kontekstu kod tih se mladih ljudi od ranih dana mogao razvijati sentiment prema ideji slobodnog umjetničkog stvaralaštva, neovisno o stilskim ili programskim preferencijama.

Bilo je i radikalnijih članova te „Dežmanove koterije“, kojoj su pripadali i Dragutin Domjanić, Branimir Vizner (Livadić), Artur Benko (Grado), Vladimir Lunaček, Mladen i Srđan Tucić. ${ }^{165}$ Možda je najpropulzivniji među njima bio Branimir Livadić, jedan od najvažnijih kasnijih zagovornika modernizma, kojeg je već s trinaest godina kaznio regens Plemićkog konvikta zbog toga što je „poticanjem učenika na književni rad odvraćao ih od školskih dužnosti“. ${ }^{166}$ Njegovi su naturalistički uradci bili zabranjivani te je on upravo u kontekstu nastanka Almanaha osmorice ušao u konflikt sa zavodskom upravom, napose Stjepanom Korenićem, istupivši sa svojim prvim manifestom za slobodu umjetničkog stvaranja, protestirajući protiv toga da se ono ,izvrgava u religiozno-moralnu didaktičnu pripovijest“, „,u putopis“, „Robinsonade“, , ,u humorističku crticu“, „,fabiole“. 167

U okviru konviktorskog društva svoj su rad započeli i neki mladi koji će kasnije sačinjavati prašku omladinu. Zbog zabrane društvenog rada nakon aktivnosti Dežmanove

\footnotetext{
163 Isto, 63-64.

${ }^{164}$ Horvat, Hrvatski panoptikum, 116.

165 Isto, 117.

${ }^{166}$ Marijanović, nav. dj., 73.

${ }^{167}$ Isto, 74.
} 
skupine, list mladeži Kraljevskog plemićkog konvikta Domovina 1892./1893. u tajnosti je uređivao Milan Heimrl ${ }^{168}$, a u njemu je surađivao i nešto mlađi Ivan Krnic, koji će kasnije preuzeti uređivanje lista. ${ }^{169}$ Njihov je rad predstavljao idejni kontinuitet $\mathrm{s}$ onime što je nešto ranije započela Dežmanova generacija. O tome svjedoči i geslo koje je Heimrl nadjenuo jednoj svojoj crtici objavljenoj 1893.: „Značajeva, značajeva daj nam Bože“, što je bila direktna referenca na Gjalskijev roman $U$ noći, a taj motiv, kao i fascinacija Gjalskim, bili su ključni impulsi i ranije generacije. ${ }^{170}$ Ideja „značaja“, čvrstog i nepokolebljivog karaktera, zasnovanog na temeljitom obrazovanju i jasnim idealima, odigrat će središnju ulogu u formiranju intelektualnog vidokruga đačkog pokreta $u$ devedesetim godinama 19. stoljeća. Ona će se razviti u opoziciji spram tadašnje društvene i političke klime, s jedne strane kao otpor ovisnosti (nacionalne) inteligencije o režimu u vidu dobivanja državnih službi, a s druge također kao otpor neodlučnosti, kolebljivosti i oportunizmu hrvatskih oporbenih političkih elita.

Upravo je takvo društveno i političko stanje Hrvatske u svojem opsežnom romanu $U$ noći opisao Ksaver Šandor Gjalski. Roman je izlazio u nastavcima u Vijencu tijekom 1886. godine te je postao jedno od ključnih formativnih djela za mlađu, modernističku generaciju. Njegov naslov funkcionira kao metafora za stanje hrvatskog društva i politike. Gjalski to stanje opisuje kao mrklu noć u kojoj vladaju divlje zvijeri i zakon jačega:

„I Bog će uslišati ovu molitvu, pa će biti dana i svježa uranka; nestat će ove teške noći, razbježat će se njene grabežljive zvijeri štono gramze u tmini njezinoj za svakakvim plijenom, razletjet će se njene strahotne sove, njeni zlokobni ćukovi, i njeni proždrljivi parcovi, njeni škodljivi miševi, oh, i njeni otrovni škorpioni, a i njene lude lepirice bez glave; otprhnut će tada sav ovaj noćni svijet, a sjajno sunce obasjat će širom svu Hrvatsku, i mladi rosni dan poljubit će svetu zemlju - grobnicu neumrlih junaka - a zatim kućicu značajnih sinova, koji će zavrijediti da izuste ponosne riječi slobodna Engleza: My house - my castle - i da se porede davnim svojim djedovima, koji su isto tako s pravom mogli reći: 'moja kućica, moja voljica!'، 171

Ova opozicija duge i teške noći i mladoga dana, povezana s opozicijom ropstva i vlasti, principa materijalne koristi nasuprot slobodi i idealnoj ljubavi spram doma savršeno se uklapala u senzibilitet i imaginarij fin de siècle modernizma. Nova generacija mogla je upravo sebe vidjeti kao ove „značajne sinove“, nositelje novog sunca, koji će se tako moći usporediti

\footnotetext{
${ }^{168}$ Prezime koristi i u varijanti Heimerl.

${ }^{169}$ Isto, 39.

${ }^{170}$ Isto.

${ }^{171}$ Gjalski, U noći, 239.
} 
sa svojim djedovima, kada su očevi već zastranili u noći. Sve noćne životinje iz navedenog paragrafa imaju svoje ljudske pandane u ostatku romana: vlastodršce silnike, korumpirane političare i činovnike, „prodane opozicionalce“, licemjerne kritičare vlasti, političke opsjenare, zanesene i zabludjele studente. Posebno su loše prošli pravaši. Iako je i sam u mladosti gajio pravaške simpatije, Gjalski iznosi razornu kritiku, posebice s obzirom na njihov utjecaj na mladež, i to upravo u trenutku zenita tog utjecaja. Glavni junak romana, Petar Krešimir Kačić, talentirani je student prava na zagrebačkom sveučilištu koji se postepeno sve više uvlači u stranačku politiku i ulazi u pravaške krugove oko njihova prvaka dr. Bolića. Od toga ga pokušava odgovoriti njegov kolega i najbolji prijatelj Živko Narančić. Nasuprot stranačkom angažmanu, Narančić smatra kako je zadaća studenta da uči, da se razvija, da se po završetku studija osamostali i da tek na temelju takvog obrazovanja i zrelosti može raditi za narod i domovinu, ne na temelju emocija, nego razuma:

„Nemojmo se u tome varati. Kad si jednom u političkoj borbi, zbogom knjige! [...] Napokon, lakše je čitati novine i brošire nego učiti znanstvene knjige, i tako prođe godina, dođu ispiti, gradivo se tek nekako svlada, samo da su mogući makar kakvi odgovori, pa mladić nema snage da si svojim znanjem osigura život, nego se utječe pod okrilje službe, pa od vatrena političara akademičkoga eto ti strašljiva šutljiva činovnika, najboljeg oruđa svačije volje. Manimo se dakle, Krešimire, jalova posla, doći će naše vrijeme, pa budemo li se sada za nj pripravljali opsežnim znanjem, eto - pobjeda je naša.“172

Kačića međutim sve više privlači (navodna) pravaška principijelnost, beskompromisnost i radikalnost. Njegov glavni rival, i na političkom i na ljubavnom planu, postaje narodnjački studentski prvak Petar Hojkić, koji je kasnije završio kao vladin čovjek, iako je samog sebe predstavljao kao narodnog pjesnika i prvaka. Oportunizam narodnjaka, svađa sa srpskim studentima, nasilništvo vlasti, ali i osobni animoziteti tjeraju Kačića sve dublje u Bolićev pravaški krug. Za to vrijeme pati njegov studij. Ulazeći sve dublje u stranačku politiku, što se negativno odrazilo i na njegovo moralno i materijalno stanje, Kačić polagano počinje uviđati licemjerstvo i neprincipijelnost pravaških prvaka. Pravaški studenti, koji su načelno odbacivali svaki autoritet, uvijek su po svoje mišljenje išli kod dr. Bolića i nikad mu se nisu usudili ni u čemu suprotstaviti. Dr. Bolić, koji se zaklinjao da radi za narod, ipak se nije ustručavao ovršiti seljaka kojega je neuspješno sudski zastupao, tjerajući ga tako u propast. Naposljetku se i sam Kačić našao na udaru Bolićeva žučljivog pera nakon što mu je odbio apsolutnu poslušnost. Kada se otrijeznio, već je bio sve izgubio: posvađao se s

\footnotetext{
${ }^{172}$ Isto, 50.
} 
najboljim prijateljem, nije položio ispite, bio je na rubu gladi. Materijalna bijeda, duboko političko razočaranje i želja za sretnim i udobnim životom primorala ga je da prihvati pisarski posao kod svojeg zakletog neprijatelja Hojkića, tada režimskog čovjeka koji je bio predviđen za saborskog kandidata vladine stranke. Međutim, uskoro ga i ovdje sustiže politika, pa mu Hojkić postavlja ultimatum: ili će postati poslušnik vladine stranke i agitirati za njega u svojem izbornom kotaru, a zauzvrat dobiti unosno namještenje, ili će dobiti otkaz. U konačnom osobnom porazu, opravdavajući si to na razne načine, Kačić pristaje na Hojkićeve uvjete i uskoro ulazi u jednu zagrebačku kavanu ne kao poderani student prava, nego kao vladin činovnik devete „dijetenklase“. Doznavši za to, njegov prijatelj Narančić izriče razarajuću kritiku svega što je dovelo do Kačićeve propasti, kao i svoju poznatu „molitvu“ koja će postati jedno od ključnih referentnih mjesta hrvatskog đačkog i studentskog pokreta krajem 19. stoljeća:

„Nisam ipak mislio da će baš tako strašno biti. Dosta mi je bilo što sam se morao bojati da neće čovjek dosta naučiti pa se zapustiti, te da neće biti od njega nego prazan vikač ili opet jednostavan sirotan, koji ide u službu da steče hljeba. Ali ovo! Ah, pa da se čudim! Uzeli mu najprije vjeru u sve, ubili mu ljubav za ljepotu i znanost, naučili ga mrziti sve ono što i neprijatelji hrvatski mrze, a onda opet morao je proniknuti u svu njihovu kukavštinu i beznačajnost. A vrijeme odmiče, život traži svoje: moralo je tako doći! Najžalosnije je uza to da nije on sam - nego ih Hrvatska ima u svakom kutu - ovih izgubljenih Kačića. [...]

Oj bijedna Hrvatska, kroz milijune svojih usta ponavljaj vječnu molitvu: „Daj nam, o Bože, pošteni kruh, oprosti nam grijehe naše, kako mi praštamo dužnicima našim; ne uvedi nas u napast, već izbavi nas od svega zla - i daj nam značajeva, daj nam značajeva!‘173

Usprkos tome što se „novosmjeraški“ modernistički pokret u velikoj mjeri razvijao kroz suprotstavljanje dominaciji pravaštva u okviru studentskog pokreta, radikalni pravaški studenti s kraja 1870-ih i početka 1880-ih godina uvelike su oblikovali (samo)percepciju studentskog aktivista, kao i retorički stil i metode studentskog političkog djelovanja. Djelatnost radikalne studentske pravaške grupe okupljene oko Ilije Milarova, Ivke Kraljeve i Paje Žetića to zorno predočuje. Oni su pokušali - naposljetku neuspješno - pokrenuti studentski časopis Svijetlo preko kojega bi širili svoje ideje, poticali mlade da se upoznaju sa suvremenim znanstvenim dosezima, napose onima u okviru prirodnih znanosti te propagirali čitanje realističke književnosti, ponajviše ruske i francuske. ${ }^{174} \mathrm{U}$ svojem nedovršenom romanu Žarko i Jelka Pajo Žetić opisao je uzornog „stekliša“, pravaški orijentiranog studenta

\footnotetext{
173 Isto, 238-239.

${ }^{174}$ Aleksandar Flaker, „O pravaškom radikalizmu 80-ih godina XIX. stoljeća“, Historijski zbornik 7, $1954,91$.
} 
Žarka, „koji svoje prijatelje potiče na proučavanje prirodnih znanosti, zastupa borbu protiv bogatstva, emancipaciju žena, izruguje moral suvremenog građanskog društva i lažni patriotizam hrvatskih političara." ${ }^{175}$ Međutim, pravaški su studentski radikali jednako tako pružali model za kritiku negativnih pojavnosti takvog tipa studentskog radikalizma, posebice zbog toga što je dobar dio njih naposljetku završio u oportunizmu i „po vladinim novinama i kancelarijama“, davajući „,iznuđene izjave lojalnosti“, što je upravo kritizirao Gjalski. ${ }^{176} \mathrm{Na}$ taj je način lik pravaškog studentskog aktivista iz samih početaka studentskog pokreta nakon osnivanja modernog zagrebačkog sveučilišta zadržan u daljnjem razvoju pokreta i kao (nepriznati) pozitivni i kao (istaknuti) negativni model, kao njegovo lice i naličje.

Đački pokret u pravom smislu riječi, koji će djelovati kao sastavni dio modernističkog pokreta u cjelini, započinje naporima oko okupljanja svih đačkih društava i listova oko jednog đačkog središta: zagrebačkog đačkog društva Nada i istoimenog časopisa. U tom pogledu, konviktorski časopis Domovina, kao i drugi đački listovi koji izlaze u razdoblju između 1885. i 1895. godine, mogu se smatrati dijelom „prednadaškog“ razdoblja đačkog pokreta u Hrvatskoj. ${ }^{177}$ Njegova je karakteristika ta da u njemu stasaju akteri kasnijeg primarno studentskog modernističkog pokreta, kao i određene njegove formativne ideje, ali se ne može smatrati pokretom u onom smislu u kojem je to bio nadaški pokret, dakle po svojoj intenciji i organizaciji. Od projekata iz tog „prednadaškog“ razdoblja, osim konviktorske Domovine, najvažnije su inicijative Frana Hrčića, tada učenika zagrebačke Velike realne gimnazije. On je 1891./1892. pokrenuo list Realac, koji je nedugo nakon toga preimenovan u Nadu. ${ }^{178}$ Iako kratkog vijeka, njegovo ime postalo je ključno za kasniji đački pokret, prvenstveno zbog njegove intencije da okuplja i ujedinjava učenike različitih zagrebačkih škola. To je po prvi puta realizirano, opet na Hrčićevu inicijativu i opet na kratko (izašao je samo jedan broj), osnivanjem zagrebačke srednjoškolske zajednice koja je primarno trebala izdavati litografirani beletristički „sveščić“ Prvijenci, a koja je, uz realce, okupljala učenike Više trgovačke škole, Velike gimnazije i Muške učiteljske škole. Paralelno s Prvijencima, učenici Velike gimnazije, predvođeni Živanom Bertićem i Ivanom Dobržanskim, osnovali su „zabavni list“, mjesečnik Tomislav, koji je izlazio u dva tečaja 1894. i $1895 .{ }^{179}$ Kasniji pripadnici „generacije 1895.“, protagonisti modernističkog pokreta i urednici njegovih časopisa, osim idejnog formiranja, tijekom svojih đačkih dana stjecali su tako i bitna

\footnotetext{
${ }^{175}$ Luetić, Studenti Sveučilišta u Zagrebu, 332.

${ }^{176}$ A. Flaker, nav. dj., 100.

${ }^{177}$ Marijanović, nav. dj., 46.

${ }^{178}$ Isto, 47.

${ }^{179}$ Isto.
} 
organizacijska i urednička iskustva svojim djelovanjem u raznim društvima i uredništvima đačkih listova.

I osječki protagonisti modernističkog pokreta imali su slična formativna iskustva $\mathrm{u}$ đačko doba. Dušan Plavšić već 1892. djeluje kao knjižničar društva Neven. ${ }^{180} \mathrm{Na}$ osječkoj gimnaziji ključnu ulogu odigralo je hrvatsko đačko književno društvo Javor, u kojemu su svoje prve korake ostvarili Živan Bertić, Ivan Dobržanski, Josip Belović i Janko Koharić. ${ }^{181}$ Svi će se oni prije 1895. preseliti u Zagreb radi nastavka školovanja, gdje će se spojiti s tamošnjom jezgrom đačkog pokreta koja se sve više okupljala oko tzv. Radićeva kruga. Da je tome tako, uz aktivan rad na zabrani držanja omladinskih listova upućuje i mjera vladina Odjela za bogoštovlje i nastavu iz 1893. kojom je zabranjeno držanje visokotiražne Prosvjete u svim srednjim i visokim školama, u kojoj su tekstovima bili zastupljeni i Livadić, Nazor, Nikolić te Bertić. ${ }^{182}$ Slično kao Radić, Dušan Plavšić sudjelovao je u nekoliko protukhuenovskih akcija i demonstracija. Tako je 1894. bio dio tzv. Kalendarske afere, u kojoj je kažnjen zbog raspačavanja zabranjenog kalendara „Bog i Hrvati“. Iste godine, četrdesetak osječkih omladinaca organiziralo je akciju skidanja i cijepanja mađarskih zastava i zastavica s uličnih slavoluka povodom posjete bana i ugarskog ministra trgovine Osijeku u kojoj je stradalo mnogo više zastava nego u mnogo poznatijoj zagrebačkoj demonstraciji godinu dana kasnije - njih gotovo stotinu. Na ljeto 1895., kao jedna od uvertira studentske demonstracije u Zagrebu, odigrala se uspješna demonstracija osječke omladine protiv gostovanja mađarskog veszpremskog kazališta u Osijeku u kojoj je sudjelovao i Plavšić. ${ }^{183}$

Školske godine 1894./1895. u Zagrebu postoji šest đačkih literarnih časopisa: Osvit u Realnoj gimnaziji, Zora, Nada i Tomislav u petom, šestom i sedmom razredu Gornjogradske gimnazije, konviktorska Domovina i Hrvat u nadbiskupskom sirotištu. Od njih, Nada će postati centar đačkog okupljanja. Zalaganjem tajnika đačkog društva Nada Dragana Galovića, ovaj će list već u svojem drugom tečaju prerasti okvire Gornjogradske gimnazije te sakupiti oko 300 pretplatnika iz raznih škola, kao i 44 suradnika, kako iz raznih dijelova Hrvatske, tako i Bosne i Hercegovine te Slovenije. ${ }^{184} \mathrm{U}$ svojem trećem tečaju školske godine 1896./1897. postaje središnji list hrvatskog đačkog, nadaškog pokreta.

Nakon Galovićeve preuranjene smrti, uredništvo lista preuzeo je Vladimir Jelovšek (Teharski), koji je ranije uređivao Osvit. Njemu će se kao glavni suradnici pridružiti Milutin

\footnotetext{
180 „Izvještaj uzajmljenih knjiga članovima društva 'Neven', Osijek, 1892.“, HR-HDA-757 Obitelj Plavšić, k. 53.

181 Marijanović, nav. dj., 23-25. O Kohariću v. Ljerka Racko, „Janko Koharić (prilog poznavanju njegova znanstvenog i publicističkog rada)“" Historijski zbornik 31-32, 1978-1979, 253-269.

${ }^{182}$ Marijanović, nav. dj. 28

${ }^{183}$ Isto, 78 .

${ }^{184}$ Isto, 44.
} 
Cihlar (Nehajev) i Milan Marjanović (Vinkov). Prije dolaska u Zagreb, Milan Marjanović u Karlovcu je početkom 1896. pokrenuo izdavanje lista Zajednica pod utjecajem studentskih demonstracija 1895. godine, odnosno impulsa o potrebi „novoga smjera“ u hrvatskom društvenom i političkom životu koji su dolazili od tada već formirajuće jezgre praških studenata. ${ }^{185}$ Iako je i ovaj list, pogotovo u svojem prvom broju, vidljivo pod utjecajem starčevićanstva, sve su jasnije prisutni elementi „novoga smjera“. Ovo potvrđuje i Svetimir Korporić u svojem pismu Stjepanu Radiću iz ljeta 1896.: „Svu nadu polažem na gimnazije, odavle nam valja započeti, za to ćemo sve sile uložiti, da list u sve gimnazije proturamo. U Karlovcu već imamo pristaša. U Zagrebu ima klub neutralaca od 35 članova, tako bar piše Heimrlu njegov brat, šestoškolac. Mladenci se sastaju, razgovaraju o svemu pa bome, sasvim prirodno, i o politici.“186 Već u svojem prvom broju Zajednica izražava ideju koja će postati ključna za đački nadaški pokret, a to je nužnost (samo)obrazovanja i (samo)organiziranja đaka kao budućih vođa nacionalnog pokreta, i to po uzoru na ilirski pokret (,valja ga [đaštvo, N.T.] ukratko uzgojiti za spas domovine“"). ${ }^{187} \mathrm{U}$ tom smislu je listu i nadjenuto ime Zajednica, jer je kao i brojni drugi listovi pretendirao na okupljanje cjelokupnog hrvatskog đaštva u jedan organizirani pokret. To je izraženo već u 2. broju od 1. veljače 1896. kada se predlaže i osnova organiziranog rada: primarna organizacija $u$ đačkim društvima, savjetovanje sa starijima (ovdje se gotovo sigurno misli na studente-aktiviste novonastajućeg pokreta), zatim međusobna pismena koordinacija te naposljetku okupljanje predstavnika svih društava i škola za vrijeme velikih praznika. ${ }^{188}$ Plan svjesnog stvaranja pokreta jasno izlazi na vidjelo: „Mi trebamo velikih priprava, jer nas veliki posao čeka.“189 Prvi zadatak svakog đaka, međutim, jest učenje, ali ne stihijsko čitanje svega što mu dopadne u ruke, nego organizirano i planirano učenje, kako su istaknuli u obavijesti o izlasku Radićeve Češke slovnice. ${ }^{190}$ Tek na temelju takvog obrazovanja mogu se formirati čvrsti, utemeljeni i nepokolebljivi ideali, kontrast slici slabog i kolebljivog intelektualca koji trpi vladinu opresiju radi očuvanja prihoda $\mathrm{i}$ egzistencije, „puki birokrata i beznačajan kruhoborac.“191 Obrazovanje mladih mora biti dvostruko: ono se mora sastojati od proučavanja njihove okoline, realnog života društva koje ih okružuje, svojeg naroda i njegove historije, ali i od proučavanja samog sebe, svojih misli i osjećaja. Ideje „starijih mladih“ doprle su do mlađih generacija i u domeni književnosti.

\footnotetext{
185 Isto, 45.

186 „Svetimir Korporić - Stjepanu Radiću, Prag, 22. VI. 1896.“, u: Krizman, nav. dj., 200.

187 „Bilješke“, Zajednica, br. 1.

188 „Prikaz knjige I. N. Jemeršića 'Majka u radu za Boga i Hrvatsku'“, Zajednica, br. 2.

189 Isto.

190 „'Češka slovnica' S. Radića“, Isto.

191 „Male refleksije“, Zajednica br. 3 i 4.
} 
Pjesnik postaje idealnim tipom pravoga umjetnika, od svakoga se zahtijeva da pjesničke ideale živi u svim aspektima svojeg života, a ne samo kroz pjesničke fraze: „Koliko li nije u ovim usplamćajima za slobodom, za domovinom, i za vjerom hinjenja, pretvaranja, imitacije, modnosti, suza koje nisu nikada ni oćutile čuvstva.“ ${ }^{192}$ Neoriginalna, neiskrena, imitativna domoljubna poezija zapravo je „oskvrnuće prave poezije, pravoga domoljublja, iskrene vjere [...]“193 Ovdje se već ocrtavaju konture glavne umjetničke ideje hrvatskog modernističkog pokreta: samo je kvalitetna i originalna umjetnost uistinu korisna za razvoj nacionalne kulture. Utjecaj starijih kolega još je očitiji na području politike: „Ne smijemo temeljiti naših prava, ni tražiti naše slobode i ujedinjenja samo u povijesti, nego poglavito u sadašnjoj svijesti naroda najvažnijeg faktora [...] Ne smijemo prilagođivati narod našim idejama, nego naše ideje moramo izvaditi iz naroda $i$ ukalupiti ih prema narodu $i$ njegovim duševnim sposobnostima.“194 Đački aktivisti razumiju da je narod kao kolektivni, masovni subjekt temeljna pokretačka sila moderne politike, ali u tome ujedno vide opasnosti manipulacije $\mathrm{i}$ razdora između vođa i masa koji dovodi do nesloge i slabosti. Nasuprot tome, oni vide kolektivni subjekt, narod, kao ujedinjeni zbir pojedinaca, obrazovanih individua koje dijele isti cilj i ideale. Jednako se tako i političke stranke kao pokretači političkog djelovanja ne smiju sastojati od slabih i povodljivih pojedinaca, nego od onih čvrstih i zasnovanih na idealima, koje se ne može pokolebati i na čije se mišljenje ne može utjecati stranačkom stegom. Osnovna individualistička postavka mlađe generacije modernista dobro je sažeta u zaključku članka „Što nam je raditi“ iz travnja 1896.: „Za to treba da se ulije u cijeli narod svijest slobode, - samostalno mišljenje i to u svakoga pojedinca člana, a ne kakovom govorancijom da se raspali svjetina... Svaki skup koji je domoljuban, ili koji bi morao biti domoljuban, ako hoće imati dobroga uspjeha, neka napiše na barjak slijedeću devizu: 'reformirajte prije svaki pojedinac unutrašnjost svoje individualnosti'.،195

Marjanović je već u Zajednici istaknuo zagrebačku Nadu kao potencijalno okupljalište svih đaka. Međutim, problem je u tome što Nada donosi samo beletrističke radove, a potrebno je ući i „,u pitanja koja mogu i moraju da zanimaju đake“, tj. u društvena i politička pitanja. ${ }^{196}$ On je, međutim, bio spreman „obustaviti separatna izdavanja, ako bi to bilo od nužde i ako bi „Nada“ poprimili sasma u svoj - i naš program““ ${ }^{197} \mathrm{Na}$ proljeće 1896. postignut je dogovor s

\footnotetext{
192 „Opažanja“, Isto.

193 Isto.

194 „ŠSto nam je raditi“, Zajednica br. 3 i 4.

195 Isto.

196 „Opažanja“, Zajednica br. 3 i 4.

197 Isto.
} 
Marjanovićem da pristupi Nadi nakon što dovrši predviđene brojeve Zajednice. ${ }^{198}$ Nakon protumađarskih demonstracija u Karlovcu u svibnju 1896. povodom mađarske milenijske proslave dio đaka koji je sudjelovao u njima osuđen je na zatvorske kazne te izbačen iz gimnazije, među njima i Milan Marjanović. On tada odlazi na nastavak školovanja u Zagreb te se uključuje u rad Nade, čime je karlovačka Zajednica prestala postojati sa svojim 4. brojem.

Nada, kao litografirani časopis učenika šestog razreda Gornjogradske gimnazije, osnovana je 1894. sa zadaćom objavljivanja đačkih književnih pokušaja. Istoimeno „hrvatsko gimnazialno literarno družtvo“ osnovano je u rujnu 1895., a na njegovoj prvoj sjednici u Ilici 27 bilo je prisutno 20 članova. ${ }^{199}$ Sjednicu je otvorio tajnik društva Dragan Galović koji je ciljeve društva oprimjerio dvama izrekama: „Na mladjima sviet ostaje“ i „Slogom rastu male stvari a nesloga sve pokvari““.200 Kao ključnu zadaću Nade istaknuo je „organizaciju svih hrvatskih gimnazija“.201 Dvije ključne odrednice nastajućeg nadaškog pokreta jasno su izražene u pravilima samoga društva. Prva dva paragrafa prvog članka (,Svrha“) Pravila hrvatskog djačkog književnog društva Nada ističu: „§1 Društvu je svrha unapredjivanje duševnih sposobnosti svojih članova. \$2 Društvo će nastojati oko što tješnje sveze (bilo u kojem pogledu) svih hrvatskih djaka." ${ }^{202}$ Potonja je ambicija također izražena u činjenici da se nakon fuzije sa Zajednicom i Osvitom u zapisnicima od 23. listopada 1895. pojavljuje oznaka „hrvatsko đačko društvo“ umjesto ranije „hrvatsko gimnazialno društvo“. Osim toga, od samoga je početka uspostavljen kontakt sa slovenskim đacima, što će se kasnije razviti u plodnu suradnju.

Unatoč početnom entuzijazmu i dobroj recepciji kod drugih đačkih društava, cilj ujedinjenja hrvatskog đaštva nije se pokazao kao laka zadaća. Na sjednicama društva vodile su se rasprave oko toga treba li ono imati i politički sadržaj, pri čemu su se često pojavljivale i različite frakcijske trzavice među đacima. Jedan je đak tako početkom 1897. godine napustio društvo smatrajući da je ono postalo ,protuhrvatsko“ zbog postojanja „slavenskih ideja“ kod nekih njegovih članova. ${ }^{203} \mathrm{~S}$ druge pak strane, u očitom pokušaju medijacije, drugi je đak završio sjednicu društva pozdravima „Slava Starčeviću!“ i „Živio Strossmayer!“204 Rad je društva, međutim, patio od brojnih problema. Jedan od najčešćih prigovora na sjednicama bio

\footnotetext{
198 „XLI. sjednica hrv. djačkog literarnog družtva 'Nade', 8. travnja 1896.“, HR-AHAZU-KN-133 Marjanović, Milan, k. 72.

199 „I. sjednica Hrvatskog gimnazialnog literarnog družtva 'Nade', 25. rujna 1895. u Zagrebu“, Isto.

200 Isto.

201 Isto.

202 „Pravila hrvatskog djačkog književnog društva 'Nade'“،, HR-AHAZU-KN-133 Marjanović, Milan, k. 64.

203 „Zapisnik sjednice hrv. djač. lit. društva 'Nade', 7. siječnja 1897.“, Isto.

204 „LIII. sjednica hrv. djačkog literarnog družtva 'Nade', 18. lipnja 1896.“, Isto.
} 
je nedostatak financijskih sredstava. Osim toga, velik je problem bio i neredovitost te neodgovornost pojedinih članova. Sjednice su društva često bile neuspješne zbog nedostatka kvoruma, a u samo dvije godine šest se đaka izmijenilo na mjestu predsjednika društva. Društvena pravila i praksa korigirani su „u hodu“, ovisno o iskustvu praktičnog rada. Kao jedna od ključnih postavki, međutim, zadržana je praksa da se đački radovi koji će biti štampani u listu prije toga čitaju na sjednicama društva te da njihovo pisanje bude preduvjet za članstvo. Dakako, ponekad je nezrelost inače vrlo ambicioznih đaka uzimala svoj danak, pa su se sjednice društva pretvarale u otvorene svađe i nadglasavanja.

Nakon Galovićeve bolesti i preuranjene smrti, najvažnija organizacijska figura društva postao je Vladimir Jelovšek. On je glavni urednik ključnog, trećeg tečaja lista te predsjednik društva od početka 1897. godine. Jedan od najaktivnih suradnika bio je dakako Milan Marjanović koji je razvijao brojne ideje u smjeru jače organizacijske aktivnosti društva. Naposljetku, Nadin suradnik iz Senja, Milutin Cihlar, početkom 1897. godine seli se u Zagreb te se također aktivno uključuje u rad društva.

U 14. broju trećeg tečaja Nade objavljen je nekrolog Draganu Galoviću iz pera Jelovšeka koji je preuzeo od njega ključne organizacijske poslove, a Cihlar mu je posvetio pjesmu. U njemu je Galović prikazan kao asketski, tragični junak, ,i otac i majka“ Nade. ${ }^{205}$ Međutim, značajno je to što je Jelovšek imao potrebu istaknuti da su Galovića ,zanosila Starčevićeva radikalna načela“ te da mu se može prigovoriti „da je možda kadikada, bio odveć velik strančar“. ${ }^{206}$ Osim toga, iako su njegove osnivačke zasluge ogromne, ,isprva je bilo odveć veliko oduševljenje“, a „sada se ide hladnije, trijeznije započetom stazom.“ ${ }^{207} \mathrm{Iz}$ toga se jasno vidi kako je u trećem godištu Nade intenziviran proces napuštanja pravaštva u okviru đačkog pokreta te je sve izraženije približavanje „novom smjeru“ u razvoju.

Svi navedeni aspekti geneze pokreta mladih kompliciraju jednostavnu sliku koja početke pokreta vezuje isključivo uz studentsku demonstraciju 1895. godine i odlazak studenata u Prag, gdje su usvojili nove ideje koje će prenijeti u hrvatski javni i politički život. Iako svakako ključni, demonstracija i odlazak u Prag samo su dio u nizu čimbenika koji su doprinijeli razvoju modernističkog pokreta mladih. Još prije njihova odlaska iz Hrvatske,

\footnotetext{
205 „Dragan Galović““, Nada, god. III, br. 14, 209.

206 Isto, 211.

${ }^{207}$ Isto, 212.
} 
mladi su bili nezadovoljni društvenom i političkom situacijom u svojoj zemlji. Studentska demonstracija 1895. bila je samo najvidljivija u cijelom nizu iskaza nezadovoljstva mladih koji su u tim godinama itekako učestali. Svijest o društvenim i političkim problemima Hrvatske i o nužnosti promjena nije se stoga probudila tek u doticaju s novim iskustvima $\mathrm{i}$ okolinom u drugim monarhijskim gradovima. Ona je postojala i ranije. Ono što su mladi dobili u susretu s novim sredinama i strujanjima jesu intelektualni i praktični alati koji su im omogućili da prilike u Hrvatskoj podvrgnu temeljitoj kritici, da promišljaju i koherentno govore o alternativama te da se organiziraju kako bi širili i provodili svoje ideje. Međutim, niti u ovome pogledu ne treba apsolutizirati značenje stranih aproprijacija. Kao što smo vidjeli, određene modernističke i „novosmjeraške“ ideje već su kolale među mladima u Hrvatskoj i prije njihova odlaska na studije vani, a ujedno je postojala i donekle razvijena tradicija đačkog i studentskog političkog i kulturnog organiziranja i djelovanja.

Kada mladi, dakle, po prvi puta javno istupaju krajem 1896. godine s proglasom Hrvatske misli, to nije bio rezultat jednostavna, linearna puta od zagrebačkog glavnog trga do „praške univerze“. Geneza modernističkog pokreta mladih obilježena je složenim procesima ispreplitanja stranih aproprijacija i lokalnih tradicija, kao i konkurentskih omladinskih grupacija i vizija djelovanja. Intelektualni transferi i translacije uklapali su se u postojeće lokalne kontekste i ispreplitali s idejama i praksama koje su definirale intelektualna, politička i kulturna polja. Hrvatski modernistički pokret na prijelomu stoljeća stoga je ujedno samo jedan u nizu fin de siècle modernističkih pokreta i modernizama, čineći jednu ili više točaka u globalnoj mreži, ali je ujedno i specifičan s obzirom na zadane lokalne okolnosti koje su definirale okvir njegova razvoja te samim time utjecale na modifikacije njegova intelektualnog sadržaja i političkih praksi. 


\section{OBLIKOVANJE I ŠIRENJE POKRETA}

„.Ah, Bože moj, još nam treba i to, da će naša djeca debatovati o politici kao odrasli?' 'Mislite li možda ... da je bolje, kad odrasli debatuju o politici kao - djeca?'“ - Al. L. Kielland, Otrov ${ }^{208}$

\section{1. Aproprijacije moderne češke politike}

U prosincu 1896. u hrvatskim se novinama pojavio „Proglas Hrvatske misli“ $\mathrm{s}$ potpisom Vladimira Skočića, studenta medicine, Milana Metelke, studenta filozofije i Frana Poljaka, studenta prava. Glavni je formulator proglasa, međutim, bio Stjepan Radić, uz uvažavanje sugestija drugih incijatora. ${ }^{209} \mathrm{U}$ listopadu je u Zagrebu održan sastanak dvadesetak ljudi na kojemu se detaljno raspravljalo o konceptu novoga studentskog časopisa. ${ }^{210} \mathrm{Na}$ sastanku su iznesena brojna, često i oprečna mišljenja: dok su Ivan Lorković i Milan Šarić predlagali da časopis ima prvenstveno literarno obilježje, neki su sudionici smatrali da bi on trebao biti glasilo nove političke stranke u nastanku. Naposljetku je prevagnulo Radićevo stajalište koje je otjelovljeno u proglasu i prvim programatskim tekstovima Hrvatske misli. Iz sačuvane korespondencije može se doznati kako je bilo ukupno trideset i četiri pokretača Hrvatske misli: jedanaest u Zagrebu, devet u Beču, osam u Pragu i šest u Grazu. Ona je dakle bila produkt koordiniranog djelovanja aktivnih „manjina“ studentskih društava u glavnim sveučilišnim centrima hrvatskih studenata. Uredništvo i izdavanje lista prepušteno je prvenstveno praškim studentima. Osim što je inicijativa ponajviše dolazila iz Praga, razlog tomu je i u prevladavajućem mišljenju da bi izdavanje časopisa u Zagrebu bilo nemoguće zbog cenzure, a da u Beču ili Grazu ne bi naišao na željenu podršku, što se navodi i u samom proglasu. Na listopadskom sastanku dogovorena je i predložena redakcija lista, u koju su trebali ući: Belović, Bertić, Heimrl, Korporić, Metelka, Poljak, A. Radić i Šarić.

Proglas Hrvatske misli započinje identificiranjem poraznog stanja među hrvatskim studentima. Rastrovani politički, društveni i literarni život, stranačka trvenja i osobne razmirice te pomanjkanje ideja odvraćaju đake od „ozbiljne nauke i priprave za život“, zbog

${ }^{208}$ Citirano prema: Milan Heimrl, „Iz novije političke povjesti češkoga naroda“, Hrvatska misao, god. I, br. 4, 126.

209 „Stjepan Radić - Mariji Dvořákovoj, [jesen 1896.?]“, u: Krizman, Korespondencija Stjepana Radića, 235.

${ }^{210}$ Flaker, Časopisi, 18. 
čega nije moguće steći „vlastitoga osvjedočenja“ niti „značaja“. Bez njih, studenti postaju ovisni o političkim skupinama, dok oni samostalniji padaju u očaj zbog nemogućnosti povezivanja i korisna rada, u čemu najveću ulogu ima „policajnim duhom zadahnuta hrvatska vlada“. Upravo zbog toga pokreće se list hrvatske mladeži u Pragu, daleko od dohvata hrvatske cenzure, te bi on trebao biti središte oko kojega će se okupljati svjesnije i neovisnije đaštvo. Kao prva zadaća lista navedena je borba protiv „teoretičkog dogmatizma“ koji je odgovoran za nepremostive stranačke opreke u Hrvatskoj:

„Mjesto natezanja za stilizaciju programa, mjesto historijskih raščinjavanja, valja da dođu velika savremena pitanja ekonomska, filozofska, literarna, kritička i specijalno politička. Valja i nama zagledati na poprište velikih modernih pokreta, na svim poljima života, valja i nama shvatiti politiku kao rad, kao život, a ne kao optuživanje i teoretizovanje.“

Na prvom se mjestu, dakle, nalazi zahtjev za novim, modernim shvaćanjem politike, nasuprot tradicionalnoj, državnopravnoj politici. Kao druga, iako označena kao „ponajvažnija“, zadaća ističe se upoznavanje s mišljenjem naroda i njegovim potrebama, nužno kako „nas pogled na prostrano obzorje zamašnih evropskih pokreta ne bi udaljio od zdravoga shvaćanja narodnih potreba i težnja“. Ideje i prakse moderne politike moraju, dakle, biti aproprirane i prilagođene domaćim, lokalnim uvjetima. Fundament nacionalne politike mora biti i ostati narodna kultura, narodni život i narodna misao. U tom smislu potrebno je, između ostaloga, ispitati što narod misli o inteligenciji, o činovništvu, o političkim idealima slobode i jedinstva domovine, kako na njega djeluju stranačke razmirice i politička agitacija, a kako procesi rasapa seoskih zadruga. Tek na temelju toga moguće je razviti političke, kulturne i gospodarske politike. Kako zaključuju: „Neda se za narod raditi, ne poznade li se njegove težnje i potrebe.“ Tek na posljednjem, trećem mjestu, kao zadaća lista navedeno je to da on mora biti „ogledalo đačkih materijalnih, intelektualnih i moralnih prilika“, pri čemu će se posebno „oštroj kritici podvrći policajni sistem na hrvatskom sveučilištu.“

Kako bi izbjegli ikakvu sumnju, pokretači Hrvatske misli jasno ističu kako „list dakle nema stranačkog obilježja, ali mu je obilježje narodno i napredno.“ On se dakle predstavlja kao sinteza nacionalne politike i modernih europskih političkih i društvenih kretanja, koje valja primijeniti kako bi se ispunili nacionalni ciljevi. U tom smislu oni „u ime narodne hrvatske individualnosti i u ime napredne civilizatorne misli“ pozivaju svoje kolege da pristupe k pokretu kao suradnici ili kao pretplatnici. Što se tiče književnog programa lista, u proglasu se navodi kako će ,primati i literarne stvari, ali samo pomanje ali to sve treba da bude iz narodnoga života (pjesme, crtice, novele)“, pri čemu pjesme i crtice mogu biti u „modernom, savremenom duhu sa strogo subjektivnim obilježjem“, ponovno naznačujući 
ideju sinteze „,narodnog“ i ,modernog“. Da su pokretači za list imali veće ambicije od pukog glasila hrvatskih studenata vidi se iz nastavka proglasa koji je više tehničkog karaktera. U njemu se navodi da će list izlaziti i u slučaju da se većina đaštva izjasni protiv njega, jer ga ne pokreću samo kao đački, nego i kao kritičko-politički list. Nastojeći preduhitriti napade, inicijatori navode da će kao protivnike lista smatrati samo one koji im se tako pismeno izjave do 1. siječnja 1897. godine, dok će sve pretplatnike smatrati pristašama smjera koji list zastupa. List će ciljati i na češke, ali i na druge slavenske (poljske, ruske) pretplatnike, te će tiskati i priloge na tim jezicima ukoliko sakupe više od pedeset pretplatnika tih jezika. Čim to bude moguće, u planu je da se list preseli u Zagreb. ${ }^{211}$

Nije trebalo čekati dugo na reakciju hrvatske političke javnosti. Hrvatska opozicija jasno je prepoznala da se istup mladih prvenstveno tiče nje. Pozdravljajući aktivnost mladih i razumijevajući njihovu ogorčenost hrvatskim političkim prilikama, prije svega dezorijentiranošću i razjedinjenošću opozicije i strančarstvom mladeži, Obzor je ipak s dozom skepse postavio pitanje: „Što hoće novi list i njihovi pokretači?“212 Obzoraši su jasno dali do znanja da budnim okom već godinama prate aktivnosti mladeži, od nezadovoljstva raspadom pregovora hrvatskih oporbenih stranaka, preko lanjske demonstracije, pa sve do doticaja s praškim studentskim pokretom i češkim političkim prilikama. Pisca Obzora, međutim, najviše je mučilo pitanje postoji li kod mladih tendencija prema osnivanju nove političke opcije. Iščitavajući proglas kao u tom pogledu nejasan, on je vidio tri mogućnosti. Prvo, da su zbog nezadovoljstva i želje za reformama unutar mladeži i opozicije pokrenuli list kao mjesto rasprave i bistrenja pojmova na temelju kojega bi se trebao formulirati program ujedinjenja i „unutrašnjeg preporoda“ hrvatskih đaka. Drugo, da su praški studenti već „sporazumni u programu kao temelju nove stranke“, ali da još s time ne žele izaći u javnost kako u startu ne bi izazvali izrazito negativne reakcije. I treće, da mladi zapravo stoje na temeljnim stanovištima hrvatske opozicije te kako žele pružiti mladeži prostor za otvorenu raspravu i suživot stranački podijeljenih tabora. Dakako da pisac Obzora najveću opasnost vidi u drugoj mogućnosti. On kao pravi smjer lista priželjkuje u kombinaciji druge dvije mogućnosti: u modernoj reviji koja treba podučavati mladež o najnovijim političkim, socijalnim i kulturnim kretanjima, ali ujedno služiti kao mjesto zbližavanja svih hrvatskih đaka na osnovu programa hrvatske opozicije iz 1894. godine. U protivnom, upozorava, „djaci neće prihvatiti list pod svoj [...] bojeći se, da bi moglo doći do novih smutnja. ${ }^{\text {“213 }}$ On stoga poziva mlade da se jasno

\footnotetext{
${ }^{211}$ Svi navodi iz: „Hrvatska misao“, Obzor, XXXVII, 286, 12. 12. 1896.

212 „Hrvatska misao“, Obzor, XXXVII, 292, 19. 12. 1896.

${ }^{213}$ Isto.
} 
izraze, doslovno im stavljajući riječi u usta: „Drugovi! Mi stojeći na temelju hrvatskog državnog prava i narodnog načela, hoćemo pokrenuti list, slobodan u kritici i nezavisan, posrednik medju svima vama; mi hoćemo složan rad.“214 Frankovačko Hrvatsko pravo bilo je mnogo manje suptilno. Oni su istaknuli kako je ,sviestno hrvatsko djačtvo“ prozrelo namjere ovog „listića“ te se nije dalo zavesti od strane ,poznatog Radića“ i njegovih pristaša koji se žele igrati stranke i urednika. ${ }^{215}$

Reakcija hrvatskih studentskih društava kojima je upućen poziv na suradnju nije bila obećavajuća. Odbor akademskog društva Hrvatska iz Graza odgovorio je da će podržati list samo ako će se voditi Starčevićevim načelima, a u suprotnom će „najodlučnije protiv njega raditi.“216 Ivan Krnic, predsjednik odbora akademskog društva Zvonimir u Beču diplomatski je formulirao odgovor, tvrdeći kako društvo ne smije raspravljati o političkim stvarima. Međutim, ističe kako je održana skupština hrvatskih studenata u Beču na kojoj se raspravljalo o pozivu Hrvatske misli. Iako ona „radi kasnog vremena (2 sata u noći) nije došla do definitivna zaključka“, Krnic izvještava kako se iz toka rasprave moglo zaključiti „da se hrvatski djaci u Beču ne slažu sa listom, jer nema unutra jasnog političkog programa i jer se s tim kani kod nas u Hrvatskoj uvesti kao nova politička stranka. “217 Iz Zagreba i Innsbrucka nisu stigli odgovori. Hrvatska misao međutim ističe kako su se u Zagrebu studenti tri puta bezuspješno sastajali, da bi treći puta njih četrnaestorica, pod utjecajem studenta prava Aleksandra Horvata zaključili da hrvatskoj mladeži ne trebaju nove ideje niti nova stranka, jer im je oboje već podario Ante Starčević, a da će oni sami u Zagrebu pokrenuti svoj beletristički list. $^{218}$

Niti sami pokretači lista nisu bili posve složni oko vlastita proglasa. Milivoj Dežman očito je vrlo dobro poznavao razmišljanje hrvatskih opozicijskih krugova jer je izrazio bojazan „da se između redaka čita tendencija listu: udariti temelj novoj političkoj stranci.“219 U svojem odgovoru, međutim, Milan Heimrl tvrdi kako je takva tendencija njemu, kao jednome od formulatora proglasa, posve nova: „Listu je glavna tendencija - a to priznajem da je u proglasu slabo istaknuto: unutrašnji preporod i ujedinjavanje hrvatskog đaštva. Bez unutrašnje zajedničke podloge ne može se doći do sjedinjenja, a jer nam je tek svrha, da izgradimo svoj zajednički program ili bolje, da ga kritički prosudimo, obradimo i za svoj priznamo, - to nijesmo u obće mogli izaći s programom, - (a da ne upadnemo u grijehe naših

\footnotetext{
${ }^{214}$ Isto.

${ }^{215}$ Agičić, Hrvatsko-češki odnosi na prijelazu iz XIX. u XX. stoljeće, 145.

216 „Da se razumijemo“, Hrvatska misao, god. I, br. 1, 26.

217 Isto, 27.

218 Isto.

${ }^{219}$ Milan Heimrl - Milivoju Dežmanu, Prag 8. XII. 1896., HR-AHAZU-KN-44 Dežman, Milivoj, k. 11.
} 


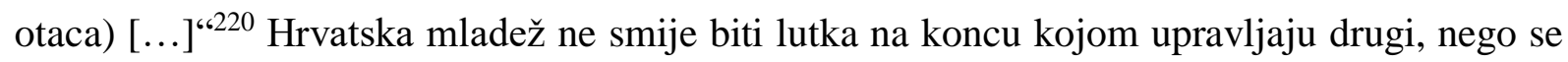
mora emancipirati i imati vlastite nazore, ponajviše što se tiče „modernih, aktuelnih pitanja, koja već kucaju i na naša vrata“. Jedino je u tom smislu to „nova stranka ili bolje nova struja, pokret“ ${ }^{221}$ Dežman je, međutim, zahtijevao dodatna pojašnjenja. Zanimalo ga je prije svega priznaju li praški mladi hrvatsko državno pravo kao temeljno političko načelo. Heimrl mu posve otvoreno odgovara kako su oni u tom pitanju podijeljeni: nekima je temeljno političko načelo hrvatsko državno pravo (Bertić, Wodwarka), a nekima je to „narodno načelo“, dok im je hrvatsko državno pravo ,sporedno, u koliko se ne kosi s nar. načelom.“222 U potonje ubraja Poljaka, Lorkovića, Korporića, Šarića i sebe. Drugim pitanjem Dežman mora da je tražio decidiran odgovor oko osnivanja nove političke stranke, jer mu Heimrl odgovara: „Ne ćemo organizirati nove stranke protiv sadašnjih. U koju ćemo stupiti ne znamo još za sada, ali - to kažem otvoreno - bude li od potrebe i shodno ne ćemo se žacati stvoriti i novu polit. stranku, držeći, da su nove smutnje, stari grijesi i zasukanost sto puta veće zlo, nego valjana nova stranka.“223 List je dakle „,neutralan“, pa svaki njegov suradnik može ostati član stranke kojoj pripada te slobodno za njega pisati.

Kako bilo da bilo, praški su studenti krajem 1896. godine svojim prvim manifestnim istupom stupili u javnost, a u siječnju iduće godine prvi broj Hrvatske misli štampan je u 2000 primjeraka i razaslan pretplatnicima i drugim potencijalnim čitateljima. ${ }^{224}$ List je nosio podnaslov: „list za književnost, politiku i pitanja socijalna.“ Uredništvo su sačinjavali isključivo praški studenti: Živan Bertić, Milan Heimrl, Franjo Hlaváček, Svetimir Korporić, Franjo Poljak i Milan Šarić. Kao glavni i odgovorni urednik naveden je Franjo Hlaváček. U prvome je broju, međutim, tiskana njegova kratka izjava „Nekoliko riječi pro domo“ u kojoj ističe kako list ne izražava u potpunosti njegove stavove te se s dosta toga ne može složiti, ali to i dalje ne uklanja njegovu odgovornost za list koji je prihvatio uređivati zbog simpatija $\mathrm{s}$ njegovom idejom. ${ }^{225}$ Bilo je, dakle, jasno da Hlaváček kao glavni urednik nije bio i glavni idejni formulator lista. Predvodnik je u tome svakako bio Stjepan Radić, koji je u većini i formulirao prve programatske tekstove ove skupine. Kako je u to vrijeme već bio na putu prema Parizu gdje je planirao nastaviti svoje obrazovanje, Radić se izuzeo od svakodnevnog uređivačkog posla na listu, zadržavajući pritom snažan intelektualni utjecaj.

\footnotetext{
${ }^{220}$ Isto.

221 Isto.

${ }^{222}$ Milan Heimrl - Milivoju Dežmanu, Prag 16. XII. 1896., HR-AHAZU-KN-44 Dežman, Milivoj, k. 11.

223 Isto.

224 „Stjepan Radić - Mariji Dvořákovoj, Prag - 15. I. 1897.“, u: Krizman, nav. dj., 240.

225 „Nekoliko riječi pro domo“, Hrvatska misao, god. I, br. 1, 32.
} 
Iz proglasa Hrvatske misli jasno je da su praški mladi inicijalno bili pod najsnažnijim dojmom čeških političkih kretanja. Iako su najavljivali široki tematski raspon lista, koji bi uključivao i društvene i kulturne teme, politička je dimenzija bila dominantna. Stoga je prvo potrebno razmotriti aproprijacije ideja i koncepata suvremene češke politike, a posredno onda i moderne masovne politike, jer će one biti temeljne za ideološko oblikovanje pokreta mladih.

Krajem 19. stoljeća intenzivirala se kriza klasične građanske liberalne političke prakse. Korjenite društvene promjene koje su obilježile europski modernitet $\mathrm{u}$ devetnaestom su se stoljeću manifestirale kroz izraženu urbanizaciju, agrarnu krizu, masovne migracije stanovništva iz sela u grad, oblikovanje radničke klase te tehnološke inovacije. Te je procese pratio i prodor novih političkih ideologija i pokreta, koji se sve više temelje na ideji inkluzije masa u politiku. U slučaju jednog od najznačajnijih modernih političkih pokreta, socijalističkog, realizacija te ideje značila je s jedne strane borbu za opće pravo glasa i oblikovanje sindikalnog pokreta kao reformističke grane opće borbe za „novo društvo“, a s druge strane održavanje tinjajuće revolucionarne ideje radničkog pokreta. ${ }^{226} \mathrm{U}$ nekim drugim slučajevima, pak, ideja uključivanja masa značila je tek iskorištavanje metoda masovne politike za političke probitke određenih grupa ili pojedinaca, što je činilo okosnicu tzv. bonapartizma. Sve snažnije i učestalije kapitalističke konjunkture i krize zaoštravale su društvene opreke i jaz između siromašnih masa stanovništva i bogate manjine, uzrokujući slom slojeva tradicionalnih sitnih obrtnika i trgovaca. U takvoj su se situaciji radikalni nacionalizam i protofašizam mogli etablirati kao relevantan politički faktor, vješto kombinirajući metode masovne politike i sublimacije društvenih frustracija i strahova $u$ simboličkog Drugog kao izvornog neprijatelja nacije ili rase. ${ }^{227}$ U svemu tome, klasični građanski liberalni parlamentarizam koji je počivao na ograničenom pravu glasa i odvajanju „javne“ i „privatne“ sfere nije mogao izaći na kraj s novim političkim izazovima. Kraj 19. stoljeća karakterizira naoko paradoksalna situacija u kojoj sve veću ekonomsku moć građanskih elita prati kriza klasične građanske liberalno-parlamentarne političke prevlasti. ${ }^{228}$

$\mathrm{Na}$ temelju ove opće slike o „krizi liberalizma“ razvijena je u uvodnom dijelu elaborirana schorskeovska paradigma koja je trebala objasniti naoko paradoksalnu situaciju paralelnog političkog poraza bečkog liberalizma te ekonomskog, intelektualnog i kulturnog uzleta koji se u tome gradu događa oko 1900. godine, a čiji su nositelji bili upravo pripadnici

\footnotetext{
${ }^{226}$ Usp, Geoff Eley, Forging Democracy: The History of the Left in Europe, 1850-2000, Oxford, 2002, posebno str. 62-123.

${ }^{227}$ Usp. Ishay Landa, Fašizam i mase: pobuna protiv posljednjih ljudi, 1848. - 1945., Zagreb, 2019, 45-161; George L. Mosse, The Nationalization of the Masses: Political Symbolism and Mass Movements in Germany from the Napoleonic Wars through the Third Reich, Ithaca i London, 1991.

${ }^{228}$ Schorske, Beč krajem stoljeća, 128-132.
} 
liberalnog građanstva. Također već iznesene kritike te paradigme posebno je dobro pratiti na primjeru praške situacije na prijelomu 19. i 20 stoljeća, koja je ujedno važna i za razumijevanje hrvatskih modernističkih kretanja u tom razdoblju. Društveni i politički život u Pragu tijekom druge polovice 19. stoljeća bio je prvenstveno definiran češko-njemačkim nacionalnim sukobom. Kao posljedica toga, u gradu su se razvile paralelne institucije, kako one državne (npr. odgojno-obrazovne, od osnovnih škola pa sve do sveučilišta), tako i institucije građanske javnosti, kao što su udruge, festivali i kulturne manifestacije. Iako su osobne i poslovne veze u svakodnevnom životu, dakako, često nadilazile nacionalne podjele, nacionalistički politički aktivisti trudili su se oko toga da se one jasno očuvaju u okviru javnog i političkog života. ${ }^{229}$ Nositeljice tih nacionalnih pokreta zapravo su bile liberalnograđanske elite. Iako su one sudjelovale u zajedničkom modelu kulturne i političke prakse europskog građanstva 19. stoljeća, njihovi konkretni politički sadržaji bili su definirani specifičnim nacionalnim okvirima. Opće forme i opća načela tako su dobivali svoje specifične artikulacije koje su u danom kontekstu mogle funkcionirati kao oprečne i sukobljene. U umjetnosti je, stoga, modernistički napad na etablirane kanone europske građanske umjetnosti 19. stoljeća mogao biti shvaćen kao napad na nacionalnu kulturu i kao izdaja ciljeva nacionalnog pokreta. Liberalno-nacionalistička građanska sinteza zahtijevala je od umjetnosti primjenu općih estetskih načela i umjetničkih konvencija na konkretni nacionalni sadržaj, s ciljem nacionalne mobilizacije i (su)kreacije nacionalne, ali i građanske estetske kulture. Baš zbog toga, modernistička su nastojanja često išla i u smjeru izbjegavanja ovakve konfrontacije, upotrebljavajući formulu larpurlartizma kao sredstva za odjeljivanje umjetničkog izazova upućenog konvencijama građanske kulture od političkog izazova nacionalističkoj politici. U tom su smislu najčešće funkcionirale aproprijacije strujanja dekadentizma. Ova je struja modernizma u Češkoj bila zastupljena oko časopisa Moderní revue pro literaturu, uměni a život koji je pokrenut 1894. godine. Grupa koju je predvodio kritičar Arnošt Procházka pronalazila je insipiraciju u djelima francuskih simbolista, europskog dekadentizma i Friedricha Nietzschea, odbacujući društveni i politički angažman modernizma okrećući se temama individualne psihologije, senzualizma, misticizma i okultnog. ${ }^{230}$ Iako je aktivno odbacivala politički angažman, i ona je ipak priželjkivala korjenite promjene u češkoj nacionalnoj umjetnosti, zagovarajući aproprijacije širih europskih

\footnotetext{
${ }^{229}$ Gary B. Cohen, „Fin-de-siècle Vienna and the Larger Central Europe 1900: The Experience of Prague's Intellectuals“, 5 .

${ }^{230}$ Isto, 8; Robert B. Pynsent, "The Decadent Nation: The Politics of Arnošt Procházka and Jiří Karásek ze Lvovic”, u: László Peter, Robert B. Pynsent, Intellectuals and the Future in the Habsburg Monarchy 1890-1914, London, 1988, 63-64.
} 
modernističkih kretanja, zbog čega je opet predstavljala prijetnju tradicionalnoj liberalnonacionalističkoj građanskoj sintezi. Mnogo decidiraniji i cjelovitiji izazov došao je od grupe okupljene oko časopisa Rozhledy. U njemu je u listopadu 1895. objavljen manifest „Češká moderna“ koji je sastavio pjesnik Josef Svatopluk Machar, a potpisala ga je skupina čeških književnika, intelektualaca i političara realističke i naprednjačke orijentacije, među kojima su bili i F. X. Šalda te F. V. Krejčí. Machar je manifest formulirao po uzoru na europska modernistička kretanja, prije svega imajući pred očima modernistički manifest Hermanna Bahra s čijom su grupacijom okupljenom oko bečkog časopisa Die Zeit češki modernisti održavali kontakte. ${ }^{231}$

Potpisnici manifesta kao svoj glavni zahtjev postavljaju pravo na slobodu govora i na „nemilosrdnu kritiku“. ${ }^{232} \mathrm{Na}$ to ih je natjerao stav starije generacije, odnosno njezina reakcija na stvaralaštvo i ideje mlađih. Zbog nepremostiva jaza koji ih dijeli, mladi su primorani odbaciti etabliranu tradiciju i krenuti vlastitim putem. Modernisti iznose svoja temeljna viđenja o kulturi i politici. Kritika je za njih kreativni, umjetnički i stručni rad te ju smatraju nezavisnim književnim žanrom koji je jednak svima ostalima. Zbog toga ona ne smije biti epigonska, diletantska niti politički uvjetovana. Kao vrhovno načelo postavljaju individualnost, koju zahtijevaju i u umjetnosti i u kritici. Jednako kao što kritika mora biti vrhunska i profesionalna, tako i umjetnost ne smije biti puki „odjek stranih tonova“, eklektička i diletantska, u kojoj se samo povezuju ,posuđene ideje i stilovi, rimovani politički programi, imitacije pučkih napjeva, versificirani folklorni kič itd.“ U situaciji „kada se sve staro urušava i novi svijet započinje“, umjetnost mora iznad svega biti zasnovana na individualnosti koja ,puca od života i stvara život.“ Individualnost nije u opreci s nacionalnošću, ali se od umjetnosti ne smije prisilno zahtijevati „češki karakter“. Ako umjetnik istinski „bude svoj“, onda će nužno biti i Čeh, odnosno u skladu s interesima nacionalne kulture. To, međutim, ne znači da se umjetnost smije svesti na pomodnost: „Za nas, moderno nije ono što je slučajno u modi: prekjučer realizam, jučer naturalizam, danas simbolizam, dekadencija, sutra sotonizam, okultizam, te efemerne lozinke koje uvijek izjednačavaju i homogeniziraju književna djela na nekoliko mjeseci i koje oponašaju literarni kicoši.“ Umjesto toga, oni zahtijevaju ,istinu u umjetnosti“, ali koja nije „fotografija vanjske stvarnosti“, nego „unutrašnja istina, čiji je jedini kriterij njezin nositelj - pojedinac.“ Kao što je već naglašeno, modernisti se ne ograničavaju na umjetničko polje. Oni i na političkom

\footnotetext{
${ }^{231}$ Cohen, nav. dj., 7.

${ }^{232}$ Svi navodi u paragrafu iz: „The Czech modern“, u: Ahmet Ersoy, Maciej Górny, Vangelis Kechriotis (ur.), Modernism: Representations of National Culture: Discourses of Collective Identity in Central and Southeast Europe 1770-1945: Texts and Commentaries, volume III/2, Budimpešta, 2010, 260-265. Prijevod moj.
} 
polju vide analogne probleme i ciljeve, koji proizlaze iz iste društvene situacije. Na najjačem se udaru našla mladočeška stranka. Mladi ih prozivaju za plitkoumnost i za razočaranje kojime je nagrađeno povjerenje koje su dobili. Za razliku od njih, mladi priznaju staročesima zasluge kao edukatorima. „Očevi“ - odnosno mladočesi - koji su preuzeli njihovu tradiciju i misiju, pokopali su ili su samo živjeli na račun njihovih postignuća, tako da će njihova djelatnost biti zapamćena kao loše razdoblje češke kulturne povijesti. Mladi su se stoga počeli brinuti sami o sebi. Za njih politika nije makijavelistička znanost niti puka pozornica za iskorištavanje entuzijazma nacije. Politika je „težak, naporan posao i samo posao.“ Ona je tih posao, koji se ne svodi na to da se uspije ući u parlament, čime tek započinje nečiji rad. Politika traži žrtvu, ,ništa za nas, sve za cilj.“ Zbog toga i u politici vrhovno načelo mora biti individualnost. Samo cijeli, oplemenjeni pojedinici mogu se vinuti takvoj zadaći.

Ovaj će manifest biti jedno od ključnih referentnih mjesta za hrvatski modernistički pokret. Hrvatska misao nikada nije krila svoje češke uzore, dapače, ona ih je svjesno i spremno stavljala u prvi plan. Milan Heimrl tako je napisao članak „Iz novije političke povjesti češkoga naroda“ objavljen u Hrvatskoj misli u nastavcima, u kojem kroz informiranje hrvatske javnosti o najnovijim političkim kretanjima u Češkoj također pruža plastičan uvid u hrvatske modernističke aproprijacije čeških uzora. Ovaj je tekst posebno zanimljiv jer kroz iznošenje povijesti češkog modernističkog pokreta mladih zapravo govori o tendencijama vlastita pokreta. Heimrl svoj članak karakteristično otvara konstatacijom o ključnoj ulozi mladeži u novijem češkom političkom životu. Ona je pokrenula pokret koji je dubok po svojim idejama i širok po svojoj namjeni jer mu je temelj u studiju ,velikih modernih pitanja i problema“, a usmjeren je „svim slojevima naroda bez razlike - cijelomu narodu.“233 Heimrlova je namjera da se i hrvatsko đaštvo upozna s ovim idejama i češkim omladinskim pokretom, a sve kako bi, kao i češki đaci, od ,praznoga vikača i fanatika“ postao „radnik“. 234 Prije emancipacije češke mladeži kroz ovaj pokret, i oni su - kao što je slučaj u Hrvatskoj više iz zanosa, nego iz uvjerenja prihvatili „slobodoumnu“, mladočešku stranku kao novu pojavu na češkom političkom nebu. ${ }^{235}$ Jasno implicirajući analogiju s pravaštvom, Heimrl kaže kako je to rezultiralo fanatizmom, stranačkom netolerancijom i ignorancijom, zato što su mladi to učinili „bez svoga vlastitog na znanju temeljenoga suda i uvjerenja“. ${ }^{236}$ Sav rad se sveo na priređivanje plesova i izdavanje izjava, a đaci su postali samo puko oruđe stranaka. Heimrla sve to podsjeća na sjednice zagrebačke Zastave u posljednjoj godini njezina života,

\footnotetext{
${ }^{233}$ Milan Heimrl, „Iz novije političke povjesti češkoga naroda“, Hrvatska misao, god. I, br. 1, 22.

${ }^{234}$ Isto.

235 Isto, 23.

${ }^{236}$ Isto.
} 
kao i na prvi sastanak hrvatskih akademičara u Zagrebu. Situacija se, međutim, počela mijenjati kada se pod utjecajem (masarykovskog) realizma među đacima počela rađati nova, naprednjačka stranka. Realizam se u češkoj politici pojavio iz velikog spora oko Zelenogorskih i Kraljodvorskih rukopisa ${ }^{237}$, poprimivši potom konture rasprave oko državnopravne politike i nacionalne kulture, da bi se razvio u „borbu za pravo slobodne kritike i slobodu mišljenja protiv mnogih fanatika staro- i mladočeških.“238 Realisti, predvođeni Masarykom, funkcionirali su jedno vrijeme kao grupacija unutar mladočeške stranke, da bi, razočarani njezinim smjerom, napustili stranku i počeli funkcionirati izvan aktivne stranačke politike, ali kao ,stroga kritika“, baš kako su praški mladi zamislili svoju ulogu. ${ }^{239}$ Heimrl općenito prikazuje Masaryka kao jednog od glavnih uzora mladih, kako u osobnom, tako u političkom pogledu. Kao profesor, Masaryk privlači brojne studente na svoja predavanja, ne libi se raspravljati s njima o svim temama te mu nije ispod časti pisati za studentski list. Što se tiče njegovih političkih ideja, Heimrl na prvo mjesto stavlja poimanje politike ne kao deklamacije, nego kao rada. Politika, također, nije jedino, pa niti najvažnije polje rada: „Prvo je i glavno unutrašnje kulturno, moralno i materijalno blagostanje

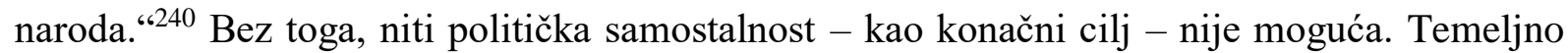
stanovište inteligencije mora biti humanizam, a njena glavna zadaća „da radi u korist onih razreda pučanstva, s kojima se dosele maćuhinski postupalo.“241 Narod sačinjavaju svi društveni slojevi, uključujući radnike i seljake. Češki su studenti prihvatili ove ideje i inicijative Masaryka i krenuli u svoju vlastitu reformu, kako bi bili spremni na zadatke koji su pred njima. Kao organ te reforme poslužio im je list, Časopis češkého studentstva, „koji bi imao da zaspe one jaruge, što dijele djaštvo od ostalih vrsta naroda, koji će nemilice šibati djačke mane, raspravljati o djačkim pitanjima - promijeniti čitav smjer djačkoga života“", baš kao Hrvatska misao. ${ }^{242}$ Naprednjački studenti postavili su se prema mladočeškim zastupnicima s jasnim političkim zahtjevima koje će u velikoj mjeri preuzeti i hrvatska napredna omladina: oštra parlamentarna opozicija, opće pravo glasa za muškarce i žene, briga za radništvo, briga za gospodarsko blagostanje naroda, pučka naobrazba, ženska emancipacija itd. Studenti razvijaju široku djelatnost na terenu, primarno među radništvom koje - u

\footnotetext{
${ }^{237}$ Riječ je o dva navodna rukopisa koji su sadržavali epske pjesme napisane na starom češkom jeziku. Tijekom 1886. godine, Masaryk i češki filolog Jan Gebauer u nizu članaka objavljenima u časopisu Athenaeum razotrkili su rukopise kao romantičarsku krivotvorinu, što je predstavljalo kritički udar na historicističko-romantičarsku češku tradiciju.

238 Isto, 60.

239 Isto.

${ }^{240}$ Isto, 61.

241 Isto.

242 Isto, 61.
} 
suprotnosti sa socijaldemokratskim internacionalizmom - senzibiliziraju za češki nacionalni program. U tom smislu, naprednjački program predstavlja bitnu promjenu češke politike. Ta se promjena sastoji ponajprije u njezinu širenju. Staročeška se stranka ograničavala na državnopravnu politiku. Mladočesi su proširili taj program na kulturna i socijalna pitanja, ali samo na općenitoj razini i bez stvarne političke operacionalizacije. Tu nastupa naprednjački program koji odgovara potrebama novog vremena: „Naprednjačka je stranka u sebi spojila oba smjera: i narodno-politički i socijalno-ekonomski, ona je prva stranka gdje rad duševni i fizički bratski sebi pruža ruku! U njezinom se programu spajaju dvije velike ideje: ideja opće dobrobiti i ideja narodne samostalnosti, naprednjački je program u najširem smislu: socijalizacija narodnog programa. “243 Oni također donose novo, otvorenije i uključivije poimanje države: „Država nije kalup, nego skup svih pojedinaca: Gradjanstvo je država, a država gradjanstvo.“244 To dakako pretpostavlja i potiskivanje ideje državnog prava nauštrb ideje narodnog prava, što je bila jedna od ključnih točaka Masarykove realističke kritike. Naprednjaci ne odbacuju u potpunosti državno pravo, ali ono za njih postaje samo sredstvo, a ne cilj po sebi. U tom smislu, oni preuzimaju neke starije ideje češke nacionalne politike, ali ih lišavaju njihovih romantičarskih zasada. Naprednjak nužno mora mijenjati i lik i habitus političara. On mora prestati biti frazer i mora postati radnik sa snažnim unutrašnjim uvjerenjem, dakle sa „značajem“; on mora raditi „iznutra“ kako bi mobilizirao „onu veliku moć i silu, koja je kao nepresušno vrelo u redovima puka. ${ }^{\text {“245 }}$ Mobilizacija te moći preduvjet je ostvarenju narodnih prava, a ne obratno. Kako bi se to postiglo, treba upoznati prave narodne potrebe, treba agitirati u inozemstvu i steći simpatije za narodnu stvar, organizirati domaće novinstvo i raditi konkretno na razini kotara $\mathrm{i}$ općina. ${ }^{246}$ To na načelnoj razini pretpostavlja promjenu poimanja naroda, odnosno njegovo konkretiziranje. Kao jedna od važnih politika ističe se i ona ekonomskog nacionalizma: „Naprednjaci nastoje, da mjesto tudjega kapitala i tudjih novaca postave češki kapital i češki novac [...] Oni uče narod

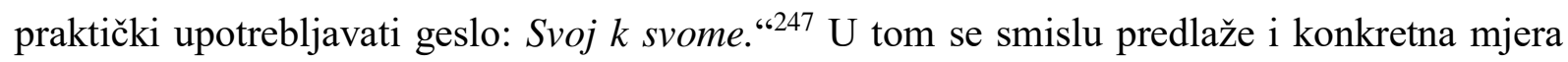
bojkotiranja stranih proizvoda, a uredništvo Hrvatske misli dodatno potcrtava važnost ove mjere napominjući kako bi se to trebalo uvesti i u Hrvatsku. Zaključujući svoj tekst, Heimrl konstatira kako je naprednjački pokret, usprkos svim svojim manama - pa naposljetku i raskola - preporodio češko đaštvo, naučio ga politički razmišljati i samostalno djelovati,

\footnotetext{
243 Isto, 89.

${ }^{244}$ Isto.

245 Isto, 90.

246 Isto.

${ }^{247}$ Isto.
} 
nasuprot ranijoj intelektualnoj i stranačkoj ovisnosti kada se nije smjelo misliti svojom glavom. ${ }^{248}$

Ako Heimrlov članak čitamo usporedno s manifestom češke moderne, jasno je da je riječ o implicitnom prevođenju čeških strujanja u hrvatski politički kontekst. Naprednjačka i realistička kritika čeških prilika mladima je poslužila kao intelektualni alat koji mogu preuzeti i primijeniti na analizu i kritiku hrvatske političke situacije. Staročesi su tako prevedeni u „djedove“, ilirce i njihove neposredne nastavljače, a mladočesi u „očeve“ ili „stare“, tadašnju hrvatsku oporbenu političku elitu. Praški mladi za sebe preuzimaju ulogu koja je pripisana mladim češkim naprednjacima, ulogu preporoditelja političkog života, njegova moderniziranja s jedne strane i širenja na sve društvene slojeve s druge. S obzirom na čvrsto ustanovljene analogije između hrvatskog i češkog konteksta, cijeli se intelektualni konstrukt češkog naprednjačkog i realističkog pokreta naprosto translatira u hrvatski okvir, od analize trenutnog stanja do konkretnih političkih zahtjeva. Međutim, translacije ipak podrazumijevaju i određene pomake u značenju. Iako je u češkim aproprijacijama mladih prisutna visoka razina imitacija izvornog materijala, koja se očitovala u potpunom preuzimanju konstrukcija i fraza, različitost je hrvatskog konteksta - usprkos svim strukturnim sličnostima - ipak nužno dovela do promjena koje su rezultirale specifičnostima hrvatskog modernističkog pokreta. Stoga je potrebno razmotriti koje su to specifičnosti i na koji je način hrvatski politički kontekst utjecao na njih.

Jedan od ključnih referentnih okvira nastajućeg pokreta mladih bio je dakako hrvatski politički kontekst. Opozicijske snage suprotstavljene Khuenovoj vlasti u Hrvatskoj nisu imale mnogo razloga za slavlje. ${ }^{249}$ Uspon pravaštva koje je doseglo svoj vrhunac u osamdesetim godinama 19. stoljeća, kada je preuzelo primat u okviru hrvatskog nacionalnog pokreta ojačano znatnijim razvojem sitne buržoazije, zaustavljen je krajem toga desetljeća. Početak devedesetih godina označava razdoblje dubinske krize i transformacija pravaštva. U izmijenjenom geopolitičkom kontekstu visoka očekivanja pravaških prvaka da će Rusko Carstvo srušiti Habsburšku Monarhiju u sukobu oko istočnog pitanja bila su iznevjerena te su posljedično vodila napuštanju izvorne starčevićanske koncepcije politike čekanja i prihvaćanju instititucionalnog političkog djelovanja. U tom smislu riječ je o procesu koji se označava kao transformacija pravaškog ideološkog sustava iz izvornog pravaštva u moderno

\footnotetext{
${ }^{248}$ Isto, 126.

249 Dijelovi teksta u ovome potpoglavlju u djelomično su izmijenjenu obliku objavljeni u članku: Nikola Tomašegović, „Jedinstvom protiv (ne)sloge: nacionalna koncepcija napredne omladine“, Tragovi - časopis za srpske $i$ hrvatske teme 1, 1, 2018, 166-190.
} 
pravaštvo. ${ }^{250}$ Transformacije pravaške ideologije u smjeru mogućnosti političkog djelovanja u okviru Habsburške Monarhije, a koje su proizlazile i iz pomicanja pravaške baze sa sitne buržoazije na više građanske slojeve i dio svećenstva, stvorile su temelje za buduću suradnju s jugoslavenski orijentiranom građanskom elitom i inteligencijom. Ideološki rasap izvornog pravaštva pratila je i frakcijska politička podjela koja je rezultirala rascjepom 1895. godine iz kojeg se proizašle dvije pravaške stranačke grupacije - Čista stranka prava Josipa Franka i matica stranka (tzv. domovinaši) - koje su svoje ranije unutrašnje trzavice i sukobe prenijele na javnu pozornicu. Upravo je suton pravaštva otvorio prostor novim ljudima i idejama koji će zauzeti mlađa generacija okupljena između ostalog i u pokretu mladih. ${ }^{251}$

Niti druga glavna hrvatska oporbena stranka - jugoslavenski orijentirana Neodvisna narodna stranka (obzoraši) - nije bila mnogo uspješnija. Nakon teških poraza na izborima u osamdesetima jugoslavenski se orijentirana inteligencija gotovo sasvim povukla u kulturnu sferu, u kojoj je čuvala svoj monopol u različitim institucijama od kojih su najznačajnije Jugoslavenska akademija znanosti i umjetnosti i Matica hrvatska. Njezin je predvodnik i ideološki formulator Franjo Rački preminuo 1894. godine, a Josip Juraj Strossmayer koji je slovio kao simbol jugoslavenske politike još se ranije povukao iz aktivnog političkog života. Glavni ideološki problem za obzoraše predstavljala je činjenica da je Khuen uspio kooptirati srpsku građansku političku i privrednu elitu za svoju politiku, čime je ozbiljno potkopana ideja srpsko-hrvatskog jedinstva, koja je u različitim varijantama stajala u središtu jugoslavenskog ideološkog sustava. Dapače, upravo je režimska Narodna stranka nakon ulaska Srpskog kluba u njezine redove propagirala stajalište kako je zapravo ona postigla cilj hrvatsko-srpske sloge. Osim toga, i sami su obzoraši ulazili u žestoke, ponekad čak i šovinističke polemike ne samo s predstavnicima Srpskoga kluba kao „izdajnicima“ ideje hrvatsko-srpskog jedinstva, nego i sa srpskom građanskom opozicijom okupljenom oko časopisa Srbobran. ${ }^{252}$ Ocijenjujući program hrvatske opozcije iz 1894. godine - koji je predstavljao pokušaj suradnje pravaške i jugoslavenske opcije - Srbobran je istaknuo kako je riječ o antisrpskom programu koji Srbima nameće „hrvatsku misao“, odnosno hrvatsku nacionalnu ideju kojom se negira samostalna politička opstojnost srpske nacije u Hrvatskoj. ${ }^{253}$ Upravo je državnopravna ideja, koja je bila u središtu političke ideologije hrvatske opozicije

\footnotetext{
${ }^{250}$ Mirjana Gross, „Nacionalno-integracijske ideologije u Hrvata od kraja ilirizma do stvaranja Jugoslavije“, u: Gross (ur.), Društveni razvoj u Hrvatskoj (od 16. stoljeća do početka 20. stoljeća, 301-302.

${ }^{251}$ Rene Lovrenčić, Geneza politike „novog kursa“, 40.

${ }^{252}$ Mato Artuković, Ideologija srpsko-hrvatskih sporova (Srbobran 1884-1902), Zagreb, 1991, 25, 95-96.

${ }^{253}$ Isto, 65-66.
} 
predstavljala, jednu od glavnih prijepornih točaka između hrvatske i srpske opozicijske politike u Hrvatskoj.

Baza svih oporbenih opcija u Hrvatskoj bilo je građanstvo. Neodvisna narodna stranka zastupala je interese uglavnom bogatije liberalne buržoazije, a redove su joj sačinjavali ponajviše pripadnici građanske inteligencije i svećenstva. Građanska je inteligencija činila također jezgru pravaštva, međutim ono je u većoj mjeri zastupalo interese sitnijeg građanstva, što se mijenja u drugoj polovici osamdesetih godina. U svakom slučaju najširi društveni slojevi - prije svega seljaštvo, ali i nastajuće radništvo - nisu imali svoje političke predstavnike u glavnim opozicijskim strankama. Uzrok tome nije bio samo u njihovom građanskom profilu, koji nije dopuštao artikulaciju klasnih interesa drugih društvenih slojeva, nego i u nedostatku ozbiljnije i razgranatije stranačke infrastrukture i organizacije. Građanske elite nisu bile ni zainteresirane ni sposobne za izravnu djelatnost na selu i među radništvom. One su za masovnijom politikom posezale jedino u trenucima održavanja izbora, kada se šire slojeve političkom agitacijom mobiliziralo za vršenje pritisaka na izbornike koji su tvorili uski sloj društva, što je posljedica restriktivna izbornog zakona prema kojemu je samo $2 \%$ stanovništva imalo pravo glasa. ${ }^{254}$ Narodni pokreti 1883. i 1903. godine, iako su predstavljani kao njezin veliki uspjeh, nisu zapravo bili rezultat političke djelatnosti hrvatske građanske opozicije. Dobar primjer nevoljkosti opozicije da zaplovi vodama masovne politike predstavljaju i nemiri koji su prvo buknuli među hrvatskim seljaštvom u proljeće 1897. uoči i za vrijeme održavanja izbora za Hrvatski sabor, a potom i u kasno ljeto i jesen među srpskim seljaštvom uoči izbora za Srpski narodno-crkveni sabor. Iako je izborna agitacija opozicije na selu morala utjecati na raspoloženje koje je dovelo do ovih nemira, što je ujedno pokazalo i prijemčivost širih narodnih masa za političko djelovanje, građanska je opozicija ubrzo nakon izbora nastavila uobičajenim parlamentarnim metodama borbe, ohrabrena relativnim uspjehom na izborima na kojima je preokrenut katastrofalni trend izbornih poraza opozicije od samog početka Khuenove vlasti u Hrvatskoj. 255

Ni obzoraši ni pravaši nisu imali ozbiljno organiziranu stranačku infrastrukturu. Khuen je vrlo lako političkim pritiscima i administrativnim mjerama razbio tanku opozicijsku mrežu mjesnih povjerenika i klubova. Na takav ležeran stav političkih elita prema stranačkoj organizaciji nije utjecao samo nedostatak svijesti o važnosti razgranate stranačke infrastrukture za moderno političko djelovanje u vrijeme razvoja masovne politike, nego i

\footnotetext{
${ }^{254}$ Vaso Bogdanov, Historija političkih stranaka u Hrvatskoj: od prvih stranačkih grupiranja do 1918., Zagreb, $1958,487$.

${ }^{255}$ Lovrenčić, nav. dj., 60-62.
} 
činjenica da je za većinu njih politika bila tek hobi, odnosno djelatnost koja je dolazila nakon njihovih primarnih građanskih okupacija i profesija u odvjetničkim uredima, župnim uredima i bankama. ${ }^{256}$ Upravo je to bitno utjecalo na polovičnost akcija građanske opozicije na svim poljima političke djelatnosti, posebice kada je riječ o izvanparlamentarnoj djelatnosti.

Stanje nije bilo značajno drugačije niti kada je riječ o srpskoj građanskoj opoziciji u Hrvatskoj. Srpske građanske elite pristale su na suradnju s Khuenom i režimskom Narodnom strankom. To je bio rezultat kako slabosti srpskog kapitala u Hrvatskoj koji bez pomoći režima nije mogao opstati u konkurenciji s njemačkim i mađarskim, pa niti s hrvatskim kapitalom, tako i nepovjerenja prema hrvatskoj građanskoj opoziciji. Usprkos opuštanju pravaškog stava prema Srbima tijekom osamdesetih godina, koje je nastupilo kao rezultat prihvaćanja realne politike i okretanja vanjskopolitičkog fokusa prema Ruskom Carstvu, kao i makar retoričkom približavanju pravaša i srpskih radikala, srpske elite u Hrvatskoj ostale su duboko nepovjerljive prema pravaškim namjerama. U odnosima s obzorašima kamen je spoticanja bila istaknuta uloga katoličkoga klera u njihovim redovima. ${ }^{257}$ Ključni je problem pak predstavljala hrvatska državnopravna ideologija koju su zastupale obje hrvatske opozicijske grupacije, kao i pitanje Bosne i Hercegovine nakon austro-ugarske okupacije 1878. godine. Srpske su elite u hrvatskoj državnopravnoj ideologiji vidjele negaciju posebnosti srpskog imena i isključenje mogućnosti autonomne srpske politike u Hrvatskoj. Riječ je zapravo o neriješenom pitanju srpske autonomije u Hrvatskoj o kojemu se raspravljalo još od obnove ustavnosti u šezdesetim godinama. Usprkos suradnji $\mathrm{s}$ Mažuranićevom vladom, ovo je pitanje, napose u kontekstu reformi u školstvu, već tada dovelo do zategnutih odnosa između hrvatskih i srpskih političkih elita u Hrvatskoj. Što se tiče Bosne i Hercegovine, i hrvatske i srpske elite svojatale su taj prostor za svoj nacionalni projekt. Zbog svih tih prijepornih točaka, srpske su elite odlučile kako im je oportunije pristati na suradnju s režimom, usprkos tendencijama mađarskih liberala prema ukinuću ili značajnom ograničenju srpske crkvenoškolske, odnosno vjerske autonomije (koja je u Ugarskoj ipak bila regulirana), nego ući u suradnju s hrvatskom opozicijom koja je bila ujedno i slabiji i nepovjerljiviji partner. Jedina srpska opozicijska grupacija u Hrvatskoj bila je okupljena oko lista Srbobran, ali, kao što je već naglašeno, ona je vodila - iz istih ranije navedenih razloga - snažniju borbu protiv hrvatske oporbe nego protiv Khuena, kojemu je upućivala samo mlaku kritiku. ${ }^{258}$

\footnotetext{
${ }^{256}$ Isto, 74-75.

257 Šidak et al., Povijest hrvatskog naroda g. 1860-1914., 132.

${ }^{258}$ Isto, 136.
} 
S takvom situacijom unutar Hrvatske, gdje je Khuen do kraja osamdesetih godina uspio gotovo u potpunosti paralizirati hrvatske opozicijske snage i uspostaviti svoju političku dominaciju, jasno je da hrvatske elite nisu bile sposobne za preuzimanje aktivnije uloge u široj monarhijskoj politici. Dok se politički prostor Habsburške Monarhije dodatno dinamizirao češkom krizom u austrijskom dijelu Monarhije i krizom dualizma općenito, hrvatske su elite bile više pasivni promatrači nego što su na bilo koji način aktivno krojile sudbinu hrvatske, a posredno i slavenske politike u okviru ili izvan okvira Habsburške Monarhije. ${ }^{259}$

Aproprijacije čeških uzora prilagođene lokalnim potrebama i okviru koji je zadan hrvatskim političkim kontekstom rezultirale su manifestom skupine oko Hrvatske misli, programatskim člankom „Što hoćemo“. Tekst članka je, dakako, formulirao Stjepan Radić. ${ }^{260}$ Naslov se referira na retoričko pitanje anonimnog pisca ranije spomenutog članka „Hrvatska misao“ objavljenog u Obzoru nakon proglasa Hrvatske misli. Umjesto očekivanog pozdrava „prijatelja napretka i slobode“, mladi su naišli na sumnje i optužbe „da hoćemo nešto nova“. ${ }^{261}$ Oni na to odgovaraju da mladi zapravo moraju donijeti nešto novo i bolje u život, inače bi njihovo postojanje bilo suvišno. Ono, međutim, „što je u nas 'novo', drugdje je već odavna staro.“262 Mladi se tako postavljaju kao nužni medijatori hrvatske kulture i politike s obzirom na suvremena europska kretanja. Na prvoj liniji njihove kritike našla se Khuenova vlada jer zatire narodnu svijest devaluacijom obrazovanja. Mladi prozivaju nastavnike, neke poimence (Gavru Manojlovića ${ }^{263}$ ), da podržavaju ovakvo stanje svojim pasivnim i konformističkim držanjem. Njihova su djela u potpunom raskoraku s njihovim riječima: „Činom svi hrvatski profesori danas bez iznimke dokazuju, da smo spali na najniže grane i da grofa Khuena drže isto tako profesori, koji slave Harmodija i Aristogejtona, kao i općinski ovrhovoditelji, koji su u mladosti mjesto klasika čitali 'befele'،“264 Za razliku od vlade, prema kojoj se postavljaju kao nepomirljivi protivnici, prema hrvatskoj opoziciji mladi ipak iskazuju nešto više simpatija. Ona je prije svega kriva zbog svojeg nerada. Iako među njima ima poštenja i znanja, prvaci hrvatske opozicije pasivno su promatrali kako „ta mladež već kroz

\footnotetext{
${ }^{259}$ Lovrenčić, nav. dj., 18-19.

260 „Stjepan Radić - Mariji Dvořákovoj, Prag - 28. XII. 1896.“, u: Krizman, nav. dj., 235.

261 „Što hoćemo“, Hrvatska misao, god. I, br. $1,1$.

262 Isto.

263 Gavro Manojlović (1856-1939), povjesničar. U Beču 1896. doktorirao filozofiju povijesti i klasičnu filologiju. Od 1880. radi kao srednjoškolski profesor u Zagrebu, Požegi i Osijeku, gdje je bio i gimnazijski upravitelj. Od 1902. redoviti profesor opće povijesti staroga vijeka na Filozofskome fakultetu u Zagrebu. Politički blizak Hrvatsko-srpskoj koaliciji, zbog čega je 1908. godine bio umirovljen na dvije godine. V. https://www.enciklopedija.hr/natuknica.aspx?id=38670 (pristup: 13. 8. 2021.).

264 „Što hoćemo“, 2.
} 
trideset godina samo buči, a taj puk da se neprestance samo uzrujava i draži." ${ }^{265}$ Hrvatska opozicija pruža tako žalostan primjer osobnih razmirica, stranačke netrpeljivosti i političkog dogmatizma. Zbog toga su mladi prisiljeni da si pomažu sami. Cilj je da se izbjegnu dvije stranputice sadašnje hrvatske mladeži, da oni ne budu ,samo igračka ili čak slijepo oruđe tudje madžarske misli“, niti pak „oduševljena ali slaba a često jadna i kukavna predstraža opozicijonih prvaka“, nego da si mladež „stvori jasno i potpuno uvjerenje o svim životnim pitanjima, da u život stupi s jakom i razvitom dušom“. ${ }^{266} \mathrm{U}$ tu svrhu okrenut će se velikim misliocima drugih naroda, napose Rusa, Čeha i Francuza, dakle onih među kojima je Radić doživio svoja formativna iskustva. Najviše od svega, praškim je studentima stalo da hrvatska mladež u potpunosti promijeni svoje razumijevanje politike. Hrvatsko je shvaćanje rodoljublja primitivno, usporedivo samo s onim mađarskim. Ono se temelji na fetišiziranju prostora, a ne na stvarnom razumijevanju naroda jer mu je odbojno čuti da njega sačinjava i ,zagorski 'mužek'“ i „lički 'kozar'“, a kamoli „vlah““. ${ }^{267}$ Nasuprot takvim shvaćanjima, dakle fetišiziranju nacionalnog (povijesnog) teritorija i ekskluzivnom poimanju naroda koji samo fingira inkluziju svih društvenih slojeva, praški se mladi zalažu za jedinstveno razumijevanje naroda i domovine utemeljeno na kulturi, odnosno u krajnjoj instanci na jeziku. Kao konzekvenca toga povlači se ideja narodnog jedinstva Hrvata i Srba, čiji je temelj upravo u nižim društvenim slojevima. U razradi ideje narodnog jedinstva Hrvata i Srba jasno se uočavaju aproprijacije masarykovskog čehoslovakizma, čiji su argumenti u jugoslavenskoj verziji prilagođeni specifičnim hrvatskim potrebama. ${ }^{268}$ Jezgra je programa praških mladih sadržana u ovim pregnantim rečenicama:

„Danas je hrvatska mladež puna romantizma, danas ona još pjeva 'u boj, u boj!' gdje s najvećim zanosom izgovara 'nek Turčin zna, kako mremo mi!' - a mi hoćemo, da ta mladež počne realno misliti, da razabere, da je narodu već do nokata dogorjelo, da narod već očajava, da propada moralno, umire materijalno. Dakle mjesto oduševljenih zdravica, brzojava, pouzdanica i izjava mi hoćemo promišljen rad na polju gospodarskom, prosvjetnom i političkom.“269

Radić, koji je i sam nekoliko godina ranije deklamirao protiv Khuenove tiranije tijekom izvođenja opere Nikola Šubić Zrinski, pod utjecajem novih, formativnih sredina u potpunosti odbacuje takvu praksu hrvatske mladeži. Ovim je riječima jasno bačena rukavica u

\footnotetext{
265 Isto.

266 Isto.

${ }^{267}$ Isto, 3.

268 Agičić, nav. dj., 147.

269 „Sto hoćemo“, 3.
} 
lice dominantnim historicističko-romantičarskim shvaćanjima dotadašnje hrvatske politike i kulture. Osim toga, nasuprot stranačkom dogmatizmu, mladi se zalažu za slobodu misli i slobodnu obranu uvjerenja, evocirajući temeljnu misao češke moderne. U ostvarenju tog programa, praški se studenti prije svega oslanjaju na mlade snage, ali ne isključuju suradnju sa starijima koji su shvatili nužnost nove političke orijentacije. 270

Specifičnost hrvatskog političkog konteksta rezultirala je time da su aproprijacije češkog naprednjaštva ukopljene u jugoslavensku ideološku matricu, odnosno da su odgovarale na tada goruće političko pitanje hrvatsko-srpskih odnosa. Ideje širenja baze nacionalne politike, kritika koncepta državnog prava, antiklerikalizam i dr. prožeti su i povezani konceptom narodnog jedinstva Srba i Hrvata. Ovaj je pak koncept usidren u razumijevanju narodne kulture kao objektivnom supstratu nacije. Inicijalne aproprijacije naprednjaštva u Hrvatskoj misli, usprkos tome što u hrvatski politički prostor unose značajne konceptualne pomake, i dalje su snažno obilježene dominantnom nacionalnom problematikom, dok su moderne socijalne teme u konkretnoj razradi pale u drugi plan.

Osim toga, Hrvatska misao u velikoj je mjeri obilježena specifičnim stilom i razmišljanjem Stjepana Radića. U prvome je broju uz manifest objavljen i njegov samostalni autorski članak „Hrvatski ideali“, odnosno njegov prvi dio naslovljen „Ideali narodnoprosvjetni“, koji se može smatrati programatskom nadopunom i pandanom prethodnom članku „Što hoćemo“. Ovaj tekst ujedno demonstrira izraziti Radićev intelektualni eklekticizam i neujednačenu upotrebu pojmova koji će stoga obilježiti i Hrvatsku misao u cjelini. Na načelnoj razini, Radić ističe kako - suprotno uvriježenom mnijenju - ideali ne pripadaju mladom ugrijanom srcu, nego zrelom i razvijenom karakteru. Jednako tako, oni ne izviru ni iz zdravica, ni iz visokog društva ili povijesnih mozaika, nego ,iz niskih potleušica sirotinje, iz tamnica nevinih odsudjenika. “271 Time se, na apstraktnoj razini, ponovno rekonceptualiziraju hrvatske kulturne i političke ideje tako da se njihov temelj izmješta iz tradicionalne historicističke paradigme prema novoj, modernoj i masovnoj paradigmi, apostrofirajući ključnu ulogu i savezništvo mladih snaga (,osuđenika“) i širokih, najnižih slojeva naroda. Posebno je važno Radićevo razumijevanje povijesnog kretanja, kao i njegov koncept napretka. On u povijesti vidi kontinuirani progres. Iako on nije nužno uvijek linearan, pa čak može doći i do nazatka, gledajući u cjelini, ,što je bilo, nikad se više ne vraća i ne može se vratiti, i u tom je sav smisao riječi napredak. “272 Zbog toga je svako razmišljanje koje

\footnotetext{
${ }^{270}$ Isto, 4.

${ }^{271}$ Stjepan Radić, „Hrvatski ideali: I. Ideali narodno-prosvjetni“, Hrvatska misao, god. I, br. 1, 5.

272 Isto.
} 
se temelji na nekim dobrim starim vremenima koja se suprotstavljaju „našem razvraćenom dobu“ promašeno. Nije se moguće vratiti na staro, niti je moguće zaustaviti prodor novoga, kojemu se samo može za kratko vrijeme zapriječiti put. ${ }^{273}$ Stoga se ideali ne smiju tražiti u prošlosti, nego samo u budućnosti. Povijest može jedino služiti kao uporište i ohrabrenje, na koje se povremeno obraćamo kao putnik koji prevaljuje dalek put. Lako je pročitati političke implikacije ovih apstraktnih, filozofskih promišljanja. Mladi ne žele u potpunosti odbaciti tradiciju hrvatske politike, ali ona ne može više ustrajati na svojim starim metodama $\mathrm{i}$ shvaćanjima. Mladi se moraju okrenuti budućnosti i novim idejama, ali čvrsto se oslanjajući na kontinuitet te tradicije. Oni su, dakle, svojevrsni inovatori u tom kontinuitetu, oni stupaju u njega kao karika, ali tako da ga preusmjere i usklade s potrebama novog vremena. To se posebno odnosi na koncept državnog prava. Radić ističe kako baš slavenski narodi ne bi trebali svoje ideale tražiti u prošlosti jer ih ona samo dijeli. Ovdje se jasno referira na probleme koje je inzistiranje na hrvatskom državnom pravu uzrokovalo u odnosima hrvatske i srpske politike u Hrvatskoj, od pitanja političkog naroda u Hrvatskoj, do državnopravne pripadnosti Bosne i Hercegovine. Ne odbacujući u potpunosti koncept hrvatskog državnog prava, ali svodeći ga na „uporište“ hrvatske politike, dakle na sredstvo, a ne „ideal“", Radić se nada minimiziranju tih problema. Kako ironično komentira, ,naša je najveća nesreća, što do sada ne imadosmo velikih političara, ekonoma i filozofa umjesto velikih povjesničara $\mathrm{i}$ filologa. “274 Nastavno na to, Radić elaborira ideju narodnog jedinstva koja je postala jedna od ključnih političkih ideja mladih. Nasuprot inteligenciji, koja je ,vazda bila u opreci s narodom“ i radila na njegovu „komadanju“ i „ujarmljivanju“, izmišljajući posebne srpske, hrvatske, bosanske, slavonske i dalmatinske programe, u narodu postoji jedinstvo „duše“, „pravne svijesti“, „nošnje“ i „običaja“, odnosno jedna „tisućljetna“ kultura. ${ }^{275}$ Nikakva tuđinska prevlast nije mogla razbiti tu jezgru narodne kulture. Za razliku od svih umjetno konstruiranih regionalnih imena, taj narod ima dva povijesno opravdana imena: hrvatsko i srpsko.

Radić otvoreno osporava koncept hrvatsko-srpske sloge koji je prevladavao u okviru hrvatske opozicije, napose obzoraša, ali i domovinaša koji su sve više napuštali pozicije pravaškog ekskluzivnog hrvatstva. Taj je koncept bio preslab da bi prevladao nastale sukobe, posebice spor oko pripadnosti Bosne i Hercegovine. Implicirajući nacionalnu odijeljenost Srba i Hrvata, on je pretpostavljao kompromis u svrhu ostvarenja zajedničkih političkih

\footnotetext{
273 Isto.

274 Isto, 6.

275 Isto.
} 
interesa, ali taj kompromis za Radića u sebi nosi klicu novog razdora. Zbog toga samo koncept narodnog jedinstva može prevladati izazove hrvatske i srpske opozicijske politike:

„Posvemašnje narodno jedinstvo naš je ideal. Ne ćemo sloge, kompromisa. Slogu uglavljuju različni elementi, slogu treba ugovarati, kog ugovaranja treba popuštati, kod popuštanja se tuži i sudi, a to vazda ostavlja žalac, koji prije ili poslije dovodi do ponovnoga rascjepa. Naša je narodna duša jedna. Sad treba to jedinstvo samo manifestirati.“276

Srpsko-hrvatsko jedinstvo nužno je u okviru hrvatske politike i u odnosu prema Bosni i Hercegovini kao akutnoj točki jugoslavenske politike. U kontekstu šire jugoslavenske politike, Radić upravo ovaj jedinstveni srpsko-hrvatski narod stavlja u njezino središte. On treba činiti jezgru na koju će se pripojiti Slovenci i Bugari. Budući da takav politički koncept ne može biti utemeljen na ideji povijesnog državnog prava, on se mora usidriti u ideji narodne kulture. Koncept narodnog jedinstva mladi tako posuđuju od jugoslavenske tradicije, ali mu daju političku operacionalizaciju u vidu utemeljenja političke nacionalne opstojnosti na kulturnoj nacionalnoj opstojnosti, odnosno u vidu prirodnog nacionalnog prava utemeljenog na ideji nacionalne kulture.

Ono što je specifično za Radića jest da naglašava kršćanski karakter hrvatske narodne kulture. Daleko do toga da je riječ o klerikalnom stavu. On uostalom nije niti moguć s obzirom na ranije navedenu ideju narodnoga jedinstva Hrvata i Srba. Zbog toga kao jedan od ideala Radić proglašava „vjersko jedinstvo katoličkih i pravoslavnih Slavena“ ${ }^{277}$ Kako ističe, on pritom ne misli na formalno jedinstvo, dakle na formalno sjedinjenje Crkava, nego na jedinstvo u „kršćanskim srcima““ ${ }^{278}$ Tome se pridružuje i inkluzija bosanskohercegovačkih muslimana, koje također smatra dijelom „našeg naroda“. ${ }^{279}$ Posredni stup između kršćanske narodne kulture, u kojoj je dakle implicirano i objektivno narodno jedinstvo Hrvata i Srba jer transcendira konfesionalne razlike, jest koncept slavenske uzajamnosti koji je tekovina slavenskih intelektualaca. Ono što sačinjava objektivni supstrat narodnog jedinstva Hrvata i Srba - narodna kultura - u koncentričnim se krugovima širi tako da obuhvaća i jugoslavensku, pa naposljetku i slavensku dimenziju. Sve Slavene vežu „zajedničke tradicije, posvema srodan narodni značaj i govor, po kom su svi Slaveni gotovo jedan narod.“280 Slavenska uzajamnost ne smije, međutim, ostati stvar oduševljenja, zdravica i prijetnji sa „sto milijuna“. Na njoj se treba raditi, treba učiti slavenske jezike kako bi se eliminirali strani

\footnotetext{
276 Isto.

${ }^{277}$ Isto, 9.

278 Isto.

${ }^{279}$ Isto, 6 .

${ }^{280}$ Isto, 8 .
} 
posrednici. Slavenska uzajamnost i međusobno upoznavanje mora postati i temelj za šire aproprijacije zapadno-europskih kretanja. Upravo suprotno od tadašnjeg stanja, kada je često njemačka kultura posrednik za slavenske, slavenska kultura mora postati osnovicom za aproprijaciju njemačke, francuske, engleske i američke. Radić ističe kako se od Čeha i Poljaka treba učiti ,realnoj politici, muževnom patriotizmu i dubokomu shvaćanju velikih evropskih pokreta.“281 Od Rusa pak treba učiti „prodahnutu književnost, objektivnu i izvanredno bogatu kritiku, smiono i nenatkriljivo pjesništvo“, što odgovara njegovu shvaćanju kršćanske narodne kulture, kao i „,velika gospodarsko-socijalna pitanja“ ${ }^{282}$ Tek tada se treba otisnuti na „veliko more svjetske organizacije“. 283

Radićevo je razmišljanje prožeto nacionalnim i kulturno-identitetskim odrednicama. U njegovu temelju stoji ideja objektivnog supstrata narodne kulture, koji sačinjava temelj i uporište nacionalne zajednice. Njegova je upotreba pojmova, međutim, nekonzistentna i nejasna. Radić ne razjašnjava odnos između koncepta narodnog i nacionalnog. Koncept narodnog ponekad koristi kao sinonim za pučko, a ponekad kao sinonim za nacionalno. Ono što se iz toga može iščitati jest da upravo kroz posrednički koncept narodne kulture, Radić nacionalno utemeljuje u pučkome. Taj pučki temelj narodne, pa onda i nacionalne kulture u njega je, međutim, izrazito idealiziran i homogeniziran. Iako govori o potrebi uključivanja društvene i ekonomske dimenzije, u Hrvatskoj misli Radić se i dalje ograničava na kulturnoidentitetsku razinu. Njegovi rekonceptualizirani „narodno-prosvjetni“ hrvatski ideali nisu opismenjavanje, sitni rad, ekonomska organizacija seljaštva itd., nego narodno jedinstvo Srba i Hrvata, vjersko jedinstvo i slavenska uzajamnost. Ideje su to koje radikalno ne odudaraju od ideološke tradicije jugoslavenstva. Radić, pa onda u velikoj mjeri i mladi, inicijalno stoga nastupaju kao unutrašnji kritičari devijacija i odustajanja od tradicionalnih zahtjeva i ciljeva hrvatske nacionalne integracije. Socijalna i ekonomska dimenzija tek će kasnije početi snažnije prodirati u ideologiju mladih, dok u incijalnom razdoblju ostaje na razini preuzetih fraza.

Možemo dakle vidjeti da je jedna od ključnih tema kojom se bave praški mladi odnos prema hrvatskoj politici općenito, odnosno prema hrvatskoj opoziciji (starima) napose. Osim kroz programatske tekstove, uredništvo Hrvatske misli u prvome je broju i direktno odgovorilo na ranije navedene prvotne reakcije hrvatske opozicijske štampe na istup mladih.

\footnotetext{
281 Isto.

282 Isto.

${ }^{283}$ Ova shema, dakako, neodoljivo podsjeća na Radićeva osobna formativna putovanja: od čeških zemalja do Rusije, od Rusije do Francuske i nazad. Mark Biondich, Stjepan Radić, the Croat Peasant Party, and the Politics of Mass Mobilization, 1904-1928, Toronto, Buffalo, London, 2000., 27-61.
} 
Na poziv Obzora da se jasno izjasne za program koalirane opozicije iz 1894. godine, mladi pomalo ironično odgovaraju kako se ne smatraju dovoljno iskusnima da bi stupili u aktivni politički život, niti im je to bila namjera. Okrećući tako patronizirajući stav Obzora protiv njega samog, oni ističu kako smatraju nedoličnim ,davati samo izjave i potpisivati adrese prvacima koje stranke“, a sramotnim „razbijati prozore svojim protivnicima ili ih čak tvorno napadati“, aludirajući ovdje na frankovačku mladež. ${ }^{284}$ Dapače, mladi su uzvratili hrvatskoj opoziciji vlastitim upozorenjem, ponovno implicitno karakterizirajući frankovce i obzoraškodomovinašku opoziciju: „Bude li politička zrelost od nas tražila, da stvorimo novu stranku, mi se toga ne ćemo žacati, jer za narod nisu nesreća nove stranke, nego nove smutnje i stara zasukanost.“285 Najveći dio svoje reakcije praški studenti posvećuju odgovoru na pitanje Obzora priznaju li hrvatsko državno pravo. Oni konstatiraju kako znaju i priznaju ,historijsko hrvatsko državno pravo“, međutim kako „pozitivno hrvatsko državno pravo“, odnosno državnopravni okvir ustanovljen Hrvatsko-ugarskom nagodbom 1868. godine, postoji samo na papiru. ${ }^{286}$ Iako je „,po toj nagodbi pravno Hrvatska posvema ravnopravna Ugarskoj“, ona je „faktično madžarska pokrajina sa širokom autonomijom, nad kojom budnim okom bdije „pouzdanik madžarske vlade“.“287 Da bi bilo drugačije, Hrvati bi morali biti jači od Madžara, što mladi smatraju nemogućim. Osim toga, ni pozitivno ni historijsko hrvatsko državno pravo ne obuhvaća ni Istru, ni Hrvate preko Drave, ni Slovence, a kamoli Srbe s kojima dapače izaziva nesporazume. Praški studenti stoga zaključuju kako se hrvatsko državno pravo kosi s „hrvatskim narodnim pravom“. Oni stoga ovdje jasno odbacuju hrvatsko državno pravo kao temelj politike: „Za to mi stojimo samo na temelju narodnoga načela, narodne svijesti, narodne snage.“288 Hrvatsko državno pravo možda „,vrijedi u znanstvenoj rasrpavi“ ili u „novinarskoj polemici“, ali „u životu, u borbi vrijedi samo narodno pravo, koliko ga ima u narodnoj svijesti. “289

Usprkos ovom rezolutnom stavu, vidjeli smo da su oko pitanja hrvatskog državnog prava postojale nesuglasice među praškim mladima. Osim toga, niti stavovi objavljeni u Hrvatskoj misli nisu bili konzistentni. Za Radića je, kao što je ranije navedeno, hrvatsko državno pravo bilo legitimno sredstvo političke borbe, ali ne i cilj, dok u odgovoru Obzoru mladi tvrde da se ono kosi s principom narodnog prava. Ove nekonzistentnosti upućuju na početne faze formiranja ideologije pokreta, ali i na narav aproprijacija stranih, u ovom slučaju

\footnotetext{
284 „Da se razumijemo“, 27.

285 Isto, 28.

286 Isto.

287 Isto.

288 Isto.

${ }^{289}$ Isto.
} 
čeških kretanja. Potpuno odbacivanje koncepta povijesnog prava u početnim je fazama pokreta naprosto preuzeto bez promišljanja praktičnih posljedica. Prvotnim istupima mladih tako dominira svojevrsni radikalizam i kriticizam. Naglasak na kritici postojećih društvenih, a napose političkih odnosa omogućio je da se u drugi plan stavi dimenzija praktične i realne politike. S daljnjim razvojem pokreta, međutim, upravo će ova dimenzija sve više i više dolaziti u prvi plan. Tako se kao jedan od karakterističnih mehanizama razvoja pokreta očituje pomak od inicijalnog radikalizma i kriticizma, koji počiva na ponekad nereflektiranim preuzimanjima stranog materijala, prema konstruktivnim primjenama i prilagodbama aproprijacija u smjeru pragmatična praktičnog djelovanja.

Unatoč ovim nesuglasicama, Obzor je nastavio redovito pratiti svaki broj Hrvatske misli. ${ }^{290}$ On pritom nije mijenjao svoj ton: pozdravljao je napore mladih, ali ih je upozoravao da je njihova prvenstvena zadaća učenje, te da imaju važnu reprezentativnu funkciju za Hrvatsku u inozemstvu, kao i zadaću upoznavanja hrvatske javnosti s tekovinama drugih „bratskih“, odnosno slavenskih naroda. Drugim riječima, umjesto da razmišljaju o osnivanju nove političke stranke, mladi trebaju izvršavati zadatke u nacionalnoj službi koji dolikuju njihovu statusu. Osim toga, Obzor je hvalio one dijelove programa mladih koji je odgovarao programu hrvatske opozicije, dok ih je od drugih elemenata odgovarao. Tako je s pohvalom isticao prihvaćanje ideje slavenske uzajamnosti, odnosno njihovo oslanjanje hrvatstva na slavenstvo, kao i napore na polju jedinstva hrvatskog i srpskog naroda. S druge strane, nije odobravao njihovo odbacivanje hrvatskog državnog prava kao temelja nacionalne politike. Obzorov zaključak savršeno rezimira njegov odnos prema mladima koji se zapravo svodi na pokušaj pridobivanja njihovih simpatija, ali ujedno i oprez usmjeren prema djelomičnom deradikaliziranju njihovih ideja: „Staro, ma i ne bilo posve dobro, ne smije se rušiti, dok se ne uzmogne nadomjestiti novim, koje je ujedno i bolje!‘‘291

Za razliku od oprezna i proračunata stava Obzora, Hrvatska domovina izrazila je gotovo bezrezervnu podršku Hrvatskoj misli. Tijekom 1897. godine doći će do sve intenzivnijih kontakata između mladih i domovinaša, u čijim redovima su našli čvrste saveznike na temelju ideje narodnog jedinstva Srba i Hrvata, kao što su Franko Potočnjak i Erazmo Barčić. U tom je pogledu posebno bio važan Potočnjak, koji je od 1896. uređivao Hrvatsku domovinu te u njoj zastupao ideje srodne onima koje će mladi razvijati u Hrvatskoj misli: prevladavanje srpsko-hrvatskog spora, složan rad obzoraša i domovinaša, politika rada,

\footnotetext{
${ }^{290}$ Agičić, nav. dj., 144.

${ }^{291}$ Obzor, 23. 1. 1897., prema: Agičić, nav. dj., 144.
} 
a ne fraza, organizirana, kontinuirana i efikasna politička aktivnost. ${ }^{292}$ Hrvatska domovina napomenula je u svojoj reakciji na prvi broj Hrvatske misli kako ideje koje praški mladi iznose nisu strane u Hrvatskoj, ali ne mogu izaći na vidjelo zbog političkih okolnosti, implicirajući tako da uz te ideje pristaju upravo domovinaši ${ }^{293}$ Za razliku od obzoraša koji su kritizirali mlade zbog odbacivanja hrvatskog državnog prava kao temelja hrvatske politike, glasilo Stranke prava pozdravlja to što se mladi drže ,narodnoga načela, narodne sviesti i narodne snage, nalazeć osnov svomu djelovanju na jedinstvu jezika i krvi, na jednoj i istoj narodnoj duši.“294 Zbog svega toga, oni novoj generaciji proriču sudbonosnu ulogu u budućnosti hrvatske politike.

Glasilo je Čiste stranke prava, s druge strane, prema Hrvatskoj misli nastupilo na posve drugačiji način. Prema Hrvatskom pravu, naziv je praškoga časopisa pogrešan ,jer se u glavnih člancih plaidira i za srbstvo i za slavenstvo.“ ${ }^{295}$ Frankovci u praškim mladima vide neprijatelje Starčevićeva nauka. U svrhu obračuna s Hrvatskom misli, kako bi pokazali da ona ne predstavlja dominantno stajalište hrvatske mladeži, frankovci su mobilizirali svoj pomladak za verbalni sukob s pražanima. Krajem siječnja 1897. godine, jedan „bogoslov“ u Hrvatskom pravu napao je Hrvatsku misao sa standardnim pravaškim repertoarom: optužio ih je za „obzoraštinu“ i ,slavoserbštinu“ te kritizirao ideju slavenske uzajamnosti. ${ }^{296}$ Par mjeseci kasnije, u Hrvatskom pravu objavljen je dopis praškog studenta Andrije Kaparovića koji izražava svoje nezadovoljstvo Hrvatskom misli, pozivajući na novi opći studentski sastanak, a njemu se ubrzo pridružio anonimni uvodničar koji je priprijetio kako će „zagrmiti svjestna hrvatska mladost tim odrodom“, ističući da će se hrvatska sveučilišna mladež - ona zagrebačka, a nada se i bečka i gradačka - odlučno usprotiviti praškim ,šarlatanima“. 297 Frankovci su se, dakle, odlučili obračunati s novim smjerom koji se javljao među hrvatskim studentima, a koji je ugrozio dominaciju pravaštva u redovima hrvatske studentske politike. Osim toga, rigidan antisrpski i protujugoslavenski stav koji su pritom zauzimali samo je dodatno služio osnaženju tvrdnje da su upravo oni pravi nasljednici izvornog starčevićanstva. ${ }^{298}$

Nakon što je izašao 2. broj Hrvatske misli, u Viencu se pojavila opsežna kritika iz pera anonimna autora „D.“ Najveći dio ovoga teksta zapravo je prikaz povijesti hrvatskih

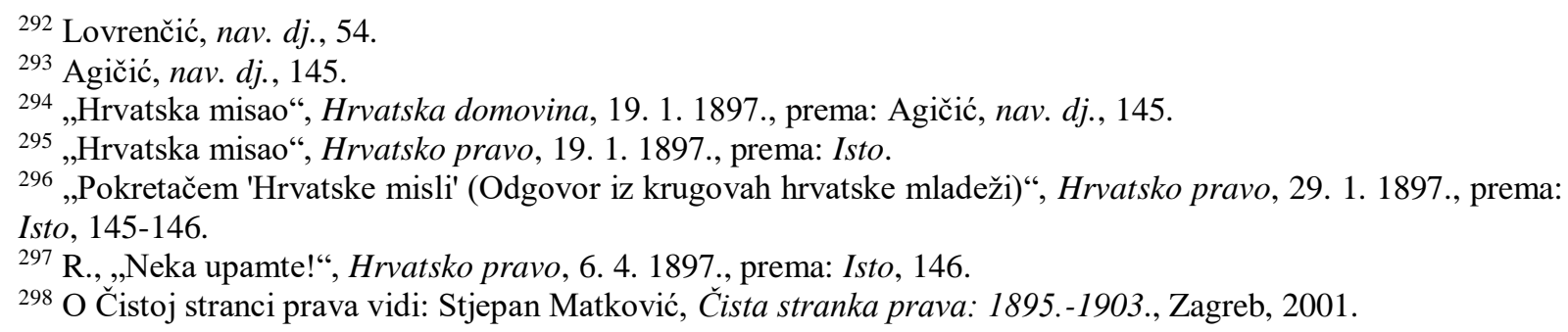


studentskih društava. Međutim, lajtmotiv je prikaza da su ta društva bila najuspješnija onda kada su se bavila znanošću i književnošću, a da su propadala zbog razdora onda kada bi se latila politike. U kontrastu s tim pozitivnim primjerima rada hrvatskih društava, kao što su Velebit, Hrvatski dom i Zvonimir, praški su mladi krenuli drugim smjerom, zagrijani uzavrelom češkom atmosferom i Masarykovim „,katedralnim socijalizmom“. 299 Autor ponavlja već učestalo mjesto da na mladima nije da se bave politikom, nego da uče i da se pripremaju za budući narodno-prosvjetni rad, kao i to da nisu pozvani kritizirati starije: „Teško onomu narodu, koji ne bi imao iskusnijih ljudi do omladine, da ga vodi.“300

Upravo je optužba za socijalizam bila upotrebljena kako bi se spriječila cirkulacija lista u školama u Hrvatskoj. Hrvatska misao javlja u 3. broju kako je do njih došla vijest „da je g. Badalić zabranio gimnazijalcima držati „Hrvatsku misao“ jer je - veli - anarhistički i socijalistički časopis.“301 To je u pismu bratu Stjepanu potvrdio Antun Radić, dodajući kako se i Bauer „,buni takodj. proti socijal., a osb. proti sjedinjenju u vjeri 'bez papine bule' itd.“302 Reakcija je Hrvatske misli bila izrazito oštra. Prozvali su Huga Badalića za nepoznavanje elementarnih pojmova, upozoravajući ga docirajućim tonom „na to, da su socijalizam i anarkizam dva diametralno protivna smjera“, da Masaryk i Hlaváček koje proziva socijalistima nisu socijalisti nego realisti, što će „g. ravnatelju biti samo nova zagonetka“ te etiketirajući ga kao „dvorskog pjesnika“ koji je „za svaku vladu“, pa mu je i svako protivljenje nekoj - u ovom slučaju mađaronskoj - vladi anarhizam. ${ }^{303}$

$\mathrm{U}$ istome broju, međutim, praški su mladi pozdravili izbornu koaliciju obzoraša i domovinaša uoči saborskih izbora koji su se trebali održati u svibnju 1897. godine. ${ }^{304} \mathrm{~S}$ druge pak strane, odmah ispod ove pohvale Hrvatska misao donosi jednako tako kratku bilješku u kojoj napominje da su se u posljednja dva tjedna u krakovskom kotaru pete kurije održale 43 izborne skupštine, s retoričkim pitanjem koliko će se takvih skupština održavati u cijeloj Hrvatskoj za čitavo predizborno vrijeme. ${ }^{305} \mathrm{U}$ narednom su se razdoblju mladi ipak aktivno uključili u predizborne aktivnosti u Hrvatskoj. U pismu obzoraškom prvaku Šimi Mazzuri od 16. travnja 1897., Stjepan Radić ističe poželjnost suradnje starih i mladih: „Čvrsto sam

\footnotetext{
${ }^{299}$ D., „Hrvatska misao“, Vienac, god. XXIX, br. 9, 10, 12, prema: Krtalić, nav. dj., 90.

300 Isto, 93.

301 „Javljaju se“, Hrvatska misao, god. I, br. 3, 95.

302 „Ante Radić - Stjepanu Radiću, Zagreb - 28. II. 1897.“, u: Krizman, nav. dj., 250.

303 „Javljaju se“, 95.

${ }^{304}$ Lovrenčić opravdano upozorava na neutemeljenost tvrdnje Josipa Horvata kako su mladi također bili zaslužni za nastanak ove koalicije. Iako su se oni načelno za nju zalagali, pa ju i pozdravili i podržali konkretnom akcijom, glavnina njih nije tada imala dovoljan utjecaj niti pristup hrvatskim političkim krugovima koji bi omogućio takvu ulogu. Lovrenčić, nav. dj., 53, bilj. 1

305 „Kako se vodi izborna borba“, Hrvatska misao, god. I, br. 3, 96.
} 
uvjeren, da bi u hrv. mladeži bilo više razbora i direktive, a u mnogih starijih više energije i oduševljenja, kad bi čvršće veze postojale medju jednom i drugom generacijom. " ${ }^{306} \mathrm{U}$ tu svrhu on daje sugestije vezano uz izbornu agitaciju, kao i uz to kako popraviti izborni program opozicije. Upućujući stare na aktivan terenski rad, Radić također predlaže da se programu dade jasnija forma: „Mjesto hrvat. drž. prava: obnova vlasti hrvatskoga bana. Mjesto pravne države i parl. vladavine: osobna sloboda, slobodna općina, prošireno pravo glasa. Mjesto fin. samostalnosti: hrv. sabor ima odredjivati porez, graditi željeznice i uredjivati luke, itd.“307 $\mathrm{U}$ međuvremenu, mladi su također u dogovoru s Frankom Potočnjakom i domovinašima naumili izdati ,za narod knjižicu“, odnosno izbornu brošuru. ${ }^{308}$ Potočnjak je, kako Živan Bertić javlja Radiću, oduševljeno pristao uz ideju, obećavajući financiranje troškova, dok su tekstove trebali producirati mladi. Brošura je trebala sadržavati četiri poglavlja: država, izbori, stranke u Hrvatskoj i Hrvat ili Srbin, a planirano je tiskanje 20 000 primjeraka na jednom arku. ${ }^{309}$ Domovinaši se nisu odlučili na suradnju s mladima samo kako bi iskoristili njihov polet i energiju te ih približili sebi, nego i iz praktičnih razloga: tisak brošure trebao se obaviti u Pragu kako bi se izbjegla moguća zapljena u Zagrebu. Osim toga, bilo je planirano da se tiska i na latinici i na ćirilici, a za ćirilično izdanje tekst za poglavlje Hrvat ili Srbin trebao je napisati Svetozar Pribićević. ${ }^{310}$ Čini se kako brošura ipak nije ugledala svjetlo dana, ali razlozi za to nisu jasni. U Hrvatskoj misli zato je neposredno prije izbora objavljen uvodnik u kojemu se mladi postavljaju prema izbornoj situaciji u Hrvatskoj. U prvom dijelu teksta oni iznose porazno stanje u Hrvatskoj: pseudoustavnost, korupcija, represija, zaustavljanje društvenog i političkog razvoja, kolonizacija i mađarizacija itd. Uza sve to, uviđa se i pasivnost hrvatske banovinske politike, koja se kontrastira s bujanjem narodne politike u Istri i Dalmaciji, što se manifestiralo u izborima za Carevinsko vijeće. ${ }^{311}$ Ipak, mladi primjećuju pomake u političkoj praksi hrvatske opozicije, pa s time i neke uspjehe. Međutim, oni upozoravaju kako se ne smije dogoditi „da s ovim izborima [...] prestane $i \mathrm{rad}$, kako se to doslije činilo, nego treba stostruko nastaviti, treba da zastupnici

\footnotetext{
306 „Stjepan Radić - Šimi Mazzuri, Pariz - 16. IV. 1897.“, u: Krizman, nav. dj., 264.

307 Isto, 265.

308 „Živan Bertić - Stjepanu Radiću, Prag - 16. IV. 1897.“, u: Krizman, nav. dj., 263.

309 „,S. Korporić - F. Hlaváčeku, Hlebine 14.IV.1897.“, u: Agičić, Dragi Franta!, 101.

${ }^{310}$ Isto.

${ }^{311}$ Mladi se ovdje referiraju na izborni sporazum dalmatinskih pravaša i narodnjaka za Dalmatinski sabor, kao i narodnjaka i Srpske stranke za Carevinsko vijeće. Ipak, oni svoju ocjenu stanja u Dalmaciji i Istri svode samo na tu dimenziju koja je njima važna u kontekstu banovinske politike. Po strani pritom ostavljaju ekonomsku devastaciju ovih regija, činjenicu da se dalmatinski pravaši koji su u političkom usponu zapravo uopće ne bave socijalnim pitanjima, sve snažnija trvenja u toj stranci, ali i povremena savezništva srpskih elita s talijanskim protiv politike sjedinjenja Dalmacije s Banskom Hrvatskom. Mladi naprosto uzimaju ono što je njima korisno u kontekstu banovinske politike, a ostatak kompleksnih političkih odnosa u Dalmaciji i Istri preskaču. Vidi Šidak et al., nav. dj., 176-179.
} 
naroda zalaze u narod, da mu polažu račun o svom radu, da ga izvještuju o radu sabora, uopće o situaciji. Zastupnik mora da bude i neprestanom kontaktu sa svojim izbornicima, a ne da ga - kako je to u nas redovno - narod vidi svakih pet godina - jedan put!“312 Uviđajući dakle neke pozitivne promjene u razmišljanju hrvatske opozicije, mladi ipak pozivaju i potiču na još snažnije i dublje promjene koje bi vodile u smjeru implementacija praksi moderne masovne politike.

Usprkos suradnji koja je uspostavljena oko izbora 1897., odnosi starih i mladih ipak nisi bili bez napetosti. Duhove je posebno uzburkala ranije spomenuta Vienčeva kritika, koja je čak pokrenula i manju polemiku između dva lista. Praške je mlade zasmetalo što je Obzor posredno stao na stranu Vienca. Korporić u tom smislu obavještava Radića kako Obzor „već 2 put upozoruje čitatelje na krasni i zaokruženi članak u Viencu o (čitaj: proti) Hrv. Misli.“313 Hrvatska misao dakako nije ostala dužna Viencu. U 4. broju štampan je „Odgovor na Vienčevu kritiku“, za koju se kaže kako „sudi po staračku i kao stari daje nam stare

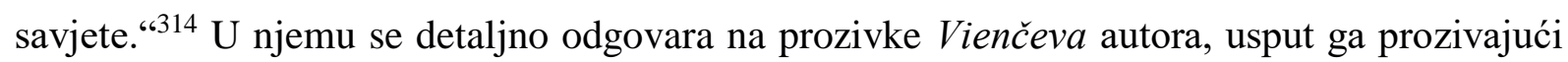
za frazerstvo i za nerazumijevanje pojmova koje koristi, napose pojma „katedralni socijalizam“. Praški studenti ponovno iznose osnovne postavke svojeg programa, a kao svoju temeljnu motivaciju navode težnju za istinom, koja podrazumijeva da se „moraju podvrći kritici naše društvene, književne i političke prilike“ kako bi se utro put novim nastojanjima i promjenama. ${ }^{315} \mathrm{Za}$ njih to ne predstavlja strančarstvo i politikanstvo, koji su doista pogubni za mlade, kako „D.“ tvrdi, nego - upravo suprotno - to predstavlja njihovu negaciju. Vienac nije nastavio ovu polemiku, iako je donio još nekoliko kratkih osvrta na naredne brojeve Hrvatske misli uz usputne, indirektne komentare. On je međutim izrazito zamjerio mladima njihov napad na Huga Badalića, koji smatra nepravednim i neprimjerenim. ${ }^{316}$ Reakcija Vienca nije ipak zaustavila praške studente da nastave kritizirati Badalića. Oni u 4. broju nastavljaju tu priču, tvrdeći kako je Badalić iznio optužbu na račun Hrvatske misli „kako smo mi prodane duše i kako imamo nečiste ciljeve pred očima. “317 Također se izvještava kako je nakon pisanja Hrvatske misli provedena istraga u gimnaziji te kako je Badalić prijetio reperkusijama onome tko je dojavio njegove riječi. Posebno oštrim tonom mladi prozivaju Badalića za licemjerje, kontrastirajući njegovo pjesništvo i njegova djela. U ovoj se razornoj kritici naziru obrisi buduće polemike mladih i starih, posebice na polju kulture, kao i temeljni princip kritike

\footnotetext{
312 „Izbori“, Hrvatska misao, god. I, br. 5, 135.

313 „Svetimir Korporić - Stjepanu Radiću, Hlebine - 24. IV. 1897.“, u Krizman, nav. dj., 269.

314 „Odgovor na Vienčevu kritiku“, Hrvatska misao, god. I., br. 4, 128.

315 Isto, 130.

316 „Književnost“, Vienac, god. XXIX, br. 12, 195.

317 „Javljaju se“, Hrvatska misao, god. I., br. 4, 130.
} 
mladih usmjerene prema starima koji se odnosi na licemjerje i diskrepanciju između riječi i djela.

S obzirom na rezultate saborskih izbora 1897., „prašni apsolutistički patenti grofa Hedervarija“ ipak još nisu bili izgubili svoju moć. Iako je opozicija ostvarila značajne iskorake u rezultatima, vladina je Narodna stranka izašla kao apsolutni pobjednik izbora. Od 88 zastupničkih mjesta, koalirana opozicija domovinaša i obzoraša osvojila je njih 26 , Čista stranka prava osvojila je 2, vladina stranka 59 te je izabran 1 neovisni zastupnik. ${ }^{318}$ Ipak, bilo je to značajno povećanje broja opozicijskih zastupnika s obzirom na prethodne izbore 1892 . godine, kada je u Sabor ušlo samo 8 predstavnika pravaša i 2 predstavnika Srpske samostalne stranke. Izbore je također obilježilo nasilje, od nemira na selu, sukoba s oružnicima koji su u nekim slučajevima završili i tragično, do političkih zatvaranja, pritisaka i makinacija. ${ }^{319} \mathrm{U} 6$. broju od 10. lipnja 1897. godine Hrvatska misao donosi opsežan uvodnik znakovita naslova „Na raskršću“ u kojem se postavlja spram rezultata izbora i načina njihove provedbe. Pasioniranim i žestokim stilom, koji upućuje na Radićevo pero, pražani napadaju i opoziciju i vlast, i stare i mlade, sve prožeto lajtmotivima krvavih događaja koji su se odvili za vrijeme održavanja izbora. ${ }^{320} \mathrm{Tu}$ se ponajprije misli na incident u Bošnjacima, u kojemu je smrtno stradalo sedam osoba, a tridesetak je ranjeno u obračunu s oružnicima, o čemu Hrvatska misao donosi i zaseban izvještaj. ${ }^{321}$ Odmah na početku teksta Hrvatska misao ističe nedovoljnu zastupljenost mlađe generacije na izbornim listama opozicije. Međutim, oni kritiziraju i svoj naraštaj, koji prozivaju za štreberstvo, beskičmenjaštvo i sebičnost te optužuju da bi žrtvovao sve „da se može kočiti po Ilici ili klanjati na Markovom trgu.“322 Izbori su pokazali, posebice u svojim krvavim epizodama, kako glavni problem u Hrvatskoj nisu stranci, nego „narodna gospoda“ koja se prema narodu ponaša gore od bilo kakva stranca. Dakako, najsnažnije su kritike usmjerene prema činovništvu koje je podleglo političkim pritiscima i koje gaji „dva morala“ - jedan javno-politički i jedan privatni. Takvo se licemjerje više ne može ničime opravdati te mladi pozivaju na sustavno prozivanje takvih osoba koje predstavljaju pravu „klatež“ i koje „zaslužuju samo naš prezir.“323 Mladenački radikalizam nije imao razumijevanja za težak položaj činovništva i političke pritiske koje su

\footnotetext{
318 Lovrenčić, nav. dj., 57; Za detaljniji pregled izbora za Hrvatski sabor 1897. godine vidi: Stjepan Matković, „Izbori za Hrvatski sabor 1897. godine: afirmacija Khuenove autokracije“, Časopis za suvremenu povijest 29, 3, 1997., 469-488.

${ }^{319}$ Lovrenčić, nav. dj., 60.

${ }^{320} \mathrm{Da}$ je Radić autor ovog uvodnika potvrđuje i Lorković. V. „Ivan Lorković - Stjepanu Radiću, Zagreb - 13. VI. 1897.“, u: Krizman, nav. dj., 276.

321 „Krvavi dogadjaji u Bošnjacima“, Hrvatska misao, god. I, br. 7-8, 227-230.

322 „Na raskršću“, Hrvatska misao, god. I, br. 6, 173.

${ }^{323}$ Isto, 175.
} 
trpili. Državni su namještenici, naime, bili prisiljeni glasati za vladinu listu pod prijetnjom gubitka radnog mjesta, a izbori su bili javni. ${ }^{324}$ I ovdje se još jednom manfiestira početni izrazito kritički nastrojen karakter pokreta koji će se kasnije ublažiti i poprimiti pragmatičniji karakter. Hrvatska misao ipak hvali napore „,neodvisne inteligencije“, napose svećenstva koje je doista odigralo važnu ulogu u izbornoj agitaciji hrvatske opozicije na selu, međutim ističe kako to nije dovoljno. Utjecaj političke agitacije hrvatske opozicije na selu, koja se u velikoj mjeri temeljila na širenju moralne panike od navodne ugroze vjere u slučaju pobjede mađarona, čiji su politički saveznici - mađarski liberali - donijeli zakon o civilnom braku i zakonske odredbe o međukonfesionalnim odnosima, vidljiva je i u pisanju Hrvatske misli:

„Ne, tek za naše narodne vlade, ima nastati borba izmedju kršćanskoga morala i židovsko-madžarske korupcije, izmedju slavenske težnje za čovječnošću i pravdom i semitsko-mongolskih navika izrabljivati i gospodovati, izmedju hrvatske i srpske narodne i državne misli i madžarske političke i gospodarske premoći. Mi hoćemo kršćansku obitelj i kršćansku školu, narodnu, slavensku upravu i sudstvo, izrazitu, hrvatsku političku individualnost. “325

Ovaj citat također upućuje na to kako aproprijacije suvremenih političkih kretanja nisu zaobišle niti sve izraženije antisemitske tendencije u Europi, ne samo one klerikalne, nego i populističke poput antisemitizma kršćansko-socijalnog pokreta Karla Luegera. Razvijajući vjersku sliku, Hrvatska misao poziva da se izborna agitacija zamijeni ,apostolatom, poukom“ koja „treba djelovati na pučku misao“, a koja je pak idealizirana kao bistra i snažna. 326 Narodni političar tako treba postati neka vrsta apostola koji pohađa neiskvareni puk, sistematizirajući i usmjeravajući njegove već postojeće sentimente i ideale. Iako su za tragične žrtve prvenstveno krivi mađaroni, koji su potom krivnju htjeli prebaciti na opoziciju koja je „uzbunjivala“ narod svojom agitacijom, mladi ističu kako bi krvi ipak „bilo manje, da je narod isto tako zrelo mislio, kako je pravo osjećao", što je primarno propust opozicije, koja bi ubuduće trebala „oduševljene govore zamijeniti trijeznom poukom, oduševljenu agitaciju požrtvovnim apostolatom. “327 $\mathrm{U}$ tom smislu kritiziraju i opozicijsko novinstvo, koje se nedovoljno bavi realnim problemima, ne prati europske trendove i rezultate suvremene političke ekonomije, nego se najboljim novinarom smatra onaj koji najvatrenije piše. Hrvatska misao posebno pozdravlja opozicijsku slogu, koju smatra jednim od glavnih faktora

\footnotetext{
${ }^{324}$ Iskra Iveljić, „Prevlast unionista. Hrvatske zemlje od 1883. do 1903. godine“, u: Mislav Ježić et al. (ur.), Hrvatska i Europa. Kultura, znanost i umjetnost, sv. 4: moderna hrvatska kultura od preporoda do moderne (XIX. stoljeće), Zagreb, 2009, 93-94.

325, ,Na raskršću“, 175.

326 Isto, 176.

327 Isto.
} 
njezina relativnog izbornog uspjeha. U ovo uključuju i slogu sa Srbima, iako su dometi te suradnje i dalje bili skromni. Prije bi se moglo reći kako je došlo do smirivanja hrvatskosrpskih sukoba, nego do suradnje u pravom smislu riječi. Ona se uglavnom svodila na individualne inicijative, u čemu su se istaknuli Franko Potočnjak i Erazmo Barčić iz redova domovinaša, dok je veći dio hrvatske opozicije ostao na razini deklaratorne podrške slozi. ${ }^{328}$ Praški mladi nadalje upozoravaju da ta sloga mora opstati i nakon izbora te da se stranke ne smiju vratiti na stare staze „strančarstva“. Izborni uspjeh opozicije nije naposljetku rezultat pristajanja naroda uz ovu ili onu stranku opozicije, nego izraz krajnjeg nezadovoljstva stanjem u Hrvatskoj i znak otpora mađaronskoj vlasti: „Narod se u svojoj tjeskobi nije molio za uspjeh ni pravaštva ni neodvišnjaštva, nego za pobjedu kršćanstva proti bezvjerstvu, hrvatstva proti madžaronstvu, narodne sloge (jedinstva) sa Srbima proti zasukanom šovinizmu. “329 Mladi daju i neke konkretne prijedloge za budući rad opozicije. Oni predlažu zahtjeve koje hrvatska opozicija treba postaviti u svojem budućem radu: što veće proširenje izbornog prava, ponovno uvođenje porote za tiskovne delikte, vraćanje autonomije općinama, donošenje zakona o pravu udruživanja, ograničavanje ovlasti činovništva, brojne gospodarske mjere, od smanjenja troškova gruntovnih prijenosa do bolje regulacije dioba zadruga itd. Ovdje se po prvi puta u osnovnim crtama pojavljuju konkretni politički zahtjevi koji će postati temelj kasnijeg programa napredne omladine, kada iz svoje nastupne kritičke faze pokret prijeđe $u$ fazu realnog političkog djelovanja. Također se na više mjesta preporuča korištenje institucije „pouzdanih skupština“ predviđene zakonom iz 1875. godine kao sredstva za postizanje slobode sastajanja bez pristupa državnih organa. Hrvatska misao zaključuje svoj osvrt na izbore 1897. pregnantnim pogledom u budućnost: „Treba dovršiti naš narodni i politički preporod. Ilirizam nam je dao riječi, jugoslavenstvo je tražilo tim riječima smisao, današnja politička borba ima smisao prema duhu i potrebama novoga vremena produbiti i riječ stvoriti djelom.“330 U tom smislu, 1902. treba postaviti kao cilj postizanja vjekovne misije „samostalnog narodnog i državnog života“ - čime se simbolički zatvara period koji traje od 1102. godine. ${ }^{331}$

Kao posljedica izbora 1897. i događaja oko njih, u mladih se tako dodatno rasplamsala misao o tome kako je na njih pala zadaća dovršenja, odnosno nastavka hrvatskog narodnog preporoda u njegovoj trećoj fazi. Tu misao pregnantno izriče Ivan Lorković u pismu Stjepanu Radiću, naglašavajući važnost pripreme mladih za preuzimanje ove nacionalne dužnosti:

\footnotetext{
${ }^{328}$ Lovrenčić, nav. dj., 54, 59.

${ }^{329}$ „Na raskršću“, 178.

${ }^{330}$ Isto, 181.

${ }^{331}$ Isto, 181-182.
} 
„Kad promatram naš razvoj od g. 1895. ovamo, sve mi se čini, da je na nas pao treći period našega preporoda i to, čini mi se, najopsežniji, najdublji i najteži. Mi smo dapače već dobrano u tom perijodu, dok nam ljetošnji izbori pokazuju, da se on javlja i u našem narodu. Terrain se sprema sve više, pak treba da se i mi što brže i bolje spremamo. Povrh toga naša je dužnost, da sebe i svoje spremanje dovedemo u sklad sa spremanjem, što se zbiva u narodu, da njegov pokret pratimo svojim očima i da ga svojom dušom shvatimo.“332

U svojem prvom organiziranom istupu, mladi nastupaju kao ambivalentni kritičari izvana i iznutra. Prostorno dislocirani, njihov je pogled ipak usmjeren prema hrvatskim političkim prilikama. Od demonstracije 1895. godine, put je mladih obilježen politikom, stoga nije čudno da ona stoji u središtu interesa njihova prvog projekta - praške Hrvatske misli. Iako se predstavljaju kao radikalni inovatori hrvatske političke prakse, oni se svjesno postavljaju u liniju kontinuiteta nacionalne politike. Oni su nasljednici, „sinovi“ nacionalnog pokreta, nedefinirana simboličkog entiteta koji krajem 19. stoljeća više ne postoji kao pokret u pravom smislu riječi, nego prvenstveno ima političku legitimacijsku ulogu. Spoznaje koje stječu vani mladima služe kao alat za kritiku i reformu nacionalne politike. Zbog toga u slučaju pokreta mladih nije riječ o istom mehanizmu transnacionalnog širenja ideja i praksi kao što je to primjerice slučaj sa socijalističkim pokretom. Dok se socijalizam kao internacionalistički pokret u Hrvatskoj javlja kao lokalna filijala širih organizacijskih struktura koje su međusobno snažno povezane, pokret mladih izvire iz nacionalnog konteksta, ali se služi transnacionalnim rezervoarom ideja koje preuzima, oblikuje i koristi u svojem lokalnom kontekstu. Načini su aproprijacija tih ideja i koncepata pritom bili složeni te su varirali od pukih imitacija, pa sve do konstruktivnih translacija koje su rezultirale originalnim sadržajem. Potonji se najviše ogledao u rekonceptualizaciji jugoslavenske ideološke matrice, naime u razradi koncepta narodnog jedinstva Srba i Hrvata, u njegovu moderniziranju i širenju njegove društvene baze. Osim toga, specifičnost pokreta mladih sastojala se i u izrazitom fokusu na pitanje nacionalne inteligencije i njezina odnosa prema nižim društvenim slojevima. Drugim riječima, specifičnost hrvatskog modernističkog pokreta očitovala se u tome što su aproprijacije modernih političkih ideja i strujanja bile fokusirane, oblikovane i uklopljene u okvir procesa nacionalne integracije, nacionalno-integracijskih ideologija i odnosa nacije, nacionalne inteligencije i naroda/puka. Ta će činjenica ujedno uvjetovati i ograničenja modernističkih aproprijacija pokreta mladih. Iako deklarativno istaknuto, socijalno pitanje zapravo nikad neće nadmašiti ono nacionalno u okviru ideologije mladih. $\mathrm{Na}$

332 „Ivan Lorković - Stjepanu Radiću, Zagreb - 13. VI. 1897.“, u: Krizman, nav. dj., 275. 
vrhuncu pokreta doći će do plodne sinteze ova dva koncepta koja se očitovala u ideji socijalizacije narodne politike, ali i dalje će naglasak biti na nacionalnom, na načinu njegova moderniziranja i produbljivanja.

Ovaj osnovni mehanizam aproprijacija jednako će tako obilježiti i područje književnosti kao drugo ključno mjesto djelatnosti pokreta mladih, kojemu se okrećemo u nastavku teksta.

\section{2. Pitanje nacionalne književnosti}

Iako je u podnaslovu Hrvatske misli istaknuto kako je ona „list za književnost, politiku i pitanja socijalna“, stavljajući dakle književnost na prvo mjesto, ona je na kraju zauzela najmanje prostora na stranicama lista. Književne produkcije u Hrvatskoj misli uopće nema, dok je književnost tematski zastupljena s tri teksta i nekoliko bilježaka. Riječ je o tekstovima Milivoja Dežmana Ivanova, „O hrvatskim književnim prilikama“, Milana Šarića, „Hrvatska književnost““ te češkog kritičara F. X. Šalde, „Pogled na noviju češku literaturu“. Iako malobrojni, oni će postati fundamentalni za hrvatski modernistički pokret na polju književnosti.

Nakon formativnih zagrebačkih gimnazijskih godina, tijekom kojih je pisanjem za đački almanah već stupio u književne i književno-kritičarske vode, Milivoj Dežman uputio se uz pomoć Račkog i biskupa Strossmayera prvo na studij medicine u Graz, a potom u Beč. ${ }^{333}$ Iako je bio dobar student, i on je upoznao čari bečkog kavanskog života. U njima je upijao atmosferu života u velegradu, kulturu intelektualnog razgovora, ali i ključne elemente modernog - umjetničkog i intelektualnog - habitusa. Nasuprot ranijim đačkim danima, kada su mu se kao autoriteti nametali profesori tradicionalnog, šenoinskog usmjerenja, u Beču je Dežman mogao susresti prvake moderne, kao što su Hermann Bahr ili Arthur Schnitzler. To se jasno očitovalo u njegovu književnom radu, koje se nastavilo i u studentskim danima. Do svojeg povratka u Zagreb početkom 1897. godine, a nakon što je doktorirao medicinu na jesen prethodne godine, Dežman se među mladima etablirao kao svojevrsni autoritet na književnom polju, objavivši 1895. u Viencu modernistički impostiranu psihološko-impresionističku crticu Ispovijed, u kojoj se očituju njegove bečke aproprijacije, napose filozofije Ernsta Macha. ${ }^{334}$ Iako je bio aktivan u krugovima modernistički nastrojenih hrvatskih studenata u Beču, s

\footnotetext{
333 Josip Horvat, Hrvatski panoptikum, Zagreb, 1965., 117.

${ }^{334}$ Viktor Žmegač, Duh impresionizma i secesije: studije o književnosti hrvatske moderne, Zagreb, 1997., 28-30.
} 
kojima je i dogovarao pokretanje modernističke književne revije, Dežman je pristao napisati članak o hrvatskim književnim prilikama za Hrvatsku misao, koja je na neki način „,pretekla“ bečke mlade i postavila ton u ovoj početnoj fazi hrvatskog modernističkog pokreta.

Prema književnopovijesnoj periodizaciji, nakon Šenoina doba u drugoj polovici šezdesetih i u sedamdesetim godinama 19. stoljeća, osamdesete i prva polovica devedesetih godina u hrvatskoj su književnosti razdoblje realizma. Kada je riječ o književnim djelima, periodizacijske su granice, međutim, porozne. Tako primjerice 1899. godine izlazi šenoinska Melita Josipa Eugena Tomića, a 1905. Tito Dorčić Vjenceslava Novaka, djelo koje se smatra ponajboljim ostvarenjem hrvatskog realizma. Glavni zadatak šenoinskog programa $u$ književnosti bio je preuzeti baštinu ilirizma, prilagoditi ju novom vremenu i stvoriti čitateljstvo za nacionalnu književnost. Šenoinska je koncepcija umjetnosti spajala tendencioznost i ljepotu, realizam i utilitarizam. Iako se smatra idejnim formulatorom hrvatskog realizma, Šenoa je u praksi reterirao od realističke poetike, od socijalnorealističkog, a kamoli naturalističkog sadržaja, u strahu od defetizma, pesimizma i odbacivanja građanskih i nacionalnih ideala romantizma/ilirizma. Kako u Hrvatskoj nije bilo društvene osnove za razvoj zapadnoeuropskog modela realizma koji je kulminirao u realističkom romanu, stvara se svojevrsna mješavina realizma i romantizma. Umjesto na suvremeno socijalno pitanje fokus se stavlja na povijesnu tematiku s odjekom u sadašnjosti, a najbolji je primjer toga Šenoin historijski roman. S odmakom od romantizma, međutim, u književnosti se sve više javlja socijalna problematika. Društvene promjene, primjerice procesi raslojavanja na selu ili problemi integracije razvojačenog krajiškog društva, kao i aproprijacije stranih književnosti, guraju hrvatsku književnost prema realizmu i temama iz provincije. S društvenim promjenama i začetkom Khuenova doba korespondira i pesimistični pomak u hrvatskoj književnosti, koji pak predstavlja vrhunac hrvatskog realizma, ali ujedno i protomodernističke tendencije koje se očituju u snažnijoj zastupljenosti individualnog i psihološkog. Prva polovica devedesetih godina 19. stoljeća u znaku je tako vrhunca realizma i protomodernističkih tendencija, a najznačaniji su književni reprezentanti Gjalski, Novak, Kozarac, Leskovar i Kranjčević.

„Šenoino desetljeće“ bilo je period uspona hrvatskog građanstva i u tom je smislu korespondiralo s Mažuranićevim dobom i projektom stvaranja modernog hrvatskog građanskog društva. ${ }^{335}$ Kulturna je produkcija u tom razdoblju uglavnom koncentrirana u Zagrebu kao političkom, intelektualnom i kulturnom središtu hrvatskog građanstva koji je

\footnotetext{
${ }^{335}$ Usp. Mirjana Gross, Agneza Szabo, Prema hrvatskome građanskom društvu: društveni razvoj u civilnoj Hrvatskoj i Slavoniji šezdesetih i sedamdesetih godina 19. stoljeća, Zagreb, 1992.
} 
njezin glavni konzument i protagonist. Ipak, kulturnim tržištem i dalje dominira strana, najviše njemačka književnost. Sloj je čitateljstva bio vrlo uzak. Brojke pretplatnika književnih listova jedva su dostizale 1000, a uglavnom je bila riječ o inteligenciji, činovništvu i nešto manje trgovcima i obrtnicima. Tijekom cijelog razdoblja realizma bilo je više pretplatnika njemačkih nego hrvatskih listova. Najznačajnija hrvatska kulturna institucija bila je Matica hrvatska koja je osnivanjem Akademije obustavila svoj rad, ali se ubrzo opet ustrojava sa zadatkom promocije hrvatske književnosti i rada na uspostavi šire čitalačke publike. Stožerni je časopis hrvatske književnosti od 1868. godine Vienac, koji zagovara šenoinski program. I Vienac i Matica hrvatska pripadaju kompleksu kulturnih institucija narodnjačke inteligencije, koja zagovara umjereno realistički program, točnije idealizirani realizam i književnost s nacionalno-pedagoškom i utilitarnom zadaćom kao dominantnu struju hrvatske književnosti. ${ }^{336}$

Upravo su ove književne prilike predmet žestoke kritike u Dežmanovu programatskom tekstu. On napada temeljne postulate tradicionalne umjetnosti. Za njega, plodonosna umjetnost nije ona koja slijedi tradiciju i radi po zakonima, nego ona koja „proizvodi dojam“, „daje nove podražaje“, „otvara nove vidike“. ${ }^{337} \mathrm{~S}$ obzirom na to, i recepcija je umjetničkog djela individualna, tako da ne ovisi o tome smatramo li mi kao konzumenti da je ono ispunilo zahtjeve tradicije ili stila, nego o tome kakav je dojam ostavilo na nas. Ako se s ovim idealom umjetničkog djela oslobođena od okova izvanjskih pravila usporede hrvatske književne prilike, rezultat je porazan. Dežman oštro konstatira kako u Hrvatskoj ima književnih djela, ali nema književnosti. „Skučena“ društvena i politička situacija u Hrvatskoj odražava se i na književnu produkciju. Umjetničko stvaranje ne vodi se samo ljepotom i istinom, nego ponajviše i ponajprije različitim „obzirima“. Tako različiti „obziri“, kao izraz nerazvijena, provincijalnog društva, postaju glavni problem daljnjeg razvitka hrvatske književnosti. Upravo je nevoljkost da se uputi jasna i otvorena kritika jedna od glavnih posljedica autocenzure nametnute poštivanjem raznih društvenih „obzira“. Umjetnička se autocenzura najakutnije manifestira u egzistancijalnoj ovisnosti književnika o državnoj službi, što je upravo slučaj kod većine hrvatskih pisaca. Rezultat je toga da hrvatska književnost ne dira u javni život, ne bavi se akutnim, socijalnim pitanjima. Ne zato što bi to bilo eksplicitno zabranjeno, nego zbog straha od gubitka službe, gubitka napredovanja, premještaja u provinciju itd. Zbog toga što se hrvatski književnici libe baviti akutnim društvenim

\footnotetext{
${ }^{336}$ Za ovaj kratki prikaz povijesti književnosti korišteni su: Ivo Frangeš, „Realizam“, u: Slavko Goldstein et al., Povijest hrvatske književnosti, knj. 4, Zagreb, 1975, 219-488; Miroslav Šicel, Povijest hrvatske književnosti XIX. stoljeća, knj. III: moderna, Zagreb, 2005.

${ }^{337}$ Milivoj Dežman, „O hrvatskim književnim prilikama“, Hrvatska misao, god. I, br. 1, 14.
} 
problemima, hrvatska književnost nema „nikakova specifičnog obilježja“, jer ne odgovara na potrebe i izazove svoje okoline - svojeg miljea. ${ }^{338}$ Za takvo stanje nije kriv samo odnos vlasti prema književnosti i književnicima, nego i stav društva u cjelini. Dežman razvija tipičnu modernističku kritiku licemjerja i zatvorenosti modernog građanskog društva, napose u njegovoj naglašeno birokratskoj inačici. ${ }^{339}$ Položaj pojedinca u hrvatskom društvu određen je njegovom „dietenklasom“, odnosno njegovim društvenim statusom. U tom smislu Dežman posebno proziva hrvatske građanske žene, koje ne drže salone kao u Francuskoj i Italiji, gdje bi svoje utočište i pristup visokom društvu mogli naći talentirani umjetnici neovisno o svom društvenom statusu. Hrvatsko je društvo skučeno, birokratsko, provincijsko društvo forme i vanjštine, koje može dati gradivo jedino za satiru.

Međutim, čak i da su društvene i političke okolnosti bolje nego što trenutno jesu, književnost se ne može kvalitetno razvijati dokle je god književnik amater koji svojim pisanjem može zaraditi tek usputni džeparac. Sve te otegotne okolnosti čine začarani krug, i moraju se mijenjati kako bi se stvorili uvjeti za kvalitetniji razvoj domaće književnosti: „Da je javni život normalniji, bio bi i društveni, da je društveni, razvilo bi se zanimanje, da je zanimanja, kupovale bi se knjige - književnici bi se dakle mogli sasma odati knjizi; da to mogu, mogli bi slobodnije i bolje pisati i bolje djelovati na javni život i na društvo. ${ }^{\text {‘340 }}$ Prema Dežmanu, „liječenje“ treba započeti sa samim književnicima: njima treba podariti materijalnu pomoć i potpunu slobodu izražavanja. Druga se razina tiče književne, preciznije nakladničke infrastrukture. Većina nakladnika primorana je izdavati kalendare i šund literaturu, različite „romantične pripovijesti sa pet do šest ubijenih ili otrovanih junaka“ kako ne bi bili na gubitku. ${ }^{341}$ Njemačka se književnost, posebice ona lošija, nudi mnogo više nego domaća, a i knjižare se ne trude dovoljno oko reklame koja je u suvremenom svijetu potrebna i najboljoj knjizi. Kao jedan od velikih problema i anomalija domaće nakladničke scene Dežman ističe monopolistički položaj Matice hrvatske. Dok prosječni nakladnik izdaje naklade od oko tisuću primjeraka, Matičina izdanja redovito izlaze u 12000 primjeraka. U razdoblju kada su se tek stvarali osnovni temelji hrvatske književnosti, takva je pokretačka uloga Matice bila dobra i poželjna. Sada je ona, međutim, štetna za daljnji razvoj domaće književnosti. Matica bi stoga morala uskladiti cijenu i vrijednost knjiga koje izdaje. Time neće izgubiti svoj položaj, pogotovo prestiž u hrvatskoj javnosti, a otvorit će vrata jačem razvoju književne infrastrukture u Hrvatskoj kao temelja za razvoj suvremene, profesionalne književnosti. Osim

\footnotetext{
338 Isto, 15.

${ }^{339}$ Usp. Stefan Zweig, Jučerašnji svijet, Zagreb, 1999., 34-36, 63-71.

340 Dežman, „O hrvatskim književnim prilikama“, Isto, br. 2, 44.

${ }^{341}$ Isto, 44.
} 
toga, time bi se pružila veća sloboda i samim urednicima, koji se uslijed većih mogućnosti objavljivanja ne bi morali voditi svakakvim „obzirima“, kao što to rade danas. Matica se, kao „u neku ruku umjetnički odsjek Akademije [...] bojazljivo čuva, da se ne zadjene.“342 Jedan od „obzira“ je i taj da se etabliranome piscu mora tiskati sve što pošalje, dok ne može svaki „kaki god“ pisati što mu padne na pamet. Najučestaliji pak izvanumjetnički „obzir“ kojime se ravnaju domaći urednici jest onaj moralni. Dežman u tom smislu s ogorčenjem konstatira kako „slikari smiju sve reći, kazalište mnogo a pisana riječ ništa.“ ${ }^{“ 343}$ On se ne slaže s onima koji smatraju da je narod „nepokvaren“, pa mu se ne smije nuditi sadržaj koji bi ga naveo na nemoral, niti s onima koji smatraju da se moralne mane ne mogu liječiti prikazivanjem tih mana, nego idealiziranim pripovijestima. U Hrvatskoj se moralni „obziri“ manifestiraju u obliku javnoga tabua. Piscu nije dozvoljeno prikazivati grijeh, mane, nemoral, odnosno on to smije samo u „konvencionalnim granicama“. Ako izađe izvan njihovih okvira, etiketira se kao „pornograf“. S druge strane u novinama se - pa čak i onim klerikalnim - svaki dan mogu čitati „najpikantniji“ tračevi. Ako književnost treba imati socijalnu misiju - a Dežman smatra da treba - onda ona upravo treba prikazivati svijet onakav kakav on uistinu jest. Koristeći medicinske metafore, on ističe kako se može liječiti samo ono što se prije toga jasno dijagnosticiralo. Socijalna je misija književnosti ta da - vodeći se isključivo kriterijem istine identificira i prikaže društvene devijacije i ljudske mane. Ona nije moralna ili nemoralna po tome što prikazuje, pa čak niti po tome kako prikazuje, nego po tome kakav dojam ostavlja na čitatelja, čime Dežman konzekventno razvija svoja početna polazišta. On ovdje iznosi učestalu modernističku kritiku viktorijanske moralnosti, odnosno onoga što modernisti vide kao viktorijansko, građansko licemjerje, a Dežman naziva „farizejskim puritanizmom“. 344 Prikazivanje golotinje, odnosno seksualnosti samo po sebi nije odmah pornografija. Pornografija je „ona umjetnička zabluda, gdje je namisao zavesti koga na nemoral.“345 To je dakle jednako moguće postići i „konvencionalnim“ sredstvima, prešućivanjem jednako kao i jasnim isticanjem, daleko sakriveno od očiju javnosti jednako kao i novinskim pikanterijama: „Mjesto da se na glas žigoše, s nasladom se raznosi nemoral od uha do uha.“346 Moderna umjetnost, koja želi mijenjati svijet, ne može se stegnuti takvim „reakcionarstvom“ koje se samo maskira moralom. Moderna umjetnost zahvaća i opisuje život, ona služi istini, ljepoti i dobroti te napreduje putem eksperimenata, za što je potrebna sloboda stvaranja. Kako

\footnotetext{
342 Isto, 45.

343 Isto, 46.

${ }^{344}$ Isto, br. 3, 82 .

345 Isto.

${ }^{346}$ Isto.
} 
Dežman zaključuje, ,nije moralan onaj, koji ne zna ništa o nemoralu, nego onaj, koji ne živi nemoralno." ${ }^{\text {347 }}$

Drugi tip „obzira“ su oni politički, ne samo prema vlasti, što je samo po sebi jasno, nego i prema opoziciji, s kojom je povezan veliki dio kritičarskih i književnih krugova. Takva situacija ne može potaknuti nužnu kritičku notu u književnosti, nego ju tjera u fraze i panegirike, u laskanje kojime se postižu namještenja i stipendije, a koje često završava i u nereflektiranu šovinizmu, npr. u prikazivanju Hrvata kao uvijek plemenitih i viteških ličnosti, dok se stranci prikazuju kao loši karakteri. To idealiziranje vlastite nacije i prešućivanje njenih povijesnih i sadašnjih mana jednako je pogubno i u suprotnosti $\mathrm{s}$ misijom moderne umjetnosti kao i tabuiziranje prikaza društvenog i individualnog nemorala. Tu su, naposljetku, i socijalni „obziri“, koji su jasna posljedica „malograđanskog birokratskoga društva“, a koji se očituju u izbjegavanju kritike pojedinih ,staleža“, napose svećenika. ${ }^{348}$ Uzimajući sve ovo u obzir, ako se netko usudi ne pridržavati ovih društvenih pravila i konvencija, Dežman zaključuje: „Na tri se načina dade pisca utući (koji se dade): ili mu se veli, da je izdajica, ili pornograf, ili da je 'naš mladi daroviti nadobudni pjesnik'. Prvo ga utuče u patriotskim krugovima, drugo u pristojnim, treće u inteligentnim.“349

Dežman se osvrće i na stanje u kazalištu. Ono dakako nije dobro, dramski tekstovi su slabi, a režija i tehnika na vrlo niskoj razini. Uzrok je tome opet „zasukanost“, odnosno nepoznavanje suvremenih europskih trendova i razvoja dramske umjetnosti: „Tehnika i režija ne da se nabubati iz kojekakih njemačkih 'Handbucha'.، 350 Dok u Europi vlada socijalna drama, kazalište s aktualnom i problemskom tematikom, u Hrvatskoj još uvijek dominira historijska drama, i to ona loše kvalitete, s ranije opisanim „šovinističkim“ tendencijama. Razmišljajući općenito o razvoju hrvatske kulture, Dežman uočava dvostruki problem njezine recepcije europskih kretanja. S jedne strane, problem je taj što razvoj hrvatske kulture nije autohton, nego je nastao posuđivanjem od stranih uzora, uglavnom njemačkih i romanskih. Međutim, i to je posuđivanje napravljeno površno, nije se dubinski promislilo „nego se to na brzo uzelo, nešto malo za nas priudesilo, a tim procesom samo se izgubilo.“ ${ }^{351} \mathrm{~S}$ druge strane, to se posuđivanje, kakvo god ono bilo, uvijek odvijalo s vremenskim kašnjenjem, tako da se ovdje romantizam javio kad je u Europi već jenjavao, a realizam se u Hrvatskoj još nije učvrstio, dok u Europi već proživljava svoju krizu. Dežman u hrvatskoj književnosti vidi dva

\footnotetext{
${ }^{347}$ Isto, 83.

348 Isto.

${ }^{349}$ Isto, 84.

${ }^{350}$ Isto.

${ }^{351}$ Isto, br. 4, 104.
} 
smjera: narodni i tuđi. Prvi je dominirao u šezdesetim godinama, htio je širiti narodno pjesništvo, pisati u narodnom duhu i graditi na narodnom temelju. Drugi, „tugjinci“, su pak samo „unašali i parafrazirali stranu robu, ništa nije bilo hrvatskog do imena i jezika.“352 Međutim, niti narodni smjer nije bio zapravo narodan, ,gospodovao je duh romanticizma što njemačkog, što poljskog - zaodjeven u narodno ruho. ${ }^{\text {“353 }} \mathrm{Ni}$ jedan ni drugi nije uspio stvoriti karakteristično hrvatsku književnost. Specifičnost neke nacionalne književnosti ne proizlazi iz njezine forme, nego iz sadržaja. Književne forme, umjetničke zasade su nužno međunarodne, ali karakterističnost neke književnosti, po kojoj se ona odmah prepoznaje kao ruska ili francuska, jest u tome što prikazuje specifičnost ruskog ili francuskog života i mišljenja. U tom pogledu hrvatska književnost ima velike mogućnosti zbog osebujnosti hrvatske kulture koja je mješavina istoka i zapada, njihov prijelazni oblik. Da je išla u korak s europskom književnošću, da ju nije pratila posredno preko posudbi iz njemačke kulture, nego iz prve ruke, danas bi bila spremna izići pred europski forum sa svojim originalnim djelima. Stoga se kao primarni zadatak nadaje smanjiti zaostajanje za europskim kretanjima, ne nužno na polju književne produkcije, nego na polju književne recepcije, praćenja i razumijevanja suvremenih tokova europskih književnosti. Tek se na tom zdravom temelju može graditi specifična hrvatska književnost koja bi imala što ponuditi Europi.

Što se tiče zadaće književnosti, Dežman ističe da ona ne smije biti larpuralrtistička, nego mora izvršavati više zadataka. Ona mora odgajati narod, međutim ne neposredno, nego posredno, preko odgajanja inteligencije, utjecanja na javno mnijenje, reforme itd. On se dakle ne zalaže za direktno utilitarnu ili pedagošku književnost, nego za sintezu umjetničke i utilitarne funkcije književnosti. Ako izvršava samo jednu od ovih funkcija, ona gubi svoju vrijednost. Književnost ilirizma tako je obavljala tada nužnu utilitarnu funkciju, ali je zastarjela jer, prema Dežmanu, nema trajne umjetničke vrijednosti. Ustrajanje na takvom tipu književnosti danas može samo škoditi. Ako je ilirsko doba bilo razdoblje zasnivanja hrvatske književnosti, šenoinsko razdoblje početnog formiranja književne i čitalačke publike, kraj 19. stoljeća je vrijeme za razvoj vrhunske, kvalitetne hrvatske književnosti nad kojom treba bdjeti kompetentna književna kritika, o čijem stanju Dežman ima izrazito negativno mišljenje, opisujući ju kao dijelom akademsku, dijelom osobnu, dijelom političku, a u svemu ne pretjerano stručnu. Upravo ona treba biti jamac kvalitete književne produkcije, ona treba paziti da se sloboda umjetničkog stvaranja ne izrodi u nešto loše. Ali da bi to mogla činiti, i kritika mora biti slobodna, mora se voditi isključivo umjetničkim kriterijima. Na taj način se

\footnotetext{
${ }^{352}$ Isto, 105-106.

353 Isto.
} 
osigurava pravilno ispunjenje funkcije i književnosti i kritike. Vrhunska književnost nikad ne može biti pogibeljna za narod, kao što niti pravedna kritika, koja se vodi isključivo umjetničkim, a ne izvanjskim, ,političkim“ kriterijima, ne može dovesti do proliferacije loše i pogubne književnosti. Jednako kao što književnost nije moralna ili nemoralna po svojem sadržaju, nego po svojem efektu, tako se ne smije procjenjivati kao „nacionalna“ ili „anacionalna“ po sadržaju, odnosno tendenciji, nego po efektu na razvoj nacionalne književnosti. Dežman ovdje želi jasno istaknuti, predviđajući napade koji slijede: sloboda umjetnosti ne znači „odnarođenu“, kozmopolitsku umjetnost. Sloboda umjetnosti nije sadržaj, pa niti forma, nego određenje uvjeta mogućnosti umjetničkog stvaranja. Zbog toga je njegov

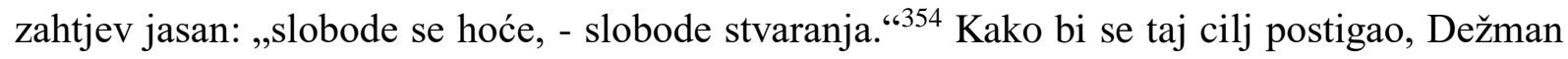
poziva književnike da se trgnu iz svojeg drijemeža, da se organiziraju i da složno nastupe protiv obzira i okova kojima se steže umjetnost. Svoj tekst, u kojem se on kao „golobrado, bezobrazno momče“ usudio suditi kao „zaslužni veteran“, završava znakovito: „Sjetimo se ruske književnosti.“" ${ }^{355}$

Za ovako povoljnu recepciju književnosti ruskog realizma među hrvatskom mladeži na prijelomu stoljeća, a onda napose i u sklopu modernističkog pokreta, zaslužni su brojni prijevodi ruske proze i članci o ruskim piscima objavljeni u hrvatskim časopisima, među kojima treba istaknuti rad Antuna Radića o ruskoj književnosti između 1890. i 1895. godine, a koji je i sam simpatizirao s naporima mladih u ovim početnim godinama pokreta. Osim recepcije ruske književnosti, za razvoj modernističke kritike mladih bilo je iznimno važno njihovo čitanje Hippolytea Tainea, čija je Filozofija umjetnosti u prijevodu objavljena u Viencu 1895. godine. Njegov je koncept miljea (le milieu) našao svoju primjenu upravo u ovom Dežmanovu tekstu. Prema tainevoskom konceptu miljea, ključni su faktori koji određuju umjetničko djelo ekonomsko stanje, odnos umjetničkog djela i publike te život društva kao korijen sadržaja umjetničkog djela, a mladima je on mogao biti privlačan i zbog implikacije da promjena društvene sredine može odlučno utjecati na razvoj književnosti. ${ }^{356}$

$\mathrm{U}$ svojem prvom programatskom nastupu na polju književnosti, pokret mladih tako u prvi plan stavlja pitanje nacionalne književnosti, njezine infrastrukture, karaktera, svrhe i zadaće. O općim filozofskim i estetskim pitanjima nema govora ili su dotaknuti tek rubno, opet u funkciji interpretracije problema nacionalne književnosti. Iako je bio bečki đak, u Dežmanovu je pristupu mnogo više češke, nego bečke moderne. On je, međutim, posve

\footnotetext{
${ }^{354}$ Isto, 107.

${ }^{355}$ Isto, 108.

356 Branka Pribić, „Idejna strujanja u hrvatskoj kulturi od 1895. do 1903.“, Časopis za suvremenu povijest IV, 1, $1972,91$.
} 
zaokupljen analizom hrvatskih književnih prilika. Baš kao i u slučaju političkih aproprijacija, modernistički se koncepti posuđuju i prevode u hrvatski kontekst, kako bi poslužili njegovoj dekonstrukciji i kritici. Dežman tako ne raspravlja o konceptima istine kao kriterija umjetnosti, slobode umjetničkog izražavanja, slobodne kritike itd. kao takvima, nego o blagodatima koje bi njihova primjena donijela hrvatskoj kulturi. Ovaj dežmanovski reformistički program etablirat će se kao dominantni smjer razmišljanja u okviru hrvatskog modernističkog pokreta na polju kulture i književnosti. ${ }^{357}$

Lokalni primjeri analiza i kritika književnih prilika bili su stoga jednako važni kao i strani modeli. Ako je Gjalskijev roman $U$ noći bio vrelo inspiracije za mlade u vrijeme njihovih formativnih srednjoškolskih dana, onda je tu ulogu u ovome periodu odigrao jedan drugi njegov roman, Radmilović. U njemu Gjalski opisuje propast talentirana pisca Marka Radmilovića u hrvatskim društvenim i kulturnim prilikama. Već se prvi prizor ovog romana može čitati kao literarni pandan Dežmanovu tekstu. Smješten u zagrebačkoj Narodnoj kavani, uz impresionistički i feljtonistički opis tamo okupljena društva, Gjalski s ironičnom distancom prikazuje njihov odnos prema književnosti i kulturi općenito. Novinski kritičar Halagović čita češke novine - samo zato jer su mu se našle pri ruci, a drugih nije bilo - u kojima se hvali pisac Radmilović, „koji je pošao novim pravcem u hrvatskoj knjizi““.358 On se, međutim, ne može sjetiti je li ikad čuo za toga Radmilovića, kojega navodno hvali veliki dio Europe te koji je preveden na nekoliko jezika. A on je ipak uspješan hrvatski kritičar kojemu ,ne bi tjedan prošao, da ne uspiše u svojim novinama, kako je književnost hrvatska onaj bedem, koji najstalnije čuva hrvatsku narodnost i kako treba da narod uzljubi domaću knjigu“, iako ih niti on sam u zadnje vrijeme baš ne čita. ${ }^{359}$ Postavši radoznao, Halagović se raspituje o Radmiloviću u kavani, ali u koje god društvo da dođe nailazi na jednako neznanje, pa i prijezir prema novijoj književnosti. „Sve ovo novo, što se piše, nije umjetnost, nije poezija. Ti ljudi ne znaju ni jezika ni metrike!“, tvrdi tako dr. Glišić, „također nekoć književnik, a i još danas rado se ubrajajući među pjesnike, jer je bio prije dvadesetak godina ispjevao bezbrojne himne na sve moguće rodove i vrste, poredane u Pokornijevoj botanici.“360 Halagović

\footnotetext{
${ }^{357}$ Dežmanovski se reformistički program slijedeći Bourdieua može čitati i kao zahtjev za dovršenjem procesa autonomizacije književnog i kulturnog polja, odnosno za ispravljanjem njegovih devijacija. Izgradnja funkcionalne književne infrastrukture, uklanjanje „,izvanjskih“ elemenata iz procesa ovjere književnih tekstova, uspostava primata estetskih kriterija, redefiniranje uloge i profila povlaštenih čitatelja (napose kritike) i postavljanje koncepta autorstva kao središnje instance književnog života imaju za cilj dovršenje izgradnje relativno autonomnog (nacionalnog) književnog polja. Tek tako izgrađeno nacionalno književno polje može, prema Dežmanu, izvršavati svoju ulogu u razvoju nacije i društva. Usp. Marina Protrka, Stvaranje književne nacije: Oblikovanje kanona u hrvatskoj književnoj periodici 19. stoljeća, Zagreb, 2008, 17-18.

${ }^{358}$ Ksaver Šandor Gjalski, Radmilović, Zagreb, 1932., 8.

359 Isto, 9.

360 Isto, 11.
} 
naposljetku doznaje o Radmiloviću od mladoga studenta Vulakovića koji pisca osobno poznaje, a koji ga upućuje na činjenicu da je Radmilović cijelo vrijeme sjedio pored njega u kavani, izričući pritom žalopojku o stanju hrvatske javnosti: „Žalosno, žalosno, da se takav pisac zapravo i ne poznaje! Oh, on piše krasno! Da je rođen u Francuskoj, Rusiji ili Njemačkoj, vjerujte mi, sav svijet bi ga poznavao. [...] Nema te evropske, svjetske slave, koja bi tako lako prekočila naš visoki zid, visoki zid sveopćeg nečitanja!“361 Taj visoki zid prikazuje se kod Gjalskoga u tipičnom obliku zaostajanja za zapadnim svijetom, kao skučena provincijalna sudbina maloga naroda na europskoj periferiji.

Osim ocjene općeg stanja hrvatske javnosti i književne kritike, koja je čak identična u nekim formulacijama, Gjalskijev Radmilović s Dežmanom dijeli i poglede na samu narav i svrhu književnosti. On je svoje radove „sastavljao i stvarao po zakonima, sudu i zahtjevima svoje duše“, ali tvrdi i kako književnik nikad ne smije zapostaviti ,pravi život“", s kojim uvijek mora biti u doticaju kako ne bi zapao u ,jednostranost“" i ,preveliku naivnost“. 362 Drugim riječima, književnik mora stvarati ne po uzorima, pravilima i šablonama, nego po svojem uvjerenju i iz svojeg uvjerenja, ali oslonac mora uvijek tražiti u stvarnome životu. I za Radmilovića, glavni je kriterij i postulat svake umjetnosti istina.

Gjalski je također na isti način kao Dežman (ili obratno) pokazao i odnos vlasti te društva općenito prema književnicima. Ismijavajući uglednog prvaka hrvatske opozicije koji organizira ples na kojemu vladaju nijemština i birokracija, te se željno očekuje dolazak samoga bana, on prikazuje potpuno zanemarivanje slavnoga književnika „N.“ kojega se tretira kao nebitna i drugorazrednog gosta. Rezigniran takvim tretmanom jednog književnika koji radi za narodnu stvar, Radmilović pada u očaj, kritizirajući pritom odnarođenu društvenu elitu, a posebice njezin ženski dio koji uopće ne mari za domaću knjigu. Uza sve to, Radmilović ipak nije bio „nikakav fanatik“ niti „nacionalistički šovinist““, te se „mogao riješiti spona i veriga preuskoga patriotizma“, pristajući uz ideje „što ih je rodio početak stoljeća“. 363 Nasuprot odnarođenoj i korumpiranoj eliti, Radmilović razvija smislen i ispunjavajuć razgovor o hrvatskoj književnosti sa siromašnom samohranom majkom i njezinom kćeri, tipičnim Gjalskijevim idealiziranim ženskim likovima, koje istinski ljube hrvatsku knjigu. Ohrabren tim iskustvom, Radmilović ipak optimistično vidi uporište hrvatskoj književnosti u jednako idealiziranom ,narodu“:

\footnotetext{
361 Isto, 14.

${ }^{362}$ Isto, 18-19.

${ }^{363}$ Isto, 48.
} 
„Pak mu bude, kao da je to prava slika cijele sudbe hrvatskoj knjizi, odnemarenoj, zaboravljenoj i nepriznatoj u raskošnim i gospodskim dvorovima otuđene aristokracije i u hvastavim odajama bogatih novčara i imućnika, ali zato ipak prigrljenoj u čednoj čestitoj kućici maloga čovjeka, u domu učiteljevu, na polici kapelanovoj, u škrinjici djačetovoj, u sobici kakve sirotice. “6364

Gjalski otvara još jedan problem koji postaje izrazito bitan za Dežmana i modernistički pokret općenito, a to je pitanje književnosti kao samostalnog zanimanja. Pritisnut materijalnim problemima, a u nemogućnosti da živi od svojeg pisanja, Radmilović je primoran zatražiti dozvolu za odvjetništvo, što mu je odbijeno upravo zbog njegova pisanja kojim je uvrijedio službene „obzire“. Naposljetku se morao povući iz Zagreba u provinciju, gdje nastavlja svoj književni rad. Njegov roman „Mučenici“, koji istinito govori o domaćim „društvenim prilikama i sociološkim načelima“, odbila je, međutim, Matica hrvatska zbog „obzira“, jer to djelo, usprkos svojoj vrhunskoj umjetničkoj kvaliteti, „nije za naše prilike“ 365 Ne htjevši iz umjetničkih razloga prihvatiti ponudu Vienca da se roman tiska u nastavcima, Radmilović se upušta u avanturu objavljivanja knjige u vlastitoj nakladi. Taj je pothvat, međutim, u potpunosti propao jer gotovo nitko nije htio kupiti nešto što nije bilo iz naklade Matice hrvatske. Nakon toga je uslijedila i kritika. S jedne je strane bila zlobna i osobna, a s druge je stranačka kritika roman ignorirala jer Radmilović nije bio pobornik nijedne stranke. Slomljen takvom recepcijom i materijalnom propašću, Radmilović je naposljetku poludio i nedugo nakon toga skončao u Stenjevcu u bijedi i bez priznanja, kao žrtva hrvatskih društvenih i književnih prilika.

Iako su mladi u Radmiloviću pronašli uzornu analizu hrvatskih kulturnih i društvenih prilika, čije su motive mogli preuzeti za vlastitu kritiku, on se ne može čitati kao puka preslika stvarnosti. Modernistički je element ovog polu-autobiografskog romana sadržan u tome da je glavni njegov lik uobličenje ideje individualnosti koja se sukobljava sa svojoj sredinom. Upravo će ta ideja individualnosti koja nadilazi ograničenja svoje sredine postati fundamentalna za modernistički pokret mladih. Ona, međutim, ima i svoje naličje u vidu prodora iracionalnog i nesvjesnog. Radmilović nije samo žrtva svoje sredine, nego i sebe samog, predstavljajući tako tip modernističkog protagonista, rastrgana intelektualaca u srazu sa svojom okolinom.

Sve ranije navedene paralele između Gjalskijeva Radmilovića i Dežmanova teksta o hrvatskim književnim prilikama u Hrvatskoj misli još jednom potvrđuju važnost lokalnog

\footnotetext{
364 Isto, 96.

${ }^{365}$ Isto, 290.
} 
intelektualnog konteksta za razumijevanje modernističkih strujanja na prijelomu 19. i 20. stoljeća. Recepcija Gjalskoga u krugovima mladih za modernistički je pokret jednako formativna kao i njihova iskustva na stranim sveučilišnim centrima te njihovi doticaji s drugim modernističkim pokretima, bilo u pozitivnom ili negativnom smislu. Uz Dežmanovu pozitivnu, u Hrvatskoj misli prisutna je i negativna recepcija Gjalskoga, i to u drugom ključnom, programatskom tekstu posvećenu književnosti. To nije tek usputni kuriozitet, nego upućuje na različite varijante modernističkog programa u kulturi koji su se oblikovali u okviru pokreta mladih. Uz Dežmanov reformistički, Hrvatska misao iznosi i radićevski socijalnopolitički književni program koji je formulirao Milan Šarić. Njihove razlike manifestiraju heterogenost modernističkog pokreta mladih i pregnantno govore o njegovoj naravi.

Drugi tekst o književnosti objavljen u Hrvatskoj misli djelo je člana uredništva Milana Šarića, a nosi jednostavan naslov „Hrvatska književnost“. Članak je popraćen citatom iz Hamleta, „Something is rotten in the state of Denmark" kao motom, što odmah ukazuje na njegovu ocjenu stanja hrvatske književnosti. Za razliku od Dežmana, koji je bio vanjski suradnik Hrvatske misli, Šarić nastupa kao autor iz same jezgre praške skupine, što se jasno vidi i u samom tekstu, koji se može čitati kao primjena programatskih načela Hrvatske misli na polje književnosti.

U Šarićevu se tekstu pojavljuju dva učestala mjesta modernističke kritike u Hrvatskoj: pozivanje na danskoga kritičara Georga Brandesa i uspoređivanje Hrvatske s Danskom. Jednako kao što je Češka bila uzor ponajviše na polju politike, tako je za hrvatske moderniste Danska predstavljala zemlju čije su strukturne sličnosti s Hrvatskom - mala europska književnost malog europskog naroda - omogućavale da se percipira kao poželjan model kulturnog razvoja. Danska je nadišla svoje probleme, pa time može poslužiti kao uzor za Hrvatsku koja se suočava s istim ili sličnim problemima: „Sve kao kod nas, samo tamo je to bilo prije trideset godina, a kod nas je to još danas. “366 U tom smislu, jasno je da se početni citat zapravo referira na stanje u Hrvatskoj, koje strukturno odgovara onome koje je Danska nadišla. Slično kao Dežman, i Šarić vidi uzroke lošeg stanja književnosti u stanju društva: „Darovitosti ima u nas dosta, ali života nema nikakvoga. Nema tu razvijenih, samostalnih pojedinaca, nema tu pravoga života narodnoga, nema života literarnoga, nema života političkoga, nema tu jasnih smjerova. Svako je samomu sebi prepušten.“367 Za razliku od Dežmana, međutim, on mnogo kritičnije nastupa prema samomu preporodu, optužujući ga da je dio problema jer je donio jednostranost u narodni život.

\footnotetext{
${ }^{366}$ M. (Milan Šarić), „Hrvatska književnost““, Hrvatska misao, god. I, br. 5, 136.

${ }^{367}$ Isto, br. 6, 191.
} 
Šarić razvija kritički pregled hrvatske književnosti u svim njezinim granama, uz iznimku drame koju svjesno preskače. Započinjući s poezijom, on kao njezino glavno obilježje vidi patvorenost i šabloniziranost. Nasuprot idealu pjesništva koje izvire iz pjesnikove „duše“ i nutrine, hrvatske su pjesme ,plod lektire, a više puta naprosto afektacija, a redovno je sve to neizrazito. ${ }^{\text {368 }}$ Poezija mora biti izraz života pojedinca ili naroda, a pravo je pjesništvo život prikazan umjetničkim sredstvima. Glavne vrste poezije koje dominiraju u Hrvatskoj su dakako ljubavna i patriotska: pjesme dragoj i domovini. Dok za ljubavnu poeziju kratko konstatira njezinu šabloniziranu narav, mnogo više pažnje posvećuje patriotskoj poeziji. Pritom doslovce ponavlja kritiku prevladavajućeg patriotizma u Hrvatskoj iznesenu u programatskim tekstovima Hrvatske misli: apstraktno poimanje naroda, nerazlikovanje pojmova naroda, domovine i države, historijsko idoliziranje, fetišiziranje teritorija itd. Kao glavne negativne primjere takve poezije Šarić vidi pjesništvo Augusta Harambašića i Ante Tresića Pavičića. S druge strane, kao svijetle primjere hrvatske poezije navodi od suvremenika Jovana Hranilovića i Silvija Strahimira Kranjčevića, a općenito Petra Preradovića, pri čemu posebno naglašava njegovo „slavenofilstvo“, ideju slavenske preporodne misije i jedinstva Hrvata i Srba.

Prelazeći na prozu, Šarić iznosi teoriju romana prema kojoj on „najbolje uspjeva, ako prikazuje savremeni socijalni život, vanjske dogadjaje i duševni život svojih suvremenika“, odnosno ako je svojevrsna ,društvena psihologija“. ${ }^{369} \mathrm{U}$ tom smislu, roman može djelovati na društvo bolje nego bilo koja kritika društva. To ne znači da treba biti tendenciozan, jer time može lako naštetiti istini. Što se tiče hrvatske proze, Šarić odmah primjećuje da je ona previše fokusirana na plemstvo. „Nije li čudno,“ pita se on, „da se aristokracijom toliko bave hrvatski pripovijedači, sinovi hrvatskoga naroda, koji danas gotovo svoje aristokracije nema, a i koliko je ima, ta je otudjena i s narodnim životom nema ništa“, ističući nasuprot tome da je hrvatski narod ,,jezgrom i brojem seljački“ ${ }^{370} \mathrm{U}$ tome što se hrvatski pisci više bave plemstvom nego seljaštvom Šarić vidi jasan dokaz u prilog tezi da je hrvatskoj inteligenciji na pameti samo položaj i titula, a ne narod. Čitajući hrvatske romane, konstatira kako se ,čovjek mora često puta pitati, da li se to dogadja u Hrvatskoj, Francuskoj ili gdje drugdje.“371 Književnost najbolje niče i raste na vlastitom tlu, a u Hrvatskoj se pisci povlače u strane zemlje i za stranim uzorima. Za razliku od Dežmana, Šarić nije nimalo impresioniran Gjalskim. Posebno ga smeta njegova fascinacija plemstvom: „Gjalski je demokrat, kod kojega se pripovijeda

\footnotetext{
${ }^{368}$ Isto, br. 5, 136.

${ }^{369}$ Isto, br. 6, 192.

370 Isto, 193.

${ }^{371}$ Isto, 194.
} 
samo o zagorskom plemstvu, kod kojega se „U noći“ i Kačić i Narančić „pl.“, kod kojega je „pl.“ Borislavić i „pl.“ Radmilović, koji progledava i raspoznaje po širokom licu sinove seljačke (kod ženskih to ne ispituje). “372 Usprkos tome, Šarić priznaje da su romani U noći i Radmilović njegova najbolja djela, iako i u njima opaža nedostatke. Makar se navodi kao jedan od prvih autora romana s filozofskim tendencijama u hrvatskoj književnosti, za Šarića je Gjalski u filozofskim pitanjima plitak i impresionist koji se lako zaokupi nekom mišlju koju onda brzo i napušta. Zbog toga je teško razabrati koje je piščevo stvarno mišljenje, odnosno koje je njegovo pravo „unutrašnje nastrojenje“, što je važna odrednica za modernističku kritiku. Nasuprot tome, kao najbolji primjer suvremene hrvatske proze Šarić vidi djela Josipa Kozarca: „Kozarac, ljubitelj ruske pripovijetke, potpuno je shvatio sveto zvanje književnika narodnoga.“373 Za njega on ima same pohvale te ga ističe kao pravi uzor za daljnji razvoj hrvatske književnosti. On dakle predstavlja svojevrsni književni pandan radićevskom političaru-narodnom apostolu, kao čovjek koji nije otuđen od naroda, koji živi i radi za narod, među narodom, kao njegov prosvjetitelj i organski intelektualac.

Šarić na analizu hrvatske književnosti primjenjuje tada popularni taineovski princip prema kojemu se određeno književno djelo može smatrati rezultatom autorova okruženja, tj. miljea. S druge strane, odstupajući od tvrde pozitivističke pozicije, on dopušta mogućnost da se pojedinci mogu uzdići iznad ograničenja svoje okoline i kritički se odnositi prema njoj. Kako uvjete za to mogu imati samo intelektualci, ulogu kritičkog odnosa prema svojem okruženju, tj. miljeu može izvršavati jedino inteligencija. Slijedeći ruskog kritičara i revolucionarnog demokrata Nikolaja Aleksandroviča Dobroljubova, Šarić stoga zaključuje da je za razvoj književnosti ključan razvoj inteligencije, kao što je i za njenu procjenu ključna ocjena stanja inteligencije. Primjenjujući to na analizu hrvatske književnosti, on uzrok njezina lošeg stanja vidi u nedoraslosti hrvatske inteligencije, odnosno, još gore, u njenoj odnarođenosti. Šarić u tom smislu ponavlja sva ključna mjesta programatskih tekstova Hrvatske misli, napose „Hrvatskih ideala“ Stjepana Radića, optužujući hrvatsku inteligenciju za nemar, zaostalost, korumpiranost, odnarođenost i pogrešno razumijevanje narodne politike. Zaključno, međutim, poziva na fundamentalne promjene:

„Ovako, kako smo pošli, ne ćemo nikamo doći. Danas stojimo na raskršću dviju doba. Novi se znaci ukazuju. U životu se dogadja po malo preokret. Doba je sada i preokretu literature. Već je vrijeme, da prestane biti domaća, a postane narodna, prava literatura.

\footnotetext{
372 Isto, 195.

${ }^{373}$ Isto, 197.
} 
Književnici moraju dublje poimati svoju zadaću, a na mjesto njihova praznoga patriotizma neka dodje narodnost, koja nužno vodi do demokratičnosti i realizma. “374

Iako se nije uže bavio pitanjem književnosti, Radić je u Hrvatskoj misli ipak iznio svoje viđenje njezine svrhe i funkcije. Učinio je to u uvodniku 2. broja, „Prva naša životna potreba“, koji je nastao kao reakcija na članak „Pred srpski književni kongres“ objavljen u Brankovu kolu u kojem autor potpisan pseudonimom „Cenzor“ upozorava na neuspjehe političke suradnje Srba i Hrvata uzrokovane (trenutnim i navodnim) suprostavljenim interesima, kao i nevoljkošću i jednih i drugih da se odreknu tradicija i historijskih prava. Nasuprot tom političkom jedinstvu, koje pripada budućnosti, autor apelira na suradnju na književnom polju bez ikakvih političkih implikacija. Književno-kulturno povezivanje, dakle, zadaća je tadašnjih pionira srpsko-hrvatske suradnje, kao nužna predradnja za dugoročne ciljeve političke suradnje i, naposljetku, političkog jedinstva. ${ }^{375}$ Radić, iako simpatizira s namjerama autora, naglašava kako je on, po njegovu mišljenju, počinio pogrešku. Ona se sastoji prije svega u strogu odijeljivanju književnosti i politike, što je za Radića nemoguće. Navodeći ruske književnike kao primjer, on ističe kako svaki književnik treba biti političar, ali ne u užem smislu riječi, nego ,političar, da tako kažemo, bez dogmatičkoga programa“ koja „pripravlja put politici s programom“ među narodom. ${ }^{376}$ Radić tako književnosti daje izrazito političku, utilitarnu funkciju. Ona treba djelovati na polju fundamentalnom za praške mlade - narodnoj kulturi koja čini supstrat svake nacionalne politike. Upravo je njena zadaća da „upoznaje narod“, njegove „potrebe“ i „težnje“, i da na temelju toga pruža orijentir za daljnje djelovanje. Pritom je iznimno važno da književnik ne bude epigon nekog partikularnog stranačkog programa, nego mora uvijek djelovati kao neovisni, ali narodni intelektualac, dakle formirani i nepokolebljivi individualac u narodnoj službi.

Šarić i Radić književnosti daju izrazito utilitaran karakter. Ona se ne sagledava iz umjetničke perspektive i ne ocjenjuje prema umjetničkim kriterijima, nego iz rakursa njezine uloge u nacionalnom životu. Književnik je kod njih stoga de facto izjednačen s nacionalnim intelektualcem i aktivistom, drugim riječima, s organskim intelektualcem nacije. S obzirom na to da je za njih nacija utemeljena u narodnoj kulturi, a njezin su pak supstrat život, običaji i mišljenje puka, istinski narodni književnik postaje tako pučki književnik. On ne mora potjecati iz puka, kao što to ne mora niti narodni političar, ali se on mora baviti problemima puka, njegovim težnjama i potrebama. U radićevsko-šarićevskoj koncepciji književnosti

\footnotetext{
${ }^{374}$ Isto, br. 7-8, 224.

375 „Prva naša životna potreba“, Hrvatska misao, god. I, br. 2, 33-34.

${ }^{376}$ Isto, 35.
} 
umjetnička i estetska pitanja nisu od prevelike važnosti. Dobar primjer toga je ranije navedena Šarićeva vrlo redukcionistička ocjena Gjalskijevih djela. Nakon što je aristokraciju a priori odstranio iz nacionalnog korpusa, a njega proglasio književnikom opsjednutim plemstvom, jasno je da ne ispunjava ulogu književnika-organskog intelektualca koju su Radić i on zamislili. Ova koncepcija književnosti u velikoj će mjeri obilježiti djelatnost praške skupine pokreta mladih, ali budući da će književnost općenito ostati na margini njihova interesa, neće imati presudnu ulogu u djelatnosti mladih na kulturnom polju u cjelini.

Treći, i posljednji tekst o književnosti objavljen u Hrvatskoj misli je pregledni članak Františeka Xavera Šalde, češkog književnika i najvažnijeg zastupnika mlade češke kritike, jednog od potpisnika manifesta češke moderne. U članku naslovljenom „Pogled u noviju češku literaturu“ on na pregledan i deskriptivan način prikazuje novija strujanja u češkoj književnosti, namjerno ne ulazeći u oštrije kritičke osvrte. Ono što je značajno, međutim, jest način na koji Šalda kategorizira i opisuje moderna književna strujanja: „Današnjom se literaturom našom, kao što možda svakom evropskom povlači spor medju dva svijeta, medju starim i mladim. Kao što svagdje drugje, bio je i kod nas motivom toga razdvoja problem umjetnički, dosta nejasno formulovan, poznat pod imenom realizma i naturalizma.“377 On različite smjerove moderne književnosti koji se razvijaju u drugoj polovici 19. stoljeća smješta pod opći pojam realističkog pokreta. Suprotstavljen idealizmu, on se na općenitoj razini zalaže za književnost blisku modernom životu. $U$ tom pogledu, njemu ne pripadaju samo autori realističkog i naturalističkog pravca, nego i ,čisti umjetnici“, impresionisti; i oni, dakle, koji su umjetnosti pridavali socijalnu zadaću, kao i oni koji su samo širili područje umjetničkih tema, metoda i nazora: „U kratko: ogroman kaos, smjerove i struje najprotivnije nalazimo u pokretu t. zv. realističnom u drugoj polovici našega stoljeća u srednjoj Evropi.“378 Ovakav pristup, koji ne suprotstavlja realizam, naturalizam i modernu, nego ih objedinjuje pod općim pojmovima realističkog i modernističkog pokreta, zanimljiv je jer će biti prihvaćen i u okviru hrvatskog modernističkog pokreta.

Iz Šaldina prikaza razvoja češke književne kritike jasno je da je ona poslužila kao uzor za hrvatsku mladu kritiku. On ističe da se svijest o zaostajanju češke literature javila krajem osamdesetih i početkom devedesetih godina 19. stoljeća, kada se i počela razvijati mlada kritika koja će napasti „prazni shematizam“, „pseudoidealizam“ i ,apstraktnu šablonu“ domaće književnosti. ${ }^{379}$ Nasuprot tome, mlada kritika tražila je od književnosti ,narodnost i

\footnotetext{
${ }^{377}$ F. X. Šalda, „Pogled u noviju češku literaturu“, Hrvatska misao, god. I, br. 7-8, 237.

378 Isto.

${ }^{379}$ Isto, 238.
} 
socijalnost, konsekventno umjetničko rješavanje psihologie i teleologie narodne.“ ${ }^{\text {“380 }}$ Ona se treba približiti punoći i slikovitosti društvenog života te djelovati u smjeru potenciranja šire socijalne pravednosti. U tom smislu, nije samo svladano „usko stanovište frazerskoga patriotizma i narodnoga fetišizma“ nego i ,umjetničke samosvrhe i eksotičnoga diletantizma“. ${ }^{381}$ Prikazujući ukratko češke javne polemike oko Kraljodvorskih i Zelenogorskih rukopisa, koje su potaknule razvoj češkog novog smjera, odnosno kako ga on naziva, „novoga preporodnoga nastojanja“, Šalda ih opisuje kao spor u kojem se sukobilo „apsolutno istinoljublje i individualna sloboda istraživanja s izvanjskim autoritetom puke tradicije i pukoga historizma.“382 Za njega je upravo kritika prokrčila put i stvorila novi pokret, što će kao načelo rada biti prihvaćeno i u okviru hrvatskog modernističkog pokreta. I ovaj tekst, dakle, kao i ranije prikazani članak Milana Heimrla o novim strujanjima u češkoj politici, upućuje na svjesne aproprijacije čeških modela u okviru hrvatskog pokreta mladih. ${ }^{383}$

Iako je književnost ostala na margini interesa praške Hrvatske misli, ove su rasprave imale fundamentalnu važnost za razvoj pokreta mladih na polju kulture. Na njezinim stranicama jasno su se ocrtale konture dvije specifične koncepcije književnosti, reformističke Milivoja Dežmana, koja je sintetizirala moderna umjetnička strujanja i nacionalne tradicije, i socijalno-političke Milana Šarića i Stjepana Radića, koja je književnost vidjela kao instrument široko zamišljene „,narodne politike“ praških studenata. I jedna i druga bile su orijentirane prema pitanju nacionalne književnosti. Među njima, međutim, postoje jasne razlike. U fokusu je Dežmanove reformističke koncepcije književnost sama, dok ju Šarić promatra samo s obzirom na njezinu društvenu i političku ulogu. Šariću je dakle mnogo više stalo do političkih implikacija književnosti nego Dežmanu, koji je fokusiran prije svega na političke uvjete razvoja književnosti same. U tome se zapravo sastoji prava razlika u pristupu književnosti između tzv. praške i bečke skupine hrvatske moderne, a ne u navodnom čistom utilitarizmu praške skupine i čistom artizmu bečke, a pogotovo ne u ignoriranju književnosti praške, a politike bečke skupine. Upravo će različit odnos prema književnosti i kulturi dovesti do pojave grupacija pokreta mladih koje će krenuti putem reforme institucija nacionalne kulture,

\footnotetext{
380 Isto.

${ }^{381}$ Isto.

${ }^{382}$ Isto, 239.

${ }^{383}$ Osim ova tri članka, o književnosti u Hrvatskoj misli nalazimo samo još jednu bilješku kojom je popraćena izvedba Vojnovićeva Ekvinocija u Pragu. Vodeći se ocjenama njima bliskog češkog novinstva, uredništvo Hrvatske misli pozdravlja činjenicu da se u Pragu izvodi jedna hrvatska drama, ali ujedno izražava žaljenje što je to baš morao biti Ekvinocij, ,koji svojom sentimentalnošću i naivnošću može djelovati samo na babe.“ Iz ove kratke bilješke teško je iščitati dublje razloge ovakve ocjene, ali Hrvatska misao svakako zaključuje da je bolje „, ne izlaziti pred tudj svijet, kad nemamo s čim čestitim.“ „Ekvinokcij [!] u Pragu“, Hrvatska misao, god. I, br. 3, 96.
} 
ali i do nesuglasica među samim mladima. U praškoj Hrvatskoj misli kao prvom programatskom istupu mladih kriju se tako klice svih smjerova budućeg razvoja pokreta, ali i njegove napetosti i ambivalencije.

\section{3. Pokret mladih i hrvatski studentski pokret}

Posljednji veliki problemski sklop na koji moramo obratiti pažnju kada je riječ o analizi početnog razdoblja pokreta jest njegov odnos prema vlastitoj generaciji i stanju u hrvatskom školstvu. On se ne svodi samo na tekstove objavljene u Hrvatskoj misli, nego obuhvaća i konkretnu organizacijsku djelatnost u okviru đačkog i studentskog pokreta. Kada je pak riječ o tekstovima, ovdje ćemo se fokusirati na one koji najbolje predstavljaju stajališta praških mladih o navedenom problemu, a to su prije svega članci Svetimira Korporića i Stjepana Radića objavljeni u Hrvatskoj misli.

Stanje u hrvatskom školstvu na prijelomu stoljeća možda i nije bilo toliko loše koliko se činilo mladima, napose u usporedbi s ranijim razdobljima, o čemu svjedoči i činjenica da je hrvatski školski postav nagrađen na Pariškoj svjetskoj izložbi 1900. godine. Iako su obrazovne ideje u Hrvatsku najčešće dolazile posredstvom srednjoeuropskih, uglavnom njemačkih, austrijskih i čeških uzora, na prijelazu stoljeća sve je izraženija vlastita incijativa u pitanjima školstva, kao i preuzimanje ideja s izvora bez medijacija. Krajem 19. stoljeća organizira se domaća naklada i autorstvo školskih knjiga, proizvodnja nastavnih sredstava, kao i obrazovanje nastavnog kadra. Čak i onda kada su se preuzimali strani predlošci, oni nisu samo preneseni u hrvatski kontekst. I Mažuranićevi školski zakoni, i Klaićevi prijevodi školskih knjiga prilagođavali su europske modele domaćim prilikama i potrebama, pri čemu su neka rješenja čak nadograđena s obzirom na originalni predložak, kao što je primjerice jednaka plaća učiteljica i učitelja ili uvođenje tjelovježbe za učenice. Austrijski model bio je presudan i za ustroj Sveučilišta u Zagrebu. Za razliku od njemačkog koji mu je služio kao uzor, ovaj je model počivao na mnogo snažnijoj kontroli države, pa su nastavnici tako imali status državnih službenika, a njihov je izbor uvelike ovisio o političkim faktorima. Sveučilište je prema osnivačkom zakonu trebalo imati četiri fakulteta: teološki, pravni, filozofski i

medicinski, međutim potonji nije osnovan sve do 1917., što je slabilo privlačnu snagu sveučilišta u usporedbi s drugim, razvijenijim monarhijskim središtima. Jedan od većih problema također je bilo nepriznavanje diploma zagrebačkog sveučilišta u austrijskom dijelu Monarhije. To je demotiviralo potencijalne studente iz Istre i Dalmacije te sputavalo razvoj 
zagrebačkog sveučilišta kao nacionalnog visokoškolskog centra. Uz političko kadroviranje i snažan utjecaj vlasti, ono što je posebno moglo smetati mlade aktiviste jest da je bilo kakva politička djelatnost na Sveučilištu bila strogo zabranjena, iako je to u praksi značilo da se kanalizirala kroz društva koja nominalno nisu imala politički značaj. Studentski pak život nije previše odudarao od tipičnih europskih primjera toga doba. Iako je dobar dio studenata bio stipendiran, iznos stipendije nije bio dovoljan da omogući bolji životni standard. To ih ipak nije spriječavalo da užvaju u čarima studentskog života, koji su uključivali zabavu u kavanama i gostionicama, pohađanje kazališta, ali i prekomjernu konzumaciju alkohola te javne izgrede, često političke naravi. ${ }^{384}$

Ranije spomenuti Vienčev kritičar mladima je posebno bio zamjerio pesimističan ton prisutan u tekstovima Milivoja Dežmana i Svetimira Korporića. I doista, Korporić u svojem članku „O indolenciji i pesimizmu u hrvatskoj mladeži“ ne daje nimalo ružičast pogled na stanje hrvatske omladine. Dapače, njegova je ocjena još poraznija od Dežmanove. Korporić u svojoj analizi također koristi taineovski, pozitivistički teorijski okvir: stanje mladeži nekog društva odraz je stanja toga društva. Postoje kritički nastrojeni pojedinci koji se mogu uzdići nad prosječnu razinu, ali njihov je utjecaj na društvo u cjelini preslab. Stanje je hrvatskog društva, koje se dakle preslikava na stanje hrvatske mladeži, dakako porazno. Za razliku od (zapadne) Europe, gdje su si moderne, slobodumne ideje postepeno i organski krčile put kroz društvene i političke borbe, u Hrvatskoj su „sve slobodoumnije uredbe umjetno naciepljene. “385 One stoga nemaju čvrsto uporište u javnosti $i$ narodu. I to je rezultat povijesnog „kašnjenja“, koje uzrokuje to da se nove ideje i institucije uvijek recipiraju izvana te da nemaju organsko ishodište u samom hrvatskom društvu. Dok cijeli svijet raspravlja o socijalnom pitanju, a napose onom agrarnom, hrvatska se javnost time uopće ozbiljno ne bavi, iako je Hrvatska agrarna zemlja par excellence. Slično je stanje i na području kulture, koje Korporić opisuje jednako sivim tonovima. Sve to upućuje na činjenicu da hrvatsko društvo nije spremno nositi se s povijesnim trenutkom, a to je trenutak prijelaza:

„Kao da živimo na prelazu. Svuda se to opaža, pa i kod nas. Stare društvene forme, stare predaje i običaji pomalo iščezavaju, ili već iščeznuše, a da nije ništa ispunilo nastale praznine. Društvo ljudsko rastvorilo se u same jedinice, koje lete odieljeno u tom kaosu interesa i nada, lete svaka, da što više uhvati.“"386

\footnotetext{
${ }^{384}$ Prikaz stanja u školstvu prema: Luetić, nav. dj.; Gross, Szabo, Prema hrvatskome građanskom društvu, $402-$ 418; Iskra Iveljić, „Prosvjeta Banske Hrvatske u 19. stoljeću - europski uzori i hrvatske posebnosti“, u: Iveljić (ur.), Zbornik Nikše Stančića, Zagreb, 2011, 125-139.

385 Svetimir Korporić, „O indolenciji i pesimizmu u hrvatskoj mladeži“, Hrvatska misao, god. I, br. 1, 24.

${ }^{386}$ Isto, 25.
} 
Taj napredak, međutim, ima i svoje tamno naličje, a to je „borba svih proti svima“, gubljenje moralnog orijentira u fragmentiranu materijalističkom društvu. Kao reakcija na to javljaju se različiti pokreti koji smjeraju obnovi etičkog i moralnog prvenstva, kao što su „misticizam“, „filozofski idealizam“, „novokršćanstvo“ i „katolicizam“. S druge strane, hrvatska inteligencija ne participira uopće u tim modernim strujanjima, ona je „bezidejni skup pojedinaca, u velikoj većini moralno iskvarenih ili slabih.“387 To je naposljetku prijetnja i samom nacionalnom opstanku, jer će „duh vremena“, a to je „duh pokvarenosti i slabosti“ pomoći „zatornicima našega narodnoga organizma“, koji u pravilu barataju većom i moćnijom državnom i društvenom silom. ${ }^{388}$

Osim ove karakteristično radićevske moralističke pozicije, Korporić primjenjuje i medicinske metafore koje su bile primamljive i Dežmanu u njegovoj analizi. Društvo koje je nezdravo u svojim temeljima prenosi svoju bolest i na novo pokoljenje: „Stupajući u svijet donosi već to pokoljenje sa sobom tjelesne poroke i duševne sklonosti, što ih je baštinilo po ocevima svojim, a teška atmosfera bolesnoga društva pritiskuje ga od prvoga dana u koljevci i prati ga kroz cio život, ne dajući mu, da se prirodno razvije. “3899 Moralna se deficijencija dakle prenosi kao urođena bolest, a održava se kontinuiranim podbačajima na području odgoja i obrazovanja. Upravo je iscrpnoj analizi odgojno-obrazovnog procesa i njegovih institucija posvećena većina Korporićeva teksta. Njegova se kritika može svesti na to da odgoj ne proizvodi čvrst ,značaj“. To se prvenstveno odnosi na građanski odgoj, koji je izvještačen i licemjeran. S druge strane, „onaj dio inteligentne hrvatske mladeži, koji je potekao iz krugova zanatlijskih, a osobito iz seljačkih, poneo je mnogo zdravijih elemenata iz svoje obitelji.“390 Idealizirajući težak život nižih slojeva koji stvara čvrst karakter, a kontrastirajući njegove zdrave temelje s nezdravim, modernim urbanim okruženjem, Korporić konstatira kako se i ti zdravi mladi seoski ,značajevi“ kvare dolazeći u grad na nastavak obrazovanja.

Škola stoga ne ispunjava svoju zadaću da odgaja čovjekov kritički duh, moralni osjećaj niti tjelesni razvoj. Kao glavnu zamjerku hrvatskom školskom sustavu Korporić ističe njegovu klasičnu orijentaciju, koja (više) ne odgovara potrebama suvremenog društva, zbog čega oslonac na klasično obrazovanje zapravo znači nazadak. Osim toga, hrvatske škole „djecu iz puka [...] odnarodjuju, a djecu obrazovanih vrsta utvrdjuju u njihovu kozmopolitizmu“, pogotovo zato što se u njima uopće ne uči o narodu, njegovu životu i

\footnotetext{
387 Isto, 26.

${ }^{388}$ Isto.

${ }^{389}$ Isto, br. 2, 49.

${ }^{390}$ Isto.
} 
običajima. ${ }^{391} \mathrm{Na}$ taj način one ne samo da imaju negativnu ulogu u pripremanju učenika za sudjelovanje u suvremenom društvu, nego ne ispunjavaju niti svoju nacionalnu zadaću. Iz njih stoga ,izlaze marljivi djaci duševno ubijeni, ostali lakoumni i besavjesni, većina pak duševno i moralno zakržljala.“392 $\mathrm{Na}$ kraju obrazovne vertikale dolazi pak sveučilište, koje je ,jednostavno sluškinja vlade“"

„S katedre se tumače i opravdavaju reakcijonarni zakoni i još reakcijonarnija praxa, moderne ideje i pokreti nemaju tu svojih tumača i branitelja. Naše sveučilište tvornica je robova. Bez viših ciljeva, bez širih vidika, bez nutarnjega jedinstva, mrtva nauka postaje puko sredstvo privrede, i ljudi je uče samo toliko, koliko je potrebno, da načine ispite, a ispite čine za to, da ih prime u službu. ${ }^{\text {“393 }}$

Od obitelji, preko škole, do sveučilišta, pa čak i političkih stranaka koje svoj utjecaj na mladež nisu iskoristile za njihovo obrazovanje, sve su karike odgojno-obrazovnog procesa zakazale. Zbog toga je hrvatska mladež prepuštena sama sebi. S obzirom na to da od sustava ne može dobiti „zdrave hrane“, ona bi trebala „da strese sa sebe sve nenaravno i pokvareno,

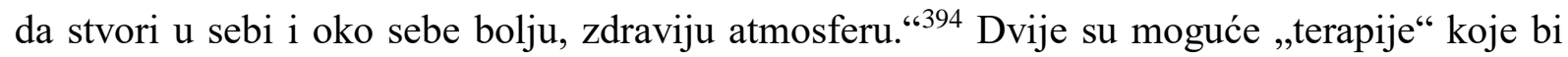
mogle voditi do ozdravljenja. Prva, preporučena, jest ta da hrvatska mladež napusti svoje kužno okruženje i pronađe neko zdravije, kao što „bolesnik, koji je obolio od vlage i nečistoće, u kojoj živi, treba da ode u drugo, zdravije mjesto, ako hoće da ozdravi.“ ${ }^{395} \mathrm{U}$ tom slučaju, Korporić svakako preporuča da se klone tradicionalnih studentskih središta kao što su Beč, Graz, Innsbruck i Pešta, gdje atmosfera nije mnogo bolja, gdje im je okolina tuđinska i gdje oskudijevaju intelektualno i materijalno. Dakako da bi bilo najbolje potražiti utočište na nekom od slavenskih sveučilišnih centara, ponajprije u Pragu, dok su ruska, belgijska, francuska i engleska sveučilišta ipak logistički previše nepristupačna. Ako već odlazak na neko strano sveučilište nije moguć, onda se kao alternativna terapija predlaže stvaranje boljih uvjeta kod kuće, napose kroz samostalno naobrazbu i čitanje. Pritom treba dakako voditi računa o tome što se čita, kao i o lošem stanju prijevoda strane literature, što bi iziskivalo uporan rad na učenju stranih jezika.

Sumirajući svoju opsežnu analizu, Korporić pruža nimalo laskavu ocjenu trenutnog stanja. Pomalo iznenađujuće, konstatira kako u Hrvatskoj nema ,nikakove djačke organizacije“, a akademska društva, koja su uglavnom nosila pridjev „literarno-zabavna“,

\footnotetext{
${ }^{391}$ Isto, br. $5,149$.

392 Isto 150

${ }^{393}$ Isto, br. 6, 199.

394 Isto, 200.

395 Isto.
} 
„literarnima nisu nikada bila.“396 Među hrvatskom se mladeži tako nikad nije niti pokušalo ozbiljno raditi. Zbog svega toga u njezinim redovima postoje dvije kategorije ljudi. Prvi su oni indolentni, ,zadovoljni sobom i svojom okolinom“, koji prolaze fazu šupljeg političkog frazerstva i na kraju završavaju kao ,parasiti na tielu naroda““ ${ }^{397}$ Drugu pak skupinu čine oni pesimistični, koji su se uzdigli nad svojom okolinom, ali uviđaju svu uzaludnost bilo kakva ozbiljnog rada uslijed porazne društvene situacije, pa i oni naposljetku sve više potpadaju pod utjecaj te okoline koju preziru. Zbog svega toga Korporić zaključuje da se Hrvatska ne treba previše uzdati u svoju mladež: „Često se govori i piše o 'zlatnoj hrvatskoj mladeži', o 'uzdanici hrvatskoga naroda'. No čemu obmanjivanje? Valja priznati, da hrvatska mladež nije ništa bolja od ostalog obrazovanog hrv. družtva, da je u ogromnoj svojoj većini ili indolentna ili pesimistična!“398

Radićev pak tekst, „N. Kareêv o samostalnom naobražavanju“, može se smatrati pozitivnim pandanom ovom Korporićevu tekstu. Kao što sam naslov kaže, a Radić to ističe i u napomeni uz tekst, on je nastao na temelju Pisama školskoj mladeži o samostalnom naobražavanju petrogradskog povjesničara i filozofa Nikole Ivanoviča Karjejeva, s kojim je Radić najvjerojatnije došao u doticaj tijekom svojeg boravka u Rusiji 1896. godine. Sažimajući i elaborirajući sadržaj knjige, Radić pruža korisne savjete hrvatskoj mladeži o tome kako organizirati proces samostalnog obrazovanja, koji se smatra nužnom nadopunom formalnom obrazovanju kako bi se mogao razviti cjeloviti karakter. Ono nije suprotstavljeno formalnom obrazovanju, nego funkcionira na temelju drugačijeg principa. Dok je formalno obrazovanje usmjereno na stjecanje znanja s ciljem osiguranja materijalne egzistencije, samostalno obrazovanje predstavlja prostor slobode usmjeren ka razvoju ličnosti. Ovdje se dakle opetuje dihotomija između materijalizma i idealizma kao vrijednosno impostirana dihotomija između neslobode i slobode, pri čemu se potonja nužno veže uz pojedinca, što je karakteristično za radićevski etički individualizam. On dakako ne isključuje, nego upravo pretpostavlja društveni angažman, jer je čovjek tek kao društveno biće potpun. Radić je u tom pogledu vrlo jasan: „Nismo mi poklonici onoga individualizma - a individualizama ima različnih -, koji je isto, što i socijalni indiferentizam (nehaj za opće dobro), individualizma, koji radi prema onoj: spavaj seko, Turci su daleko, jer takav je individualizam samo druga

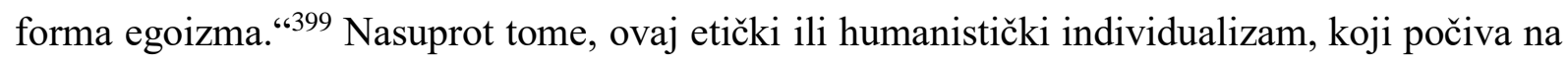
samostalnom obrazovanju i izgradnji moralnog karaktera, nužno je usmjeren i upravo

\footnotetext{
${ }^{396}$ Isto, 202.

397 Isto.

398 Isto.

${ }^{399}$ Stjepan Radić, „N. Karêev o samostalnom naobražavanju“, Hrvatska misao, god. I, br. 4, 99.
} 
kulminira u radu za opće dobro. Iako je svaki individualizam nužno utemeljen na pretpostavci da je društvo „samo organizacija duhovnih i materijalnih odnošaja pojedinaca“, odnosno da je u društvu realna „samo ličnost“, on ne povlači sa sobom „,apologiju slobodne konkurencije“, „eksploataciju slabijega“ ili „težnju za pukim privatnim dobitkom“. 400 Društveni angažman mora podrazumijevati priznavanje drugih kao jednakopravnih i jednakovrijednih ličnosti. On se ne smije voditi apstrakcijama, što često završava u nametanju vlastite ličnosti drugome, nego na poznavanju pojedinaca, njihovih želja i težnji. Radićev program usmjeren mladeži podrazumijeva tako kao svoj cilj stvaranje nove nacionalne inteligencije:

„Ne čusmo li, gdje poriču znanost i obrazovanost radi toga, što neposredno ne koriste narodu, gdje poriču inteligenciji pravo da opstoji, jer da je ona suvišno i nekorisno breme na narodu? A ipak ne valja poricati svega toga, nego nastojati, da to sve koristi narodu, a ponajprije treba iz sebe samoga s pomoću znanosti i obrazovanosti stvoriti korisna i vrsna pregaoca. “401

Nastavljajući tamo gdje je Korporić u svojoj kritici postojećeg stanja stao, Radić zaključuje kako odgovor ne smije biti indolencija i pesimizam, cinično odbacivanje uloge inteligencije uopće, nego moralni preporod koji ima stvoriti nove „pregaoce“ na narodnom polju.

Kao i u slučaju književnosti, praški mladi na obrazovanje gledaju kroz prizmu njegove nacionalne uloge. Ono je uspješno ili neuspješno u onoj mjeri u kojoj proizvodi nacionalno osviještena građanina, spremna da preuzme aktivnu ulogu u nacionalnom životu. Stručni, znanstveni, etički i humanistički aspekti obrazovanja nisu stoga svrha sami za sebe, nego su u funkciji razvoja cjelovita karaktera buduće nacionalne inteligencije, baš kao što su estetski i umjetnički kriteriji književnosti podređeni njezinoj nacionalno-didaktičkoj ulozi. S obzirom na to da su u obrazovnom sustavu u Hrvatskoj vidjeli opasnost za nacionalni identitet i osobni integritet učenika i studenata, praški su mladi zamišljali paralelni sustav obrazovanja koji bi na srednjoškolskoj razini uključivao program samostalne naobrazbe čitanjem preporučene literature, a na visokoškolskoj nastavak studija na nekom od poželjnih, napose slavenskih, sveučilišnih centara. Tako formirani pojedinci mogli bi potom popuniti redove ,pregaoca na narodnom polju“, koji će se izboriti za poželjne promjene, uključujući i reformu obrazovanja u smjeru osnaženja njegova nacionalnog karaktera.

Osvrnut ćemo se još na tekst zagrebačkog suradnika Hrvatske misli Ivana Lorkovića koji se pobliže pozabavio zadaćom sveučilišta. Ovaj je tekst zanimljiv zato što predstavlja

\footnotetext{
${ }^{400}$ Isto, 103.

${ }^{401}$ Isto, br. 6, 185.
} 
drugačiji pristup problematici obrazovanja. Prema Lorkoviću, sveučilište nije tu da gaji čistu znanost usmjerenu prema sebi samoj, nego prema praktičnoj primjeni i koristi. To ne znači da sveučilište mora raditi po diktatu države, nego da ova dva subjekta moraju uspostaviti partnerstvo usmjereno na zadovoljavanje društvenih potreba. Država mora primjenjivati rezultate znanosti ,na život narodni u svojoj sferi; a znanosti samoj mora dopustiti slobodan razvoj،“402 Modernoj državi je potrebna znanost kako bi rješavala probleme koji joj se nameću, a i jedna i druga su se približile u zadaći da služe društvenom životu. Što se tiče njegove obrazovne funkcije, sveučilište ima pripremiti mlade stručnjake koji će biti sposobni raditi na društvenom planu. Njihova je zadaća „da na svome mjestu, što će ga u domovini zauzeti, dodje s doličnom spremom pred svako pitanje, s kojim se sretne“ ${ }^{403}$ Drugim riječima, zadaća je sveučilišta „da znanosti socijalizuje, da spremi ljude, koji će ih umjeti u životu društvenom primjenjivati i tako izvršavati socijalnu zadaću znanosti.“404

U Lorkovićevu je pristupu mnogo manje zastupljena nacionalno-identitetska dimenzija obrazovanja. Njegova je vizura pozitivistička i tehnokratska. I dalje je u fokusu zadaća obrazovanja s obzirom na „domovinu“, ali ona se ne sastoji u formiranju ,pregaoca na narodnom polju“, nego „stručnjaka“ koji će biti spremni suočiti se s društvenim problemima koje sa sobom nosi moderni svijet. Ova razlika u pristupima između Radića i Korporića s jedne i Lorkovića s druge strane, uz to što zrcali razlike u pristupu književnosti, upućuje na to da su se divergentna modernistička strujanja na prijelomu stoljeća prelila i u okvir hrvatskog modernističkog pokreta. ${ }^{405}$ Modificirana procesima aproprijacija, činila su tako lokalne varijetete širih modernističkih koncepcija. U ovom slučaju riječ je s jedne strane o pozitivističkoj fascinaciji dosezima moderne znanosti, kao i mogućnostima njezine društvene primjene kod Lorkovića, dok je kod Radića i Korporića s druge strane prisutan upravo skepticizam spram „modernog materijalizma“ i naglasak na moralističkom individualizmu koji je nacionalno impostiran. Činjenica da ove dvije međusobno u mnogočemu suprostavljene koncepcije supostoje na ideološkom horizontu mladih dovoljno govori o eklektičnosti njihovih aproprijacija.

Dakako da se djelatnost praške skupine na polju omladinske politike nije ograničavala na pisanje tekstova za Hrvatsku misao. U njima je elaboriran jedan u velikoj mjeri cjelovit pogled na tadašnje stanje hrvatske mladeži, njezina odgoja i obrazovanja, kao i ideje

\footnotetext{
${ }^{402}$ Ivan Lorković, „Sveučilište“, Hrvatska misao, god. I, br. 2, 46.

403 Isto, 48.

404 Isto, 49.

405 Plastičan prikaz ključnih tema prijeloma 19. i 20. stoljeća daje Philip Blom, Vrtoglave godine: Europa, 1900.1914., Zagreb, 2015.
} 
usmjerene prema promjeni tog stanja i revitaliziranju uloge mladih u nacionalnoj politici. S druge strane, pražani su i dalje bili uključeni u strujanja u okviru hrvatskog studentskog $\mathrm{i}$ đačkog pokreta, koji se sve više dinamizirao.

Već smo istaknuli da su pokretanje Hrvatske misli nepovoljno primila gotovo sva hrvatska studentska društva. Hrvatsko akademsko društvo Velebit iz Innsbrucka zamjerilo je Hrvatskoj misli što je u svojem prvom broju donijela ironičan komentar na izostanak odgovora iz Velebita na svima odaslani proglas, zbog čega je u trećem broju objavljen ispravak, koji je uredništvo Hrvatske misli opet popratilo ironičnim komentarima. ${ }^{406} \mathrm{U}$ svojem posljednjem dvobroju Hrvatska misao nastavila je s ismijavanjem Velebita donoseći dopis jednog Čeha iz Innsbrucka koji je bio njegov član. U njemu se ruglu izvrgava tadašnji predsjednik Velebita Jakov Račić koji se, prema dopisniku, ponašao kao predsjednik nekog njemačkog Burschenschaft-a, izazivajući na dvoboj svakoga tko bi mu se usprotivio i služeći se samo nijemštinom iako se društvo zaklinjalo na slavensku solidarnost. ${ }^{407}$

Najvažniji je, međutim, odnos praških mladih s najvećim hrvatskim akademskim društvom - bečkim Zvonimirom. Za razliku od otvoreno neprijateljskog odnosa s Velebitom, odnosi s bečkim Zvonimirom i dalje su bili hladni, tek pritajeno neprijateljski. U kratkoj bilješci u trećem broju Hrvatska misao tako pozdravlja ideju objavljivanja almanaha povodom petnaest godina rada Zvonimira, ali ujedno mu zamjera što poziv nije odaslan i Hrvatskoj misli. Osim toga, oni ne smatraju poželjnim to što se predviđa da za almanah pišu bivši članovi Zvonimira, tada istaknuti hrvatski literati, jer bi svrha almanaha trebala biti „da bude ogledalo duševnoga stanja u današnjem 'Zvonimiru'“, da pokaže narodu „da mu djaštvo radi!“408 $U$ tome je dakle sadržana implicitna kritika da se Zvonimir previše oslanja na tradiciju i stare, a da ne radi na aktivaciji postojećeg studentskog tijela. Ova je bilješka nagnala Zvonimir da se javi Hrvatskoj misli s ciničnim ispravkom: „Na bilješku u Vašem cijenjenom listu čast nam je upozoriti Vas, da izvolite pomnjivije pročitati društvenu objavu glede 'Almanaka', pa će vam onda ono biti jasno, što Vam se po Vašoj opasci čini nejasnim“, na što je uslijedio jednako ciničan odgovor Hrvatske misli: „Na Vaš cijenjeni dopis čast nam je upozoriti Vas, da izvolite pomnjivije pročitati svoju društvenu objavu glede 'Almanaka', pa će vam onda biti jasno, što Vam se po našoj opasci čini nejasnim. “"409

Nakon početnog šoka uzrokovanog demonstracijom u listopadu 1895. godine $\mathrm{i}$ represalijama koje su uslijedile, tijekom 1897. godine nastavila se politička aktivnost

\footnotetext{
406 „Iz 'Velebita'“, Hrvatska misao, god. I, br. 3, 94.

407 „Iz 'Velebita'“', Isto, br. 7-8, 259.

408 ,'Zvonimir' izdaje Almanak“, Isto, br. 3, 96.

409 ,'Zvonimiru'“, Isto, br. 5, 171.
} 
studenata i na zagrebačkom sveučilištu. Ondje je tako 22. ožujka održana skupština, o kojoj za Hrvatsku misao izvještava Ivan Lorković. Skupštinu je sazvalo dvadeset studenata, pripadnika pravaške „većine“, a točka dnevnog reda je bila „da se osnuje hrv. akad. liter.-zabavno društvo““. ${ }^{410}$ Pravaški su studenti dakle zaključili da je došlo vrijeme da se obnovi studentski društveni rad u Zagrebu nakon zabrane ranijeg društva Zastava, a htjeli su iskoristiti situaciju da se nametnu kao osnivači i predvodnici tog projekta. U tom smislu izvještava i Lorković opisujući skupštinu kao puku formalnost kojom se samo ozakonjuje ono što je već od vodstva odlučeno. Na njoj će disciplinirana većina izglasati već pripremljene zaključke, manjini će biti dopušteno da malo govori kako bi se stvorio dojam „liberalnosti“, a pritom će se demonstrirati i brojčana snaga većine. Nikakvi argumenti pojedinaca pritom neće igrati ulogu. Tako je, prema Lorkovićevu izvještaju, predsjednik skupštine Aleksandar Horvat vrlo autoritativno vodio sjednicu, izbacio je sve izvanredne slušače, što se ranije nije radilo, te je uvjerio nazočne da je od „kompetentne strane“ dobio garancije potvrde društva. Izvjestitelj Hrvatske misli to ironično uspoređuje $\mathrm{s}$ držanjem, „članova X. i IX. dietenklase, kad sanjaju o promaknuću, uvjereni, da kompetentna strana ima potpuno povjerenje u njihovu privrženost ili baš ništa ne drži do njihove 'oporbenosti'.“"411 Predsjednik skupštine nije dopustio da se raspravlja o dnevnom redu. Lorković objašnjava ponašanje predsjedavajućeg i pravaške većine prisutnošću Ujedinjene hrvatske $i$ srpske omladine, koju se htjelo spriječiti u remećenju planiranog tijeka sjednice. Znalo se, naime, da će ona predložiti osnivanje hrvatsko-srpskog akademskog društva. Kako bi se u korijenu sasjekao taj prijedlog manjine od sedamdeset ljudi, kako navodi Lorković koji je i sam pripadao toj grupaciji, pravaška je većina odmah preglasala taj prijedlog, pozdravljajući rezultate „čudnom vikom, u kojoj je bila nota neobuzdanoga veselja, što se radja u čovjeku, koji je srećno na čas otklonio pogibao.“412 $\mathrm{Na}$ ovoj je skupštini tako po prvi puta nastupila Ujedinjena hrvatska i srpska akademska omladina, o kojoj će više riječi biti kasnije, kao glavna konkurentska struja pravaškoj većini na zagrebačkom sveučilištu, te glavna točka razvoja „novosmjeraških“ tendencija među zagrebačkim studentima u ovom, početnom razdoblju modernističkog pokreta, čija će ključna politička postavka biti teza o narodnom jedinstvu Hrvata i Srba.

Iako je Lorković bio zagrebački suradnik i partner Hrvatske misli, te iako su kontakti između praške i zagrebačke skupine već bili uspostavljeni, kao i konkretni projekti na kojima su zajednički radili (brošura povodom izbora 1897.), nisu se svi praški mladi slagali s idejama

\footnotetext{
${ }^{410}$ Ivan Lorković, „Dopis iz Zagreba“, Isto, br. 4, 126.

411 Isto.

${ }^{412}$ Isto, 128.
} 
Ujedinjene hrvatske i srpske akademske omladine. Živan Bertić tako je u pismu Radiću izrazio svoje nezadovoljstvo idejom o hrvatsko-srpskom akademskom društvu na hrvatskom sveučilištu. Prema njemu, to nije taktički mudro te bi podrazumijevalo da se konzekventno dalje u svim formulacijama koristi taj „dualistički“ naziv. U tom je smislu i govorio u krugovima praških mladih, međutim, kako se žali Radiću, ostali se „nemarno drže prema toj stvari“, a Hlaváček je čak zaprijetio da će istupiti protiv Hrvatske misli ako se ona slučajno usprotivi nastojanjima zagrebačke hrvatsko-srpske omladine, smatrajući ih posve ispravnima. ${ }^{413}$ Čini se, dakle, da su disonantni glasovi o pitanju ideje narodnog jedinstva Hrvata i Srba, pa onda i suradnje s Ujedinjenom hrvatskom i srpskom akademskom omladinom, u Pragu bili u manjini.

Najvažniji događaj 1897. godine u okviru studentskog pokreta trebao je biti treći opći đački sastanak. I ovoga je puta inicijativa krenula iz bečkog Zvonimira. Tamo je, naime, u ožujku konstituiran petnaesteročlani centralni odbor, čiji je predsjednik bio Dragan Altman, a tajnici Krsto Krile i Dušan Plavšić. Taj je odbor odaslao poziv na osamnaest najvažnijih središta hrvatskih studenata, između ostalog i praškoj Slaviji. Neovisno o ovome, iz Praga je također krenula inicijativa za sazivanjem trećeg đačkog sastanka. Ona, međutim, nije došla od kruga oko Hrvatske misli, nego od „ostalih“, dakle od studenata koji nisu pristajali uz Hrvatsku misao. Oni su se krajem ožujka javili bečkome Zvonimiru s apelom da on kao najveće središte hrvatskih studenata pokrene prireme za treći sastanak. Dopis je potpisao Andrija Kaparović, koji je također i u Frankovu Hrvatskom pravu pozvao na novi opći studentski sastanak. „Ostali“ - zapravo pravaški orijentirani studenti - ističu kako potreba za novim sastankom proizlazi između ostalog iz pojave novih nazora i struja: „Da li nam ravnodušno može biti, da se pojavlja 'srbo-hrvatstvo', da se pojavlja indiferentizam: 'Hrvat ili Srbin' - to je sve jedno.“" ${ }^{\text {414 }}$ Hrvatska omladina mora biti jedinstvena i ujedinjena, i mora prionuti ne samo na politički, nego i na kulturni i prosvjetni rad među narodom po uzoru na češke studente. U tom smislu doista postoji potreba za pokretanjem đačkog lista, „ali lista sveukupne hrvatske mladeži.“ Jasno je da se Hrvatska misao ne vidi kao takav list, nego kao glasilo manjine koja unosi razdor u cjelokupni studentski pokret. U tom smislu, očito je da ova praška pravaška studentska grupa nudi savezništvo bečkome Zvonimiru s ciljem da se kroz organizaciju novog općeg studentskog sastanka regrupira dotadašnja većina u studentskom pokretu te da se tako majoriziraju i marginaliziraju nova strujanja. Upravo je u

413 „Živan Bertić - Stjepanu Radiću, Prag, 24. IV. 1897.“, u: Krizman, nav. dj., 270.
414 „Braćo i drugovi!“”, HR-HDA-757 Obitelj Plavšić, k. 40. 
vezi toga Dežman ranije upozoravao Radića, pišući mu da ne smatra taktički mudrim pretjerano naglašavati ideju narodnog jedinstva Srba i Hrvata:

„Vidit ćeš na sastanku spljetskom ako do njeg dogje. Frankovi bit će avangarda Hrvatstva, za njih izvrstan manevar. Ili misliš, da seljanu koji jedva shvatio da nije Ličanin nego da je Hrvat, da će mu bit lako srušit sve to pa reći ili Srbin gdje je naučen na Srpstvo kao na oprieku. Aj bog da mu veliš da smo braća i da treba sloge, a ne tako na glavu postaviti, u ostalom sve se dade natezati radi se o effectu - i to je glavno držim da će bit loš. “415

Nasuprot tome da se postulira da su Srbi i Hrvati objektivno jedan te isti narod, pa da se iz toga izvlače konzekvence, Dežman drži da je pametnije početi od činjenice nepostojanja subjektivne svijesti o tom jedinstvu, i na tom temelju polagano raditi kako bi se u budućnosti uskladile subjektivna i objektivna razina. U taktičkom smislu, on upozorava Radića da praški mladi ne smiju biti prerigidni u svojim stavovima jer će time od sebe otuđiti ostale studente. Osim toga, on javlja Radiću i to da se u njegovu odsustvu situacija u Pragu ponešto pogoršala po pitanju discipline i idejnog jedinstva kruga oko Hrvatske misli.

S obzirom na činjenicu da je zadnji sastanak u Osijeku bio onemogućila policija, za mjesto održavanja ovogodišnjeg sastanka centralni je odbor predložio Split, „buduć da nam ni pod kojim uvjetom ne bi bilo moguće ma gdje u Banovini trijezno i što je glavno iskreno raspravljati. “416 Izgleda da je upravo pravaška struja inzistirala na Splitu kao mjestu održavanja sastanka jer tu istu ideju spominju i praški pravaši u svojem dopisu. Jednako tako, bilo je predviđeno da se sve neraspravljene točke od prošle godine stave na dnevni red novog sastanka, kao i da se primaju prijedlozi za sasvim nove točke. Za vrijeme održavanja predložen je period oko 25. srpnja, dakle za vrijeme trajanja ljetnih praznika. Centralni odbor naposljetku je pozvao sve hrvatske studentske centre da organiziraju svoje ,pokrajne odbore“ i da se odazovu ovom pozivu za treći opći đački sastanak. Ovaj je poziv Hrvatska misao objavila te kratko komentirala kako se slažu s idejom đačkog sastanka, ali da ujedno žele da se na njemu uistinu raspravlja o važnim pitanjima i da se „sastanak ne izvrgne lih u pijače, bankete itd., što odvraća ili bar priječi ozbiljnom raspravljanju, a stoji mnogo novaca.“417

Na poziv su stigla samo tri odgovora: iz Graza, Zagreba i Praga (od Hrvatske misli). Osim toga, javio se i problem sa Splitom kao mjestom održavanja sastanka. Naime, centralni je odbor upozoren kako bi đački sastanak tamo bio moguć jedino „kad bi se moglo jamčiti, da će velika većina gjaka na sastanku biti onoga političkoga mišljenja, koje je milo

\footnotetext{
415 „Milivoj Dežman - Stjepanu Radiću, Beč, (prva polovica 1897.?)“, u: Krizman, nav. dj., 281.

416 „Hrv.-slovenski klub 'Slavije'“،, Hrvatska misao, god. I, br. 5, 170.

${ }^{417}$ Isto, 171.
} 
Spljećanima“, što nije bio slučaj. ${ }^{418}$ Također, iz suradnje pražana s dijelom zagrebačkih i bečkih studenata proizašla je ideja o organiziranju sastanka pristaša „novog smjera“ u Zagrebu, zbog čega je značajno pao interes za planirani opći sastanak u Splitu. Zbog svega toga, na sastanak centralnog odbora za pripremu trećeg općeg đačkog sastanka zakazan za 26. lipnja odazvalo se samo osam ljudi, signalizirajući propast ove inicijative. S propašću organizacije trećeg općeg đačkog sastanka postalo je jasno da je bečki Zvonimir izgubio primat u okviru hrvatskog studentskog pokreta. Tempo su diktirali „novosmjeraši“ - koalicija praških, bečkih i zagrebačkih studenata predvođena krugom oko Hrvatske misli.

Razlog takvom razvoju događaja djelomično leži i u unutrašnjim trvenjima u bečkom Zvonimiru. U posljednjem dvobroju Hrvatske misli od 10. srpnja 1897. objavljen je anonimni dopis $^{419}$ iz Beča u kojem se konstatira kako se o Zvonimiru izvan Beča, a pogotovo u domovini, zna vrlo malo, osim da je ,najveće hrv. gjačko društvo izvan domovine, da napreduje dobro i da običava davati godimice po jedan koncerat. “420 $\mathrm{S}$ druge strane, o brojnim stvarima koje su se događale unutar društva moralo se šutjeti da se ne bi suočilo s optužbama o „denuncijaciji“. Dopisnik navodi „tiranizovanje ljudi, koji su se 'drznuli' misliti drukčije nego većina, izbacivanje novina, potpuno rasulo društvenoga života megju gjacima“. ${ }^{421}$ Međutim, takvo je ponašanje vodstva društva izazvalo kontraefekt. Mlađi naraštaj koji je dolazio u Beč, navodi dopisnik, počeo se zanimati za stavove manjine koja je zbog njih bila progonjena. Uvidjeli su „da je ta manjina sastavljena od ljudi, koji nijesu zadovoljni sa smjerom, koji vlada u društvu, jer nijesu zadovoljni sa strankom u domovini, na čije se dogme zaklinjala većina $u$ društvu. “422 Drugim riječima, mlađi su počeli uviđati da dominantni smjer Zvonimira zapravo služi pravašima i da oni svoje neistomišljenike samo denunciraju kao izdajnike cijelog naroda. Manjinsko „novosmjeraštvo“ nastupalo je protiv „programa na papiru“, „novinskog polemizovanja“, „idolopoklonstva“, „osobničarenja“, „cjepkanja i državnopravnih programa“, smatrajući da će samo „sloga i rad oko ekonomskoga i prosvjetnoga napretka naroda“ donijeti korist cijelom narodu. ${ }^{423}$ Zbog svega toga, studenti su se sve više počeli okupljati oko ove manjine te je u Zvonimiru do kraja prvoga semestra ove godine došlo do svojevrsnoga obrata. On je ,od društva, u kojem je intolerancija i strančartvo [sic!] ubijalo svaki rad“ postalo „društvom, u kom je mjesta za svakoga hrv. gjaka, bio on ma

\footnotetext{
418 -č- [Fran Hrčić], „Beč, 2. srpnja“, Isto, br. 7-8, 253.

${ }^{419}$ Prema Stanislavu Marijanoviću, autor dopisa je Fran Hrčić, tadašnji tajnik društva. Marijanović, Fin de siècle hrvatske moderne, 65.

420 ,Beč, 2. srpnja“, 252.

421 Isto.

422 Isto, 253.

423 Isto.
} 
kojega mišljenja i u kom većina članova hoće, da počne ipak već jednom ozbiljno raditi.“424 Nekadašnja se većina, međutim, neće dati bez borbe. Oni su pokrenuli akciju protiv novoga odbora u kojem su očito prevladali pristaše „novog smjera“, koristeći se svim mogućim sredstvima opstrukcije kako ne bi dopustili da Zvonimir padne u ruke ,izdajica, odmetnika, slavoserba, i socijalista““ ${ }^{425}$ Dopisnik javlja kako Hrvatska misao slovi za neslužbeni organ među studentima koji pristaju uz novi smjer, zbog čega je ranija većina neuspješno pokušala provesti njezino izbacivanje iz društvenih čitaonica. U svemu tome navodno je određenu ulogu odigrao i Josip Frank, koji je u lipnju posjetio Zvonimir i održao povjerljivi sastanak s dijelom njegova članstva, najvjerojatnije s dijelom nezadovoljnim novim kretanjima unutar društva. U takvom je stanju Zvonimir dočekao kraj ove akademske godine, ,godine krize za 'Zvonimir'“‘. O ishodu ovoga sukoba ovisit će hoće li on „nestati ili će on konačno ipak jednom postati hrv. mladeži u Beču ono, što bi joj već odavna morao da bude.“426

Dinamika općih đačkih sastanaka odražavala je tako dinamiku unutar studentskog pokreta. Dok je prvi sastanak tek signalizirao postojanje nove struje u okviru hrvatskog studentskog pokreta, buduće praške jezgre koja se tada kao uvjerljiva manjina suprotstavljala pravaškoj većini, u pripremama drugog sastanka manifestirao se vidan porast važnosti te nove struje, kao i pojava sličnih tendencija u bečkom Zvonimiru koji je i u okviru novog smjera pokušao zadržati svoj primat u studentskom pokretu. Pripreme za treći sastanak pokazale su pak uvjerljivi pomak težišta inicijative s bečkog na praško središte, ujedno označavajući kraj projekta općih studentskih sastanaka u onom smislu kako je bio incijalno zamišljen - kao mjesto ujedinjavanja hrvatske omladine na platformi „starih“ organizacijskih struktura: tradicionalnih akademskih društava. Postalo je jasno da je od projekta ujedinjavanja hrvatske omladine važnija borba za primat i unutrašnja preobrazba samog studentskog pokreta. Iako je zajednički neprijatelj - do tada dominatno pravaštvo, u novije vrijeme uglavnom $\mathrm{s}$ frankovačkim predznakom - ujedinjavalo praške i bečke „novosmjeraške“ skupine, njih je ujedno razdvajao i tinjajući rivalitet oko centralne uloge u vođenju studentskog pokreta koji se u cjelini postepeno pomicao prema politici novog smjera. U svemu tome zagrebačka je „,novosmjeraška“ jezgra igrala svojevrsnu posredničku ulogu. $\mathrm{Na}$ taj se način otkriva specifična dinamika nastajućeg modernističkog pokreta koji je funkcionirao kao cjelina sastavljena od heterogenih dijelova - nodalnih centara - čije su međusobne silnice djelovale u

\footnotetext{
${ }^{424}$ Isto.

425 Isto.

${ }^{426}$ Isto.
} 
isto vrijeme i centripetalno i centrifugalno, ponekad onkraj ideoloških sličnosti i razlika koje su često padale u drugi plan.

Naposljetku, za praške je mlade posebno bio važan odnos s „,najmlađima“, posebice srednjoškolcima. U posljednjem dvobroju Hrvatske misli objavljena je svojevrsna poslanica maturantima pod naslovom „Abiturijentima“. Pražani upozoravaju svoje buduće kolege da ne trebaju preuranjeno slaviti svoj odlazak iz gimnazije. Ako su smatrali da je gimnazija u Hrvatskoj loša, na zagrebačkom sveučilištu tek ih čeka razočaranje. Međutim, odluka da nastave školovanje u Zagrebu može imati dalekosežne posljedice po njihovu budućnost. U njegovoj zatrovanosti, u društvenoj situaciji koja tamo vlada, oni će se pretvoriti upravo u ono što su kao gimnazijalci strastveno kritizirali - u stupove mađaronskog režima: „Kroz osam godina oduševljeno ste govorili, pjevali i deklamovali o slobodi - u četiri godine postat ćete krvnici njezini.“ Zbog toga, nužno je da đaci što prije napuste Zagreb, ,izvor sve kuenske podlosti i demoralizacije“, i nastave svoje formiranje drugdje.

Ako ne u Zagrebu, gdje onda? Iako većini hrvatskih školaraca prvo na pamet padaju Beč i Graz kao tradicionalna središta hrvatske akademske emigracije, praški studenti decidirano kažu da to nije dobar izbor. Graz zapravo nema ni razvijeno sveučilište ni razvijeno društvo iz kojeg bi studenti mogli crpiti poticaje za svoj razvoj i rad. U Beču dakako postoji i jedno i drugo, ,al u to društvo zatvorena su vrata Slavenu, Hrvatu, a kad i ne bi bila zatvorena, to društvo nije za nas.“ Ono nije za hrvatske studente jer njime dominiraju austrijski Nijemci, koji „kao neki 'državni' narod“ imaju sasvim drugačije interese od Hrvata kao potlačenoga naroda „koji treba da radimo, da se izbavimo ispod tudjega gospodstva.“ Osim toga, pomalo kontradiktorno, „Beč je narodnosno indiferentan grad, od kojega njemačka kultura nema velike koristi.“ Naravno, Hrvatska misao kao najpoželjniju destinaciju za hrvatske studente preporuča Prag. On je potpuna suprotnost Beču: „Tu imamo potpunu analogiju naših odnošaja, naših potreba.“ U Pragu se student može upoznati sa svim suvremenim političkim, kulturnim i intelektualnim strujanjima; može učiti o organizaciji narodne politike i inspirirati se time za svoj rad u domovini; može slušati istaknute profesore i mislioce poput Masaryka itd. Osim Praga, bilo bi dobro na kraće vrijeme posjetiti i Krakov i Lavov. Među Poljacima hrvatski bi studenti mogli naučiti o uzaludnosti revolucionarnog puta kojemu ne prethodi ozbiljan rad na moralnom, kulturnom i ekonomskom uzdizanju naroda. Mladi naposljetku pregnantno zaključuju:

„Zaradi svega toga, što Vam sada spomenusmo, mi Vam, drugovi, opet kažemo: 'Nit u Gradac, nit u Beč!' - U Gracu i u Beču ili ćete po kavanama zjake prodavati, ili ćete buljiti u škripta, ili ćete se potezati od dosade po našim društvima. Jedni ćete otići možda u antisemite, 
drugi u socijaliste, treći u odlučne 'ateiste' - no kako ćete to površno prihvatati, tako ćete i ostati samo 'moderni'...

Nama, narodu našem, treba ljudi narodnih, koji će znati osjećati za svoj narod, taj narod razumjeri i cijelu svoju naobrazbu uptorebiti u gospodarskom i prosvjetnom radu za nj - zato Vas zovemo, hrvatski abiturienti, da dodjete amo k nama!“427

Kako bi pomogla svojim budućim kolegama, Hrvatska misao donijela je i brojne praktične informacije o studentskom životu u Pragu, kao što je cijena smještaja, prehrane, prijevoza te osnovne informacije o tamošnjim visokim učilištima. ${ }^{428} \mathrm{U}$ istu svrhu preporučila je svim potencijalnim praškim studentima Almanah Slavije u kojemu se mogu naći brojne praktične informacije, ali i poučni članci kao što su „Inteligencija i socijalizam“, „Narodnost, medjunarodnost i beznarodnost“, „O spolnoj ćudorednosti“ itd. ${ }^{429} \mathrm{Za}$ almanah je o prilikama hrvatskih studenata pisao Svetimir Korporić. Osim toga, posebno se ističe članak predsjednika Slavije o samostalnoj naobrazbi studenata, koji bi trebao biti uzor i poticaj za slična nastojanja kod hrvatskih studenata.

U srpnju 1897. godine izašao je posljednji dvobroj Hrvatske misli. Plan je bio da list ne izlazi tijekom tri mjeseca ljetnih praznika te da ponovno krene početkom nove akademske godine. Također, u planu je bilo da se list proširi i poljepša. ${ }^{430}$ Međutim, na ljeto je hrvatska vlada zabranila njegovu distribuciju u Hrvatskoj „radi socijalističke i anarhističke tendencije“. ${ }^{431}$ Takvu odluku uredništvo je protumačilo kao znak slabosti režima u Hrvatskoj nakon relativna uspjeha opozicije na nedavnim izborima. Mladi ističu kako ih zabrana neće pokolebati, nego upravo suprotno potaknuti na još odlučnije djelovanje. Završavaju u prijetećem tonu: „Mi poručujemo kasinašima, da kažu svome 'ženijalnom' vodji, da će 'Hrv. Misao' daleko preživjeti 'bansku' karijeru grofa Khuena, i da će mu baš ona odgojiti ljudi, koji će njemu, tudjincu i pouzdaniku tudjnaca, doskora jasno dokazati, da se malo prerano nazvo pacifikatorom Hrvatske... “432

Odmah nakon zabrane Hrvatske misli krenule su pripreme za izdavanje novog lista mladih, o čemu će biti više riječi kasnije. Sada je potrebno razmotriti ocjenu Hrvatske misli kao pionirskog poduhvata hrvatskog modernističkog pokreta. Milan Marjanović konstatirao je kako je usprkos tome što je izlazila samo u jednom godištu, „utjecaj te male revije bio jak“,

\footnotetext{
${ }^{427}$ Svi navodi iz: „Abiturijentima“, Hrvatska misao, god. I, br. 7-8, 209-211.

428 „Život u pragu“", Isto, 260.

429 „Almanach 'Slavie'“, Isto, 261.

430 „Poziv na pretplatu“, Isto, 205.

431 „Zabrana Hrvatske Misli u Hrvatsku“, Isto, 255.

432 Isto.
} 
posebice što se tiče najmlađe generacije kojoj je i sam pripadao. ${ }^{433}$ Jedan takav primjer je karlovački gimnazijski krug, gdje su glavni diseminatori ideja „novog smjera“ bili Petar Skok, Henrik Krizman i Milan Marjanović. Skok je primao Hrvatsku misao i ubirao za nju pretplatu koju je trebao prosljeđivati Draganu Šašelu, praškom studentu iz Karlovca, zbog čega je skoro izbačen iz škole. ${ }^{434}$ To svjedoči o određenom uspjehu u izgradnji mreže diseminacije Hrvatske misli među hrvatskim srednjoškolcima. S druge pak strane, naklade svih časopisa mladih bile su male, redovito bi od tih malih naklada dio ostao neraspačan, a znatan dio neplaćen. ${ }^{435} \mathrm{U}$ tom smislu, moglo bi se reći da publika nije bila velika, međutim, Hrvatska misao po svojem sadržaju i cilju nije niti trebala biti list sa širokom čitalačkom bazom, nego glasilo jedne nove struje u okviru studentskog pokreta, usmjereno prije svega prema studentima i đacima, napose onim aktivnim, a onda i prema hrvatskoj intelektualnoj i političkoj eliti. U smislu recepcije kod tih grupa, može se zaključiti da je list bio uspješan te da je ispunio svoju svrhu.

Prema Dragutinu Prohaski, praška je skupina mladih ,pokazivala jasan pravac u

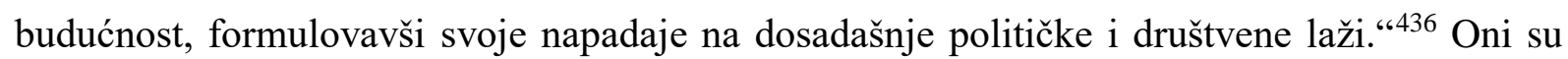
stvorili „na osnovi Masarykovih misli onu političku i društvenu dispoziciju, koja je revolucionirala mladi naraštaj i dala Modernoj značenje pokreta i odredjene ideologije.“437 Vida Flaker s druge strane naglašava da ,iako ideali koje je proklamirala 'Hrvatska misao' i časopisi što su je nastavili, ideali narodnog jedinstva, narodne samostalnosti, narodne vlade i slavenske uzajamnosti, nisu sami po sebi značili novost, jer su se otprije javljali u programatskoj sferi hrvatskih oporbenih stranaka, mladi su pokušali da im dadu nove temelje, posebno ističući važnost širokih, 'nižih' socijalnih slojeva.“"438 Osim toga, ona naglašava kako Hrvatska misao nije ispunila svoju proklamiranu zadaću na književnom polju, u sferi konkretne književne produkcije, što je imalo posljedice na pokret, „,izazvavši zasebni nastup 'bečke' grupe“, o čemu će biti više riječi kasnije. ${ }^{439}$

Najdublju i najobuhvatniju ocjenu Hrvatske misli dao je Rene Lovrenčić. Prema njemu, „Hrvatska misao bila je tipičan omladinski list, vehementan i ambiciozan, prilično difuzan u kritici a još više u konstrukciji, često se kretao po površini života, ratujući više s posljedicama nego s uzrocima, više je poticao analizu stanja i razvoja Hrvatske nego što se u

\footnotetext{
${ }^{433}$ Marjanović, Hrvatska moderna, I, 30.

${ }^{434}$ Agičić, nav. dj., 151.

${ }^{435}$ Marjanović, Hrvatska moderna, II, 29.

${ }^{436}$ Dragutin Prohaska, „Utjecaj T. G. Masaryka na modernu jugoslavensku kulturu“, u: Prohaska (ur.), T. G. Masarik: zbornik, Beograd i Prag, 1927, 151.

${ }^{437}$ Isto, 103.

${ }^{438}$ Flaker, Ċasopisi, 21.

${ }^{439}$ Isto.
} 
nju sam upuštao.“440 Ipak, ona je imala invoacijsku ulogu jer je otvarala teme koje su do tada u hrvatskoj javnosti bile slabije ili nikako zastupljene. Iako su „posuđivali metode a češće i zaključke iz češke i druge strane političke i socijalne literature“, praški su studenti u svojoj mladenačkoj ,„potrazi za novim, širokim horizontima“ otvarali nove vidike drugima. ${ }^{441}$ Mladi su pokušali ,naći put iz močvara malih interesa i sporova građanske opozicije, zavijenih u plašteve velikih ciljeva“, ali su ,više posuđivali tuđu teoriju i praksu negoli je stvaralački primjenjivali“, stare su fraze zamijenili novima te su ,nedovoljno osnovane postavke predstavljali kao nepobitne sudove“. ${ }^{442}$ Ipak, zaključuje Lovrenčić, „usprkos neizbježnim slabostima list je nudio ono što je politici u Hrvatskoj bilo prijeko potrebno - novu orijentaciju. “443

Kao ključna pitanja, dakle, postavljaju se značenje lista i njegova utjecaja na tadašnje društvene, a pogotovo političke prilike, te ono izvornosti i ideološke sustavnosti iznesenih ideja. Jasno je da jedan omanji studentski list nije mogao ostvariti veliki društveni i politički utjecaj. Tek ako se gleda retrospektivno, Hrvatska misao može se smjestiti na začetak modernističkog pokreta koji će u svojoj cjelini ostaviti bitne posljedice u hrvatskom političkom i kulturnom životu. U vremenu neposredno nakon prestanka njezina izlaženja, može se ustvrditi kako njezina važnost prvenstveno leži u okviru promjena koje se odvijaju unutar hrvatskog studentskog pokreta. Hrvatska misao u tom će smislu odigrati ulogu fokaliziranja i kataliziranja „,novosmjeraških“ studentskih i đačkih strujanja. Izvan toga, ona je i dalje relativno marginalan fenomen, koji se ipak pojavio na radaru mjerodavnih opozicijskih i vladinih krugova, prvenstveno zbog simboličkog kapitala koji su zagrebački „,relegirci“ odnijeli sa sobom u Prag.

Mnogo je kompleksnija tema izvornosti i ideološke sustavnosti ideja iznesenih u Hrvatskoj misli. Kako bismo mogli ponuditi adekvatne odgovore, moramo napustiti tradicionalnu shemu sagledavanja prevladavajućih „utjecaja“ na mlade. Jasno je da su praški studenti u svojoj novoj okolini bili pod raznim utjecajima: svojih novih profesora, napose T. G. Masaryka, češkog studentskog pokreta, modernističkih čeških literarnih strujanja, previranja u češkoj politici, društvenih promjena, a preko svega toga i širih monarhijskih te europskih kretanja. Odgovor na pitanje izvornosti ideja nije nam relevantan u smislu usporedbe originalnog predloška i aproprirane reprodukcije. Ono što je ključno jest

\footnotetext{
${ }^{440}$ Lovrenčić, nav. dj., 46.

${ }^{441}$ Isto.

442 Isto.

${ }^{443}$ Isto, 47.
} 
identificirati načine aproprijacije, prije svega različite upotrebe ideja u novom društvenopolitičkom kontekstu.

Iako su učestalo upućivali na analognu strukturu češke i hrvatske društveno-političke situacije, i samim je pražanima bilo jasno da je intenzitet društvenih promjena u češkim zemljama i Hrvatskoj neusporediv. Dok su češke zemlje sigurno stupale u smjeru industrijalizacije i urbanizacije, u Hrvatskoj su te dubinske društveno-ekonomske promjene tek bile u začetku. Zagreb - glavni grad Banske Hrvatske i ujedno hrvatsko nacionalno središte - 1890. godine imao je 38742 stanovnika, a taj je broj 1900. porastao na 57690.444 Usprkos veliku postotnom porastu koji upućuje na intenziviranje urbanizacijskih procesa, to su i dalje u apsolutnim brojkama skromni razmjeri. Osim toga, Zagreb je bio jedini grad u Banskoj Hrvatskoj koji je pokazivao takve postotke rasta. Ukupno gledano, gradovi su 1890. činili 7\% stanovništva Hrvatske i Slavonije, a naselja s više od 2000 stanovnika 11\%, dok su 1900. ti postotci porasli za svega $1 \% .^{445}$ To se odražava i na ekonomskoj strukturi stanovništva: 1890 . godine $84.56 \%$ stanovništva zaposleno je u primarnom sektoru, a svega 8.09\% u obrtu i industriji, čemu se mogu pridodati kategorije „nadničari“ s $0.57 \%$ i kućna služinčad s $0.82 \% .{ }^{446}$ Deset godina kasnije, u primarnom sektoru radilo je $82 \%$ stanovništva, a u obrtu i industriji $8.37 \%$, dok nadničari čine $1.40 \%$ te kućna služinčad $0.94 \% .{ }^{447}$ Hrvatska i Slavonija imala je, osim Dalmacije, najveći postotak poljoprivrednog stanovništva u cijeloj Monarhiji. ${ }^{448}$ Sve to upućuje na početni stadij industrijalizacijskih i urbanizacijskih procesa. U izostanku snažnije industrijalizacije, koju je u velikoj mjeri kočio upravo (sub)dualistički okvir, procesi raslojavanja na selu koje je katalizirala europska agrarna kriza nisu mogli dovesti do formiranja industrijskog proletarijata, nego do snaženja uloge kapitalističkog veleposjeda i sloja seljačkih poluproletera. ${ }^{449}$

Iako je Hrvatska misao pozivala mlade da se ugledaju na probleme kojima se bave suvremeni zapadni društveni pokreti, jasno je da jednostavno prepisivanje ove problematike u hrvatski kontekst nije bilo moguće. Ključno europsko socijalno pitanje druge polovice 19. stoljeća - radničko pitanje - u Hrvatskoj naprosto još nije moglo dobiti zamah uslijed stvarnih društveno-ekonomskih ograničenja razvoja. Stoga ne čudi konstatacija Renea Lovrenčića da je „kulturna sfera dobila znatno više mjesta u njihovu listu nego ekonomska i socijalna.“450

\footnotetext{
${ }_{444}$ Božena Vranješ-Šoljan, Stanovništvo gradova Banske Hrvatske na prijelazu stoljeća, Zagreb, $1991,48$.

445 Isto, 49.

446 Isto, 102.

447 Isto.

448 Šidak et al., nav. $d j ., 139$.

449 Isto, 128-129.

${ }^{450}$ Lovrenčić, nav. dj., 46.
} 
Doista, ako pogledamo sadržaj Hrvatske misli, nije teško potvrditi takvu konstataciju, a to je razvidno i iz naše gornje analize. Većina članaka objavljena u listu tiče se političke problematike. Usprkos pozivima da se upozna i prouči narod i njegove težnje, niti jedan članak u Hrvatskoj misli nije posvećen tome. Od socijalne, mnogo je zastupljenija nacionalna problematika, čak i u onim člancima koji su bili posvećeni prikazu stanja u inozemstvu. Tako možemo pročitati tekst K. S. Mežnaršiča o hrvatsko-slovenskim odnosima, prikaz knjige L. Gumplowicza o slovenskom pitanju te članak Franje Hlaváčeka o rumunjskom pitanju u Ugarskoj. ${ }^{451}$ Jedini članak koji je uže povezan sa socijalnom problematikom bio je onaj Franje Hlaváčeka posvećen seljačkom pokretu u Galiciji. ${ }^{452} \mathrm{Uz}$ to bi se mogao dodati i članak o pučkoj prosvjeti, koji je ipak više kulturno-prosvjetne provenijencije. ${ }^{453}$ Od ekonomske problematike u listu možemo pronaći samo dvije kratke bilješke, obje objavljene u zadnjem dvobroju: kratak prikaz industrijskih prilika u Hrvatskoj iznesen prema izvještaju „Trgovačkog i obrtnog svijeta“ te još kraću bilješku o „našoj trgovačkoj zaostalosti““. ${ }^{454} \mathrm{U}$ oba ova kratka teksta prisutne su ideje ekonomskog nacionalizma karakteristične za ovo razdoblje. $^{455}$

Iz svega ovoga postaje jasno da listom dominiraju teme koje su i inače bile najzastupljenije u hrvatskom javnom prostoru sve od razdoblja ilirizma: političke, nacionalne i kulturno-prosvjetne teme. Originalnost Hrvatske misli tako ne leži u otvaranju novih tema, nego u zalaganju za nove pristupe u okviru onih već postojećih. Mladi zagovaraju diskontinuitet $\mathrm{u}$ kontinuitetu, a ne novi kontinuitet. Oni se zalažu za unutrašnju reformu hrvatske građanske politike, za njezino otvaranje novim idejama i pristupima koje je trebalo aproprirati iz stranih uzora, za njezino dinamiziranje i prilagođavanje novonastajućim društvenim i političkim prilikama. Ali ključno je to da oni nastupaju iznutra, ne u smislu stranačke pripadnosti, nego prije svega prihvaćajući kontinuitet tradicionalne hrvatske politike kao polazišnu i završnu točku svoje kritike. U tom smislu, novi se pokret ne može usporediti sa suvremenim masovnim pokretima koji su napadali liberalno-građansku glavnu struju izvana, utemeljujući svoju politiku na posve drugačijim principima, bilo antiprosvjetiteljskim i antimodernističkim, bilo klasno-socijalnim. On je prije svega reformistički pokret unutar te glavne struje, što će i omogućiti njegovu kasniju inkorporaciju u nju.

${ }^{451}$ K. S. Mežnaršič, „O hrvatsko-slovenskim odnošajima u novije doba“, Hrvatska misao, br. 3, 4, 5, 7-8, 84-87, 115-120, 159-164, 243-248; Franjo Poljak, „Slovensko pitanje (Louis Gumplowicz: La quéstion slovène)“, Isto, br. 2, 62-64; Franjo Hlaváček, „Rumunjsko pitanje u Ugarskoj“, Isto, br. 6, 7-8, 186-191, 230-234.

452 Franjo Hlaváček, ,Seljački pokret u Galiciji“, Isto, br. 1, 2, 3, 4, 5, 16-21, 53-59, 75-81, 108-115, $150-158$.

453 -lić, „O pučkoj prosvjeti. I. Historijski pregled popularizacije nauke“, Isto, br. 1, 9-13.

454 „Industrijske prilike u Hrvatskoj“, Isto, br. 7-8, 257-258; „Naša trgovačka zaostalost“, Isto, 258.

455 Max-Stephan Schulze, Nikolaus Wolf, „Economic nationalism and economic integration: the AustroHungarian Empire in the late nineteenth century“, The Economic History Review LXV, 2, 2012, $652-673$. 
U svjetlu toga nema dvojbe da je službeno obrazloženje zabrane uvoženja Hrvatske misli u Hrvatsku zbog socijalističkih i anarhističkih tendencija samo neutemeljena izlika. Ipak, zadnje retke ovog poglavlja posvetit ćemo analizi odnosa Hrvatske misli prema socijalizmu jer on isto tako dobro ilustrira njihovu vlastitu poziciju i samopercepciju. Već u prvome broju lista objavljen je izvještaj sa sastanka hrvatske socijaldemokratske stranke, koja je osnovana 1894. godine. Izvjestitelj, „Spectator“, odmah se osvrće na domaću percepciju socijalizma koja je kasnije iskorištena i za zabranu Hrvatske misli:

„U širim krugovima (n. pr. u Hrvatskoj) se drži, da je socijalizam od prilike isto što i anarhizam i da biti socijalista znači na vrat na nos srušiti sve temelje današnjega društva bez ikakve brige, što će iza toga biti. Socijalizam je u tim krugovima negacija svake religije, izdajstvo narodnosti, u kratko: pod rječju socijalizam misli se na sve najludje i najmanje moguće.“

Nasuprot tome, „Spectator“ upozorava da je socijalizam jedan od pokreta koji počivaju na velikom socijalnom pitanju, a koje „,danas pokreće gotovo cijelim svijetom, nezna za granice ni geografske ni državne, nego ih prekoraćuje, a da se ne brine nimalo, što se državnicima mršti čelo a vladama klecaju koljena.“ Za njega, socijalno pitanje nije samo radničko pitanje, ono je pitanje „kako da se društvo u opće uredi, kako da se društvene uredbe promijene (a ne poruše). “ U tom smislu, ,pitanje takve promjene i novog uredjenja postoji i u zemljama, gdje danas nema radništva“, pa se njemu „ne mogu ugnuti ni posvema agrikulturne zemlje.“ Ono se ne tiče samo ekonomskog položaja stanovništva, nego je ono i „pitanje moralno“, ono podrazumijeva i „socijaliziranje“ i „demokratiziranje“ znanosti i umjetnosti, pitanje narodnosti, ,a pogotovo se novija politika socijalizuje, tj. prestaje biti politikom diplomacije, dinastijâ i vlada, a postaje politikom puka, njegovih potreba i težnja."456 Za Hrvatsku misao socijalno pitanje postaje tako opći nazivnik suvremenog doba, ključna prizma kroz koju se moraju sagledavati svi društveni, kulturni i politički problemi. Na taj način oni i svoju viziju politike mogu usidriti kroz pojam suvremenog socijalnog pitanja, a da ono ujedno ne podrazumijeva zauzimanje socijalističkog stanovišta. $\mathrm{S}$ obzirom na to da su mladi u Hrvatskoj misli zapostavili socijalnu problematiku nauštrb političke i nacionalne, jasno je da i ovaj stav ima tek deklarativni karakter tipičan za početni stadij pokreta. Iako je izvještaj uglavnom pozitivno intoniran, Hrvatska misao jasno se distancira i kritički postavlja spram hrvatske socijaldemokracije. Ona pozdravlja njezinu ideju o izdavanju znanstvene smotre koja bi bila posvećena socijalnom pitanju, njihov aktualni politički program koji je ,i narodan i

\footnotetext{
${ }^{456}$ Spectator, „Sastanak hrvatske socijalno-demokratske stranke“, Isto, br. 1, 29.
} 
napredan“" (što su i sami praški mladi preuzeli kao epitete kojima opisuju svoju poziciju) te političku borbu s parolom općeg prava glasa. $\mathrm{S}$ druge strane, oni zamjeraju hrvatskim socijalistima njihovo „dogmatičko stajalište u pitanju agrarnom“, nedostatak „posebnog agrarnog programa“, kao i ,način propagande i taktike prema hrvatskoj opoziciji.“457

Čini se da je u hrvatskoj javnosti bio prepoznat pozitivan ton ovog izvještaja. U četvrtom broju Hrvatske misli objavljen je odgovor „gospodinu Franjinu u Zagrebu“ koji se obratio redakciji riječima podrške, ali i žaljenja što mladi misle svoj rad za narodno dobro „otpočeti na socijalizmu.“ Mladi ističu kako su i s drugih strana čuli ovaj prigovor. Iz odgovora Hrvatske misli najbolje se vidi njihov odnos prema socijalizmu: „Mislimo, da iz Hrv. Misli ne može niko vaditi zaključka, da smo mi socijaliste. Istina i Bog, nije nam socijalizam niti strašilo, od koga bismo bježali na sto hvati daleko, kao što to obično čine naši ljudi. Mi i njemu idemo blizu, priznajemo, što je u njemu dobra, motrimo ga, a kad jedanput progovorismo o njemu, onda ćete već vidjeti, da socijaliste nismo.“ Praški mladi ističu kako su ,pišući o onom sastanku u glavnom htjeli ovo reći našim drugovima: gledajte ljudi božji, istom počeli - pa vidite, šta već rade, kakav program imadu, na kakvu li se organizaciju spremaju; istom počeli - pa već misle, da sagrade sebi tiskaru, da osnuju pučke novine, a do sada su i bez novina toliko već radili i agitovali medju narodom, da u seljaštvu imaju danas jačega oslona nego stranka prava, koja već trideset godina 'vodi hrvatski narod'،“458

U članku pak iz petog broja Hrvatske misli, „Socijalizam u Srijemu“, Živan Bertić osvrnuo se na stav hrvatske opozicije prema Khuenovu nasilnom gušenju socijalističke agitacije među srijemskim seljacima, koja se tamo snažno razmahala prije izbora 1897. godine. On je napao hrvatsku opoziciju da je u svojem sljepilu pomogla Khuenu da prije izbora značajno osujeti cjelokupni opozicijski zamah. Hrvatska opozicija u procvatu socijalizma u Srijemu vidjela je ugrozu za patriotizam, a nije prepoznala da taj pokret među seljacima „nema ništa zajedničkoga sa socijalizmom osim pukoga imena“. ${ }^{459}$ Za Bertića, socijalisti su samo upornom agitacijom uspjeli nametnuti svoje ime pokretu koji je zapravo usmjeren protiv režima u Hrvatskoj. Za razliku od socijalista, „gospoda“ iz hrvatske opozicije nisu se potrudili zaći među narod i upoznati njegove probleme i težnje, pa nisu niti mogli prepoznati njegov sentiment prilikom pristajanja na socijalističku agitaciju, držeći tako ljestve represivnoj mađaronskoj intervenciji.

\footnotetext{
${ }^{457}$ Isto, 30-31.

458 „Gospodinu Franjinu u Zagrebu“, Isto, br. 4, 132.

459 Živan, ,Socijalizam u Srijemu“, Hrvatska misao, god. I, br. 5, 164.
} 
Pozicija praških mladih analogna je dakle onoj reformistički orijentiranih europskih intelektualaca i pokreta, odnosno građanskoj konceptualizaciji socijalnog pitanja. Kao i njihovi uzori, i oni se jasno ograđuju od socijalizma, kritizirajući neke od njegovih ključnih postavki, posebice klasno zasnivanje politike. $\mathrm{S}$ druge strane, oni vide brojne pozitivne elemente socijalističkog pokreta od kojega se štošta može naučiti, napose na području organizacije i agitacije. U tom smislu, analizu „,novosmjeraškog“, naprednjačkog studentskog pokreta nužno je čvrsto usidriti u okviru razmatranja unutrašnjih kretanja građanske politike i kulture na prijelazu stoljeća.

Nakon razdoblja prilagođavanja novoj okolini, Hrvatska misao bila je prvi pokušaj mladih da javno izlože svoje ideje. Ona stoga manifestira sve pozitivne i negativne strane koje prvi pokušaji nose sa sobom. U jednu ruku ona pokazuje elan i intelektualnu svježinu, a s druge eklektičnost, inkonzistentnost, nepreciznost u upotrebi pojmova i povremeno radikalnost bez pokrića. Neke od nedostataka u narednim će godinama ispraviti iskustvo, a neki će pratiti pokret do samoga kraja. Iako je primarno bila projekt praških studenata, Hrvatska misao s pravom se može smatrati prvim organiziranim istupom mladih u cjelini, ne samo zato što su takvu ocjenu kasnije prihvatili i sami akteri pokreta, nego jer su se na njezinim stranicama razvili obrisi gotovo svih modernističkih koncepcija koji će u narednim godinama kolati hrvatskim javnim prostorom. U tom smislu njezina je eklektičnost bila pravo rasadište ideja i koncepata. U retrospektivi, najvažnija zasluga mladih u početnom razdoblju pokreta nije oblikovanje neke konkrentne, značajne ideološke koncepcije, nego postavljanje pitanja koja su se trebala postaviti, kritički istup spram postojećeg društvenog i političkog stanja i otvaranje vrata hrvatske javnosti suvremenim intelektualnim strujanjima. Pod utjecajem Hrvatske misli, i drugi će studenti početi promišljati o društvenim i političkim problemima Hrvatske na sličan način, pa će se praškoj jezgri pokreta početi pridruživati druge grupacije sa svojim projektima i specifičnim pogledima.

\section{4. Formiranje zagrebačke skupine mladih}

Kao što smo već spomenuli, nakon prvotnog razdoblja represije koja je uslijedila kao reakcija na studentsku demonstraciju 1895. godine, tijekom akademske godine 1896./1897. ponovno se pokrenula politička djelatnost studenata na zagrebačkom sveučilištu. Studentske skupštine opet su iznjedrile pravašku, tada de facto frankovačku većinu. Glavnina opozicijske, „,novosmjeraške“ skupine studenata koja se u Zagrebu formirala od početaka 1890-ih godina 
napustila je zagrebačko sveučilište tijekom 1896. godine. Ipak, 1897. godine stvara se nova studentska opozicijska grupacija, okupljena oko Ujedinjene hrvatske $i$ srpske akademske omladine, koja će javno nastupiti almanahom Narodna misao.

Kao što i samo ime kaže, jezgru Ujedinjene hrvatske $i$ srpske akademske omladine činili su - uz antifrankovački nastrojene hrvatske studente - srpski studenti zagrebačkog sveučilišta. Njima je bio zabranjen pristup Hrvatskom akademskom društvu za podupiranje ubogih i bolesnih sveučilišnih građana na kr. sveučilištu Franje Josipa I u Zagrebu (HAPD), koje je od njegova osnivanja krajem 1894. kontrolirala frankovačka većina. Društvena pravila nalagala su da članom društva može biti svaki Hrvat i Slaveni koji nemaju svoje društvo, misleći pritom primarno na Slovence. ${ }^{460}$ Kako je nakon demonstracije 1895. zabranjeno studentsko društvo Zastava, a formalno političko organiziranje studenata nije bilo dozvoljeno, HAPD je funkcionirao kao neformalno političko tijelo studenata, oko čije kontrole su se borile različite studentske političke grupacije. Zbog frankovačke premoći u HAPD-u, a koja se manifestirala kroz navedene formulacije u društvenim pravilima, srpski su studenti bili upućeni na uspostavu vlastitih društava i organizacija. Pravaški su se studenti, međutim, svojski trudili osujetiti bilo kakav oblik organiziranja srpskih studenata na zagrebačkom sveučilištu. Tijekom 1890-ih godina učestali su njihovi izgredi na Sveučilištu, zbog kojih se vlada ustručavala potvrditi pravila zasebnog Srpskog akademskog potpornog društva. ${ }^{461}$ Kada su pravila napokon potvrđena, sastanci društva morali su se održavati izvan Sveučilišta, a ploča društva postavljena u njegovu predvorju 1896. godine postala je uobičajena meta napada frankovačkih studenata. Kulminacija je antisrpskih izgreda frankovačkih studenata dakako bila demonstracija protiv srpske zastave na zgradi pravoslavne crkvene općine $\mathrm{u}$ Zagrebu tijekom kraljeva boravka 1895. godine.

Usprkos svemu tome, srpski su studenti nastavili sa svojim aktivnostima na zagrebačkom sveučilištu. Tijekom 1894. i 1895. godine grupa srpskih studenata koji su osnovali Srpsko akademsko potporno društvo izdavala je i prvi studentski mjesečnik na zagrebačkom sveučilištu - list Omladina. ${ }^{462}$ Časopis je izlazio na ćirilici u kontinuitetu od 1. siječnja 1894. do 1. svibnja 1895. Sveukupno je dakle objavljeno 17 brojeva na 376 stranica. Časopis je tiskala Srpska štamparija u Zagrebu, kao odgovorni urednik i nakladnik bio je naveden Pero Belobrk, a stvarno uredništvo je povjereno Kamenku Subotiću, bivšem studentu

\footnotetext{
${ }^{460}$ Gross, „Studentski pokret“, 458; Luetić, nav. dj., 337. O ustroju i funkcioniranju društva detaljno piše Luetić u „Hrvatsko akademsko potporno društvo (1894.-1914.)“, Zbornik Odsjeka za povijesne znanosti Zavoda za povijesne i društvene znanosti Hrvatske akademije znanosti i umjetnosti 29, 2011, 311-332.

${ }_{461}$ Gross, nav. dj., 458.

${ }^{462}$ Isto.
} 
zagrebačkog i praškog sveučilišta, koji je bio jedan od osnivača praškog društva srpskih studenata Šumadija. ${ }^{463}$ Njegov naslov svjesno upućuje na srodnost s naprednjačkim i realističkim strujanjima među češkim studentima. Osim toga, list je surađivao s F. V. Krejčijem, književnim kritičarom realistički usmjerenog lista Rozhledy. ${ }^{464}$ Nije stoga čudno da su se u tom listu očitovale ključne strukturne ideološke sličnosti s ,novosmjeraškim“ strujanjima među hrvatskim studentima, koje su upravo omogućile njihovo kasnije zbližavanje. Iako su promicali srpski nacionalni program, studenti oko lista Omladina odbacivali su bilo kakvo povezivanje sa srpskim političkim strankama, odbijajući stranačko instrumentaliziranje studenata te kritizirajući uobičajene patriotske fraze. Zadatak je studenata da rade i proučavaju društveni život, da se upoznaju s najnovijim znanstvenim i kulturnim strujanjima te da steknu osobno osvjedočenje koje je preduvjet za slobodu mišljenja. Tek na temelju toga može se razviti ozbiljan rad na korist srpskog naroda. ${ }^{465}$ Jasno je da nisu upitne ne samo paralele, nego i ideološka, a vjerojatno i osobna te organizacijska povezanost s hrvatskim pristašama „novog smjera“, tzv. Radićevom grupom, već od tog ranog perioda 1894. godine. U jeku zaoštrenih hrvatsko-srpskih odnosa, u kojima je sudjelovala i hrvatska i srpska opozicija, studenti okupljeni oko Omladine držali su se suzdržano te su izražavali nade u buduću srpsko-hrvatsku suradnju. Određeni članovi te grupe srpskih studenata nazivali su se „realistima“, a imali su i sličnu recepciju u okviru srpskog građanstva koje ih je smatralo radikalnim socijalistima. ${ }^{466}$ Osim toga, oni su održavali veze sa srpskim studentskim društvom Šumadija iz Praga osnovanim 1892. godine, preko kojega su im svakako mogle biti posredovane naprednjačke i realističke ideje. ${ }^{467} \mathrm{Na}$ polju književnosti, Omladina je, napose Kamenko Subotić, razvila bogatu kritičku djelatnost, pozivajući na uranjanje „u more bogate nauke naprednih naroda. ${ }^{\text {"468 }} \mathrm{U}$ tom smislu popularizirali su stavove i teorije Thomasa B. Macaulaya, Hippolytea Tainea i Aleksandra Hercena, kao i modernu skandinavsku književnost. Naposljetku, Omladina je također održavala veze sa srpskim srednjoškolcima, na koje je htjela ideološki utjecati te ih pripremati na budući aktivistički rad. ${ }^{469}$

Logično je stoga da je upravo iz ovih krugova srpskih studenata potekla grupacija koja će obnoviti „novosmjerašku“ opoziciju na zagrebačkom sveučilištu nakon 1895. godine te ostvariti kontakt i suradnju s praškim mladima. Povezivanje srpskih i hrvatskih studenata na

\footnotetext{
${ }^{463}$ Marijanović, Fin de siècle hrvatske moderne, 50.

${ }^{464}$ Isto.

${ }^{465}$ Gross, nav. dj., 458.

466 Isto, 458.

${ }^{467}$ Isto, 459.

${ }^{468}$ Marijanović, nav. dj., 51.

${ }^{469}$ Isto, 50.
} 
zagrebačkom sveučilištu simbolično je započelo u Zagrebu 22. veljače 1896. na proslavi sedamdesete obljetnice rođenja Svetozara Miletića koju je organizirala srpska akademska omladina, a kojoj je prisustvovao i dio hrvatske akademske omladine. Kako kaže Dušan Mangjer, jedan od organizatora, ,poslije više godina megjusobnog nesuglasja i trvenja, iza nesrećne demonstracije pred srpskom crkvom, što samo bješe plod tudjeg utjecaja, omladina se tad ipak prenula, pohitala na Miletićevu slavu, da dade oduška srcu svom, izraza osjećajima i mislima svojima i da po mogućnosti razvidi, mogu li se ideali hrvatski i ideali srpski asimilovati, pa stvoriti jednu cjelinu, imati jedne aspiracije, jedne težnje. “" ${ }^{\circ 70}$ On izvještava da se na Miletićevoj proslavi moglo vidjeti „do jučer zavagjene sinove jednog naroda, gdje na slavi narodnog mučenika, u bratskom zagrljaju, pjevaju omiljenu: 'Lijepa naša domovino', i 'Onamo, onamo...', a pjevajući te narodne himne i Hrvat i Srbin misle na zajednički narod, kojega su oni sinovi.“471 Osim toga, uz Miletića se slavio Franjo Rački, a brzojavno je pozdravljen i Erazmo Barčić. Mangjer naglašava da povezivanje hrvatske i srpske omladine na Miletićevoj večeri nije bilo rezultat spontana entuzijazma, nego je pomno osmišljeno. Studenti su ovom akcijom željeli simbolički premostiti jaz „što ga otvoriše tugjin i domaći izrodi“ te dati impuls i starima da krenu istim putem. ${ }^{472}$ Ključna ideja koja je vodila omladinu bila je ideja narodnog jedinstva Srba i Hrvata, u suprotnosti s navodnom hrvatskom i srpskom opozicijskom politikom sloge koja je rezultirala međusobnim sukobima i trvenjima. U potpunosti se podudarajući s Radićevim riječima iz „Hrvatskih ideala“, Mangjer jasno konstatira: „Zajednički nas ideali zagrijaše, jedna nas je misao napojila i zadnje riječi one večeri bijahu namijenjene: ne slozi nego narodnom jedinstvu Srba i Hrvata. “473

Rezultat suradnje započete na Miletićevoj proslavi početkom 1896. godine bilo je povezivanje u Ujedinjenu hrvatsku i srpsku akademsku omladinu te objavljivanje almanaha Narodna misao na Uskrs 1897. godine. Kao izdavači za Ujedinjenu omladinu navedeni su Jovan P. Banjanin, Milan Kostić, Ivan Lorković, Dušan Mangjer, Lav Mazzura i Svetozar Pribićević. Osim uvodnika Dušana Mangjera u almanahu su objavljena četiri teksta: "Đuro Daničić" Jovana Banjanina, "Misao vodilja Srba i Hrvata" Svetozara Pribićevića, "Rački" Ivana Lorkovića i "Historijsko državno pravo" D. Dimovića, kratka priča Milana Budisavljevića „Sjeni“ i odgovori različitih uvaženih javnih ličnosti na pitanje omladine o tome što misle o srpsko-hrvatskom sporu (između ostalih J. J. Strossmayera, mitropolita Mihajla, M. Bana, M. Polit-Desančića, E. Barčića, B. Bogišića, T. Smičiklasa, N. Nodila, Š.

\footnotetext{
470 „Zagreb, na Uskrs 1897.“, Narodna misao, Zagreb, 1897., 1.

${ }^{471}$ Isto, $1-2$.

472 Isto.

${ }^{473}$ Isto.
} 
Mazzure, F. Potočnjaka, F. Vrbanića, M. Derenčina itd.). Neki su tekstovi tiskani na ćirilici, a neki na latinici, predstavljajući ideju o dva pisma jednog te istog naroda.

Kao što je istaknuto u Mangjerovu uvodniku, ključni lajtmotiv cijelog almanaha je ideja narodnog jedinstva Hrvata i Srba. U svojim temeljnim idejama i formulacijama, on je posve podudaran s idejama i formulacijama o tom pitanju iznesenima u Hrvatskoj misli. No, za razliku od Hrvatske misli, djelatnost je ove zagrebačke skupine, pa tako i almanaha Narodna misao, fokusirana gotovo isključivo na pitanje nacionalne politike, dok druge teme u njemu nisu prisutne. ${ }^{474}$ I zagrebačka skupina smatra da je ,jedinstvo omladine preteča narodnom jedinstvu“, odnosno da bi (,novosmjeraška“) omladina trebala imati ključnu ulogu u budućoj nacionalnoj politici i generacijskoj smjeni; da nesloga Srba i Hrvata služi „,intencijama falange, koja pod devizom: 'Drang nach Osten' polagano se šulja sve više i u najzabitniji kutić naših krajeva [...]“; da je ključna zadaća inteligencije „širiti prosvjetu i udariti temelje daljnjem narodnom usavršavanju, ekonomskom i kulturnom“; da vjersko razlikovanje nije relevantan kriterij nacionalnog razlikovanja jer je ono pitanje izbora pojedinca, „hrana duši, pa kakovu ko izabere“; da se umjesto historijskog državnog prava za temelj politike mora prihvatiti ,narodno pravo, pravo svakog naroda, da bude samo svoj u svomu“ te da za rješenje hrvatsko-srpskog spora ne traže „nikakve ugovore, nikakve ustupke“, nego da treba ići „umom, srcem ne k slozi nego narodnom jedinstvu!“475 To je u velikoj mjeri rezultat konteksta u kojem djeluje zagrebačka skupina. Hrvatsko-srpski sukob uvelike je definirao konture javnog diskursa, što kroz stanovište Srpskog kluba u podupiranju Khuenove vlade, što kroz polemike hrvatske i srpske opozicije, te krah opozicijske politike srpsko-hrvatske sloge. U tom smislu, djelatnost je Ujedinjene omladine također primarno usmjerena prema hrvatskoj, odnosno srpskoj opozicijskoj politici, ali je kanalizirana kroz

\footnotetext{
${ }^{474}$ Nisu stoga utemeljene ocjene da almanah Narodna misao predstavlja preteču budućeg jugoslavenskog unitarističkog programa, odnosno, ta bi se ocjena konzekventno onda nužno morala protegnuti i na praški krug oko Hrvatske misli. Tako npr. Tihana Luetić, u inače vrlo preciznu prikazu političke djelatnosti zagrebačkih studenata, primjećuje da se u uvodniku "pojavljuje i nova koncepcija, svojstvena nešto kasnijoj unitarističkoj struji, o tome kako su Hrvati i Srbi zapravo 'jedan narod s dva imena'", ali tu karakteristiku ne primjenjuje na opis ideologije praških studenata koja je u ovom pogledu identična ne samo u ideji, već i u konkretnim formulacijama. Tihana Luetić, nav. dj., 344. Zapravo se ne radi o novoj koncepciji, već o reinterpretaciji klasične jugoslavenske ideje kako je formulirana već kod Račkog. Da je riječ o reinterpretaciji izvornog jugoslavenstva ne upućuje ideja narodnog jedinstva Srba i Hrvata koja je prisutna i ranije, nego to što mladi oko Narodne misli odbacuju koncept hrvatskog državnog prava koji je imao važno mjesto u Račkijevoj misli. Oni svoju interpretaciju predstavljaju kao povratak na izvorno jugoslavenstvo kako bi joj dali snažniju legitimaciju. Ipak, još uvijek se ne može govoriti o jugoslavenskom unitarističkom programu, koji nastaje u razdoblju neposredno prije Prvog svjetskog rata. Zasebno kategoriziranje zagrebačke grupe studenata na temelju primata nacionalnog pitanja u njihovim interesima prvi je monografski primijenio Mate Ujević odredivši ih kao "nacionalističku grupu", iako kasnije i sam ističe kako je to samo "donekle opravdano." Mate Ujević, Prilozi za povijest pokreta hrvatske omladine koncem XIX i početkom XX stoljeća, s osobitim osvrtom na borbu starih i mladih, Zagreb, 2015, 70, 140.

475 „Zagreb, na Uskrs 1897.“, 2-6.
} 
ključno pitanje njihove potencijalne suradnje, odnosno trenutačnog spora. Mangjerov uvodnik tako programatski sažima osnovne postavke ostalih priloga u almanahu: rekonceptualizacija hrvatsko-srpskih odnosa i politike koja se temelji na ideji o narodnom jedinstvu Hrvata i Srba, nastavljajući se na intelektualnu tradiciju Đure Daničića i Franje Račkog, koji su dobili svoju zasebnu obradu u almanahu, ali ujedno odbacujući državnopravnu politiku u korist narodne politike utemeljene na ideji prirodnog prava. Upravo se na to referira naslov almanaha: narodna misao kao sinonim za nacionalnu politiku utemeljenu na prirodnom pravu, nasuprot ideji historijskog državnog prava.

Od tekstova objavljenih u Narodnoj misli, njezine osnovne postavke najbolje elaborira onaj Svetozara Pribićevića, „Misao vodilja Srba i Hrvata““ ${ }^{476}$ Pribićević polazi od temeljne pretpostavke objektivnog narodnog jedinstva Srba i Hrvata. Hrvatsko-srpski spor prema tome nije samo štetan, već je i neprirodan. On se ,ne može uzeti kao nacionalno pitanje, jer Srbi i Hrvati nijesu dva različita, nego su oni dijelovi jednoga, istoga naroda. “477 Zbog toga niti sporazum ne može biti rješenje tog umjetno, od tuđinaca „odozgo“ proizvedena spora, čiji uzrok također leži u državnoj rascjepkanosti naroda, odnosno njegove oslonjenosti na različite političke i kulturne centre. Iz toga logično proizlazi zaključak, koji ovdje još nije ekspliciran, da rješenje hrvatsko-srpskog spora ne leži samo u njihovu kulturnom, već i političkom ujedinjenju.

Za razliku od Radića koji polazi od teze o narodnom jedinstvu kao od aksioma koji nije potrebno dokazivati nego samo provesti u djelo, Pribićević - iako više puta ističe očiglednost te teze za svakoga koji ima iskrene namjere - ipak nudi određene dokaze $\mathrm{u}$ njezinu korist, koristeći se metodom eliminacije. Ispitujući temelje mogućih razlika između Hrvata i Srba, on želi pokazati kako niti jedan od njih nema nacionalno obilježje, odnosno oni koji predstavljaju objektivni kriterij nacionalnosti, kao npr. jezik, u slučaju Hrvata i Srba ne igraju diferencijacijsku ulogu. Tako krv ili porijeklo, odnosno rasa ne predstavljaju kriterij nacionalnosti ,jer bi se na taj način [...] sociologija utopila u antropologiju, a razviće naroda značilo bi isto, što i razviće životinjske vrsti.“4778 Za jezik je već spomenuto da ne predstavlja razlikovno obilježje između Hrvata i Srba. Međutim, Pribićević također elaborira apsurdnost teze o ,prisvajanju jezika“ koju ističu različiti ekskluzivistički pisci, a koja se svodi na to da su jedinstveni štokavski standard zapravo ,prisvojili““ jedan ili drugi narod i lažno ga predstavili kao vlastiti narodni jezik. Prema Pribićeviću, takva je teza nelogična i historijski

\footnotetext{
476 Analiza preuzeta iz članka Nikola Tomašegović, „Jedinstvom protiv (ne)sloge: nacionalna koncepcija napredne omladine“, Tragovi - časopis za srpske i hrvatske teme 1, 1, 2018, 166-190.

${ }^{477}$ Svetozar Pribićević, "Misao vodilja Srba i Hrvata“, Narodna misao, 56.

${ }^{478}$ Isto, 57.
} 
neodrživa, a ako bi se logički konzekventno izvela, onda bi vodila u isti zaključak narodnog jedinstva Hrvata i Srba. Jer ako je jedan narod „prisvojio“, odnosno prihvatio jezik drugog naroda, onda je zapravo prihvatio i tuđu nacionalnost, pa se ne može govoriti o dva različita, već o jednom, jedinstvenom narodu. Na taj način nacionalni partikularizmi koji se temelje na „,narcizmu malih razlika“ dosljedno izvedeni logično vode u njihov nacionalni unitarizam. Što se tiče vjere, ona također ne može u načelu funkcionirati kao kriterij nacionalnosti jer više naroda dijeli istu vjeru, a i jedan narod može pripadati različitim vjeroispovijestima. Osim toga, vjera može biti temelj socijalnog grupiranja samo kod primitivnih zajednica. Najviše prostora Pribićević posvećuje razlici povijesnog razvoja. Iako priznaje da su Srbi i Hrvati gotovo kroz cijelu svoju povijest živjeli u različitim državnim tvorevinama i granicama, ističe kako su usprkos tome oni zadržali ,jednaki način mišljenja i shvatanja, isti pravac misli [...], jednake moralne i intelektualne karaktere, dakle sve one psihološke elemente, koji sastavljaju ono, što s pravom možemo nazvati dušom jednoga naroda. “479 I za Pribićevića, kao i za Radića, nacionalnost je utemeljena u kulturi širokih narodnih slojeva. Osim toga, starija povijest zapravo i nije relevantna za nacionalno pitanje jer kulturni pojam naroda nije postojao u ranijim razdobljima. U tom smislu, „,ne može za nas biti u pogledu naše podjele odlučno, da li smo se klanjali Dušanovoj sili, ili smo se zaklinjali na Zvonimirovu krunu.“480 Primjer nadilaženja povijesnih i faktičnih političkih podjela trebao bi biti talijanski nacionalni pokret koji je njima usprkos ostvario svoj zadatak. Historijsko utemeljenje nacije, odnosno „izdvajanje“ na temelju povijesne tradicije i povijesne političke individualnosti, na koju bi se jednako mogli pozvati i „Bosanci“ i „Crnogorci“, predstavlja zapravo „,izdajstvo narodne misli“،. ${ }^{481}$

Nasuprot tome Pribićević ističe pozitivne objektivne faktore koji upućuju na narodno jedinstvo Hrvata i Srba: zajednički jezik, materijalna kultura, gospodarski interesi i neprekinuti teritorij. Međutim, ti objektivni faktori nisu dovoljni za konstituiranje narodnosti. Potreban je još i subjektivni faktor, odnosno „narodna svijest“, a kako jasno navodi Pribićević, „nje nemamo“.482 To ipak ne negira datost, jer on dalje navodi kako su ti objektivni faktori „kadri da prije ili kasnije izazovu svijest o narodnoj našoj zajednici.“483 Iako sadrži subjektivni, odnosno voluntaristički faktor, Pribićevićev je pojam narodnosti dakle objektivistički, s obzirom da je svijest o narodnosti bitna za njezino cjelovito ostvarenje, ali

\footnotetext{
${ }^{479}$ Isto, 60-61.

${ }^{480}$ Isto.

${ }^{481}$ Isto, 63-64.

482 Isto, 65.

483 Isto.
} 
izostanak te svijesti ne znači ujedno i izostanak temeljnog uvjeta opstojnosti neke narodnosti. Drugim riječima, narodnost postoji neovisno o postojanju svijesti o njoj, u svojim objektivnim izražajima kao što su jezik, kultura i običaji, a pobuđivanje narodne svijesti preduvjet je tek za njezino puno ostvarenje i snagu. Pribićevićevim riječima: „Za nas dakle nije pojam naroda, pojam istorijski, politički, nego pojam kulturno-socijalni.“484 To zapravo znači da njega ne definira ni državni okvir, ni povijesna tradicija, nego isključivo objektivni kulturni, ekonomski i društveni odnosi. „Prema tome“, zaključuje Pribićević, „kad kažemo Hrvatska i Slavonija ne mislimo mi pod tijem zaokruženi komad zemljišta, niti političku individualnost, nego jedan nerazdruživi dio našeg narodnog tijela. “485 Narodni prostor Hrvata i Srba, kao jedne nacionalne individualnosti, proteže se kao kontinuirana cjelina neovisno od kontingentnih povijesnih i političkih tvorevina. Hrvatski nacionalni prostor nije ograničen na Hrvatsku, niti je on isključivo - pa niti primarno - hrvatski („Ne poznajemo šire ili uže domovine $[\ldots]^{\text {(486 }}$ ). Jasne su političke implikacije koje iz toga proizlaze. Ako kontinuirani nacionalni prostor Srba i Hrvata transcendira postojeće i povijesne granice, onda trenutna situacija njegove razdijeljenosti $u$ okviru različitih država ne odgovara ideji realizacije narodnog, odnosno prirodnog prava. Budući da je Srbija ipak nacionalna država Srba (a iz Pribićevićeva pristupa slijedi: i Hrvata), jasno je da politička realizacija prirodnog prava Srba i Hrvata na njihovu neprekinutom teritoriju podrazumijeva svrgavanje habsburške vlasti kao preduvjeta nacionalnog ujedinjenja. Pribićević dakako ne iznosti eksplicitno koncept Srbije kao jugoslavenskog Pijemonta, ali je on prisutan između redaka u njegovu tekstu. Snažniji oslonac na Srbiju inhibirala je prohabsburška orijentacija trenutne vladajuće dinastije Obrenovića, koja nije bila po volji mladima okupljenima oko Narodne misli.

Nastavljajući u prikriveno „,veleizdajničkoj“ noti, Pribićević ustvrđuje kako „svaki narod ima neosporno pravo na samostalan život i razvitak. “487 Još na samom početku teksta on je u načelnu izlaganju iznio tvrdnju kako je nacionalna ideja fundamentalna ideja modernog doba, komplementarna individualnom principu slobode pojedinca koji je rezultat ukinuća feudalizma, i kako bi idealno stanje podrazumijevalo njezino potpuno oživotvorenje, odnosno uspostavu univerzalnog sistema nacionalnih država. Reformacija je oslobodila savjest, (Francuska) revolucija čovjeka, a nacionalna ideja treba osloboditi narode. U ovoj trostrukoj povijesnoj strukturi, nacionalna svijest nužno počiva na individualnoj samosvijesti. Pravo naroda na samostalnost, odnosno drugim riječima pravo naroda na vlastitu nacionalnu

\footnotetext{
${ }^{484}$ Isto, 67.

485 Isto.

486 Isto.

${ }^{487}$ Isto.
} 
državu, ne proizlazi dakle iz neke pravice koja se može ili ne može dokazati, nego isključivo iz kolektivne narodne volje koja je suverena: „Jasno mora biti za svakoga, da nije nužno narodu dokazivati, kako on ima pravo na samostalnost, on ima to pravo, jer postoji kao narod, jer hoće, da živi kao narod, jer osjeća snagu, da to svoje pravo provede.“488 Iz toga jasno slijedi da je državnopravna politika posve promašena jer provođenje nacionalne ideje ovisi isključivo o snazi suverene volje naroda. Zbog toga je zadatak nacionalne inteligencije podizati narodnu svijest, onaj subjektivni faktor koji nadograđuje objektivne odnose, a o kojem ovisi snaga naroda i njegova sposobnost da iznese i oživotvori svoju nacionalnu ideju.

Zbog nužnosti zauzimanja stanovišta o narodnom jedinstvu Srba i Hrvata na cjelokupnom njihovu teritoriju, nije moguće nacionalnu politiku ograničiti na problematiku srpsko-hrvatskih odnosa u Trojednoj kraljevini, a pogotovo ne na politiku „sloge“, „kompromisa“ ili „suradnje“. Pribićević kritizira taktiku podilaženja Beču u nadi da će vladajući krugovi Monarhije zauzvrat Hrvatskoj podariti određene ustupke, „list papira, na kojem će stajati napisano, da nam se priznaje pravo na život.“489 Posebice na udar dolazi podržavanje habsburškog imperijalističkog prodora na Balkan, u čemu Pribićević vidi opasnost i za hrvatstvo i za srpstvo, odnosno on u „sluganskoj“ politici koja se nudi kao oslonac za prodor na slavenski jug vidi najveću opasnost za narodno jedinstvo, pa i opstanak Hrvata i Srba. Ta je kritika jednako zahvaćala i srpske i hrvatske vladajuće krugove u Hrvatskoj koji su podržavali Khuenovu vladu, ali i opoziciju i njezin pristup posebice prema pitanju pripadnosti Bosne i Hercegovine. Iz Pribićevićeva izlaganja jasno je da bi istinska narodna politika trebala podržati zahtjev Srbije za pripajanje Bosne i Hercegovine, kad je ionako riječ o jedinstvenom nacionalnom teritoriju Srba i Hrvata. Osim toga, jednaka kritika upućuje se hrvatskim političkim elitama u pogledu teorije o hrvatskom političkom narodu. Nasuprot tome, ono što je potrebno jest da se Srbi i Hrvati u Trojednoj kraljevini ujedine ,u jednu narodnu stranku, koja će podržavajući kulturne veze s ostalijem dijelovima našega naroda zahtijevati samostalnost Trojednice na osnovu načela narodne suverenosti.“490 $\mathrm{U}$ ovome je zapravo sažet temeljni kratkoročni politički zahtjev zagrebačkih mladih: ujedinjenje hrvatske i srpske opozicije, promjena političke strategije koja podrazumijeva prihvaćanje prirodnog narodnog prava te vanjskopolitička preorijentacija u smjeru jugoslavenstva $\mathrm{s}$ osloncem na Kraljevinu Srbiju. Da je taj zahtjev kratkoročan, i da su projekcije budućnosti mnogo šire od okvira Trojedne kraljevine, pa i Habsburške Monarhije, razvidno je iz zahtjeva

\footnotetext{
${ }^{488}$ Isto, 68.

${ }^{489}$ Isto, 72.

${ }^{490}$ Isto, 76.
} 
da ,jedna misao spaja Biograd, Zagreb, Spljet, Sarajevo, Cetinje i Prizren“ te iz konstatacije da se „s faktičnim našim, narodnim položajem ne možemo nikako pomiriti. “491 Kao najvažniji zadatak stoga postavlja se ,da u našem narodu dižemo i jačamo svijest o ukupnoj narodnosti, jer je to prius, kome će kao posterius slijediti narodno ujedinjenje Srba i Hrvata.“492

Osim što je zagrebačka skupina okupljena oko Narodne misli suzila program mladih isključivo na pitanje srpsko-hrvatskih odnosa i politike, Svetozar Pribićević ga je elaborirao naglašavajući perspektivu srpske politike u Hrvatskoj. Upotrebom koncepata narodnog jedinstva Srba i Hrvata i prirodnog prava, on zapravo reinterpretira dvije tendencije srpske politike u Hrvatskoj: redefiniranja političkog naroda u Hrvatskoj i oslonca na Kraljevinu Srbiju. Koncept narodnog jedinstva podrazumijeva da politički narod u Hrvatskoj tvori jedinstveni dvoimeni narod Srba i Hrvata, a u široj slici da se taj narod proteže onkraj granica Trojedne kraljevine, pa time i Habsburške Monarhije, te s Kraljevinom Srbijom i Bosnom i Hercegovinom čini jedinstvenu cjelinu. Koncept pak prirodnog prava poništava nesuglasice koje otvara pitanje interpretacije i upotrebe hrvatskog državnog prava i srpske narodnocrkvene autonomije koji počivaju na konceptu povijesnog prava, a ujedno na širem planu predstavlja sredstvo političkog ujedinjenja Srba i Hrvata na njihovu cjelokupnom teritoriju. U svjetlu svega navedenoga, postavlja se pitanje mogu li se ideje zagrebačke Ujedinjene omladine uopće okarakterizirati kao modernističke? Njihov tematski i referentni okvir, njihovi koncepti i zahtjevi u potpunosti su uklopljeni u već postojeće okvire hrvatske i srpske politike. U njihovim tekstovima ne vide se aproprijacije širih modernističkih kretanja, ili su prisutne samo u rudimentarnom obliku i podređene argumentaciji klasičnih nacionalističkih političkih zahtjeva i ideja. Ako su aproprijacije modernističkih ideja u praškoj Hrvatskoj misli bile eklektične i nesustavne, u Narodnoj misli u potpunosti su upitne. Pa ipak, praška je skupina u Ujedinjenoj omladini vidjela svoje prirodne saveznike koje je tretirala kao pripadnike jedinstvena pokreta mladih. Iako su bili svjesni nedostataka, pa i nepodudarnosti njihovih razmišljanja s programom Hrvatske misli, nisu imali previše izbora ako su se nadali da će se njihove ideje proširiti u Zagrebu kao hrvatskom političkom i kulturnom centru. Osim toga, Ujedinjena omladina na neki je način utjelovljivala ideju narodnog jedinstva Hrvata i Srba, koju su i praški mladi postavili u svoje središte. Primjer zagrebačke Ujedinjene omladine tako je možda najbolji pokazatelj kontekstualne uvjetovanosti razvoja pokreta mladih.

U svim se tekstovima almanaha provlače iste osnovne ideje, pa i identične formulacije. Ostala tri teksta ove temeljne misli koje je iznio Pribićević fokusiraju kroz prikaze djelatnosti

\footnotetext{
491 Isto, 73.

${ }^{492}$ Isto, 74.
} 
Đure Daničića i Franje Račkog, te kritiku historijskog državnog prava. Dimović u tekstu o historijskom državnom pravu, ujedno najkraćem u almanahu, odbacuje taj koncept i kao svrhu i kao sredstvo političkog djelovanja. Kao sredstvo ono je nedostatno ,jer ne involvira u sebi sve potrebe i težnje narodne i jer ono ne živi u svijesti narodnoj“, odnosno iza njega ne stoji moć koja svakome pravu daje praktičnu svrhu. ${ }^{493}$ Ono je, dakle, ,prazna puška“, puka „historijska činjenica, koja spada u arheologiju, a ne u narodnu političku borbu. “494 Prikazima Daničića i Račkog dominira pak nastojanje da se oni prezentiraju kao prethodnici ideja Ujedinjene omladine, odnosno, da se ideje Ujedinjene omladine prikažu kao izvorno, vjerno tumačenje njihovih ideja. U tome se jasno očituje taktika mladih da svoja nastojanja predstave kao povratak na sam izvor nacionalnog pokreta, kao ponekad implicitna, a ponekad eksplicitna kritika „očeva“, tj. starih. Jovan Banjanin tako vezano za Daničića tvrdi da je on „u pogledu na jezik istakao načelo, koje je i ujedinjena omladina postavila za osnovu svoga rada, t. j. načelo jedinstva i istovetnosti naroda srpskoga i hrvatskoga, a raznovarsnosti narodnijeh imena.“495 Tadašnje pak elite nisu dorasle mislima i ciljevima koje su istaknuli Rački i Daničić. Umjetno proizvedeni zaoštreni odnosi između Hrvata i Srba, a zapravo samo hrvatske i srpske inteligencije i elite, došli su do točke kada su promjene postale nužne i neizbježne. U toj ulozi nastupa Ujedinjena omladina, koja se vraća na ideje Daničića i Račkog kao korektivima stranputice u koju su narodnu politiku doveli stari. U konkretnom smislu, baš kao i Hrvatska misao, kao prvi korak prema novoj politici srpsko-hrvatskog narodnog jedinstva Banjanin vidi zajednički literarni kongres koji bi trebao iznjedriti književno jedinstvo. Zadaća je književnika stoga da razvijaju svijest o narodnom jedinstvu u samom narodu, koji prije toga nužno moraju upoznati. Književnost se, dakle, iz vizure zagrebačke skupine okupljene oko Narodne misli u potpunosti promatra kroz prizmu nacionalne politike, te u tom smislu ne odskače od starijih nacionalno-romantičarskih, utilitarno-pedagoških zasada. U okviru pokreta mladih, njihova bi koncepcija svakako bila bliža onoj Šarića i Radića nego Dežmana, iako nije dovoljno elaborirana da bi se mogla napraviti detaljnija analiza na teorijsko-konceptualnoj razini.

Dobar primjer književnosti kako ju je zamišljao krug oko Narodne misli je kratka priča „Sjeni““ Milana Budisavljevića objavljena u almanahu. Ona prikazuje život, odnose i tragičnu pogibiju idealiziranih hrvatskih i srpskih seljaka - pastira - u obrani svojeg zavičaja od navale otuđene države i stranog kapitala. Smješteni u neiskvarenu, idealiziranu prirodu,

\footnotetext{
${ }^{493}$ D. Dimović, „Historijsko državno pravo“, Narodna misao, 228.

${ }^{494}$ Isto, 229, 233.

495 Jov. P. Banjanin, „Đuro Daničić““, Isto, 9.
} 
mladi slavenski pastiri jednako su tako neiskvareni i idealizirani. Oni žive u prirodnom stanju, u potpunosti u skladu sa svojom okolinom, koju njihov imaginarij napučava vilama i drugim bićima stare slavenske mitologije. U svojoj izvornoj, neiskvarenoj zajednici oni žive u jedinstvu i zajedništvu, neopterećeni nacionalnim razlikama. Oni su svjesni svojih razlika, napose onih konfesionalnih, ali to ni na koji način ne utječe na njihovu samopercepciju zajedništva i jedinstva. Oni uopće ne razumiju implikacije pitanja o etničkim razlikama koje im postavlja pripovjedač, došljak iz grada. ${ }^{496} \mathrm{U}$ konačnici, oni zajedno pogibaju u obrani svojeg luga, svoje zajednice i iskonskog svijeta i načina života. Jasno tendenciozno postavljena, ova priča suprostavlja idealiziranu i zamišljenu izvornu narodnu zajednicu Hrvata i Srba i otuđeno suvremeno, urbano društvo inteligencije koja umjetno proizvodi podjele i uništava iskonsko narodno zajedništvo. Kroz primjer pripovjedača, ona poručuje gradskoj inteligenciji da se uputi među narod, da tako spozna njegove neiskvarene nacionalne stavove te na taj način utemelji svoju politiku na ideji narodnog jedinstva Srba i Hrvata, kako u nacionalnom, tako i u socijalnom pogledu. Jasno je da je pastirski narod kako je ovdje ocrtan zapravo tek romantizirana ideja jer je teško zamisliti da su onodobni pastiri baratali s modernom idejom nacije i imali razvijenu nacionalnu svijest.

Lorkovićev tekst o Račkomu zauzima 140 stranica, odnosno gotovo 40\% cijelog almanaha. U njemu je iscrpno prikazan ilirizam, njegov europski kontekst, intelektualna strujanja koja su utjecala na njegov razvoj, te ponajviše misao Franje Račkog. Ne ulazeći u njegovu detaljnu rekonstrukciju, s obzirom na činjenicu da se u osnovnim idejama ne razlikuje od već prikazanih tekstova, bitno je istaknuti da je Lorković posebno naglasio komponentu prirodnog prava i ideje narodne prosvjete u Račkijevoj misli. Neovisno o tome je li takva interpretacija opravdana ili ne, ona pokazuje kako način aproprijacije Račkoga podcrtava ono što je bitno za same mlade. Njegovim simboličkim prisvajanjem oni su željeli osnažiti svoje vlastite stavove, jednako kao što se u okviru pravaštva vodila borba za prestiž „čiste“ interpretacije Starčevićeve misli. Kod Lorkovića je posebno istaknuta ideja o nastojanjima mladih kao trećoj fazi preporoda, o čemu je ranije već pisao Radiću. Ta treća faza zapravo bi trebala iznijeti konačne ciljeve preporoda, čije ostvarenje nije bilo moguće u doba ilirizma, a zašlo je u stranputicu zbog slabosti, dezorijentiranosti i razjedinjenosti starih. „Preporod naroda hrvatskoga ili srpskoga nije dovršen“, zaključuje Lorković, i zadaća je mladih da on zahvati čitav narod. ${ }^{497}$ Upravo su ograničenja ilirizma proizvela takvu situaciju. Iako je bio zasnovan na „narodnoj misli“, on je uspio stvoriti samo narodnu inteligenciju.

\footnotetext{
${ }^{496}$ Milan Budisavljević, „Sjeni“, Isto, 245-246.

497 „Rački“, Isto, 212.
} 
Slaba i nepovezana sa širokim slojevima naroda, ta je inteligencija pod stranim utjecajima pretvorena jednim dijelom u lojalnu birokraciju, koja se brine samo za svoje sinekure, a s druge strane u zavađenu i uskogrudnu partikularističku inteligenciju koja upravo proizvodi hrvatsko-srpski spor, na korist tuđinskih vladajućih elita. Nakon što je skršena „vlast plemićska“, ona je predana inteligenciji koja se prozvala narodom, pa se njene zavade onda smatraju i narodnim zavadama. ${ }^{498}$ Narod je, međutim, u najvećoj mjeri ostao „čist“, ali nacionalno neosviješten. Sada treba da i tom drugom dijelu naroda - koji smo „članom narodnim proglasili“ - ,pripadnu ideje našega preporoda“, treba dakle ,izvesti preporod najširih slojeva, ponajpače seljaštva, koje je po narodni život najvažnije; treba ga izvesti u duhu narodnoga jedinstva, ćudoredne naobrazbe i narodne prosvjete. “499 Tek kada se to postigne, završava Lorković, nestat će jaz između inteligencije i puka, a time će se osigurati budućnost jedinstvenog naroda $\mathrm{u}$ vremenu velikih društvenih i ekonomskih prijeloma modernog doba.

Zanimljiv je i posljednji dio almanaha, „Naša pisma“. Ujedinjena omladina pismeno se obratila brojnim uvaženim hrvatskim i srpskim javnim ličnostima s kratkim obrazloženjem svojih načela i molbom da podijele svoje mišljenje o hrvatsko-srpskom sporu. Pristigli odgovori, njih 27, objavljeni su u almanahu. Kako tvrdi Milan Marjanović, i zbornik i prikupljanje odgovora poznatih rodoljuba bili su napravljeni na savjet Natka Nodila. ${ }^{500}$ Zanimljivo je da brojni odgovori, pozdravljajući inicijativu studenata, nude odgovore utemeljene upravo na načelu koji su mladi žestoko kritizirali i odbacili u almanahu - onom hrvatsko-srpske sloge. Neki od eksplicitnih odgovora u tom smislu su oni L. Borčića, M. Polit-Desančića, V. Matijevića, J. Ristića (koji govori o „ova dva Naroda“501), M. Šrepela i F. Vrbanića. Kod nekih pak odgovora vidi se mnogo veća bliskost s načelima Ujedinjene omladine, npr. u onim E. Barčića, B. Bogišića, N. Nodila, Š. Mazzure, F. Potočnjaka te M. Derenčina. U tom smislu pokazuje se kako (opozicijska) hrvatska i srpska politika i dalje razmišlja u okvirima politike srpsko-hrvatske sloge, ali se naziru i ideološki pomaci u smjeru ideje narodnog jedinstva Hrvata i Srba, upravo kod onih starih koji će biti ključni za razvoj suradnje između mladih i starih. Kako ističe Mirjana Gross, jača unitaristička varijanta ideje narodnog jedinstva Srba i Hrvata u danim se okolnostima nije mogla afirmirati, ali su pod dojmom slabljenja hrvatske i srpske opozicije uslijed jačanja sprsko-hrvatskog spora stari postali prijemčiviji za blažu, osnovnu ideju agitacije mladih: politiku suradnje hrvatske i

\footnotetext{
498 Isto, 216.

${ }^{499}$ Isto, 217-218.

${ }^{500}$ Marjanović, Moderna I, 34.

501 „Naša pisma“, Narodna misao, 275.
} 
srpske opozicije. ${ }^{502}$ Osim toga, ovaj dio almanaha upućuje i na to da se Ujedinjena omladina mnogo više trudila oko svojeg odnosa sa starima, s kojima je praški krug imao daleko hladniji odnos. Milan Marjanović donio je podatak da je Khuenova cenzura zadržavala objavljivanje

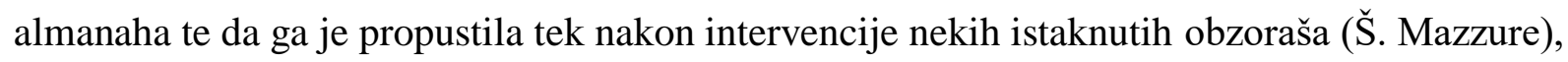
kao i to da je almanah dobio slab publicitet te da je raspačan u malom broju, a da su dug u Dioničkoj tiskari djelomično pokrili stari. ${ }^{503}$ Krug oko Narodne misli nastupao je prvenstveno s idejom utjecanja na opozicijsku politiku u Hrvatskoj, prije svega na pomirenje i ujedinjenje hrvatske i srpske opozicije na novim političkim načelima. Zbog toga i nije razvio tako široki tematski raspon kao Hrvatska misao, nego su se fokusirali na ono što su vidjeli kao ključni problem hrvatske politike, a to je srpsko-hrvatski spor. Zanimljiva je u tom smislu činjenica da je Jovan Jovanović Zmaj u Glasu Crnogorca na jesen 1897. godine objavio pjesmu „Za ujedinjenu hrvatsku i srpsku akademsku omladinu“, koja je nedugo nakon toga u Splitu, vjerojatno preko Dušana Mangjera, zasebno otisnuta kao „Himna Ujedinjene hrvatske i srpske akademske omladine“:

„Bogu slava, Bogu hvala,

Zatrpan je izvor zâlâ;

Sad nam svjesna duša poje:

„Mi smo jedno, nismo dvoje.““

Ko god rani Srba brata,

Ranio je i Hrvata;

Ko Hrvatu bol zasniva,

Taj i Srbe izaziva.

Jedno tjelo, jedan rad,

Jedna misô, jedan nad.

Neće više tudje tane

Pogadjat nam slabe strane,

Odbiće se i njih trista

\footnotetext{
502 Gross, Studentski pokret, 460-461.
}

${ }^{503}$ Marjanović, nav. dj., 34. 
Od oklopa, od jedinstva.

Kad Hrvatu sunce sine,

Ogrijaće i Srbine;

Što zacvjeta Srbu bratu,

Zacvjetaće i Hrvatu.

Jedno tjelo, jedan rad,

Jedna misô, jedan nad. “504

Međutim, kako ističe Rene Lovrenčić, ovaj dio almanaha također upućuje i na ograničenja takvih nastojanja zagrebačkih mladih. U odgovorima dominiraju obzoraši, dok se od prvaka domovinaša javlja jedino F. Potočnjak koji je među njima bio donekle specifična figura, mlađi i dinamični političar koji će uskoro i napustiti stranku. Dalmatinskih pravaša uopće nema, a najfrapantnija je činjenica što odgovor nije poslao niti jedan predstavnik srpske politike u Banskoj Hrvatskoj, uključujući i Srpske samostalne stranke. Uz općenitost većine odgovora, koji se uglavnom svode na načelno i deklarativno pozdravljanje napora omladine, uz ponavljanje već ustaljenih političkih i ideoloških fraza, nerijetko u raskoraku sa stvarnom političkom praksom hrvatske opozicije, ova činjenica upućuje na i dalje snažan faktor animoziteta hrvatske i srpske političke elite, kako međusobnih, tako i unutar samih stranaka i frakcija. 505

Upravo je ovaj posljednji dio almanaha izazvao kritike praških mladih u Hrvatskoj misli. Oni su u posljednjem dvobroju Hrvatske misli izrazito pohvalno prikazali almanah Narodna misao. ${ }^{506}$ Tekst je gotovo sigurno napisao Stjepan Radić, na što upućuje i činjenica da se u njemu obilno citira iz njegova članka „Hrvatski ideali“ te iz programatskog teksta „Što hoćemo“" koji je on oblikovao. Cilj takva obilnog citiranja jest da se pokaže programatska sličnost praške skupine mladih i Ujedinjene omladine, napose u pogledu ideje narodnog jedinstva Srba i Hrvata. U tom smislu, posebno je pohvaljen tekst Svetozara Pribićevića. Praške je mlade međutim zasmetao posljednji dio almanaha s pismima starih. Za njih je takav pristup promašen jer se mladi ne bi trebali oslanjati na autoritet starih, nego bi trebali krenuti svojim putem te samostalno izboriti promjene i povesti hrvatsku politiku u novom smjeru. Osim toga, oni primjećuju da se u odgovorima starih vidi „mjesto djelotvorne, žive ljubavi

\footnotetext{
504 „Himna Ujedinjene hrvatske i srpske akademske omladine“, HR-HDA-757 Obitelj Plavšić, k. 48.

505 Lovrenčić, nav. dj., 51-52.

506 „Narodna misao“, Hrvatska misao, god. I, br. 7-8, 212-215.
} 
prema cijelomu narodu, uvidjavnost, da će pojedini djelovi naroda - eventualno i sav narod štetovati ili čak propasti bez - sloge“, odnosno da „mjesto dubokoga uvjerenja tu govori žalosno iskustvo... “507

Pojava Narodne misli označila je tako početak (ponovnog) organiziranja „novog smjera“ u Zagrebu i formiranje nove jezgre bujajućeg modernističkog pokreta, sa značajnim udjelom srpskih studenata. Međutim, ona je ujedno jasan pokazatelj kako su specifične okolnosti utjecale na strategije aproprijacije i primjene ideja. Zagrebački je krug okupljen oko Narodne misli tako naglašavao specifične aspekte modernističkog programa koji su odgovarali na ono što se u njihovoj sredini percipiralo kao ključno političko pitanje, a to su bili nacionalni odnosi Srba i Hrvata te (ponovno) ujedinjenje opozicije na temeljima ideje narodnog jedinstva. Te su specifične razlike unutar zajedničkog, dijeljenog ideološkog okvira zapazili i sami akteri, jasno manifestirajući heterogeni karakter pokreta mladih. Studenti koji su sačinjavali zagrebački krug mladih već su bili politički involvirani i intelektualno formirani te su $\mathrm{u}$ tom smislu bili opterećeni onodobnim političkim temama. $\mathrm{S}$ druge strane, modernističke su ideje počele kolati i među srednjoškolcima, koji su za razliku od zagrebačkih studenata bili mnogo prijemčiviji za širi spektar modernističkih strujanja. Oni su stoga od svih grupacija pokreta razvili tematski najobuhvatniju djelatnost koja je ujedno imala i modernistički karakter.

\section{5. Modernističke ideje u okviru đačkog pokreta}

Na početku školske godine 1896./1897. zagrebački đački list Nada postao je ključno središte hrvatskog đačkog pokreta. Osim što je baštinio tradiciju đačkih društava i listova, nastajući fuzijom nekoliko đačkih aktivističkih grupacija, sve su intenzivniji njegovi kontakti sa studentskim „novosmjeraškim“ pokretom. Prije početka izlaženja Hrvatske misli među srednjoškolcima u Hrvatskoj cirkulirao je Radićev elaborat „o potrebi novih pogleda i metoda u politici i o pripremanju omladine za narodnu politiku“, a do ljeta 1897. godine veze su dodatno učvršćene sudjelovanjem predstavnika nadaškog pokreta na sastanku mladih u Zagrebu. $^{508}$ Time se tijekom 1897. intenzivirao proces okupljanja i povezivanja raznih modernističkih studentskih i đačkih grupacija u jedinstveni pokret mladih.

\footnotetext{
${ }^{507}$ Isto, 215.

${ }^{508}$ Marjanović, nav. dj., 29.
} 
U svojem trećem godištu, još uvijek litografirana, Nada je okupila vrlo širok krug suradnika, njih $60{ }^{509}$ List je izlazio dva puta mjesečno. Većina priloga i dalje su bili književni pokušaji srednjoškolaca, ali su sve zastupljeniji programatski i posebice kritički tekstovi, čime ona poprima konture tipična modernističkog lista. U tom su pogledu najvažniji suradnici i najaktivniji članovi svakako bili Vladimir Jelovšek, Milan Marjanović i Milutin Cihlar.

Odmah u prvome broju ovog godišta Cihlar objavljuje tekst „Zadaća hrvatske mladeži u književnosti“ u kojemu identificira stagnaciju hrvatske književnosti nakon Šenoina doba uzleta. Uzrok tomu vidi u nepovoljnim političkim prilikama, ali i u nedostatku središta nacionalnog književnog pokreta. Tradicionalni listovi u tom su pogledu podbacili, dapače, oni su jedan od glavnih izvora problema zato što Vienac i Prosvjetu vode ljudi koji se više bave politkom nego književnošću. ${ }^{510}$ Niti novi pokušaji starih ne obećavaju jer je Tresić u svojem Novom vieku izjavio da neće primati radove početnika. Upravo suprotno takvu stavu, Cihlar smatra da se hrvatska književnost mora otvoriti novim, mladim glasovima koji mogu donijeti novi polet. Međutim, i na mladima je dio odgovornosti za sadašnje stanje, jer su njihova društva uvelike neaktivna te zabavljena političkim trvenjima. Za književni uspjeh nije dovoljan samo talent, nego rad i nauka te vanjski poticaj. U tom smjeru trebao bi djelovati „sveobći djački pokret, koji bi išao za tim, da se djaci duševno oboružaju, naobraze i tim na rad potaknu. “511 Oni bi potom u budućnosti sačinjavali jednu novu, čvršću i obrazovaniju publiku koja bi bila jamac razvoja hrvatske književnosti. Time bi se ispravio i posljednji uzrok tadašnjeg poraznog stanja, a to su materijalna oskudica književnika i financijski problemi književnih listova.

U drugom dijelu teksta, Cihlar se posvetio zadaćama Nade kao lista. S obzirom na to da listovi trebaju podučavati i izražavati ideje neke skupine, te da su beletristični listovi ključni u suvremenoj književnosti, Nada mora biti ogledalo mišljenja hrvatskih đaka. ${ }^{512}$ Ona ne smije biti list $z a$ đake, nego dački list, odnosno, đaci ne smiju biti pasivni recipijenti, nego aktivni sudionici u njegovu nastajanju. Ipak, potreban je kritički nastrojen i angažiran urednik koji bi ulagao truda u selektiranje i popravljanje radova, jer radovi slabe kvalitete - koji su se mogli naći u listu u prošlom godištu - mogu samo odvraćati đake od čitanja i sudjelovanja. Uredništvo je Nade u kratkom odgovoru na ovaj tekst napisalo da se s njime u potpunosti slaže i da je njegov program ujedno i njihov. ${ }^{513}$

\footnotetext{
509 Isto, 45.

${ }^{510}$ M. Borišev, „Zadaća hrvatske mladeži u književnosti“, Nada, god. III, br. 1, 8.

${ }^{511}$ Isto, 11.

${ }^{512}$ M. Borišev, „Zadaća 'Nade“, Isto, br. 2, 26.

${ }^{513}$ Isto, 27.
} 
Ponekad su se u listu razvijale i polemike među đacima. U 5. je broju tako jedan učenik iz Petrinje pod pseudonimom „Karlov“ napisao tekst „Koji je smjer u lijepoj književnosti najshodniji da se pospješi kulturni razvitak naroda Hrvatskoga?“ u kojem se zalaže za idealizam u književnosti. ${ }^{514}$ Potaknuti tim tekstom, Jelovšek i Cihlar napisali su zajednički odgovor na postavljeno pitanje u kojem razlažu svoje poglede na književnost. Odmah na početku odbacuju ono što nazivaju „modernom školom“, koja se po njima svodi na pokušaj pisca da „briljira svojom osebujnošću“, pri čemu je jedino bitno „da je novo, da ti se čini čudnovato, originalno.“515 Oni općenito nastupaju protiv koncepta književnih smjerova i škola, čemu suprostavljaju princip umjetničkog genija koji se zna „uzvinuti nad tu masu svojim umom" te na koji se ne mogu primijeniti takve konvencionalne podjele. ${ }^{516}$ Genij stvara svoju vlastitu filozofiju i estetiku, on je sam svoj princip i svrha. Međutim, genij je iznimka, a rasprava se vodi o smjeru nacionalne književnosti, što se nužno odnosi na veliku većinu prosječnih literarnih radnika. Stoga, ako je već potrebno birati određenu školu ili smjer, Jelovšek i Cihlar smatraju da je ,po umnog radnika sadašnje dobi“ najprikladniji ,realizam ili čisti naturalizam.“517 Pod time ne misle na „onaj jadni naturalizam, koji uživa u crtanju i prikazivanju gnjusnih i niskih zgoda“, nego na umjetnički princip prema kojem „,jjelo treba da posvema odgovara istini“", kako u dobrim aspektima, tako i u onim lošim. ${ }^{518}$ Ono treba „držati zrcalo pred ljudskim očima“, pa stoga ne smije biti samo sredstvo zabave, nego i pouke. ${ }^{519}$ Zbog toga je tendencija u literaturi opravdana, „osobito u ovome vijeku nervoze i nemorala.“520 Općenito društveno komešanje, kao i pretjerani naturalizam osamdesetih godina, uzrokovali su napredak idealizma kao reakcije, napose u Francuskoj, ali mladi su autori uvjereni kako će on uskoro splasnuti te ustupiti mjesto upravo čistome naturalizmu ili realizmu. Iako se i Hrvatska mora uključiti u suvremena kulturna strujanja, u dogledno je vrijeme najbolje, smatraju mladi intelektualci, „da se priprosti puk ne umiješa u te struje, već gleda, da se moralno i materijalno podigne. ${ }^{\text {“521 }} \mathrm{Na}$ inteligenciji je da u tom pogledu nastupa prosvjetiteljski, pri čemu na realizmu zasnovana književnost može služiti kao sredstvo.

\footnotetext{
${ }^{514}$ Karlov, „Koji je smjer u lijepoj književnosti najshodniji, da se pospješi kulturni razvitak naroda Hrvatskoga“, Isto, br. 5, 74-75.

515 „Tendencija i smjer hrvatske literature“, Isto, br. 8, 121.

${ }^{516}$ Isto, 122

517 Isto.

518 Isto.

519 Isto, 123

520 Isto.

${ }^{521}$ Isto, br. $9,137$.
} 
Narod-bolesnik se treba podvrgnuti „nemilosrdnoj analizi i liječenju dobrohotnog liječnika. “522

Jelovšekov i Cihlarov književno-kulturni program u velikoj je mjeri podudaran s onim koji je u praškoj Hrvatskoj misli iznio Milivoj Dežman. Tendencija je u književnom djelu poželjna, ali ona se ne smije kositi s istinom kao vrhunskim principom umjetnosti. Suvremena nacionalna književnost mora biti sinteza narodnog života i općih umjetničkih načela. Ipak, Jelovšek i Cihlar još snažnije naglašavaju ulogu inteligencije u formiranju i diseminaciji nacionalne kulture. Prema njima, „puk mora stajati podaleko od vrtuljka svjetske pseudocivilizacije, pa primati samo ono, što mu je korisno i potrebno po napredak", a to određuje inteligencija koja „mora da bude u živoj svezi s vanjskim svijetom“ i kojoj je slobodno da se upozna sa svim njegovim stranama, i dobrim i lošim. ${ }^{523}$ Na njoj je da procijeni što je za razvoj nacionalne kulture korisno, a što štetno i što stoga treba preuzeti, a što odbaciti.

Marina Protrka Štimec stoga s pravom zaključuje kako je jedna od promjena koje mladi unose u književno i kulturno polje ,'demokratizacija' i istodobno hermetizacija i sakralizacija umjetnosti - kao jedan od paradoksa modernizma. “524 Stavljanje demokratizacije pod navodne znakove ipak ukazuje da je riječ o prividnu paradoksu. Niti jedna od grupacija modernističkog pokreta mladih nije isticala zahtjev za neposrednim uključenjem širih slojeva kako u političku, tako i u kulturnu sferu. I jedno i drugo trebala je posredovati nova, moderna nacionalna inteligencija. Ono u čemu su se razlikovali je stupanj tog posredovanja. Đački modernisti pokazivali su najviši stupanj hermetizacije i sakralizacije umjetnosti, drugim riječima elitizma. Nacionalna inteligencija kod njih postaje pravi pedagog koji kao prosvijetljeni učitelj upravlja razvojem neobrazovane mase. Ovakav koncept nacionalne inteligencije, koji počiva na proširenju ideje umjetničkog genija, đački modernisti nisu mogli preuzeti od praške skupine mladih. To upućuje na činjenicu samostalnih modernističkih aproprijacija u okviru đačkog pokreta. Iako je neupitno da su bili upoznati s idejama i kretanjima među hrvatskim studentima u Pragu, oni su tek potaknuli najmlađi modernistički krug da i sami započnu s istraživanjem suvremenih europskih strujanja. Zbog toga se u okviru

\footnotetext{
${ }^{522}$ Isto, 138. Možda je baš recepcija Dežmanove jednočinke Svršetak dobar pokazatelj stanja hrvatske literarne javnosti i odnosa nadaša prema njoj. U svojem kratkom prikazu, Cihlar prenosi atmosferu frapirane začuđenosti s premijere predstave, koja nije imala daljnje reprize. Za njega, ona predstavlja početak naturalističke drame $u$ Hrvatskoj. Međutim, to je u ovome trenutku ipak previše za hrvatsku javnost, u kojoj se još uvijek nije učvrstio niti realizam kao nekontroverzni umjetnički smjer. M. Borišev, „Zabludjela ovca“, Isto, br. 12, 186. Osim ovoga, Dežmanova će se kritika Matice hrvatske jasno odraziti i na gotovo istovjetnu kritiku nadaša. ,'Matica Hrvatska'“, Isto, 187.

523 Isto.

${ }^{524}$ Protrka Štimec, nav. dj., s. p.
} 
đačkoga pokreta razvija specifična varijanta modernizma koja će s njezinom integracijom u studentski pokret mladih donijeti nove elemente u ionako već heterogeno i kompleksno ideološko zdanje hrvatskog modernističkog pokreta.

Unutar ,trijumvirata“ Jelovšek-Marjanović-Cihlar bilo je i nesuglasica. Marjanović se u jednom dopisu kritički osvrnuo na kazališne recenzije u Nadi. One podsjećaju na pregledne izvatke iz novina te nisu prilagođene svojoj svrsi, a to je da đake upoznaju s kazalištem. ${ }^{525}$ Umjesto da se bavi glumcima, recenzent bi se morao baviti djelom i njegovim mislima, jer svrha kritike nije „da odgoji glumce, nego samostalne značajeve“, ne novinare, nego „inteligentne, naobražene borioce“, ne stručnjake, nego „ljude samostalne, svestrane, neograničene i svijesne. “526 Jelovšek, koji je uglavnom bio autor prozvanih kazališnih prikaza, stao je u njihovu obranu, a podržao ga je i Cihlar, koji je kasnije preuzeo pisanje te rubrike. ${ }^{527}$ Tekstovima i polemikama u đačkome listu mladi su modernisti razvijali habitus javnog intelektualca. Vježbali su kritički diskurs i razvijali individualni stil. Pritom su pokazivali zavidnu razinu samopouzdanja, pa je moguće da je i to utjecalo na snažnu prisutnost elitizma u njihovoj misli.

Marjanović je tako u Nadi nastavio razvijati svoje nazore o književnosti, koje je ranije započeo izlagati u karlovačkom Svjetlu i u svojoj Zajednici. Važan rani tekst u tom pogledu bio je književni prikaz Gjalskoga objavljen u deset nastavaka u Svjetlu 1895. godine. Kontrastirajući ilirsko i svoje doba, Marjanović ukazuje na paradoksalnu situaciju u kojoj je ilirsko doba uzdizalo sve „narodno“, dok se danas hvali sve što je tuđe, a potcjenjuje domaće, koje se više cijeni vani nego kod kuće. ${ }^{528}$ Za njega Gjalski nije najbolji kao romanopisac, nego kao kroničar „,narodnjega zagorskoga života“ u manjim formama. ${ }^{529} \mathrm{U}$ tom pogledu, on je pravi zastupnik turgenjevljevskog realizma u hrvatskoj književnosti, koji je očito blizak Marjanoviću. Nasuprot tome, on kritički nastupa prema „novom realizmu“, tj. naturalizmu na Zapadu jer umjetnost ne može funkcionirati kao znanost. Ona mora stvarati „obćenite tipove“ (ali „na hrvatskom tlu“) međuigrom života i mašte. ${ }^{530}$ Gjalski je najbolji primjer; njegovi su junaci „pravi hrvatski tipovi“ $\mathrm{u}$ taineovskom smislu. ${ }^{531}$ On nije larpurlartist, njegova je umjetnost u službi uzdizanja života, ali bez moraliziranja i propovijedanja. Pomalo u kontradikciji s početnom konstatacijom, za Marjanovića je najbolje Gjalskijevo djelo roman

\footnotetext{
${ }^{525}$ M. Borišev, „O kazališnim recenzijama“, Isto, br. 6, 90.

${ }^{526}$ Isto.

${ }^{527}$ Isto, 91-92.

528 „Ksaver Šandor-Gjalski“, Svjetlo, god. 10, br. 10.

${ }^{529}$ Isto.

${ }^{530}$ Isto, br. 11.

${ }^{531}$ Isto, br. 12.
} 
Radmilović, a uz bok mu u hrvatskoj književnosti stavlja jedino Kozarca. ${ }^{532}$ Naposljetku, izrazito kritički nastrojen prema Zoli, Marjanović nastupa kontra zapadne „,nadriznanosti“ te se zalaže za slavenski „povratak kršćanstvu“ i misticizam, koji smjeraju unutrašnjem preobraženju čovjeka kao zalogu za preporod cijelog čovječanstva. ${ }^{533}$

U Marjanovićevim se tekstovima u Nadi vide mnogo snažniji utjecaji praškog ,novog smjera“. On i dalje odbacuje moderne smjerove i škole kao „književnu modu“, te pravog književnika shvaća kao genija, međutim, on više nije nalik na mistika, nego na liječnika. ${ }^{534}$ Njegova je zadaća da bude pripadnik prave nacionalne inteligencije koja će smanjiti jaz između sebe i puka, ne tako da postane dio puka, nego da svoj rad temelji na proučavanju društva koje ju okružuje. Književno djelo prave je vrijednosti jedino ako u njemu čitamo „istinitu sliku života. “535 Umjetnički se mesijanizam prizemljuje i dobiva nacionalnu zadaću. Književnik mora prožeti svoje djelo nekom filozofijom koja izražava specifične nazore na svijet $\mathrm{i}$ život, ali ona ne smije biti tendenciozno prezentirana nego prikrivena. ${ }^{536}$ Tek u kolopletu takvih djela, koji se stilski i idejno naslanjaju jedno na drugo, može se razviti nacionalna književnost, a upravo je trenutak krize najbolja prilika za njezin razvoj. Zadaća je đaka da proučavaju nacionalnu književnost i njezinu vezu s društvom, ali i da ju uspoređuju sa stranim književnostima kako bi usvojili njihove visoke uzore i standarde. Nova književnost mora se riješiti „sviju predsuda i tradicijonalnih stranputica“, njoj treba pružiti „najveću slobodu“, ali ona mora ujedno „obuhvatiti cio narod“ i „prikladno pisati za sve slojeve“. 537 Zato je potreban organizirani i zajednički rad omladine, kako na sebi, tako i na društvu koje ju okružuje: „Dosta je u nas bilo Radmilovića, zato smo vegetirali, zato smo zaostali.“538

Ono što je detaljnije razrađeno u pojedinačnim tekstovima istaknuto je na općenitoj, programatskoj razini u proglasima uredništva. Kao ključne okosnice uvijek se ističu dvije točke. Prva je imperativ (samo)obrazovanja, koje je garancija razvoja čvrste i sposobne ličnosti kao uloga u izgradnji budućih nacionalnih aktivista i patriotski osviještenih građana. Druga je nužnost povezivanja i udruživanja đaštva, što predstavlja organizacijsku pretpostavku za ispunjenje cilja prve točke. Krajem 1896. godine Milan Marjanović i Vladimir Jelovšek sastavili su proglas koji je litografski umnožen i razaslan srednjoškolcima u Zagrebu i izvan Zagreba te je priložen 9. broju Nade. Na početku proglasa identificira se

\footnotetext{
${ }^{532}$ Isto, br. 14, 15.

533 Isto, br. 16.

${ }^{534}$ Branislav Vinkov, „Književna pisma“, Nada, god. III, br. 7, 105.

535 Isto, 106.

${ }^{536}$ Isto.

${ }^{537}$ Isto, br. 8, 121.

${ }^{538}$ Isto.
} 
pogibeljna situacija u kojoj se nalazi hrvatski narod, kojemu prijete brojne opasnosti: na prvome mjestu tuđa kultura, „koju uvađaju tuđinci, kojima nije do našega napretka, već do našega ropstva“, zatim korupcija, nemoral, otpaci prave civilizacije, a neprijatelji se služe sredstvima materijalnim i moralnim, prije svega oslanjajući se na domaću neslogu. Velika odgovornost za takvo stanje leži na inteligenciji koja je također razjedinjena, te koja i sebe i puk tješi „pustim frazama o slavnoj prošlosti i sjajnoj budućnosti“, a zapravo se traži odlučan rad. Najvidljiva je posljedica tadašnji akutni problem koji je često služio za produciranje moralne panike u javnosti, a to je emigracija „domaćeg“ stanovništva i naseljavanje „stranog“. Nakon identificiranja takva poraznog stanja, nadaši prelaze na pozitivni dio, na ono što oni hoće: „Hoćemo, da stari naraštaj, koji je svojim radom skrivio to bijedno stanje zamijeni novi svježi, mladi i napredni, koji će odlučnošću i znanjem popraviti stare grijehe novim vrlinama.“ Zahtjev za smjenom generacija postavlja se u okvire opozicije starosti i mladosti koji za sobom povlače druge vrijednosne konotacije: starost je „zasukana“, mladost je napredna; starost je trula, mladost je svježa; starost je kolebljiva, mladost je odlučna. Oni sebe dakle vide u liniji kontinuiteta od svojih „djedova“ (ilirci), kao one koji moraju obnoviti elan zamišljenoga nacionalnog pokreta, ali ujedno i diskontuniteta jer je on zamro zbog stranputice u koju su ga doveli „očevi“. Plan rada je jasno zacrtan: „Mi dakle preporučamo: naobrazujmo se - to je naš sadašnji rad; budimo međusobno složni u dobru - to je naša politika; spoznajmo bistro sadašnje stanje i pripravljajmo se za budućnost - to je naš patriotizam.“ Bez daljnjega potrebno je čuvati se strančarstva i gajiti ljubav prema narodu, „bio on koje vjere“. U neposrednoj budućnosti prvi zadatak je samoorganizacija đaštva. Od mnogo buke i demonstracija nema velike koristi, samo velike štete jer će uslijediti uhićenja i izbacivanja iz škola. Nausprot tome, đački se aktivisti zalažu za ozbiljan i organiziran rad na okupljanju hrvatskih đaka oko jednog centra, koji će onda služiti kao mjesto za obrazovanje budućih ,značajeva i radnika“. Za razliku od ranijeg pisanja karlovačke Zajednice, jasno se ističe da je od ,prijateljskog dopisivanja“ mnogo bolja „centralizacija svih sila“. Dakako da je kao središte predviđen list Nada, kao „vidljivi simbol naše sloge.“539

Zanimljivo je da pojavljivanje nadaških proglasa korespondira s pojavom proglasa i prvih programatskih tekstova praške Hrvatske misli. Baš nakon što je izašao prvi broj Hrvatske misli, u 11. broju Nade izlazi proglas „Naše težnje“ u kojem se po uzoru na praške mlade iznose temeljne okosnice đačkog pokreta. Dok je raniji proglas Nade analogan proglasu Hrvatske misli, ovaj je pak posve prispodobiv s programatskim člankom praške skupine, „Što

\footnotetext{
${ }^{539}$ Svi citati iz „Braćo i drugovi!“”, Isto, br. 9, s. p.
} 
hoćemo“. Đaci potpuno otvoreno ističu cilj svojeg djelovanja: „Mi hoćemo da položimo u srednjim zavodima temelj, na kojem budemo mogli sazdati u višim učilištima zidine one zgrade, što treba da je u poznije doba u javnosti, dogotovimo.“ Ističući „potpunu prosvjetu svih članova ljudskog roda“ kao cilj čovječanstva, đaci potcrtavaju kako je došlo vrijeme da se hrvatski narod aktivno uključi u kulturne procese napretka ljudskog društva. U suprotnome, smatraju oni - koristeći darvinističke postavke - prijeti mu nestanak kao smetnji neumitna napretka. Dok su drugi narodi stvarali civilizaciju, „naš ju je branio i obranio“, ali je došlo vrijeme da i on stvara kulturne stečevine, a ne da ih, kao do tada, samo prima. Uloga je đaka u tom smislu ključna kao temelja na kojem će se graditi nova inteligencija, spremna povesti nacionalni pokret - koji dakle postoji kao simbolički koncept - u smjeru izgradnje nove kulturne paradigme koja mora stati uz bok drugim europskim narodima. Zbog toga oni taksativno-programatski navode što žele da među hrvatskim đacima nestane, a što pozitivno da nastane. Nestati trebaju „indiferentizam, apatija i frazerstvo“; „političko strančarstvo“; „povodljivost i doktrinarstvo“; ,gojenje osobnih ambicija, separatistički duh i sitničave zadjevice“; „padanje vjerskoga čuvstva, moralne svijesti“ i druge „niske strasti“ te „prikrivanje hrvatstva i zatajivanje uvjerenja pred svijetom.“ S druge strane, žele da đaci „razmišljaju trijezno o životnim prilikama“; „nastoje upoznati terrain za budući svoj rad“; „stvore općenite temeljne ideje, što će ih voditi u budućem životu“; „,megjusobno probude svijest solidarnosti i uzajamnosti u dobru“; „ustale značaj, vjeru, samosvijest i idejale“ te „nastoje dati sebi i svome krugu hrvatsko obilježje.“ Sve se to treba postići „učenjem u školi“; „čitanjem i proučavanjem izvanškolskim“; „općenjem s inteligentim krugovima i s prostim pukom i promatranjem javnih i privatnih prilika u našem narodu i u stranom svijetu“ te „medjusobnim razgovorima, ferijalnim zadružnim putovanjima, svezama, dopisivanjem, podupiranjem centralnoga lista, priredjivanjem zabava, čitanja, deklamacija, vježbanjem u govoru, uzajamnim bodrenjem i poticanjem.“ Naposljetku, oni zaključuju: „Mi želimo dakle: slobodu svijesti, misli i govora, snosljivost, objektivnost, želimo boj ideja, djela, osviješćenja, pripravljanja; jednom riječju: nutarnju reformu, da tako pripravljeni stupimo jednom u javno djelovanje za dom i rod." ${ }^{\circ 540}$

Oko Nade stvara se tako novi, đački modernistički krug. Hrvatska misao bila mu je uzor u određenim idejama, formi i izričaju, što se može vidjeti iz gornje analize. Pa ipak, daleko od toga da bi Nada bila kopija Hrvatske misli. Ona je u sebi spojila tradiciju đačkih društava, ideje praških mladih i vlastite aproprijacije modernističkih strujanja. Osim

\footnotetext{
${ }^{540}$ Svi navodi iz „Naše težnje“, Isto, br. 11, 168-171.
} 
originalnog ideološkog sadržaja o kojemu smo ranije govorili, najočitija je razlika s obzirom na Hrvatsku misao mnogo veća tematska obuhvatnost đačkih modernista. Oni se doista ne bave politikom u užem smislu riječi, kao što to čini Hrvatska misao, jer je to iz pozicije đaka teško i nepoželjno. Međutim, oni zato razvijaju široki raspon interesa koji jasno manifestira političnost u širem značenju tog pojma, a uključuje razmatranje različitih fenomena, napose kulturnih, s obzirom na njihov utjecaj i ulogu u društvu. U tom pogledu, njihovi će listovi, uz one bečkih modernista, biti pravi predstavnici fin de siècle modernizma, mnogo više od onih praške skupine čiji je odnos spram ideje modernizma ambivalentan.

Dakako da školske vlasti nisu blagonaklono gledale na đački aktivizam. Jedna od učestalih tema lista i sastanaka društva je zapljena i zabrana držanja lista u različitim školama, zbog čega je većina članaka potpisana pseudonimima. U rubrici „Iz djačkih krugova“ također se pisalo i o nesuglasicama oko Nade među đacima, kao i o pokušajima pokretanja konkurentskog lista. ${ }^{541}$

Važan uspjeh Nade bila je uspostava plodne suradnje sa slovenskim đacima. U 9. broju objavljen je proglas „Braćo Slovenci“ kojim ih se poziva na zbližavanje i suradnju. ${ }^{542}$ Slovenski đaci pisali su za list, a također su redovito objavljivane i vijesti iz slovenskog đačkog života. S druge strane, iako je Marjanović predlagao sličnu inicijativu i prema srpskim učenicima, u tom pogledu nije bilo većih iskoraka. Slovenski su đaci također inicirali organiziranje zajedničkog abiturijentskog sastanka u Ljubljani koji bi uključivao i izlet u Prag. ${ }^{543}$ On se, međutim, nije ostvario zbog financijskih poteškoća. Umjesto toga, jedan đački dopis predlagao je da se abiturijenti pridruže planiranom općem sastanku studenata. Kao najpraktičnije mjesto dopisnik vidi okolicu Rijeke, npr. Sušak te smatra da bi abiturijenti na njemu trebali imati pravo govora, ali ne i pravo glasa, dok bi se Slovenci pozvali kao gosti. Što se tiče Praga, umjesto izleta, abiturijenti bi trebali otići tamo na studij, kao najbolje mjesto za pripremu za daljnji rad. ${ }^{544}$ Kao što je ranije opisano, treći opći studentski sastanak nije se održao, ali su zato đaci okupljeni oko Nade sudjelovali na ljetnom zagrebačkom sastanku zagovornika „novog smjera“.

Još jedna karakteristika nadaškog pokreta jest ta da su se u njemu - doduše sramežljivo - počele javljati teme ženskog pokreta i ženske emancipacije. U 14. je broju objavljeno pismo „Za žene“. Isprva se pomalo opravdavajući kako nisu do tad govorili o

\footnotetext{
541 „Iz djačkih krugova“, Isto, br. 3, 47.

542 „Iz djačkih krugova“, Isto, br. 9, 142.

543 „Zapisnik sjednice hrv. djač. lit. društva 'Nade', 21. siječnja 1897.“, HR-AHAZU-KN-133 Marjanović, Milan, k. 64.

544 ,'Vijenac' i 'Hrvatska misao'“،, Isto, br. 15, 237.
} 
ženama, ,jer tim bi kazali, da moraju one imati neki posebni program“, u nastavku pisma zalažu se za ideju jednakosti muškaraca i žena te ističu potrebu postojanja ženskog pokreta. ${ }^{545}$ Za nadaški pokret, inkluzija žena postaje jedan od prioriteta: „Koračimo korak po korak k cilju. Prvi je korak bio ideja svedjačkog lista; drugi je korak bio brojni odziv hrv. djaštva; treći je bio učinjen ove godine, kadno smo stali uz zabavu donašati i nama doličnu pouku, kada smo počeli govori o djaštvu kao važnom faktoru; četvrti je korak poziv na Slovence i njihov odziv; peti bi bio odziv ženstva it. d.“"546 To je ostalo slovo na papiru, jer ozbiljnijeg odaziva ženskih suradnika nije bilo.

Kada je u Pragu pokrenuta Hrvatska misao, odmah je uspostavljena komunikacija s đacima okupljenima oko Nade. Već na društvenoj sjednici u prosincu 1896. godine članovi Nade su obaviješteni o pismu Frana Poljaka kojim je najavljivao Hrvatsku misao. ${ }^{547}$ Đaci su isprva toj inicijativi pristupili oprezno, odlučivši se u prosinačkom broju objaviti samo kratku najavu izlaženja novog lista, nakon čega bi poveli raspravu o svojem stajalištu prema praškoj inicijativi. ${ }^{548}$ Nakon izlaska prvog broja Hrvatske misli, na sjednici društva od 27. siječnja odlučeno je da se Nada neće izjasniti ni za ni protiv lista jer se još uvijek ne može u potpunosti sagledati njegov karakter. ${ }^{549}$ Ipak, u 10. broju Nade objavljen je pozitivno intoniran osvrt na prvi broj Hrvatske misli. Đaci su pozdravili novi list kao „,neovisni objektivni list“ te su istaknuli kako se u potpunosti slažu s idealima „objektivnosti i liberalnosti““ za koje se on zalaže. ${ }^{550}$ Iako se kao beletristički list ne želi osvrtati na političku dimenziju Hrvatske misli, Nada staje u njezinu obranu od ranije spomenutih kritika kako hrvatske političke javnosti, tako i drugih studentskih društava. Prije svega, đaci se ne slažu s optužbom da pokretanje novog lista znači pripremu za osnivanje nove političke stranke te im se ona čini kao izmišljotina onih ,koji znadu, da imade dosta toga, što bi valjalo pomesti s njihova praga. ${ }^{651}$ Osim toga, rezolutno odbacuju tvrdnje da se mladi ljudi ne bi trebali baviti politikom kao „sredovječne predrasude“ ljudi koji nisu upoznati sa sličnim pokretima u inozemstvu. ${ }^{552}$ Što se tiče kritika drugih studentskih društava, đaci smatraju da je a priori odbacivanje i osuđivanje novih inicijativa uskogrudan i nerodoljuban postupak, „koji se

\footnotetext{
545 ,Za žene“, Isto, br. 14, 221.

546 Isto, 222.

547 „Zapisnik sjednice hrv. djač. lit. društva 'Nade', 5. prosinca 1896.“, HR-AHAZU-KN-133 Marjanović, Milan, k. 64.

548 „Svaštice“, Nada, god. III., br. 7, 112.

549 „Zapisnik sjednice hrv. djač. lit. društva 'Nade', 23. siječnja 1897.“, HR-AHAZU-KN-133 Marjanović, Milan, k. 64.

550 „Hrvatska misao“, Nada, god. III, br. 10, 157.

551 Isto.

${ }^{552}$ Isto.
} 
jedino dade shvatiti i ispričati kao refleks pogrješaka naših otaca. “553 U raskoraku sa zaključkom sjednice društva, Nada ,iskrenom radošću pozdravlja“ novi list mladih. ${ }^{554}$ Nisu svi đaci bili sretni s ovime, pa je baš zbog obrane Hrvatske misli određeni broj preplatnika iz Senja otkazao svoju pretplatu. ${ }^{555}$ Može se pretpostaviti da je razlog tome i dalje snažna prisutnost pravaštva u đačkim krugovima izvan centara gdje su intenzivnije kružile nove ideje, a to su prije svega bili Zagreb i Karlovac.

Treće godište Nade zaključeno je 19. brojem jer planirani 20. nisu uspjeli izdati zbog financijskih poteškoća. ${ }^{556} \mathrm{U}$ završnom obraćanju svojoj „miloj braći“, uredništvo je kao svoj najveći uspjeh istaknulo pridruživanje slovenskih đaka. $S$ druge strane, iako je širenje poučnog dijela lista također uspjeh, on je za sada još uvijek jednostran jer se odnosi samo na beletristiku, stoga ovdje vide mjesto za daljnji rad. ${ }^{557} \mathrm{Za}$ sve će iskorake, međutim, biti potrebna snažnija financijska podrška, što je bio najveći problem s kojim se suočavalo društvo ove godine.

Doista, jesen je donijela veliki iskorak što se tiče đačkog pokreta i lista. Najaktivniji pripadnici pokreta odlučili su da će se list od nove školske godine izdavati u tiskanom, a ne litografiranom izdanju. Zbog toga je na jesen 1897. godine izašao prvi broj lista koji se zvao Nova nada, baš kako bi se naglasio taj kvalitativni iskorak. List je tiskan u Dioničkoj tiskari. Dotadašnji glavni urednik, Vladimir Jelovšek, završio je školovanje i otišao na studij medicine u Prag. Unatoč tome, on je i dalje u prva dva godišta pred vlastima potpisivan kao izdavač lista, dok je to u trećem godištu bio Andrija Milčinović. Jelovšek je bio obećao da će iz Praga materijalno (i moralno) potpomagati list. ${ }^{558}$ Uredništvo su, međutim, preuzeli Milan Marjanović i Milutin Cihlar, a pridružili su im se Andrija Milčinović i Anton Kristan ${ }^{559}$, koji se iz Ljubljane preselio u Zagreb. ${ }^{560}$

Osim promjena u formatu lista, primjetne su i razlike u sadržajnom pogledu. Dio lista posvećen „pouci“ sada je mnogo opsežniji te je posve ravnopravan, pa možda čak i preteže

\footnotetext{
553 Isto.

${ }^{554}$ Isto. Još su eksplicitnije i daleko opširnije u obranu Hrvatske misli stali nakon napada Vienca. Vidi ,'Vijenac' i 'Hrvatska misao'“, Isto, br. 15, 236.

555 „Od uredništva“, Isto, br. 19, 304.

556 „Mila braćo“, Isto, 298.

557 Isto, 299.

${ }^{558}$ Ujević, nav. dj., 97.

${ }^{559}$ Anton Kristan (1881-1930), slovenski političar, gospodarstvenik i publicist. Nakon angažmana u zagrebačkoj Novoj nadi i Narodnoj misli nastavlja studij na Trgovačkoj akademiji u Pragu, gdje je blizak krugu realista oko Masaryka. Kasnije se pridružuje slovenskom radničkom pokretu, u sklopu kojega zastupa bernsteinovski revizionizam. Član je socijaldemokratske stranke od 1899. do 1921. godine, kada prestaje s političkim djelovanjem. Prije toga je bio ministar za šume i rude i poslanik u Ustavotvornoj skupštini. Obnašao je niz gospodarskih funkcija. V. https://www.slovenska-biografija.si/oseba/sbi304973/ (pristup: 13. 8. 2021.)

${ }^{560}$ Marjanović 46
} 
nad ,zabavom“, tj. literarnim pokušajima. Retke pouke uglavnom su ispunjavali Marjanović i Cihlar, pri čemu je potonji pogotovo bio zaokupljen opsežnom mjesečnom kazališnom kronikom. Jedno je od ključnih obilježja Nove nade snažna zastupljenost obavijesti i prikaza stranih književnosti, kao i suvremenih filozofskih i kulturnih kretanja. Već u prvome broju donose se prikazi iz ruske književnosti, Cihlarova studija o Zoli i Tolstoju - zapravo filozofska rasprava o njihovim temeljnim intelektualnim polazištima kroz koju se dotiče tema znanosti i religije, materijalizma i idealizma te budućnosti čovječanstva - ali i osvrt na islandsku književnost, kao uzor za druge „manje narode“, koji se „,danas javljaju u kolu većih

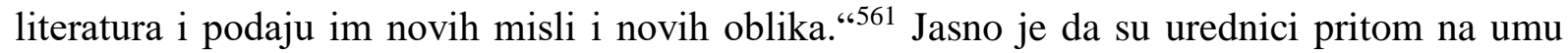
imali prije svega hrvatsku književnost, te da je naglašavanje pouke, posebice vezane uz europsku književnost, trebalo stvoriti preduvjete za transformaciju hrvatske književnosti u skladu sa suvremenim literarnim kretanjima. Kroz svoja tri tečaja i petnaest brojeva, Nova nada donijela je brojne obavijesti i sažete prikaze stranih književnosti, autora i mislilaca, uključujući: simbolizam, G. Flaubert, G. Sand, A. France, J.-K. Huysmans, G. D'Annunzio, F. Nietzsche, M. Nordau, G. Hauptmann, H. Ibsen, B. Björnson, G. Brandes, A. Kielland, É. Zola, L. Tolstoj, S. Przybyszewski itd. Osim toga, novitet je bila pojava tekstova s prirodoznanstvenom tematikom, npr. članak slovenskog suradnika pod naslovom „Descendentalna teorija in teorija selekcije“ ili „Nova hipoteza o kometnim repovima“.562 Ova dva obilježja, široki spektar interesa koji obuhvaća kulturu, društvena pitanja, prirodnu znanost itd. i usredotočenost na posredovanje suvremenih intelektualnih i kulturnih kretanja, definitivno su etablirali Novu nadu kao tipičan fin de siècle modernistički list.

Uz prvi broj Nove nade priložen je proglas naslovljen „Mlada Hrvatska“. Njegov je ton kritičniji i oštriji nego što je to bio slučaj u ranijim proglasima nadaša. U njemu se pitaju „ima li 'mlade Hrvatske', koja će novim silama zamijeniti staru?“ te se govori o „kulturnoj borbi, za koju se odgaja mnoštvo mladeži naše na gimnazijama, realkama, licejima i učiteljskim školama“. ${ }^{563}$ Naziv Mlada Hrvatska počinje se koristiti kao ekvivalent za nadaški pokret. Tekst je zapravo vrlo kritički intoniran spram mladeži, optužujući ju za nemar prema knjizi i slabo podupiranje nacionalnih kulturnih inicijativa. Nova nada poziva hrvatsku mladež da privatnom lektirom upozna suvremeno vrenje ideja, da međusobno razmjenjuje mišljenja i oštri duh te da se pripremi za zadatak koji ih čeka, a to je da za svoj narod iz svih

\footnotetext{
561 „Island“, Nova nada, god. I, br. 1, 30.

562 S. B., „Descendentalna teorija in teorija selekcije“, Isto, II, 1,27-30; Thales, „Nova hipoteza o kometnim repovima“, Isto, II, 4-5, 165-166.

563 „Mlada Hrvatska“, Isto, I, 1, s. p.
} 
tih ideja izabere one najbolje i najkorisnije. ${ }^{564}$ Pred Mladom Hrvatskom velika je zadaća jer upravo će ona jednoga dana zauzeti mjesto nacionalne inteligencije. Mladost je iznijela ilirski pokret, ali je ona djelomično odgovorna i za današnje mrtvilo. Zbog toga ona mora prvenstveno raditi na sebi. I đaci se referiraju na Gjalskoga i ponavljaju njegovu molitvu „Gospode, daj nam značajeva!“565 Za razvoj ,značaja“ ključno je, dakako, obrazovanje, shvaćeno ne (samo) kao formalno obrazovanje, nego kao široka humanistička naobrazba, koja se temelji i na kontinuiranu intelektualnom i moralnom usavršavanju. Neobrazovan čovjek nije samostalan nego je podređen volji drugoga. Zbog toga ,masa zna samo za fanatizam i apsolutno pokoravanje volji jednoga." ${ }^{\text {"566 }}$ Principu mase, s kojim je povezan moderni materijalizam, suprotstavlja se princip individualističke racionalne kulture. Ono što vrijedi za pojedinca vrijedi i za narod, jer je on sačinjen od pojedinaca; narodi „koji nemaju samostalne kulture, nego su pod jakim uplivom tudjinstva“ propadaju jednako kao „ljudi, koji nemaju svojih misli. “567 Zbog toga mladež, koja će preuzeti kormilo vođenja naroda, mora prvo od sebe napraviti samostalne, čvrste i obrazovane „značajeve“, jer „da budeš pravi patriota, potrebna je kud i kamo više samostalnost duše, stečena naobrazbom. “568 U nadaškom se pokretu tako odvija svojevrsna sinteza građanskog individualizma zasnovanog na humanističkom idealizmu i nacionalizma, kao specifičan odgovor na izazove moderne masovne politike. Umjesto utapanja u masi i suvremenom materijalizmu, koje nužno vodi u nacionalnu degeneraciju i propast, vodstvo naroda moraju preuzeti snažni i obrazovani patriotski nastrojeni pojedinci.

Usprkos retoričkim koncesijama ženskom pokretu, lik je mladog patriota i nacionalnog aktivista u okviru nadaškog pokreta bio izrazito maskuliniziran. Kada je u drugom broju drugog tečaja lista objavljen članak autorice „Milke“ o George Sand, koji se posredno bavio idejom ženske emancipacije i ženskim pokretom, uredništvo je imalo potrebu osvrnuti se na tekst s bilješkom da je objavljen ,ne dirajući hotice u njeno stanovište u razloženom pitanju. ${ }^{\text {“569 }} \mathrm{U}$ istome je broju objavljen tekst „Riječ našim srednjoškolkama“ u kojemu se urednici sa skepsom odnose prema suvremenom ženskom pokretu. Prema njima, radi želje da se žene oslobode ,i pravih i umišljenih lanaca“, na zapadu se rodila emancipacija koja se izvrgla u modu, a koja u dobrom smislu znači samo duševno podizanje žene. ${ }^{570}$

\footnotetext{
564 Isto.

565 Isto.

${ }^{566}$ Isto, br. 2, 79

${ }^{567}$ Isto, 80.

568 Isto.

569 Milka, ,George Sand“, Isto, II, 2, 62.

570 „Riječ našim srednjoškolkama“, Isto, 83.
} 
Ženska emancipacija je dakle prihvatljiva samo u duhovnoj, odnosno intelektualnoj sferi, ali ona postaje „t.zv. oslobodjenje žene“ kada zadobiva svoje vanjske manifestacije. Umjesto da voze bicikl, puše, „švapčare“ i čitaju „nebolomne romane“, trebalo bi raditi na tome da se kod žena jave „plemenitija čuvstva za narod, mar za knjigu i razumijevanje naših kulturnih potreba“ jer su one kao majke važan faktor za narodno blagostanje. ${ }^{571}$ Unatoč povremenim programskim koncesijama ideji ženske emancipacije i ženskome pokretu, kao i otvaranju svojih stranica suradnicama, od kojih su neke kasnije razvile plodnu književnu djelatnost, jasno je da je, u dominantno muškom dijelu jezgre nadaškog pokreta, razumijevanje uloge žena u nacionalnoj politici i kulturi ostalo u biti istovjetno onome u doba ilirskog pokreta.

Za razliku od drugih skupina pokreta mladih, krug oko Nove nade ipak je surađivao s kasnije istaknutim spisateljicama, intelektualkama i ženskim aktivistkinjama. Jedna od njih bila je Zofka Kveder, rođena i školovana u Ljubljani, koja se hrvatskoj književnosti predstavila na stranicama Nove nade. Ova je modernistička književnica 1900. godine u Pragu objavila svoju prvu zbirku crtica na slovenskom jeziku, Misterij žene, a tamo je studirala zajedno sa svojim budućim mužem, Vladimirom Jelovšekom. Kasnije je razvila bogatu književnu, publicističku i prevoditeljsku karijeru. Od 1904. do 1914. bila je urednica lista Domači prijatelj, a 1917. pokrenula je reviju Ženski svijet, kao i Jugoslavensku ženu godinu kasnije. Između ostaloga smatra se i jednom od prvih slovenskih feministkinja. ${ }^{572}$ Također valja spomenuti Adelu Milčinović, rođenu Sisčanku, koja se kasnije udala za drugoga urednika Nove nade, književnika Andriju Milčinovića. S njim je 1903. godine objavila knjigu Pod branom, u kojoj tematizira društveni položaj žene pod utjecajem feminističkog pokreta. Kasnije je razvila samostalnu književnu, publicističku, ali i društveno-političku djelatnost. Radila je kao podtajnica Financijskog odsjeka Narodnog vijeća u Zagrebu i tajnica Narodnog ženskog saveza. Kao istaknuta borkinja za ženska prava sudjelovala je na skupštini Međunarodne lige za žensko pravo glasa u Rimu 1923. godine. ${ }^{573}$ Činjenica da su ove književnice i feministkinje stasale u ozračju fin de siècle modernizma najbolje govori o njegovoj ambivalentnosti, heteogenosti i eklektičnosti, koja je mogla iznjedriti i feminističke ideje i skepsu spram suvremenog ženskog pokreta.

U programskom smislu za nadaški je pokret ključno drugo godište izlaženja Nove nade 1898. godine. Tada su objavljena dva proglasa - oba naslovljena „Braćo i drugovi!“ -

\footnotetext{
${ }^{571}$ Isto, 84.

572 O Zofki Kveder vidi: Helena Sablić Tomić, „Izazov korespondencije Zofke Kveder“, Dani Hvarskoga kazališta 33, 1, 2007, 420-431; Dunja Detoni Dujmić, Ljepša polovica književnosti, Zagreb, 1998, $187-197$.

573 „Milčinović, Adela“, Hrvatska enciklopedija, URL: https://www.enciklopedija.hr/natuknica.aspx?id=40832 (pristup: 19. 9. 2021.); Antonija Bogner Šaban, „Uspjeh gospodina Crownenshielda (Mr. Crownenshield's Success)“, Dani Hvarskoga kazališta, 32, 1, 2006, 281-296; Detoni Dujmić, nav. dj., 197-209.
} 
koji su predstavljali službenu programsku jezgru pokreta. Prvi je priložen prvome broju drugog tečaja objavljenom početkom 1898. godine. Konstatirajući kako se posvuda u svijetu opaža težnja, da stvori neko novo, bolje doba, đaci ističu kako je upravo zadaća mladeži da bude predvodnik ideje napretka. ${ }^{574}$ Međutim, ona ne smije tome zadatku pristupiti olako i nepromišljeno, ne smije se baviti „sanjarijama“, ne smije pisati „puste riječi“ i dati se impresionirati „blještavim frazama“ koje koriste „krivi auktoriteti“, što vodi u „beznačajnost“ i „nesamostalnost“.575 Snaga hrvatskog naroda, kao malena naroda, leži prvenstveno u njegovoj kulturi i inteligenciji. Zbog toga, kao budućim pripadnicima te nacionalne inteligencije, prvi je zadatak mladeži da se priprema za taj odgovoran posao. Mladi ne trebaju raditi na tome da budu dobri odvjetnici, ekonomisti ili učenjaci, nego čvrsti karakteri, „prosvjetitelji naroda“, pokretači njegove kulturne snage i „,borioci prave prosvjete“. 576

Još je važniji tzv. Drugi proglas, tiskan kao brošura u lipnju 1898. prije školskih praznika u 10000 primjeraka i razaslan na brojne škole kao središnji program nadaškog pokreta. U njemu se kao temeljna ideja razlaže „,načelo napretka“, koje se sastoji u tome da je dužnost svakoga pojedinca konstantno (samo)usavršavanje, te da je rad na sebi ujedno i rad na boljitku društva. Svi koji se protive tom načelu mogu se smatrati „,beskorisnim parazitima društva““ ${ }^{577}$ S obzirom na to da je narod samo ,jedno veliko organizirano društvo“, i pravi patriotizam sastoji se „u tom realnom radu, kojim treba da se stvore potpuni ljudi“. ${ }^{578}$ To je prva i jedina zadaća srednjoškolske mladeži, koja se priprema da jednoga dana preuzme kormilo narodne inteligencije.

Kroz glavninu proglasa ekstenzivno se nabrajaju problemi s đačkim organiziranjem razradom negativnih tipova đaka: ,aristokrata“, cinika, lijenčine, kruhoborca, snoba itd. Kao jedan od ključnih problema navodi se međusobni antagonizam đaka, kako između različitih škola, tako i razreda, pa čak i unutar njih. Dotadašnji načini organiziranja nisu urodili plodom, pa je vrijeme da se pokuša drugačije, da se izgradi jedan novi tip pokreta. Umjesto programa, riječi, pjevanja i buke, potreban je ozbiljan i postojan rad. ${ }^{579}$ Temelj je, dakako, samousavršavanje. Kao ključna metoda u tom pogledu navodi se privatna lektira, koja ne smije biti kaotična, nego mora biti metodična i vođena principom strogog kritičkog čitanja. ${ }^{580}$ Nadaški je koncept privatne lektire razrađen u mehanizam aproprijacije intelektualnih i

\footnotetext{
574 „Braćo i drugovi!““, Isto, II, 1, s. p.

575 Isto.

576 Isto.

${ }^{577}$ Braćo i drugovi!, Zagreb, 1898, prema: Krtalić, nav. dj., 145.

578 Isto, 141.

${ }^{579}$ Isto, 147.

${ }^{580}$ Ideja privatne lektire jedna je od temeljnih koncepata nadaškog pokreta, stoga je i učestalo razrađivana u tekstovima objavljenima u Novoj nadi. Vidi npr. „Mladi naraščaj“, Nova nada, II, 2, 69-72.
} 
kulturnih dobara. Prvi je korak upoznavanje naroda, ponajviše preko pučke književnosti i običaja u kojima se zrcali narodna duša. Nakon što spoznaju narodnu dušu, đaci će znati od općih kulturnih tekovina preuzeti ono što joj odgovara, napose među onim naroda koji su srodni „po krvi i jeziku“ i čije je iskustvo pokazalo pozitivne i negativne strane određenih kulturnih strujanja. ${ }^{581}$

Ono što Dežman predlaže na polju književnosti - originalnu, suvremenu književnost sadržajno utemeljenu na nacionalnim specifičnostima - krug oko Nove nade proteže na cjelokupno područje kulture, pa i šire. Sinteza nacionalnog i kozmopolitskog, posebnog i općeg, osigurala bi željeni kulturni i društveni napredak koji jedini može zajamčiti opstanak maloga naroda, koji se ne može oslanjati na materijalnu silu. Pritom se koristi romantičarski koncept narodne duše kao objektivnog kulturnog supstrata, koji je, kao što smo vidjeli, bio fundamentalan i u koncepcijama praške skupine mladih.

Naposljetku, u proglasu se razrađuju metode zajedničkoga rada usmjerene postizanju ciljeva pokreta. Predviđa se tako osnivanje čitaonica koje bi se financirale manjim prilozima đaka. U njima bi se održavali sastanci i diskutiralo o raznim temama te o pročitanom štivu. Čitaonice bi trebale okupljati više razreda i zavoda kako bi se razgovorom uklonili nepotrebni antagonizmi. Osim toga, potrebno je razviti korespondenciju među pripadnicima pokreta koji se ne mogu sastajati uživo zbog prostorne udaljenosti. Međusobna komunikacija ključna je za održavanje dinamike pokreta. Tome bi posebno trebalo doskočiti tijekom ljetnih praznika, kada bi đaci morali putovati zemljom te se međusobno upoznavati, kao i upoznavati narod za koji će kasnije raditi. Kruna ljetnih ferija trebao bi biti veliki đački sastanak. Dakako, najvažniji glas pokreta i njegovo okupljalište je njegov list, Nova nada, koju treba zdušno i odgovorno podržavati. ${ }^{582}$

Na stranicama se Nove nade često raspravljalo o posebnim organizacijskim pitanjima. Jasno je da je problem organizacije pokreta bio jedan od ključnih koji je zaokupljao đačke aktiviste. Tako je prikazom ideja Dragana Galovića - koji je do tada već postao mitska figura pokreta - u povodu godišnjice njegove smrti, zapravo prikazana osnova organizacijskog rada pokreta. U tom se pogledu predviđalo da na svakom srednjoškolskom zavodu bude jedna skupina odabranih đaka, koja će druge okupljati oko sebe i prenositi im ideje pokreta, a sve bi te skupine bile povezane s centralom u Zagrebu. ${ }^{583}$ Svake bi se godine na početku ferija trebao organizirati ne samo abiturijentski, nego sveopći sastanak srednjoškolaca, nakon čega

\footnotetext{
${ }^{581}$ Braćo i drugovi!, 148-149.

582 Isto, 150-151.

583 ,Mladi naraštaj“, Nova nada, II, 1, 30.
} 
bi se razišli i u grupama putovali po domovini. ${ }^{584}$ Upravo je tome posvećena posebna pažnja, te su u zasebnom članku razrađene detaljne upute đacima za njihov rad tijekom praznika, kako to vrijeme ne bi bilo uzalud potraćeno. ${ }^{585}$ Da je samorazumijevanje nadaškog pokreta preraslo okvire okupljanja oko literarnoga rada pokazuje i činjenica da je predložen zajednički znak raspoznavanja za sve članove pokreta: hrvatska trobojnica preko prsiju s natpisom „Nova nada“. 586 Planirani se đački sastanak do kraja izlaženja Nove nade 1899. godine ipak nije ostvario. Valja ipak primijetiti da je đački nadaški pokret bio mnogo formaliziraniji od studentskog pokreta mladih, što je također jedna od njegovih specifičnih karakteristika. Đački modernisti nisu bili zainteresirani samo na to da svoje ideje kolegama prenesu putem intelektualnog rada, nego i konkretnim organiziranjem. Stoga nije čudno da će se ulaskom istaknutih predstavnika nadaškog pokreta u krugove studentskih modernista ovaj organizacijski impuls preliti i na pokret mladih, te da će u tom trenutku započeti njegova transformacija u organiziranu Hrvatsku naprednu omladinu, čime se bavimo u petome poglavlju rada.

Jedan od glavnih ciljeva Nove nade kao lista bio je da u njoj budu što je više moguće jednako zastupljeni hrvatski i slovenski radovi. Kao što navodi Milan Marjanović, Slovenci su prednjačili u lirici, dok su Hrvati bili zastupljeniji u noveli i drami. ${ }^{587} \mathrm{U}$ prvoj je knjizi Nove nade sadržano pet pjesama petorice hrvatskih suradnika te trinaest pjesama sedmorice slovenskih suradnika, odnosno sedam pripovijedaka i crtica petorice hrvatskih autora i jedna slovenskog. Osim toga, paralelno s člankom „Mlada Hrvatska“ objavljivan je i članak „Mlada Slovenska“ kao njegov pandan. Usprkos tome, na kraju prve knjige uredništvo se moralo braniti od prigovora sa slovenske strane kako slovenski članci nisu jednako zastupljeni te kako slovenski đaci imaju problema s čitanjem tekstova na hrvatskom jeziku. ${ }^{588}$ Uredništvo je dakako odbilo krivnju za takvu situaciju, napose vezano uz potonji prigovor, jer kao „organ ujedinjene mladeži hrvatske i slovenske“ Nova nada treba stremiti tome da se đaci međusobno upoznaju, što uključuje i međusobno učenje jezika. ${ }^{59}$ Kako bi se još jače naglasilo hrvatsko i slovensko đačko jedinstvo, u drugoj godini izlaženja lista odvojene rubrike „Mlada Hrvatska“ i „Mlada Slovenska“ zamjenjuje zajednička „Mladi naraštaj“, odnosno „Mladi naraščaj“. Omjer zastupljenosti u beletrističkom dijelu drugog i trećeg godišta još je ravnopravniji: što se poezije tiče, šesnaest pjesama dvanaestorice hrvatskih i

\footnotetext{
${ }^{584}$ Isto.

585 „Praznici“, Isto, br. 4-5, 187-189.

${ }^{586}$ Isto, 189.

${ }^{587}$ Marjanović, nav. dj., 47.

588 „Od uredništva“, Nova nada I, 5, 188.

${ }^{589}$ Isto.
} 
dvadeset i šest trinaestorice slovenskih suradnika, a u pripovijetci i crtici sedamnaest četrnaestorice hrvatskih i jedanaest devetorice slovenskih autora. Zanimljivo je da nije bilo pokušaja sličnog istupa prema srpskim učenicima, o čemu ne postoje objašnjenja niti stajalište užeg kruga pokreta.

Namjera je jezgre nadaškog pokreta bila da preraste okvire đačkog literarnog društva i da se snažnije naglasi njegov socijalni i politički aspekt. ${ }^{590}$ Ipak, čini se da je on svoj najveći trag ostavio na području knjižvenosti, i to književne kritike. Na stranicama su Nove nade svoj talent brusili uspješni budući književnici i književni kritičari. U tom su pogledu dominirala dva imena: Milan Marjanović i Milutin Cihlar, a u njoj se po prvi puta književnim kritikama javlja i Petar Skok. S obzirom na mladenačku dob, njihovo poznavanje domaćih, a pogotovo stranih suvremenih književnih strujanja bilo je impozantno. Poučni i kritički tekstovi Nove nade odišu duhom europskog fin de siècle-a, s njegovim specifično ambivalentnim odnosom prema modernitetu. Mladi intelektualci problematiziraju suvremene procese komercijalizacije novinstva i popratni razvoj senzacionalizma. ${ }^{591}$ Kritički se odnose prema sličnim procesima u književnosti, napose u Sjedinjenim Američkim Državama. Zolin imperativ materijalne neovisnosti književnika kao preduvjeta za slobodu stvaralaštva tamo je poprimio oblik komercijalizacije književnosti koja je postala roba koju književnici prodaju, pa se stoga vode impulsima tržišta, tj. ukusa najšire publike. To je dovelo do toga da pisci laskaju i služe masi, umjesto da joj zapovijedaju. ${ }^{592}$ Nadaši općenito nastupaju kao žestoki kritičari literature za zabavu. S jedne strane oni staju u obranu vrhunske, elitne književnosti, koju prati ideja o književniku kao posvećeniku, geniju koji stoji iznad društva i masa. S druge pak strane, kako svoju djelatnost vide u okvirima nastavka hrvatskog narodnog preporoda, oni su ujedno zagovaratelji utilitarne, pedagoške zadaće književnosti namijenjene široj publici. Gotovo identično kao Dežman, oni stoga imaju dvostruku viziju naravi i zadaće književnosti. Ona mora pratiti najsuvremenija europska kretanja i ići u korak s „naprednim“, „kulturnim“, narodima, ali i izvršavati svoju prosvjetiteljsku ulogu prema najširim slojevima društva koji još uvijek nisu zahvaćeni narodnim preporodom, pa tako nisu niti uključeni u nacionalni kulturni život. Ovdje se ponovno presijecaju „narodno“ i „napredno“; samo „,narodni“ sadržaj može osigurati originalnost vrhunske književnosti koja se može pred Europom plasirati kao svježa književnost jedne male nacije, dok opet samo „napredno“, suvremeno razumijevanje književnosti i njezine društvene uloge može pridonijeti stvaranju književnih djela

\footnotetext{
590 „Mlada Hrvatska“, Isto, III, 3, 110.

591 „Novac i štampa“, Isto, I, 2, 58.

592 Isto.
} 
namijenjenih širim narodnim slojevima koja bi ujedno podizala njihov estetski ukus, a ne bi samo propovijedala i moralizirala. Raspravljajući o kozmopolitizmu i nacionalizmu u književnosti, oni navode da su, iako moderna književnost ima više kozmopolitske karakteristike, ruska, skandinavska, a u novije vrijeme i talijanska književnost pokazale da je isticanjem nacionalnih specifičnosti moguće doseći prvo mjesto u svijetu. ${ }^{593}$ Đaci oko Nove nade nastupaju kao hrvatski brandesovci, doduše eksplicitno se ograđujući od njegove kasnije, nietzscheanske faze. Prikazom njegovih nazora i intelektualnog razvoja, oni zapravo ističu misli koje su i njima ključne, a to je shvaćanje umjetnosti kao sredstva za razumijevanje i izražavanje života, ali ne kao gole kopije i tendencije, nego kao individualnog umjetničkog poduhvata. ${ }^{594}$ Svjesno gradeći analogije s Danskom u sferi književnosti, pri čemu je intelektualni posrednik Brandes - baš kao što su praški mladi svjesno radili političke analogije s Češkom, koristeći Masaryka kao intelektualnog posrednika - krug oko Nove nade i hrvatsku literaturu vidi kao bolesnu i zagovara dubinsku raspravu o njezinu stanju i smjeru razvoja.

U Novoj nadi mladi kritičari objavljuju svoje prve velike, zrele kritičke studije domaćih književnika. Fokus je na trojici: Leskovaru, Kozarcu i Gjalskome. Leskovarom se pozabavio Cihlar u možda prvoj ozbiljnijoj studiji mladih nadaških kritičara, dok se Marjanović fokusirao na Kozarca. Oba su teksta primjer filozofsko-psihološke kritike koju će razvijati mladi, a u Cihlarovoj studiji prisutni su i elementi impresionizma. Za đačke kritičare, ova su tri pisca pravi predstavnici osebujne književne individualnosti koju su i sami zagovarali. Stoga se oni ne mogu, tvrdi Marjanović, svrstati u neku određenu umjetničku školu - iako ih često svrstavaju među realiste - jer su te škole „formalna strana umjetnosti““, odnosno čak „umjetnička moda, koja ipak nije nikada mogla ugušiti jaču umjetničku individualnost. “595 Piščeva se „duša“ neizbježno ,zrcali“ u njegovim produktima, pa je stoga $i$ zadaća kritike ne samo da ocijeni umjetničku i formalnu stranu djela, nego da pronikne u samu piščevu dušu, njegovo intelektualno, moralno i duhovno „nastrojenje“. Takvi su pisci, kroz čija djela „prodire“ njihova duša, razbijajući okove forme i škola, upravo primjer „genija“ koji su pozvani ne samo da stvaraju, nego i da kroz to stvaranje vode. Pritom se kao glavno pitanje postavlja odnos inteligencije prema narodu, s tendencijom da se pokaže da ga treba promijeniti. Upravo u ovom aspektu najjasnije do izražaja dolazi mesijanski individualizam nadaša, čvrsto povezan s idejom dovršetka narodnog preporoda.

\footnotetext{
593 „Izam“, Isto, II, 3, 119.

594 ,Brandes“, Isto, III, 1, 19-20.

595 Milan, „Kozarac“, Isto, III, 1, 14.
} 
Na stranicama Nove nade ispisane su i prve kritike književnih pokušaja mladih, napose u trećem godištu, kada je već započeo njihov proboj u književnu javnost. Cihlar, koji je bio zadužen za kazališnu kroniku, prikazom Trulog doma Srđana Tucića najavio je proboj „Mlade Hrvatske“ u drami. Tome svjedoči cijeli niz naslova koji su, doduše, obično prikazivani najviše dva puta, ali koji zasigurno nisu prolazne vrijednosti: Dežmanov Svršetak, Tucićev Povratak, pa i Nehajevljev vlastiti Prelom. ${ }^{596}$ U njima se ,zrcali udrijemana a još ne kristalizovana, neskupljena i neuredjena energija i elementarna snaga Mlade Hrvatske, koja hoće da probije led, da se potisne na prva mjesta. “597 S time se slaže i Petar Skok (Mikov) koji u Novoj nadi nastupa recenzijom Nehajevljeve Svjećice. Za njega razvoj moderne umjetnosti u 19. stoljeću zrcali razvoj moderne duše. Ona sve više i više sa sebe baca ,iluziju za iluzijom, ideal za idealom; samo da dodje što bliže svojoj nutrinji, svojoj istini. “598 Za razliku od stare, nova umjetnost ne prikazuje samo unutrašnji život, nego ga i analizira; za razliku od stare romantike, ona je, kako kaže Bahr, „romantika nerva“, a za to je potrebna prava individualnost. ${ }^{599}$ Analiza moderne duše, pak, ima i socijalnu aspiraciju, zbog čega je nova, moderna umjetnost - ,apostolska umjetnost“. 600

Nisu svi mladi, modernistički autori dobili jednako povoljan tretman. Baš se bivši urednik Nade, Vladimir Jelovšek, našao na udaru đačke modernističke kritike. ${ }^{601}$ Recenzent „Našić“ ocijenio je njegovu zbirku pjesma Simfonije kao knjigu u kojoj će se najmanje naći poezije te u kojoj vladaju „užasna disharmonija“ $\mathrm{i}$, ,degenerirani izrazi““.602 a recenziju oštro zaključuje sa željom da Jelovšek više ne izdaje svoje pjesme. Na to je u idućem broju reagirao Milan Marjanović s mnogo boljom i nijansiranijom kritikom. On se slaže da su Jelovšekove Simfonije zapravo „'Disonacije' [sic!]“ ne baš virtuozne“ te da su „refleks neprekuhanih dojmova iz dalekog i jednostranog gledanja života i nesredjenosti protuslovnih utjecaja modernih knjiga, disonacije kaotičkog i tjeskobnog nerazumijevanja života, u čem autor ne može nikako da se snadje.“603 Za razliku od „Pribyszewskoga [sic!]“ na kojega se ugleda, on nije individualnost, nego je tek neiskuskni mladić. On dakle ne odgovara kriterijima samostalne umjetničke individualnosti koja bi bila sposobna primati utjecaje i dojmove i prerađivati ih na originalan način. To, međutim, ne znači da ga treba naprosto odbaciti.

\footnotetext{
596 M., ,Truli dom“, Isto, III, 1, 26.

${ }^{597}$ Isto, 29.

${ }^{598}$ Mikov, „M. Nehajev: Svjećica“, Isto, br. 4-5, 171.

${ }^{599}$ Isto, 171, 175.

${ }^{600}$ Isto, 176.

${ }^{601}$ Negativnu je kritiku Nove nade zaradio i Vladoje Schmidt Jugović, jedan od pokretača bečke Mladosti, za svoju knjigu Slike iz života. H., „Vladoje S. Jugović. Slike iz života“, Isto, 176-177.

602 Našić, „Vladimir Jelovšek: Simfonije“", Isto, br. 3, 120.

${ }^{603}$ B. V., ,Jelovšekove 'Simfonije'“, Isto, br. 4-5, 167.
} 
Upravo suprotno, treba ga pozvati da radi i dalje, pa da se vidi može li postati „muž i jedinstveni individuum“. ${ }^{604}$ Osim toga, njegove su Simfonije znak vremena u domaćem književnom i društvenom životu jer predstavljaju nagli prijelaz iz tradicionalizma $u$ modernizam, što sa sobom donosi i pozitivne i negativne posljedice, kao što su snobizam i „kozmopolitska modernost"“ ${ }^{605}$ To, međutim, ne treba nikoga plašiti jer će ta nagla promjena iskristalizirati snažne invidiualnosti, dok će oni slabi pokleknuti. Osim toga, više različitosti znači i više života i više uvjeta boljoj budućnosti. ${ }^{606}$

Nasuprot Jelovšeku, pravi primjer moderne, mlade pjesničke individualnosti za Marjanovića je Mihovil Nikolić. U impresionističkoj kritici, obilježenoj sinestezijom, Marjanović karakterizira Nikolićevu poeziju, okupljenu u zbirci Pjesme, kroz tri značajke fin de siècle modernosti: revitalizaciju faustovskog problema, odnosno pad vjere u znanost, koja se u pjesništvu manifestira kroz tolstojevski princip da umjetnik mora bilježiti čuvstva i osjećaje, a ne tendenciozno filozofirati; razumijevanje umjetnosti kao „objavljenja duše“, kao nečeg subjektivnog što ,živi za sebe“; te princip umjetničkog individualiteta. Nikolić, međutim, nije samo moderni pjesnik europskog fin de siècle-a. Njegova poezija ima i sve značajke „naše narodne - 'sjetne lirike'“, on stvara „umjetne, moderne pjesme, a ipak su

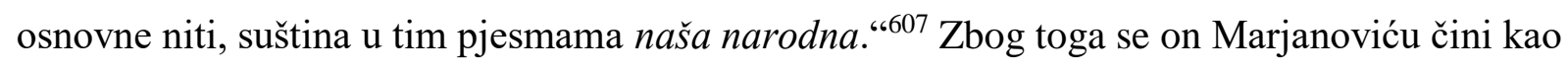
„pjesnički Lisinski““, čini mu se „čovjekom i pjesnikom modernim, značajnim za ovo doba, a opet našim, našim, sasma našim. “608 On je pravi primjer umjetničke individualnosti koja se zahtijeva u proglasu „Češke moderne“ iz 1895. godine.

U Novoj nadi tako su se pokazale sve ambivalentnosti ideja modernosti na prijelomu 19 i 20. stoljeća. S jedne strane to je modernost napretka, obrazovanja, radišnosti, čvrstog karaktera $\mathrm{i}$ moraliteta, a s druge strane modernost duše, vjere, nepovjerenja u znanost i umjetničkog genija. Ona je europska, kozmopolitska modernost, ali i žuđena nacionalna modernost, sinteza „,narodnog“ i ,naprednog“. Točka u kojoj se spajaju sve te divergentne, pa čak i kontradiktorne, ideje jest princip individualnosti, koji se može smatrati središnjom idejom nadaške ideologije. Samo jaka individualnost može u sebi sintetizirati sva brojna suvremena strujanja i dovesti ih u vezu s nacionalnom tradicijom, a da ne poklekne pred privlačnostima kozmopolitske mode, dekadentizma i (fingirana ili stvarna) nervnog rastrojenja, ili pak jednostranosti uskogrudna nacionalizma. Samo ona može balansirati

\footnotetext{
${ }^{604}$ Isto, 169.

${ }^{605}$ Isto, 168-169.

${ }^{606}$ Isto, 169.

${ }^{607}$ B. V., ,Mihovil Nikolić“, Isto, 153.

${ }^{608}$ Isto.
} 
između znanosti i vjere, masovnog društva i bogatstva unutrašnjosti duše. Naposljetku, samo snažna individualnost, koja svoj razvoj započinje već u školskim klupama, može pretendirati na vodstvo svojeg naroda, na odgovornu poziciju nacionalne inteligencije u doba masovne politike.

Nije stoga čudno da su nadaši uvijek odbijali bilo kakve optužbe ili insinuacije da zagovaraju neki umjetnički ili, još gore, politički smjer. Slično kao Hrvatska misao, predstavljaju svoj list kao forum za učenje, vježbanje i raspravu svih srednjoškolaca, kao mjesto na kojem oni trebaju brusiti svoj intelekt i karakter za buduće zadaće. Zbog toga je izlišno u njihovu pokretu tražiti „zametke kakve nove generacije književne ili političke“. 609 Posebno su se branili od optužbi za kozmopolitizam, što je zapravo značilo optužbu za zapostavljanje i izdaju nacionalne kulture nauštrb strane i tuđe, a što je bila jedna od centralnih točaka prijepora mladih i starih. Za krug oko Nove nade, veći fokus na svjetsku književnost opravdan je samom činjenicom zajedničke conditio humana jer ,problemi, koji sižu i preko granica našega naroda, treba da nas jednako zanimaju, jer su u njima pitanja važna za cijelo čovječanstvo.“610 Osim toga, nije im uopće žao što ne donose patriotske budnice koje se očekuju od mladeži, u kojima bučne riječi nadomještavaju manjak ideja, jer je njih već ionako dovoljno. ${ }^{611}$ Mladeži ne treba više zanosa, nego više ozbiljnosti.

Budućnost je demantirala nadaše. Njihov je pokret doista bio jedan od zametaka nove književne i političke generacije. Iako su ambicije za razvoj lista konstantno rasle, pa je tako čak postojala ideja da postane zajedničko glasilo svih đaka - uključujući i studente - stvarnost je ipak bila drugačija. ${ }^{612}$ Kvalitativni razvoj sadržaja lista pratio je kvantitativni pad njegove infrastrukture. Već su u drugoj godini izlaženja akumulirani veliki dugovi. Uredništvo se zato učestalo žali na financijske probleme, za koje uglavnom krive nemar pretplatnika i općenito slabu novčanu potporu listu. U posljednjem dvobroju lista objavljen je svojevrsni ultimatum uredništva: ako se ne poboljša situacija s podmirivanjem pretplate i dugova, budućnost lista je upitna. To bi bila velika šteta ako se uzme u obzir da se nadaški pokret doista proširio po cijeloj Hrvatskoj te da u Hrvatskoj nema zavoda, na kojem se ne bi znalo za njihove temeljne ideje. ${ }^{613} \mathrm{Za}$ pokrivanje deficita organizirani su i koncerti srednjoškolaca. Jelovšek tako izvještava o jednom koncertu koji su đaci organizirali u Sisku, a koji nije baš dobro završio:

\footnotetext{
609 „Od uredništva“", Isto, II, 4-5, 190.

${ }^{610}$ Isto, 190-191.

611 Isto, 191.

${ }^{612}$ Isto, 191-192.

613 „Mlada Hrvatska“, Isto, III, 4-5, 158.
} 
„Pilo se sve u šesnaest, plaćali su aranžeri Novonadaši urednici! A na koncu nijesu ostali ništa htjeli dati za 'N. Nadu'... “614

Apeli očito nisu pali na plodno tlo. S dvobrojem 4-5 treće knjige, 1899. godine prestala je izlaziti Nova nada i s njom je zamro i nadaški pokret. To upućuje na činjenicu da je pokretačka jezgra pokreta možda prenaglašavala njegove stvarne dimenzije. Da je pokret doista bio toliko raširen i aktivan, vjerojatno ne bi ovisio isključivo o entuzijazmu uredništva i najbližih suradnika lista. S njihovim napuštanjem đačkih klupa pokret ostaje obezglavljen i praktički nestaje s pozornice. Milan Marjanović, Milutin Cihlar, Vladimir Jelovšek i drugi pridružit će se jezgri modernističkog i naprednjačkog studentskog pokreta.

Đački je modernistički krug u kratkome razdoblju prošao intenzivni razvojni ciklus od malog srednjoškolskog literarnog društva, preko sveopćeg đačkog pokreta, pa sve do gašenja pokreta i odlaska njegove jezgre na studij, gdje su se pridružili studentskom pokretu mladih. Ovaj je razvojni put odredio specifičnosti modernističkih aproprijacija u okviru đačkog pokreta. Đački je modernizam nastao kao sinteza ranijih tradicija đačkih literarnih društava i listova, praških poticaja u duhu „novoga smjera“, aproprijacija europskih modernističkih strujanja i konkretnih organizacijskih iskustava. Zbog toga se u Nadi i Novoj nadi, kao središnjim organima đačkog modernističkog kruga, razvija specifična varijanta hrvatskog fin de siècle modernizma, čija su obilježja izraziti individualizam i kriticizam, koji poprima oblike intelektualnog elitizma i mesijanizma, tematska i problemska raznolikost s naglaskom na posredovanjima suvremenih intelektualnih kretanja i usredotočenost na organizacijska pitanja pokreta. Iako su uspjeli razviti razgranatu i živahnu djelatnost, s odlaskom jezgre nadaškog pokreta naglo prestaje njegov rad. Stoga se opravdano može postaviti pitanje o razmjeru i intenzitetu raširenosti novih ideja. Čini se da je glavni pokretački impuls đačkoga pokreta ipak bio izoliran na užu skupinu najaktivnijih članova oko uredništva Nade i Nove nade, što u potpunosti odgovara načinu funkcioniranja većine modernističkih skupina $\mathrm{u}$ ovome razdoblju. Ideja đačkoga pokreta, međutim, neće nestati te će se u narednim godinama uvijek iznova javljati kao poticaj za nove pothvate idućih generacija đačkih aktivista.

\footnotetext{
614 „V. Jelovšek - F. Hlaváčeku, Zagreb 13.VIII.1898.“, u: Agičić, Dragi Franta!, 77.“
} 
Tijekom 1896. i 1897. godine pokret mladih počinje dobivati svoje ideološke i organizacijske konture. To je proces koji je isprepleten s jedne strane s aproprijacijama stranih strujanja, a s druge s promjenama u okviru hrvatskog studentskog i đačkog pokreta, te on teče paralelno s prvim javnim istupima mladih. Zbog toga ne govorimo o „početku“ pokreta mladih, nego o njegovu „oblikovanju“. Mladi nisu istupili s već formiranom ideološkom i organizacijskom strukturom, nego je oblikovanje i razvoj pokreta tekao paralelno i isprepleteno s njegovim javnim životom. On je stoga cijelo vrijeme svojeg trajanja svojevrsni work in progress. Zbog toga je nemoguće fiksirati ideologiju mladih izvan dinamična konteksta u kojem oni djeluju i s kojim su u konstantnoj interakciji. Mladi će određene ideje prisvajati, modificirati i upotrebljavati na različite načine ovisno o kontekstu i zadanim ciljevima pokreta.

Drugi razlog zašto nije moguće čvrsto odrediti konkretnu ideologiju pokreta mladih jest njegova heterogena stuktura. U početnim stadijima „novi smjer“ kao jedan od najučestalijih naziva za nastajući pokret bio je gotovo isključivo vezan za svoju prašku jezgru, koja je kao centrala održavala veze s različitim raštrkanim istomišljenicima. Tijekom 1897. godine formiraju se pak i druge skupine koje će početi koristiti ideje i vokabular pokreta mladih. Iako su te skupine dakle komplicirale situaciju kada je riječ o ideološkoj i organizacijskoj strukturi pokreta - ponekad su bile u međusobno konkurentskim, pa čak i neprijateljskim odnosima - ipak su gotovo svi akteri bili svjesni da sudjeluju u zajedničkom temeljnom idejnom okviru $\mathrm{i}$ da dijele iste ili slične osnovne ciljeve. U tom smislu, proliferaciju modernističkih skupina i časopisa, kao i veliku javnu polemiku sa starima koja je potom uslijedila, na samome vrhuncu pokreta mladih pratila je i rastuća (samo)svijest o njegovoj naravi, ciljevima i povijesnoj ulozi, kao ključnim odrednicama identificiranja aktera s pokretom. 


\section{VRHUNAC POKRETA}

\section{1. Socijalizacija nacionalne politike}

Prestanak izlaženja Hrvatske misli kao pionirskog pothvata pokreta mladih nije bio kraj, nego zapravo početak formiranja praške skupine. Prije proliferacije modernističkih grupacija i širenja ideja pokreta nema toliko smisla govoriti o zasebnoj praškoj skupini, iako se oni i u tom, početnom periodu vrlo snažno identificiraju na toj osnovi. Tek s formiranjem drugih skupina, koje će unijeti nove momente i naglaske u pokret, praška skupina kao zaseban koncept dobiva svoju analitičku važnost. Njezin će intelektualni vrhunac uslijediti s Novim dobom, listom koji je naslijedio Hrvatsku misao. Osim što je zrelija i tematski obuhvatnija, u njoj su praški mladi elaborirali koncept socijalizacije narodne politike koji će postati fundamentalan za političku misao i praksu cjelokupnog pokreta, značajno utječući i na hrvatsku građansku politiku općenito. Kao vrhunac praške skupine, međutim, prestanak izlaženja Novog doba signalizirat će i njezinu stagnaciju te transformacije pokreta mladih koje će uslijediti.

Kao što je već ranije spomenuto, kontakti praške skupine i Ujedinjene omladine nisu bili ograničeni na prikaze u listovima. Na temelju već opisane suradnje oko izbora 1897. godine, nastavljeni su razgovori o daljnjoj zajedničkoj djelatnosti. Njih je posebno katalizirala zabrana Hrvatske misli, što je otvorilo prostor za još užu suradnju oko pokretanja novog lista. Iako su postojale ideje da Ujedinjena omladina pokrene svoj list, one su napuštene u korist zajedničkog rada na Hrvatskoj misli. ${ }^{615} \mathrm{U}$ srpnju su se u tom smjeru intenzivirali razgovori između praške i zagrebačke skupine. Fran Poljak dogovorio je s Ivanom Lorkovićem sastanak predstavnika ovih grupa na kojemu su trebale biti raspravljene ključne točke suradnje: načelni stav oko pitanja srpsko-hrvatskih odnosa i praktični dogovor oko pokretanja novog lista. ${ }^{616}$ Ovaj je sastanak ujedno bio organiziran nasuprot trećem općem đačkom sastanku (koji se na kraju nije odvio), kao zaseban sastanak studenata pristaša „novog smjera“, na što upućuje i njihov preklapajući termin. U prethodnim razgovorima iskristalizirala se ideja da se promijeni ime lista - dakle da ono više ne bude Hrvatska misao - te da se on pretvori u zajedničko glasilo hrvatske i srpske akademske omladine. Ujedinjena omladina u toj bi fuziji znatno proširila svoje gledište na pitanje narodnog jedinstva Srba i Hrvata te ga ne bi više

615 „Ivan Lorković - Stjepanu Radiću, Zagreb, 13. VI. 1897.“, u: Krizman, nav. dj., 275-276.

616 „F. Poljak - F. Hlaváčeku, Banija 25.VII.1897.“, u: Agičić, Dragi Franta!, 157. 
sagledavala samo iz formalnog narodnosnog rakursa, nego sa raznih drugih gledišta: socijalnoga, kulturnoga i političkoga. Pražani bi dakle otvorili svoje redove drugim skupinama mladih te bi proširili svoj list u smislu predstavljanja i hrvatske i srpske omladine, dok bi zagrebački mladi prihvatili masarykovski realizam kao temeljnu ideološku potku političkog djelovanja. Svetozar Pribićević trebao je doći u Prag i pridružiti se redakciji, a Srbi bi se onda pobrinuli za pretplatnike u Srbiji. Planiralo se udvostručiti opseg lista, povećati format i estetski ga preinačiti. Kako Poljak tvrdi neposredno prije sastanka, svi su bili suglasni s ovim planom. ${ }^{617}$

Sastanak se održao 28. i 29. srpnja 1897. godine u zagrebačkoj Streljani. Na njemu nisu sudjelovali samo predstavnici praške i zagrebačke skupine, nego i širi krug pokreta: M. Dežman, V. Jelovšek i još neki nadaši, a bili su pozvani i A. Radić, F. Hrčić i karlovački abiturijenti, koji nisu mogli doći. ${ }^{618}$ Okupilo se vjerojatno oko 20 sudionika. ${ }^{619}$ Pročitani su i pisani prilozi onih koji nisu mogli biti prisutni, npr. F. Hlaváčeka. Sastanak nije baš protekao harmonično kako je bilo predviđeno. Prvog dana bilo je riječi o načelnim pitanjima. Bertić kratko izvještava da se raspravljalo o državnom pravu, pri čemu su „za“ državno pravo govorili on, Korporić i Dežman. ${ }^{620}$ Mnogo je detaljniji i jasniji bio Poljak, koji razgovore prvog dana opisuje kao grozne polemike, u kojima se nije moglo doći do riječi. ${ }^{621}$ Dogovor je ipak postignut, a sastojao se u tome da se historijsko državno pravo ne može smatrati ishodištem narodne borbe, pa mu prema tome nije mjesto u narodnom programu, ali se može koristiti kao sredstvo u političkoj borbi, što je ipak bilo većinsko stajalište u okviru obje skupine koje se jasno manifestiralo i u programatskim tekstovima. ${ }^{622}$ Osim toga, raspravljalo se i o pitanju Bosne i Hercegovine, oko čega je - kako izvještava Lorković - preostalo još nekih razlika. Zanimljivo je kako su se ključne neuralgične točke u odnosima hrvatske i srpske građanske politike u Hrvatskoj prelile i na sastanak mladih koji su deklarativno raskidali upravo s takvim trvenjima i polemikama starih, što je primijetio i Poljak. ${ }^{623}$ Sastankom je bio nezadovoljan i Fran Hrčić, koji je zagrebačkim mladima posebno zamjerio njihovu jednostranu fokusiranost na problem narodnog jedinstva Srba i Hrvata i zapostavljanje socijalnog pitanja. ${ }^{624}$

\footnotetext{
${ }^{617}$ Isto.

618 „F. Poljak - F. Hlaváčeku, Banija 18.VIII.1897.“, Isto, 162.

619 „Ž. Bertić - F. Hlaváčeku, Zagreb 29.VII.1897.“, Isto, 23.

${ }^{620}$ Isto.

621 „F. Poljak - F. Hlaváčeku, Banija 18.VIII.1897.“, Isto, 163.

622 „I. Lorković - F. Hlaváčeku, Zagreb 7.VIII.1897.“, Isto, 129.

623 „F. Poljak - F. Hlaváčeku, Banija 18.VIII.1897.“, Isto, 163.

624 „F. Hrčić - D. Plavšiću, 12. 8. 1897.“, Uredništvo časopisa Mladost R7134, NSK.
} 
Drugoga je dana sastanka tema bila list, a ta rasprava ocijenjena je kao mnogo plodnija. ${ }^{625} \mathrm{~S}$ obzirom na to da bi list trebao biti glasilo i hrvatske i srpske akademske omladine, nije se činilo korektno da nosi samo hrvatsko ime u naslovu. U tom se smislu raspravljalo i o tome da se prihvati ime Narodna misao. Taj je prijedlog iznio Hlaváček na temelju svoje korespondencije s Ivanom Šajkovićem, praškim studentom iz Srbije. Kao pristaša Hrvatske misli, Šajković je za vrijeme ljetnih praznika u Beogradu agitirao za list među srpskim studentima. Iako je postigao stanovite uspjehe - čak se formirao stanoviti uži krug studenata i profesora u Beogradu koji su bili spremni i za tješnju suradnju - uvijek je kao problem iskakalo ime lista. Hrvatska misao u Srbiji je imala prizvuk starčevićanstva. ${ }^{626} \mathrm{Zbog}$ toga je Šajković predlagao da se ime lista promijeni u Narodna misao, što uostalom i adekvatnije izražava njegova stajališta. ${ }^{627}$ Međutim, protiv toga su prijedloga bili upravo Srbi, koji su smatrali da bi se to protumačilo kao ustupak njima te da se u javnosti ne bi blagonaklono gledalo na izbacivanje hrvatskog imena. Zbog toga je zaključeno da u nazivu lista treba ostati hrvatsko ime: „Takvoga hrvatstva, kakvo zastupa 'H. M.', vele, da se nijedan Srbin ne boji.“628 Naposljetku je zaključeno da će ime lista odrediti redakcija u Pragu prema okolnostima. Kao vlasnici lista dogovoreni su M. Heimrl, S. Korporić, M. Šarić, F. Poljak, Ž. Bertić, I. Lorković, V. Rizner, V. Jelovšek, J. Banjanin i S. Pribićević. Podijeljeni su i konkretni zadaci za tekstove te je dogovoren novi sastanak na kraju ferija kada bi trebalo sve konačno prirediti za izlazak novog lista. ${ }^{629}$

Na jesen, međutim, još uvijek nije bilo jasno kako će se novi list zvati, a niti pripreme nisu tekle glatko. Lorković tako prije početka školske godine piše Hlaváčeku da nedostaje i građe i novaca za izdavanje lista. Ipak, očekivao se dolazak „njekoliko vrlo dobrih mladih ljudi“ u Prag koji bi mogli preuzeti inicijativu oko izdavanja lista, a i ,glavni naš suradnik Radić“ se dobro oporavljao od bolesti u Švicarskoj te se računalo na njegovu plodnu suradnju. ${ }^{630}$ U Zagrebu, s druge strane, nije bila tako dobra situacija. Krug oko Narodne misli u većini se rasuo. Lorković izvještava da se Mangjer nakon završetka studija vratio u Split, Kostić i Mazzura odrađivali su vojni rok, Banjanin je apsolvirao i daje ispite, dok su Pribićević, Dimović i sam Lorković na 4. godini te se moraju jače posvetiti studijskim

625 „F. Poljak - F. Hlaváčeku, Banija 18.VIII.1897.“, Isto, 163.

${ }^{626}$ O slaboj recepciji inicijativa mladih u Srbiji vidi: Ivan Šajković, Nekoliko momenata iz omladinskoga pokreta (1893-1903), Subotica, 1929. Tekstu, međutim, treba pristupiti s dozom opreza. Šajković se već 1903. razišao s mladima, optuživši ih - napose Stjepana Radića - za prikriveno starčevićanstvo i velikohrvatske tendencije. Racko, „Pokret hrvatske moderne“, 10-11.

${ }^{627}$ Agičić, Hrvatsko-češki odnosi, 152-153.

628 „I. Lorković - F. Hlaváčeku, Zagreb 7.VIII.1897.“, Isto, 128.

629 „F. Poljak - F. Hlaváčeku, Banija 18.VIII.1897.“, Isto, 163-165.

630 „I. Lorković - F. Hlaváčeku, Zagreb 20.IX.1897.“, Isto, 130. 
obavezama. ${ }^{631}$ Fokus i nade tako se na jesen 1897. prebacuju na novi praški list, oko kojega će se koncentrirati najveći dio modernističkog pokreta mladih.

Oko imena novoga lista i dalje nije bilo konsenzusa. Tako npr. Dragan Šašel čak u 11. mjesecu piše Hlaváčeku da on nije za ime Novo doba, nego Novi smjer, s čime se složio i Poljak. ${ }^{632}$ Lorković je pak smatrao da je preuranjeno izbacivanje hrvatskog imena iz naslova lista te da bi za hrvatsko-srpske odnose bilo ljekovito kada bi srpski suradnici pisali za list koji nosi hrvatsko ime. ${ }^{633} \mathrm{U}$ tom su ga smjeru ohrabrivale i vrlo povoljne vijesti iz Beograda o uspjehu Hrvatske misli među Srbima. Zbog toga je predlagao prijelazno razdoblje u kojem bi list još uvijek nosio samo hrvatsko ime, a u kojem bi se razvila svijest o potrebi oba imena u naslovu lista. Lorković je čak imao ideju da se predloži pokretanje Srpske misli u Beogradu, koja bi onda propagirala istovjetne ideje u Srbiji, a nakon takve pripreme terena moglo bi se provesti ujedinjenje oba lista, što bi po njegovu mišljenju predstavljao vrlo važan politički čin. ${ }^{634}$ Nakon što je početkom studenoga Novo doba postalo najizgledniji kandidat za novo ime lista, s podnaslovom „list ujedinjene hrvatske, srpske i slovenske omladine“, Lorković je tvrdio da je to preuranjeno jer ,ujedinjujemo narod u nekolikim osobama, a narodne mase ostavljamo daleko za sobom.“635 Ova latentna neslaganja doprinijet će tome da će se zagrebački krug okupljen oko Narodne misli odlučiti za izdavanje svojeg, istoimenog lista u Zagrebu paralelno s Novim dobom, o čemu će više riječi biti u sljedećem poglavlju.

Uvijek problematična situacija s financijama i redovitim pisanjem članaka nije bila bolja niti tijekom priprema za izdavanje prvoga broja novog lista praških mladih. Hlaváček je i dalje imao važnu organizacijsku i koordinacijsku ulogu, zbog čega nije bio pretjerano zadovoljan, napose jer je neprestano morao pritiskati pismima zagrebačke mlade da izvrše preuzete zadatke. ${ }^{636}$ Lorković mu početkom studenoga piše: „Kad biste Vi, dragi prijatelju, znali, kakvo je kod nas mrtvilo i nehaj, kaki nedostatak ideja i energije, onda se ne biste čudili, što nema ni članaka ni novaca. “637 Njegova je prognoza poprilično pesimistična: „Osim Potočnjaka, sav naš pokret stoji u rukama njekolicine djaka, koji imaju da se bore protiv mlitavosti onih, koji dobro misle, i protiv zakonitosti onih, koji zlo misle. Borba je s tijem teža, što potonjih ima mnogo više od prvih. Za našu stvar ne rade ovdje profesori, bivši i

\footnotetext{
631 „I. Lorković - F. Hlaváčeku, Zagreb 8.X.1897.“, Isto, 132.

632 „D. Šašel - F. Hlaváčeku, Banija 12. XI. 1897.“, Isto, 200; „F. Poljak - F. Hlaváčeku, Karlovac 11.XI.1897.“, Isto, 171.

633 „I. Lorković - F. Hlaváčeku, Zagreb 8.X.1897.“, Isto, 133.

${ }^{634}$ Isto, 133-134.

635 „I. Lorković - F. Hlaváčeku, Zagreb 4.XI.1897.“, Isto, 135.

636 „D. Šašel - F. Hlaváčeku, Banija, Karlovac 18. I. 1898.“, Isto, 204.

${ }^{637}$ „I. Lorković - F. Hlaváčeku, Zagreb 4.XI.1897.“, Isto, 136.
} 
sadašnji ministri, kao što rade u Srbiji. “638 Osim na Potočnjaka, koji je obećavao i financijski pomagati neke mlade, računali su i na A. Radića koji je bio blizak s krugovima u hrvatskoj opoziciji, napose među obzorašima. ${ }^{639}$

Usprkos svim problemima, u prosincu 1897. objavljen je poziv na pretplatu Novog doba, novog lista mladih. Izražavajući zadovoljstvo uspjehom Hrvatske misli, redakcija novog lista jasno ističe da on predstavlja njezin nastavak, ali proširen i dopunjen srpskom i slovenskom omladinom. Imperativ narodnog jedinstva izbija na prvo programsko mjesto:

„Daleko od plemenskih predrasuda, bez strančarske žuči, obuhvatajući u težnjama svojim dobrobit cijeloga naroda, pokreće hrvatska, srpska i slovenska omladina u Pragu list, da okupljuje oko njega, kao omladina jednoga naroda, da poruši plemenske predrasude, koje potječu iz nepoznavanja, te da nebratsku braću ujedini, e bi jednom Hrvati, Srbi i Slovenci zajedničkim silama uzradili o dobru svom i naroda svoga. “640

Na drugo mjesto dolazi cilj ,nepristrane kritike javnoga rada“, neovisno o političkom i ideološkom predznaku, kao i upoznavanje sa „zamašnim i socijalnim pitanjima“, koja postaju ključna u novom dobu. ${ }^{641}$ Fuzija između Hrvatske misli i Narodne misli rezultirala je dakle posebnim isticanjem onog dijela programa Hrvatske misli koji je bio u fokusu zagrebačke Ujedinjene omladine, a to je ideja narodnog jedinstva.

Kao treća i posljednja ključna programska točka novoga lista ističe se ujedinjenje hrvatske, srpske i slovenske inteligencije među sobom, ali posebice njezino ujedinjenje s narodom, i to na kulturnoj podlozi. U tom pogledu daje se ključ za razumijevanje svrhe i uloge književnosti: ona mora biti „odrazom života narodnoga, te prema tomu i duhom $i$ mišljenjem narodnim zadojena, a namijenjena cijelomu narodu [...] ne bismo li jednom dočekali da narod zadojen jednim duhom uzima jednu svoju narodnu književnost. “642 Slično kao i kod Hrvatske misli, iako je u pozivu najavljeno da će se list obazirati „na svaku znantniju književnu pojavu u Hrvata, Srba i Slovenaca“, to nije bio slučaj te je problematika književnosti ostala na margini fokusa Novog doba. Ipak, s većim angažmanom Milana Marjanovića, a Dežmanovim približavanjem krugovima okupljenima oko bečkog lista Mladost, razumijevanje svrhe i uloge književnosti u okviru praške skupine doživjet će bitne promjene.

\footnotetext{
${ }^{638}$ „I. Lorković - F. Hlaváčeku, Zagreb 8.X.1897،“, Isto, 132.

${ }^{639}$ Vidi Potočnjakova i Radićeva pisma u Agičić, Dragi Franta!, 182-190 i 191-193.

${ }^{640}$ „Novo doba“, Vienac XXIX, 50, 808.

641 Isto.

${ }^{642}$ Isto.
} 
U prosincu 1897. godine objavljen je prvi broj lista Novo doba (s još dvije varijante imena na naslovnoj stranici: slovenskom i ćiriličnom), a podnaslov je glasio: „list sjedinjene hrvatske, srpske i slovenačke omladine za književnost, politiku i socijalna pitanja“. Dilema oko imena lista tako je riješena otklanjanjem i naziva Hrvatska misao i Narodna misao, dok je osnovna ideja lista signalizirana u podnaslovu. Naziv Novo doba varijacija je Masarykova Našeg doba. Iako je bilo planirano da članci srpskih suradnika budu štampani na ćirilici, to nije bilo moguće jer u štampariji nije bilo dovoljno ćiriličnih slova. Kao izdavač i urednik lista figurirao je Vice Iljadica-Grbešić jer František Hlaváček to više nije mogao, ali redakcijski poslovi uglavnom su obavljani kolektivno i prema mogućnostima aktivnih članova.

U prvome broju lista objavljen je proglas Novoga doba koji na opsežniji način elaborira ključne programatske točke izložene u pozivu na pretplatu. Proglas započinje refleksijom na sam pokret mladih. Njegovo je ishodište, tvrde pražani, u demonstraciji 1895. godine, što je postalo uvriježeno i u kasnijim historiografskim studijama ovog fenomena. Ti su burni događaji uzburkali vodu, a pod utjecajem aproprijacija stranih kretanja, ona se brzo pretvorila u bujicu. Ta bujica probija barijere staroga doba i uvodi mladež, a s njome i cjelokupni narod, u novo doba. Tri su ključna obilježja te bujice, odnosno omladinskog pokreta: nadilaženje plemenskih i stranačkih mržnji i predrasuda, usvajanje kritičkog i antidogmatskog stava te otvorenost aproprijacijama svjetskih kretanja, doduše onih koje smatraju „plodnima“ i „zdravima“. Kao rezultat nastala je Hrvatska misao, a onda i Narodna misao, kao dvije glavne pojave novog duha, dok Novo doba predstavlja nastavak tog kretanja. ${ }^{643}$

Ipak, zadaća je Novog doba mnogo šira jer ono nije samo organ jednog dijela hrvatske, „novosmjeraške“ omladine, nego treba okupiti i srpsku i slovensku omladinu koja misli na sličan način. Upravo u tom uspješnom okupljanju „,mladeži ovih jugoslavenskih grana“ leži najveći uspjeh projekta koji je započet s Hrvatskom misli. ${ }^{644}$ Kao što je hrvatska omladina sebi pronašla „skup novih reformnih misli za specijalno hrvatske prilike“, tako trebaju postupiti i srpska i slovenska omladina, a zadatak je Novog doba da to omogući, da olakša međusobnu komunikaciju i usklađivanje tih misli ne samo među sobom, nego i $\mathrm{s}$ „universalnim čovječanskim idejama“. ${ }^{645}$ „Novo doba“" kao masarykovski topos na prvome se mjestu dakle pojavljuje kao novo doba suradnje hrvatske, srpske i slovenske - odnosno

\footnotetext{
643 „Novo Doba“, Novo doba, god. I, br. 1, 1.

644 Isto.

${ }^{645}$ Isto, 2.
} 
jugoslavenske - omladine, a tek onda kao novi tip političkog razmišljanja i djelovanja, kao novo, suvremeno ekonomsko i društveno razmišljanje ili kao novo doba u književnosti i umjetnosti. Iako mnogo sistematičniji i programski određeniji od eklektične Hrvatske misli, na prvo programsko mjesto Novoga doba ponovno dolazi nacionalna problematika.

Kao jedna od glavnih zasada koje Novo doba preuzima od svojih prethodnika ističe se dakle narodno jedinstvo Hrvata i Srba, čija je „objektivna bitnost“ dokazana u Narodnoj misli. ${ }^{646}$ Što se tiče Slovenaca, misija Novog doba ne temelji se na ideji kulturnog sjedinjenja, nego „zbliženja“, jer „, spoljašnje prilike i sveopće mišljenje kod Slovenaca ide za razvojem slovenske grane južnoga slovjenstva kao posebnoga naroda.“647 Zbog toga, potrebno je „prepustiti konačnu odluku u toj stvari samim Slovencima.“648 U cilju ostvarenja misije kulturnog ujedinjenja Hrvata i Srba, a kulturnog zbližavanja sa Slovencima, predlažu se i konkretne simboličke akcije, kao što je međusobno učlanjivanje u Maticu hrvatsku, Srpsku književnu zadrugu i Maticu slovensku te učenje slovenskog, odnosno srpskog ili hrvatskog jezika. Naposljetku, takva politika kulture može predstavljati temelj za mnogo otvorenije političke ambicije: „Težnja za kulturnim jedinstvom mora buditi i težnju za spojenjem političkim, za jugoslovjenskim federalizmom političkim. “649 Ovaj politički cilj nije, međutim, detaljnije elaboriran, tako da se pitanje okvira tog jugoslavenskom federalizma - unutar ili izvan Habsburške Monarhije - namjerno ostavlja otvorenim. Ono što je jasno vidljivo jest da mladi preuzimaju karakteristični fokus jugoslavenstva na hrvatsko-srpske odnose, dok ostali narodi ostaju u drugom planu. Za njih se predviđa program kulturnog zbližavanja i političkog gravitiranja srpsko-hrvatskoj jezgri, koja stoga čini okosnicu jugoslavenskog programa. U tom smislu, jugoslavenstvo mladih ne predstavlja neke značajnije inovacije u samoj ideološkoj matrici, nego njegovu rekontekstualizaciju i reaktualizaciju. Oni ga smještaju u kontekst moderne masovne politike i ističu politički imperativ rješavanja hrvatsko-srpskog spora, iz čega se javlja novi impuls jugoslavenskom programu u okviru hrvatske građanske politike koji će obilježiti prva dva desetljeća 20 . stoljeća. ${ }^{650}$ Jugoslavenstvo mladih tako predstavlja prijelaznu fazu iz izvornog programa šezdesetih godina 19. stoljeća, koji je naglašavao kulturno povezivanje i razvoj moderne građanske nacionalne kulture, u politički radikalnije varijante jugoslavenstva koje se javljaju prije Prvog svjetskog rata, a u kojima se povezuju koncepti organskog razumijevanja nacije i političke neovisnosti. Ključan koncept u

\footnotetext{
${ }^{646}$ Isto, 2.

${ }^{647}$ Isto, 3 .

${ }^{648}$ Isto.

${ }^{649}$ Isto, 3-4.

${ }^{650}$ Usp. Mirjana Gross, „Nacionalne ideje studentske omladine u Hrvatskoj uoči I svjetskog rata“, Historijski zbornik XXI-XXII, 1968-1969, 75-143.
} 
tom smislu upravo je bio onaj socijalizacije narodne politike, čije konzekvence u okviru ideologije mladih nisu još izvedene do svojih krajnjih granica, nego se samo naslućuju u nejasnim i ambivalentnim formulacijama koje smo do sada susretali.

Drugi cilj istaknut u pozivu na pretplatu - kritički i antidogmatski nastup spram svih pojava javnog i društvenog života - u programskom se smislu manifestira u tvrdnji da Novo doba „nije za sada organom nikakoga odredjenoga, organizovanoga i disciplinovanoga smjera, i zato ne izlazi s nikakvim detaljnim programom.“651 Ovdje se dakle ponavlja stajalište izneseno u Hrvatskoj misli da mladež ne smije biti pukim instrumentom stranačke politike te da $\mathrm{u}$ tom smislu i njihov list mora biti otvoren i kritički nastrojen forum za zajedničko obrazovanje i raspravu. Zbog toga se u listu može očekivati raznolikost nazora, ali se od svih suradnika očekuje da svoje tvrdnje obrazlože i argumentiraju. Odbacivanje točno razrađenoga i detaljnog programa na kojemu bi imao biti zasnovan rad mladih ne znači da oni nemaju svoja jasno artikulirana mišljenja te da list nema svoj smjer. Riječ je prije svega o fundamentalnom političkom stavu protiv preranog ulaska mladih u stranačku politiku, a čime se i dodatno odbacuju optužbe za političko-stranačke aspiracije praške skupine. Osim toga, stranice Novog doba otvorene su i članovima starije generacije, koji se s njime slažu. Kao i ranije, praški mladi ne žele da se njihova svojevrsna bespoštedna kritika protumači kao nepomirljivost i objava rata starijoj generaciji, nego kao proces (samo)obrazovanja, kao oblikovanje autonomnih ličnosti i kao razvoj samostalna mišljenja. Tek na temelju toga moguća je istinska suradnja između mlađe i starije generacije, koja ne bi počivala na eksploataciji mladih u svrhu partikularnih interesa stranačkih elita.

Treći pak programski cilj - ukidanje razdora i opreka između naroda i inteligencije $-\mathrm{u}$ proglasu se jasno operacionalizira kao prvi politički zadatak, a to je proširiti narodni preporod na najšire slojeve puka. Općenito govoreći, upravo je ova programska točka ideološki najrazrađenija kada je riječ o praškoj skupini te predstavlja najveći novitet u odnosu na dotadašnju hrvatsku političku tradiciju. Ovdje se najjasnije očituje aproprijacija modernih političkih kretanja te njihova aplikacija na specifične hrvatske prilike. Za praške mlade, hrvatski narodni preporod, baveći se prvenstveno pitanjem jezika i odnosa jezika i nacije, bio je u bitnome smislu ,preporod buržoazije“, dok se tek vrlo slabo dotakao ,puka, onoga puka, koji je baš prava jezgra našega naroda،“652 Prema tome: „Politika narodna pako kročeć dalje ideama preporoda, bila je u jednu ruku nacionalna, u drugu ruku — al to vrlo slabo i nejasno — demokratička u smislu demokracije gradjanske, bogatijega, srednjega razreda, nikako pak

\footnotetext{
651 „Novo doba“, 2.
}

${ }^{652}$ Isto, 4. 
najširih slojeva puka.“653 Političkim je strankama narod tek „stafažom $i$ orudjem“, on je odalečen od političkog života, a iz toga proizlazi sama slabost hrvatskih političkih stranaka. ${ }^{654}$ Njihova se ,idilička ljubav k puku protezala više na njegove pjesme, običaje, nošnju — dok se pritom zaboravljalo na njegovu sve veću materijalnu bijedu i duševnu zaostalost. “655 Stoga je potrebno politiku obogatiti socijalnim elementom, odnosno puk, narodne mase moraju postati bitnim faktorom politike, a ne tek njezinim povremenim oruđem. Drugim riječima, ono što je potrebno jest socijalizacija politike, unošenje socijalnih elemenata u političko rezoniranje i djelovanje, odnosno aproprijacija tekovina moderne masovne politike.

Ipak, ono što je potrebno naglasiti, a to pokušavamo učiniti s naslovom ovoga potpoglavlja, jest da je riječ o reformulaciji građanske nacionalne politike, a ne o radikalnom diskontinuitetu s postojećom političkom praksom. Mladi ne koriste nacionalno pitanje kako bi propagirali određeni socijalni program, nego koriste socijalno pitanje za osnaženje nacionalnog programa. Njihov pojam naroda sintetizira upravo te dvije dimenzije, on povezuje masovnost i nacionalnost, ideju pučke kulture s idejom nacionalne kulture. Narod je za mlade nacionalizirani puk, i to u objektivnom smislu, kao supstrat nacionalnog identiteta $\mathrm{i}$ kulture. Približavanje građanske nacionalne politike tom pučkom izvoru nacionalnog identiteta ne odvija se stoga kao nacionalizacija socijalne baze, nego kao socijalizacija nacionalne politike. Ona podrazumijeva uključivanje tog zamišljenog supstrata u političko razmišljanje i djelovanje nacionalne političke elite. Ovako shvaćen narod stoga i dalje ne postaje subjekt političke prakse, koji je i dalje isključivo nacionalna inteligencija i politička elita, nego njezin konstitutivni element. Naglasak je stoga na transformaciji nacionalne inteligencije i političke elite, a ne samoga naroda. U tome se sastoji fundamentalni koncept političke ideologije mladih na kojemu će se osnivati cjelokupni njihov daljnji politički program i rad.

Preduhitrujući moguće kritike na temelju prethodnog iskustva s Hrvatskom misli, praški mladi ističu kako njihov zahtjev za socijalizacijom politike nikako ne znači podržavanje socijalizma. Zbog toga jasno izlažu da za njih socijalizam nije tek „crveno strašilo“, kao što je za neke već i sama riječ „,socijalno“. Promatrajući socijalizam kritički, ali i otvoreno po uzoru na suvremeni „naučni svijet“, oni u njemu vide i dobre strane, napose u smislu oštre kritike društva i ideje kolektivnog vlasništva, što bi se moglo primijeniti na

\footnotetext{
${ }^{653}$ Isto.

${ }^{654}$ Isto.

${ }^{655}$ Isto.
} 
modernu revitalizaciju seljačke zadruge. ${ }^{656}$ Praški mladi dakle vrlo jasno ističu da nisu ni socijalisti ni anarhisti, iako vide njihove dobre strane koje bi se mogle primijeniti na različitim poljima života. Identičan stav iznose i u vezi sa socijaldemokracijom. Ne priznajući historijski materijalizam, pa tako ni političke konzekvence koje iz njega proizlaze, oni ipak vide opravdanost velikog dijela njihovih zahtjeva, a posebice im priznaju kao zaslugu rad i osvješćivanje znatnog dijela naroda s kojima nitko ranije nije politički radio. Upravo se $\mathrm{u}$ recepciji socijalizma kod mladih jasno manifestira karakter njihova koncepta socijalizacije politike. Aproprijacije moderne masovne politike za koje se zalažu selektiraju se s obzirom na njihovu potencijalnu korist kada je riječ o širenju socijalne baze nacionalne politike. Oni stoga nisu ograničeni konkretnom socijalno-ekonomskom ideologijom, npr. liberalizmom, koji u ovom periodu prolazi krizu te je izrazito nepopularan u javnom diskursu. Kao prenositelji suvremenih kretanja mladi su izraziti eklektici, ali se te divergentne aproprijacije uklapaju u jednu cjelinu čiju logiku diktira ranije raspravljeni koncept naroda i na njemu zasnovane nacionalne politike s izraženom socijalnom komponentom.

Usprkos cjelokupnoj ovoj političkoj i ideološkoj razradi, glavni cilj lista ostaje priprema đaka za politički rad, a nikako politički rad sam, za koji još nemaju temelja. Zbog toga će fokus lista biti na političkoj kritici, pouci i studiju političkih znanosti. Ne pretjerano iznenađujuće, tema kulture, a napose književnosti dolazi poslije svega navedenoga, iako jasno ističu kako i ona ima važne političke implikacije. U prvom se redu ističe skandinavska književnost, koja je zaslužna za visoku ocjenu skandinavskih naroda u svijetu. U tom pogledu najavljivali su osnivanje literarno-znanstvene biblioteke u bližoj budućnosti, kao i prevođenje znamenitih, napose znanstvenih djela. ${ }^{657}$

Karakteristično, tek se na posljednjem mjestu proglasa pojavljuje problematika đaka, njihova obrazovanja i života. I ovdje praški mladi najavljuju oštru kritiku, kao i primjenu pozitivnih aspekata đačkog života drugih naroda. Ako novo doba nastupi u životu mladeži, zaključuju oni, onda će preko nje doći i cijelome narodu. ${ }^{658}$

Ovaj općeniti, zajednički program lista razrađen je potom u tri specifične varijante tekstovima trojice autora: drugi dio članka „Hrvatski ideali“ Stjepana Radića, članak „Srpska

\footnotetext{
${ }^{656}$ Isto, 5 .

${ }^{657}$ Isto, 6 .

${ }^{658}$ Isto.
} 
narodno-crkvena avtonomija“ Svetozara Pribićevića te članak „Položaj in zadača Slovencev“ Ivana Žmavca ${ }^{659}$ (pseudonim Ivan Jaroslavec).

Jednako kao što je prvi dio Radićeva teksta „Hrvatski ideali“ u prvome broju Hrvatske misli slijedio programatski uvodnik te s njime činio idejno-programsku cjelinu, tako i drugi dio ovog njegova teksta, s podnaslovom „Ideali narodno-politički“, ispunjava istu funkciju u prvome broju Novog doba. On elaborira neke od ključnih programatskih točaka uvodnika te ih primjenjuje i konkretizira u pogledu hrvatske politike. Tri su ključne sastavnice svakog političkog ideala za Radića: čovječnost, narodnost i ličnost. One pak upućuju na tri stožerna elementa široko shvaćene ideologije mladih: humanizam, nacionalizam i individualizam. Ako se u tom nizu obznanjuje vrijednosni prioritet, onda se, s druge strane, njegova praktična izvedba odvija u obrnutu slijedu: razvojem i (samo)usavršavanjem pojedinca stvara se aktivna nacionalna inteligencija koja treba raditi na prosvjećivanju naroda, a to pak pridonosi ukupnom napretku ljudskoga roda. Ova jednostavna formula zapravo je temeljna potka ideologije praške skupine mladih, najjasnije izražena u tekstovima Stjepana Radića kao jedne od ključnih ličnosti pokreta.

Još snažnije i dublje nego ranije Radić kritizira i odbacuje glavne smjerove hrvatske političke tradicije. Umjesto oportunističke i za hrvatske interese pogubne reciklaže starog staleškog ideala „osamstogodišnjeg bratimstva“ Hrvatske i Ugarske, Radić postavlja moderni narodno-politički ideal „bratimstva s narodom madžarskim.“660 Njegovo oživotvorenje, međutim, u tadašnjim uvjetima nije moguće jer

“dok je madžarska državna idea Moloh, komu se žrtvuju čitavi narodi — a imao bi se žrtvovati i hrvatski — dok je madžarska nacionalna politika u svojoj neobuzdanoj mržnji na Slavene samo batina njemačkomu 'Drang nach Osten', dok je socijalna politika madžarska, politika buržoaskoga liberalizma, židovskega velekapitala, pod kojim gine radnik, i veleposjedničkog isisavanja, proti kojemu se očajno bori siromašni alfeldski seljak — dakle politika globljenja vlastitoga puka: — dotle o takovom bratimstvu s Madžarima ne može u hrvatskoj narodnoj politici biti ni govora." 661

U ovome su citatu okupljene gotovo sve negativne slike koje su sačinjavale političku imagologiju praške skupine mladih. Mađarski nacionalizam izjednačen je s njemačkim imperijalizmom, buržoaskim liberalizmom, židovskim kapitalom i veleposjedničkim

\footnotetext{
${ }^{659}$ Ivan Žmavc (1871-1956), slovenski sociolog, filozof i knjižničar. Doktorirao filozofiju i prirodoslovlje u Pragu, gdje potom radi kao knjižničar u Sveučilišnoj knjižnici. Bio je jedan od osnivača Čehoslovačkojugoslavenske lige i redoviti član Slavenskog instituta.

${ }^{660}$ Stjepan Radić, „Hrvatski ideali. II. Ideali narodno politički“, Isto, 7.

${ }^{661}$ Isto.
} 
rentijerstvom. Svi su oni zapravo projekti izrabljivačke elite, nasuprot kojih se postavlja siromašni i podjarmljeni puk. Analitičko pojednostavljivanje, koje primjerice ne razlikuje politiku njemačke buržoazije i ugarskog veleposjedničkog plemstva, zajedno s bazičnom opozicijom elite i naroda, upućuje na populističku notu u Radićevu razmišljanju. S druge strane, Radić je bio snažni branitelj ruskog carizma, jer je u njemu vidio organski izraz ruske narodne duše i istinsku narodnu vlast, što ga je dovelo u sukob s ostatkom pokreta. ${ }^{662}$ Osim toga, ovaj citat ilustrira izrazito negativan odnos praške skupine mladih prema mađarskoj kulturi i politici. O njoj se piše gotovo isključivo u kritičkom, pa čak i šovinističkom smislu, a uz to je karakteristično da mladi na svim poljima - naravno, uz pojedinačne iznimke zaobilaze aproprijacije mađarskih intelektualnih strujanja, čak i onih modernističkih. To također potvrđuje da je nacionalna logika, bilo svjesno ili nesvjesno, utemeljivala i strategiju stranih aproprijacija.

Ništa nije manje odlučna niti Radićeva kritika starčevićanstva, koje smatra materijalizmom najgore vrste jer se brine samo za prostor i zemlju, a nije ga briga za to kako narod živi. Starčević je u tom smislu samo "učenik madžarske političke škole", a njegova je filozofija "Hrvatima i Srbima više škodjela od dvoličnosti bečke, od megalomanije peštanske i od rastrovanosti carigradske.“663 I mađaroni i pravaši stoga su za Radića samo „dva rukava madžarske politike“ koja je „u Pešti imala u prvom redu biti protuaustrijska, a u Zagrebu protusrpska, posvuda pak protuslavenska.“664 Iako umjerenije, on kritički piše i o ilirizmu i jugoslavenstvu. Prvi je podbacio jer se puka „nije ni kulturno dirnuo“, dok jugoslavenstvo čak nije zahvatilo niti većinu inteligencije. ${ }^{665}$

Sve su te političke tradicije u većoj ili manjoj mjeri preživljene. Kao službena predstavnica hrvatske politike, koalirana opozicija stoga nema „narodnoga političkog ideala“, a do prošlogodišnjih izbora nije imala ni programa. Pomankanje narodnih političkih ideala ne proizlazi iz njihove pokvarenosti ili dvoličnosti, nego iz stvarne nemogućnosti da razumiju i artikuliraju takav tip politike. Oni to ne mogu ,jer je u njima svjema više stranačkih tradicija, historije i diplomacije, nego li poznavanja naroda, njegovih zbiljskih potreba i njegove prave snage. “666 Zbog toga čak i oni među njima koji su demokratski nastrojeni ne znaju razgovarati s pukom, a kamoli za njega razumljivo pisati i s njime živjeti. Rezultat je to pogrešne političke pedagogije koja polazi od činjenice da narod nema svojih uvjerenja i ideala, nego da

\footnotetext{
${ }^{662}$ Biondich, nav. dj., 52.

663 Radić, ,Hrvatski ideali“‘, Isto, 7-8.

664 Isto.

665 Isto.

666 Isto.
} 
mu političke elite trebaju te ideale stvoriti. Mnijenje je to koje proizlazi iz fundamentalne društvene diskrepancije koja dijeli narod i elitu, odnosno „puk“ i „gospodu“. Zbog toga, kao prvi politički ideal Radić navodi „narodno jedinstvo društveno“: „Iz toga unutrašnjega narodnoga socijalnoga jedinstva razvit će se istom ravnopravnost svih stališa, harmonija svih socijalnih narodnih sila. Iz toga i radi toga jedinstva namiće se sama po sebi ustavna reforma, u prvom redu reforma izbornoga reda.“667 Kao prvi politički zahtjev koji proizlazi iz ovog temeljnog političkog načela navodi se dakle proširenje prava glasa. Rad na tom zahtjevu nužno podrazumijeva približavanje političke elite širim slojevima naroda, jer je to direktni rad za njihovu inkluziju u politički aktivan narod. Radićevim riječima: „Ne radi se naime o tome, da se narod pogospodi, nego da se gospoda ponarode. ${ }^{\text {(668 }}$

U drugome dijelu teksta, objavljenom u drugom broju Novoga doba, Radić dalje razrađuje politički program praške skupine mladih. Idealizirajući narod i mitologizirajući njegovu prošlost, polazi od pretpostavke da narodna svijest o „starim pravicama“ podrazumijeva svijest o jednakosti svih ljudi te da je ona bila pripadna izvornoj slavenskoj narodnoj zajednici. Tu je svijest iskrivila zapadna kultura koja ih je „nadarila kmetstvom“, dok je produkt „naprednog devetnaestog vijeka“ stvaranje „nove vrste vlastele: školane gospode“. ${ }^{669}$ Sada je pak potrebno da se ta školovana gospoda vrati izvornim narodnim principima i narodnom razumijevanju „starih pravica“, koje sačinjavaju istinsko historijsko pravo. Moderni politički zahtjev za proširenjem prava glasa Radić tako u ideološkom smislu spaja s panslavističkim toposom izvorne nepokvarenosti Slavena i njihove misije moralnog preporoda dekadentna Zapada. Riječ je dakle o specifičnoj aproprijaciji europskih modernističkih kretanja, odnosno o specifičnoj varijanti utemeljenja moderne masovne politike. U svijetu treba tražiti misli i razvijati umne sposobnosti, ali političke ideje i direktivu treba utemeljiti u narodu. ${ }^{670}$

To je polazište za artikulaciju i drugog narodno-političkog ideala. S obzirom na to da se neposredni svijet života, a time onda u velikoj mjeri i politička svijest naroda kreće u okviru zadruge, sela i općine, kao drugi ključan politički zahtjev nameće se reforma samouprave, odnosno težnja za „,narodnom gospodom, za narodnom upravom“, koja počiva na drugom narodno-političkom idealu: ,idealu narodnoga zakonodavstva i narodne samouprave“. ${ }^{671}$ To ipak ne znači da bi narod trebao sam preuzeti vlast i upravljati samim

\footnotetext{
667 Isto, 9.

${ }^{668}$ Isto, 10.

${ }^{669}$ Isto, br. 2, 53.

${ }^{670}$ Isto, 57.

${ }^{671}$ Isto, 55.
} 
sobom, jer on za to nema potrebnih znanja i sposobnosti. Politička operacionalizacija tog zahtjeva podrazumijevala bi da nacionalno orijentirana elita (,narodna gospoda“) preuzme ključne lokalne upravne pozicije. I ovdje se jasno vidi da je koncept socijalizacije politike usmjeren prvenstveno na nacionalnu politiku kao dinamični politički faktor i subjekt, dok je narod shvaćen kao njezin statični i nepromjenjivi supstrat.

Naposljetku, kao treći ideal narodne politike hrvatske i srpske, koji se nadograđuje na prva dva, Radić navodi narodnu vladu. ${ }^{672}$ Ovaj cilj predstavlja vrhunac iznesenog stupnjevitog sustava koji upućuje na strategiju političkog djelovanja: od „sitnoga rada“ u narodu, koji služi i za podizanje narodne svijesti, ali i za ,ponarođenje“ gospode, preko borbe za proširenje prava glasa i narodnu samoupravu, pa sve do cilja postavljanja narodne vlade. To je ukratko sukus konkretne političke operacionalizacije općenitih programatskih točaka mladih koju predlaže Radić.

Radić je u okviru pokreta mladih ujedno i predvodnik i specifična figura koja u mnogo čemu odskače od ostalih aktera. U literaturi o njemu često se spominje osjećaj nacionalne misije, iz kojega je proizlazila težnja za osobnim vodstvom, ali i eklektičnost u biranju sredstava za postizanje ciljeva. ${ }^{673}$ Ove su ga kvalitete ujedno pogurale na mjesto vođe i ideologa praške skupine, ali i konfliktne figure koja je često izazivala prijepore i neslaganja. Fascinaciju Radićevom karizmom i entuzijazmom kod ostalih je aktera pokreta postepeno počela zamijenjivati svijest o njegovoj nagloj naravi, netaktičnosti i čestim promjenama mišljenja koje nisu uvijek pratile ideološki konzistentnu liniju. Zbog toga je njegov utjecaj na razvoj pokreta izrazito ambivalentan. S jedne strane on je zaslužan za njegov organizacijski polet i snažan prodor u javnost i među mladima, ali s druge je odgovoran za eklektično i ponekad nekonzistentno prenošenje naprednjačkih ideja te za skepsu i otklon od zapadnih modernističkih strujanja koja su bila u nesuglasju s njegovim tradicionalnim pučkim, kršćanskim, pa i patrijarhalnim vrijednostima. Dok većina pokreta mladih ideje traži u zapadnoeuropskim i srednjoeuropskim strujanjima, Radić je pod najsnažnijim utjecajem ruske političke i socijalne misli, napose narodnjačke. ${ }^{674}$ Upravo će ideološko stasanje ostalih aktera u okviru naprednjaštva i njihovo postepeno emancipiranje od Radićeva utjecaja dovesti do kasnijeg raskola među mladima i formiranja dvije distinktivne političke grupacije.

\footnotetext{
672 Isto, 57.

${ }^{673}$ Biondich, nav. dj., 42; Šidak, „Idejno sazrijevanje“, 388. O Radiću se dakako pisalo vrlo mnogo. Osim navedenih, za klasičan biografski prikaz v. Perić, nav. dj. Bogdan Krizman je svoje izdanje Radićeve korespondencije popratio obimnom uvodnom studijom „Stjepan Radić-život-misao-djelo“, nav. dj., 25-70. O Radićevim progonima pisala je Bosiljka Janjatović, Stjepan Radić: progoni, zatvori, suđenja, ubojstvo: 1889.1928., Zagreb, 2003.

${ }^{674}$ Lovrenčić, nav. dj., 84.
} 
Fundamentalna ideološka napetost među njima zapravo je već prisutna u unutrašnjim ideološkim napetostima praške skupine između modernističkog naprednjaštva i konzervativnog agrarizma, koje u ideološki nerazvijenim oblicima pratimo na stranicama Hrvatske misli i Novog doba.

Drugi dio konkretnije razrade općih programatskih načela Novog doba koji se tiče srpske politike u Austro-Ugarskoj, napose Hrvatskoj, sadržan je u tekstu „Srpska narodnocrkvena avtonomija“ Svetozara Pribićevića. U njemu je iznesena kritika srpske politike u Ugarskoj, koja počiva gotovo isključivo na narodno-crkvenoj autonomiji. Srpske elite grade svoju politiku na tezi da je politički otpor mađarskoj prevlasti uzaludan, te da je pomaganje hrvatskih opozicijskih nastojanja zapravo podrška izgradnji velike Hrvatske. Pribićević u tome vidi regresiju srpskog pitanja u Austro-Ugarskoj koje je prije 1868. godine bilo državopravno, nakon 1868. je postalo administrativno, a u najnovije je doba tek pitanje narodno-crkvene autonomije. Zbog jedinstvena apsolutiziranja narodno-crkvene autonomije, kod Srba zapravo nema političkih stranaka. Zato što su priznale politički i državnopravni status quo, njih ništa ne dijeli od vladajućih stranaka - Narodne stranke u Hrvatskoj i Liberalne stranke u Ugarskoj. ${ }^{675}$ Zbog toga ne čudi što je narod počeo gubiti vjeru u svoju snagu. Kao što Radić kritizira hrvatsku inteligenciju, Pribićević konstatira da je srpska inteligencija napustila narod, zbog čega je ovaj postao madžaronskim izbornicima. ${ }^{676}$ Stvarni politički rad zamijenjen je pukim formalizmom i ispraznom deklamacijom: „Stara srpska patrijarhalnost ideal je rodoljuba, gusle javorove i sveto pravoslavlje isključivo i iscrpivo oružje, za krst časni i slobodu zlatnu njihova lozinka, uvjerenje zamjenjuju s oduševljenjem, formalizam im je umjesto realnog rada, nema tu pojma naroda u višem etičnom smislu, $u$ smislu modemom. ${ }^{\text {6677 }}$ Nasuprot takvoj politici Pribićević dakako ističe program Narodne misli kao temelj za izgradnju nove, moderne srpske politike u Hrvatskoj i Ugarskoj.

Naposljetku, slovenski program Novog doba izložen je u tekstu „Položaj in zadača Slovencev“ Ivana Žmavca. I optimisti i pesimisti glede ljudskog napretka, piše Žmavec, priznaju da je novo doba donijelo nove potrebe i nova pitanja. Najvažnija su socijalno i nacionalno pitanje, koja su doduše usko isprepletena. Naročito je to tako kod Slovenaca, jer je u oba slučaja izvor problema u tuđinskoj prevlasti. Njihova je nacionalna potlačenost rezultat socijalne inferiornosti, perpetuirane nacionalnom dominacijom Nijemaca. To je rezultat duga povijesnog razvoja, zbog čega nije moguće modernu slovensku politiku temeljiti na konceptu

\footnotetext{
${ }^{675}$ Svetozar Pribićević, ,Srpska narodno-crkvena avtonomija“, Isto, 14.

${ }^{676}$ Isto.

${ }^{677}$ Isto, 15.
} 
povijesnog prava. Ne samo to, već je i samo nacionalno slovensko ime, pa dijelom i zasebna nacionalna svijest rezultat ovakva povijesnog razvoja, koje je teklo u smjeru izolacije Slovenaca od slavenskog juga. Zbog toga, zaključuje Žmavec, „ako smo torej socijalni političarji, smo to zaradi tega, ker smo narodnjaki, Slovenci.“678

U istome tonu kao Radić i Pribićević, i Žmavec kao ključni problem vidi odnarođenje inteligencije, konkretno njezino germaniziranje. I on daje posve idealiziranu sliku ,priprostog ljudstva“ koje je „pridno, delavno, ukaželno, plemenito, zdravo in slovensko“. ${ }^{679}$ „Naše ljudstvo nam je v ponos,“ zaključuje stoga Žmavec, „to je temelj, na katerem nam je staviti bodočnost. Nas izobražence je nemška kultura odtujila našemu narodu, nam se treba vrniti nazaj - k Slovenstvu. “680 Potrebno je stoga revitalizirati nacionalnu kulturu spajajući taj „prirodni“, narodni kulturni supstrat s modernim tekovinama i potrebama. Drugim riječima, treba ići „,k narodnemu programu na trdni znanstveni podlagi.“681 $\mathrm{S}$ obzirom na temeljnu isprepletenost nacionalnog i socijalnog pitanja, prva je zadaća materijalno uzdizanje naroda. Gospodarska moć i neovisnost preduvjeti su za nacionalnu slobodu. Tek na zdravu socijalnom temelju može se graditi moralna i duhovna snaga naroda, odnosno njen nacionalno-kulturni izraz. Ipak, kada je riječ o nužnim protagonistima te promjene - inteligenciji - redoslijed je obrnut, jer se oni prvo moraju moralno preporoditi i vratiti nacionalnom programu kako bi mogli provoditi politiku socijalnoga i ekonomskoga osnaživanja naroda. Stoga su pesimizam i skepticizam u pogledu znanosti i napretka neprihvatljivi jer se na njima ne može graditi pozitivna, realna i radišna politička praksa. Potrebno je usvojiti „svetovnega naziranja na podlagi prirodnih ved in znanstvene etike. ${ }^{6682}$ Naposljetku, dakako, Žmavec zaključuje da slovenski intelektualci moraju posvetiti više pažnje učenju hrvatskog ili srpskog, te ruskog jezika jer ,pač zadnji čas je, da se Slovenci jasno zavedamo, da ne spadamo $k$ Nemčiji, temveč k Slovanstvu, vsaj k slovanskemu balkanskemu polotoku!“683

Sva tri teksta dijele osnovne teorijske premise, ali ujedno manifestiraju i razlike $\mathrm{u}$ naglascima specifične za politički kontekst koji analiziraju. Ključna je zajednička premisa povezivanje socijalnog i nacionalnog, $\mathrm{i}$ to $\mathrm{kroz}$ ideju preporoda nacionalne političke elite $\mathrm{i}$ inteligencije. Njihova je socijalizacija ujedno i nacionalizacija, jer se nacija pod pojmom naroda utemeljuje u širokim društvenim slojevima i njihovoj zamišljenoj autohtonoj kulturi. Zbog toga se, također, nacionalno pitanje povezuje sa socijalnim. Njegovo rješenje nije više

\footnotetext{
${ }^{678}$ Ivan Jaroslavec, „Položaj in zadača Slovencev“, Isto, 18.

${ }^{679}$ Isto, 20.

${ }^{680}$ Isto.

${ }^{681}$ Isto, 21.

682 Isto.

${ }^{683}$ Isto, 22.
} 
problem priznavanja povijesnih prava, nego podizanja ekonomske i društvene snage naroda kao osnove za otpor stranom prodoru. Razlike se manifestiraju u specifičnim kontekstima hrvatske, srpske $\mathrm{i}$ slovenske politike, $\mathrm{i}$ to napose $\mathrm{u}$ odnosu prema percipiranom narodnom neprijatelju. U slučaju slovenske politike, socijalizacija nacionalne politike shvaća se kao nužni preduvjet otporu njemačkom prodoru i germanizaciji nacionalne elite. U hrvatskom i srpskom slučaju mnogo je veći naglasak na kritici same nacionalne političke elite i inteligencije koja, doduše, nije odnarođena u smislu gubitka nacionalnog identiteta, ali je odalečena od naroda i u kulturnom i u ekonomskom pogledu, a sve pod utjecajem dominacije mađaronske politike kao okosnice mađarskog nacionalizma i njemačkog imperijalizma.

Jedan od temeljnih lajtmotiva u tekstovima Novoga doba upravo je snažna dihotomija između širokih narodnih slojeva, odnosno puka i društvene elite, napose inteligencije. Takav je smjer već bio naznačen u Hrvatskoj misli, ali on sada dobiva gotovo središnje mjesto. Narod ili puk pogotovo je idealiziran u moralnom smislu, jer je čuvar pravih društvenih vrijednosti poštenja i pravednosti koje počivaju na neiskvarenu kršćanskom osjećaju. Nasuprot tome, „odnarođenje“ inteligencije upravo se očituje relativiziranjem pravih vrijednosti. Narodni je karakter izvoran, čvrst i postojan, a onaj odnarođene inteligencije umjetan, filistarski, nestalan i kolebljiv: „Mi smo 'gospoda' svi veći ili manji — nagodbenjaci. Nikada muževne, odrešite riječi, nikada jasnoga, odredjenoga zahtijeva. Mi smo praktični..., a narod je naš — pošten... “684 Za „male“ je pak narode posebno važno da njihov politički i društveni život ne počiva na materijalnoj sili, nego na moralnoj snazi. Zbog toga je ključ nove narodne politike $u$,ponarođenju“ inteligencije, odnosno u njezinu povratku „pravim“, ,istinskim“ narodnim vrijednostima.

U tom je pogledu bio iznimno važan utjecaj ideje Zbornika za narodni život i običaje južnih Slavena, odnosno Osnove za sabiranje i proučavanje građe o narodnom životu Antuna Radića. Općenito se može reći da je Novo doba vrhunac utjecaja braće Radić na pokret mladih, prije svega Stjepana, koji je napisao veliki dio tekstova za list, a onda indirektno i njegova brata Antuna. Na temelju tekstova i stajališta Antuna Radića, Ivan Lorković razradio je za Novo doba koncept odnosa naroda, inteligencije i politike. Temeljni ideološki supstrat ovog koncepta je esencijaliziranje naroda. Narod nije politički princip niti princip koji je osmislila inteligencija, on je duševni princip. Zbog toga, politički život i život inteligencije nisu nužno izraz narodnog života. Oni mogu, ali i ne moraju biti u skladu s narodnim životom, kao „ekvivalentom narodne duše u spoljašnjem svijetu.“ ${ }^{685}$ Kako su njihovi principi posve

\footnotetext{
684 „Moralna snaga“, Isto, br. 2, 50.

${ }^{685}$ Ivan Lorković, „Veliko djelo“, Isto, br. 3-4, 101.
} 
različiti, njihov nesklad ne znači nužno uništenje narodne duše i narodnog života, čija snaga izvire iz njih samih. Inteligencija i politika mogu se uskladiti s narodnim životom i time postati narodna inteligencija i narodna politika, ili mogu ostati „odnarođeni“, u kojem slučaju se ovaj dualistički shvaćen život nastavlja u staleškoj disharmoniji. Socijalizacija moderne masovne politike dakle ide ruku pod ruku s esencijalizacijom nacionalnog, a usvajanje modernih političkih metoda - socijalnog i ekonomskog rada među masama - s ideološkim učvršćenjem romantičarskog razumijevanja narodne duše. U daljnjoj konkretizaciji ovog fundamentalnog koncepta, narodna duša se shvaća kao slavenska duša. Upotrebom panslavističkog toposa ova „slavenska psiha narodna“ pojavljuje se kao mlada i snažna, te njoj pripada (eshatološka) budućnost. ${ }^{686}$ Budući da su široki slojevi, odnosno radništvo i seljaštvo ,jedini nosilac prave narodne duše i žive narodne snage“, narodna politika inteligencije može se voditi jedino kao ,unutrašnji rad oko kulturnih socijalnih i ekonomnih problema“, odnosno ključna je socijalna i gospodarska organizacija. ${ }^{687}$ Kao prvi korak, međutim, Lorković se slaže s Antunom Radićem da bi đaci morali imati važnu ulogu u prikupljanju podataka za Zbornik. Oni bi se tako upoznali sa životom, potrebama i težnjama naroda, a ujedno bi pomogli razvoju jedne nove, istinske narodne znanosti na kojoj bi trebala ubuduće počivati svaka narodna politika.

U posljednjem trobroju Novog doba kao dvije temeljne ideje svoga pokreta praški mladi ističu puk i slavenstvo. ${ }^{688} \mathrm{U}$ puku su, tvrde oni, sadržana sva načela unutrašnje, a u slavenstvu međunarodne politike. Oni se, međutim, ograđuju od onog slavenstva koje se ,po uzoru centralizacije pruske, francuske i engleske“" oduševljavalo zajedničkim, konstruiranim književnim jezikom, pa čak i zajedničkom državnom vladom. ${ }^{69}$ Umjesto toga, slavenstvo je za prašku skupinu kulturni, pa čak i duševni princip, a samostalni literarni i politički razvoj slavenskih naroda zalog i jamstvo slobodnoga razvitka misli i svestranoga napretka. Oni dakle odbacuju panslavizam kao politički program, a u smislu kulturnog programa kritiziraju njegovu unitarističku varijantu koja bi stremila stapanju slavenskih jezika i kultura. Riječ je zapravo o ekstenziji njihova razumijevanja jugoslavenstva, u okviru kojega također odbacuju kulturni i politički unitarizam, ali kao (federalistički) politički program on ipak, kao što smo vidjeli, ostaje otvorena mogućnost. Kao i u svim programatskim tekstovima Novog doba, i ovdje dominira mišljenje Stjepana Radića. U pismu Šimi Mazzuri uoči slavenskog novinarskog sastanka u Pragu on je detaljno izložio svoje poglede na ovu temu. Ogromna

\footnotetext{
${ }^{686}$ Isto, 101.

${ }^{687}$ Isto, 104.

688 „Pedeset godina našega narodnoga naprezanja“, Isto, br. 8-10, 300.

${ }^{689}$ Isto, 298.
} 
većina slavenskih naroda, tvrdi Radić, osjeća težnju za zbliženjem i za zajedničkim radom. ${ }^{690}$ Problem je, međutim, u tome što se slavenski intelektualci međusobno ne razumiju jer rijetko kad dolaze u dodir s drugim slavenskim jezicima. I separatizam, i ideja o zajedničkom slavenskom jeziku - napose ruskome - kao odgovori na taj problem nisu dobri. Radić predlaže inicijativu za zbližavanje dviju velikih grupa slavenskih jezika: južnih i sjevernih. Svi južni Slaveni trebali bi usvojiti sve južnoslavenske dijalekte, a sjeverni svoje jezike, primjerice češki, poljski i rusinski. Na taj bi način svakome južnome Slavenu bilo dovoljno da nauči jedan sjeverni slavenski jezik, i sporazumijevanje bi bilo moguće, kao i obratno. Umjesto šest grupa jezika, de facto bi postojale dvije. „U kratko“, zaključuje Radić, „umjesto teorije o književnom zajedničkom jeziku, praksa o razumijevanju najbližih slav[enskih] jezika.“691 Usprkos tome, Radić nije bio protivnik ruskog samodržavlja. Za njega je ono „patriarhalna forma vladavine, koju hoće sav ruski puk. To je slavenski 'demokratski imperializam Napoleona'.“692 Za njega problem ruske politike nije bio na unutrašnjem, nego na vanjskom planu. Upravo će ovo Radićevo stajalište prema ruskom samodržavlju izazvati velike trzavice i njegov sukob s ostatkom praške skupine mladih.

Puk kao ključna ideja pokreta dobiva svoju operacionalizaciju u Radićevoj tezi da slavenska politika u Austro-Ugarskoj mora biti fokusirana na borbu za izbornu reformu. Kao većina u Monarhiji, slavenski narodi morali bi zajednički zahtijevati ravnopravnost izbornoga reda i izbornu slobodu. ${ }^{693}$ I zahtjevi za južnoslavensku politiku neovisno o državnim granicama jasno su konkretizirani na stranicama Novog doba. Za Slovence to je ,priznanje narodnoga slovenskoga područja“; za Hrvate „narodna banska vlada“ s uključenom Dalmacijom, Rijekom i Međimurjem; za vojvođanske Srbe „narodna crkvena avtonomija izvan svake sumnje“; za Srbe u Kraljevini Srbiji „unutrašnja sredjenost i prvenstvo u vanjskoj narodnoj politici“; za Bugare „,narodna slavenska dinastija“; a u Makedoniji „narodna slavenska škola““ ${ }^{694}$ Dakako, osnovni ,aktuelno-politički program rada“ temelji se na radu među pukom: protiv oskudice, protiv lihvara, protiv „plemenskih“ sporova kojih je puna inteligencija „koja se napila duha židovsko-njemačkoga“ i „koja se nadojila mlijekom madžarsko-turskim“. 695

Oblikovanje novog, modernog intelektualca u središtu je djelovanja svih skupina modernističkog pokreta mladih. U slučaju praške skupine, taj novi intelektualac morao bi biti

\footnotetext{
690 „Stjepan Radić - Šimi Mazzuri, Pariz, 21. V. 1898.“, u: Krizman, nav. dj., 315.

${ }^{691}$ Isto, 316.

692 Isto, 317.

${ }^{693}$ Isto, 317.

${ }^{694}$ „Pedeset godina našega narodnoga naprezanja“, 299-300.

695 Isto.
} 
narodni političar. Ideal narodnog političara kao cilj pripreme mladih detaljno je razradio Stjepan Radić u seriji tekstova „O pripravi za rad u narodnoj politici“. S obzirom na to da Radić politiku općenito definira kao „sposobnost upotrebljavati na opće dobro poznavanje socijalnih sila“, socijalna dimenzija dobiva jedno od ključnih mjesta u pripremi za budući politički rad. ${ }^{696}$ Međutim, njega zanima isključivo narodna politika, koju definira kao „,nastojanje oživotvoriti narodne ideale radom politički karakternih i politički obrazovanih rodoljuba.“697 S obzirom na to da je „,narodne ideale“ već izložio u svojim drugim programatskim tekstovima, fokusira se na određivanje značajki tih rodoljuba.

Hrvatskoj politici, prema Radiću, nije manjkalo rodoljublja, ali je zato itekako bolovala od nedostatka obrazovanja i političkog karaktera, koji se očituje u vjernosti političkim idealima i sredstvima za političku borbu. Tri su ključne sastavnice političkog karaktera: „dobro srce“, „zdrava pamet“ i ,željezna volja““ ${ }^{698}$ Problem je dotadašnje hrvatske politike što su u njoj dominirali jednostrani karakteri, ljudi dobrih namjera bez dobrog političkog rezoniranja ili volje; ljudi jake volje, ali loših namjera; ili pak pametni pojedinci bez osobita uvjerenja. U Radićevu konceptu političkog karaktera narodnog političara njegovo „dobro srce“ izjednačeno je s kršćanskom orijentacijom. Zbog pretpostavke fundamentalnog kršćanskog karaktera samog naroda, jedino kršćanin može biti pravi narodni političar. Kršćanska ljubav koja je primarno usmjerena prema vlastitom narodu nije u opreci s univerzalizmom Kristova učenja. Isus nije pozvao na ljubav prema cijelom čovječanstvu, nego na ljubav prema bližnjemu, a narodnom je političaru bližnji upravo narod. Zbog toga narodni političar mora biti „kršćanin narodni“, a „kršćanin i narodnjak, nacijonalac — došljedno je i demokrat, pučanin.“6999 Iako su ovdje jasno vidljivi elementi europskog kršćanskog socijalizma te napose socijalnog nauka Katoličke crkve, primjerice u tvrdnji da kršćanstvo nije ni skup dogama, ni privatna stvar, nego da su u kršćanstvu velika načela socijalnoga reda i civilizacije, Radićevu poziciju ne treba brkati s modernim inačicama klerikalizma, pa niti s kršćansko-socijalnim pokretom. Njegov ideološki temelj nije vjerski, nego je vjera bitan element esencijalistički shvaćenoga „naroda“ koji je pravi supstrat njegove političke ideologije. Zbog toga on kaže da političari koji nisu kršćani ne mogu biti ni Hrvati, Srbi ili Slovenci. Oni samo mogu zapadnim liberalnim i radikalnim doktrinama dati narodni okvir, ali nikad neće moći stvoriti pravi narodni program niti ga provesti u djelo. Kršćanstvo je važan dio narodne politike zato što je ono bitan element narodne kulture, narodnog života i

\footnotetext{
${ }^{696}$ Stjepan Radić, „O pripravi za rad u narodnoj politici“, Isto, br. 3-4, 125.

${ }^{697}$ Isto.

${ }^{698}$ Isto, br. 6-7, 271.

${ }^{699}$ Isto, 272.
} 
običaja, i u tom smislu je nepohodno kao ulaznica narodnog političara među narodne mase. Treba spomenuti da je iz ovoga proizlazio i Radićev antisemitizam, koji je ostao zanemaren u okviru hrvatske historiografije. ${ }^{700}$

S druge strane, politički karakter nije dovoljan za oblikovanje cjelovita narodnog političara. Njemu je potrebno i temeljito političko obrazovanje, koje ne treba brkati s formalnim obrazovanjem u nečijoj struci. To što je netko dobar advokat ili filolog, pa je uz to i pošten, ne znači da će biti dobar narodni političar. Dva su ključna elementa političkog obrazovanja narodnog političara, on mora ujedno biti narodan i svjetski čovjek. Narodna dimenzija političkog obrazovanja za Radića je usko vezana uza socijalni aspekt, dok je svjetska povezana sa svestranošću. Temelj je dakako narodni, ali ne u smislu spekulativnih predodžbi ili povijesnih konstrukcija, nego u poznavanju narodne sociologije i ekonomije. ${ }^{701}$ Tek na tom sigurnom temelju može se nadograđivati svestranim svjetskim znanjem. U protivnom, političar riskira da se uobrazi i nastupa s visoka prema svojem narodu koji zapravo ne poznaje.

Nadalje, osim moralne i intelektualne snage, njemu su potrebne socijalna i ekonomska snaga. Narodni političar morao bi biti društveno utjecajan i ugledan te ekonomski neovisan. Onaj tko ovisi o vlasti za svoju egzistenciju stoga nikad ne može u potpunosti biti pravi narodni političar. Ako bi se svi ovi kriteriji primijenili na ocjenu hrvatske politike, jasno je da bi ona bila porazna. Zbog toga nije čudno što se ona ne može prilagoditi novom dobu, novim političkim potrebama i metodama. Umjesto da shvati da je ključ moderne politike u stjecanju masovne podrške realnim političkim radom, ona i dalje ustraje na klasičnoj građanskoj politici koja je fokusirana na svoje prvake, dok širi slojevi služe samo za izbornu agitaciju i povremeno sakupljanje novčanih sredstava: „Umjesto da ih uči, da svaki vrijedi samo na svom pravom mjestu, ta je politika priredjivala poklonstva, hodočašća i „skupštine“. Mješte

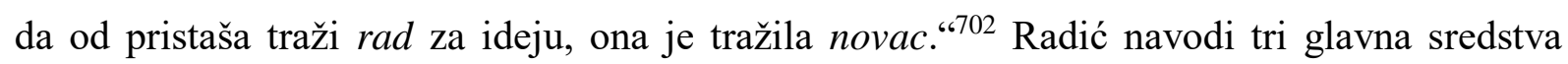
političke borbe: pasivnost ili čekanje, oportunizam ili nadmudrivanje i radikalizam ili zahtijevanje. Pasivnost se protivi samome pojmu narodne politike jer narodni političar mora biti uvijek aktivan. Oportunizam također nije poželjan u narodnoj politici jer se zapravo svodi na pogađanje, a „kad se radi o živom narodu, tu nema pogadjanja.“703 Preostaje stoga samo radikalizam, koji je za Radića jedini način narodne politike. Međutim, on za njega ne znači neumjerenost $\mathrm{u}$ zahtjevima ili besplodnu buku, nego odlučnost i ustrajnost u razumnim

\footnotetext{
${ }^{700}$ Biondich, nav. dj., 52-53.

${ }^{701}$ Isto, br. 8-10, 318-319.

${ }^{702}$ Isto, br. 3-4, 129.

${ }^{703}$ Isto, br. 6-7, 274.
} 
zahtjevima. Naravno, glavni imperativ za narodnog političara je njegovo ispravno shvaćanje narodnog jedinstva, a to je upravo ono shvaćanje koje je prisutno u samom narodu. Pod hrvatskim, slovenskim i srpskim imenom jednoga te istoga naroda ,vodi se u ovaj čas očajna borba protiv prodiranja njemačkoga u narodno tijelo naše, protiv tlačenja madžarskoga usprkos najočitijim uzakonjenim pravima našim; protiv pohlepe i nadutosti talijanske.“704 Zbog toga je potrebno da narodni političari budu s pukom ,jedno i u svaćanju narodnoga jedinstva“, kao što su s njim ,jedno u kršćanstvu“, pa će tako biti nepobjedivi. ${ }^{705}$

Treba, međutim, napomenuti da redakcija lista nije bila pretjerano zadovoljna ovim Radićevim pristupom. Za praške je mlade on bio odveć spekulativan, jer Radić uzima neke narodne stihove i izreke, na osnovu kojih izvodi svoje zaključke. Živan Bertić mu otvoreno predbacuje da idealizira narod. ${ }^{706}$ Ovaj raskorak u odnosu prema narodu, napose seljaštvu, pri čemu će Radić ustrajati u njegovu idealiziranju i ideji da se u njemu nalazi apsolutno izvorište svake politike, dok će većina praške skupine zauzeti pragmatičniji pristup bliži strujanjima moderne masovne politike $\mathrm{u}$ kojem moderni političar nastupa ujedno i kao vođa i kao odgojitelj narodnih masa, bit će upravo jedan od najvažnijih uzroka njihova kasnijeg razlaza.

Uz političku, socijalna problematika doista dominira stranicama Novoga doba. Brojni se tekstovi dotiču raznih dimenzija socijalnog pitanja na prijelomu stoljeća: „O socijalnom pitanju (po E. de Laveley-u)“, „Zemljoradničke zadruge u Srbiji“ (Ivan Šajković, Dorđe Ranojević), „Socijalizem kot Veda“ (Ivan Benkovič), „O zadruzi“ (Živan Bertić), „Pravo puka na obrazovanje (izvadak iz predavanja G. Séaillesa)“ itd. Značajnije je, međutim, to što se u Novom dobu pojavljuje prvi razrađeniji i konkretniji ekonomski program mladih. Upravo u tome oni vide jednu od svojih glavnih razlikovnih točaka s obzirom na stare. U tekstu „Ekonomska pitanja u hrvatskoj politici“, Milan Krištof se zalaže za formuliranje jasnog i provedivog ekonomskog programa opozicije koji bi trebao adresirati ključne gospodarske probleme, kao što su problem lihve, manjka kreditnih linija, nepostojanje seljačkih i drugih ekonomskih asocijacija, problem slabe industrijalizacije itd. Nije dovoljno da opozicija samo označuje probleme gospodarstva, ona bi trebala provoditi svoju ekonomsku politiku neovisno o vladi, što dakako pretpostavlja aktivan i energičan organizacijski i terenski rad. ${ }^{707}$ Narodna opozicija treba dakle početi djelovati kao svojevrsna alternativna vlada na terenu, ako je već u Saboru samo oporba. Dakako da iz pozicije oporbe ekonomski napori narodne politike ne mogu riješiti makroekonomske probleme. Krištof je svjestan da razvoj industrije, na primjer,

\footnotetext{
${ }^{704}$ Isto, br. 8-10, 323.

705 Isto, 322-323.

706 „Živan Bertić - Stjepanu Radiću, Prag, 26. III. 1898.“, Krizman, nav. dj., 305.

${ }^{707}$ M. K., „Ekonomska pitanja u hrvatskoj politici““, Isto, br. 6-7, 268.
} 
nije moguć u dovoljnoj mjeri dokle god ne postoji potpuna građanska i politička sloboda. Hrvatskoj je, „kao jedinoj madžarskoj koloniji“, ključno pitanje financijske neovisnosti, bez koje nije moguća samostalna ekonomska politika usmjerena razvoju industrije, agrikulture i trgovine. ${ }^{708}$ Dapače, potpuno će ostvarenje tog cilja biti moguće tek ujedinjenjem svih narodnih sila, dakle i onih Srba, Slovenaca i Hrvata. Mladi su bili svjesni ograničenja koje je ekonomskom razvoju Hrvatske nametao nagodbeni okvir. Ugarska je vlada u svojim rukama imala sve instrumente financijske distribucije, tako da su ulaganja zajedničkih sredstava svjesno usmjeravana na prostor uže Ugarske, dok je budžet za hrvatske autonomne poslove jedva bio dovoljan da pokrije troškove redovitog poslovanja. Upravo je manjak državnih investicija, ključan za prvobitnu akumulaciju kapitala i davanje početnog impulsa industrijalizaciji, uzrokovao usporeni razvoj hrvatske ekonomske strukture. Željeznička politika ugarske vlade ciljano je radila na periferizaciji hrvatske privrede, što je kulminiralo 1873. godine $\mathrm{s}$ dovršetkom trase Budimpešta-Rijeka, u potpunosti tako marginalizirajući tranzitni potencijal tradicionalne rute koja je iz Zemuna Hrvatskom i Slavonijom vodila do Primorja. Rezultat je ekonomske politike ugarske vlade i nagodbenog okvira bio taj da je hrvatska privreda svedena na status jeftinog izvora sirovina za ekonomski razvijenije dijelove Monarhije, kao i uvoznog tržišta za industrijska dobra izvana. ${ }^{709}$ Suočeni s takvom situacijom, mladi su razmišljali o načinima kako zaobići ograničavajući nagodbeni okvir neposrednim gospodarskim radom na terenu, kako bi se nedostatak makroekonomskih državnih poticaja nadomjestio mikroekonomskim akcijama koje bi trebala predvoditi hrvatska opozicija.

Na sličan se način rezonira i u drugim tekstovima ekonomske problematike, kao što su „O konsumnih društvih“ A. Dermote ili „O reorganizaciji gospodarskih podružnica“ Dragana Turka. S obzirom na aproprijacije čeških kretanja, nije čudno da je upravo logika ekonomskog nacionalizma dominantna u razmišljanjima praške skupine mladih. Ona se povezuje s karakterističnom nacionalnom imagologijom, u kojoj bogate južnoslavenske prirodne predjele, koji bi mogli omogućiti vrhunskom bugarskom rataru, štedljivom Slovencu, poduzetnom srpskom trgovcu i hrabrome hrvatskom mornaru da budu među najbogatijim narodima Europe, podjarmljuju i iskorištavaju židovski špekulanti, njemački eksploatatori, turski i mađarski nasilnici itd. ${ }^{710} \mathrm{Na}$ temeljnoj idejnoj razini ovo razmišljanje počiva na pretpostavci uske isprepletenosti, odnosno interkauzalnosti ekonomskog razvoja i političke neovisnosti određene nacije. U kontekstu multinacionalnih imperija, ekonomski nacionalizam

\footnotetext{
${ }^{708}$ Isto, br. 8-10, 309.

709 Šidak et al., nav. dj., 125-128.

710 „Pedeset godina našega narodnoga naprezanja“, 297.
} 
manifestirao se u političkom zahtjevu za nacionalnom teritorijalnom autonomijom, a prema kraju 19. stoljeća sve više jača veza između nacionalnog pokreta i gospodarskog kooperativističkog pokreta. ${ }^{711}$ Drugim riječima, nacionalistička politika sve više i više integrira elemente neposredne ekonomske organizacije, čime ekonomska problematika postaje izrazito nacionalizirana. Ekonomske organizacije tako na prijelomu stoljeća postaju sastavni dijelovi masovne nacionalističke politike. Upravo je to cilj predložene ekonomske politike praških mladih. U izostanku političke vlasti na svojem nacionalnom teritoriju, hrvatska bi politika trebala započeti proces izgradnje masovnih nacionalnih ekonomskih organizacija na terenu, kao zalog za predstojeću žestoku političku borbu i preuzimanje političke vlasti.

Isprva je odnos Novog doba prema hrvatskoj opoziciji bio poprilično blag. Usprkos njezinim nedostacima, praški su mladi ipak u njoj vidjeli jedinu alternativu trenutnoj nenarodnoj vlasti. $U$ već spomenutom tekstu, nakon kritike hrvatske opozicije zbog nedostatka konkretna ekonomskog programa i terenskog političkog i gospodarskog rada, Milan Krištof ipak zaključuje: „Zato mi od koalirane oporbe ne očekujemo spasa narodnjega, ali se nadamo, da će biti kadra, da otme narodnu vladu iz ruku krvoloka i mameluka, koji je učiniše narodnim stratištem, pa da bude barem čuvarica poštenja i morala — dakle barem vjesnicom narodnoga spasa. To je najviše, što od nje očekujemo. “712 U uvodniku dvobroja 3-4 iz veljače 1898. godine, naslovljenom „Prostitucija madžaronske 'stranke'“, nakon žestoke i bespoštedne kritike Khuenove vlasti i madžarona, praški mladi pak o hrvatskoj opoziciji pišu u najljepšim tonovima od početka samog pokreta: „No vremena se promijeniše. Antej se dodirnuo majke zemlje i preporodio se: Opozicija se približila narodu i osjetila je čvrsto, sigurno tlo pod nogama. Gdje god bila, ona je svagdje narodnom pretstavnicom. ${ }^{\text {"713 }}$ Hrvatska opozicija više nije samo predstavnica stranaka u Saboru, ona je uistinu predstavnica naroda. Prateći njezin rad, mladi vide fundamentalne pomake u razumijevanju narodne politike. Rodoljublje je pobijedilo nad strančarstvom, hrvatska opozicija više nije stranka, ona je sada narod. Jedino što još mora shvatiti jest da ona nije predstavnica samo hrvatskog naroda, nego cjelokupnog hrvatskog ili srpskog naroda. „Preporodjenoj, narodnoj hrvatskoj opoziciji to će biti lako“, zaključuju mladi, ,,ako shvati još i to, da je ona i narodna opozicija srpska.“714

\footnotetext{
711 Schulze, Wolf, „Economic nationalism and economic integration: the Austro-Hungarian Empire in the late nineteenth century“, 657.

712 „Ekonomska pitanja u hrvatskoj politici“, 255.

713 „Prostitucija madžaronske 'stranke'“, Isto, br. 3-4, 98.

${ }^{714}$ Isto, 100.
} 
Mladi su naglašavanjem pozitivnih aspekata rada hrvatske oporbe pokušali utjecati na nju da prihvati sugestije i u ostalim segmentima političke djelatnosti, ali takav pristup nije bio uspješan. Ubrzo nakon ovog gotovo panegiričkog teksta uslijedio je potpuni obrat odnosa mladih prema starima, odnosno hrvatskoj opoziciji. Još $\mathrm{u}$ istome broju Jovan Banjanin kritizira držanje opozicije u vezi nemira i nemilih događaja u Sjeničaku u rujnu prethodne godine. Umjesto da je prepoznala činjenicu ,da narod s madžarskom zastavom dovodi u svezu sve svoje goleme terete“ $\mathrm{i}$ da je na temelju toga gradila svoju narodnu politiku, osnovanu na shvaćanju da je „naša socijalna i ekonomska borba istovjetna s narodnom“, ona je nastavila sa svojom romantičarskom i „kabinetskom“ politikom. ${ }^{715} \mathrm{U}$ istome se broju također kritici podvrgava govor baruna Đure Rukavine u Saboru te se propitkuje prikladnost njegova izbora za predsjednika koalirane opozicije. ${ }^{716}$ Praški su se mladi također obrecnuli i na Frana Vrbanića zbog njegova odlaska na objed kod bana Khuena. ${ }^{717}$ Umjesto toga, bilo bi potrebno provesti „boycott proti stupovima Khuenovske vlade“ jer „niti s madžaronom niti s Talijanom niti s Madžarom nikaka prijateljstva nit bratske zabave — dok ne postane Talijan i Madžar čovjek, a madžaron: čovjek i Hrvat!“718 S druge pak strane, izrazito su se pohvalno izrazili o govoru dr. Marijana Derenčina o seljačkom pitanju u proračunskoj raspravi. ${ }^{719}$ Izgleda da je mlade zasmetalo to što su listovi hrvatske opozicije mahom ignorirali pojavu Novog doba. ${ }^{720}$ Takav su odnos očekivali od madžarona, ali ne od oporbe.

Zbog ovakva konfuznog odnosa prema hrvatskoj opoziciji, idući uvodnik upravo je posvećen raščišćavanju ovog pitanja. Kao ključni problem odnosa starih i mladih navodi se nesposobnost starih da podnesu bilo kakvu kritiku, pa makar ona bila objektivna $\mathrm{i}$ dobronamjerna. Kao primjer navode Jurja Vrbanića, koji je zbog kritike Novog doba na račun svojeg brata Frana otkazao pretplatu, zatim Gjuru Arnolda koji je to isto napravio s Hrvatskom misli prošle godine, te Ante Tresića Pavičića koji je pokrenuo žučljivu polemiku nakon kritike upućene njegovu pjesničkom radu. Zabrinjavajuće je to „da cijela naša starija generacija stoji prama nama ovako, kao što ova tri gospodina samo s tom razlikom, da nas drugi odbijaju i odsudjuju, dok nas nisu još ni čitali — a ova nas gospoda odbiše, tek kad ih se dotakosmo.“721 Upravo bi takvo držanje starije generacije moglo biti odgovorno za razdor i podjelu na mlade i stare, što bi bilo pogibeljno za narod koji je već podijeljen po etničko-

\footnotetext{
715 Jovan P. Banjanin, „Nemiri u Hrvatskoj“, Isto, 145, 146, 148.

716 ,'Nadopunjak saborskoga govora' Jurja baruna Rukavine“, Isto, 172.

717 „Dr. Vrbanić na 'banskom' objedu“, Isto, 176.

718 „Politika i prijateljstvo“, Isto, br. 5, 222.

719 „Govor dra. M. Derenčina u proračunskoj raspravi“, Isto, br. 3-4, 169.

720 „Naše novine“, Isto, 174.

721 „Mi i naši 'stari'“‘, Isto, br. 5, 178.
} 
nacionalnim i stranačkim linijama. Mladi nikako ne priželjkuju takvu podjelu, jer vide njezine negativne posljedice u Češkoj. Krivnja za razdor nikako ne može biti na strani mladih jer su oni naprosto izabrali život i borbu u situaciji posvemašnje beznadnosti i pasivnosti. Oni su na to bili prisiljeni. Ako su ponekad možda bili preoštri, to je bilo samo iz ljubavi prema narodnoj stvari. Njihov motiv nikada nije bila osobna mržnja ili netrpeljivost, nego nezadovoljstvo s očajnim stanjem i želja da što prije bude bolje. Krivnja je, dakle, samo na strani starih, koji neprestance kritiziraju i osuđuju mlade, a ne trude se konstruktivno argumentirati svoje primjedbe i pokazati u čemu doista tako griješe. ${ }^{722}$

$\mathrm{Na}$ samom začelju posljednjeg broja Novoga doba, praški su mladi zajedljivo prokomentirali držanje opozicijskih novina o zabrani uvoza lista u Hrvatsku. Oni nisu sigurni, kažu, jesu li novine suosjećale s njima ili se veselile s grofom Khuenom. Hladan i služben stav prilikom prenošenja ove vijesti oni pripisuju zamjeranju starih zbog kritika upućenih na njihov račun. ${ }^{723}$ Takav voluntaristički, osobni i nesamokritički odnos spram politike prema njima je rezultat dubinska utjecaja khuenovštine na hrvatski javni život. Novo doba je tako počelo izlaziti u ozračju entuzijazma oko pomaka u političkoj praksi hrvatske opozicije, a završilo je s dubokim zahlađenjem odnosa između mladih i starih.

Jednako kao i Hrvatska misao, Novo doba je u svojem podnaslovu isticalo da je, između ostalog, posvećeno „književnim pitanjima“. Međutim, književnost je i u ovom slučaju ostala u drugom planu. Dok su u Hrvatskoj misli objavljena dva ključna teksta mladih na polju književnosti, Novo doba donosi tek malobrojne prikaze i kritike knjiga i drugih časopisa. ${ }^{724}$ Zapravo je najvažniji tekst posvećen književnosti iz Novoga doba prijevod članka češkog modernističkog kritičara Františeka Václava Krejčíja „O kritici“ izvorno objavljen u listu Rozhledy 1895. godine. On u njemu brani modernu kritiku - kao ključnu granu modernih literarnih strujanja koja ,donosi iz tudjine ne samo nova ishodišta za svoj rad, nego i bogate perspektive novih duševnih obzorja za cijeli narodni život“ - od napada da je hladna i cinička te da ruši literarne i rodoljubne ideale. ${ }^{725}$ Kako ne bi bila skučena osobnim diskusijama o pristojnosti i blagonaklonosti, potrebno je temeljito razmotriti njezine prave postulate i temelje. Moderna u svakom slučaju „kod nas“ ne znači neki novi literarni smjer ,jer ono, čemu se veli 'moderno', znači stanovitu skepsu i preživjelost prema svim smjerovima, znači nervozno tapati i tražiti na nesigurnom tlu, znači težnju za nezavisnošću vlastitoga 'Ja'

\footnotetext{
${ }^{722}$ Isto, 179.

723 „Progovoriše!“", Isto, br. 8-10, 403.

${ }^{724}$ Npr. prikaz Inferna A. Strindberga, zbirke Trnje i cvijeće F. Davidovića Marušića, knjige Bolgarija in Srbija A. Bezenšeka, časopisa Hlas itd.

${ }^{725}$ F. V. Krejčí, „O kritici“, Isto, br. 1, 24.
} 
umjetnikova na sve strane, znači umjetničku anarhiju i bezprogramnost.“726 Zbog toga je pitanje kritike, njezinih postulata, iskrenosti i otvorenosti ključno pitanje moderne književnosti. Moderni kritičar ne teži tome da bude nepristrani sudac pojedinog umjetničkog djela vodeći se navodno objektivnim formalnim estetskim kriterijima. On se s umjetničkim djelom suočava i sam kao umjetnik, on traži izraz svoje duše i talenta, cijele svoje subjektivnosti. Kritičar mora biti individuum jednako kao što i od umjetnika traži da bude individuum i da njegovo djelo održava njegovu nutrinu. Za modernog kritičara umjetničko djelo samo je sredstvo ,za studij svih sila, koje su ga rodile: umjetnikove duše, njezine okoline, odgoje, momenta kulturnog i društvenoga. ${ }^{\text {“727 }} \mathrm{U}$ tom smislu moderna kritika ima dvije struje: dojmovnu (impresionističku, subjektivističku) i analitičku (znanstvenu, sociološku), koje naglašavaju njezinu subjektivnu, odnosno objektivnu stranu. Kritika dakle nije „samo znanošću o umjetnosti, nego i umjetnošću razmišljati, rasudjivati i pisati o umjetnosti.“728 Ipak, svojevrsna ,,anarhija“ za koju se može reći da karakterizira takav pristup ne znači rušenje svih normi i ideala - kako onih umjetničkih, tako i onih društvenih - jer on miče kritičara iz lagodne pozicije sudačkog autoriteta i baca ga samog u borbu za opstanak. Kao i književnici, samo najbolji kritičari ukorijenit će se u općem mišljenju i u potomstvu. Ključno je, dakle, obilježje moderne kritike ,velika liberalnost prema svakomu smjeru i velika skepsa prema svemu, što dolazi sa zahtjevima dogama i vječnih orakula.“729 Zbog toga Krejčí podvrgava žestokoj kritici sve one oblike književne kritike koji se vode upravo zahtjevima dogmi: tradicionalnu formalno-estetsku, vjersku, moralističku, patriotsku, političku ili socijalnu kritiku. Međutim, moderni kritičar ovdje mora pokazati svoju toleranciju jer društvo ima drugačije imperative od „čiste“, visoke umjetnosti kojom se on primarno bavi: „Mislim, da baš subjektivni kritičar ima tu da pokaže najviše snosljivosti, jer ako traži za se potpunu slobodu izraziti svoj dojam, ne smije je uskratiti ni moralistu, ni ortodoxnomu vjerniku, ni političaru i socijologu, jer i ovi izražavaju samo svoj 'dojam'.“730

Odmak Novog doba od tekstova programatskog karaktera u kojima se kritički razmatra općenito stanje hrvatske književnosti - kao što su bili oni Milivoja Dežmana i Milana Šarića u Hrvatskoj misli - prema konkretnoj književno-kritičkoj praksi rezultat je sve snažnijeg angažmana Milana Marjanovića s praškom skupinom, dok je u isto vrijeme Milivoj Dežman svoju aktivnost preusmjerio prema užoj suradnji s bečkom skupinom pokreta mladih.

\footnotetext{
${ }^{726}$ Isto, 23.

${ }^{727}$ Isto, br. 5, 183.

${ }^{728}$ Isto, br. 3-4, 112.

${ }^{729}$ Isto, 113.

${ }^{730}$ Isto, br. 5, 189.
} 
Ta se promjena, međutim, nije pretjerano osjetila u samom pristupu književnosti. Postulati moderne književne kritike koje Krejčí iznosi u svojem tekstu nisu baš zaživjeli na stranicama Novoga doba. U njima i dalje prevladava izrazito utilitaran odnos prema književnosti, čija je zadaća prvenstveno shvaćena u narodno-prosvjetnim terminima. Dakako da se to može opravdati činjenicom da kritike Novog doba doista nisu fokusirane na djela visoke književnosti, pa zapravo potpadaju upravo pod posljednju Krejčíjevu točku one književnosti koja se može ili mora razmatrati vodeći se drugim, primarno društvenim kriterijima. Međutim, i dalje je indikativno odsustvo Marjanovićevih modernističkih kritika u Novome dobu, dok istovremeno producira upravo takvu vrstu kritike u Novoj nadi. Dapače, u Novom dobu Marjanović će svoju kritičku oštricu usmjeriti prema bečkoj Mladosti, za koju bi se moglo reći da upravo pokušava slijediti Krejčíjeve postulate koje je u prijevodu donijelo Novo doba. Ono tako u svojem pristupu književnosti nastavlja kurs koji je u Hrvatskoj misli zacrtao Milan Šarić kao predstavnik razmišljanja praške skupine mladih.

Uz Krejčíjev tekst, Novo doba obiluje posredovanjima čeških strujanja, napose onih naprednjačkih i realističkih. Od članaka tako je tu „Preporodjaj u Češkoj“ češkog povjesničara i političara Zdeněka V. Tobolke, „Narodni napori Lužičkih Srba“ slavista Adolfa Černýja te naravno neizostavni tekstovi T. Masaryka: „Politiške zahteve“ (na slovenskom, iz knjige Naše nynějši krize iz 1895. godine) i „František Palacký kano povijesni filozof i političar“ (preveden iz bečkog lista die Zeit). Osim toga, Nikola Fugger kompilirao je članak „O zadacima djaštva“ prema odabranim Masarykovim tekstovima. Novo doba je također nastavilo praksu izvještavanja hrvatske mladeži o prednostima praškoga češkog sveučilišta te đačkog života u Češkoj, pri čemu se ističe serija tekstova „Iz života češkoga djaštva“. 731

Može se reći da je Novo doba djelomično opravdalo svoje samoodređenje kao list sjedinjene hrvatske, srpske i slovenske omladine. Što se tiče tekstova, slovenski su studenti zamjetno zastupljeniji od svojih srpskih kolega, posebice onih iz Srbije. Od potonjih objavljeni su samo tekstovi „Zemljoradničke zadruge u Srbiji“ Ivana Šajkovića i Đorđa Ranojevića te „Pogled na unutrašnju politiku Srbije od prvoga rata za oslobodjenje do ustava 1869.“ Vojislava Miloševića. Za usporedbu, slovenski članci čine oko $20 \%$ svih tekstova objavljenih pod rubrikom „Članci“. Iako slabije, organizacijske veze pokreta sa studentima iz Srbije ojačale su u usporedbi sa situacijom za vrijeme Hrvatske misli. O tome svjedoči organiziranje Daničićeve večeri u Beogradu posvećene radu ujedinjene hrvatske, slovenske i

\footnotetext{
${ }^{731}$ Isto, br. 6-7, 240-246; Isto, br. 8-10, 334-341, 349-357.
} 
srpske omladine, što su praški mladi pozdravili kao prvu javnu manifestaciju naše zajedničke misli prekosavske srpske braće. ${ }^{732}$

I što se tiče đačkih i obrazovnih tema, Novo doba nastavlja liniju Hrvatske misli. Još otrovnije kritizira vodstvo i profesore zagrebačkog sveučilišta, npr. Franju Speveca, Josipa Šilovića i Nikolu Tomašića. ${ }^{733}$ U žestoku dopisu sa zagrebačkog sveučilišta, Fran Hrčić tu instituciju opisuje kao „bilježnički kurs pod vignetom 'univerze““ te ju uspoređuje s ruševinama starih feudalnih posjeda oko kojih buja novi život. ${ }^{734}$ Umjesto da prati napredak suvremene znanosti, Sveučilište stagnira kao puka filijala mađaronske vlade. Zbog toga bi bilo bolje, zaključuje otrovno Hrčić, ,prigodom 25-godišnjice univerzu zatvoriti a otvoriti magazin, gdje bi se prodavala skripta, što bi bolje odgovaralo svrsi no ovako, kako je danas. ${ }^{\text {"735 }}$

Novo doba naslijedilo je od Hrvatske misli i zategnute odnose s različitim akademskim društvima hrvatskih studenata. Praški mladi tako objavljuju dopis razočarana studenta iz Innsbrucka koji govori o poraznu stanju u tamošnjem hrvatskom akademskom društvu Velebit, koje se uglavnom bavi duelima, a ne socijalnim i ženskim pitanjem, novim smjerovima u znanosti i književnosti. ${ }^{736}$ Slično je intoniran i dopis Josipa Selaka („M.“) iz Graza, u kojemu opisuje zatrovanu atmosferu u akademskom društvu Hrvatska na primjeru slučaja čestitke u povodu Strossmayerova rođendana. Ipak, on zaključuje u nešto pozitivnijem tonu, ističući da su prilikom neuspješna glasovanja o nepovjerenju predsjedniku iz redova frankovačke većine za prijedlog glasali uglavnom mlađi članovi društva. Iako su se „stare kuće“ na to „samo porugljivo smijale glupim 'brucošima'“, Selak zaključuje da te nisu pomislile, da će baš mlađi zadati smrtni udarac njihovim trulim idejama u tom društvu. ${ }^{737} \mathrm{Tu}$ manjinu ipak ne veže neka čvrsta zajednička ideologija, a kamoli „novi smjer“, jer i većina njih misli da politika sloge sa Srbima ne može uspjeti. Ona se može okarakterizirati kao nefrankovska ili protufrankovska struja među kojima ima pristaša svih hrvatskih političkih stranaka. Dopisnik stoga zaključuje da se u Hrvatskoj „vodi borba čestitosti i zdravih ideja protiv sile i zasukanosti.“738

Dakako da je najveća pažnja praške skupine bila usmjerena prema situaciji u studentskoj politici Zagreba i Beča. Dopisnik iz Zagreba kao glavni problem među tamošnjim

\footnotetext{
732 „Daničićevo veče“, Isto, br. 2, 96.

733 „Spevec“, „Šilović“, Isto, br. 2, 47.

${ }^{734}$ F.-H., ,Sa zagrebačkog sveučilišta“, Isto, br. 5, 206.

735 Isto, 208.

736 „Insbruck, u rujnu“, Isto, br. 2, 90.

${ }^{737}$ M., ,Gradac, koncem ožujka“, Isto, br. 6-7, 285.

${ }^{738}$ M., „Gradac, u svibnju“, Isto, br. 8-10, 377.
} 
studentima ističe posvemašnje mrtvilo i izostanak bilo kakve rasprave, iako ne priželjkuje povratak ranijih vremena kada je na Zastavinim skupštinama bilo burno. ${ }^{739}$ Pravi politički život na sveučilištu ne postoji. Među studentima ima mnogo frakcijskih opredjeljenja obzoraši, domovinaši, „čisti Hrvati“ (frankovci), „,̌isti Srbi“, mađaroni, Ujedinjena omladina - ali većina njih nema jasne političke i ideološke predodžbe, a kamoli organizaciju. Između njih nema rasprave, ali se povremeno rasplamsaju mržnja i prepirke. Jedino Ujedinjena hrvatska i srpska omladina ima jasan politički pravac, ali i njoj nedostaje prave organizacije. Takvo je konfuzno stanje rezultiralo time da je na posljednjim izborima za Hrvatsko akademsko potporno društvo - koje je djelomično funkcioniralo kao supstitut za nemogućnost političkog studentskog udruživanja - sve te hrvatske stranke nekoliko ,čistih“ vodilo na uzici protiv Ujedinjene hrvatske i srpske omladine. Dopisnik također govori o tome kako su Senat i rektor Armin Pavić odbili molbu Ujedinjene omladine za otvaranjem čitaonice jer ne razumiju kako može postojati hrvatsko-srpsko društvo, iako Pavić u svojim predavanjima zastupa Daničićevu tezu o hrvatskom ili srpskom jeziku te kao zastupnik Narodne stranke u Saboru tvrdi da je ona praktički riješila hrvatsko-srpski spor. Nisu čak još uvijek potvrđena niti pravila hrvatskog akademskog literarnog društva koje je trebalo biti osnovano upravo na poticaj službenih krugova. Kao drugi primjer lošeg stanja među studentima zagrebačkog sveučilišta dopisnik navodi skupštinu koja se održala s ciljem usvajanja adrese upućene biskupu Strossmayeru, tema koja je uzrokovala razdor i među gradačkim studentima. Bez ikakve rasprave, većina je majorizirala adresu koju je predložila Ujedinjena omladina. Pritom su frankovci glasali za adresu obzoraša i domovinaša zato da padne adresa Ujedinjene omladine, a „čisti Srbi“ glasali su za adresu Ujedinjene omladine samo zato da pokušaju srušiti adresu koalicionaša. Hrvatskom bi sveučilištu, zaključuje na temelju toga dopisnik, trebalo društvo koje bi stvorilo uvjete za zdravi studentski život. A do tada ostaju kavane kao posljednje utočište studenata u kojemu ne postoje nikakvi problemi i gdje se dosada ubija kartanjem i igranjem biljara, a savjest ušutkava primjerom drugih koji svoje vrijeme trate na jednak način. Ne treba stoga čuditi što se „u toj duševnoj atmosferi malo govori i raspravlja o 'Novom Dobu'“, koje, čini se, ne drži nijedna zagrebačka kavana. ${ }^{740}$

Novo doba tako i dalje ostaje, kao i Hrvatska misao, središnje mjesto okupljanja za sve studente nezadovoljne trenutnom situacijom među hrvatskom omladinom, u cijelom spektru od onih koji su prihvatili ideje „novog smjera“, preko antifrankovački nastrojenih studenata, pa do onih koji su tek nejasno željeli promjene bez jasne vizije budućnosti. O odnosu praške i

\footnotetext{
739 Justus, ,Sa hrvatskoga sveučilišta“, Isto, br. 6-7, 277.

${ }^{740}$ Isto, 278.
} 
bečke skupine bit će više riječi u zasebnom poglavlju, jer čini osnovicu razumijevanja unutrašnjih odnosa modernističkog pokreta mladih.

Kao i Hrvatska misao, Novo doba prestaje izlaziti u srpnju 1898. godine zbog uskrate raspačavanja poštom u Hrvatskoj. Ono je bilo drugi i posljednji časopis modernističkog pokreta mladih koji je izdavan u Pragu, jednom od ključnih izvorišta pokreta. Međutim, s prestankom izlaženja Novog doba nije prestala publicistička aktivnost praške skupine. Nakon manje od godinu dana pojavit će se njihov novi list - Glas ujedinjene hrvatske, srpske $i$ slovenačke omladine, ovoga puta u Beču. I on je, doduše, bio kratkotrajan. Izašlo je svega pet brojeva, prvi u svibnju 1899., a zadnji je bio dvobroj iz siječnja 1900. Kao glavni urednik lista naveden je Fran Podgornik, slovenski publicist u Beču. Administracija lista je dijelom bila smještena u Beču, a dijelom u Zagrebu, dok su kao vlasnici lista funkcionirali Stjepan Radić i Svetozar Pribićević. Već je iz same strukture vlasnika i urednika lista, kao i iz njegova naziva, jasno da je kao svoju ključnu ideju naglašavao, na tragu dotadašnjih publikacija praške i zagrebačke grupacije pokreta, jugoslavensko narodno jedinstvo, odnosno političko i kulturno jedinstvo Hrvata, Srba i Slovenaca.

Nakon prestanka izlaženja Novoga doba praški su mladi imali podvojene osjećaje oko uspjeha i perspektive svojeg pokreta. Iako početak nove akademske godine nisu dočekali spremni s novim listom kao do tada, Stjepan Radić je bio optimističan: „Uopće se opaža, da je novi hrvatski pokret zahvatio duboke korene u mladeži, a prelazi pomalo i u šire slojeve inteligencije. ${ }^{\text {“741 }} \mathrm{Na}$ ljeto je u Zagrebu održan sastanak praške i zagrebačke skupine okupljene oko lista Narodna misao, na kojem su započete pripreme za obnovljeni zajednički rad u idućoj godini. ${ }^{742}$ Ideja je bila da od nove godine izlaze tri lista. Prvi je trebala biti smotra Novo $d o b a$, čija je glavna svrha da skupi građu za politički program u obliku knjige. ${ }^{743}$ Mladi su, naime, bili zaključili kako usprkos svemu trudu oni trenutačno nemaju politički program u pravom smislu riječi jer ideje same po sebi ne čine program ako ne postoji plan njihove praktične realizacije. Građu za program, pa tako i za smotru, trebalo je crpiti iz narodnoga života, ali i iz svjetske literature, napose one češke, francuske, nizozemske, engleske i ruske. Smotra je bila zamišljena tako da u prvom dijelu donosi mišljenje naroda o ključnim društvenim i političkim pitanjima (gospodarstvo, uprava, sudstvo itd.), nakon čega bi slijedili članci o tome kako su ta pitanja uređena u drugih naroda. Na kraju bi dolazili „subjektivni“

\footnotetext{
741 „Stjepan Radić - Mariji Dvořákovoj, Križevci, 5. VIII. 1898.“, u: Krizman, nav. dj., 327.

742 „D. Šašel - F. Hlaváčeku, Zagreb 17.VII.1898.“, u: Agičić, Dragi Franta!, 211-212.

743 „D. Šašel - F. Hlaváčeku, Karlovac 21.VIII.1898.“, u: Isto, 214.
} 
tekstovi, naime političke i literarne kritike, prikazi knjiga, bilješke itd. ${ }^{744}$ Posebno je na davanju veće važnosti književnosti u listu inzistirao Vladimir Jelovšek, koji je dotadašnju praksu ignoriranja tog segmenta smatrao nepromišljenom, pozivajući se pritom na Masarykov autoritet, jer je opće priznata činjenica da literatura ima ogroman utjecaj na inteligenciju, a donekle i na puk. ${ }^{745}$ Zbog toga mu se čini smiješnim „,kad ima ljudi našega pokreta, koji na nju gledaju s visoka kao na nešto sporednoga, manje važnoga od političarenja, dapače ju izravno preziru kao nešto sasma suvišnoga, kao neki šport, luksus.“746 Smotru su trebali uređivati ljudi koji su završili studij te više nisu đaci, a uredništvo je trebalo biti smješteno u Zagrebu, dok bi se list štampao u Pragu. Usprkos tome, istaknuto je da egzistencija nijednog od suradnika ne smije biti vezana uz te listove te da će se sav prihod upotrebljavati za unaprjeđenje listova i pokreta. ${ }^{747}$

Drugi list koji je trebao izlaziti bio je nastavak zagrebačke Narodne misli. Međutim, ona je trebala biti redefinirana, smanjena $u$ opsegu te pretvorena $u$ jednostavni tjednik usmjeren ka političkoj edukaciji srednjeg sloja u vezi ustavnih i građanskih prava, kao i širenju praktičnih gospodarskih rezultata rada među hrvatskim i srpskim narodom. ${ }^{748}$ Redakcija je trebala biti ista kao i ona Novog doba, a glavni je cilj lista bio stvoriti publiku za budući dnevnik koji bi propagirao planirani politički program. Naposljetku, kao treći list zamišljen je ,pučki tjednik“ koji bi na isti način trebao pripemati puk i niže slojeve naroda. ${ }^{749}$ „Građanski“ list trebao je izlaziti na Rijeci, a pučki u Čakovcu, u dvjema mjestima koja simboliziraju opasnost stranog prodora, a s praktičnim ciljem mobiliziranja rodoljubnog sentimenta i izbjegavanja cenzure i zapljena. ${ }^{750}$ Vodila se također rasprava i o pokretanju biblioteke, te o tome prema kojim bi naslovima ona trebala biti orijentirana, odnosno bi li njen karakter trebao biti politički, odgojni i/ili literarni. Za neke je ona čak trebala biti središnji projekt pokreta jer samo reprezentativna djela mogu dubinski razlagati koncepte koji su bili fundamentalni za razvoj pokreta. ${ }^{751}$ Vrlo je indikativno koje knjige Franjo Poljak predlaže kao prve dvije za prijevod: Braća Karamazovi i Narodno gospodarstvo Charlesa Gidea. U prvoj knjizi „najbolje i najdublje se očituju naši moralni i etički nazori, naša vjera“, pri čemu „naš pokret i onako ima možda najviše zahvaliti, da postoji i da je takav, upravo utjecaju ruske literature“, dok druga naginje „kooperativnoj školi“ koja je najsrodnija ekonomskim

\footnotetext{
${ }^{744}$ Isto, 214-215.

745 „Vladimir Jelovšek - Draganu Šašelu, Prag, 6. XII. 1898.“, u: Krizman, nav. dj., 334.

746 Isto.

747 „D. Šašel - F. Hlaváčeku, Karlovac 21.VIII.1898.“, 217.

748 Isto, 215.

${ }^{749}$ Isto.

${ }^{750}$ Isto, 216.

751 „Franjo Poljak - Stjepanu Radiću, Prag, 6. XII. 1898.“, u: Krizman, nav. dj., 335.
} 
pogledima mladih te bi bila dobra alternativa knjizi Blaža Lorkovića koja slijedi liberalnu političku ekonomiju. ${ }^{752}$

Ovaj elaborirani plan trebao je revitalizirati pokret i ponovno ujediniti rad praške i zagrebačke skupine, te tako lišiti krug oko Narodne misli protektorata E. Barčića i F. Potočnjaka. ${ }^{753}$ Kruna svega rada trebala je biti velika skupština na jesen 1900. godine na kojoj bi se konačno odredio odnos pokreta prema tadašnjim strankama, kao i način budućeg političkog rada. Velika većina ovih ambicioznih ljetnih planova ostala je, međutim, bez realizacije. Tek u siječnju 1899. održan je sastanak u vezi pokretanja novog lista. Na njemu je odlučeno da će se list zvati Narodni pokret te da će se tiskati u Pragu, gdje će se obavljati samo korektura i ekspedicija. ${ }^{754}$ Prije toga, međutim, trebalo je podmiriti dosta veliki dug tiskari nakon prestanka izlaženja Novog doba. Zbog nezadovoljstva ponašanjem Vice Iljadice, František Hlaváček - koji je ionako odrađivao najveći dio posla u Pragu što se tiče izdavanja Novog doba - ponovno je zamoljen da primi odgovorno uredništvo, na čemu mu Antun Radić zahvaljuje. ${ }^{755}$ Ipak, Hlaváček nije bio pretjerano entuzijastičan jer je smatrao da se Pragu iz Zagreba prebacuju neugodni poslovi. ${ }^{756}$ Jezgra pokreta sve se više premještala u Zagreb kako su se njegovi inicijatori i glavni pokretači približavali kraju svojih studija. Šašel tako govori o zagrebačkome odboru koji je „,vrhovni nadzornik i upravljač“ pokreta te o redakcijskom uredu u Zagrebu koji bi trebao postati središnje okupljalište svih pristaša. ${ }^{757}$ Jelovšek je smatrao da bi Zagreb morao postati novo središte pokreta jer je neprirodno kad se pokreti smještaju izvan domovine. Kod Hrvatske misli bio je to prvi udarac, negativna oštra opozicija, niknula pod tuđim utjecajem i od ljudi, koji su morali boraviti izvan domovine. ${ }^{758}$ Vrijeme je da Zagreb preuzme inicijativu te da postane pravo središte pokreta, jer ako to i nadalje ostane Prag, sve će se opet svesti samo na izdavanje lista. Izdavanje lista u Zagrebu, međutim, nije bilo moguće zbog jasne perspektive zapljena i globa.

U ožujku 1899. godine Nikola Fugger rezignirano piše Hlaváčeku da pokret nije uspješan. ${ }^{759}$ Iako praški mladi nisu odustajali, dio inicijatora pokreta tada je već bio pri završetku ili je završio studij te su bili spremni pronaći stalno zaposlenje i situirati se u

\footnotetext{
${ }^{752}$ Isto, 337. Riječ je o knjizi Počela političke ekonomije ili nauke obćeg gospodarstva profesora političke ekonomije Blaža Lorkovića iz 1889. godine. S obzirom na to da je on bio otac Ivana Lorkovića, mogli bismo reći da potraga za alternativom njegovoj knjizi dobro oprimjeruje odnos mladih prema starima.

753 „D. Šašel - F. Hlaváčeku, Karlovac 21.VIII.1898.“, 216.

754 „A. Radić - F. Hlaváčeku, Zagreb 6.I.1899.“, Isto, 191.

755 Isto, 192.

756 „D. Šašel - F. Hlaváčeku, Karlovac 3.I.1898.“, Isto, 202.

${ }^{757}$ Isto, 203.

758 „Vladimir Jelovšek - Draganu Šašelu, Prag, 6. XII. 1898.“, u: Krizman, nav. dj., 333.

759 „N. Fugger - F. Hlaváčeku, [Zagreb, ožujak 1899.]“, u: Agičić, Dragi Franta!, 37.
} 
građanskom životu. Jezgra pokreta koja se bila okupila u Pragu 1896. godine polako se rastakala. Kako izvještava Fugger, u listopadu 1898., kada se trebalo raditi na novom listu, situacija je bila loša, „Živan [Bertić] u vojsci, ja u Zemunu, Krištof u Njemačkoj, Lorković u

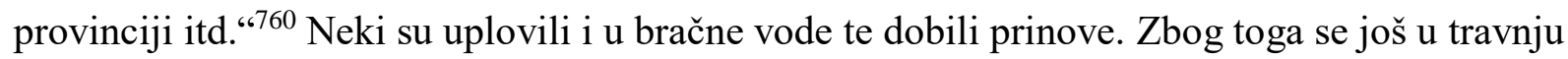
1899. godine, kada je već otposlan prvi broj Glasa, koji je naposljetku tiskan u Beču, i dalje tražio njegov urednik. ${ }^{761}$ Hlaváček nije bio zadovoljan takvom situacijom. ${ }^{762}$ Ipak, Fugger je optimistično branio perspektivu lista i pokreta, tvrdeći da se ozbiljno radi, da se sakupilo članaka i novaca te da će se novim listom naći ljudi koji će nastaviti rad, a da se u Pragu o stvari odviše „bagatelno“ govori. ${ }^{763}$ Sve se više i jasnije isticala nužnost smjene generacija. Iako su se žalili što list izlazi u Beču, a ne u Pragu kao do tada, razlog je bio što je Podgornik prihvatio uredništvo lista, a on je boravio u Beču. Njegovo je uredništvo, međutim, bilo samo na papiru, dok je stvarna redakcija bila u Zagrebu, kamo se cijeli list namjeravao preseliti $u$ listopadu 1899. godine. S Podgornikom je tako i dogovoreno, jer on nije imao vremena doista se baviti listom. ${ }^{764}$

Glas ujedinjene hrvatske, srpske $i$ slovenačke omladine s podnaslovom ,za književnost, politička i socijalna pitanja“ počeo je izlaziti u svibnju 1899. godine te je u neregularnim intervalima objavljeno pet brojeva zaključno s dvobrojem 4-5 u siječnju 1900. Prvi broj Glasa već tradicionalno donosi uvodni tekst za cijeli list, ovoga puta iz pera Nikole Fuggera. Međutim, u ovom slučaju to nije precizan programski članak, koji zapravo nije potreban jer je Glas nastavak Hrvatskoj Misli i Novome Dobu. Zbog toga se u uvodniku iznosi tek nekoliko napomena koje su mladi na početku željeli naglasiti. Prije svega, Fugger ističe kako Glas nije organ niti jedne stranke. Svaki napredak ljudskog društva proizlazi iz nezadovoljstva postojećim i iz reakcije na to stanje. I pokret je mladih niknuo upravo iz nezadovoljstva, koje ih je potaknulo da promišljaju o uzrocima takva lošeg stanja. Zaključivši da je glavni uzrok u nedostatku čvrstog karaktera, oni su kao ishodište svojem radu postavili upravo stvaranje novih, karakternih ljudi. Umjesto da zahtjevaju slijepu poslušnost i pokoravanje autoritetu, stari bi trebali - ako im je doista stalo do narodne stvari, a ne samo do njih samih - prihvatiti ovakvo nastojanje mladih.

Ideja narodnog jedinstva Hrvata, Srba i Slovenaca nije stoga jedina i glavna misao vodilja, nego je posljedica naprednijeg shvaćanja života. Po prvi puta jasno ističući primat

\footnotetext{
760 „N. Fugger - F. Hlaváčeku, [Zagreb, 2.V.1899.]“, Isto, 39.

761 „N. Fugger - F. Hlaváčeku, [Zagreb, 26.IV.1899.]“, Isto, 38.

762 „N. Fugger - F. Hlaváčeku, [Zagreb, 2.V.1899.]“, 38.

763 Isto, 39.

764 „N. Fugger - F. Hlaváčeku, [Zagreb, 18.V.1899.]“, Isto, 39-40.
} 
naprednjaštva nad nacionalizmom u ideologiji mladih, Fugger naglašava kako oni od narodnosti ne prave idola, nego ju shvaćaju kao vrijednosno pozitivnu, prirodnu činjenicu života ljudskog društva koja daje okvir njihovu djelovanju. Za razliku od šovinista, za mlade je narodnost ujedno i više i manje: više jer je cijene pozitivno do te mjere da mogu zamisliti supostojanje, a ne samo protimbu narodnosti, a manje jer imaju i drugih ideja.

Upravo ta činjenica širenja horizonata, napose što se tiče socijalnog pitanja, iskorištena je za optužbu mladih da su anarhisti i socijalisti, što Fugger označava „mađaronskom fintom“. On još jednom jasno ponavlja da se mladi ne slažu sa socijalnom demokracijom, ali ju shvaćaju i priznaju kao ravnopravnu jer im je zajednička briga za malog čovjeka. Za razliku od onih koji propovijedaju idealizam, ljubav i patriotizam, a u praksi malo toga čine, mladi ističu upravo socijalno pitanje i rad s malim čovjekom kao ključno nacionalno pitanje. „Naš narod u svojoj jezgri i po svojem kvantumu i jest taj mali čovjek“, zaključuje Fugger, stoga „moramo porušiti onu visoku ogradu, kroz čije pukotine gleda mali čovjek u perivoj, gdje se gospoda šeću.“ Naposljetku, mladi pozivaju đaštvo i sve ostale na rad, prije svega rad na sebi. Do ostvarenja ideala može se doći jedino jačanjem „moralnoga osvjedočenja“, a za to je potrebno podići se „naukom i samoodgojem.“ U tom radu dobrodošli su svi koji pružaju ruku, bilo s lijeva ili s desna. ${ }^{765}$

Promatrajući u cjelini, Glas doista ne donosi idejne iskorake s obzirom na Novo doba. Dapače, moglo bi se reći kako je sadržajno oskudniji i analitički slabiji od svojih prethodnika. Osim poprilično neredovita izlaženja, znatan dio njegova sadržaja sačinjavaju prijevodi. ${ }^{766}$ Uvodnim tekstovima - koji su do tada u časopisima praške skupine imali programatski karakter - dominira moralistički ton i šturo ponavljanje već iznesenih ideja i fraza. ${ }^{767} \mathrm{Njih}$ uglavnom piše Nikola Fugger, a zamjetno je potpuno odsustvo Radićevih tekstova, iako on i dalje figurira kao vlasnik lista uz Svetozara Pribićevića. Radić se u to vrijeme nalazi u Parizu te je njegov utjecaj na ostatak praške skupine počeo jenjavati, dijelom zbog toga što su mu zamjerali pokušaje nametanja za vođu pokreta. ${ }^{768}$

Upravo se Pribićevićev prilog, „Hrvatska i srpska opozicija prema našim narodnim aspiracijama“, može smatrati intelektualno najznačajnijim doprinosom Glasa. Iako u njemu uglavnom ponavlja ključne točke iz svojih ranijih tekstova u Narodnoj misli i Novom dobu, on ipak donosi određenu analitičku novinu. Napose se to odnosi na analizu unutrašnje i

\footnotetext{
765 Svi citati iz: N. F., „Glas“, Glas, god. I, br. 1, 1-3.

766 Primjerice „Jedro socijalizma“ njemačkog sociologa A. Schäfflea, „Ljubav prema bližnjemu i rad“ T. G. Masaryka, „Djak i socijalno pitanje“ E. de Amicisa itd.

${ }^{767}$ Primjerice „Policajni moral“ i „Narodnost i pravednost“ Nikole Fuggera te „Narod i glad“ Živana Bertića.

${ }^{768}$ Biondich, nav. dj., 56.
} 
vanjske politike Kraljevine Srbije s obzirom na njezinu proklamiranu pijemontsku ulogu kada je riječ o Južnim Slavenima. Pribićević kritizira s jedne strane nedemokratske prakse i gušenje sloboda na unutrašnjem planu Srbije, a s druge njezin oslon na Austro-Ugarsku, odnosno Njemačku u vanjskoj politici. ${ }^{769}$ Demokracija i nacionalna politika za Pribićevića su povijesno usko povezani i isprepleteni fenomeni koji izviru iz Francuske revolucije, do te mjere da prvu smatra preduvjetom za potpuno ostvarenje nacije. Ali on u taj koloplet dodaje još i socijalno pitanje, bez čijeg rješenja nije moguće pravo nacionalno jedinstvo, o čemu svjedoče društveni sukobi na Zapadu gdje je nacionalno pitanje - barem formalno - uglavnom riješeno. Zbog toga on od Srbije zahtijeva da osim promjene vanjskopolitičke orijentacije od fokusa na „Staru Srbiju“ i Makedoniju - što vodi u sukobe s Bugarskom - prema zapadu (Hrvatskoj i BiH kao jezgri jugoslavenstva), ujedno postane i svojevrsni svjetionik slobode i socijalne pravednosti, te da među Južnim Slavenima postane poželjna i po svojim političkim i društvenim institucijama.

Ovdje se stoga očituje plodna analiza koja upotrebljava središnji koncept praške skupine razvijen još u Novom dobu, a to je socijalizacija (nacionalne) politike. Kao što je već ranije rečeno, Glas u idejno-programskom smislu ne donosi ništa novo ideologiji mladih. Njegov književni dio iscrpljuje se u nekoliko prikaza književnih djela te u crticama o seoskom životu Živka Bertića, koji će ostati jedini književni reprezentant praškoga kruga. ${ }^{770}$ Glas tako predstavlja izraz krize i stagnacije praške skupine, što je došlo do izražaja već u pripremama za njegovo pokretanje. On će biti njezin posljednji samostalni projekt, a u trenutku njegova gašenja pokret mladih u cjelini već je bio prošao svoj vrhunac te je krenuo putem jenjavanja i fundamentalnih transformacija.

Iako su najavljivali skoro izdavanje II. tečaja lista, to se nikad nije dogodilo. I ovoga su puta mladi bili pritisnuti financijskim problemima. Redakcija se požalila kako od 600 pretplatnika njih 400 nije podmirilo svoje dugove. ${ }^{771}$ Međutim, mnogo važniji razlog za kraj poduhvata samostalnog izdavanja lista praške skupine bile su strukturne transformacije koje su zadesile sam pokret. Od 1900. godine njihova je međusobna korespondencija puna izvještavanja o tome gdje je tko otišao i što radi nakon završetka studija. Praška se jezgra postepeno razgradila. Nikola Fugger tako u ožujku izvještava o ,zagrebačkoj novosmjeraškoj čitaoni““ koja okuplja „do 40 ljudi“, kao i o „užem krugu novosmjeraša“ u Beču, dok ujedno

\footnotetext{
${ }^{769}$ Usp. „Ne smije nam se zamjeriti, ako iskreno priznamo, da Srbija sa vječitim kolebanjem u spoljašnoj svojoj politici, s neprestanim unutrašnjim trzavicama i krizama, koje se uvijek i redovno završuju s upravnim apsolutizmom, nije shvatila visoku svoju zadaću ni razumjela smisao svoje uloge." Svetozar Pribićević, „,Hrvatska i srpska opozicija prema našim narodnim aspiracijama“““, Glas, I, 1, 13.

770 Živko Bertić, „Bilješke sa sela“, Isto, br. 1 i 3.

771 „Zaključna riječ“, Glas, I, 4-5, s. p.
} 
govori o uklanjanju „fiktivne“ Ujedinjene omladine i Radića kao vlasnika lista. ${ }^{772}$ I Lorković konstatira kako bi bilo od prijeke potrebe da ih u Zagrebu bude što više. ${ }^{773}$ Težište se pokreta od 1900. ipak sve više premješta u Zagreb, a skupine koje su do tada djelovale počinju se rastakati i miješati, signalizirajući tako novu, završnu etapu u razvoju pokreta mladih.

\section{2. Ograničenja modernističkih aproprijacija}

Iako je praško Novo doba nastupilo kao zajednički projekt i nastavljač kako praške Hrvatske misli, tako i zagrebačke Ujedinjene omladine okupljene oko almanaha Narodna misao, nedugo nakon početka njegova izlaženja pojavila se inicijativa za izdavanjem drugog lista u Zagrebu koji bi se direktno nastavljao na Narodnu misao. Zagrebački mladi okupljeni oko tog almanaha - popularno unutar pokreta nazivani „mišljaši“ - željeli su nastaviti svoj započeti rad i kapitalizirati na ostvarenim kontaktima s pojedinim predstavnicima hrvatske i srpske političke i intelektualne elite. Novi list koji oni pokreću nastaje stoga u suradnji s dvojicom istaknutih predstavnika hrvatske građanske politike. Narodna misao, tjednik s podnaslovom ,jedinstvu i slobodi naroda, ljubavi i uzajamnosti braće“ započeo je izlaziti 3. veljače 1898. godine, a prestao je s 27. brojem 4. kolovoza 1898. Vlasnici, nakladnici i izdavači lista bili su Erazmo Barčić i Franko Potočnjak, koji je ujedno bio i njegov glavni urednik. Analiza njegova sadržaja, međutim, otvara pitanje o stvarnim dometima modernističkih aproprijacija. Iako nije sporno da su zagrebačka Ujedinjena omladina i njezini projekti dio šireg pokreta mladih, pitanje je do koje mjere ona doista sudjeluje u modernističkim strujanjima na prijelomu 19. i 20. stoljeća. Analizom djelatnosti ove skupine pokušat ćemo stoga odgovoriti na pitanje ograničenja modernističkih aproprijacija u dijelu pokreta mladih.

U pismu Hlaváčeku, Ivan Lorković ističe kako je izdavanje novoga lista mladih zaključeno na sastanku u Rijeci sredinom studenog 1897. godine na kojemu su sudjelovali Barčić, Potočnjak, vođa Srpske radikalne stranke Kosta Taušanović te Lorković i Pribićević kao predstavnici mladih. ${ }^{774}$ Inicijalno je bilo predviđeno da izlazi tri puta tjedno. List je trebao stajati na stanovištu Hrvatske misli i Narodne misli, a jamac tome trebao je biti redakcijski odbor na čijem čelu bi doduše bio Potočnjak, ali koji bi bio sačinjen isključivo od mladih.

\footnotetext{
772 „N. Fugger - F. Hlaváčeku, [Zemun], 14.III.1900.“, u: Agičić, nav. dj., 44.

773 „I. Lorković - F. Hlaváčeku, Zagreb 10.IV.1898.“, Isto, 147.

774 „I. Lorković - F. Hlaváčeku, Zagreb 27.XI.1897.“”, u: Agičić, nav. dj., 138.
} 
„Prema tomu vidite,“ potcrtava Lorković, „da je čitavi list u našim rukama.“775 Kako najavljuje, uz mlade su u listu trebali surađivati još Erazmo Barčić, Lovre Monti, Marijan Derenčin, Natko Nodilo, Kosta Taušanović, Danilo Majaron ${ }^{776}$ iz Ljubljane, a Lorković moli i Hlaváčeka da bude njihov češki dopisnik.

Za Lorkovića, Narodna misao i Novo doba bili su dva lista jednoga pokreta. ${ }^{777} \mathrm{~S}$ time se nije slagao Antun Radić koji je smatrao da treba postojati samo jedan list te da ili Novo doba treba prestati izlaziti, ili Narodna misao ne bi trebala uopće početi. Lorković je pak smatrao da izdavanje dvaju lista omogućuje veću fleksibilnost i podjelu rada unutar pokreta. Narodna misao tako bi poprimila karakter novina koje bi se doticale svakodnevnih, dnevnopolitičkih pojava, dok bi Novo doba moglo u potpunosti odbaciti žurnalistički ton te postati ozbiljno glasilo. ${ }^{778}$

Pražani nisu bili pretjerano entuzijastični zbog pokretanja zagrebačkih političkih novina mladih. Posebno su bili skeptični u vezi Potočnjaka i suradnje s predstavnicima starih. Stjepan Radić je smatrao da mladima ne trebaju novine koje će se obraćati inteligenciji, nego puku, a namjeravao ih je pokrenuti nakon svog povratka iz inozemstva. ${ }^{779}$ Braneći ideju lista, Lorković mu je opravdano odgovorio da ni Novo doba ni Hrvatska misao nisu bili listovi za puk, nego za inteligenciju, te da tadašnje stanje pokreta zahtijeva ovakav način rada. ${ }^{780}$ Razlika naspram svih ostalih novina bit će u nezavisnosti od stranačkih obzira i u žestokoj kritici postojećeg stanja, napose inteligencije. Lorković se pak složio s Hlaváčekom da Potočnjak zapravo nije „mišljaš“, ali je dodao da to nije problem jer on prihvaća sve što mladi kažu. ${ }^{781}$ Što se starih pak tiče, on ponavlja da oni neće imati presudnog upliva na sadržaj lista. Ako Narodna misao podbaci, zaključuje Lorković, to će biti isključivo zbog samih mladih, njihove nedoraslosti ili neaktivnosti. ${ }^{782}$ Franjo Poljak je, međutim, u svojoj korespondenciji s Hlaváčekom iznio neke povjerljive stvari koje je Lorković izostavio u svojim pismima. Naime, prema Poljaku, Lorković uopće nije bio zadovoljan sa situacijom u kojoj se našao. On se upustio u projekt uređivanja novina zato što je Potočnjak bio svakako naumio izdavati novine, pa je Lorković zaključio da je bolje da se mladi tome pridruže nego da se nepotrebno

\footnotetext{
775 Isto, 138.

776 Danilo Majaron (1859-1931), slovenski pravnik i političar. Dugogodišnji predsjednik pravničkog društva, urednik Slovenskog pravnika i predsjednik ljubljanske odvjetničke komore, bio je jedan od glavnih organizatora jugoslavenskih pravničkih kongresa. Pisao je o pravnim, političkim i kulturnim temama. Bio je jedan od glavnih zagovaratelja osnivanja Sveučilišta u Ljubljani te je vodio pripreme za to nakon 1918. godine.

777 „I. Lorković - F. Hlaváčeku, Zagreb 2. XII. 1897.“, Isto, 139.

${ }^{778}$ Isto.

779 „F. Poljak - F. Hlaváčeku, Banija 27.XII.1897.“, Isto, 177.

780 „Ivan Lorković - Stjepanu Radiću, Zagreb, 10. I. 1898.“, u: Krizman, nav. dj., 296.

781 „I. Lorković - F. Hlaváčeku, Zagreb 28.XII.1897.“, u: Agičić, nav. dj., 142.

${ }^{782}$ Isto, 142.
} 
cijepkaju sile. Međutim već u startu je postalo jasno da je sav rad spao na Lorkovića, a da je Potočnjak zašao u mutne vode, u posudbu 2.000 forinti od Taušanovića u nekoj srpskoj banci za kauciju listu. ${ }^{783}$ Niti među Ujedinjenom omladinom nije bilo mnogo onih na koje bi se Lorković mogao kvalitetno osloniti, jer većina njih nije dobro razumijevala osnovne postavke pokreta. Najveći je problem ipak u samome Potočnjaku, o kojemu Poljak piše izrazito oštro kao o intelektualno i moralno nesposobnu čovjeku prevelikih materijalnih potreba koji ne može razumjeti rad mladih. ${ }^{784}$ Niti Antun Radić nije bio ništa blaži. Ljut nakon što je primio prvi broj lista, on ga je ocijenio plitkim i sramotnim, te je izrazio žaljenje što mlade u Zagrebu ne predvodi Derenčin umjesto Potočnjaka:

„Čudim se Lorkoviću, da se je dao pod krila ovako plitkoga vikača, koji bi narodu tringeldere dijelio. A onaj prokurvani Barčić po gotovo ne spada u kolo ove mladeži. No što je najgore, čujem, da je 'Nar. Mis.' osnovana na mjenici od 2000 for., koju je žirirao Taušanović. Po tom sam uvjeren, da je 'Nar. Misao' u ovom obliku ogranak dinarskosrbobransko-srpske politike, koja ide za pripremanjem terena za okupaciju i državno raširenje granica: stara teritorijalna, velika politika kulisâ. Gadi mi se. “785

Postojao je, međutim, još jedan faktor koji je uvelike otežavao projekt izdavanja novina mladih u Zagrebu. Ako se vlast trudila svim silama suzbiti njihove listove koji su izlazili u Pragu, bilo je za očekivati da će se Narodna misao naći na još jačem udaru. Lorković stoga nije bio siguran hoće li uopće uspjeti izdati prvi broj. ${ }^{786}$ I doista, već nakon prvih brojeva Narodna misao bila je zabranjena u Srbiji, dok su se u Hrvatskoj zaredale zapljene. $^{787}$

Prvi broj Narodne misli dakako donosi programatski uvodnik naslova „Što namjeravamo“. On očekivano elaborira osnovnu ideju o narodnom jedinstvu Slovenaca, Hrvata i Srba, za koju zagrebački mladi tvrde da je znanstveno potvrđena, a da je oduvijek živjela među narodom. Ta se ideja očitovala kroz cijelu povijest, od „Ljutovida, Trpimira, Dušana, Nemanje i drugih“, pa sve do danas, kada je preporođena kroz „veliki narodnosni pokret“. Razdoblje prije toga preporoda okarakterizirano je jarmom, s jedne strane „otomanskoj sili“, a s druge Zapadu, na koji su Hrvati i Slovenci bili „nenaravno naslonjeni““. Upravo je takva povijesna situacija uzrokovala zaseban razvoj Slovenaca, Hrvata i Srba te osujetila za dulje vrijeme njihovo narodno jedinstvo, koje se ponovno revitalizira. Zbog toga

\footnotetext{
783 „F. Poljak - F. Hlaváčeku, Banija 27.XII.1897.“, 177.

784 Isto, 178.

785 „Ante Radić - Stjepanu Radiću, Zagreb, 4. II. 1898.“, u: Krizman, nav. dj., 300-301.

786 „I. Lorković - F. Hlaváčeku, Zagreb 9.I.1898.“, u: Agičić, nav. dj., 144.

${ }^{787}$ Krizman, nav. dj., 340.
} 
što je takav odvojen razvoj jedinstvena naroda zapravo rezultat vanjskih utjecaja koji ide na korist silama koje žele dominirati južnoslavenskim prostorom, put naprijed mora biti radikalno drugačiji te se mora temeljiti na zajedništvu $i$ jedinstvu, a ne separatizmu $i$ ekskluzivizmu. Dakako da se taj cilj neće moći ostvariti preko noći, a njemu ne pomažu nasilni i umjetni putevi nametanja narodnog jedinstva, kao što je izmišljanje zajedničkog narodnog imena. Svatko neka se stoga krsti imenom kojim želi, ali uz rad na svijesti da je to ime zapravo sinonim za druga imena, kao oznaka jednog naroda i narodnosti.

Cijeli ovaj programatski tekst zapravo se čita kao siže almanaha Narodna misao. Snažniji utjecaj Hrvatske misli i Novog doba vidi se u isticanju važnosti socijalnog pitanja, koje je do tada bilo u drugom planu zagrebačkih mladih. Prihvaćajući koncept socijalizacije narodne politike, oni najavljuju kako će glavnu brigu posvećivati životu i potrebama puka jer seljaci, radnici i obrtnici sačinjavaju osnovu naroda, pa je prema tome nacionalno pitanje sadržano u seljačkom i radničkom pitanju. Zbog toga će se zalagati za materijalni preporod seljaka i radnika, obranu prava sirotinje te se boriti za ravnopravnost i jednakost svih, kako pojedinaca, tako i skupina. Kao logičan zahtjev stoga se nameće opće pravo glasa, sloboda sastajanja i udruživanja te sloboda štampe. Narod je „po naravi svojoj demokratičan“, a tadašnje je stanje posljedica tuđinske dominacije, koja je jasno vidljiva i na ekonomskom polju.

Što se tiče kulturnoga polja, zagrebački mladi ističu da će pratiti svako važnije strujanje, ali vodeći se načelom da je potrebno stvoriti vlastitu narodnu kulturu, a ne uvoditi stranu koja bi bila protivna narodnom duhu i naravi. Ako kultura prikazuje dušu naroda, onda ona mora imati istinski narodno obilježje. Modernistička bi se nastojanja na ovome polju stoga iz ovoga rakursa mogla pokazati problematičnima. Naposljetku, narodna je borba južnih Slavena uklopljena u širi slavenski okvir. Iako u slavenskom svijetu prednjači Rusija, „zapadno-sjeverna naša braća u ovoj monarkiji“ dokazala su se u borbi protiv „germanskog Golijata“, dok je važnost južnih Slavena u njihovu ključnom geografskom položaju. ${ }^{788}$

Narodna misao predstavlja se kao nezavisni list koji ne zastupa nijednu stranku, ne služi nijednoj osobi i nije „list nijedne pokrajine posebno“. ${ }^{789}$ Njen je jedini zadatak da promovira ideju narodnog jedinstva Srba, Hrvata i Slovenaca, pa će stoga hvaliti sve stranke i pojedince koji će raditi u tom smjeru, kao i kritizirati one koji će tu ideju osujećivati. ${ }^{790}$ I po

\footnotetext{
788 Svi su navodi iz: „Što namjeravamo“, Narodna misao, god I., br. 1, 1-3.

${ }^{789}$ Isto.

${ }^{790}$ Povod za potonje očito je brzo stigao, jer već u četvrtom broju Narodna misao odgovara na neke kritike upućene na svoj račun. Likujući nad time da nitko nije napao princip narodnog jedinstva, nego samo njegovu praktičnu neprovedivost i opasnost po hrvatsko ime, posebno apostrofira kritike Crvene Hrvatske i Hrvatske
} 
formi i po sadržaju, Narodna misao tipičan je politički list. Ona politički operacionalizira temeljne postulate almanaha Narodna misao i kruga okupljenog oko njega. Najveći dio lista tako zauzima (dnevno-)politički pregled fokusiran na "Slovenski svijet“, a njegova je podrubrika „Naša domovina“, u koju spada: „Hrvatska i Slavonija“, „Dalmacija“, „Istra“, „Gorica“, „Trst“, „Kranjska“, „Štajerska“, „Koruška“, „Medjumurje“, „Banat i Bačka“, „Bosna i Hercegovina“, „Srbija“, „Crna Gora“, „Stara Srbija i Makedonija“. Na taj se način politički program pretočuje u sadržajni i formalni okvir lista. Osim toga, članci u listu objavljivani su kombinirano na ćirlici i latinici, neovisno o temi i autoru teksta. Politički je program Narodne misli najeksplicitnije dakako iznesen u njezinim uvodnicima. Oni, međutim, u pogledu ideja ne donose ništa supstancijalno novo, nego samo izlažu ono što je već razrađeno kroz ranije publikacije mladih, ali u formi prikladnijoj jednom tjedniku. ${ }^{791}$

Ono po čemu list Narodna misao predstavlja iskorak s obzirom na istoimeni almanah jest tematsko širenje interesa na problematiku ekonomije i kulture. Dakako da se na njih u glavnini primjenjuje načelo narodnog jedinstva i nacionalni fokus. Što se tiče ekonomije, list je dobio rubriku „Narodno gospodarstvo“. Karakteristično je, doduše, da njome gotovo u potpunosti dominiraju teme iz područja agrikulture. Osim kraćeg bavljenja zemljoradničkim zadrugama, skoro je cijeli prostor ove rubrike u vremenu izlaženja lista zauzela tema zaštite seljačkoga posjeda. ${ }^{792}$ To je dakako odgovaralo temeljnoj ideji da seljaštvo predstavlja supstrat srpske, odnosno hrvatske nacije, ne samo u kvantitativnom, nego i u kvalitativnom smislu.

Jedan od ključnih analitičkih koncepata koji dominira cjelokupnim listom jest onaj njemačkog Drang nach Osten, odnosno prodora na (jugo)istok. ${ }^{793}$ On se primjenjuje na svim obrađivanim područjima, od politike, preko ekonomije, pa sve do kulture i svakodnevice. Zagrebački mladi tako kritiziraju nijemštinu u svakodnevnom govoru zagrebačkog društva, ali i prisutnost predstava njemačkih pučkih izvođača (Volkssänger) u Hrvatskoj. ${ }^{794}$ Njemački nacionalizam u Austriji za njih je jedan od ključnih argumenata za potrebu širenja ponude studija na zagrebačkom sveučilištu, kao i uzdizanja beogradske visoke škole u rang sveučilišta. Slavenski studenti u Beču, Grazu i Innsbrucku prepušteni su nasilju njemačkih

\footnotetext{
Domovine koje su protiv njih uperile ,denuncijacije o Slavenstvu, škiljenju preko granica i o centrifugalnoj sili, koja tjera van 'okvira'“،, a koje „mogu ići u račun Madjarima, Nijemcima, Talijanima i Židovima, ali ne nama.“ „Malo odgovora“, Isto, I, 4.

791 Vidi primjerice „Dalmacija prema narodnom načelu“, Isto, I, 4; „Hrvatska i Slavonija prema narodnom načelu“, Isto, I, 5; „Naš narod u Ugarskoj prema narodnom načelu“, Isto, I, 7 itd.

792 ,Zemljoradničke zadruge“, Isto, I, 2; „U zaštitu seljačkoga posjeda“, Isto, I, 3-9 i 13.

${ }^{793}$ Usp. Ivo Žanić, „The Symbolic Identity of Croatia in the Triangle Crossroads-Bulwark-Bridge“, u: Pål Kolstø (ur.), Myths and Boundaries in South-Eastern Europe, London, 2005, 51-54.

794 ,Tingl-Tangli širom naše domovine“", Isto, I, 4.
} 
studenata koji su favorizirani i zaštićeni. Ali neovisno o tome, potreba kulturne samostalnosti iziskuje potpunu samostalnost na obrazovnom polju, a dok ona ostvari, preporučuju južnoslavenskim đacima nastavak studija na slavenskim, a ne na germanskim sveučilištima. ${ }^{795}$ Njemački nacionalizam također je argument i razlog zašto odbacuju koncepte federalizma i jugoslavizma u okviru Monarhije, odnosno bilo kakvo „okviraško“ rješenje (južno)slavenskog nacionalnog pitanja. ${ }^{796}$ Habsburška je Monarhija za njih u bitnome smislu dio njemačkog imperijalističkog projekta, avangarda njemačkoga širenja na (jugo)istok. Ovo izrazito nacionalno gledište prevladava i u njihovu odnosu spram socijalizma, odnosno socijaldemokracije. Iako se slažu s određenim društvenim zahtjevima socijalizma, optužuju njemačku socijaldemokraciju za nacionalizam i šovinizam prema Slavenima. Nasuprot socijalističkom internacionalizmu koji prema njima samo prikriva njemački imperijalizam, oni bi pozdravili „,narodni socijalizam“: „S tim se mi nipošto ne ogradjujemo i proti pravednim socijalnim reformama, koje ima na programu socijalna demokracija - mi želimo socijalizma u Hrvatskoj, no socijalizma hrvatskog, srpskog, narodnog!“6797

Dakako da je kao kontrapunkt njemačkoj kulturi i politici - u smislu uzora za Južne Slavene - postavljena češka politika i kultura. Najjači utjecaj praške skupine mladih vidi se upravo u aproprijacijama čeških kretanja. Narodna misao tako se pozicionira kao list koji u Hrvatskoj najsnažnije zagovara aproprijacije čeških strujanja. Od 12. broja objavljuje se opsežno „Praško pismo“ s pregledom češkog političkog života, u 18. i 19. broju piše se o češkom realizmu i o češkoj „političkoj organizaciji“, a učestali su i prijevodi Masarykovih tekstova. $^{798}$

Najveći iskorak u usporedbi $\mathrm{s}$ ranijim almanahom list Narodna misao donosi na području kulture. U podlistku se objavljuje književna produkcija, ali i pregledni članci. ${ }^{799}$ Osim podlistka, list je imao zasebnu rubriku s kazališnim prikazom u kojemu su bile zastupljene scene u Zagrebu, Beogradu i Ljubljani. Iskorak je ostvaren i u širenju opsega tema. Tako se donosi vrlo opsežan prikaz izložbe V. Vereščagina u Zagrebu, a posebno je zanimljiv tekst posvećen narodnoj glazbi jer na najbolji način oprimjeruje odnos spram umjetnosti općenito. Narodna glazba promatra se kroz nacionalno-romantičarsku perspektivu: ona je produkt narodne duše i zato svaki narod razvija svoju specifičnu narodnu glazbu, koja

\footnotetext{
795 „Germanski šovinizam i naši kulturni zadaci“, Isto, I, 5.

796 „Što mi hoćemo“, Isto, I, 24.

797 „Socijalna demokracija i medjunarodna politika“, Isto, I, 17.

798 „Češka kriza“, Isto, I, 16 i d.; „Politički zahtjevi“, Isto, I, 26 i 27.

799 Tako npr. od 5. broja gotovo kontinuirano podlistak zauzima tekst A. K. Gorjančeva, „Slovensko pjesništvo u najnovije doba (1890. - 1898.)“.
} 
ovisno o svojoj kvaliteti pridonosi razvoju svjetske civilizacije. ${ }^{800}$ Mladi se stoga zalažu za uzdizanje narodne glazbe što je ujedno zalog za razvoj narodne kulture, ali i doprinos čovječanstvu u cjelini. Zadatak uzdizanja narodne glazbe prvenstveno pada na pleća „narodnog glazbenika“. Analogno „,narodnim političarima“, zadatak je „narodnih glazbenika“ da na temelju „prirodne narodne glazbe“ stvore „specijalnu umjetnu narodnu glazbu“. 801 Drugim riječima, narodni je glazbenik ,samo onaj koji je tačno proučio i shvatio onaj velebni glazbeni materijal, što mu ga pruža sam narod, i koji je taj materijal upotrebio za osnov svomu daljnjemu radu. Za narodnoga glazbenika vrijedi dakle ono isto što i za narodnoga književnika narodnoga pravnika i. t. d.“" ${ }^{802}$ Zagrebački mladi tako ovdje razvijaju specifičan podtip nacionalnog aktivista $\mathrm{i}$ intelektualca koji je specijaliziran za glazbu, a sličan podtip bi trebao postojati za svako područje javnog života. U nastavku se predlaže i konkretan program razvoja narodne glazbe, od temeljne glazbene obuke u narodnom duhu, preko učestalijeg izvođenja „prirodne narodne glazbe“, pa sve do stvaranja vrhunske „umjetne narodne glazbe“. ${ }^{803}$ U svemu tome važnu je ulogu imala djelatnost F. Ks. Kuhača, njegova zbirka narodne glazbe, priručnik za učenje glasovira, kao i koncepcije o narodnoj glazbi općenito.

Književna je produkcija u Narodnoj misli uglavnom tendenciozna i kao jedini književni reprezentant mladih pojavljuje se Živan Bertić sa svojom crticom „Sa sela“. Nasuprot tome, tekstovi su o književnosti u listu iznenađujuće modernistički nastrojeni. Tako se u članku „Nova vlast“ brane moderna načela književnosti, a kritici podvrgavaju ona tradicionalna i realistička/naturalistička: umjesto Aristotela i Tainea, trebalo bi prigrliti Brandesa i Tolstoja. ${ }^{804}$ Zazivajući ,vlast umjetnosti“, u tekstu se velika važnost stavlja na ulogu književne kritike, što je ponovno karakteristično obilježje moderne. Dakako da je konačni cilj „narodna literatura“ koja - baš kao i „umjetna narodna glazba“ - predstavlja na kvalitetan umjetnički način obrađeni materijal narodne „duše“ i života, kao specifično dostignuće koje je ujedno doprinos univerzalnoj ljudskoj kulturi. Uz ovaj, potrebno je istaknuti i utjecajan tekst Ivana Krnica, „Hrvatska kritika“, u kojem analizira i podvrgava kritici različite varijante književne kritike prisutne u Hrvatskoj: „službena“ (koju veže uz Maticu i njezin poguban monopolistički položaj), „nadgrobna“, ,strančarska“ i ,,aristokratska“

\footnotetext{
800 „Narodna glazba“, Isto, I, 9.

801 Isto.

${ }^{802}$ Isto.

${ }^{803}$ Isto, br. 10.

804 „Nova vlast“", Isto, I, 26.
} 
(odnosno akademska). Umjesto njih, Krnic se zalaže za „dobru, pravednu, iskrenu i zdušnu“ kritiku čiji bi primarni zadatak bio obrazovanje čitalačke publike. ${ }^{805}$

Neovisno o tome, opravdano se može postaviti pitanje može li se uopće o Narodnoj misli govoriti kao o modernističkom listu? I po svojem formatu i sadržaju ona više odgovara tradicionalnom političkom dnevniku, nego modernističkoj reviji s prijeloma 19. i 20. stoljeća. U najboljem se slučaju stoga može govoriti o modernističkim impulsima u njezinu sadržaju, međutim, i oni su ograničena dosega. Ako izuzmemo ideju narodnog jedinstva Srba i Hrvata, Narodna misao nema drugih koncepata koji bi povezivali raznolike segmente - politiku, ekonomiju i kulturu - u jedinstvenu cjelinu. Ova ideja pak sama po sebi nema modernistički sadržaj, nego ga u ideologiji praških mladih dobiva tek u kolopletu s drugim modernistički impostiranim konceptima. Zbog toga što je u vizuri zagrebačke skupine mladih ideja narodnog jedinstva izrazito dominantna, ona je zasjenila sve aproprijacije modernističkih kretanja koji čine ključan inovacijski element ideologije mladih te ih je svela na sporadične $\mathrm{i}$ međusobno nepovezane pojave. Nije stoga čudno što se Narodna misao čita kao jedan ne posebno inovativan zagrebački politički list, $\mathrm{s}$ povremenim iskakanjima izolirana modernističkog sadržaja.

Izdavanje ovakva lista u Zagrebu pokazalo se kao iznimno težak zadatak. Tomu svakako nije pomoglo to što je Narodna misao u svojem 10. broju na naslovnici objavila otvoreno pismo F. Potočnjaka upućeno grofu Khuenu u kojemu ga indirektno naziva „prostom varalicom“ i koje završava povikom „Dolje infamni!‘"806 Milan Marjanović navodi kako su svi brojevi Narodne misli, osim prvoga, bili plijenjeni. ${ }^{807}$ Sama se redakcija više puta u listu žalila na pritiske, zapljene i cenzuru, a ujedno je i objavljivala članke u kojima se zalaže za slobodu štampe i sastajanja, koji su također bili cenzurirani. ${ }^{808} \mathrm{U}$ zadnjem broju Narodne misli objavljena je obavijest o privremenoj obustavi izdavanja lista. Nakon konstantne cenzure i zapljene, nakon zabrane uvoza lista u Cislajtaniju i Bosnu i Hercegovinu, nakon opstrukcija austrijske pošte u vezi pošiljki za Crnu Goru te zabrana pojedinih brojeva u Srbiji, naposljetku je listu uskraćen i postdebit, a sve je to primoralo uredništvo da privremeno obustavi izdavanje lista koje očito nije moguće u Banovini pod postojećom vlasti. ${ }^{809}$ Osim vlasti, uredništvo misli proziva i „patriotičnu štampu“ zbog njezine uloge u gašenju Narodne misli. Privremena je obustava ipak na kraju postala trajna. Potočnjak se više nije upuštao u

\footnotetext{
${ }^{805}$ Ivan Krnic, „Hrvatska kritika“, Isto, I, 23.

806 „Otvoreno pismo Gospodinu Dragutinu grofu Khuen-Hedervaryju“, Isto, I, 10.

${ }^{807}$ Marjanović, Hrvatska moderna I, 34.

${ }^{808}$ „Na obavijest“, Isto, I, 11; „Našim čitaocima“ Isto, I, 15; „Javno mišljenje i javni zborovi“ Isto, I, 6; „Sloboda štampe“ Isto, I, 9.

809 „Našim čitaocima“, Isto, I, 27.
} 
obnovu lista, a njegovi su odnosi s mladima - posebice s pražanima - s vremenom postali hladniji. Najaktivniji dio zagrebačkih mladih nastavio je pak svoju djelatnost u suradnji s praškom skupinom na izdavanju Glasa. ${ }^{810}$

Nedugo nakon obustave izlaženja Narodne misli jedna grupa Ujedinjene omladine pokrenula je inicijativu za izdavanjem novog lista, ovoga puta u Dalmaciji. U pozivu na pretplatu na novi list Nezavisnost od 10. kolovoza 1898. godine poptisani su Josip Arambašin, Jerko Karlovac, Gjuro Pokrajac i Dušan Mangjer, koji je ujedno bio predvodnik ove skupine i glavni urednik novog lista. ${ }^{811}$ List je zamišljen kao pokušaj širenja ideja Narodne misli u Dalmaciji, gdje je problematika hrvatsko-srpskih političkih odnosa također bila izrazito aktualna. „Naš je program;““ piše se u pozivu na pretplatu, ,program ljubavi i sloge, a po tome i rada. Pozivajući sve patriote u jedno kolo hoćemo da složnim silama pomognemo šta više, da se podigne moralno i ekonomsko stanje svega našeg naroda hrvatskog i srpskog imena, osobitom pažnjom na našu Dalmaciju. “812

Nezavisnost je počela izlaziti 8. listopada 1898. u Splitu kao dvotjednik, s ciljem da u budućnosti postane tjednik. Bilo je planirano da se neki članci tiskaju na ćirilici, ali to nije bilo izvedivo iz tehničkih razloga ${ }^{813}$ Po svojoj formi ovaj je list blizak zagrebačkoj Narodnoj misli, a ideološka povezanost razvidna je već iz citata Jovana Jovanovića Zmaja, Natka Nodila i Lovre Montija koji su iskorišteni kao motto lista, a koji afirmiraju ideju narodnog jedinstva Srba i Hrvata. I u formalnom i u sadržajnom smislu Nezavisnost izgleda više kao klasični dnevno-politički list nego kao modernistički časopis. Osim standardnog uvodnika, njegove su stranice ispunjene polemičkim političkim komentarima, vijestima iz Dalmacije i Hrvatske, Austro-Ugarske te drugih (južno-)slavenskih zemalja, člancima o društvenim pitanjima, književnim prikazima i podlistkom. Kvaliteta je tekstova, međutim, niža nego u ostalim listovima pokreta mladih, te se može reći kako se određene ideološke postavke mnogo više reproduciraju kao fraze, nego kao promišljeni analitički i programski tekstovi.

Programatski uvodnik iz prvog broja lista jasno navodi ideju narodnog jedinstva Srba i Hrvata kao temeljnu ideju vodilju Nezavisnosti. ${ }^{814}$ Krug oko Nezavisnosti želi primijeniti ideje razvijene u almanahu Narodna misao na situaciju u Dalmaciji i kao analitički aparat i kao politički projekt. Kao što se hrvatsko-srpski spor u Hrvatskoj i Slavoniji iz vizure Narodne misli javio kao devijacija ideja ilirizma i Račkijeva jugoslavenstva, tako je i u Dalmaciji

\footnotetext{
${ }^{810}$ Isto.

811 „Gospodine“, HR-AHAZU-KN-44 Dežman, Milivoj, k. 6.

${ }^{812}$ Isto.

813 „Našijem prijateljima“, Nezavisnost, I, 1.

814 ,Spljet, 8. Oktobra“, Isto.
} 
trenutna situacija političke razdvojenosti (u hrvatsku Narodnu stranku i Srpsku stranku) napuštanje izvornih i uspješnih principa narodnog preporoda u Dalmaciji iz 1860-ih. U suprotnosti s praškom skupinom, za Nezavisnost je pitanje hrvatsko-srpskih odnosa primarno i krucijalno pitanje hrvatske politike, nakon čega tek dolaze problemi socijalnog i ekonomskog napretka: „Uzalud je samo govoriti o socijalnom i ekonomskom napretku sve dotle, dok se ne riješi ovaj nesretni, ovaj zlokobni spor srpsko-hrvatski, a smiješno ga je pak ne priznati kad je on tu, kad postoji. “815 Ona dakle na fundamentalnoj razini ne povezuje nacionalno i socijalno pitanje, što je bio ključan iskorak praških mladih na polju politike, nego zapravo nastupa upravo na onaj način koji je naišao na žestoku kritiku mladih, a koji se sastoji u primatu nacionalno-političkog nad svim ostalim sferama života. Ovaj fokus na nacionalno pitanje, zajedno sa žurnalističkom formom lista, utjecao je na pad njegove analitičke kvalitete, što se jasno očitovalo u brojnim tekstovima koji se uglavnom temelje na ponavljanju patetičnih fraza bez posebne socijalno-političke analize koja je ipak bila prisutna u većini tekstova praške skupine. ${ }^{816}$ Osim toga, ponovno karakteristično za zagrebačke mlade, a protivno idejnim postulatima praške skupine, krug oko Nezavisnosti uvelike se oslanja na autoritet starih, pa tako osim već navedenih citata koji su služili kao motto lista donosi i zasebnu rubriku „Misli i izreke“ u kojoj prenosi citate istaknutih javnih ličnosti koji idu u prilog ideji narodnog jedinstva Srba i Hrvata, kao što su J. J. Strossmayer, B. Bogišić, M. Polit Desančić, E. Barčić itd. ${ }^{817}$ Dapače, uvodnik drugoga broja lista bio je posvećen pjesniku Jovanu Sundečiću, koji je splitskoj Ujedinjenoj omladini uzvratio pjesmom. ${ }^{818}$ Ujedinjena omladina u Splitu izdala je i brošuru Zadnja riječ $d r$. Lovra Monti-a, koju je reklamirala na stranicama Nezavisnosti, skupa s almanahom Narodna misao.

Dakako da su ubrzo nakon pokretanja Nezavisnosti uslijedili napadi i kritike, mahom identični kao oni upućivani ranijim časopisima mladih: od pravaške kritike ideje narodnog jedinstva Hrvata i Srba, pa do narodnjačke kritike drzovitosti mladih koji još nisu spremni za ozbiljno bavljenje politikom. ${ }^{819}$ Kada je riječ o politici Banske Hrvatske, krug oko Nezavisnosti bio je kritičan spram sve tri hrvatske opozicijske stranke. Za njih su sve one de facto bile starčevićanske, uključujući i obzoraše, koji su iznevjerili misli ilirizma i jugoslavenstva. ${ }^{820}$ Napuštanje izvornog ilirskog i jugoslavenskog programa, kao i otuđivanje omladine, učinilo je od njih impotentnu opoziciju te je omogućilo Frankovoj Čistoj stranci

\footnotetext{
${ }^{815}$ Isto.

${ }^{816}$ Vidi npr. „Nezavisnosti“ ili „Svetozar Miletić“, Isto.

${ }^{817}$ Isto.

818 „Jovan Sundečić““, Isto, br. 2; „Omladini okolo časopisa 'Nezavisnost'“, Isto, br. 3.

819 „Spljet, 21. Oktobra“, Isto, br. 2.

820 „Prilike u Hrvatskoj“", Isto, br. 3.
} 
prava da se razmaše i pobijedi na recentnim izborima za zagrebačko gradsko zastupstvo. Uzalud Obzor plače iz Zagreba kako je ovaj poraz signal za uzbunu i kako budućnost leži na mladima. Nezavisnost podsjeća urednika Obzora, Josipa Pasarića, kako je do nedavno napadao listove mladih i kako je puhao u isti rog sa Stjepanom Korenićem, urednikom Katoličkog lista. ${ }^{821}$

Neuspjesi opozicije u Banskoj Hrvatskoj trebali su poslužiti kao poučan primjer za hrvatske i srpske stranke u Dalmaciji. Fragmentacija i međusobna svađa mogu jedino doprinijeti uspjehu autonomaša i drugih nenarodnih političkih opcija. Nezavisnost se posebice okomljava na pravaše koje smatra odgovornima za neuspjeh dogovora oko zajedničkog hrvatsko-srpskog kandidata u Dubrovniku na izborima za Carevinsko vijeće, zbog čega su Srbi koalirali s autonomašima i pobijedili. ${ }^{822}$ Za krug oko Nezavisnosti formula za uspješnu narodnu politiku u Dalmaciji je jednostavna: ponovno ujedinjenje hrvatske i srpske politike u okviru obnovljene Narodne stranke. Zanimljivo je, međutim, da je Nezavisnost pritom kritički nastupala prema „starom zadarskom prevrtljivcu“, Narodnom listu i njegovu zagovaranju korištenja njemačkog kao kulturnog jezika umjesto talijanskog s ciljem ostvarenja veće materijalne koristi. ${ }^{823}$ Za krug oko Nezavisnosti takva je politika neprihvatljiva, ne samo zato što se kulturni jezici ne biraju, nego izranjaju kao produkt povijesnog razvoja, već i zato što je talijanski jezik, premda dominantan uglavnom među građanstvom i često suprotstavljen narodnim interesima, ipak oplemenio i obogatio nacionalnu kulturu: „Ne samo da nas talijanski jezik ne plaši, već smo za to da se taj jezik, poslije materinjeg nam, najviše uči, da se u našim školama mjesto njemačkog ustupa više pomnje i više pažnje talijanskom jeziku. Jer smo uvjereni da će omladina naša uz lijepe talijanske knjige naučiti kako se ljubi domovinu i svoj narod.“" ${ }^{824}$ Jasno je ipak da prava narodna kultura počiva među težačkim stanovništvom, koje mahom koristi narodni jezik. ${ }^{825}$ Ipak, ovdje se jasno očituje refleks općeg antigermanskog sentimenta među mladima, barem onoga dijela bližeg praškim političkim strujanjima, koji je u širenju utjecaja njemačkog jezika i kulture vidio opasnost razaranja narodne kulture kao temelja obrane od njemačkog Dranga.

Budući da je u programatskom uvodniku za Nezavisnost kao prioritet lista postavljeno širenje ideje narodnog jedinstva Srba i Hrvata, nije čudno što se socijalna i ekonomska

\footnotetext{
${ }^{821}$ „Glas iz Zagreba“, Isto. Ne treba niti spominjati kako je krug oko Nezavisnosti bio jasno neprijateljski nastrojen prema Khuenovu režimu. Ipak, iako bi ime lista moglo sugerirati drugačije, zanimljivo je da je u svojem petom broju od 5. prosinca 1898. godine objavio izrazito lojalistički članak povodom pedesete vladarske obljetnice Franje Josipa. V. „Spljet, 3. Decembra“, Isto, br. 5.

822 „Spljet, 30. Prosinca“, Isto, br. 7.

${ }^{823}$ „Kulturni jezik“, Isto, br. 4.

${ }^{824}$ Isto.

${ }^{825}$ Isto.
} 
problematika našla u drugom planu. Osim nekolicine gospodarskih vijesti, najistaknutiji su članci na tu temu „Domaće radništvo“ i „Naš seljak“. Dok potonji razmatra porazno stanje na dalmatinskom selu, koje dakako i za krug oko Nezavisnosti sačinjava nacionalni ideološki supstrat, autor u članku „Domaće radništvo“ - za koje je doduše uredništvo napomenulo da se ne slaže sa svime u njemu izrečenim - kritički se osvrće na konkurenciju talijanskog radništva koje je mnogo bolje osposobljeno nego domaći radnici. ${ }^{826}$ Nekontrolirana proletarizacija hrvatskog sela i sitnog obrtništva ne prijeti samo u pogledu slabije konkurentnosti u usporedbi sa stranim radnicima, nego i u pogledu širenja utopijskih ideja, te „strašne falange internacijonalizma“. ${ }^{827}$ Rasprava se o socijalnim i ekonomskim temama tako i ovdje vodi dominantno u nacionalnom ključu, s jasno izraženim neprijateljstvom prema socijalizmu, što nije karakteristično za većinu tekstova mladih.

I u domeni kulture Nezavisnost jasno ističe primat nacionalnog pitanja. Raspravljajući o osnivanju Narodnog kazališta u Splitu, list se zalaže za moderni, ali ipak u prvom redu narodni repertoar. Program Narodnog kazališta trebao bi na neki način biti narodno jedinstvo na daskama, tendenciozno propagirajući ovu nacionalno-političku ideju. ${ }^{828}$ Jednako tako, izvještavajući o slikarstvu i djelatnosti Vlahe Bukovca, Nezavisnost ističe kako se nada da će on kao Dubrovčanin uspjeti spojiti Srbe i Hrvate na umjetničkom polju. ${ }^{829}$ Osim toga, na stranicama Nezavisnosti preštampane su i rasprave Dragutina I. Ilijića i Ksavera Šandora Gjalskog iz Vienca o ideji hrvatsko-srpskog književnog jedinstva, kao i rasprava I. Ćipika koji se pridružuje inicijativi iz dalmatinske perspektive, upozoravajući na tamošnje posvemašnje književno mrtvilo na narodnom jeziku. ${ }^{830}$ Zanimljivo je, međutim, da iako je propagirala nacionalno tendencioznu umjetnost, Nezavisnost se ujedno nije libila stati u obranu modernističkih autora na udaru kritike, kao što je primjerice Vladimir Jelovšek, čiju poeziju donose i u podlistku, ali i secesijske izložbe Hrvatski salon, koja je bila u središtu polemike modernista i antimodernista te godine. ${ }^{831}$ Slično kao Narodna misao, ona stoga prati moderna kretanja, ali sporadično, nekoherentno i samo u domeni kulture, ne povezujući ih s političkom i socijalnom dimenzijom. Kao i u slučaju Narodne misli, može se stoga zaključiti da Nezavisnost nije bila modernistički, nego tipičan politički list, koji je očitovao povremene, nekonzistentne i nepovezane modernističke utjecaje.

\footnotetext{
${ }^{826}$ „Naš seljak“, Isto, br. 5, 6, 7, 8; „Domaće radništvo“, Isto, br. 4.

${ }^{827}$ Isto.

828 „Narodno pozorište u Spljetu“, Isto, br. 3.

829 „Vlaho Bukovac“, Isto.

${ }^{830}$ Isto, br. 5, 6, 8 .

${ }^{831}$ Isto, br. 5, 7, 8 .
} 
Jezgra pokreta mladih, koja je u razdoblju izdavanja Nezavisnosti radila na ranije opisanim ambicioznim planovima za nove listove i projekte, nije bila njome pretjerano oduševljena. Vladimir Jelovšek tako ju je opisao kao „dnevno političarenje“ i „visoko politizovanje““ ${ }^{832}$ Ono što zapravo najviše upućuje na odnos jezgre pokreta prema ovome projektu dijela Ujedinjene omladine jest njegovo gotovo potpuno odsustvo iz planova, razgovora i korespondencije, kao i kasnijih sjećanja i prikaza tijeka pokreta. A s obzirom na kratkoću njezina izlaženja, Nezavisnost nije ostavila dubljeg traga niti u javnome prostoru Dalmacije. Završavajući s 8 . brojem od 14. siječnja 1899. godine, bez nekog posebna objašnjenja, ovaj list bio je posljednji samostalni projekt (dijela) Ujedinjene omladine, koja će se ponovno združiti s praškom skupinom oko pothvata izdavanja lista Glas. Pokušaj da Split postane novo žarište modernističkog pokreta mladih nije uspio, ali je zato 1898. godinu obilježio proplamsaj u Beču, koji će pokrenuti jednu od najvećih polemika hrvatske javnosti u 19. stoljeću.

Primjer Narodne misli i Nezavisnosti pokazuje koliko je formativni kontekst bio važan za intenzitet i načine aproprijacija modernističkih strujanja. Udaljeni od Praga i Beča kao centara intelektualnih posredovanja, uronjeni u kontekst hrvatske dnevne politike, zagrebački su mladi primali intelektualne poticaje svojih kolega na vrlo jednostran način. Dakako da je to poprilično variralo od pojedinca do pojedinca. Lorković i Pribićević su tako svakako iskakali od ostatka po pitanju razumijevanja i usvajanja suvremenih strujanja. Ne treba isključiti niti to što su oni u svojem radu bili upućeni na suradnju s predstavnicima starih. Na neki način, oni nisu imali luksuz bespoštedne kritike iz daljine kao praški mladi, ako su htjeli postići nešto u tadašnjem trenutku. Sama činjenica da su bili locirani u Zagrebu i Splitu stoga je bila sporedna. I đački je modernistički krug primao modernistička strujanja iz daljine, ali neopterećeni pritiskom dnevne politike i utjecaja oporbenih prvaka. Formativni kontekst ne sačinjava stoga puko mjesto u kojem se odvija, nego milje, koji tvori specifični intelektualni i društveni kontekst.

\section{3. Bečka i hrvatska moderna}

Tijekom 1897. godine Prag se definitivno etablirao kao vodeći centar hrvatskog modernističkog pokreta mladih. Bečki Zvonimir, tradicionalno središte hrvatskih studenata, i

\footnotetext{
${ }^{832}$ „Vladimir Jelovšek - Draganu Šašelu, Prag, 6. XII. 1898.“, u: Krizman, nav. dj., 333.
} 
dalje je bio u krizi. Iako su se i unutar njega razvijale „novosmjeraške“ snage, dotad dominantni pravaši i dalje su bili dovoljno utjecajni da blokiraju bilo kakav produktivni rad društva. U takvoj situaciji, bilo kakva „,novosmjeraška“ inicijativa mogla je jedino poprimiti oblik projekta grupe pojedinaca. Iako su svi priznavali prašku Hrvatsku misao kao središnji list mladih, određeni dio njih nije njome bio pretjerano zadovoljan. Prema Franu Hrčiću, ona je zadovoljila samo dio nada koje su se u nju polagale. ${ }^{833}$ Neki su mislili da je list suviše politički orijentiran, smatrajući da bi za mlade bilo mnogo bolje da svoju pažnju usmjere na modernistička strujanja na području kulture, napose književnosti, te da bi stoga bilo poželjnije kada bi se započelo s izdavanjem lista koji bi zapravo nastavljao tradiciju dotadašnjih studentskih literarnih publikacija, ali s novim, modernističkim sadržajem. Drugi su pak prigovarali Hrvatskoj misli da je iznevjerila svoju sveobuhvatnu programatsku osnovu koja je trebala uključivati i umjetnost. I doista, osim dva vrlo važna teorijsko-programatska članka o književnim pitanjima te nekolicine kritičkih prikaza i bilježaka, književnost je ostala na margini interesa praške skupine mladih i Hrvatske misli, a književne produkcije, iako najavljene, na njezinim stranicama nije bilo.

Jedna grupa bečkih studenata odlučila je stoga pokrenuti vlastiti list koji bi se fokusirao upravo na područje moderne umjetnosti. Zapravo je riječ o ponovnom oživljavanju ideje lista koju je već u svojim pripremama za II. opći đački sastanak elaborirao Dušan Plavšić (v. drugo poglavlje ovog rada). Malobrojni inicijatori novog lista bili su, osim Plavšića, bečki studenti Guido Jeny, Vladoje Schmidt Jugović, Viktor Tausk ${ }^{834}$ i Oto Kraus, a važnu ulogu odigrao je i bivši bečki student, zagrebački liječnik, pisac i političar Milivoj Dežman. Ovome inicijativnome krugu u provedbi projekta pridružit će se i druga važna imena modernističkog pokreta, kao što su Fran Hrčić, Ivo Pilar i Artur Benko Grado.

U svojoj nedovršenoj i neobjavljenoj autobiografiji, jedan od inicijatora lista, Guido Jeny, opisao je svoje razloge za pokretanje novog lista mladih. Za njega manjkavost Hrvatske misli nije bila samo u njezinu ignoriranju književne dimenzije, nego i u samom shvaćanju politike koje su propagirali praški mladi: „Ja sam žestoko agitirao za socijalizam među našim đacima i bio sam protivan onakvoj državnopravnoj politici, kakvu su tjerale hrvatske stranke, pak je po mom sudu i politika 'Hrv. misli' bila prejednostrana. Ona se tek bila modernizirala pod uplivom naprednih Čeha. Ja sam bio za takvo publicističko djelo, koje bi obuhvatilo sav

\footnotetext{
833 „F. Hrčić - D. Plavšiću, 12. 8. 1897.“, Uredništvo časopisa Mladost R7134, NSK.

${ }^{834}$ Naveden kao H. Tausk, ali je zasigurno riječ o Viktoru Tausku. Vidi: Branimir Donat, „Viktor Tausk, Sigmund Freud i hrvatska moderna okupljena oko zagrebačko-bečkoga časopisa Mladost", Književna republika V, 3-4, 2007, 68-90.
} 
socijalni i kulturni život, a ne samo nacionalističku politiku. “835 Za Jenyja, Hrvatska misao i dalje je predstavljala deklamatorsku politiku; ,,kolikogod modernije misli i govori, ipak pliva starim vodama pustih političkih teorija, snova i metoda isključivo nacionalističkih." ${ }^{836}$

Ova važna opaska sugerira kako razlike među mladima nisu bile samo u naglasku na politiku ili književnost, nego u posve različitu shvaćanju i jedne i druge. Praški su mladi svoja nova politička, društvena i kulturna shvaćanja stjecali u okruženju koje je uvelike definirala nacionalistička politika i sukobljeni nacionalni pokreti Čeha i Nijemaca, pa su stoga i njihove aproprijacije mogle biti primijenjene na hrvatsku (i jugoslavensku) nacionalističku političku i kulturnu matricu. Aproprijacije su pak hrvatskih bečkih studenata obilježene upravo antinacionalističkim sentimentom s mnogo izraženijim utjecajem socijalističkog internacionalizma i bečkog modernističkog kozmopolitizma. Zbog toga će se upravo na ovom pitanju odnosa prema nacionalnom razviti najsupstancijalna polemika kako sa starima, tako i među mladima samim.

Zbog svih tih razlika u shvaćanjima, Jeny je smatrao kako se novi list mladih treba kloniti uskog političkog određenja te kako treba imati univerzalno obilježje. Svaki suradnik morao bi imati slobodu da iznese svoje mišljenje, neovisno o tome odgovara li ono jezgri pokreta. Sve što treba zahtijevati jest „stvarnost i ozbiljnost shvaćanja modernih problema“, čime će se „sami eliminirati zaostali i natražnjački elementi.“" ${ }^{837}$ Drugim riječima, mladi ne bi trebali zagovarati određenu - socijalističku, nacionalističku, liberalnu, dekadentsku i dr. modernost, nego modernost kao takvu, modernistički habitus i stav te okrenutost sadašnjosti i budućnosti.

Dobru formulaciju idejnih osnova i programa koji su lebdjeli pred očima pokretača Mladosti dao je Fran Hrčić u svojem pismu Plavšiću:

„Program lista ima biti takav, da literarni historik, koji će pisati makar i ne posve minucijoznu povjest hrv. literature, ne će smjeti ni moći mimoići ovaj list! [...] Mi hoćemo preporod naše knjige, mi hoćemo novo u literarnoj i socijalnoj kritici. Mi hoćemo, da ovim korakom prekoračimo svu našu mizeriju na tome polju i da se tim korakom postavimo na stupanj ostale prosvijećene mladosti drugih naroda. Mi želimo prebroditi sve dosadanje literarne etape od klasicizma pa do naturalizma (koji je i u nas sad već u cvijetu) i hoćemo da

\footnotetext{
835 „Opis života Guida Jeny-ja starijega, rođ.g.1875.“, 7-8, HR-AHAZU-KN-80 Jeny, Guido st.

${ }^{836}$ „Iz Jenyjevih memoarskih zapisa“, u: Marijanović, nav. dj., 186.

${ }^{837}$ „Opis života Guida Jeny-ja starijega, rođ.g.1875.“, 8.
} 
poput drugih inteligentnih ljudi u Evropi pogjemo u potragu za onim formama, koje sad traži čitav naobraženi svijet." ${ }^{838}$

Hrčić je također predlagao da se list zove Mlada Hrvatska ili Kolo po uzoru na Stanka Vraza, smatrajući da bi ime Mladost moglo imati negativne konotacije za hrvatsku javnost te da bi ograničavalo polje njegova djelovanja. ${ }^{839}$

O ovoj je problematici u svojim memoarima pisala i Vilma Vukelić, tada osamnaestogodišnjakinja koja je poznavala Plavšića, čiji je otac bio prijatelj i suradnik njezina oca, a za kojega kaže da joj je davao modernističku literaturu, kao npr. minhenski modernistički časopis Jugend. Ona ističe kako su ti osječki bečki studenti, ,inficirani duhom koji je vladao u Beču“, pokrenuli list kojim su ,pokušali književnosti vratiti njezino internacionalno značenje i zadaću, onaj duh pomirenja koji svakom narodu ostavlja njegovu osobitost, ali istovremeno u stalnim interakcijama približava književnost drugim narodima i time pospješuje razumijevanje i uzajamno pomirenje.“ ${ }^{(840}$ List se jednim dijelom oslanjao na bečku modernu, a drugim na socijaldemokratske ideje koje su očitovali studenti okupljeni oko udruženja Sloga.

I doista, osim po onome što su čitali, knjižara koje su pohodili - gdje bi razgovarali o najnovijim literarnim trendovima - ali i neizostavnih bečkih kavana, ovi su utjecaji razvidni i iz tvrdnje Jenyja kako su on i Plavšić išli po radničkim skupštinama i sastancima radničkih obrazovnih društava, po knjižarama i po izložbama i galerijama. ${ }^{841}$ Jeny pripovijeda kako je do ideje pokretanja bečke Mladosti došlo tijekom razgovora između njega, Dušana Plavšića i Vladoja Schmidta Jugovića o praškoj Hrvatskoj misli. Razočarani time što se u Hrvatskoj nije pokrenuo moderni list, odlučili su preuzeti inicijativu u svoje ruke. ${ }^{842}$ Jeny se nadao da bi do financijskih sredstava mogli doći preko bankarskih veza Plavšićeva oca, predsjednika osječke Trgovačko-obrtničke komore. Međutim, Schmidt-Jugović se tada ponudio da financira projekt nasljedstvom svoje tetke (kojoj je za volju dodao prezime Jugović), te da će ujedno kao dioničar zagrebačke Dioničke tiskare tamo isposlovati povoljne uvjete za štampanje lista. S tako postavljenom financijskom osnovom, krenuli su u projekt pokretanja modernističkog lista Mladost.

U retrospektivi, Jenyju se činilo da su u svojem mladenačku entuzijazmu malo previše zagrizli, te da njihov rad nije bio dovoljno organiziran i promišljen kako bi se pothvat mogao

\footnotetext{
838 „F. Hrčić - D. Plavšiću, 19. 9. 1897.“, Uredništvo časopisa Mladost R7134, NSK.

839 „F. Hrčić - D. Plavšiću, 3. 11. 1897.“, Isto.

${ }^{840}$ Vilma Vukelić, Tragovi prošlosti, Zagreb, 2003, 300, usp. također 321-350.

841 „Iz Jenyjevih memoarskih zapisa“, u: Marijanović, nav. dj., 186.

${ }^{842}$ „Opis života Guida Jeny-ja starijega, rođ.g.1875.“, 8.
} 
uspješno održati. Načelni je dogovor bio taj da će se Plavšić baviti pjesništvom i beletristikom, a Jeny likovnom umjetnošću, filozofijom, znanošću, tehnikom, socijalnim i gospodarskim pitanjima. Razgovora o političkim temama su se uglavnom skanjivali. Prešutna pretpostavka je bila da nisu bili zadovoljni politikom hrvatskih stranaka te da su stoga propagirali reforme i napredne pokrete. Jeny, međutim, ističe kako je mnogo više razmišljao o tim temama od Plavšića. Zanimljiva je diskrepancija između ovog dvojca koju on opisuje u svojim sjećanjima:

„Prema svemu tomu ja sam zauzimao veoma kritičan stav. Mrzio sam iz dna duše stihotvorce ('pjesnike') [...] Meni se tada vidjelo, da 'pjesnici', 'moderni pjesnici', osobito u nas, hoće zvučnim i gromkim stihovima skriti nedostatak misli i sadržaja. S najvećim bih prezirom i gnušanjem slušao i čitao o 'modernim smjerovima', 'stilovima', 'individualitetima' i koječem u 'pjesništvu', 'literaturi', 'umjetnosti' itd. [...] U tom sam bio protivan Plavšiću koji je često lebdio u pjesničkim i političkim oblacima, u estetskim fumisterijama. Zbog toga bi često rekao: Ne treba nam nikakve 'literature'. Htio sam time reći: Ne treba nam praznih riječi, nego zdravo, sadržajno štivo. Ne treba nam takvih ljudi koji se znadu praviti važnima, već takvih koji će se požrtvovno boriti i ozbiljno raditi.“"843

Ove dvije osobe koje su činile pokretačku jezgru Mladosti stoga su na neki način utjelovljivale upravo ona dva idejna utjecaja koja je Vilma Vukelić istaknula kao ključna za Mladost: bečku modernu (Plavšić) i socijaldemokratska strujanja (Jeny). Iz toga je proizlazilo njihovo različito poimanje i umjetnosti i politike, ali ono što ih je povezivalo, sačinjavajući idejni temelj Mladosti, jest težnja za aproprijacijama modernih strujanja na svim poljima ljudske djelatnosti, te vjera u otvoreni, kritički dijalog kao osnovu za diseminaciju tih strujanja i ideja.

Važna osoba u organizaciji projekta Mladosti bio je Milivoj Dežman, koji je igrao ulogu zagrebačke veze bečkog uredništva. On je još ranije imao ideju da bečki studenti pokrenu književni časopis zajedno s učenicima okupljenima oko Nade. ${ }^{844}$ Fran Hrčić je čak bio predlagao da se uredništvo ipak premjesti u Zagreb te da ga preuzme Dežman, koji je već bio relativno etabliran u književno-umjetničkim krugovima, započeo je liječničku karijeru pa je u tom pogledu bio samostalan, te je imao kontakte u Dioničkoj tiskari. ${ }^{845}$ Iako je isprva bio sklon takvoj ideji, nakon što mu je Plavšić ponudio uredništvo kao osobi koja je bila najpozvanija da bude vođa pokreta, Dežman je naposljetku odbio, pristajući na to da preuzme

\footnotetext{
843 „Iz Jenyjevih memoarskih zapisa“, u: Marijanović, nav. dj., 186.

${ }^{844}$ Flaker, Časopisi, 28.

845 „F. Hrčić - D. Plavšiću, 19. 9. 1897.“, Uredništvo časopisa Mladost R7134, NSK.
} 
poslove oko tiskanja lista u Zagrebu te da pomogne suradnjom i savjetima. ${ }^{846}$ Milivoj Dežman se tako ponovno pojavljuje kao iznimno važna osoba pokreta, u kojoj su se presijecali kontakti raznih skupina mladih, kao i kontakti između mladih i starih. ${ }^{847}$

U sklopu priprema za izdavanje lista, uredništvo se pismima obratilo brojnim istaknutim domaćim i stranim autorima s pozivom na suradnju. Nacionalna i sveučilišna knjižnica u Zagrebu čuva brojnu korespondenciju uredništva s raznim važnim osobama tadašnjeg književnog života koji su se na ovaj ili onaj način odazvali pozivu. Antun Gustav Matoš tako se npr. složio s Jugovićem da je ,zastarjela struja u svim našijem listovima. I u literaturi - da ne spominjem politike - držimo se mi europske mode od prije dvadesetak godina“, ustupajući pritom uredništvu svoje kontakte u Srbiji. ${ }^{848}$ Brojni poznati europski autori odgovorili su na poziv za suradnju, među njima Louis Léger, Jules Lemaître, Émile Zola, Catulle Mendès, Knut Hamsun, Tomaš G. Masaryk itd. Kontakt je uspostavljen i s krugom oko Nove nade. ${ }^{849}$ Ovakav pristup bečke skupine postat će karakterističan i za daljnje kulturne pothvate modernističkog pokreta: za razliku od pražana, koji su zahtijevali potpunu emancipaciju mladih od autoriteta, napose onih političkih, bečani su težili međugeneracijskoj integraciji na zajedničkoj platformi stilskog i misaonog pluralizma koji mora počivati na slobodi govora i mišljenja. U tom je smislu zanimljivo što su upravo oni izazvali veći otpor starih nego što je to bio slučaj s praškom skupinom.

Početkom prosinca 1897. godine iz Beča je razaslan poziv za pretplatu na Mladost: smotru za modernu književnost $i$ umjetnost. Kontrastirajući domaću situaciju sa živahnim književnim radom u inozemstvu, urednički trio ističe kako hrvatske prilike „ne daju književnosti, da proživi snažnim životom, samo u nas kao da nema živog, slobodnog daha.“ Tako se odmah na prvome mjestu pojavljuje pitanje neslobodnih hrvatskih književnih prilika koje je u svojem programatskom tekstu iz Hrvatske misli kao glavni problem istaknuo Dežman. Mladost pak želi okupiti ozbiljne ljude, koji zdravo gledaju na svijet i nastoje razviti uvjete primjerene modernom životu. Njihova je poruka jasna: oni u svoje kolo zovu i priznate borce, ali prvenstveno mlađe koji nemaju svojeg središta. Za krug oko Mladosti, mladost nije prvenstveno dobna i generacijska oznaka, nego oznaka duševnog stanja. Nasuprot mladosti, koju karakterizira istina i životni elan, stoji surovost, ,„što no se licemjerno ogrće plaštem morala i konvencijonalnih zakona“. Mladost stoji nasuprot „duševnog staraštva“, stoga su pozvani svi koji žele raditi na idejama primjerenima novome dobu:

\footnotetext{
846 „Plavšić - Dežmanu, 24. IX. 1897.“, prema: Flaker, nav. dj., 28.

${ }^{847} \mathrm{O}$ tome jasno svjedoči brojna korespondencija između Dežmana i Plavšića koja se čuva u NSK, R7134, II.

848 „Matoš - Jugoviću, 18. XI. 1897.“, Uredništvo časopisa Mladost R7134, NSK.

849 „Cihlar - Jugoviću, 1. XII. 1897.“, Uredništvo časopisa Mladost R7134, NSK.
} 
„Mi moramo da si stvorimo mišljenje, pošto ono naših otaca nije za nas; oni su ga stvorili za sebe - za svoj svijet. [...] Nama se ni najmanje ne pristoji, da pogledavamo zadovoljno na do sada stečeno; za to će biti doba u starosti. Ne kanimo rušiti, što su oni sazdali. Dičimo se stvorenim. No ne ćemo gledati prekrštenih ruku, klanjajući se prošlim vremenima. Novo doba - nove zadaće.“

Iako se u Hrvatskoj već donekle razvija moderni društveni život, pa se onda na njegovu temelju razvija i mišljenje koje tom životu odgovara, ono što nedostaje jest uistinu moderna književna produkcija, koja bi zastupala osjećaje i misli ljudi novoga kova. Mladost dakle svjesno stavlja fokus na ono što je u Hrvatskoj misli izostalo, a to je prije svega moderna književna produkcija, a onda i dominacija tema iz područja umjetnosti i kulture. U pozivu se jasno ističe da je profil lista kulturno-umjetnički, a ne politički. U tom smislu oni će se truditi da hrvatskoj publici predstave sve ,zdrave“ kulturne plodove tuđih naroda, „osobito slovjenskih“. Iako se ističe kako će se u listu donositi izvorni i prevedeni tekstovi svjetskih književnosti modernog smjera, posebno se apostrofiraju zapadni i sjeverni kulturni narodi. Orijentaciju na slavenske i nordijske književnosti posebno je zagovarao M. Dežman. ${ }^{850}$ Ovim fokusom na aproprijacije stranih književnosti modernog smjera nije se, međutim, željelo pridonijeti razvoju njihovih imitacija. Osim toga, potrebno je nadići bedem provincijalizma koji je okružio hrvatsku kulturu, te se povratiti u krug europske i svjetske literarne republike. Naposljetku, reiterirajući ideju slavenske književne uzajamnosti, to je osobito važno „u pogledu slovjenskih naroda, a po gotovo pako, što se tiče Srba, koji su nam najbliži svojim čučenjem, životom i jezikom.“

Još su dvije važne teme koje bečki mladi ističu kao fokus svojeg lista. Prva od njih tiče se ,znanstvenog nastajanja oko upoznanja istine čovječje duše i njenih kulturnih odnošaja prema prirodi i prema društvu.“ Riječ je, dakle, o tematici moderne psihologije koja je tada bila popularna tema javnih rasprava. Druga važna tema jest ona „oko naravi i društvenog položaja žene“, odnosno žensko pitanje. Ističući da „u nijednoj stvari možda ne ima toliko presuda i protunaravnih nevaljalih nazora, kao što u pogledu potreba ženske naravi“, oni konstatiraju kako se „do sada u kulturnom radu obaziralo na njih malo ili nikako, već se samo nastajalo, kako tako da ih se pokori stanju, što ga one nijesu stvorile." U tom pogledu oni se obraćaju „hrvatskim i srpskim ženama“, napose spisateljicama, da same progovore o ovom pitanju na stranicama Mladosti.

850 „Dežman - Plavšiću, nedatirano“, prema: Flaker, nav. dj., 29. 
Inicijatori lista sumirali su svoj program i cilj na sljedeći način: „Da se prokrči put slobodnoj misli, da se osvježe narodne sile“, nakon čega je uslijedio podulji popis stranih i domaćih autora koji su obećali svoju suradnju. ${ }^{851}$ Važno je istaknuti da nigdje u pozivu ne postoji jasno stilsko, a kamoli političko opredjeljenje lista, osim općenite formulacije modernosti koja prvenstveno funkcionira kao opreka starijim, preživljenim kulturnim formama i kao kišobran koji obuhvaća brojne pristupe i stilove. Poziv na pretplatu Mladosti tako se čita kao svojevrsna operacionalizacija programa koji je u svojem tekstu „O hrvatskim književnim prilikama“ u Hrvatskoj misli ocrtao Milivoj Dežman: sloboda stvaranja i suvremenih aproprijacija kao temelj za pomlađivanje i razvoj moderne hrvatske književnosti, koja treba ujedno biti i nacionalna i internacionalna, a po svojoj kvaliteti vrhunska.

Utoliko je zanimljivije što kratki uvodni, programatski tekst iz prvog broja Mladosti od 1. siječnja 1898. godine - koji je upravo proizašao iz Dežmanova pera - u bitnome odstupa od ove matrice. On se pak čita kao pomodna imitacija europskog dekadentizma. Tekst je na kraju objavljen bez potpisa kako se Dežmana ne bi, „više nego je potrebno“, istaknulo „duševnim ocem 'Mladosti' i njezinih pokretača“. ${ }^{852}$ Ipak, takvi su tekstovi u javnoj percepciji, napose starih, možda više obilježili Mladost od većine njegova sadržaja. Usporedimo li Dežmanov programatski uvodnik s poznatim manifestom Die Moderne Hermanna Bahra, lako možemo uočiti odakle je Dežman crpio svoje ideje i formulacije, ali i to da je njegov pokušaj mnogo više tek skica i imitacija europskih uzora, nego dubinski razrađen književni program koji bi bio primjenjiv na hrvatske književne i kulturne prilike. Bahr opisuje duhovno stanje svojeg vremena koristeći pojmove kao što su lutanje, bijeg i očaj, gladna želja bez odgovora, nepodnošljiva bol i krik za spasenjem. Bolest stoljeća za njega se sastoji u tome što je moderni život napustio duh, odnosno što se razvoj života i duha, tijela i duše nije odvijao komplementarno, tako da zastarjeli duh više ne može odgovoriti potrebama novog vremena. Unutrašnja borba za smisao tako poprima oblik borbe između prošlosti (preživjela duha) i sadašnjosti (modernog života). ${ }^{853} \mathrm{Na}$ sličan način duševno stanje svojeg vremena opisuje i Dežman:

„Evo nas u takoj dobi. Ozlojegjeni, izmučeni, uzrujano tražimo. Kruti realizam umjesto da nas je izbavio dvojbe, još nas je više ogorčio i još smo više zamrzili na svijet. Preplašili smo se krute zbilje i utičemo se snatrenju, uvlačimo se u tajno skrovište duše naše.

\footnotetext{
${ }^{851}$ Svi citati iz: „Poziv“, Mladost, I, 1, s. p.

852 „Hrčić - Plavšiću i Jenyju, 30. 11. 1897.“ Uredništvo časopisa Mladost R7134, NSK. Programatski je tekst „sasma u 'dekadentskom' ruhu“ urednicima ponudio i Branimir Livadić, koji je smatrao da jedino on uz Dežmana predstavlja hrvatske dekadente. „Livadić - Plavšiću, 5. 11. 1897.“, Isto.

${ }^{853}$ Hermann Bahr, „Die Moderne“, Moderne Dichtung. Monatsschrift für Literatur und Kritik I, 1, $1890,13$. Prijevod moj.
} 
[...] Sve patnje i kušnje ostavile su trag, sve boli i nade prijašnjih generacija sastale su se u nama. ${ }^{\text {" } 854}$

Za Bahra postoje dvije mogućnosti odgovora na izazov sadašnjice: prvi je rezignacija u nekoj vrsti apokaliptičnog hedonizma, a drugi, koji on zagovara, jest obnova vjere $u$ budućnost putem nove umjetnosti kao sredstva stvaranja novog duha koji će odgovarati modernom životu. Drugim riječima, duh se treba očistiti od svih preostataka prošlosti, treba otvoriti prozore „mladome majskom suncu“ i pustiti da stvarnost sadašnjosti prodre u unutrašnjost: „Moramo postati prazni, prazni od svih učenja, od svog vjerovanja, od svake znanosti očeva, potpuno prazni. Tek se tada možemo ispuniti. “855 $\mathrm{Za}$ to je potrebno otvoriti svoja osjetila i pustiti da istina - koja je stvarnost - ispuni unutrašnjost duše. Nova umjetnost stoga nije ništa drugo nego sinteza duha i tijela, njihova harmonija, a njezin jedini zakon je istina.

Dežman, čini se, ipak ide drugim, dekadentskim putem. Iako se koristi gotovo istim frazama i pojmovima kao Bahr, za njega nova umjetnost nije u potrazi za harmonijom sa stvarnosti, nego bijeg od nje, povlačenje duha u sferu istine koja transcendira vanjsko i materijalno:

„U toj živčanoj trzavici, usred patnja i nade digla se nova umjetnost. Nije to stanoviti pravac teoretički konstruiran, - ne, nego je to odraz duševne borbe nove generacije. Borba protiv materijalizma u umjetnosti je deviza. Još tapka po tmini, tek ovdje - ondje sine koja zraka novog sunca. Zvali se moderni: symbolisti, dekadenti, impresionisti itd. jedno im je zajedničko: traže nove ciljeve, idu neutrtim stazama; bježe svijet. Gube se u tihoj čežnji za novim idealima! Sensitivni, sjetni, gotovo mystici! Na oko čini se slabi, kraj snažnih pojava naturalističnog smjera, no zavirimo li im dublje u dušu, vidimo, da to nije propadanje, nego da su to preteče nove snažne erupcije. “656

Dežman se tako pokazuje kao vrlo ambivalentna ličnost. U Hrvatskoj misli on nastupa kao reformator nacionalne književnosti, ali prije svega $s$ fokusom na probleme slobode stvaranja, književne kritike, izdavaštva, publike i društvenog statusa književnika. S druge pak strane u Mladosti istupa kao dekadent, kao predvodnik nove književne generacije u borbi sa starima. U isto vrijeme, on će biti i jedan od ključnih posrednika između mladih i starih, kao i između različitih grupacija mladih. To nas upućuje na višeslojnost povijesnih aktera koje je teško jednoznačno definirati čak i u sinkronijskoj perspektivi. Ovisno o kontekstu i o

\footnotetext{
854 „Mladost, 1. siječnja, 1898.“, Mladost, I, 1, 1.

${ }^{855} \mathrm{Bahr}$, nav. dj., 14.

${ }^{856}$ „Mladost, 1. siječnja, 1898.“, 2.
} 
ciljevima, Dežman je prilagođavao svoj nastup, svoj habitus i oscilirao između imitacija i konstruktivnih aproprijacija stranih uzora. Upravo mu je to omogućavalo konstantno repozicioniranje na različitim poljima - kako političkim, tako i kulturnim - čije su silnice i odnosi moći definirali kontekst za moguće djelovanje. ${ }^{857}$

Prvi broj Mladosti izašao je 1. siječnja 1898. godine. Iako je preuzeo mjesto glavnog urednika lista, slovenski književnik i publicist Fran Podgornik odmah se ogradio od odgovornosti za sadržaj lista u posebnoj izjavi. ${ }^{858}$ Stvarni urednici bili su već spomenuti trojac bečkih studenata Plavšić, Jeny i Schmidt-Jugović, administrator je bio O. Kraus, a list se tiskao u zagrebačkoj Dioničkoj tiskari posredstvom Dežmana i Schmidt-Jugovića. Sadržaj je Mladosti bio mnogo bliži uredničkom pozivu na pretplatu nego Dežmanovu uvodniku. U književnoj produkciji koju list donosi zastupljeni su razni književni smjerovi, uključujući i realizam i naturalizam, a ne samo oni modernistički. Međutim, kako ističe Milan Marjanović, nekolicina tekstova zapravo je obilježila recepciju Mladosti na način na koji njezini pokretači nisu uopće priželjkivali. ${ }^{859}$ Osim Dežmanova uvodnika i simbolističke crtice „Okovi“ objavljene u prvom broju lista, tu je još i satirični članak Artura Benka Grada „Mlada Hrvatska“ iz četvrtog broja u kojemu on ironično predstavlja modernističke tendencije u književnosti.

Iako podnaslov Gradova teksta („laka studija“) jasno upućuje na njegov satirični karakter, opaska uredništva „Rado priopćujemo, prem se u svem ne slažemo sa cijenjenim g. piscem“ lako je mogla pridonijeti nesporazumu u vezi njegove naravi. Zanimljivo je, međutim, da je ova opaska zapravo integralni dio Gradova rukopisa, napisana njegovom rukom, tako da je moguće da je njegova namjera upravo bila da navede čitatelja na krivi trag. ${ }^{860}$ I u svojim kasnijim radovima on će se korisiti metanarativima kao integralnim dijelovima književnog teksta. ${ }^{861}$ Gradov je tekst zapravo modernistička satira modernističkih tendencija, međutim, on nema jednoznačno izraženih vrijednosnih sudova. On se jednako

\footnotetext{
${ }^{857}$ To što dekadencija odbacuje izravni angažman umjetnosti ne znači da je apolitična. Odbacivanje izravnog angažmana sastoji se u odmaku od utilitarne, pedagoške, odnosno direktno tendenciozne zadaće umjetnosti. U njezinu se shvaćanju jezika, kao i njegovoj upotrebi, međutim, nalazi subverzivni potencijal, a i dekadentni su se pisci međusobno povezivali i stvarali predloške izgradnje vlastitog autorskog lika koji je trebao izazvati konvencije građanskog društva. U tom smislu treba čitati i Dežmanove aproprijacije dekadentizma, koje supostoje s naoko kontradiktornim njegovim nastojanjima u drugim kontekstima. Ipak, kako ističe Medić, recepcija je dekadencije u hrvatskoj javnosti jedan je od uzroka toga da su „najutjecajniji hrvatski književnici prve polovice 20. stoljeća [...] prema esteticizmu zadržali ambivalentan odnos uporno umanjujući utjecaj esteticizma na oblikovanje vlastitih poetika." Igor Medić, Esteticizam Oscara Wildea i književnost hrvatske moderne, doktorski rad, Zagreb, 2021, 222.

${ }^{858}$ Fran Podgornik, „Izjava“, Isto, s. p.

${ }^{859}$ Marjanović, Hrvatska moderna I, 36.

860 „Mlada Hrvatska“, HR-HDA-790 Benko Grado, Artur, k. 96.

${ }^{861}$ Primjerice: Arthur Grado, ,John Gabriel Piclick (literarni portrait iz prijateljstva)“, Hrvatski salon, sv. 3.
} 
može čitati kao unutrašnja (samo)kritika, kao i kritika javne percepcije modernističkih strujanja. Naposljetku, ipak je i sam Grado nastupao kao modernistički autor. Da Grado u svojem tekstu satirički udara i na mainstream hrvatske javnosti i na mlade moderniste jasno je već iz samog uvodnog odlomka. Kritizirajući hrvatsku kritiku, koja se autorima bavi tek nakon njihove smrti, on također podbada mlade ističući kako se želi baviti književnicima koji su stvorili vrlo malo toga, ili pak ništa. Pa ipak, mnogi od njih za njega su „despotići“. Iako neki od njih proklamiraju socijalizam, on je zapravo nespojiv s književnosti u kojoj vlada prirodna selekcija i zakon jačeg individualiteta. Ona stoga nije republika, kako se često govori, nego despocija u kojoj se svatko bori za vlast:

„Hoću ovdje samo da spomenem, da naša mladja literatura nema ni jednoga svesilnoga despote, već oveći broj despotića, tako da mi se mlada Hrvatska čini u neku ruku ko oligarhija. To već dokazuje veliki broj revua i beletrističkih listova. Bilo bi dosadno, da ih ovdje izbrajam. Ali njihov broj govori dosta jasno. Ima u Hrvatskoj mnogo ljudi koji hoće da budu književnici. Jesu li doista književnici ili samo snobi - to hoću da istražim. “862

Za Grada, snob je čovjek velika talenta imitacije, a dobar je primjer upravo predvodnik bečke moderne, Hermann Bahr, koji je ipak dovoljno kvalitetan da je blizu da postane književnik. Osim snobizma, u cvijetu je i diletantstvo. Ismijavajući u isto vrijeme i Dežmanov uvodnik i Bahrov programatski tekst bečke moderne, Grado ističe kako ovakva „dispozicija duha“ odgovara „,našemu nervoznome vijeku“ te da se „tapkajući za srećom“ zapravo „,igramo slijepoga miša"“:

„Jer stara je bludnja da se misli, da književnik mora bit čovjek ozlovoljen, po mogućnosti pesimista. U toj maniji došli smo pače već tako daleko, da smo pobrkali sve pojmove. Već je teško razlikovati snoba od književnika a moderne literature rodile su toliko novih struja, da im već nema ni imena. Simbolisti, dekadenti, diabolici, nietzscheanci, mazohiste, tolstojevci, neoheleniste, budiste, naturiste itd. “683

Iako ističe kako hrvatsko društvo nije još došlo do stadija razvijenih europskih društava, smatra da se i u njemu počelo stvarati svojevrsno europsko kozmopolitsko društvo, koje je obilježeno međusobnim imitacijama. To se društvo svugdje „odmaklo daleko napred od naroda.“ ${ }^{664}$ Ovo kozmpolitsko društvo ,ima svoj način mišljenja, svoju vjeru, svoje umjetnike, svoje književnike i svoje listove“ te se svakim danom sve više širi posredstvom

\footnotetext{
${ }^{862}$ Artur Grado, „Mlada Hrvatska“, Mladost, I, 4, 178.

${ }^{863}$ Isto.

${ }^{864}$ Isto, 181.
} 
brzih modernih komunikacija. ${ }^{865}$ Tako i u „mladoj Hrvatskoj ima jedna klasa ljudi koji misle kosmopolitski - dok narod tek bije romantički boj za svoju narodnu slobodu. “866 Ti su se ljudi prenaglili u svojem duševnom razvoju te su se snažno zaletjeli napred, da bi se potom zaustavili pred nepremostivim preprekama. Iz ovoga je jasno da je Gradova satira zapravo prije svega upućena na glavne naglaske javne polemike oko moderne. Kroz satiru on zahvaća suvremeni trenutak i dosege razvoja hrvatskog društva i kulture, koji se kao duh vremena reflektiraju u pesimizmu mlade Hrvatske. ${ }^{867}$

Iako su ovakvi tekstovi - nehotice - definirali javnu percepciju Mladosti, njezin je stvarni sadržaj u većini bio mnogo raznolikiji i s drugačijim naglaskom. Već u prvome broju, u kojem je objavljen i programatski Dežmanov uvodnik, Guido Jeny u tekstu o ruskom slikaru Vasiliju Vereščaginu ide posve drugim putem. Dok je za Dežmana kruti realizam bio jedan od uzroka očajna stanja sadašnjice, za Jenyja je on - kao i naturalizam - upravo odgovor na suvremene probleme. Sasvim obratno od Dežmana, za Jenyja idealizam u sebi krije opasnost da čovjeka odvrati od objektivnog poimanja svijeta, a onima koji nisu jaka duha idealističko se mišljenje lako može pretvoriti u praznu formu bez života i istine. ${ }^{868}$ Osim toga, u prvome je broju objavljen i poziv za natječaj - doduše nikada realiziran - za najbolju novelu iz narodnog života, u kojemu se ističe da se traži ,zdrava mladenačka krv, a ne crnilom zamazano pero, da se što više osjeti zrak svježa života, nego li prah pisaćeg stola i folijanata estetike.“869 Isti je poziv tiskan ćirilicom ponovljen i u trećem broju.

Možda je najvažniji aspekt Mladosti, čak važniji od domaće književne produkcije, bila njegova uloga posrednika europskih modernističkih strujanja. ${ }^{870} \mathrm{Na}$ njezinim su stranicama objavljeni prijevodi Gabrielea D'Annunzija, Knuta Hamsuna, Catullea Mendèsa, Marcela Prévosta, Vasilija Vereščagina, Arthura Schnitzlera. Zanimljivo je da su bečki mladi također preveli novelu Mariana mađarskog autora Tome Kóbora, kao i tekst prevoditelja Mavre Špicera „Dvije tri riječi o novijoj magjarskoj književnosti“, ne iskazujući tako zazir, pa i svojevrsnu šovinističku notu prema mađarskoj kulturi koja je bila prisutna u listovima praške skupine. „Hvalim naum 'Mladosti',“ piše Špicer, „da se riješi kobnih predsuda i da stupce svoje otvara čitavoj svjetskoj literaturi. Ta stečevine ljudskoga duha zajednička su baština čovječanstva, pa je tim vrijednije, da se pozabavimo sa literaturom Magjara, koji spadaju

\footnotetext{
865 Isto.

${ }^{866}$ Isto.

${ }^{867}$ Isto, 187.

${ }^{868}$ Guido Jeny, „Vasilij V. Vereščagin“, Mladost, I, 1, 23.

${ }^{869}$ „Natječaj“, Isto, 56.

870 Usp. Nevenka Košutić-Brozović, „Evropski okviri hrvatske Moderne“, u: Aleksandar Flaker i Krunoslav Pranjić (ur.), Hrvatska književnost prema evropskim književnostima, Zagreb, 1970, 345-363.
} 
medju naše najbliže susjede. ${ }^{671}$ I u slučaju Mladosti kao i u slučaju Nove nade, južnoslavenska se orijentacija uglavnom svela na obilniju zastupljenost slovenskih autora, dok ostalih, napose srpskih, gotovo uopće nema. Objavljene su pjesme Fr. Ellera i Otona Župančiča, novele Ivana Cankara i Frana Govékara te tekst Fr. Vidica „O novejši slovenski literaturi“. Osim ovoga, među poučne članke još spadaju onaj Dinka Politea o Alphonseu Daudetu i Adolfa Donatha ${ }^{872}$, „Novija češka lirika“.

Za aproprijacije stranih modernističkih strujanja posebno je, dakako, važan podlistak. U njemu su doista obuhvaćene sve sfere umjetnosti, od književnosti i kazališta, preko slikarstva i kiparstva, pa sve do glazbe. Kazalište je bilo razmjerno najviše zastupljeno, ponovno pokazujući važan utjecaj bečke umjetničke sredine. Fran Hrčić izvještavao je o hrvatskom, Fran Govékar ${ }^{873}$ o slovenskom, a Dušan Plavšić o bečkom glumištu. O vizualnim umjetnostima uglavnom je pisao Jeny. Njegova je motivacija u tom pogledu proizlazila iz sasvim neadekvatne recepcije strane umjetnosti, koju je opažao u hrvatskim listovima. Umjesto da educiraju domaću publiku o važnim djelima strane umjetnosti, pa makar i kritički nastupajući, oni „donašaju dosadne kojekakove njemačke i talijanske slike, što ih u onim zemljama donašaju listovi trećega reda, za koje ozbiljni ljudi ne mare.“ „Čini se,“ zaključuje ironično Jeny, „e njima patriotizam brani, da Hrvatima priopće tugje dobre stvari, a da im dopušta širiti tugje, što ne vrijedi skoro ništa. “674 Iz njegova pera izašla su tri portreta likovnih umjetnika: V. Vereščagina, A. Böcklina i V. Bukovca. Posebno se tekst o Böcklinu može smatrati programatskim tekstom za modernizam u slikarstvu. Kritizirajući i akademizam, i realizam, i naturalizam, Jeny se zalaže za svojevrsnu nietzscheansku dionizijsku umjetnost kroz koju se umjetnik povezuje sa stvarajućom životnom energijom prirode:

„Ako od slike ne tražimo drugo, već samo da u njoj kao u zrcalu vidimo lice svijeta, onda je dakako to bolja slika što je vjernije oponašanje prirodnih forma. No ako nam slika treba da prikazuje prirodu u svom čitavom bitisanju i čitavom biću, to mora slika sama da bude čitavim bivstvom svojim nešto u nama živo, tvorno - jer priroda je živa, tvorna. [...] Ako nam slika, umjetnina treba da podade svijest bitnosti prirode, to ona mora da bude sama rezultat životne sile, što u prirodi djeluje, rezultat tvorne sile u umjetnika, koji hoće da njome

\footnotetext{
${ }^{871}$ Mavro Špicer, „Dvije tri riječi o novijoj magjarskoj književnosti“, Mladost, I, 2, 90.

872 Adolph Donat (1876-1937), pjesnik i kritičar. Porijeklom iz židovske moravske obitelji, studirao je pravo i filozofiju u Beču gdje započinje novinarsku i književnu karijeru. Proslavio se objavljivanjem serije židovske poerzije Judenlieder. Kasnije se uglavnom bavi likovnom kritikom i poviješću umjetnosti.

${ }^{873}$ Fran Govekar (1871-1949), slovenski književnik. Bio je intendant i ravnatelj ljubljanskog kazališta, kao i urednik kulturne rubrike u časopisu Slovenski narod. Pisao je novele, romane i drame, među kojima se ističu naturalistički roman $U$ krvi (1896) i drama Kvrga (1910).

${ }^{874}$ „G. J., „Umjetnost““, Mladost I, 1, 51.
} 
udovolji svojoj duši, potrebi srca svog, ne možda samo u težnji za kakovom fantazijom, za pustim idealom, već za izražajem u duši doživjelog djela, onoga, što nije samo želja duše, već gotova činjenica njena života.“ “875

Književnost, kazalište i slikarstvo čine temeljnu okosnicu interesa Mladosti. Ipak, kao što je već spomenuto, niti glazba, napose opera, nije bila zapostavljena. O bečkoj operi izvještavao je Oto Kraus. Naravno, neizostavne su i obavijesti o novim knjigama, njihovi prikazi, kao i prikazi stranih listova i smotri.

Bečani, dakako, nisu propustili priliku da hrvatsku javnost obavijeste o djelatnosti predvodnika bečke moderne Hermanna Bahra, kao i događanjima oko bečke secesije. Glavni je cilj tih objava bio da potaknu i domaće književnike i umjetnike na takvu praksu. Izvještavali su tako, primjerice, o „konferencijama“ Hermanna Bahra, odnosno njegovim javnim čitanjima i promoviranjima djela mladih književnika, a na prijedlog književnika Rudolfa Straussa ${ }^{876} \mathrm{Na}$ sličan su način obavještavali i o događanjima oko bečke secesije, ističući kako tu nije riječ o nekom novom smjeru umjetnosti, nego o odvajanju od Künstlergenossenschaft iz razloga što njegovi članovi ne gledaju umjetnost s umjetničkog, nego s trgovačkog gledišta. Dakako da nisu propustili obavijestiti i o glasilu bečke secesije, listu Ver Sacrum, čiji je prvi broj izašao na isti datum kada i prvi broj Mladosti. ${ }^{877} \mathrm{U}$ tom smislu ne može se tvrditi da je Mladost od samoga početka bila direktna aproprijacija Ver Sacruma, isto kao što niti secesija u Hrvatskoj nije direktan refleks ili imitacija bečke secesije, jer se ti procesi odvijaju paralelno i zapravo označavaju lokalne iteracije mnogo širih, europskih modernističkih strujanja. Međutim, osim u idejnom smislu, utjecaj je Ver Sacruma sve jasniji u okviru bečkog kruga mladih, a najsnažnije je došao do izražaja u vizualnoj opremi lista, napose u šestom (i posljednjem broju), koji obiluje secesijskim dekoracijama. Osim toga, secesijska strujanja nisu zaobišla niti Prag kao jedno od najvažnijih izvorišta ideja za hrvatske mlade, dapače, ona su čak prethodila događajima u Beču. Tako je npr. Arnošt Prochászka, jedan od najistaknutijih čeških dekadenata, u svojem članku za Almanah Secesije (Almanach Secese) iz 1896. godine opisao nastojanja novih umjetnika kao bijeg i sklanjanje u njihovu istinsku domovinu, zemlju snova, gdje mogu, ,iskusiti ono što im stvarnost uskraćuje“, a što je jasno našlo odjeka u ranije spomenutom Dežmanovu programatskom uvodniku za Mladost. ${ }^{878}$

\footnotetext{
${ }^{875}$ Guido Jeny, „Arnold Böcklin“, Isto, br. 3, 125.

876 dnp, „Conférence Hermana Bahra“, Isto, br. 1, 49.

877 D. J., „Secesija i 'Ver Sacrum'“،, Isto, br. 3, 150-151.

${ }^{878}$ Wittlich, Prague, 15.
} 
Najava Mladosti da će se baviti temama moderne znanosti, a napose psihologije, realizirala se jedino u seriji članaka - doduše pseudoznanstvenih - ekscentrična Gustava Gaja, odvjetnika i političara iz Jastrebarskog. Baveći se u slobodno vrijeme spiritizmom i okultizmom, Gaj je za Mladost napisao seriju tekstova u kojima promovira spiritistička učenja ${ }^{879}$ Ovakav odabir uredništva nije iznenađujuć, s obzirom na to da su modernistička strujanja u nadnaravnom, fantastičnom i transcendentnom pronalazila izvor svojih ideja, motiva i tema, kao način otklona od krutog realizma i naturalizma. Osim toga, čini se da se zajednička poveznica mogla pronaći i u ideji odbacivanja dogmatizma i škola u svakom pogledu, pa stoga i u pogledu percipirane dogmatičnosti i krutosti službene znanosti.

Slična je situacija i s problematikom ženskog pitanja. Iako najavljena, ona je naposljetku bila zastupljena tek jednim značajnijim tekstom, i to iz pera Jenyja, a ne samih Žena, kako je bilo priželjkivano. U tom tekstu, naslovljenom ,Ženski pokret“, on primjenjuje različite argumente i teorijske impulse kako bi pokazao uzroke potlačena stanja žena. Kao jedan od glavnih navodi materijalne, ekonomske odnose, jasno se oslanjajući na marksističku analizu. Kritizirajući patrijarhat, on potcrtava problem nejednaka odgoja, pristupa poslovima, dvostruka morala (problem prostitucije) itd. S druge pak strane, niti on nije odolio na prvo mjesto staviti odgojnu zadaću žene, ponovno je tako vezujući uz domaćinstvo i one iste ekonomske i patrijarhalne odnose koje je ranije kritizirao: „Treba da izraste pleme, jako pleme, komu ne treba ograda. A takovo pleme mogu roditi samo majke, koje su same jake, takovo pleme mogu da odgoje samo majke, koje su samosvjesnog značaja i koje su svojom naobrazbom dorasle i dozrelom sinu - i dozreloj kćeri. “" ${ }^{680} \mathrm{Na}$ taj način jasno se manifestiraju posljedice aproprijacija suvremenih intelektualnih kretanja, ali i njihova ograničenja koja su zadana okvirom dosegnute razine rasprave prisutne u javnome prostoru. Iako je nedvojbeno važan, ovaj tekst u cjelini lista, pa i pokreta mladih općenito zapravo ostaje popratni fenomen. U cijelom tečaju Mladosti kao autorica nije bila zastupljena niti jedna žena, bilo u pogledu književne produkcije, bilo u pogledu autorstva članaka i tekstova. Žensko pitanje stoga $\mathrm{u}$ okviru pokreta mladih ostaje na razini proklamacije i upućuje na onaj aspekt aproprijacija koji se svodi na retoričko osnaživanje habitusa i poze modernosti.

U sadržajnom smislu Mladost tako karakterizira izraziti eklekticizam. U njemu je moguće naći i pohvale realizmu i naturalizmu, i kritiku krutog realizma, i članke o

\footnotetext{
${ }^{879}$ Gustav Gaj, „Nešto o magičnim svojstvima duše“, Mladost, I, 1, 39-44; „O telepatiji“, Isto, br. 2, 95-98, br. 3, $136-141$ br. 5, 222-231.

${ }^{880}$ Guido Jeny, „Ženski pokret“", Mladost, I, 2, 83.
} 
pozitivizmu A. Comtea, kao i impresionističke krokije modernog života ${ }^{881}$, bijeg od stvarnosti, kao i propagiranje marksističko-socijalističke kritike i promjene te stvarnosti. ${ }^{882}$ Mladost je stoga - daleko od toga da bi bila glasilo hrvatskih dekadenata - nastupila kao otvoreni forum za razna strujanja koja se mogu podvesti pod opći i neodređen pojam modernosti. Kao takva, ona prije svega nastupa protiv zatvorenosti u uske okvire obzira, škola i nacionalne, tj. provincijske perspektive, zalažući se za slobodu stvaranja, mišljenja, pa ako treba i imitiranja.

U pogledu onoga što je uslijedilo posebno je bio važan 6. broj Mladosti. On je izašao s nekoliko mjeseci kašnjenja zbog tehničkih i financijskih problema koji su stalno morili izdavače lista. Kao tematski broj bio je posvećen Gjalskome i Bukovcu. Ovaj odabir njih je jasno postavio kao umjetničke uzore mlađoj generaciji, ali i javno izrazio tendencije koje su već bile u procesu ostvarivanja, a to su književno-umjetničko udruživanje i secesijski pokret u Hrvatskoj. U svojem impresionističko-psihološkom portretu Gjalskoga, Dežman ga je prikazao kao ambivalentnu i kompleksnu ličnost. S jedne strane on je bio Radmilović, živi primjer hrvatskog društva i književnih prilika kako ih je Dežman opisao u Hrvatskoj misli: „On je perovogja Babić, a nije romancier Gjalski - a tim je sve rečeno. [...] On kao književnik imao je druge nazore, drugojačije je živio, a družtvo oko njega nije htjelo da odobri tu individualnu slobodu mišljenja i živovanja njegova, i bilo je protiv njega. “883 Kao socijalni pisac, Gjalski je sveobuhvatni kritičar hrvatskih društvenih, kulturnih i intelektualnih prilika. On je u tom pogledu tendenciozan, ali upravo na način koji Dežman zagovara: to nije moraliziranje i direktno poučavanje, nego se ostvaruje u cjelini njegova djela kao nemilosrdna analiza društva, kao prikaz njegovih mana i problema. Socijalno angažirani umjetnik mora i dalje prije svega biti umjetnik, a ne političar koji se koristi umjetnošću za svoje svrhe jer umjetnost ne smije biti patriotska haranga, niti etnografska studija, niti propovijed. ${ }^{884}$ Jasno aludirajući na prašku i zagrebačku skupinu pokreta mladih, Dežman navodi kako se ta struja koju naziva „narodniki“ - razvila uslijed političkih prilika nakon 1895. godine. Te pristaše „narodnog (t. pučkog) pravca“ za njega su neupitno dobri patrioti, no rijetko umjetnici. ${ }^{885}$ Iako ne dovodi u pitanje da je ta struja nužna i korisna s patriotskoga gledišta, ona se ne može

\footnotetext{
881 Usp. npr. „Mi moderni ljudi ljubimo zvuk velegradskih zvona i šum bučnoga života. Mi ljubimo dah nepatvorene naravi i miris njenih baršunastih ružica; nježni lahor juga i hladne uvale sjevera. Tako si stvaramo naše svijetove, tako se radjaju tajne naših duša. Tako nastaju velebne pjesme. Život i narav jedino su im gradivo, a u njima se sjaju najkrasnije boje i zvuče najiskreniji glasovi.“ Adolf Donath, „Novija češka lirika“, Isto, br. 5, 219.

${ }^{882}$ Miša Zemljanić, „Agrarna pretresivanja“, Isto, br. 4, 188-196.

${ }^{883}$ Ivanov, „Ksaver Šandor Gjalski““, Isto, br. 6, 270.

${ }^{884}$ Isto, 273

${ }^{885}$ Isto.
} 
odobriti s književnog gledišta jer vodi do patriotske retorike, političke brošure ili folkloristike. Djelo velike umjetničke vrijednosti, zaključuje Dežman, ipso facto će ispuniti i svoju patriotsku svrhu, dok će neumjetničko, a patriotsko djelo djelovati kratkotrajno i to samo onda, ako ga dobiju u ruke oni kojim je zbilja namijenjeno, što najčešće nije slučaj. Zbog svega toga, Gjalskog treba gledati kao most između hrvatske i europske književnosti. ${ }^{886}$

Dežmanu je Gjalski osobno mnogo bliži kao moderni subjektivist, što se naročito očituje u njegovim najnovijim radovima prožetim impulsima spiritizma i misticizma. Na taj način njegov je portret Gjalskoga ujedno i portret samoga sebe, kao i pokreta mladih u cjelini. S jedne strane socijalno angažiran, a s druge izrazito subjektivistički nastrojen; okrenut prema suvremenim europskim strujanjima, ali istovremeno snažno investiran u pitanja nacionalne politike i kulture, Gjalski je metonimija promjena u hrvatskom društvu i kulturi. Upravo je on primjer pripadnika starije generacije koji je zapravo mlad. S njime je počela nova faza, on je vođa i uzor mlađem naraštaju u hrvatskoj književnosti. ${ }^{887}$

Ono što je Gjalski za mlade hrvatske književnike, to je Bukovac za mlade hrvatske umjetnike. ${ }^{888}$ Pišući njegov portret u kojem ga prikazuje kao pariškog impresionista južnjačkoga temperamenta, Jeny ga predstavlja kao umjetnika u potpunom smislu riječi, slikara svjetskoga glasa, koji je svojim znanjem i vještinom oplodio i potaknuo rad drugih. ${ }^{889}$ Čak više od Gjalskoga, on nije samo vođa i uzor mlađoj generaciji, nego je utemeljitelj hrvatske umjetnosti.

Fokusirajući se u svojem posljednjem, 6. broju na Gjalskoga i Bukovca kao domaće umjetnike, bečka je skupina jasno istaknula smjer svojeg daljnjeg djelovanja. Mladost je u tom smislu bila svojevrsna pripremna radnja, postavljanje terena na način otvaranja prema modernim strujanjima i aproprijacijama europskih kretanja. U drugom koraku bit će potrebno krenuti prema izgradnji moderne hrvatske umjetnosti, odnosno prema ostvarenju preduvjeta za njezin razvoj, a to je sloboda stvaralaštva i razvoj umjetničke infrastrukture: od društva i listova, pa do izložbenih prostora i obrazovane publike.

Mladost je imala izrazito buran život. Ubrzo nakon njezina pokretanja postalo je jasno da Schmidt-Jugović neće moći ispuniti svoja obećanja vezana uz financiranje lista, te da je njegova priča o velikom nasljedstvu u velikoj mjeri - samo priča. Već od trećeg broja njegovo se ime više ne pojavljuje među izdavačima lista. O njihovu poprilično ružnom raskidu održan

\footnotetext{
886 Isto.

${ }^{887}$ Isto, 277.

${ }^{888}$ U ovome se razdoblju termin umjetnici upotrebljavao sinonimno za likovne umjetnike. Zato se govori o udruživanju književnika i umjetnika, a Kuhač piše pamflet o anarhiji u hrvatskoj književnosti i umjetnosti, misleći pritom na likovnu umjetnost (više o tome kasnije).

${ }^{889}$ Guido Jeny, „Vlaho Bukovac, Isto, 278.
} 
je sastanak u Jugovićevu bečkom stanu, o kojem je vođen i zapisnik. ${ }^{890}$ Osim toga, Jeny ističe kako su protiv Mladosti aktivno u Dioničkoj tiskari lobirali njezini protivnici iz redova starijih, kao i neki mladi ${ }^{891}$ To je rađeno na način da se pokuša potkopati kredit izdavača Mladosti u Dioničkoj tiskari, što je naposljetku i uspjelo. Jeny s ogorčenjem piše kako nisu dobili nikakvu materijalnu ili inu pomoć od zagrebačkih literarnih i intelektualnih krugova koji su ih deklarativno podržavali. ${ }^{892}$ Čak se govorkalo da je i Dežman sudjelovao u propasti Mladosti, ali to je ostalo na razini glasine. Dionička tiskara počela je stvarati probleme izdavačima već s 5. brojem, da bi situacija eskalirala s posebnim, 6. brojem. Ona je odbila izručiti tiskani broj dok se ne podmire sve obaveze, iako je to bila praksa s gotovo svim beletrističkim listovima. Jeny stoga zaključuje da je posrijedi bio plan da se osujeti daljnji razvoj Mladosti koja bi s luksuznim 6. brojem stekla brojne pretplatnike i oglašivače. ${ }^{893}$ Dionička tiskara, jedna od ključnih institucija starih, očito nije bila sklona izdavačima Mladosti ponuditi iste beneficije koje je nudila ostalim svojim klijentima. Iako je imala veliki broj pretplatnika - Jeny navodi da ih je Mladost imala više od svih drugih hrvatskih beletrističnih listova - pritisak duga bio je prevelik. ${ }^{894} \mathrm{U}$ travnju 1898 . bio je pripremljen ponovljeni poziv na pretplatu za drugi kvartal Mladosti koji je trebao početi sa 7 . brojem. ${ }^{895}$ Međutim, do njega nikad nije došlo. Mladost je završila svoj kratkotrajan život sa 6 . brojem i nepunih pola godine izlaženja. Usprkos tome, ona će izazvati reakciju koja je nadmašila čak i prvu pojavu praške omladine s njihovom Hrvatskom misli.

\section{4. Secesija i mladi: udruživanje književnika i likovnih umjetnika}

Rad na izdavanju Mladosti dovodio je bečku skupinu u kontakt s brojnim hrvatskim umjetnicima i književnicima. I Plavšić i Jeny često su boravili u Zagrebu kako bi obavljali razne poslove za redakciju lista, te bi pritom pohađali kavane koje su se sve više - po uzoru

\footnotetext{
890 „Zapisnik o raskidu s Jugovićem, Beč 13. II. 1898.“, u: Marijanović, nav. dj., 229-231.

891 „Nešto o časopisu i pokretu 'Mladosti' iz g. 1897./98.“, HR-AHAZU-KN-80 Jeny, Guido st.

892 „Iz Jenyjevih memoarskih zapisa“, 188.

${ }^{893}$ Isto, 191.

${ }^{894}$ Isto, 193.

${ }^{895}$ U njemu je najavljena suradnja brojnih novih autora, između ostalih Petera Altenberga, Georga Brandesa, Čehova, Maeterlincka, Nazora, Borothe, Kozarca itd., kao i različiti tekstovi „o nazarenstvu; o Henriku Ibsenu; o Josipu Kozarcu; o zvanju žene; o naravnom odgoju djece; o zabludama modernih znanosti; o modernim literaturama u Nijemaca, Skandinavaca i Italije; o Matiji A. Relkoviću; iz historije umjetnosti u južnih Slavena; putopisne utiske iz krajeva u Hrvatskoj i Slavoniji, u kojima vlada glad; o narodnostnom pitanju u književnosti; o degeneriranim slojevima našeg pučanstva i t.d. i t.d.“ „Poziv na pretplatu!“, Uredništvo časopisa Mladost R7134, I, NSK.
} 
na Beč i šire europske trendove - formirale kao važno mjesto kulturnih kontakata. ${ }^{896}$ Tamo su se susretali s nastajućim hrvatskim fin de siècle umjetničkim miljeom. U kavanama se nije samo družilo i razgovaralo o umjetnosti i književnosti, nego su se rađali i konkretni projekti. Jeny se tako prisjeća prvih impulsa stvaranja društva književnika u kavani Bauer, projekta koji je Dežman zagovarao od svojeg prvog teksta u Hrvatskoj misli. Sjedeći u društvu s Mihovilom Nikolićem, on je poveo riječ o potrebi osnutka društva književnika kao institucije koja bi širila suvremene napredne ideje. Budući da je Nikolić iskazao interes za ideju, Jeny je predložio da se stvar konkretizira i da se sazove skupština književnika. Kako tvrdi, oni su potom na kavanskom stolu sastavili nacrt poziva književnicima, a Nikolić je preuzeo na sebe da pronađe potpisnike i preda poziv novinama. ${ }^{897}$ Iako Jeny tvrdi da se njegov potpis nije našao na ovome pozivu jer se nije smatrao književnikom u užem smislu te riječi, njegov je potpis ipak završio - zajedno s Plavšićevim - na „Pozivu za ustrojenje Književnoumjetničkog društva“ u lipnju 1898. godine, dakle nakon prestanka izlaženja Mladosti. Nastavljajući se na iskustva izdavanja tog lista, Jeny i Plavšić su predlagali osnivanje „Prvog hrvatsko-srpsko-slovenskog književnog i umjetničkog društva“ kao dioničkog društva sa sjedištem u Zagrebu. Kao program društva navodi se unapređivanje duševnog i kulturnog razvoja naroda na osnovi slobode. Osim podupiranja književnika i umjetnika te propagiranja domaće umjetnosti i književnosti među narodom, njegova bi glavna zadaća bila izdavanje lista koji bi trebao nastaviti rad Mladosti, fokusirajući se na literaturu i umjetnost, znanost i pitanja modernog života, osim politike. ${ }^{898}$ Vanjsku opremu lista uređivali bi hrvatski likovni umjetnici kao primjer suradnje književnika i likovnih umjetnika. ${ }^{899}$ Osim lista, društvo bi izdavalo i određeni broj knjiga u vlastitoj nakladi.

Prema svemu sudeći, međutim, ovaj poziv nije nikada ugledao svjetlo dana. Inicijativu u okupljanju hrvatskih književnika i umjetnika preuzeo je Dežman. Tako se i na ovome polju pokazivala svojevrsna konkurencija između aktera pokreta koji su pokušavali za sebe ishoditi najbolju poziciju u njegovu daljnjem razvoju. Mihovil Nikolić u svojoj autobiografiji uopće ne spominje Jenyja kao idejnog začetnika književnog društva, nego u središte tog pokreta smješta Dežmana i sebe. ${ }^{900}$ Na poziv Dežmana, Nikolića i Tucića gotovo dvadeset hrvatskih književnika okupilo se u hotelu Imperial te su 26. svibnja donijeli rezoluciju o osnivanju

\footnotetext{
${ }^{896}$ Usp. Ines Sabotič, Stare zagrebačke kavane i krčme s kraja 19. i početka 20. stoljeća, Zagreb, 2007, $214,224$. ${ }^{897}$ „Iz Jenyjevih memoarskih zapisa“, 187.

898 „Poziv za ustrojenje Književno-umjetničkog društva“, Hrvatsko književničko društvo R7338, NSK.

899 Usp. Vladimir Maleković, „Secesija i hrvatska likovna umjetnost“, u: Julijo Martinčić, Dubravka Hackenberger (ur.), Secesija u Hrvatskoj: zbornik radova znanstvenog skupa, Zagreb i Osijek, 1999, 34-35.

${ }_{900}$ Mihovil Nikolić, „Fragmenti iz moga života“, u: Vinko Brešić (ur.), Autobiografije hrvatskih pisaca, Zagreb, $1997,561$.
} 
književničkog kluba kao osnove za ustroj Društva hrvatskih književnika. ${ }^{901} \mathrm{U}$ tom smislu išli su stopama hrvatskih umjetnika koji su se u rujnu 1897. godine odcijepili od Kršnjavijeva Društva umjetnosti te osnovali Nezavisni klub društva hrvatskih umjetnika koji je ubrzo postao Društvo hrvatskih umjetnika. ${ }^{902} \mathrm{O}$ incijativi za osnivanje Hrvatskog književničkog društva Dežman je u lipnju 1898. godine pisao u Obzoru. On je ovu incijativu vrlo pomirljivo predstavio kao napor mladih da ujedine sve hrvatske književnike neovisno o njihovu opredjeljenju i kao zalog za nadilaženje nesuglasica koje su nastale. Zajedničkim radom rasplinut će se međusobni anatognizam te će se jasno vidjeti da su svi, usprkos stilskim i umjetničkim opredjeljenjima, prije svega hrvatski pisci. Stari će stoga imati priliku uvidjeti na mladi nisu tako crni kao što misle: „Za cielo nitko od nas ne kani sliepo sliediti tradicije, no izkustvo njihovo trebamo, a opet ne možemo zatajiti razdraganost, kad smo blizu onih, na čijim smo se tvorevinama oduševljavali za umjetnost. Zahvalnost nas nagoni, da dodjemo do njih i da ih umolimo, da budu s nama.“903

Provizorni Klub hrvatskih književnika nastanio se iznad kavane Bauer u kojoj je i niknula ideja o njegovu osnivanju. ${ }^{904}$ Razlog zašto se osnovao provizorni klub bio je i taj što se očekivalo da će Khuenova vlada otežavati formalno osnivanje Društva hrvatskih književnika, što se pokazalo točnim. U hotelu Imperial ponovno je 25. i 27. lipnja 1898. godine održan sastanak hrvatskih književnika koji je trebao iznjedriti pravila novoga društva. ${ }^{905}$ Sastanak je otvorio Ivan Trnski kao ugledan stari književnik i ilirac, a za predsjedavajućeg je izabran Gjalski. Time je zapravo odaslana poruka suradnje starije i mlađe generacije u cilju osnaživanja cjelokupne hrvatske književnosti. Na sastanku su sudjelovali predstavnici i starih i mladih, između ostalih Hugo Badalić, Milutin Cihlar, August Harambašić, Bartol Inhof, Iso Kršnjavi, Ivan Krnic, Franjo Marković, Antun Radić, Ante Tresić itd. Spiritus movens je dakako bio Dežman, koji je kao izvjestitelj iznio glavna načela nastajućeg društva. Ono je prije svega trebalo biti usmjereno ka socijalnom udruživanju književnika, a tek onda na širenje hrvatske knjige među narodom. U raspravi koja je

901 „Rezolucija od 26. 5. 1898. o osnivanju Književničkog cluba“, HR-AHAZU-KN-44 Dežman, Milivoj, k. 5.

902 O secesiji u Hrvatskoj i usporedbi s kretanjima u Beču vidi: Petra Vugrinec, „Hrvatski salon i bečka secesija: slikarstvo u Zagrebu i Beču oko 1900.“, u: Irena Kraševac, Petra Vugrinec (ur.), Izazov moderne: Zagreb i Beč oko 1900. Slikarstvo, kiparstvo i arhitektura zagrebačke $i$ bečke secesije, Zagreb, 2017, 57-124; Usp. također Rachel Rossner, ,'The secessionists are the Croats. They've been given their own pavilion. . .': Vlaho Bukovac's Battle for Croatian Autonomy at the 1896 Millennial Exhibition in Budapest", Nineteenth-Century Art Worldwide 6, 1, 2007. URL: http://www.19thc-artworldwide.org/spring07/141-qthe-secessionists-are-the-croatstheyve-been-given-their-own-pavilion-q-vlaho-bukovacs-battle-for-croatian-autonomy-at-the-1896-millennialexhibition-in-budapest.

${ }^{903}$ Iv., „Hrvatsko književničko družtvo“, Obzor, XL, 140, 22. 6. 1898.

${ }^{904}$ Nikolić, nav. dj., 565.

905 „Zapisnik sastanka hrv. književnika u Hotel Imperialu u Zagrebu dne. 25. i 27. lipnja 1898.“, HR-AHAZUKN-44 Dežman, Milivoj, k. 5. 
uslijedila, a koja se ticala točne definicije književnika, pa time i potencijalnih članova društva, ponovno je istaknuto da kvaliteta nečijeg rada ne smije biti kriterij za članstvo jer je društvo zamišljeno prije svega kao socijalna udruga književnika. Na taj način izbjegnute su teme koje bi eventualno mogle uzrokovati razdor među književnicima, postavljajući društvo na donekle neutralan teren općeg strukovnog udruženja. Molba za potvrdu pravila Društva hrvatskih književnika koja je odaslana Zemaljskoj vladi na temelju ove skupštine nije, međutim, bila odobrena. ${ }^{906}$ Zbog toga je Klub hrvatskih književnika morao nastaviti svoj rad kao provizorno udruženje, a ujedno je bio upućen na ostvarivanje uže suradnje s Društvom hrvatskih umjetnika koje je formalno već bilo ustrojeno. Na taj je način posljedica ovakva razvoja događaja bila još veće zbližavanje mladih hrvatskih književnika i umjetnika, što je kulminiralo u možda najznačajnijem događaju pokreta mladih i hrvatske secesije, Hrvatskom salonu.

Hrvatski salon bila je prva izložba hrvatske likovne secesije, ali ujedno i velika kolaboracija modernistički nastrojenih hrvatskih književnika i likovnih umjetnika, u kojima su važnu ulogu odigrali mladi. Ključni rezultat u tom pogledu bila je popratna publikacija u četiri sveska naslovljena Hrvatski salon, koja nije bila tek katalog izložbe s reprodukcijama izloženih djela, nego i važna programatska formulacija hrvatskog fin de siècle modernizma. Glavnu ulogu u uređivanju ove publikacije koja je izašla između prosinca 1898. i veljače 1899. godine imao je Milivoj Dežman. Osim reprodukcija izloženih djela, u njoj su tiskani i manji književni radovi (pjesme, crtice, novele) mladih i mladima naklonjenih hrvatskih književnika, kao i dva ključna programatska teksta: Gjalskijev predgovor i Dežmanov članak „Naše težnje“. U tom smislu, Hrvatski salon nastavlja se na temelje postavljene u posebnom, 6. broju Mladosti.

U svojem pozdravnom pismu hrvatskim umjetnicima koje je funkcioniralo kao predgovor Hrvatskom salonu, Gjalski je odmah iznio ključnu tezu hrvatskog modernističkog pokreta u umjetnosti koju je još 1897. godine Dežman postavio u svojem programatskom članku u Hrvatskoj misli: „Mene poglavito i najviše veseli, što vidim da ste moderni i razumijete svoju dobu -, pak vašu hrvatsku umjetnost po tom stavljate u isti red s umjetnošću vascielog naprednog svieta. I po tom ne samo da najbolje služite umjetnosti samoj, već i najsigurnije koristite svojoj domovini, svome narodu i njegovom kulturnom nastojanju.“907 Drugim riječima, ako je secesija u službi umjetnosti, onda je ona nužno i u službi nacije, jer samo vrhunska moderna umjetnost može služiti suvremenom nacionalnom kulturnom

\footnotetext{
906 „Zapisnik sastanka hrv. književnika 7. 12. 1899.“, HR-AHAZU-KN-44 Dežman, Milivoj, k. 6.

907 Šandor Gjalski, [Predgovor], Hrvatski salon, sv. 1, 1.
} 
razvoju. Prošla su vremena kada je za narodnu stvar i za umjetnost bilo korisno raditi po šablonama i zahtjevima škole, te se direktno obraćati i jezično obrazovati narod. Sam narod osjeća potrebu i zahtijeva da ga se upozna sa širokim vidicima moderne umjetnosti. Ako mu se to ne podari, upravo suprotno od onoga što tvrde kritičari moderne, on će svoje potrebe zadovoljiti u inozemstvu, a to će onda tek biti sigurna propast za svako domaće nastojanje. Moderni pravac u umjetnosti proširio je njezine horizonte i geografski, i tematski, i osjećajno, i misaono. Sve što on zahtijeva jesu sloboda i otvorenost. Zadržavanje umjetnosti u ograničenim međama značilo bi njezinu sigurnu stagnaciju, a stagnacija je smrt i misli i umjetnosti. Moderni pravac u umjetnosti za Gjalskoga dakle nije neka određena škola, nego upravo negacija škola i bilo kakvih izvanjskih ograničenja i određenja umjetnosti. U tom smislu on otvara nebrojene mogućnosti razvoja narodnih elemenata $u$ sklopu moderne umjetnosti: „I baš za to, jer moderna struja nastoji sve zahvatiti i jer se otima tome, da pojedini individij padne u apsolutizam jedne odabrane škole, baš za to, ja se radujem i nadam se od nje i za naše narodne umjetne elemente.“ Upravo suprotno od optužbi za odnarođenost i kozmopolitizam, on se razvoju moderne umjetnosti u Hrvatskoj može veseliti „kao nacionalista“. Njezin je najdublji princip dakle sloboda, a ona ne može biti u sukobu s narodnim interesima jer je ona samo potencija i osnova za razvoj. „A na koncu želim da vam još kažem, “ zaključuje svoje pozdravno pismo Gjalski, koji je nedavno bio otpušten iz službe zbog svojeg književnog angažmana, „da čuvajte i ljubite uvijek kao najveću svetinju slobodu, - slobodu svoga uvjerenja, svoje misli i svoga ukusa.“908

$\mathrm{Na}$ istim je temeljima Milivoj Dežman postavio svoj program hrvatskog modernističkog pokreta, koji je pod naslovom „Naše težnje“ objavljen u prvom svesku Hrvatskog salona. Osim što je važan kao program pokreta, on ujedno ukazuje i na narav suradnje mladih i likovnih umjetnika okupljenih u secesijskom Društvu hrvatskih umjetnika. Mladi su u toj suradnji funkcionirali kao svojevrsni teoretičari i propagatori moderne umjetnosti, dok su likovni umjetnici kao protagonisti javno najvidljivijeg kulturnog događaja tih godina otvarali prostor za plasiranje modernističkih ideja. Za razliku od Mladosti, gdje je nastupao kao dekadent, Dežman se ovdje postavlja kao predvodnik hrvatskog modernističkog pokreta u umjetnosti i književnosti, postavljajući njegove temelje mnogo šire, inkluzivnije i politički prihvatljivije. Kao i Gjalskome, njemu je stalo pokazati da modernistički pokret nije u sukobu, nego upravo u službi hrvatskih nacionalnih interesa.

${ }^{908}$ Isto, 2. 
„Zamuknule su ilirske davorije, ne čuju se više plameni govori. Stari su borci zamuknuli, a ravnodušnost je kao mora sjela na grudi naše. Nezadovoljni trošili smo svoje sile u sitnim prepirkama. Velike, zvučne riječi narodne borbe još su uvijek ozvanjale no narodne svijesti je nestajalo.“909 $\mathrm{Na}$ ovaj, već poznati način Dežman identificira stanje u kojem se našla hrvatska kultura. I mladi su sudjelovali u ispraznim, zastarjelim manifestacijama i besplodnim stranačkim deklamacijama, ali duboko u sebi su osjećali neko protuslovlje i potrebu za novim putem. Kada to nisu mogli dobiti od svojih očeva, krenuli su sami. Krenuli su s iskrenom željom da doprinesu narodnoj stvari, ali su odmah dočekani na nož. ${ }^{910}$ Njihovo odbacivanje starih formi nije, međutim, bio rezultat obijesti, nego nužde. Mladi su uvidjeli da je za uspjeh u sadašnjosti i budućnosti potrebno krenuti novim putevima, osloboditi se okova obzira koji vezuju tradiciju uz patriotizam te prilagoditi svoj rad novim uvjetima i potrebama. Iako rade isto ono što su u svoje vrijeme radili ilirci, što su 1870-ih godina radili romantičari, a 1880-ih realisti, oni su optuženi za izdaju. ${ }^{911}$ Aproprijacije stranih uzora nisu hir indolentne mladeži, nego nužnost vremena u kojima se nalaze. Mladi poštuju što su stari napravili za narodnu stvar i priznaju im njihovo mjesto u povijesti, ali ona ne smije sputavati sadašnjost i budućnost. Mnogo žuči proisteklo je iz nesporazuma i nerazumijevanja modernog pravca u umjetnosti. Tako je bilo onih koji su ih iz neznanja proglasili naturalistima, a moderna je upravo nastala u opoziciji spram naturalističke škole kao protivnice modernog individualizma. Dežman još jednom ponavlja kako moderna nije stanovita škola i stil u umjetnosti. Zbog tog nerazumijevanja, on iznosi jednu od najvažnijih definicija moderne u okviru hrvatskog modernističkog pokreta:

„Moderni pokret je borba individua za slobodu. Moderni umjetnik ne pripada nijednoj školi. Moderna mrzi epigonstvo - ona hoće da ljudi živu u sadašnjosti, da se oslone na svoju dušu, da svojim djelima dadu pečat svoje osobe. Svaki neka živi svojim životom. [...] Moderna nastoji obuhvatiti cijelog čovjeka, ona teži za sintezom idealizma i realizma, ona hoće da nagje sredstvo, kojim bi čovjek najbolje i najljepše mogao izraziti svoje biće i zadovoljiti svojem pozivu. Ona ne otklanja nijedan osjećaj, nijednu misao, jer se bori za prava pojedinca, kao što i zahtjeva od pojedinca: da bude svoj. To je glavno načelo moderne - po mom shvaćanju - a sve što se naziva simbolizmom, dekadentizmom, diabolizmom itd. - to je

\footnotetext{
${ }^{909}$ Ivanov, „Naše težnje“, Isto, 8.

910 „Još nijesmo ni pravo izrekli što hoćemo a već su nas potvorili, da hoćemo sve dosadanje javno djelovanje zabaciti. Proglasili su nas odmetnicima, rekli nam da potkupljeni radimo samo na svoju korist. Naša iskrenost smatrala se drzovitošću, naša želja za napretkom revolucijonarnošću, naša borba protiv zatajivanja svemogućih mana nemoralom. "Isto.

911 „Ako mi sad tražimo ne samo u narodu nego i izvan domovine uzore, zar smo za to izdajnici? Pita se, da li je koristno ili štetno? Zar nijesu i naši pregji, učiniv novi korak, morali pogaziti barem djelomice tradicije. Jedno je ostalo u svim epokama stalno - a to je ljubav prema domovini - a tko nam tu smije poreći?" Isto.
} 
samo želja svjetskih registratora da strpaju pojedine individue u stanovite etiketirane pretince. “912

Onaj tko samo oponaša, tko ne misli svojom glavom i ne stvara iz svoje nutrine nije moderni umjetnik u pravom smislu riječi, jer moderna zahtijeva da se sloboda stvaranja koristi za izražavanje vlastite individualnosti: „Nama nije do toga, da donesemo ovamo posudjene ideje kojeg modernog pisca, nama je da izvojštimo sebi pravo, misliti svojom glavom, makar i zlo, izraziti svoje osjećaje, reći svoje nazore o svemu, ako su i krivi. Slobode nam se hoće; hoćemo da živimo u sadašnjosti, da prisluškujemo duhu vremena i da sami gradimo a ne da čuvamo samo stražu pred starim tvrgjavama." Takva sloboda, i takvo korištenje slobode nije opasnost, nego je nužda za Hrvatsku. Ona treba „razvitih individua koji živu životom svog naroda, koji pojme sadanje narodne potrebe; ljudi slobodnih u duši svojoj.“ Mladim hrvatskim umjetnicima i književnicima treba dati šansu. Ako se pokažu „kao umjetnici u duši bit će im djela umjetnine“, zaključuje Dežman „,- i kao takove koristiti će narodu. “913

Umjetnička izložba svečano je otvorena - zajedno s novim Umjetničkim paviljonom 15. prosinca 1898. godine. Samo otvorenje nije odudaralo od praksi održavanja sličnih događanja. Na njemu su se okupili svi najvažniji javni i politički akteri, uključujući i bana Khuena koji je izložbu svečano otvorio i održao prigodni govor. Jasno uočavajući nesuglasice u okviru hrvatske opozicije kada je riječ o podršci mladima, kao i mogućnost da ovaj događaj uklopi u svoj politički narativ, Khuen je pohvalio kritičnost mladih umjetnika jer ona omogućuje napredak u kojem Hrvatska više nije samo dionik, nego i aktivni faktor. I Umjetnički paviljon, i ova izložba dokaz su toga, pri čemu je ban suptilno povezao ovaj kulturno-umjetnički razvoj s rezultatima vlastite kulturne politike. ${ }^{914}$ Khuenov je politički cilj u Hrvatskoj bio učvrstiti (sub)dualistički sustav, a pritom raditi na postepenu sužavanju hrvatske političke autonomije u okviru Ugarske i jačanju njezina položaja ekonomske periferije. Njegova je kulturna politika u tom kontekstu imala dvojaku funkciju. Promičući izgradnju kulturnih institucija i urbani razvoj po uzoru na druga monarhijska središta, ona je trebala kulturnom unifikacijom poticati habsburški lojalizam, a s druge je strane njegovu vladavinu prikazivala kao korisnu za razvoj hrvatskog naroda u Ugarskoj i Monarhiji općenito. Kulturni je razvoj tako trebao nadomjestiti političku represiju i ekonomsku

\footnotetext{
912 Isto, 9.

913 Isto.

914 „Svečano otvorenje umjetničke izložbe i umjetničkog paviljona dne 15. prosinca 1898.“, Isto, sv. $2,22$. Umjetnički paviljon je bio građen prvenstveno za ugarsku milenijsku izložbu 1896. godine, a razmimoilaženje oko pristupa toj izložbi između Kršnjavija i Bukovca bio je povod za secesiju likovnih umjetnika od Kršnjavijeva Društva umjetnosti.
} 
stagnaciju. Glavno je lice Khuenove kulturne politke bio Isidor Kršnjavi, predstojnik vladina Odjela za bogoštovlje i nastavu od 1891. do 1896. godine. Kao izrazito agilan organizator i pragmatičan političar, on je zaslužan za uspostavu niza škola (privremeni ženski licej u Zagrebu, stručne škole, realne gimnazije), reprezentativnih građevina (Školski forum, nova zgrada HNK, sušačka gimnazija), proširenje sustava stipendiranja itd. ${ }^{915}$ Između ostaloga, Kršnjavi je u Zagrebu okupio hrvatske likovne umjetnike, ukljujući i tada već renomiranoga Bukovca, koje je zaposlio na svojim brojnim projektima i na taj način znatno podigao razinu likovne produkcije u Zagrebu. Pravo je utjelovljenje toga bio projekt uređenja zgrade vladina Odjela za bogoštovlje i nastavu u Opatičkoj 10. On je bio u funkciji estetizacije političke i upravljačke funkcije, ali prije svega je naglašavao primarno mjesto prosvjetne politike u sklopu nagodbenog sustava, kao i njezina visoka dostignuća. Pod utjecajem njegova obrazovanja, Kršnjavijev nacionalizam bio je definiran suvremenim europskim strujanjima, a njegov kulturni projekt, ostvaren političkim pragmatizmom, predstavlja još jednu iteraciju motiva „sustizanja“ europskih trendova. To se očituje i u ikonografiji prostora palače u Opatičkoj. Ona je ujedno poligon za oformljenje skupine umjetnika koji će stvarati umjetnost u službi nacije te od Zagreba učiniti nacionalno središte kulture, izraz Kršnjavijevih tradicionalnih akademskih estetskih pogleda i klasicističko-humanističkih ideala te zorni prikaz hrvatske državopravne ideologije i zamišljenog mjesta u okviru Habsburške Monarhije. ${ }^{916}$ Međutim, Kršnjavi je ujedno bio i vrlo autoritativna figura, a njegov je osobni odnos prema likovnim umjetnicima, napose Bukovcu kao njihovu predvodniku, u velikoj mjeri bio uzrok hrvatske likovne secesije, mnogo više nego radikalno razilaženje u idejnom smislu, kojega zapravo nije bilo. Zbog toga su likovni umjetnici nakon raskida s Kršnjavijem u mladima našli nove saveznike, koji su njihovu secesiju obilježenu osobnim sukobima (re)interpretirali kao sraz tradicionalnog i modernog razumijevanja umjetnosti te joj dali idejno-konceptualni okvir.

Iako bi se ovakav Khuenov pristup kulturnoj politici mogao smatrati analognim politici austrijskog ministra predsjednika Ernesta von Koerbera, koji je u podršci secesiji vidio mogućnost izgradnje jedne svemonarhijske, lojalističke umjetničke paradigme i konkurenta dominantnim romantičarsko-historicističkim paradigmama, njegova je logika bila prvenstveno pragmatična i uvjetovana lokalnim političkim okolnostima. ${ }^{917}$ Stoga nije čudno

\footnotetext{
915 Za obuhvatniji pregled vidi: Marina Bregovac Pisk, Kristian Gotić (ur.), Iso Kršnjavi - veliki utemeljitelj, Zagreb, 2012; Olga Maruševski, Iso Kršnjavi kao graditelj, Zagreb, 2009.

${ }^{916}$ Usp. Iskra Iveljić, „Kulturna politika u Banskoj Hrvatskoj 19. stoljeća“, Historijski zbornik LXIX, 2, 2016, 362-366; Olga Maruševski, Iso Kršnjavi: kultura i politika na zidovima palače u Opatičkoj 10, Zagreb, 2002.

${ }^{917}$ Usp. Schorske, nav. dj., 248-249.
} 
da ni Narodne novine nisu bile otvoreno neprijateljski nastrojene prema mladima, te su im čak ponekad ustupale svoje stupce. Sve to sigurno je dodatno utjecalo na porast sumnje među starima kada je riječ o namjerama i ciljevima mladih. Khuen je mogao biti zadovoljan; ako i nije uspio pridobiti mlade na svoju stranu (što je bilo teško za očekivati), uspio je produbiti generacijski razdor u okviru hrvatske opozicije.

Izložba je polučila zadovoljavajući uspjeh za organizatore. Posjetilo ju je više od 11 000 građana. Organizatori posebno ističu da su među njima bile i učenice viših djevojačkih škola, učenici gimnazija, te naročito radništvo. U tom smislu ona je postigla jedan od ciljeva mladih, da se širi slojevi zainteresiraju za hrvatsku umjetnost. ${ }^{918}$ Osim toga, ovo je bila do tad najveća izložba domaće umjetnosti u Hrvatskoj. Organizatori, međutim, žale što nisu uspjeli okupiti baš sve najvažnije hrvatske umjetnike, jer su po strani ostali Celestin Medović i Nikola Mašić. Ne treba, međutim, zaboraviti da je ova izložba poslužila i kao sredstvo povezivanja mladih s dijelom starih, nastavljajući se na razgovore oko osnivanja Društva hrvatskih književnika, dok je opet s druge strane katalizirala sukob s drugim dijelom starih koji nije odobravao takav smjer razvoja hrvatske kulture. Tako su na izložbi javna predavanja održali profesor Franjo Marković, doajen starije generacije, kao i Ante Tresić Pavičić, jedan od najžešćih kritičara mladih, napose praške skupine. ${ }^{919}$ Iako su oni iskoristili ovu priliku da kritiziraju određene aspekte secesije, što nije naišlo na odobravanje dijela mladih, ipak je to bila gesta koja je pokazivala otvorenost za suradnju sa svima kojima je stalo do napretka hrvatske umjetnosti.

Hrvatski salon bio je jedan od najvažnijih rezultata umjetničko-književničke suradnje mladih, ali nije bio posljednji. Već prilikom njegova zatvaranja 10. ožujka 1899. godine, u tijeku su bile pripreme za sudjelovanje na Pariškoj izložbi 1900., ali i planovi za organiziranje velike jugoslavenske izložbe. ${ }^{920} \mathrm{U}$ tim je planovima i daljnoj suradnji važnu ulogu imao Dušan Plavšić, koji je bio jedan od organizatora sudjelovanja hrvatskih umjetnika na petrogradskoj Izložbi umjetnosti i umjetničkog obrta naroda Austro-Ugarske 1899. godine. ${ }^{921}$ Ovo je razdoblje općenito obilježeno procvatom kulturno-umjetničkog života u Zagrebu. Ivo Pilar tako sredinom rujna 1898. godine piše Plavšiću u Beč o tome kako Zagreb ima mnogo potencijala i da u njemu, za razliku od Beča, pulsira snažan umjetnički život, baš kao u Pragu. U podtekstu je naravno riječ od nacionalnom umjetničkom životu. Sva se nacionalna

\footnotetext{
918 „Bilješke“, Isto, sv. 4, 44.

919 „Bilješke“, Isto, sv. 3, 32.

920 ,Bilješke“", Isto, sv. 4, 44.

${ }^{921}$ D. N. P, „Petrogradska izložba“, Život, I, 4, 141-145.
} 
intelektualna snaga usmjerila prema umjetnosti jer je političko polje zatrovano. ${ }^{922}$ Iako se kulturni život u Zagrebu razvija pod snažnim utjecajem Beča, neki akteri te kulture vide Beč kao odnarođeno, dekadentno središte. Ono može dati svojevrsne impulse i uzore, ali ti se uzori moraju prilagoditi tako da budu u skladu s ciljevima razvoja specifične nacionalne kulture. ${ }^{923} \mathrm{Na}$ sličan je način novoosnovani Klub hrvatskih književnika bio mjesto transfera modernističkih kulturnih praksi, ali i političke borbe. U prostorije Kluba zalazili su i slikari i kipari, iako su imali svoje vlastito društvo. Na dan otvorenja Hrvatskog salona, kako prenosi Mihovil Nikolić, tamo su se okupili umjetnici da dočekaju svoje prvake, Bukovca i Gjalskog. „Sve je bilo u zanosu, poletu i oduševljenju“, prisjeća se on, „sve je osjećalo da će se otpočeti raditi i stvarati: da će se dizati hrvatska književnost i umjetnost. Ar se zdižu mladi... “924

Mladi su osjećali da su u naletu. Ivo Pilar je tako nagovarao Plavšića da pristane na poziciju glavnog urednika Vienca ako mu to uspiju isposlovati na temelju njegove novostečene reputacije kao urednika Mladosti. Cilj je bio preuzeti, spasiti i obnoviti Vienac, a ako to ne bi uspjelo, za Plavšića je bilo predviđeno mjesto urednika novog lista mladih koji je trebalo izdavati Društvo hrvatskih umjetnika. ${ }^{925}$ Mladi su tako u domeni kulture mnogo jače napali pozicije starih nego na području politike. Razlog je tome taj i što je hrvatska opozicija bila mnogo jača na polju kulture, kamo se zapravo povukla uslijed političkog poraza u srazu s banom Khuenom. Zbog toga je i sukob mladih i starih mnogo snažnije plamtio na području kulture nego politike, jer su ovdje bile ugrožene one pozicije na koje je hrvatska opozicijska elita polagala pravo monopola. Baš zbog toga, Milivoj Dežman je shvaćao da jači prodor mladih neće biti moguć bez kompromisa makar s jednim dijelom starih, te je u tom smislu i djelovao u svojim inicijativama. I dio starih je shvatio da nema previše koristi od otvorena sukoba s mladima te da bi se njihova energija mogla mnogo konstuktivnije usmjeriti, pa i kontrolirati suradnjom. Tako je 6. listopada 1899. godine u Matici hrvatskoj održan sastanak

922 „Pilar - Plavšiću, Zagreb, 14. 9. 1898.“, HR-HDA-757 Obitelj Plavšić, k. 39. Objavljeno u: Stjepan Matković, „Ivo Pilar: Pisma Dušanu Plavšiću (1897.-1898.)“, u: Srećko Lipovčan, Zlatko Matijević, Prinosi za proučavanje života i djela dra Ive Pilara, sv. 2, Zagreb, 2002, str. 159-167.

${ }^{923} \mathrm{U}$ tom pogledu Ines Sabotič vrlo pregnantno zaključuje kada je riječ o transferima kulture kavana: „Ako ima tame u mladenačkim dušama Zagreba i Beča, ipak postoje razlike. Prvi se nalaze u svijetu koji se tek modernizira i koji se teško razvija. Traži se sloboda. Drugi su, pak, u razvijenom, pa čak i dekadentnom središtu. Ovdje su mladi svjedoci rušenja njihova svijeta. Stoga, mladi hrvatski pisci imaju ambivalentni stav. Slijede književne inovacije i žive boemskim životom kao svi mladi europskih gradova. Međutim, taj transfer nije potpun. Vrijednosti jednoga dekadentnog građanstva ipak se ne mogu ukorijeniti u društvo koji se tek modernizira. Hrvatski boemi ne mogu apstrahirati političke probleme i nacionalnu baštinu. Kao što moderna u sebi nosi određenu političku dimenziju, nose je i kavane i njezini gosti. “ Sabotič, nav. dj., 224. U Budimpešti je, primjerice, kavana Central poslužila kao sjedište uredništva časopisa Héta (Tjedan), tada najvažnijeg mađarskog književnog tjednika. László Kontler, Povijest Mađarske: tisuću godina u Srednjoj Europi, Zagreb, 2007, 317, 321-322.

${ }^{924}$ Nikolić, nav. dj., 561.

925 „Pilar - Plavšiću, Zagreb, 14. 9. 1898.“, „Pilar - Plavšiću, Zagreb, 28. 9. 1898.“, HR-HDA-757 Obitelj Plavšić, k. 39. 
hrvatskih književnika na kojemu je odlučeno da je potrebno osnovati „obće hrvatsko književničko društvo" te je u tu svrhu izabrana delegacija (Luka Marjanović, Josip Šilović, Milan Krešić, Milan Grlović i Gjuro Deželić), koja bi o tome trebala pregovarati s delegacijom Kluba hrvatskih književnika. Obraćajući se upravnom odboru književničkog kluba, koji je formalno funkcionirao u sklopu Društva hrvatskih umjetnika, Deželić je molio da se odazovu na razgovor u Maticu hrvatsku te da ponesu pravila Društva hrvatskih književnika koja su ranije neuspješno podnijeli na odobrenje vladi. U slučaju dogovora, oni su bili spremni obećati materijalnu i moralnu potporu Matice hrvatske: „Ako se slože književnici svih struka, stari i mladi u Zagrebu mogli bi novo stoljeće pozdraviti svojim samostalnim za život podobnim književničkim društvom. Da Bog da!“926 Klub hrvatskih književnika pristao je na ove pregovore koji su rezultirali osnivanjem privremenog odbora na čelu s Gjurom Deželićem koji je trebao pripremiti nova pravila. Njegov je sastav odražavao kompromis mladih i starih: N. Andrić, V. Bukovac, Gj. Deželić, M. Dežman, M. Grlović, M. Krešić, L. Marjanović, S. Miletić, M. Nikolić, J. Šilović i S. Tucić, uz pomoć T. Smičiklasa i I. Kostrenčića. Pravila koja je privremeni odbor pripremio pretresana su na novom sastanku hrvatskih književnika održanom u Streljani 7. prosinca 1899. godine. ${ }^{927}$ Kompromis je polučio uspjeh. Zemaljska vlada je 17. ožujka potvrdila pravila novog Društva hrvatskih književnika. Time je ostvaren jedan od najvažnijih ciljeva mladih koji je Dežman zacrtao još u svojem programatskom članku u Hrvatskoj misli.

Kompromisno osnivanje Društva hrvatskih književnika nije, međutim, potpuno uklonilo trvenja između mladih i starih, nego im je dalo institucionalni okvir. Nakon osnivanja društva u njega su se učlanili i oni stari koji su bili najžešći protivnici i kritičari mladih. Nedugo nakon osnivanja broj pravih članova popeo se na gotovo $250 .{ }^{928}$ Tada se razvila borba za kontrolu nad društvom. Na konstituirajućoj sjednici Društva hrvatskih književnika za predsjednika je aklamacijom izabran Ivan Trnski sa sva 103 glasa. Za mjesta u upravnom i nadzornom odboru, međutim, razvilo se mnogo žešće nadmetanje. Pojavile su se četiri kandidacijske liste: prva je bila bliska privremenom odboru, odnosno onoj grupaciji starih koja se okupila u Matici hrvatskoj i ponudila mladima suradnju oko osnivanja društva; druga je bila lista mladih; treća je bila lista starih koji su polemizirali s mladima, ali su bili spremniji na suradnju; dok je četvrta bila grupacija najsnažnije antimodernistički istaknutih aktera. Naposljetku su mladi stupili u koaliciju s trećom listom, dakle ne s onim dijelom

\footnotetext{
926 „Deželić - Dežmanu“, 6. 10. 1899،“, HR-AHAZU-KN-44 Dežman, Milivoj, k. 11.

927 „Zapisnik sastanka hrv. književnika 7. 12. 1899.“, HR-AHAZU-KN-44 Dežman, Milivoj, k. 6.

928 „Društvo hrvatskih književnika“, Život, I, 5, 179. Vidi popis članova do 22. travnja 1900 u HR-AHAZU-KN44 Dežman, Milivoj, k. 6.
} 
starih s kojima su formirali privremeni odbor, nego s onim starima s kojima su vodili žestoke polemike (Arnold, Harambašić, Hranilović, Tresić itd.). Kao razlog tome mladi spominju pogrešku privremenog odbora koji je taktizirao s izborom kandidata na takav način da izbjegne nesuglasice, sastavivši „listu pretežno indiferentnih ličnosti.“ Takav kompromis nije zadovoljio „književničke dotično socijalno-političke grupe“, koje su željele „svaka da dodje do odlučne riječi.“929 Zbog toga su se mladi sporazumjeli s dijelom starih oko Trnskog kao kandidata za predsjednika te su na izborima zadobili većinu u upravnom odboru, dok je najlošije prošla posljednja lista antimodernista. Potrebno je ipak naglasiti kako ove grupacije nisu uvijek nužno slijedile jasne ideološke linije, nego su često ovisile o osobnim poznanstvima i vezama, kao i o pojedinačnim idiosinkrazijama. Zbog toga se ova trvenja u okviru Društva hrvatskih književnika ne mogu jednostavno čitati kao indikator borbe između mladih i starih, odnosno kao refleks omjera snaga, ali pružaju važan uvid u pragmatične i realpolitičke aspekte cijelog procesa. Javno proklamirani stavovi i polemike nisu nužno uvijek morali imati iste ishode i na razini borbi oko zauzimanja pozicija u institucijama i različitim interesnim sferama.

Nisu svi u redovima mladih bili zadovoljni ovakvim razvojem događaja. Vladimir Jelovšek je u pismu Dežmanu kritizirao njegovu spremnost na kompromis sa starima, opisujući ga ironično kao „blagonakloni smješak zrelog i trijeznog nad naivnim bučnim radikalizmom mladenaštva“. On Dežmanove postupke vidi kao svojevrsnu izdaju ranije proklamiranih ideala, dok imenovanje Trnskog za predsjednika Društva hrvatskih književnika naziva „lakajštinom“.930 Kompromis također nije zaustavio trvenja u Društvu hrvatskih književnika. Ivan Trnski tako u listopadu 1900. piše Dežmanu da je spreman ponuditi svoju ostavku na mjesto predsjednika društva zbog nesuglasica koje u njemu vladaju. ${ }^{931}$ Ipak, institucionalizacija u okviru Društva hrvatskih književnika djelovala je na različite načine na dinamiku pokreta mladih, napose u pogledu unutrašnjih raslojavanja i razbijanja njegove kohezije, te je u tom smislu bila jedan od signala njegova jenjavanja.

Paralelno s naporima oko osnivanja Društva hrvatskih književnika, nakon prestanka izlaženja Mladosti i dovršenja posla oko Hrvatskog salona, radilo se i na pokretanju novog književnog lista mladih. Inicijativa je krenula još iz provizornog Kluba hrvatskih književnika. Krajem lipnja 1899. održan je sastanak s predstavnicima Društva hrvatskih umjetnika na kojem je Dežman iznio ideju pokretanja novog lista čiji bi izdavač bilo Društvo hrvatskih

\footnotetext{
929 Isto.

930 „Jelovšek - Dežmanu, Prag, 2. 5. 1900.“, HR-AHAZU-KN-44 Dežman, Milivoj, k. 11.

931 „Trnski - Dežmanu, 13. 10. 1900.“, Isto.
} 
umjetnika do osnivanja Društva hrvatskih književnika, nakon čega bi list postao zajednički projekt tih dvaju društava. ${ }^{932}$ Prijedlog koji je iznesen bio je zapravo modificirani „Poziv za ustrojenje književno-umjetničkog društva“ koji su ranije sastavili Plavšić i Jeny. Uz Dežmana i Plavšića, inicijatori su bili Stjepan Miletić, Robert Frangeš Mihanović, Bela Čikoš, Rudolf Valdec i Isaković ${ }^{933}$. Redakcijski odbor lista trebalo je činiti dvanaest književnika i šest umjetnika, čime je nastavljena praksa književničko-umjetničke suradnje. Na sjednici 8 . listopada odlučeno je da se uredništvo povjeri Dežmanu, tajništvo Tuciću, dok su uredništvo likovno-umjetničkog dijela lista preuzeli Frangeš i Viktor Kovačić. ${ }^{934}$

Nakon temeljitih priprema, 1. siječnja 1900. godine pojavio se prvi broj časopisa Život, mjesečne smotre za književnost i umjetnost. Ukupno je izašlo tri sveska lista s po šest brojeva, dakle osamnaest brojeva tijekom 1900. i 1901. godine (zadnji je trobroj travanj-lipanj iz 1901. godine). Odmah upada u oči da je Život prvi časopis pokreta mladih koji ne nastupa s određenim uvodnim, programatskim tekstom. Umjesto toga, istaknut je motto časopisa, citat ilirca Josipa Kundeka iz 1832. godine:

„Ar se zdižu mladi, posluju marljivo

Ter podžižu v stareh, kaj bilo vglaslivo.“

Već sama ta činjenica upućuje na karakter lista i na općenitu intenciju iza tog projekta. To više nije borbeni list mladih, nego egzemplarni list zamišljene nove, reformirane hrvatske književnosti i kulture. On se temelji na ideji suradnje svih hrvatskih književnika i umjetnika, neovisno o pripadnosti određenim školama ili stilovima, a osnovna je potka te suradnje sloboda stvaralaštva i izražavanja. ${ }^{935} \mathrm{U}$ tom smislu, specifični stavovi koji su zastupani $\mathrm{u}$ ovom listu mogu se iščitavati samo kroz pojedinačne tekstove, kritike i polemike. Nedvojbeno je da je to i dalje list mladih i onog dijela starih koji je podržavao njihove napore, ali on ujedno pokazuje sve znakove pokreta koji ulazi u svoju završnu fazu: zamjena manifestnog stava pluralitetom sadržaja, otvorenost za širu suradnju umjesto konfliktnosti, raslojavanje i različitost pozicija i pristupa unutar samih mladih.

Najvažniji niz tekstova programatskog karaktera za Život je napisao Branimir Livadić. U tekstu „Hrvatska književnost i siromaštvo“ on je na tragu Dežmana analizirao utjecaj društvene i političke situacije na hrvatsku književnost. Budući da zanimanje književnika u

\footnotetext{
932 Flaker, nav. dj., 37.

${ }^{933}$ Najvjerojatnije je riječ o Aleksandru Isakoviću, mužu Ljerke Šram.

934 Isto, 38.

935 Tako je npr. na stranicama Života Ante Tresić Pavičić branio i obrazlagao estetska načela svoje historijske tragedije Katarina Zrinski, dok je o talijanskoj književnosti pisao Jakša Čedomil. Za Život je čak pisao i Franjo Spevec. Ante Tresić, „Katarsa i tehnika Katarine Zrinjske“, Život I, 1-3; Jakša Čedomil, „Giovanni Pascoli“, Isto, 1; Franjo Spevec, „Proslava 500-godišnjice sveučilišta krakovskoga“, Isto, II, 1.
} 
Hrvatskoj ne može biti samostalno, većina njih primarno je obvezana poslu kojim zarađuju za život, što znači da se ne mogu u potpunosti posvetiti svojoj umjetnosti. Osim toga, u takvu su odnosu nužno sputani strahom od gubitka posla, kao i raznim društvenim obzirima. Rezultat je svega toga potpuna nesloboda stvaranja. Osim toga, siromaštvo hrvatskoga društva utječe i na sam sadržaj književnosti. Ono „unosi u književnost onaj plačljivi ton propovjedaonice na mjesto čistoga glasa umjetnosti, koji propovijeda prije svega život", ili pak s druge strane pjesnik izbjegava u potpunosti konfrontaciju sa stvarnošću i svoj materijalni položaj sublimira u idealnome, a taj idealizam ,prija svim faktorima u zemlji, koji su mjerodavni. “936 Sve to spriječilo je razvoj zdravog realizma u hrvatskoj književnosti. Jedina je iznimka pučka realistička pripovijest, ali iako su takvi pisci u doticaju s narodnim životom, nisu u mogućnosti sagledati šira svjetska kulturna kretanja, pa njihov rad ostaje umjetnički nerazvijen. Nastavljajući na ovu analizu, Livadić kritički sagledava i razvoj najnovije hrvatske književnosti. Iako je zamjetna mnogo veća književna produktivnost nego ranije, on u toj pojavi ne vidi pozitivnu, nego upravo negativnu tendenciju razvoja domaće književnosti. Ta je povećana produktivnost zapravo rezultat loša obrazovanja i stanja u društvu u kojem bavljenje književnošću služi kao svojevrsna kompenzacija, a rezultat je diletantizam. ${ }^{937}$ Osim toga, Livadić podvrgava kritici i ono što vidi kao pretjerani individualizam moderne iz kojeg također proizlazi diletantizam. Skrivajući se iza individualističke devize, stvaraju se brojna djela koja neće moći izdržati test vremena jer nisu sposobna zahvatiti univerzalnost ljudskog iskustva. U jednoj od prvih unutrašnjih kritika same moderne, Livadić upozorava da pjesnički individualitet nikako ne smije zasjenjivati samo djelo, koje je temeljni produkt i cilj umjetničkog stvaranja. Naposljetku, u svojem trećem tekstu staje u obranu temeljnog načela moderne umjetnosti, a to je sloboda stvaranja. Odgovarajući na učestale optužbe za pornografiju i nemoral prikazivanja života u modernoj književnosti, on iznosi tezu koju je Dežman već ranije elaborirao u Hrvatskoj misli: prikazivanje svih aspekata ljudskog života i duše nužno je u svrhu njihova pronicanja. Prvi i glavni ideal umjetnosti ne može biti briga za moral ili bilo koji izvanjski čimbenik, nego samo ljepota. ${ }^{938}$

\footnotetext{
${ }^{936}$ Branimir Livadić, „Hrvatska književnost i siromaštvo“, Isto, I, 5, 170.

937 „Kad nisam za drugo, bit ću književnik, možda će mi ondje ruže cvasti!“ Branimir Livadić, „O najnovijoj hrvatskoj književnosti“", Isto, II, 5, 173.

938 „Ljudska duša, taj najsilniji misterij svega bivstva, to najuzvišenije, najbolje i najsvetije, što nam je dala priroda, ljudska duša neka bude predmet svega našega umjetničkoga rada. Svagdje, gdjegod se javlja, budi prigušeno tajnim čuvstvom budi glasno u povicima sreće i blaženstva, svagdje neka je traži umjetnikovo oko. Dok god bude njegovo opažanje ispravno, njegovo prikazivanje iskreno, istinito, istini dolično, bit će i njegov uspjeh siguran. To je bez sumnje najdublja tajna ljepote.“ Branimir Livadić, „Za slobodu stvaranja“, Isto, II, 6, 209.
} 
Osim u pojedinačnim člancima, programatsko stajalište Života najbolje se vidi u odgovorima uredništva na razne kritike koje su dolazile na račun lista. Te su kritike upućivali i mladi i stari. Dio starih, napose onaj blizak klerikalnim krugovima, optuživao je Život za širenje bezboštva i slavljenje protuvjerskih ideja. Dio mladih mu je pak zamjerao šutnju, kukavičluk i nepodizanje glasa protiv reakcionarnih tendencija u društvu. Odgovarajući i jednima i drugima, uredništvo objašnjava svoje držanje:

„Život zastupa u umjetnosti i književnosti slobodoumno stanovište, a to znači braniti slobodno uvjerenje i slobodu stvaranja. Naše nam stanovište ujedno nalaže toleranciju dakle i štovanje protivničkih mnijenja. Mi nismo nikakovi antiklerikalci. Pitanje odnosa izmedju znanosti i umjetnosti s jedne a vjere s druge strane za nas je riješeno i kulminira u stavci: NE DIRATI NI U ČIJE VJERSKE NAZORE, ZAŠTIĆIVATI SLOBODU ISTRAŽIVANJA U ZNANOSTI I SLOBODU STVARANJA U UMJETNOSTI.“ “939

Drugim riječima, urednici Života jasno naglašavaju da se neće staviti ni u čiju službu, nego će uvijek nastojati održati svoju neovisnost: „Mi dobro znamo, kud ciljaju pod tom krinkom patriotizma, za to ćemo ODLUČNO braniti i SVOJE HRVATSTVO i SLOBODU SVOJEG MIŠLJENJA I STVARANJA. Mladjima pako moramo naglasiti, da mi ne ćemo nikoga izazivati bez potrebe. ${ }^{\text {(9940 }}$

Važno je obilježje Života to da se u sklopu njega programu reformirane, moderne hrvatske umjetnosti i kulture pridružuju i druge grane umjetnosti: glazba i arhitektura. $\mathrm{O}$ glazbi je u tom smislu pisao Srećko Albini u tekstu „Za hrvatsku glazbu“. Primjećujući da razvoj hrvatske glazbe zaostaje za ostalim umjetnostima, on je kritički nastupio prema dvije krajnosti koje je uočavao u pristupu hrvatskih skladatelja. S jedne strane oponaša se narodna glazba, ali bez dovoljne tehničke rafiniranosti koja bi omogućila da takva glazba dostigne razinu vrhunske europske umjetnosti, dok se s druge strane oponašaju strani uzori, a da se u to ne integriraju elementi i motivi narodne glazbe koji bi skladbama davali specifični karakter, pa time i originalnost. Jedini tko je donekle uspio pomiriti ove dvije tendencije bio je Ivan Zajc. Zalažući se za wagnerijanski program u glazbenoj umjetnosti, Albini predlaže sintezu narodnog i internacionalnog, odnosno vrhunsko formalno i tehničko uobličavanje i uzdizanje narodnih glazbenih motiva i tema na razinu moderne umjetničke glazbe. ${ }^{941}$ Osim ovog programa za razvoj moderne hrvatske glazbe, Albini predlaže i infrastrukturne iskorake po uzoru na Društvo hrvatskih umjetnika i Društvo hrvatskih književnika: hrvatski glazbenici

\footnotetext{
939 „Iz književnog i umjetničkog svijeta“, Isto, I, 5, 172.

940 Isto.

${ }^{941}$ Srećko Albini, ,Za hrvatsku glazbu“, Isto, I, 1, 17.
} 
trebali bi se okupiti u vlastitom društvu i početi izdavati list. Ako dakle sagledamo ovaj tekst i njegove prijedloge u cjelini, posve je očito da on predstavlja doslovnu primjenu Dežmanova programa za modernu hrvatsku književnost na hrvatsku glazbenu umjetnost: vrhunska, europska umjetnost koja svoj sadržaj pronalazi u narodnim motivima i temama, što ju čini originalnom, a ne pukom imitacijom vanjskih uzora, kao i nužni razvoj umjetničke infrastrukture koji treba podržavati takav umjetnički rad.

$\mathrm{O}$ arhitekturi je u istom, reformskom pogledu pisao Viktor Kovačić. On se pak u potpunosti oslanja na poglede bečkog modernističkog arhitekta Otta Wagnera. Kovačić prenosi Wagnerovu kritiku historicizma, lažnih fasada, imitacija prošlih stilova i neusklađenosti s miljeom i potrebama suvremenog, modernog života. Primarni zahtjev moderne arhitekture je logičnost i praktičnost, čime ne prestaje biti umjetnost. Upravo suprotno, kao takva ona mora biti individualna i suvremena. ${ }^{942}$ „Ta tendencija“, zaključuje Kovačić, „umjetničke ciljeve spojiti sa praktičnošću, mora da prevladjuje kod modernog arhitekte. I to od najmanje sitnice, od zapora na vratima, od stolca do osnove za kaku palaču sve je to polje za arhitekta - i on mora u svakoj sitnici kao i u osnovi imati na umu savremeni život i njegove zahtjeve.“9943

Osim ovoga, Život uglavnom nastavlja kurs koji je zacrtan već u Mladosti: originalni domaći beletristički radovi i prijevodi, kao i prikazi stranih književnosti, kritike i recenzije kazališta i novih knjiga itd. Jednako tako nastavljene su i konkretne sugestije u smjeru reformiranja hrvatskog književnog života, od prijedloga vezanih za planiranu organizaciju proslave četristote godišnjice hrvatske književnosti, pa do prijedloga za reformu Matice hrvatske koji se temelje na Dežmanovim sugestijama iznesenim još 1897. godine u Hrvatskoj misli. On tako iznosi detaljan opis promjena koje bi se trebale dogoditi u funkcioniranju Matice hrvatske kako bi ona ponovno mogla uspješno obavljati svoj temeljni zadatak u okviru nacionalne kulture. Ona se prije svega mora vratiti slobodoumnim načelima koji su obilježili začetke hrvatskog nacionalnog pokreta. Isti oni krugovi koji nastupaju radikalno i zahtijevaju slobodu u javnom životu, u kulturnom su životu reakcionarni. To nesuglasje između političke i kulturne prakse hrvatske elite generira trenutnu krizu koja se svakim danom sve snažnije osjeća. ${ }^{944}$ Jasno je da je ova Dežmanova kritika uperena prema hrvatskim opozicijskim elitama i njihovu dominantnom položaju u nacionalnim kulturnim institucijama. Njegovi reformski prijedlozi stoga su usmjereni na slabljenje njihovih prevladavajućih praksi u tim

\footnotetext{
${ }_{942}$ Viktor Kovačić, „Moderna arhitektura“, Isto, 27.

943 Isto, 28.

${ }^{944}$ Iv., „Matica hrvatska godine 1899.“, Isto, II, 1, 14.
} 
institucijama, a kao krajnji cilj imaju ulazak mladih u te institucije te njihovu reformu u skladu s idejama i programom koji su zagovarali. Na sličan je način Dežman nastupio i prema Hrvatskom narodnom kazalištu. Analizirajući postignuto, iznoseći kritiku tadašnjeg stanja te prijedloge za budućnost, on je kao dva ključna cilja reforme kazališnog rada postavio uklanjanje financijskog deficita i podizanje umjetničke kvalitete. ${ }^{945} \mathrm{U}$ tom smislu on iznosi cijeli niz reformskih prijedloga koji se tiču pitanja od dramaturgije, preko režije, pa sve do broja izvedbi pojedinih komada. Osim toga, Dežman predlaže i integraciju kazališne mreže diljem cijele Hrvatske, pri čemu bi zagrebačko kazalište služilo kao centar. Tako se i na ovome polju očituje specifičan dežmanovski pristup reformi hrvatskog kulturnog života koji obuhvaća i kvalitetu umjetničke produkcije, ali i njezine praktične aspekte, spajajući pritom oboje s dominantnim pitanjem daljnjeg smjera razvoja nacionalne kulture.

Kao i svi ostali listovi mladih, i Život se uskoro našao u financijskim problemima. Troškovi su bili veliki, posebice zbog reprodukcija koje je list donosio. Iako je iza njega stajalo Društvo hrvatskih umjetnika, ono nije imalo dostatna sredstva da nastavi uzdržavati list. Uz to, već tradicionalno je podbacilo podmirivanje dugova pretplatnika. U obavijesti o obustavi izdavanja lista uprava je navela iznos od 4.000 kruna nepodmirenih obaveza pretplatnika. Osim toga, Društvo za umjetnost i umjetni obrt, koje je davalo godišnju potporu od 2.000 kruna za izdavanje lista, odjednom je bez obrazloženja uskratilo svoju podršku. ${ }^{946}$ Zbog svega toga, Život je s posljednjim trobrojem (4-6) trećeg godišta, koji je uredio Srđan Tucić nakon što se Dežman povukao s uredničkog položaja, završio svoj život.

U literaturi o pokretu mladih postavljalo se pitanje je li Život bio posljednji list modernističkog pokreta, te je li njegovim prestankom zapravo završio i sam modernistički pokret mladih. ${ }^{947}$ Kako smo se već uvodno postavili protiv stroga određenja početka i kraja pokreta mladih, jer sam njegov karakter odolijeva takvoj interpretaciji, i ovdje je potrebno izbjeći jednoznačan odgovor. Ipak, kao što je ranije rečeno, Život pokazuje obilježja koja ga opravdano svrstavaju na razmeđu onoga što nazivamo vrhuncem pokreta mladih i faze njegova jenjavanja. Marjanović ga stoga naziva „tribunom modernom, ali ne naročito 'modernističkom' ،“948 Bitna obilježja pokreta, kao što su generacijska pripadnost studentskom i đačkom korpusu, borbenost i manifestnost, u Životu blijede i prepuštaju mjesto strukturnoj poziciji mlade građanske inteligencije, koja nastupa zrelo i konstruktivno. Ključni akteri pokreta sazreli su i „stupili u život““, njihove ideje nisu više radikalna novina koja tek treba

\footnotetext{
945 Ivanov, „Hrvatsko kazalište“, Isto, II, 2, 65.

946 ,Život“", Isto, III, 4-6, 195.

${ }_{947}$ Flaker, nav. dj., 40-41.

${ }_{948}$ Marjanović, Hrvatska moderna I, 50.
} 
izboriti pravo javnosti, stoga nastupa faza njihova razvoja u kojoj se paralelno odvija jenjavanje pokreta kao pokreta, i njegova inkorporacija u tokove hrvatske građanske kulture i politike. Diskontinuiteti se pretvaraju u kontinuitete, transformirajući pritom sve strane uključene u taj proces.

\section{5. Polemike unutar pokreta mladih}

Iako su se okupljale pod kapom široke oznake pokreta mladih, njegove različite grupacije često su bile u konkurentskim, pa čak i zategnutim odnosima. Na to su utjecale osobne idiosinkrazije, ali i ozbiljna razmimoilaženja u pogledima, stavovima i habitusu. Iako zajednički vrlo općeniti ciljevi obično nisu bili dovedeni u pitanje, postojale su bitne razlike u poimanjima metoda i sredstava rada usmjerenih ka postizanju tih ciljeva. Već smo vidjeli kako se to odrazilo na odnose između bečkih i praških studenata $u$ razdoblju geneze $i$ oblikovanja pokreta, što je rezultiralo svojevrsnim nadmetanjem za primat u nastajućem pokretu mladih.

Pojavljivanje bečke Mladosti nije samo kataliziralo polemike između mladih i starih (o čemu će više riječi biti u sljedećem poglavlju), nego je potaknulo i razvoj javne polemike među samim mladima. Već je i sama najava novog modernističkog lista izazvala ambivalentne reakcije kod ostatka pokreta. Dok je Lorković Mladost vidio kao dobru dopunu praškoj Hrvatskoj misli zbog njezina fokusa na modernu umjetnost i književnost, Franjo Poljak izvještavao je da Ante Radić želi osujetiti izdavanje tog lista te da nagovara Dežmana da pokrene s grupom sposobnih ljudi novi list slična formata u Zagrebu. ${ }^{949}$ Nije stoga čudno da je prva bilješka o Mladosti u Novome dobu bila vrlo neutralno intonirana. Jedina opaska praške skupine bila je da je „list s tako obilnim programom svakako preuranjen za naše općinstvo. “950 No već nakon prvog broja Mladosti ton i stav praških mladih se promijenio. Napose je Dežmanov uvodni programatski tekst izazvao negativne reakcije. Lorković je ponovno bio najblaži, smatrao je da bi se list mogao poboljšati s više prijevoda, a manje originala. Ipak, i za njega je Dežmanov uvodnik posve nerazumljiv. ${ }^{951}$ Mnogo je oštriji bio Franjo Poljak, koji je smatrao da je Mladost dezavuirala Šarićev programatski tekst o hrvatskoj književnosti iz Hrvatske misli te da je upravo on trebao biti zadužen za literarnu

949 „I. Lorković - F. Hlaváčeku, Zagreb 20.IX.1897““; „F. Poljak - F. Hlaváčeku, 11.XI.1897.“, u: Agičić, Dragi Franta!, 130, 170.

950 „Bilježimo“, Novo doba, I, 1, 48.

951 „I. Lorković - F. Hlaváčeku, Zagreb 9.I.1898“; Agičić, nav. dj., 145. 
reviju mladih. Prema njemu, logika je Mladosti pomodarska. U Hrvatskoj nema nervoznoga drhtanja koje je iz Beča donio Dežman, zbog čega će dekadentizam naići na osudu i nerazumijevanje. Ono što je za Poljaka opravdano u programu Mladosti je zalaganje za književnu slobodu, ali to je onda nespojivo s Dežmanovim uvodnikom. Iako nije za bojkot, smatra da je Mladost najsiromašniji pokret, koji će Hrvatsku najmanje preporoditi. ${ }^{952} \mathrm{U}$ drugome je pak broju Novog doba objavljena vrlo pozitivno intonirana bilješka (bez potpisa), koja o Mladosti govori kao o dijelu sveopćeg europskog literarnog pokreta i hvali njezinu suvremenost. ${ }^{953}$ Jedan od razloga za takvo djelovanje je komotnost i uskogrudnost starijih, zbog čega je mlađa generacija morala stvoriti svoja središta te se okupiti u samostalnome radu. Na ovu je bilješku pak žestoko reagirao Dragan Šašel, koji se nije mogao načuditi redakciji zbog odluke da ju objavi. Ona je prepuna ,gluposti“, a onaj tko ju je napisao trebao je smoći hrabrosti da se potpiše, jer ,nadrljati“ nekoliko stranica ne znači koračati usporedno s Europom k napretku. ${ }^{954}$

Ovaj je propust ispravljen već u idućem dvobroju Novog doba, u kojem je Milan Marjanović objavio kritički osvrt na dotadašnje brojeve Mladosti. On odmah ističe već uočenu diskrepanciju između teksta poziva na pretplatu Mladosti i Dežmanova programatskog uvodnika, koji se zapravo čita kao zagovor dekadentizma. Za Marjanovića, književnost mora biti plod narodne duše, odnosno u njoj se mora zrcaliti karakter naroda. Posežući za dežmanovskim principom iz Hrvatske misli protiv Dežmana u Mladosti, on ističe umjetnost kao silu koja narodu osigurava opstanak i mjesto u kolu civiliziranih naroda, ali na način da predstavlja njegov individualni karakter. Zbog toga, ,,presadite li pako u jedan narod čuvstva i težnje drugog naroda, za koji nema i ne može imati razumijevanja ma s kojega razloga, učinili ste, te se je presadila biljka, kojoj u novoj domovini manjkaju uslovi porasta i napretka.“ Upravo je to slučaj s Mladosti. Iako su djelomice krenuli dobrim putem predstavljajući Vereščaginov lik i djelo, naglašavajući dekadentizam „posnimači te zablude evropske kulture misle unijeti u našu literaturu svježine, koja da ju pomladi time, što intelekt zapostavljaju materiji, što daju, da instinkti i životinjski dio čovjeka gospoduju nad karakterom i duševnom snagom, što čvrstu volju, koja jedina djela stvara, podredjuju sanjarenju i mističkim tlapnjama!“ Takav pokret nije kadar zadovoljiti želje i potrebe većine domaće inteligencije koja ipak osjeća pripadnost slavenstvu. Zbog toga se tim „prisiljenim, nezdravim, protunaravnim pokretom“ samo ,pooštrava opreka izmedju naroda i inteligencije,

\footnotetext{
952 „F. Poljak - F. Hlaváčeku, Banija 21.I.1898.“, Isto, 179, 180.

953 „Mladost“", Novo doba, I, 2, 93.

954 „D. Šašel - F. Hlaváčeku, Karlovac 24.I.1898.“, u: Agičić, nav. dj., 210.
} 
proširuje jaz, koji ih dijeli.“ Dekadentizam ne može odgovoriti potrebama aktivna narodnog rada, nego će upravo suprotno dodatno doprinijeti malaksanju snaga i gubljenju volje za pozitivnim radom. U ovo doba krize, „kad bi trebalo, da si duševno jaka, znanjem snabdjevena, poletnih misli i čvrsta značaja mladež poda ruke, da priskoči u pomoć domovini, pa da kao jaka falanga ustane na obranu narodnoga obilježja i narodnog individualiteta, u to doba vidimo, da nema prečega posla, nego da plod, bolje zabludu evropske superkulture sadi u svoje srce i u grudi narodnje. “955 Zanimljivo je da su - iako ne u istom smislu i s istim ciljem - i praška skupina mladih i stari koristili slične argumente i identične motive u svojim kritikama kruga oko Mladosti: odnarođenost, importiranje strane kulture koja djeluje negativno na zdrave narodne snage, pomodnost i bijeg od pravih zadaća mlade nacionalne inteligencije. Na gotovo je identičan način o Mladosti pisala zagrebačka Narodna misao. I ona im zamjera uvođenje zapadnoeuropskih kulturnih modela koji ne odgovaraju narodnim idealima i potrebama. Ne negirajući potrebu za univerzalnošću ljudske kulture, smatra da akteri u napretku čovječanstva nisu pojedinci nego narodi, pa u tom smislu i hrvatsko-sprskoslovenskom narodu predstoji uzdizanje na razinu koja bi mu omogućila da bude takav akter, ali ne imitacijom strane kulture, nego razvojem i izgradnjom svoje autohtone. Upravo je oslanjanje na transfer stranih kulturnih obrazaca doveo do trenutnog lošeg stanja, a za njegovo poboljšanje ovoga puta čak nije niti moguće posegnuti za stranim uzorima, jer uvjeti za to nisu zreli. ${ }^{956}$

Uredništvo Mladosti nije imalo običaj odgovarati na sve pojedinačne kritike koje su stizale na njegov račun. U prilogu trećem broju, naslovljenom „Da se razumijemo“, ipak je doduše odlučilo progovoriti i razjasniti svoju poziciju o pitanjima koja su potezali njihovi kritičari. Ključna je zadaća Mladosti da bude slobodna i neovisna revija u kojoj će moderni književnici svih usmjerenja moći objavljivati svoje radove bez preventivne cenzure koju provode gotovo svi beletristički listovi u Hrvatskoj. U tom smislu Mladost nije organ niti jedne literarne, političke ili društvene skupine. Posebno se osvrćući na prigovor Narodne misli, urednici Mladosti ističu da se njihov fokus na razvoj domaće književnosti vidi iz književnog natječaja koji su raspisali, a da ni u kojem slučaju slavenske književnosti neće biti zapostavljene. Za njih među mladima nema spora, oni naglašavaju da imaju gotovo isti

\footnotetext{
955 Sperans, ,'Mladost'“, Novo doba, I, 3-4, 155-157.

956 „Po našem mišljenju“, zaključuju stoga „,mišljaši“, „,'Mladost' nije udarila putem, kojim bi se mogle odstraniti pogrješke naše književnosti i umjetnosti, kad je smetnula sasvim s uma narodno njezino obilježje pa se bacila u naručaj naroda tudjih. Taj nedostatak u nje najodlučnije osudjujemo, dok nijesmo načelno protivni i novim tudjim smjerovima, ako oni svojim dojmom ne podržavaju ili povećavaju mizeriju naše nenarodne umjetnosti i našega nenarodnoga života.“" „Mladost“", Narodna misao, I, 8.
} 
program u umjetnosti kao što je onaj Narodne misli u politici. ${ }^{957} \mathrm{Na}$ taj su se način pokušali javno čvrsto pozicionirati unutar pokreta mladih kao njegova zasebna grupacija.

Doduše, Narodna misao nije bila pretjerano zadovoljna tim odgovorom, smatrajući da Mladost nije shvatila njezine primjedbe. Narodni karakter književnosti ne proizlazi iz narodnosti njezina autora ili jezika na kojem je nastala, jednako kao što se niti narodna politika ne svodi na narodne fraze odnarođenih političara. U tom smislu Narodna misao dvoji da s Mladosti dijeli isti program. Ipak, ona ostavlja prostora za to da ih se uvjeri u suprotno, pa stoga nastupa mnogo pomirljivije nego u prvom tekstu. ${ }^{958}$ I Novo doba htjelo se ograditi od identificiranja svog programa s onim Mladosti. Odgovarajući Katoličkom listu, koji je izjednačio sve što za njih predstavlja „novo“ i „mlado“ - i Novo doba, i Narodnu misao, i Mladost, pa čak i Tresićev tradicionalistički list Novi viek - urednici Novog doba ističu kako se Mladost ne može smatrati tek literarnim pravcem praškog časopisa. Već su više puta naglasili kako je njihov smjer etički i kršćanski te se slažu s Katoličkim listom u njegovu protivljenju pornografiji i zahtjevu da hrvatska književnost bude odraz narodnog života, pa da stoga ima kršćanski karakter. Ipak zamjeraju Katoličkom listu što insinuira skrivene loše namjere pokretačima tog lista, za koje tvrde da su iskreni i pošteni. Osim toga, oni smatraju da treba čitati, dakako kritički, i one pisce s kojima se ne slažu, jer se u svakome djelu može pronaći i pokoja dobra misao, pa stoga treba paziti da se čupajući kukolj ne bi iščupala i pšenica. ${ }^{959}$

Novo doba se $\mathrm{u}$ više navrata negativno osvrtalo na modernističke tendencije $\mathrm{u}$ književnosti i kulturi. Nikola Fugger ih je tako, sintetizirajući Masaryka, usporedio s nečistoćom: „Nečistoća - to je nakaza našeg društva, to nakaza moderne literature. Pariški roman, pariška drama, pariška umjetnost tog genra to je izljev nečistog života. Nekoji to uvidjaju, nu to nije dosta, mnogi uz grižnju savjesti učestvuju pri modernim orgijama. “960 $\mathrm{U}$ jednom dopisu iz Beča, Mladost se opisuje kao „prilično nesolidni pothvat - dvojice, trojice, koji u djačkom životu u Beču ne igra nikakove uloge“, nastao u ,intelektualnoj močvari“, u „moralnoj kaljuži“ Beča. ${ }^{961}$ U završnoj bilješci prije kraja izlaženja lista, kada je Mladost također već bila ugašena, Novo doba najjasnije je do tada razložilo svoj stav prema Mladosti i njezinu mjestu u okviru pokreta mladih. Iako ih je javno mnijenje poistovjetilo, zajedno s Narodnom misli i Novom nadom, praški mladi naglašavaju svoju distinktivnost od Mladosti i

\footnotetext{
957 „Da se razumijemo“, Mladost, I, 3, s. p.

958 ,'Mladost“", Narodna misao, I, 6.

959 „Katoličkom listu“, Novo doba, I, 3-4, 172-173.

${ }^{960}$ N. F., „Djak treba da živi čisto“, Isto, 6-7, 244.

961 -k., ,Beč, 2. srpnja“, Isto, 8-10, 371, 376.
} 
Nove nade. Međutim, također priznaju i brojne stvari koje ih povezuju. Prije svega to su novi odnos prema Srbima i Slovencima i težnja za modernim napretkom. ${ }^{962}$ Iako naglašavaju distinktivnost njihova rada, ipak se ističe zajednička težnja za slobodom mišljenja, za kritičnošću, za uzajamnim radom sa Srbima i Slovencima i za radom uopće. Ne želeći se deklarirati kao antimodernisti, oni uvode razliku između svoga modernizma i modernizma Mladosti. Njihov je modernizam utemeljen na sintezi narodnjaštva, individualizma i socijalne orijentacije, s naglašenom kršćanskom dimenzijom. ${ }^{963} \mathrm{Na}$ kraju izlaženja Novoga doba i Mladosti, nakon inicijalnog razdoblja konkurencije i nepovjerljivosti, polako se dakle učvršćivalo poimanje koje je sve te različite i raznorodne pothvate vidjelo kao grupacije i strujanja jednog te istog pokreta mladih, koji karakteriziraju opća obilježja kritičnosti, želje za radom i promjenama i otvorenosti za moderna pitanja i strujanja.

Da je tome tako, svjedoči vidni izostanak rasprava o zagrebačkim umjetničkoknjiževničkim strujanjima i kretanjima u korespondenciji praške skupine. Doduše, tijekom razdoblja najžustrijih polemika u drugoj polovici 1898. i većem dijelu 1899. godine oni nisu imali svoj list u kojem bi se mogli osvrtati na ta događanja. U rijetkom i usputnom osvrtu, Vladimir Jelovšek je Hlaváčeku komentirao kako je činjenica „da imademo nevaljalih starih i - nemoćnih mladih. Jer ovo, što je danas u nas 'moderno' - to nije drugo, nego jedno trzanje nemoćnih mušica. Kod nas je moderno nešto sasma negativnoga: što stari psuju, to je moderno. [...] Ta negativnost je vrlo opasna po mladi pokret, ona od njih stvara ili fanatične sektare ili nekritične literarne gigrle [kicoše, N. T.], katkad koga i ubije.“964 Kada je pak pokrenut Glas, tek je u posljednjem dvobroju objavljen kratak osvrt na časopis Život. Kritizirajući Vienac, koji je u Šenoino doba predstavljao napredak i razvoj hrvatske književnosti, a tada znači stagnaciju i nazadak, ističe se sloboda stvaranja kao pozitivan princip Života, ali se očekuje da će stvoriti i nešto valjana. ${ }^{965}$ Kako su se dakle razilazili u ritmovima izdavanja svojih publikacija, nakon obustave Novog doba i Mladosti izostala je i produbljenija javna rasprava između praške i bečke skupine o naravi njihova odnosa.

Posve je drugačija situacija bila u odnosima između praške i zagrebačke skupine mladih. Dok su odnose praške i bečke skupine karakterizirali manjak međusobne komunikacije i javne trzavice, Hrvatska misao, Novo doba i Narodna misao javno se su proklamirali kao bratski listovi jednoga te istoga pokreta, te su njihovu djelatnost obilježili obilna međusobna korespondencija i sastajanje. To ipak nije spriječilo da se i među njima

\footnotetext{
962, ,Da nas razumiju“, Isto, 398.

963 Isto, 400.

964 „V. Jelovšek - F. Hlaváčeku, Zagreb 13.VIII.1898،“, u: Agičić, nav. dj., 81-82.

965 ,Život“", Glas, I, 4-5, 158.
} 
razviju nesuglasice, pa i svađe. Već smo vidjeli kako su praški mladi posebice u privatnoj korespondenciji izražavali svoje nezadovoljstvo s određenim pogledima zagrebačkih „mišljaša“, odnosno kako ih Fugger naziva „ujedinjenaša“.966 S druge pak strane, zagrebački Srbi u pokretu - pri čemu Fugger isključuje Pribićevića o kojemu pražani govore pohvalno predbacivali su praškoj skupini navodne socijalističke i pravaške tendencije. ${ }^{967}$ Ovo posljednje odnosilo se prvenstveno na pitanje hrvatskog državnog prava, oko kojega je i među praškim mladima bilo različitih, pa i oprečnih stavova. Posebno je oštar prema zagrebačkoj skupini bio Jelovšek, inače radikalniji član pokreta mladih. Za njega je upravo njihovo ponašanje - koje uključuje pijančevanje, pohađanje bordela i sl. - razlog zašto je pokret na zlu glasu u Zagrebu. Osim toga, oni su, tvrdi Jelovšek, ideje „,novog smjera“ usvojili samo kao fraze, ali zapravo razmišljaju i djeluju jednako kao stari:

„Pogriješili smo, što se izjavismo solidarnim i s njima, - i oni nijesu naši ljudi, oni su isto što i naši stari, oni su tek izmijenili riječi. Umjesto Velike Hrvatske rekoše Jugoslavija, mjesto samo Hrvati rekoše Srbi i Hrvati, mjesto 'okvira' rekoše 'nema okvira' i - basta. Unutrašnje, seriozne i solidne reformacije, reformacije djelotvorne: načela, nazora, teorija, filozofije, rada i t. d. - to nema. Par fraza o narodnoj duši i jedinstvu, često vrlo maglovite, nije ni program, nije filozofski sustav, nije u opće ništa drugo, nego fantom za naivnu djecu. “968

Usprkos skepsama, pa i otvorenu protivljenju nekih praških mladih, nije se odustalo od tijesne suradnje ove dvije grupacije, koja je naposljetku rezultirala izdavanjem zajedničkog lista Glas. Iako su javno proklamirali da su Hrvatska misao/Novo doba i Narodna misao zapravo dva lista jednog te istog pokreta, pražani su ipak htjeli obznaniti određene razlike. Najviše ih je smetao nedovoljan odmak zagrebačke skupine od starih. U članku „Da nas razumiju“, u kojem su jasno ocrtali svoje viđenje unutrašnje dinamike pokreta mladih, ističu da je ključna razlika ta što oni ne traže protektore za svoj rad, dok je krug oko Narodne misli s tom lošom praksom započeo već s almanahom, a nastavio navodeći Barčića i Potočnjaka kao glasnogovornike tjednika. Posebno su bili oštri prema Potočnjaku jer se on sve više percipirao kao glavni predstavnik novog pokreta s obzirom na to da je na raspolaganju imao i saborsku govornicu. Za praške mlade, međutim, on je ostao „učenikom stare škole parlamentne, novinarske a donekle i 'viteške'“،, odnosno, kako pišu, ,srce i prirodna inteligencija Dra Potočnjaka veže ga s novim pokretom a politička njegova naobrazba i navika sa starom

\footnotetext{
966 „N. Fugger - F. Hlaväčeku, b. mj., b. dat.“, Agičić, nav. dj., 36

967 „N. Fugger - F. Hlaväčeku, [Zemun, 11.VIII.1898.]“, Isto, 41.

968 „V. Jelovšek - F. Hlaváčeku, Zagreb 28.-29.VIII.1898.“, Isto, 86.
} 
političkom školom.“ Zaključak je praške skupine, dakle, da Hrvatska misao i Novo doba tvore jedinstveni pokret samo s autorima alamanaha Narodna misao, a nipošto s njezinim autoritetima, i s radnicima tjednika Naroda misao, a ne s njegovim glavnim urednicima i vlasnicima. ${ }^{969}$

Najmanje je ambivalentan odnos svih grupacija bio prema đačkoj skupini oko Nove nade. Budući da ih se gledalo kao na pomladak pokreta, svi su pokušavali ostvariti snažniji utjecaj na tu skupinu. U Novom dobu je Nova nada pozdravljena kao vrlo lijep list najmlađe literarne generacije u kojem pozorno prate najnovije literarne pojave u svijetu, a o kojima stariji svečano šute. ${ }^{970}$ Posebno ističući kritički dio lista, koji „odaje veliku oštroumnost, gotovo mušku objektivnost i spremnost“, kao i činjenicu suradnje Slovenaca i Hrvata, praški mladi u tu generaciju polažu velike nade. Ona u sebi ima sve uvjete da se razvije u jaku generaciju, doraslu velikim preokretima koji se spremaju u dvadesetom stoljeću. ${ }^{971}$ Nije stoga čudno što su već u ljeto 1898. godine predstavnici Nove nade sudjelovali na sastancima koje su organizirali praški mladi. Iako je bilo određenih kritičkih glasova - Ante Radić je npr. izdavanje Nove nade smatrao izlišnim pothvatom koji đake ometa u učenju - većina ih je objeručke prihvatila te tako glavne protagoniste novonadaškog pokreta Jelovšeka, Marjanovića i Cihlara uže vezala uz praški krug.

Nakon prestanka izlaženja Nove nade početkom 1899. godine, đački pokret okupljen oko tog lista ostao je bez svojeg idejnog i organizacijskog središta. U narednim godinama pojavilo se nekoliko inicijativa koje su željele ponovno oživjeti đački pokret okupljen oko Nove nade, ali sve su one bile bezuspješne. Jedna od njih bio je list Nova zvijezda, koju je 1901. u Zagrebu pokrenuo Franjo Kolaković. ${ }^{972}$ Ona se programski vrlo jasno i eksplicitno nadovezivala na Novu nadu. U uvodnom tekstu, „Naše težnje“, đaci su opisali sumornu atmosferu koja je zavladala među hrvatskim srednjoškolcima nakon prestanka nadaškog pokreta te su istaknuli potrebu za organiziranjem novog đačkog središta. Kako više nisu imali zajednički cilj i pokret, u đačkim je redovima ponovno zavladala fragmentacija, strančarstvo i međusobna napetost. Međutim, više nema oduševljenja za prazne političke fraze. Utjecaj je Nove nade ipak doprinio tome da se đaci ne mogu istinski zanimati za manifestacije bez realna sadržaja. Zbog toga je trenutno stanje čak gore nego što je bilo prije, jer je zavladala

\footnotetext{
969 „Da nas razumiju“, 399, 400.

970 „Mladost“", 93.

971 ,'Preporod' i 'Nova nada'“, Isto, 3-4, 163.

972 O Franji Kolakoviću nema gotovo nikakvih podataka. Čovjek istog imena i prezima se spominje 1905. kao član Hrvatskog tipografskog društva iz Senja, iako nije jasno je li riječ o istoj osobi. Međutim, s obzirom na postojanje naprednjačkih organizacija u Senju još od 1898. godine, moguće je da jest. Vlado Oštrić, „O počecima radničkog pokreta u Senju, 1874-1914.“, Senjski zbornik 7, 1, 1979, 22.
} 
potpuna apatija. Više čak ne izlaze niti amaterski litografirani listovi koji su ranije bujali u raznim školama i razredima. ${ }^{973}$ Nova zvijezda ipak nije uspjela obnoviti đački entuzijazam. Nakon svega pet brojeva prestala je s izlaženjem, ne ostavivši većega traga. Na istom su se tragu pojavile neke još kratkotrajnije incijative. Tako je u Zagrebu 1902. izašao svega jedan broj đačkog lista Jedinstvo, a u Karlovcu se u studenome iste godine pojavio također jedan jedini broj Zore, koja se deklarirala kao „književno glasilo hrvatsko-srbske-slovenske omladine“, a čiji je odgovorni urednik bio Pavao L. Weiser, karlovački tiskar, dok je stvarno uređivanje vjerojatno obavljao nepoznati đački krug. ${ }^{974}$ Neuspjeh ovih inicijativa zapravo mnogo govori o naravi samog nadaškog pokreta. U velikoj je mjeri on ovisio o svojim glavnim akterima, a također i o općoj dinamici modernističkog pokreta u Hrvatskoj, koja je u razdoblju ovih propalih inicijativa bila u silaznoj putanji.

Ključni akteri đačkog modernističkog pokreta napustili su đačke klupe te su se kao mladi studenti priključili pokretu mladih. Ono što karakterizira ovu skupinu njihov je širok raspon rada. Kako nisu stasali u okviru ranije definiranih grupacija, nego kao samostalna skupina, njihov je položaj u pokretu bio u određenoj mjeri autonoman, te su stoga surađivali i s praškim i s bečkim mladima, a pritom su nastavili i svoju vlastitu djelatnost. Tako se zapravo razvila još jedna skupina pokreta mladih, koja se često naziva „naprednjačkom“ ili „zagrebačko-karlovačkom“ skupinom, iako niti jedan od ova dva naziva ne zahvaća isključivo obilježje ove skupine, a to je njezino izvorište u đačkom, nadaškom pokretu, zbog čega ju mi nazivamo đačkom modernističkom skupinom mladih.

Njihov specifičan, samostalan položaj unutar pokreta mladih došao je do izražaja kroz njihovu djelatnost u karlovačkom Svjetlu, lokalnom listu koji je vodio Dušan Lopašić, a koji je bio otvoren za đake još od sredine 1890-ih. Nakon prestanka Nove nade, Svjetlo de facto postaje njihov organ. U dogovoru s Lopašićem preuzimaju uređivanje glavnine lista, dok je on zadržao uređivanje lokalne rubrike. ${ }^{975}$ Njihov je predvodnik u tom projektu bio Milan Marjanović, koji je preuzeo uredništvo literarnog dijela lista. U malo više od pola godine tijekom 1900., oni su uspjeli ovaj list izdići izvan njegovih lokalnih okvira, osigurati mu široku suradnju i učiniti od njega neovisan, nepolitički i nestranački moderni tjednik, a ujedno osigurati sebi govornicu za iznoženje i propagiranje svojih stavova. Posebno je snažno bila razvijena književna kritika, koja je općenito bila najjači segment djelatnosti ove skupine u okviru pokreta mladih. U Svjetlu važne kritičke tekstove pišu Marjanović, Petar Skok

\footnotetext{
973 „Naše težnje“, Nova zvijezda, I, 1, 1.

${ }_{974}$ Marjanović, Hrvatska moderna II, 22; „K našem prvom broju“, Zora, I, 1, 1.

${ }^{975}$ Marjanović, Hrvatska moderna I, 51.
} 
(Mikov), Milutin Cihlar i dr. Jedan od naziva kojim se označavala ova skupinu bivših novonadaša koji su se okupili oko karlovačkog Svjetla i drugih zajedničkih projekata je najmlađi. Razlog je taj što možda najbolje označava njihov strukturni položaj unutar pokreta mladih. Oni su se ujedno identificirali s općim ciljevima pokreta, ali su se i svjesno trudili diferencirati spram ostalih njegovih skupina, napose u trenutku kada su se počele javljati tendencije koje su za njih označavale skretanje s puta i krajnjeg cilja pokreta.

Iako su i sami surađivali u njemu, pripadnici najmlađe skupine pokreta najviše od svega nisu bili zadovoljni kompromisnim smjerom kojim je krenuo Život, odnosno djelatnost bečko-zagrebačke, „secesijske“ grupe u cjelini. Nakon što je u jednom feljtonu u Narodnim novinama krajem 1899. godine Mihovil Nikolić odbacio koncept secesije i borbe starih i mladih, te optužio „,simfonijske drugove, što se kupe oko karlovačkoga 'Svjetla'“ da „ruju“ protiv njih, Milan Marjanović odgovorio mu je u karlovačkom Svjetlu tekstom „Secesija fantom?" koji izvrsno ilustrira neslaganja mladih i najmlađih. ${ }^{976}$ On tumači Nikolićevu poziciju kao pokušaj da se stariji dio mladih prikaže konstruktivnima i spremnima za kompromis tako da mlađe prokaže kao rušilačke i uistinu secesionističke (u doslovnom značenju te riječi) elemente. U svrhu raščišćavanja pozicija, Marjanović oštro javno nastupa jer se javne stvari trebaju rješavati javno, a ne privatno, tajno i intimno. Upravo u tvrdnji da je secesija fantom, tj. nepostojeća obmana koja zamućuje odnose mladih i starih, on vidi izvor cijelog problema, odnosno napuštanje ideja i ciljeva koji su do tada vodili cjelokupni pokret, a koje je sam Dežman, predvodnik kompromisne struje, izvorno izložio u Hrvatskoj misli: „Pokret 'Moderne' nije imao da bude akcijom za koji specijalni moderni smjer, nego boj za slobodu: biti samostalnima $i$ iskrenima $u$ javnosti. Nezadovoljstvo sa kukavnim prilikama svelo je zajedno 'mlade'. 'Secesija' i bojkot - bilo je sredstvo. 'Modernizam' je bio - fantom.“ Dakle ne samo da se napušta modernistička paradigma, što zapravo nikada nije niti bilo vezivno tkivo cijeloga pokreta, nego je ključno to što se napušta zajednički prihvaćeno sredstvo borbe koje je usko povezano s ciljem, a to je sloboda javnoga izražavanja. Temeljna je pretpostavka mladih bila ta da se sloboda može izboriti samo slobodom, odnosno kritičkim i odlučnim javnim istupanjem, iznošenjem mišljenja i borbom: „Bez borbe nema izrazitosti, ni karaktera, bez javnog rada nema kritike, nema života, ni interesa ni publike. Smjelosti nam treba reći što hoćemo, mislimo i ćutimo u formi kako mi to hoćemo. A onda rad zajednički ide za tim, da se omogući ta smjela i otvorena riječ.“ Sloboda se ne može dobiti kao milost od literarnih monarha, mecena ili sabora, kao niti filistarskim akademskim raspravama i

\footnotetext{
976 „Kako živimo? (Iz literarno-umjetničkoga kluba)“, Narodne novine, br. 258, 25. XII. 1899.
} 
pregovorima. Takvi kompromisi demoraliziraju život, publiku i literaturu. Zbog toga je danas radikalizam ,jedino sredstvo, da se prenemo iz ove apatije“, ali radikalizam ,iz krute nužde“, a ne iz „obijesti ili mladosti ili prkosa“.977 On se očituje naprosto kao beskompromisna i otvorena javna borba za slobodu.

Nikolić se u svojoj optužbi na najmlađe referirao kao na „simfonijske drugove“ jer je time aludirao na stavove koje je Vladimir Jelovšek iznio u predgovoru svoje pjesničke zbirke Simfonije II. Naslovljen „Moj credo“, on u njemu kao svoje temeljno načelo iznosi apsolutnu individualnu slobodu, koja podrazumijeva da svatko ima pravo da bezobzirno i slobodno iskaže svoje mmijenje, sud, čuvstva i misli, neovisno o tome jesu li ispravni ili pogrešni i jesu li u skladu sa službenom dogmom. U vrijeme vrenja i kriza nužno je nastupati slobodno te se uklanjati bilo kakvim kompromisima koji ubijaju napredak. Deklarirajući se kao zakleti neprijatelj kompromisa, Jelovšek se ograđuje od svih domaćih literarnih i političkih struja, uključujući i modernu: „I sva ta oficijelna 'moderna' u nas toliko je iznijela slabašnoga, neizrazitoga, kompromisnoga, tako je djelovala literarno beskarakterno, nedostojno, neradikalno, - da nikako, nikako ne mogu s njome simpatizovati. U nas se sasma zanemario onaj krasni princip, koji sam vidio na pr. kod mladih Čeha konzekventno i krasno proveden: princip literarne karakternosti..." Kao najbolji primjer literarne beskarakternosti on navodi držanje mladih prema starima, jer nastavljaju s njima surađivati usprkos svim napadima, klevetama i optužbama, nastavljaju ,primati honorare iz ruku svojih beznačelnih protivnika“, dopuštaju da im oni „sakate i mijenjaju“ članke, te ih još primaju u svoje listove, proglašavajući to ,pobjedom 'svoje' misli“. Umjesto toga, umjesto neiskrene revolucionarnosti koja se ubrzo pokazuje kao „puka vanjska maska, djetinjsko capkanje, modno majmunisanje“ u vidu povratka pod ,,jaram kakve stare, vrlo stare stranke, ili dapače vlade“, Jelovšek se nada da će neki od najmlađih ipak „sačuvati svoj karakter“, te da će „,bezobzirnim radikalizmom zastupati svoju ideju i braniti svoje nazore. “978 Ovaj razlaz glede metoda postizanja ciljeva koje su kao opće prihvaćali svi akteri pokreta mladih definitivno je potvrdio Nikolić u svojem odgovoru na Marjanovićev članak. On je otvoreno izjavio da ne želi secesiju u književnosti i likovnoj umjetnosti koja bi se htjela obračunati sa svime što se dotad radilo i koja priznaje vrijednost samo novome. Ako secesija znači nezadovoljstvo pojavama koje priječe slobodni razvoj umjetničke individualnosti, pa samim time i kulture,

\footnotetext{
977 „Naša pisma“, Svjetlo XV, 1, 7. I. 1900.

${ }^{978}$ Vladimir Jelovšek, „Moj credo“, Simfonije II, Prag, 1900, u: Marjanović, Hrvatska moderna I, 105, $106,108$.
} 
onda se i on smatra secesionistom. Ipak, Nikolić zaključuje da polemike ni u kojem slučaju nisu produktivne $\mathrm{i}$ da ih se treba kloniti. ${ }^{979}$

Krug koji se okupio ovo Svjetlosti stoga je koncem rujna 1900. godine istupio proglasom „Mlada Hrvatska“ koji je otisnut kao prilog 40. broju Svjetla. Dvanaest potpisnika tog proglasa bili su: Vladimir Jelovšek, Slavoljub Jutriša, Janko Koharić, Henrik Krizman, Zofka Kveder, Milan Marjanović, Adela Milčinović, Andrija Milčinović, Stjepan Osterman, Milan Prelog, Petar Skok i Milan Šnidaršić. Za razliku od kruga oko Života, oni naglašavaju supstancijalnu različitost i nepomirljivost ideala starih i mladih. To je razlika između „naprednih i natražnih elemenata“, između „duha i mišljenja dvaju suprotnih generacija“, između „duha okorjele tradicionalnosti i duha slobodnoga napretka.“ Priznavajući i naglašavajući ovu razliku, oni se jasno svrstavaju k mladim i naprednim elementima. Iako protestiraju protiv cjelokupnog načina na koji stari vode borbu, uključujući laži, klevete, osobne napade itd., prvenstveno istupaju kako bi se ogradili i očitovali o držanju mladih u tom sporu, čiji pokret očito proživljava krizu. Oni izjavljuju da se ne mogu pridružiti pokretu političko-socijalne grupe, koja je proizašla iz Hrvatske misli i Narodne misli, jer nikada nisu imali jedinstven i definitivno određen političko-socijalni program, niti kane u tom smjeru aktivno politički djelovati. Jednako se tako ne mogu identificirati niti sa smjerom Mladosti i Života jer je njihova orijentacija pak preusko određena na literarno-umjetnička pitanja. Osim toga, nikako se ne mogu složiti s Dežmanom koji tadašnju borbu vidi samo kao društveni sukob slobodnih umjetnika i klika, dok ju oni shvaćaju kao sukob starih i mladih i kao borbu za slobodnu kulturu, kao borbu dvaju u principima, duhu i tendencijama potpuno oprečnih generacija. To je potrebno posebno naglasiti jer su reakcionarne snage nastupile jače nego ikada u provedbi rezolucija I. katoličkog kongresa. Zbog svega toga oni se izjašnjavaju kao zasebna skupina koja je proistekla iz pokreta Nove nade, a obilježava ih to da „nismo stajali pod odgojnim uplivom starog duha, da smo uvijek shvaćali našim zadatkom ne rad politički, niti rušenje prilika i ljudi, nego rad oko stvaranja čitavih i jakih ljudi, kao boj o novog čovjeka, o novi duh, o novo shvatanje, kao rad pripravni, kao rad kulturni uopće.“ Oni stoga iznose program svojeg daljnjeg rada koji se uvelike poklapa s programatskim smjernicama nadaškog pokreta: ideal unutrašnje slobode pojedinca i čvrsta karaktera, kriticizam („odlučni, otvoreni, javni, beskompromisni kriticizam“), individualizam (,da odgojimo valjanu publiku, t. j. individualizovani svijesni krug, a ne slijepu masu“), naprednjaštvo (,složni smo u istupanju proti svakom natražnjaštvu, što sputava slobodni razvoj pojedinca i društva“"),

979 „Naša pisma“, Svjetlo XV, 2, 14. 1. 1900. 
društveni i politički realizam (,shvaćamo i patriotizam kao realni (kulturni i socijalni) rad za sve realne pojedince ovoga skupa, koji se priznaje hrvatskim narodom“) i evropejstvo („Hoćemo da radimo kao napredni Europejci za ovaj naš hrvatski narod ovdje u njegovoj sredini“"). Sumirajući svoj program, oni najavljuju nastavak svojeg rada u Svjetlu, kao i druge projekte i inicijative. ${ }^{980}$

Stari su dakako pratili polemike među mladima te nisu propustili priliku da doliju ulje na vatru. Jovan Hranilović, tadašnji urednik Vienca i žestoki polemičar starih, predstavio je tako prepirke među mladima kao „secesiju od secesionista“ te je pozvao Dežmana i grupu okupljenu oko njega da se pridruže starima koji njeguju prave nacionalne tradicije. ${ }^{981}$ Dežman naravno nije mogao preuštjeti ovako otvorenu prozivku kako od strane mladih, tako i od strane starih. Pišući pod dojmom rezolucija Prvog katoličkog kongresa, on je žestoko odgovorio Jovanu Hraniloviću da modernim umjetnicima i književnicima ne pada na pamet pristupiti njihovu kolu, koje nije drugo nego kolo natražnjaštva i reakcije, s ciljem podvrgavanja književnosti političkim svrhama. ${ }^{982}$ Dežman se ne slaže da borbu treba prikazivati kao onu između starih i mladih, nego kao „,borbu slobodnih književnika protiv klike, farizejstva $i$ reakcijonarstva." ${ }^{\text {"983 }}$ A upravo ovo posljednje, a ne nastavljače Gaja, Preradovića i Šenoe - koji su gajili liberalni, a ne klerikalni duh - predstavlja Hranilović i grupa okupljena oko rezolucija Katoličkog kongresa. Oni nisu predstavnici starih, nego „antimoderne“, koja se „krivo zove čuvaricom tradicija, nasljednicom ideja ilirskih preporoditelja.“984 Što se pak tiče mladih, Hranilović se pogrešno ponadao da je među njima došlo do raskola. Za razliku od njega, koji ne trpi bilo kakva odstupanja od rigidne stege svoje klike, Dežman se veseli samostalnu duhu i nastupu najmlađih.

Krug oko Svjetla ponovno se, međutim, nije složio s Dežmanovim ocjenama aktualne situacije. Kako bi uspješnije ispunili zadatke zacrtane u svojem manifestu „Mlada Hrvatska“, njegovi su članovi odlučili pokrenuti vlastiti list u Zagrebu pod nazivom Novo Svjetlo. Već su se na prvim koracima, međutim, susreli s velikim problemima. Nisu naime mogli pronaći tiskaru, što zbog nevoljkosti da ga štampaju na kredit, što zbog neslaganja sa smjerom koji bi list zagovarao. Zbog toga je dio njih napravio kompromis s Josipom Frankom koji je ponudio

\footnotetext{
980 „Mlada Hrvatska“, Svjetlo, br. 40 (prilog), 1900, u: Marjanović, Hrvatska moderna II, 195-198.

981 „Depravacija hrvatske kritike“, Vienac XXXII, 41, 13. 10. 1900, 646-647.

${ }^{982}$ Za Dežmanove opaske i bilješke povodom rezolucija kongresa vidi: HR-AHAZU-KN-44 Dežman, Milivoj, k. 5.

983 „Mladi i stari“, Život, II, 5, 180.

984 „I za to nas uzalud zove Hranilović u svoje kolo. Kad bi on zbilja bio u kolu ljudi, koji nastavljaju djelo Gaja $\mathrm{i}$ Preradovića, ne bi se mi protiv njega ni borili, ali baš za to, jer su ih zatajili, za to ne ćemo u to kolo. Mi vanredno dobro znamo, da njima nije u duši do klerikalizma, mi znamo za što su se uhvatili te posljednje slamke." Isto.
} 
svoju štampariju. To je izazvalo bijes dijela članova te skupine koji su u prosincu 1900. godine istupili u Svjetlu s izjavom kako ni na koji način ne stoje u vezi s novim najavljenim listom, jer ne odobravaju kompromise u cilju širenja ideja Mlade Hrvatske, posebice s političkim strankama. ${ }^{985}$ Ovu izjavu potpisalo je pet od dvanaest potpisnika manifesta „Mlada Hrvatska“: Zofka Kveder, Vladimir Jelovšek, Petar Skok, Milan Prelog i Milan Šnidaršić. Preostali dio kruga ipak je nastavio raditi na listu, no ubrzo su i oni shvatili da Frankova benevolentnost ne dolazi bez cijene. Rezultat je stoga bio porazan: Novo svjetlo izašlo je samo u jednom broju na samom početku 1901., da bi se ova skupina pokreta raspala i prije nego je započela svoju pravu djelatnost. Ironično je da su se razišli upravo na pitanju koje je činilo osnovicu njihove kritike kolega iz redova mladih: pitanju kompromisa za ostvarenje ciljeva pokreta.

Ipak, u prvom i jedinom broju Novog Svjetla, koji je i uredio, Milan Marjanović odgovorio je Dežmanu na njegov tekst iz Života. Za njega, Dežmanovo je stajalište potpuno pogrešno jer se temelji na krivoj pretpostavci „da je klerikalizam moda, da imamo posla samo sa jednom klikom epigona, te da je današnja kriza samo boj književni.“ Prema Marjanoviću, kriza je mnogo šira, a uzroci su joj dublji: klerikalizam nije tek moda, nego je dobro organizirana (re)akcija, te se prema „dobro promišljenoj osnovi uhvatio nacionalne ideje i patriotizma“, što je u Hrvatskoj posebno atraktivno, napose u doba akutne krize koja trenutno traje. Za Marjanovića je posve pogrešno braniti „očeve“ i starije tako da ih se strogo diferencira od postojećih klika i epigona na temelju njihove naklonosti liberalizmu. Oni se moraju smatrati odgovornima za tadašnje stanje jer su stvarali uvjete u kojima se formirao hrvatski javni, kulturni i politički život. ${ }^{986}$ Što se pak tiče širine krize, ona nije tek pomodna zadjevica među književnicima koja se temelji na nesporazumu, nego je ona „bankrot zlo ili nepotpuno shvaćenih ili krivo provađanih ideja vremena - patriotizma, nacionalizma, prosvjete i t. d.“ Zbog toga se ne treba smatrati velikim uspjehom ako se uspije izboriti sloboda nekolicini talentiranih književnika da istupe u svijet. To je tek uspjeh reprezentacije, a pravi bi uspjeh bio ostvariti ,slobodnu literaturu, slobodnu literarnu publiku, slobodan društveni milieu, slobodnu kulturu.“ Zbog svega toga trenutni boj nije „samo boj slobodnih književnika, nego boj svih slobodnih duhova.“ Marjanović naposljetku zaključuje, sumirajući ključnu prijepornu točku najmlađih i mladih:

\footnotetext{
985 „Izjava“, u: Krtalić, Nekrolog hrvatskoj modernoj, 208-209.

986 „Nijesu li ti 'epigoni' pravi nasljednici otaca naših? Da, naši 'starci' imali su više oduševljenja, uvjerenja i poštenja - pa su oni kao pojedinci, kao ljudi i poštovanja vrijedni - ali oni su bili i javni ljudi, oni su položili temelje tom našem životu. Prednosti njihovog temperamenta i karaktera još ne isključuju kritike njihovoga sistema i ne isključuju misao, da je taj bio promašen ili pogrešan. A to je on i bio.“ Milan Marjanović, „Ne samo slobodni književnici, nego i duhovi“, Novo Svjetlo, I, 1, u: Marjanović, Hrvatska moderna II, 206.
} 
„Ako se kriza ne shvati ovako duboko, s temelja, ako se shvati samo jednostrano, površno, osobno polemički, onda ćemo morati i uz promjenu personala i baterija uvijek računati s duhom, a to znači, da se nije postiglo ništa. Zla se treba iz temelja riješiti. Zakrpavati se više ne smije. Kompromisa sa duhom starih ne može biti.،987

Tijekom njegova vrhunca, pokret je mladih dakle obilježavala konstantna rasprava oko pitanja tko uopće sačinjava sam pokret. Ta je rasprava pak otkrivala različite koncepcije važnih ideoloških postavki pokreta. Mogli bismo reći da je u njima do izražaja došlo drugačije razumijevanje modernizma i modernosti. Za krug oko Mladosti modernizam se očitovao u otvorenosti spram svih suvremenih strujanja i u usredotočenosti na probleme modernog društva. Za praške je mlade pak modernizam kao takav sporedna odrednica. Međutim, u želji da se ograde od antimodernizma, oni pak svoj modernizam opisuju kao sintezu suvremenih strujanja i narodne orijentacije, koja dakako uključuje i kršćansku komponentu. U tom smislu i sama modernistička odrednica pokreta uključuje vrlo neodređen, heterogen, pa i međusobno kontradiktoran sadržaj, što uostalom odgovara intelektualnim strujanjima fin de siècle razdoblja. Druga važna linija rasprave među mladima bila je ona koja se ticala pitanja granica kompromisa sa starima. Ovdje je pak u prvi plan došla generacijska podjela unutar samih mladih jer je mlađi dio pokreta predvodio unutrašnju kritiku ističući problem površna shvaćanja sukoba starog i novog, što je također zadiralo u samu srž poimanja ključnih ciljeva i sadržaja pokreta. Na taj se način očitovala zanimljiva dinamika u kojoj se labava struktura i ideološka heterogenost pokreta rastvarala u polemikama iznutra, do te mjere da je ponekad teško balansirati između teza o jedinstvenom pokretu mladih i o razlitičim pokretima koji se samo uvjetno mogu povezati kronološkom i generacijskom podudarnošću. S druge pak strane, polemike koje su mladi vodili sa starima ponovno su ih okupljale u isti tabor i osnaživale osjećaj zajedničke pripadnosti. To ponovno potvrđuje opravdanost ključnog mjesta odrednice mladi, koja naglašava negativnu definiciju pokreta, a ne njegov pozitivni sadržaj koji se u velikoj mjeri ne može fiksirati u koherentan ideološki sustav.

\section{6. Polemike mladih i starih}

Intelektualnu povijest u Hrvatskoj na prijelomu je stoljeća obilježila jedna od najvećih javnih polemika u njezinoj povijesti - ona između mladih i starih. Inače eluzivni, ovi su

\footnotetext{
${ }^{987}$ Isto, 204-207.
} 
pojmovi upravo polemikom dobili svoj konkretan sadržaj. Jednako kao što je naziv mladi označavao i široki spektar svih koji su podržavali nove ideje i strujanja, i uži krug aktivista modernističkog pokreta, tako je i naziv stari ujedno funkcionirao i kao oznaka za sve koji zastupaju stare ideje, ali i kao oznaka za konkretnu grupaciju ljudi unutar tog šireg skupa, naime za hrvatsku građansku opozicijsku elitu. $U$ tom smislu polemika koja se vodila $u$ velikoj je mjeri zapravo polemika između starije i mlađe generacije hrvatske građanske opozicijske elite u politici, a posebice u kulturi, dok su prorežimske snage i prema jednima i prema drugima funkcionirale kao „apsolutni“ neprijatelj, iako su i one u ovoj polemici lukavo manevrirale, pažljivo birajući strane i sredstva.

Kao i sam modernistički pokret mladih, i ova je polemika dakle analogna sličnim pojavama u drugim europskim sredinama. Ova analogija nije slučajnost, jer su akteri polemike s obje strane posezali za vanjskim izvorima (napose češkim i austrijskim) kao rezervoarima ideja i argumenata kojima su se potom koristili - u izvornom ili adaptiranom obliku - u domaćem kontekstu. U tom se smislu i polemika mladih i starih uklapa u postavljenu istraživačku matricu koja presijeca horizontalne (sinkronijske) aproprijacije ideja i koncepata s vertikalnom (dijakronijskom) dinamikom razvoja hrvatske politike i kulture u 19. i 20. stoljeću.

Zbog pukog obima tekstova u sklopu ove polemike nije ih moguće iscrpno prikazati, niti bi to služilo svrsi ovoga rada. Fokusirat ćemo se stoga na ključne tekstove koji su definirali tokove rasprave, kao i na osnovne stavove i argumente koji su u njima iznošeni. U polemiku su se na ovaj ili onaj način uključili gotovo svi relevantni akteri tadašnje javnosti, a osim u novinama, karakteristično je da su tekstovi objavljivani i kao brošure i pamfleti. Ranije smo se već osvrnuli na prvotne reakcije na pojavu praške Hrvatske misli. Inicijalna reakcija većine listova starih (Vienca, Obzora, Katoličkog lista) bila je oprezna i suzdržana. Stari nisu htjeli antagonizirati omladinu koja je svojom demonstracijom 1895. i progonom stekla simpatije javnosti i veliki simbolički kapital. Na oštre kritike mladih odgovarali su mirno, iako donekle patronizirajuće.

Ono što se oblikovalo kao polemika mladih i starih započelo je početkom izlaženja bečke Mladosti. Nešto prije toga, a zapravo paralelno s počecima ove velike polemike, jedinu veću raspravu s praškom skupinom mladih vodio je Ante Tresić-Pavičić koji je od 1897. godine u Splitu izdavao pravaški list Novi viek. On je u seriji tekstova naslovljenoj „Rane otačbine“ tijekom cijele 1897. godine vrlo žustro polemizirao s praškom Hrvatskom misli i Novim dobom. Polazeći od pretpostavke da je patriotizam uzvišeni zakon etike i prirode, Tresić sličnim tonom kao i ostatak starijih kritizira praške mlade da su zbog svojeg neznanja, 
nestrpljivosti i bahatosti počinili grijeh prema domovini odbacujući hrvatsko državno pravo i prihvaćajući ideju narodnog jedinstva Srba i Hrvata. ${ }^{988}$ Iako svoje ideje prikazuju kao nove, one nisu ni nove, ni jasne, ni izvedive, niti vode do sreće naroda, nego su zapravo nezrela megalomanija, koja se je pokazivala u formi panslavizma, ilirizma, jugoslavenstva i srbohrvatstva, kao obmane koje su prigušivale hrvatsku svijest. ${ }^{989}$ Kako je godina odmicala, Tresićev je ton postajao sve agresivniji i žučljiviji. Na isti način, ali još ogorčenije on istupa protiv omladine okupljene oko almanaha Narodna misao. Tresić stoga protiv mladih ustaje s tipičnim pravaškim argumentima o „slavoserbštini“ i nacionalnoj izdaji: „Slavosrbići naši nisu nego pogreška u etničkoj mašini našega razvitka, oni su princip zla. “990 Iako je njegova namjera možda bila da odvrati hrvatsku omladinu od praških listova te da ju privuče natrag starčevićanstvu i okupi oko svojeg lista - koji je 1898. premjestio iz Splita u Zagreb - nije postigao željeni učinak. ${ }^{991}$ Prepoznavši da si je Tresić sam naštetio svojim tonom i nastupom, mladi su mu odgovorili kratkim satiričnim člankom u kojem su ismijali njegove polemičke tekstove. ${ }^{992}$ Slična je dinamika nastavljena kroz cijelo razdoblje izlaženja praškog Novog doba. Dok Tresić nije propuštao nijednu priliku da napadne mlade zbog njihova „,naprednjačko-narodno-jugo-srbsko-slovensko-hrvatsko-slavjansko-uzajamno-mudro-širokoidejnoga-slavosrbizma“, oni su mu uglavnom odgovarali kratko, ironično i satirično, ističući nedosljednosti u njegovoj argumentaciji. ${ }^{993}$

Na posve je drugačiji način nastupao jedan od najvažnijih suradnika Novog vieka Jakša Čedomil (Jakov Čuka). ${ }^{994}$ On se tada već bio profilirao kao umjeren, upućen i promišljen polemičar, što su opazili i priznali i sami mladi. Jakša Čedomil je u seriji članaka pod naslovom „Mladji naraštaj u književnosti“ informirano obavještavao o suvremenim kretanjima u talijanskoj i francuskoj književnosti, nakon čega se osvrnuo i na situaciju u Hrvatskoj. Iako je sam bio tradicionalist, prema mladima je izvorno nastupio bez predrasuda, pozivajući i ostale da ih puste da rade, a tek onda da sude njihov rad na temelju njihovih djela. ${ }^{995}$ Pristup Jakše Čedomila mladi su pohvalili kao muževan i iskren, što se dotad nije

\footnotetext{
988 Ante Tresić-Pavičić, „Rane otačbine“, u: Krtalić, Anarkija, 246, 248.

989 Isto, 257.

${ }^{990}$ Isto, 273.

${ }^{991}$ Zbog toga nije čudno što je Novi viek o srednjoškolskim novonadašima pisao vrlo pohvalno u nadi da ih pridobije. Ujević, nav. dj, 218.

992 „Introitus dra Tresića“", Novo doba, I, 1, 45-46.

993 „Pametno iz Novoga Vieka“, Isto, 46; „Dr. Tresić“, Isto, 2, 94-95; „,Rane otačbine“, Isto, 3-4, 176 itd.

994 O Jakši Čedomilu vidi: Cvjetko Milanja, Jakša Čedomil, Zagreb, 1985.

995 „Ali neću da budem surov sudija sa mladošću. Mladež ima to dobra što je mlada i što može iz nje mnogo liepa biti s vremenom. Neću ju dakle sudit po obećanjima, po težnjama, po programima. Neka žive, neka radi, ne gušimo joj poleta, ne strižimo joj krila, ne sputajmo ju okovima. Nek samo počne raditi. Kad bude rada, ostaviti
} 
moglo reći za druge kritičare. Doduše, kako se Tresić u bilješci djelomično ogradio od članka Jakše Čedomila, mladi nisu propustili priliku da ga bocnu i po tom pitanju. ${ }^{996}$ Iako ova polemika između praških listova mladih i Novoga vieka nije imala konture ozbiljne javne polemike, nego više žurnalističke zadjevice, ona je anticipirala određene momente velike javne polemike u nastajanju.

Prava polemika između mladih i starih buknula je sredinom 1898. godine, nakon žestoke reakcije dijela starih na pokretanje lista Mladost i književničko-umjetničko organiziranje koje je uslijedilo. Sama ta činjenica mnogo govori o naravi polemike i razlozima reakcije starih. Čak i oni listovi i pojedinci koji su relativno benevolentno gledali na pokret mladih u domeni politike i društva žestoko su ustali protiv pojave modernizma u kulturi i umjetnosti. To upućuje na zaključak da su stari osjećali mnogo veću ugrozu upravo na tom polju, gdje su pronašli svoje utočište i očuvali svoju dominaciju nakon političkog poraza od Khuenova režima. Dok su mladi kritizirali stare na političkom polju oni nisu ugrožavali njihov dominantan položaj jer je on već odavno bio izgubljen, pa je stoga njihova kritika i politička aktivnost mogla - makar prešutno - biti pozdravljena kao potrebno osvježenje političkog života. Međutim, kada se kritika mladih prelila i na područje kulture, napose književnosti, ona je direktno ugrozila dominantnu poziciju starih iz koje su oni izvlačili simbolički legitimitet predstavnika hrvatskog nacionalnog pokreta i nasljednika iliraca. O tome dobro svjedoči upozorenje Dinka Politea u pismu Šimi Mazzuri: „,...] nove škole u literaturi su [...] podobne da fatalno utječu na naš politički život, više no što se to u obće misli $[\ldots]^{6997}$ Njihova žestoka reakcija tako je odavala važnost i narav borbe koja je uslijedila.

I prije nego što je izašao prvi broj Mladosti, Kerubin Šegvić napao je njezine pokretače kao „najmladje Slavosrbe“ koji su u „turskoj (!!) ulici u Beču“ začeli list s namjerom da „utamani 'Novi Viek'.“ Već sama ta pretpostavka bila je dovoljna da ga okarakterizira kao ,protuotačbenički pothvat“. Međutim, ono što je Šegviću načelno smetalo bili su sami ciljevi Mladosti: borba za slobodu mišljenja i zastupanje najnovijih strujanja u književnosti i umjetnosti. Sloboda mišljenja za njega je dopuštena u onim stvarima koje nisu ,jasne, očevidne, stalne, i to, dok takove ne postanu.“ Kako su načela etike i estetike nepromjenjiva, ,proglasiti „svu slobodu mišljenja“, znači otvoriti vrata svakojakim zabludam na moralnom i estetičkom polju.“ Ignoriranje vječnih i nepromjenjivih načela u slučaju

ćemo na stranu rieči mladenačke, a obazriet ćemo se na mladenački rad.“ Jakša Čedomil, „Mladji naraštaj u književnosti“, u: Krtalić, nav. dj., 372.

996 „Varia“, Novo doba, I, 5, 217.

997 „D. Politeo - ك̌S. Mazzuri, b. d.“, u: Lovrenčić, nav. dj., 79. 
pokretača Mladosti - koju je rodila „tudjinka“ - razotkriva njihov manjak načela uopće, kako etičkih i estetskih, tako i vjerskih i patriotskih. Upravo zato njihovo zagovaranje najnovijih strujanja predstavlja pokušaj „,moralnog trovanja naroda“. 998

Ovaj Šegvićev napad na Mladost u osnovnom je obliku iznio gotovo sve najvažnije topose buduće polemike starih i mladih. Iako je Šegvić pisao iz pravaške pozicije, na identičan će se način prema mladima postaviti i oni kritičari koji su zastupali obzoraške ideje. Tako je npr. Katolički list, čiji je urednik Stjepan Korenić inače blago nastupao prema Hrvatskoj misli zbog simpatija prema obzoraštvu, pojavu Mladosti - koju stavlja uz bok ostalim bespotrebnim novotarijama kao što su Mlada Hrvatska i Novi Viek - protumačio kao simptom pomankanja autoriteta u hrvatskoj književnosti kakav je bio Šenoa. Ova „preuzetnost i obijest“ mladeži koja je tek „prhnula iz gimnazije“, a već želi da se „nametne vodjem i ravnateljem hrvatskoga naroda u intelektualnom i moralnom obziru“, trebala bi zabrinuti svakog patriota. Još je strašnije, međutim, to što mladi izvrgavaju ruglu vjeru, a „vječne zakone morala i etike“ cinički smatraju „zaprašenima“. Tako se na stranicama Mladosti otvoreno brani „hulitelj sviju ljudskih svetinja njemački pjesnik i prljavi žid Heine“, a „nesrećni Ivanov iz Zagreba“ na prvim stranicama donosi tekst koji obilježava „glupost i smiješnost onakoga izražaja pijanoga i strastvenoga delirija.“ Stoga Korenić zaključuje da si je ovaj nasreću mali dio hrvatske mladeži - iza čijih se leđa „sakriva druga tajna sila“ - uzeo za zadatak da u teškom trenutku za hrvatski narod „,neprijateljima rodjene si grude još pripomogne zabijati žalosni čavao u njezin lijes. “999

Mladost je dakako odgovorila na ove napade, ali svega u dva navrata i bez žučljivih tonova. Šegviću su ukratko razjasnili svoje namjere i genezu ideje samog lista, odbacujući tvrdnju da je njegov temeljni cilj uništiti Novi Viek. Osim toga, urednici Mladosti doveli su u pitanje njegovu kompetenciju kada piše o modernim smjerovima u književnosti, kao i pravo da prosuđuje tko je „izrod“, a tko nije. ${ }^{1000} \mathrm{U}$ drugom, općenitijem odgovoru svojim kritičarima, Mladost ističe da je potpuno promašeno to što im se predbacuje da nisu jasno iznijeli svoja politička ili vjerska uvjerenja, a s druge strane da su premladi da bi ovako preuzetno iznosili svoja mišljenja. Njihova je namjera upravo bila da osnuju list koji neće biti vezan nikakvim izvanumjetničkim - bilo političkim, bilo vjerskim, bilo generacijskim obzirima, te da time uzdrmaju hrvatski kulutrni život i potaknu ga na napredak. Odgovarajući konkretno Katoličkom listu, urednici Mladosti ističu kako njegova kvalifikacija da su oni

\footnotetext{
${ }^{998}$ Fra Ch. Š., „Nakon pet mjeseci“, Novi Viek, I, 10, u: Krtalić, nav. dj., 152, 156.

999 „'Mladost'“', Katolički list, 49, 3, u: Isto, 181-183.

1000 „Našim napadačima!“،, Mladost, I, 1, s. p.
} 
pornografi, naturalisti i bezbošci posve jasno ukazuje na nerazumijevanje suvremenih kretanja u književnosti i umjetnosti. Modernistička su strujanja nastala upravo u opoziciji spram naturalizma. Što se pak tiče vjere, oni strogo razlikuju vjerovanje i klerikalnu reakciju: „U prvo, ne diramo, protiv drugoga ćemo se boriti.“ Ono što je ispravno u pisanju Katoličkog lista jest da se oni doista razlikuju u razumijevanju odnosa umjetnosti prema moralu i vjeri. Za Mladost nema moralne i nemoralne umjetnosti, nego samo dobre i loše. Naposljetku, Mladost ističe da Korenićevo pisanje, koje obiluje pogrdama i insinuacijama, nije dostojno jednog svećenika. ${ }^{1001}$ Mladi okupljeni oko Mladosti u ovoj početnoj fazi polemike nastupaju mirno, hladno i argumentirano.

Iako su brojni argumenti koji će se kasnije ponavljati već izneseni u ovim prvim reakcijama na Mladost, prava javna polemika između mladih i starih rasplamsala se nakon početka procesa književničko-umjetničkog udruživanja i priprema za Hrvatski salon. Nju je lansirao polemički pamflet koji je sredinom 1898. godine pod naslovom Anarkija u hrvatskoj književnosti $i$ umjetnosti: poslanica umjetničkim secesionistima i književnim dekadentima objavio muzikolog Franjo Ksaver Kuhač. Rođen kao Franz Xaver Koch u Osijeku, Kuhač se smatra utemeljiteljem hrvatske muzikologije, napose etnomuzikologije. Jedan je od glavnih formulatora nacionalnog programa u hrvatskoj glazbi, smatrajući da narodna glazba treba biti temelj za umjetničku glazbu. U estetskom je pogledu bio blizak konzervativnom bečkom muzikologu Eduardu Hanslicku, a glavno mu je djelo zbirka Južno-slovjenske narodne popievke, izdana u četiri knjige od 1878. do 1881. godine.

Već sam naslov otkriva temeljnu Kuhačevu premisu. Iako ih nigdje eksplicitno ne imenuje - nego se referira jedino na bečki Ver sacrum - on optužuje mlade okupljene oko lista Mladost i kasnije u Klubu hrvatskih književnika pri Društvu hrvatskih umjetnika, kao i secesijske umjetnike tog društva, da su zavedeni od „tudjih agitatora, koji idu za tim, da sprieče Hrvate u njihovom naravnom razvitku, da im otruju krv i mozak i nadju za svoje svakom se moralu i pameti rugajuće proizvode 'Absatzgebiet' u Hrvatskoj. “1002 Laskajući im, ti strani agitatori nagnali su hrvatske umjetnike da u zemlju uvedu pogubna strujanja koja ruše sve patriotske i moralne tekovine koje su sazdali „djedovi“ te time unesu anarhiju u hrvatsku kulturu, trujući mladež i otvarajući vrata stranom kulturnom prodoru po principu divide et impera. Kako bi tome stali na kraj, Kuhač svoju brošuru piše u ime nekolicine hrvatskih književnika, pedagoga i umjetnika, koji žele hrvatski narod upozoriti na pravac te nove

\footnotetext{
1001 „Da se razumijemo“, s. p.

1002 Franjo Ksaver Kuhač, Anarkija u hrvatskoj književnosti i umjetnosti: poslanica umjetničkim secesionistima $i$ književnim dekadentima, Zagreb, 1898, 4.
} 
umjetnosti. ${ }^{1003} \mathrm{Na}$ temelju dviju ključnih pretpostavki, one izdajstva (morala, odnosno vjere i domovine) i nestručnosti (diletantizma) mladih, on u preskriptivističkoj maniri gradi tekst oko šest ključnih pojmova (lijepo, ružno, jasnoća, istina, ćudorednost, patriotizam), kritizirajući modernističke postavke i prakse - a često zapravo ono što je on vidio kao modernizam, odnosno secesiju i dekadentizam - te braneći postavke tradicionalne estetike, etike, kao i patriotske i vjersko-moralne uloge književnosti. ${ }^{1004}$

Za Kuhača, glavni je kriterij svake umjetnosti narod, tj. narodna kultura. To proizlazi iz romantičarske pretpostavke da je lijepo „ono što se u kulturnim narodima smatra liepim“, odnosno da je lijepo „,izraz čuvstava kulturnih naroda. “1005 Lijepo, za razliku od znanosti, nije univerzalan pojam, već ovisi o „rasi“, „temperamentu“, „vanjskim prilikama“, „religioznom mišljenju i odgoju“ pojedinog naroda. ${ }^{1006}$ To kao konzekvencu povlači za sobom zaključak da se narodna tradicija ne smije rušiti jer je ona dio „bića naroda“. Promjene u kulturi moraju biti postepene i moraju se graditi na narodnoj tradiciji. S druge pak strane, pojam ružnog veže se uz univerzalnu konstantu, a to je (ne)moral. Umjetničko prikazivanje ružnog problematično je ako grijeh prolazi nekažnjeno i ako nema moralne utjehe i pouke za gledatelja, odnosno katarze. Pretpostavka je dakle da prikazivanje grijeha bez njegove katarzične osude navodi na sam grijeh. Ključno je stoga da je umjetničko djelo lijepo po formi: ružno se smije prikazivati, ali na lijep, odnosno estetski i etički prihvatljiv način. ${ }^{1007} \mathrm{U}$ osnovi istu argumentaciju Kuhač iznosi i u vezi jasnoće, pri čemu u secesionistički oblikovanim slovima vidi nametanje starih germanskih (,gotskih“) pisama slavenskim narodima, a općenito se protivi njemačkom posredovanju kulturnih tekovina. ${ }^{1008}$ On dakle insinuira da je pojava modernizma u Hrvatskoj povezana s njemačkom politikom Drang nach Osten, iako mu je glavni oslonac kritika bečke secesije i Ver sacruma, koja je upravo kroz kulturnu politiku ministra predsjednika Koerbera pokušala biti pretvorena u lojalističku, habsburšku kulturnu paradigmu, a zbog čega je najčešće iz nacionalističke vizure kritizirana kao kozmopolitska. ${ }^{1009}$ Za Kuhača, (bečki)

\footnotetext{
1003 Isto, 3.

1004 Zanimljivo je da Kuhač s ponosom ističe kako se hrvatski glazbenici nisu priključili novoj, ,anarhističkoj“ struji koju predvodi Wagner. Kao učenik konzervativnog bečkog muzikologa Eduarda Hanslicka on je bio protivnik wagnerijastva. Međutim, wagnerijastvo bi zapravo mnogo više odgovaralo (neo)romantičarskoj, etnomuzikološkoj Kuhačevoj orijentaciji od strogo formalističkog koncepta „apsolutne glazbe“ E. Hanslicka. Problem wagnerijanstva za Kuhača je vjerojatno bio političke prirode, jer je ono dakako bilo vezano uz pangermanski nacionalizam. Isto, 10.

1005 Isto, 5 ,

1006 Isto.

${ }^{1007}$ Isto, 8-10.

1008 Isto, 13.

${ }^{1009}$ Schorske, nav. dj., 248-249.
} 
kozmopolitizam je samo krinka za njemački šovinizam. ${ }^{1010}$ Što se pak tiče istinitosti umjetničkog prikazivanja, Kuhač odbacuje naturalizam kao pretjeran u oponašanju i zbog toga prostački. Iako je istina jedan od glavnih uvjeta svake umjetnosti, realizam treba predstavljati idealiziranu, uljepšanu istinu: „To će reći da realizam ili istina mora biti u umjetničkom djelu poljepšana, idealizovana; poljepšana po jeziku, po stilu, po činu i po materijalu. Seoska odijela na pozornici treba da budu od finijeg materijala, kroj te odjeće po svetačnoj narodnoj nošnji; glas glumca i grlo pjevačevo zvonko i čisto, osobe pristale.“1011 Iako se secesionisti kunu u istinu, oni iznose same fantazije. Glavni ideal secesije za Kuhača je tjelesni užitak, što je razvidno u prikazima nuditeta. On je pak prihvatljiv jedino u religiozne svrhe jer umjetnik mora stvarati po uzusima sadašnjosti, a ne prošlosti, a to su uzusi građanstva. Kuhaču je bitno istaknuti da građanstvo, a ne inteligencija, čini glavni kontingent čitalačke javnosti. On također radi dihotomiju između inteligencije i naroda te poziva na izgon one inteligencije koja radi nauštrb naroda.

Iako poziva javnost da ne dozvoli da modernisti teroriziraju hrvatski narod i skroz pokvare njegovu mladež, Kuhač priznaje da je dio odgovornosti i na starima, koji su često neljubazno odbili ne samo nevješte, nego i prilično vješte mlade sile, koje su željele sudjelovati u kulturnom radu. ${ }^{1012}$ Stoga on poziva i ,neljubezne starije“ i ,nestrpljive mladje“ da „poprave svoju pogrešku“ i da osnuju „oveću književničku i umjetničku zadrugu“ ne na „lažiliberalnim i frivolnim“, nego na „kršćansko-moralnim i hrvatsko-patriotičnim“ temeljima: „Osvjedočen o tom, da samo kršćansko-moralan i hrvatsko-patriotičan temelj može biti spasonosan za hrvatsku kulturu i za hrvatsku umjetnost, te da je često spomenuti najnoviji smjer veoma pogibeljan za budućnost i opstanak samoga naroda, žigosao sam taj smjer mnogo oštrije, nego što sam vičan govoriti mladjim pregaocima.“1013

Nakon cijelog pamfleta žučljivih napada, uvreda, insinuacija i prijetnji, ovaj poziv na suradnju na samome kraju nije nikako mogao pasti na plodno tlo. Kuhača su dakako podržali Novi Viek i Katolički list kao dotadašnji najveći protivnici modernističkog pokreta, međutim znatan dio javnosti zamjerio mu je previše oštar ton. ${ }^{1014}$ Kako u trenutku izdavanja ove brošure nisu više izlazili ni Mladost, ni Novo doba, ni Narodna misao, odgovor Kuhaču iako neizravan - stigao je u obliku serije članaka iz pera Ive Pilara u Viencu, koji su potom objelodanjeni kao zasebna brošura pod naslovom Secesija: studija o modernoj umjetnosti, s

\footnotetext{
${ }^{1010}$ Isto, 23.

1011 Isto, 15.

1012 Isto, 25.

1013 Isto, 26.

1014 „'Anarhija u hrvatskoj književnosti i umjetnosti“, Novi Viek, II, 4, u: Krtalić, nav. dj., 530-532; Ujević, nav. dj., 146.
} 
posvetom koja glasi: „Svim protivnicima novih smjerova posvećeno.“ ${ }^{1015}$ Pretpostavljajući da zazor (intelektualne) javnosti prema novom umjetničkom smjeru proizlazi ponajviše iz njegova nepoznavanja, Pilar piše ovu studiju s namjerom da pouzdano informira općinstvo o ciljevima i principima toga novoga smjera, a sve da bi s razumijevanjem došlo shvaćanje i ljubav prema novoj umjetnosti kojoj pripada budućnost. ${ }^{1016}$ Oslanjajući se na bečki Ver Sacrum, on stoga iznosi historijat pojma secesije koji uzima kao opće ime za novi pokret u umjetnosti, kao i pregled kretanja u Parizu, Münchenu i Beču. Za Pilara ovakav tip previranja u umjetnosti nije ništa neobično, nego predstavlja primjer vjekovne borbe starog i novog koja rađa povijesni napredak umjetnosti. Stoga secesija nije umjetno proizvedeni „otrov“ kako bi htjeli njezini protivnici, nego dio organskog razvoja umjetnosti i društva u cjelini, psihološkom potrebom nastala faza, uvjetovana kulturnosocijalnim prilikama, a nipošto umjetno stvoren pokret. ${ }^{1017}$ Pilar stoga secesiju definira kao težnju za preporodom umjetnosti. Ona nije nova škola, nego je upravo borba protiv škola uopće, a napose protiv škola dotadašnje umjetnosti. Secesija nije jedinstveni smjer, nego skupina najraznoličnijih smjerova. Ona je „ratna stranka“, koja ne ovisi o nekom geniju ili mesiji, nego o radu mnogih koji se trude oko preporoda umjetnosti, a ujedno signalizira i promjene koje će nužno uslijediti na političkom i kulturno-socijalnom polju općenito. ${ }^{1018}$ Kao što se može vidjeti, ova Pilarova konceptualizacija „secesije“ vrlo se lako može izjednačiti s općim konceptom i idejama pokreta mladih, moderne i ,novog smjera“.

U daljnjem tekstu Pilar detaljnije razlaže određene aspekte koji proizlaze iz ove osnovne definicije secesije. Za njega je ključna kritika imitacije koja prevladava $\mathrm{u}$ dominantnim umjetničkim „školama“ 19. stoljeća: „Duša je umrla, a ostalo tek tijelo, mumija; sasvim prosto kumirstvo tradicionalne forme.“1019 Osim toga, secesija se protivi posredovanjima duhovnih tvorevina iz druge ili treće ruke: uvijek treba ići na sam izvor. U tom smislu ona ne znači pretjerano radikalnu promjenu u umjetnosti, nego proširenje njezinih elemenata onima iz prirode i drugih kultura, a s ciljem proširivanja izražajnih mogućnosti koje umjetniku omogućava da stvara umjetnost za novo doba koje ima nove, šire i veće potrebe. U podlozi toga dakle stoji temeljna ideja historizacije umjetnosti, odnosno da je umjetnost dio društva koje se konstantno mijenja, pa i ona sama mora prolaziti odgovarajuće

\footnotetext{
1015 Ivo Pilar, Secesija: studija o modernoj umjetnosti, Zagreb, 1898.

1016 Isto, 6.

1017 Isto, 9.

1018 Isto, 11.

1019 Isto, 16.
} 
promjene, što uključuje i odbacivanje koncepta nepromjenjive i vječne ideje ljepote. U osnovnim idejama on stoga slijedi ranije analizirane teze Hermanna Bahra o moderni.

Pilar iznosi četiri osnovna zahtjeva, odnosno principa secesije: 1. „umjetnik mora imati apsolutnu individualnu slobodu stvaranja“ (jer je nemoguće odrediti granice slobodi, a vrijeme će razdijeliti žito od kukolja), 2. „treba ujednostaviti spoljašne forme“ (jednostavnost u raznolikosti motiva), 3. „valja sadržaj umjetnosti obogatiti“ (sadržaj umjetnosti mora biti ideja), 4. „umjetnost valja raširiti u sve slojeve pučanstva“ (uz pomoć tehnike). ${ }^{1020}$ Osim tih općih ideja koje su zajedničke za sve smjerove obuhvaćene pojmom secesije, postoje još i različite ideje posebnih smjerova koje nisu karakteristične za cjelinu: „Ona je poput bujice, koja provali nasipe, pak nosi sve sobom, što je po putu otplavila - ona nosi gotovo sve moderne ideje, koje možemo i u literaturi i inom životu zamijetiti, tako n. pr. simbolizam, misticizam, titanizam, razne socijalističke elemente itd.“1021

Dakako da Pilar nije propustio priliku da odgovori na Kuhačeve napade. Osim što argumentira po ključnim točkama Kuhačevih zamjerki, on upozorava čitateljstvo na interese koji stoje iza grčevite reakcije starih na pojavu novih umjetničkih tendencija. Iza konzervativnosti u umjetnosti uvijek vrebaju stagnacija i nazadak, a one pak sakrivaju neznanje, duhovno siromaštvo i ponajviše interese onih koji su dotad bili privilegirani, a nemaju više intelektualne snage da se promijene, pa se grčevito drže starog i brane svim sredstvima, jer osjećaju da propada njihova moć i utjecaj. ${ }^{1022}$ Ne samo da secesija ne ugrožava hrvatske nacionalne interese, nego njezina ovako rana pojava signalizira da „nastaje nova faza u našem narodnom životu“ “ ${ }^{1023}$ Hrvatska javnost više ne prosuđuje djela samo po tome jesu li pisana $\mathrm{u}$ rodoljubnu duhu ili ih je pisao rodoljub, nego traži ,djela prave umjetničke vrijednosti, a prosudjuje ih svjetskim mjerilom“, što je ,posljedica uvjerenja, da je naš narodni opstanak na svaki način osiguran. “1024 Dobri rezultati secesije u Hrvatskoj vjerojatno proizlaze i iz kompatibilnosti psihološko-subjektivističkog smjera sa „slavenskom čuvstvenom naravi““ ${ }^{1025}$ Naposljetku, zaključuje Pilar, ovaj umjetnički pokret u Hrvatskoj znači da Hrvati neće uvijek nekoliko desetljeća zaostajati za općim razvojem ideja, nego će se smjelim skokom staviti u prvi red europskih kulturnih naroda. ${ }^{1026}$

\footnotetext{
${ }^{1020}$ Isto, 25.

1021 Isto.

1022 Isto, 34.

1023 Isto, 41.

1024 Isto.

1025 Isto.

${ }^{1026}$ Isto.
} 
Kuhač nije propustio priliku da odgovori Pilaru u seriji članaka u Hrvatskoj domovini, koji su potom objavljeni kao zasebna brošura pod naslovom $O$ secesiji: Odgovor gosp. J. [sic!] Pilaru. Kuhač je u ovom tekstu vrlo očigledno ublažio svoj ton, iako raniji žučljivi ispadi ponovno iskaču na pojedinim mjestima. On ističe kako je njegov napad bio mnogo više usmjeren na književni dekadentizam nego na likovnu secesiju, pa mu je žao što je Pilar ignorirao taj aspekt, ne shvaćajući stoga da Pilar svojim pojmom secesije obuhvaća sva strujanja nove umjetnosti. Kuhača je također zasmetalo to što Pilar smatra da stari nisu upućeni u suvremena umjetnička kretanja, pa njegov ton smatra patronizirajućim. Još jednom se dakle kao lajtmotiv primjedbi starih ponavlja arogancija i nepoštovanje mladih, odnosno nepriznavanje autoriteta. Kuhačevo ublažavanje narativa očituje se u tome što on razlikuje dva smjera secesije: umjetničko-socijalistički i umjetničko-anarhistički. Prvi je pozitivno intoniran, konstruktivan i sastoji se u odbacivanju lošega i unapređenju dobroga iz tradicije. Drugi je destruktivan i smjera uništavanju svake tradicije i poretka općenito. Prvi se veže s nacionalnim, a drugi s internacionalnim, odnosno anacionalnim i kozmopolitskim. $\mathrm{U}$ tom pogledu Kuhač ponavlja, u donekle modificiranu obliku, da je ovaj „anarhistički“ smjer secesije zapravo opsjena stranih (njemačkih/bečkih) agitatora koji žele zatrovati i uništiti hrvatsku kulturu, a time i hrvatski narod općenito. ${ }^{1027}$ Kuhačevo razlikovanje između ova dva smjera secesije zapravo je taktika koja otvara vrata mogućem utjecaju starih na smjer razvoja novih umjetničkih kretanja. Ovdje se samo u novome ruhu pojavljuje standardni lajtmotiv starih o potrebi postepena razvitka i skladne smjene generacija u okviru nacionalne kulture i politike. Zbog toga Kuhač $u$ prvom dijelu teksta $-\mathrm{u}$ kojem piše o ,umjetničkosocijalističkom"smjeru secesije - nastupa pomirljivije i u mnogo toga se slaže s Pilarom. On zapravo konstruira koncept tog smjera kako bi ga mogao uskladiti s tradicionalnim idejama koje je sam zastupao. Kuhač se primjerice slaže s Pilarom da ne postoji univerzalni kriterij ljepote, ali onda zahtijeva da za taj kriterij bude uzeto ono što je lijepo za hrvatski narod; ili, on se slaže da je umjetnosti potrebno proširenje njezinih elemenata, ali traži da se oni preuzmu iz hrvatske narodne kulture: „Tudje proučavati, a vlastito napustiti, to nije zdravi socijalizam, nego za nas Hrvate anarkizam, jer tudje ubiti će naše.“1028 Čim je započeo raspravu o tzv. anarhističkom smjeru secesije, Kuhačev ton se brzo povratio na onaj stari iz Anarkije. Pale su teške riječi kao „poživinčenje“, „,barbarstvo“, „divljaštvo“ itd., pa čak i usporedba secesijskog napada na tradiciju s atentatom na caricu Elizabetu: „Neograničena sloboda u ma kojim prilikama života, pa i u umjetnostima, vodi do mahnitosti, do absurduma,

1027 Franjo Ksaver Kuhač, O secesiji: odgovor gosp. J. Pilaru, Zagreb, 1898, 23.

${ }^{1028}$ Isto, 22. 
do zločina, t. j. do anarkije.“1029 Iznoseći klasične viktorijanske argumente, Kuhač tvrdi da jasno ograničenje umjetničke slobode mora biti ono što je društveno i javno (ne)prihvatljivo: jednako kao što čovjek neće gol hodati po ulici, tako umjetnik neće javno prikazivati golotinju. Isti taj argument primjenjiv je na sve aspekte umjetničkog djela, od izvedbe pa do (moralnog) učinka na konzumenta. Kuhač se naposljetku ne slaže s Pilarom da će nova faza koju će u hrvatskom nacionalnom životu inaugurirati secesija donijeti išta dobro, naprotiv. Jedina nada za spas je da mladi odbace umjetnički anarhizam koji im poturaju strani agitatori te da zadrže zdravi umjetnički socijalizam, a da uz njega prihvate hrvatski umjetnički patriotizam i kršćanski moral. U tom slučaju stari su spremni zaboraviti sve uvrede koje su im nanesene i ponovno prihvatiti ,zalutale ovce“ u stado. ${ }^{1030}$ To su uvjeti za pomirbu generacija: „Istom poslie okršaja mogu nastati mirni pregovori, a može doći, ako je jedna i druga stranka uvidjavna i razlozima pristupna, i do pomirbe.“1031

Kuhačev napad bio je prvenstveno usmjeren na Bukovca kao predvodnika likovne secesije, te na mlade oko Mladosti koji su bili svojevrsna inteligencija secesije. Dušan Plavšić i Guido Jeny, kao glavni adresati Kuhačeva napada, pripremali su vlastiti odgovor u obliku brošure naslovljene Odgovor na Kuhačevu Anarkiju, koja nikad nije ugledala svjetlo dana. ${ }^{1032}$ Oni ističu kako Kuhačev pamflet samo nastavlja seriju reakcija vladajuće generacije na pojavu prvih djela umjetničke mladeži. Stariji nisu nastupili kritički, nego su prema mladima usmjerili „napadaje najprostije vrsti“ koji su uništili svaku mogućnost za ponovnu izgradnju međusobnog povjerenja. Takvi žučljivi napadi onemogućavaju bilo kakvu konstruktivnu raspravu temeljenu na argumentima. Ipak, Jeny i Plavšić ulaze u polemiku s Kuhačem i poglavlje po poglavlje pobijaju njegove tvrdnje. Njihov temeljni argument upućen je protiv teze o univerzalnosti umjetničkih kriterija (koju je, doduše, Kuhač odbacio u svojem odgovoru Pilaru) i nepromjenjivosti ljudske spoznaje, ukusa i interesa. Umjetnički kriteriji mijenjaju se i u horizontalnoj (kronološkoj) i u vertikalnoj (društvenoj) mijeni, oni nisu isti u različitim razdobljima i u različitim društvenim slojevima. Upravo zbog toga određeno umjetničko djelo može se nekome činiti nerazumljivim: „Dok će se narodna znanost popularizovati i dok će si široki puk na njenom temelju stvoriti zajedničku modernu spoznaju

\footnotetext{
1029 Isto, 28.

${ }^{1030}$ Isto, 38

${ }^{1031}$ Isto. O polemici vidi: Željka Metesi Deronjić, „Polemika o secesiji u Hrvatskoj: Franjo Ksaver Kuhač i Ivo Pilar“, Cris XI, 1, 2009, 229-237; Antun Pavešković, "Moderna i tradicija”, Dani Hvarskoga kazališta 27, 1, 2001, 37-46. O Pilarovu odnosu prema naprednjaštvu vidi: Stjepan Matković, „Ivo Pilar i naprednjaštvo“, Pilar VIII, 15-16, 2013, 69-112. O Kuhaču vidi: Stanislav Tuksar, „Franz Xaver Koch vs. Franjo Ksaver Kuhač. Kuhačevi glazbeni i drugi identiteti: skica za psihogram“, Arti musices 43, 2, 2012, 205-211.

1032 Jenyjev dio nije sačuvan. Dio Plavšićeva teksta se čuva u NSK, Plavšić, Dušan R7228, III., a dio u HDA, HR-HDA-757 Obitelj Plavšić, k. 42
} 
svijeta, onda će i naša danas „,nerazumljiva“ umjetnost postati svojina puka. A dotle budimo sretni što u opće ima individua koji shvaćaju vrijeme te rade za bolju našu budućnost." Ukusi publike nisu dakle ultimativni kriterij umjetničke prakse, nego se na njima treba raditi. Osim toga, oni odbacuju Kuhačeve ideje o uljepšavanju istine, a koje su karakteristične za romantičarsko-realističku stilsku matricu. Istina je istina, poručuju mladi, i istini u umjetnosti zadovoljit će umjetnik ako ne pazi ni na koga osim na svoj umjetnički nagon. Tko želi zadovoljiti konvencionalnim hirovima estetičara, taj crpi iz nečista vrela i nije umjetnik. ${ }^{1033}$

Upravo zbog ovakvih teza mladima su prišili etiketu da nisu narodni, što je opća optužba upućena svima njima neovisno o njihovim velikim međusobnim razlikama. Pretpostavka je ovakve optužbe da su stari prisvojili monopol nad epitetom narodnog. Nasuprot tome, Plavšić i Jeny tvrde da, ,osim nekih rijedkih pojava nijesmo nikada ni imali narodnu književnost.“ Uzrok je tome taj što u umjetnosti u Hrvatskoj glavnu riječ ne vode umjetnička pitanja, nego ona izvanjska: politička, društvena i klerikalna. Ako je umjetnost izražaj ljudskoga života uopće, onda je besmisleno od nje zahtijevati određene svrhe. U onoj mjeri u kojoj slobodna umjetnost buja kao izraz života, u toj će i odgovarati potrebama tog istog života (pojedinca, naroda, društva) iz kojeg proizlazi. Upravo iz pokušaja izvanjskog nametanja zahtjeva umjetnosti mimo narodnog života proizlaze Kuhačeve kontradikcije (kao predstavnika starih). On bi ujedno htio da umjetnost bude lijepa i narodna, ali da ne prikazuje ružne strane narodnog života; da bude istinita, ali ne odviše istinita. Baš zato što kljaštri istinitost narodnog života, ona ne može biti uistinu narodna, onako kao što narodna poezija prikazuje narodni život onkraj zahtjeva ljepote i tendencije. Strah od internacionalnog u umjetnosti, nadalje ističu Jeny i Plavšić, posve je neopravdan. Zar je uopće bilo razdoblja kada hrvatska umjetnost i književnost nije bila na ovaj ili onaj način dijelom velikih međunarodnih kretanja? Razlog lošeg stanja hrvatske umjetnosti ne dolazi izvana, već upravo iznutra. A uzroci toga nisu umjetničke, nego političke prirode. Prvi je taj što „nismo ni slobodni ni zarobljeni, što nemamo ni samovladu, ni konstituciju, nego nešto polovičnoga što uništava svaki jači poriv“, a drugi je držanje „očeva“, koji „tjeraju besavjesnu diplomatičnu politiku.“ Zbog toga mi nismo ni „europski moderni“ kao Slovenci, ni „narodni“ kao Srbi. Uzrok lošeg stanja stari bi stoga trebali u velikoj mjeri potražiti u sebi samima: „Nije Njemačka kriva ni njena moderna umjetnost, što naši očevi nijesu znali da vrše svoju dužnost kako bi valjalo, da bi se kultura i u nas razvila postepeno.“ Ako su mladi doista nepatriotični, onda su za to krivi upravo stari koji im nisu znali prenijeti ljubav i poznavanje naroda, nego

${ }^{1033}$ Guido Jeny i D. N. Plavšić, Odgovor na Kuhačevu Anarkiju!, Beč, 1898, NSK, Plavšić, Dušan R7228, III. 
su ih učili „lažnoj zapadnoj konvenciji“ i „o tzv. slavnoj našoj povijesti“. Ilirski pokret je u Hrvatsku donio velike moderne pojmove, ali u razdoblju nakon njega hrvatska politika $\mathrm{i}$ kultura nije uspjela te pojmove povezati s narodnim životom: „Koliko smo drugačiji mi! Naša spoznaja svijeta temelji se na modernim prirodoslovnim, znanostima i sociologiji. Mi više ne vjerujemo u pojmove, ali prisluškujemo glas života. Za mnogoga se od nas ni nezna, da li je ikada vikao „Živila Hrvatska“, mi više ne uživamo u demonstracijama, ne dajemo političkih izjava, ne vjerujemo u diplomatične programe, oni su nam tek nuzgredna sredstva, ali smo mi već nikli iz bijede našega naroda, ona nam je urasla u srce i dušu.“ Zbog toga će, kažu Jeny i Plavšić, iz „našega naraštaja izići prva hrv. pučka stranka“ te će se u „našim djelima u istinu ostvariti i težnje naših otaca, kojim oni nijesu bili dorasli, a koje u našim djelima više ne poznadu.“

Umjetnici su produkt svojeg doba i okruženja, pa su stoga hrvatski mlađi umjetnici nikli kao proizvod razrovanih društvenih odnosa. Iz njih je nastao „naraštaj nezadovoljnika, stalež bohemijena, struje dekadenata i secesionista kao prisilno sredstvo naravi našega naroda, a kao ekstrahat naših žalosnih odnošaja." Kuhač uopće ne razumije doba u kojem živi, a koje će nužno donijeti dubinske promjene, i to ne samo na polju umjetnosti: „A to će ići tako dalje, dok se posvemašnjim nutarnjim rasulom ili uplivom novih mladih elemenata ne promijene naši ekonomski odnošaji i naš društveni život.“"1034 Plavšić i Jeny pomiču tako raspravu o umjetnosti s usko umjetničkog na šire društveno i ekonomsko polje, ne, dakako, u pogledu kriterija za ocjenu pojedinog umjetničkog djela, nego kao ključnih faktora za analizu stanja umjetnosti određenog naroda.

Zanimljivo je da je jedini eksplicitno direktan odgovor na Kuhačev pamflet došao od Josipa Franka, koji je prvo u Hrvatskom pravu, a onda kao zasebnu brošuru, objavio niz polemičkih tekstova pod naslovom $U$ obranu hrvatskih umjetnika: odgovor na poslanicu $F r$. Š. Kuhača „Anarkija u hrvatskoj književnosti $i$ umjetnosti“. Frankov odgovor pisan je pravničkim diskursom. Za njega Kuhačeva brošura nije „poslanica“ nego „libell“ kojim se mladima navješćuje rat na život i smrt te se moralnom panikom pokušava mobilizirati javnost. $^{1035}$ Koristeći se gotovo identičnim arugmentima kao mladi, on brani hrvatske umjetnike od napada da nisu patriotični, ističe njihove zasluge za razvoj hrvatske kulture i njezinu promociju $\mathrm{u}$ inozemstvu, te poziva na rješavanje spora $\mathrm{s}$ gradskom upravom oko korištenja prostora Umjetničkog paviljona. I ovaj Frankov prilog raspravi dio je njegovih

\footnotetext{
${ }^{1034}$ Dušan Plavšić, „Narodna umjetnost. Mi i naši stari“, HR-HDA-757 Obitelj Plavšić, k. 42.

1035 Josip Frank, U obranu hrvatskih umjetnika: odgovor na poslanicu Fr. Š. Kuhača “Anarkija u hrvatskoj književnosti i umjetnosti”, Zagreb, 1898, 1-2.
} 
pokušaja da pridobije mlade na svoju stranu i tako politički kapitalizira od previranja na hrvatskoj opozicijskoj sceni.

Otvaranje prve hrvatske secesijske izložbe poslužilo je kao povod za daljnje rasplamsavanje rasprave. Iso Kršnjavi, koji je imao i osobnih motiva za to, nije propustio priliku da se uključi u polemiku. On u Narodnim novinama objavljuje seriju tekstova koji su potom tiskani kao zasebna brošura naslovljena Kritična razmatranja. Kršnjavijev je ton mnogo hladniji, a diskurs stručniji od onog ranijih polemičara starih. Njegova je glavna strategija da općenito umanji važnost modernističkog pokreta u Hrvatskoj, cijeli „moderni pokret u književnosti i umjetnosti“ samo je ,jeka velikom bukom inscenirane t. zv. „Secesije“ u Beču. “1036 On u Hrvatskoj nije stvorio niti jedno značajno, uistinu moderno umjetničko djelo, pa stoga nije ni bilo pravoga povoda za pretjerano strastvene napade kakav je bio onaj Kuhačev, kao ni za obranu zapravo u praksi nepostojećeg modernizma. Obijesni stav mladih izazvao je stare, a sve to dovelo je do nepotrebna i besmislena sukoba. Ne samo da hrvatska secesija nije neki poseban događaj s obzirom na općeniti razvoj hrvatske kulture, nego i secesijska kretanja uopće ne predstavljaju epohalni novitet ako se pogleda povijest (zapadne) umjetnosti: „Oprekâ, napredka u borbi i napredka u mirnoj evoluciji bilo je uviek i svagdje; „secesija“ je danas svagdje, a po gotovo u nas, jedno pusto modno ime.“1037 Kršnjavi nastupa izrazito akademski i autoritativno, izmišljanje raznih „-izama“ ne pokazuje upućenost mladih u suvremena kretanja, nego njihovu pomodnost. S druge pak strane izložba Hrvatski salon uz iznimku Frangeša i Csikosa - nije ponudila ničeg suviše modernog ili što bi se kosilo s „dosadašnjim pojavima duševnoga našega razvitka“ ${ }^{1038}$ Kršnjavi daleko upućenije od svojih polemičkih prethodnika iz redova starih razlaže svoje poglede na odnos umjetnosti i prirode, odnosno ljepote i istine. ${ }^{1039}$ Za njega je secesija zapravo ekskluzivistička i elitistička, ona se upravo ponosi time što ju širi slojevi ne razumiju. Koristeći prispodobu o golome kalifu Kršnjavi ismijava samopercepciju moderne umjetnosti: „L'art pour l'art, t. j. umjetnost samo za umjetnike - to znači odkinuti umjetnost od narodnoga života, što je za umjetnost smrtna osuda.“1040 Dekadentizam može funkcionirati za vrlo malobrojne, neuravnotežene i nezdrave pojedince, ali on ne može biti temelj na kojem se gradi narodna umjetnost. A usprkos

\footnotetext{
${ }^{1036}$ Iso Kršnjavi, Kritična razmatranja, Zagreb, 1899, 3. Ovu je istu tezu Kršnjavi ponovio i kasnije u „Pogledu na razvoj hrvatske umjetnosti u moje doba“. On tada tvrdi da nije postojao nikakav unutrašnji razlog za odvajanje mladih umjetnika od Društva umjetnosti, a kamoli da bi on tome bio glavni krivac. Za njega su i to, i književni dekadentizam, samo odjeci bečkih strujanja. Iso Kršnjavi, „Pogled na razvoj hrvatske umjetnosti u moje doba“, Hrvatsko kolo, knj. 1, 1905, 281-282.

${ }^{1037}$ Kršnjavi, Kritična razmatranja, 7.

1038 Isto, 3.

${ }^{1039}$ Također će i mnogo blaže i umjerenije nastupati prema pitanju nuditeta u umjetnosti. Isto, 20-21.

${ }^{1040}$ Isto, 11.
} 
internacionalnom karakteru umjetnosti, ipak je njezin cilj da obogaćuje i razvija narodnu kulturu. U tom smislu on se osvrće i na ekonomske argumente prvaka Društva hrvatskih umjetnika. Motivacija umjetnika ne smije biti materijalne naravi. Vlada i društvo moraju se pobrinuti za egzistenciju umjetnika (što i jesu, Kršnjavi ispravlja natuknicu o Bukovcu iz Hrvatskog salona da je on stvorio umjetničku koloniju u Zagrebu, nego je to učinila hrvatska vlada, koja je umjetnike obilno stipendirala, sagradila im ateliere i dala im službu). Ali oni moraju raditi za narod kao što rade i drugi duhovni radnici, koji uz to nemaju privilegiju da budu zapamćeni i slavljeni kao što imaju umjetnici. ${ }^{1041}$ Drugim riječima, osim što ističe svoje zasluge, Kršnjavi poručuje umjetnicima da shvate kontekst u kojem se nalaze, zadaće i ciljeve koje stoje pred njima, i da odbace pomodne formule koje propagiraju obijesni mladići, a koje ionako nemaju rezultata u umjetničkoj praksi.

Dakako da su se o Hrvatskom salonu kritički izrazili i dotadašnji glavni polemičari protiv mladih okupljeni oko Novog vieka i Katoličkog lista. Ante Tresić Pavičić već je ranije opsežno pisao protiv Pilarove Secesije, a u svojem je govoru na izložbi nastupio s argumentima koji su izrazito slični onim Kršnjavijevim. Niti za njega nema pravoga razloga trvenju među hrvatskim umjetnicima, nego je ono rezultat odjeka bečke secesije za kojom su se mnogi poveli, ali samo na površnoj razini, a glavni je uzrok tome taština. I za njega je izložba uglavnom zadovoljavajuća, iako žali što na njoj nisu zastupljeni svi hrvatski umjetnici (posebice Rendić i Medović) i što nema više hrvatski karakter. ${ }^{1042}$ Stjepan Korenić je pak kroz brojne tekstove u Katoličkom listu nastupao po sadržaju i tonu mnogo bliže Kuhaču, optužujući secesioniste za moralno uništavanje hrvatskog naroda. ${ }^{1043}$

Franjo Marković također je zastupao stajališta starih u svojem predavanju na izložbi Hrvatskog salona. On kao filozof i estetičar nije iznosio ocjene izloženih umjetničkih djela, nego je ušao u polemiku s Pilarom, Dežmanom i Gjalskim oko osnovnih načela secesije. Koristeći izrazito filozofski akademski diskurs, Markovićev je prilog možda argumentativno najsnažniji doprinos starih ovoj polemici. Prema njemu, kontradiktorno je da se kao osnovno načelo secesije navodi borba protiv svih škola i apsolutna sloboda umjetnika kada ona sama prihvaća i prenosi konkretne ideje iz Beča, odnosno bečke secesije. Time se ona u stanovitu širem značenju te riječi ipak formulira kao škola. Marković ovdje ponavlja - doduše u apstraktnijem i manje konfliktnu obliku - već ranije više puta proklamiranu tvrdnju starih da

\footnotetext{
1041 Isto, 22.

1042 „Konferenca dra. A. Tresić Pavičića: O izložbi hrvatskih umjetnikah“, u: Krtalić, nav. dj., 645, 647.

1043 S. Korenić, „Iz hrvatskog salona umjetnosti“, Isto, 696.
} 
je secesija strani import u Hrvatsku i da ne proizlazi iz njezina organskog razvitka i narodnog života:

„Narod malena obsega; narod sa sto neprilika, koje su oni narodi već davno prevladali; narod, u kojem se tek od dvadesetak godina javlja umjetnički rad slikarski i kiparski: kod nas je borba secesionistička danas kud i kamo prerana, ili, da pravije kažem, nije nikla iz nikakve naše potrebe, nije nikla organičkim načinom iz naših prilika, nego je priesad, imitacija iz tudjine, $\mathrm{i}$ to imitacija nečesa $u$ tudjini, što je ondje baš najnovije, najmodnije, $\mathrm{i}$ što ondje najviše pravi senzacije, buke.“1044

Druga Markovićeva teza uperena je protiv secesijskog načela apsolutne umjetničke slobode. Piščeva sloboda, tvrdi on, ograničena je njegovim dužnostima prema općinstvu. Kada to ne bi bilo tako, onda javnost ne bi piscu nikad smjela ništa prigovoriti, odnosno ona bi od njega bila potpuno odijeljena kao relevantan faktor, jer pisac mora gledati samo na sebe i potrebe umjetnosti. Drugim riječima, apsolutna sloboda umjetnika znači apsolutnu neslobodu publike, koja je time svedena na pukog promatrača umjetničke genijalnosti. ${ }^{1045}$ Kao svoju treću ključnu tezu Marković navodi da napredak u svim sferama ljudske djelatnosti počiva na pretpostavci generacijske predaje, čak i kada se radi o kritici postojećeg. Prihvaćanje određene tradicije, škole i predaje ne znači nužno slijepo obožavanje i epigonstvo. Uvijek postoji prostor za kreativnu interpretaciju u okviru općih načela. Umjesto da se odbacuje koncept umjetničkih škola, što je potencijalno pogubno s obzirom na početničke i neuređene prilike koje vladaju u hrvatskoj kulturi, mladima treba savjetovati da uče dugo i savjesno, a da potom mogu na svoj osobiti način primjenjivati opće zakone estetike i posebne zakone svoje umjetnosti. ${ }^{1046}$ Naposljetku, Marković kao i svi stari poziva umjetnike na patriotski umjetnički rad.

Markoviću je u Viencu odgovorio Gjalski kao jedan od prozvanih propagatora secesije. On pritom inzistira na prijeko potrebnim terminološkim razjašnjenjima: umjesto secesije i secesionizma zalaže se za naziv Moderna, koji pak treba opet razlikovati od pridjeva moderan. I doista, kako se rasprava odmicala od izložbe Hrvatskog salona, u javnoj je upotrebi sve češće naziv moderna, odnosno hrvatska moderna, a sve manje secesija, koja se počela ograničavati na vizualne umjetnosti. Gjalski nastupa pomirljivo, on je od samoga početka govorio protiv sukoba mladih i starih te je savjetovao mladima da ne istupaju previše oštro. Međutim, stari su bili ti koji su krenuli u napad i pokrenuli cijeli sukob. Njegov

\footnotetext{
${ }^{1044}$ Franjo Marković, „Predavanje u izložbi 'Družtva hrvatskih umjetnika'“, Isto, 672.

1045 Isto, 669-670.

${ }^{1046}$ Isto, 676.
} 
odgovor Markoviću jednako je tako umjeren. On ulazi u svojevrsnu filozofsku raspravu o pitanjima ljepote i analogijama sa zakonima biologije, kemije, astronomije i sl. Zato što i on smatra da stari nisu dobro razumjeli namjere mladih, odnosno modernista općenito, Gjalski ponavlja svoj umjetnički credo. Njegov opus demonstrira njegovu temeljnu ideju koja ga je približila mladima, da umjetnik ne smije robovati imperativima niti jedne škole: „Mogao sam tako činiti, jer nisam priznavao školu i bila mi uviek glavna zadaća u mom stvaranju, ne da budem vjeran realističnoj školi i njezinim zahtjevima, već da budem vjeran svojoj individualnosti i onome, što je njoj od potrebe, da stvori i da rekne.“"1047 Da moderna nije stanovita škola dokazuje i to što Gjalski ne prihvaća brojne ideje koje su u njoj učestale, kao što su fokus na formu nauštrb sadržaja ili larpurlartizam. Osim toga, o otvorenosti moderne svjedoči i to što su oba pozvana predavanja na izložbi Hrvatskog salona održali upravo njezini protivnici, što on osobno nije smatrao dobrim. Što se tiče izgradnje binarne opreke između nacionalnog i europskog/kozmopolitskog kojom su operirali stari, Gjalski ponavlja svoje uvjerenje iz pisma Hrvatskom salonu da europejstvo moderne nije u suprotnosti s nacionalnim. Dapače, njezin individualizam doprinijet će razvoju snažnih osobnosti koje će onda moći podići razinu nacionalne kulture i time pomoći razvoju same nacije. Moderna stoga uistinu može biti hrvatska moderna. Gjalski naposljetku zaključuje:

„Zato mogu mirne duše prihvatiti profesorovu apostrofaciju mladeži: 'uči se ter uči, dugo i savjesno, dok ne izučiš.' Tu se razilazimo g. profesor i ja - jer ja ću izostaviti opće zakone estetične iz takove apostrofacije - pak ću nastaviti: - da 'budeš snažan i jak, a po tom samostalan, da uzmogneš razviti svoju umjetničku individualnost i vršiti njezine potrebe i predavati svietu ono, što joj je najljepše i najbolje!'‘1048

Polemiku mladih i starih pratili su i đaci okupljeni oko Nove nade. Za njih Kuhačeva brošura nije studija o umjetnosti, nego pamflet na umjetnike, koji ne može pretendirati na izricanje mišljenja cijelog hrvatskog naroda. Mladima je ona samo koristila jer je ,pokazala golotinju jednoga od starih. “ ${ }^{1049}$ Osim toga, dobro je da se otvorila javna debata o nečemu što inače nije prisutno u hrvatskoj javnosti. Ona bi mogla dovesti do raščišćavanja pojmova koji se u javnosti koriste konfuzno, do te mjere da vlada prava pojmovna anarhija, kao što je demonstrirala i Kuhačeva Anarkija, ironični su đački modernisti. Ne samo to, nego je

\footnotetext{
1047 Ksaver Šandor Gjalski, „Književna pisma“, Isto, 681-682.

1048 Isto, 691.

1049 „Cijela stvar izgleda kao nekako čeretanje i nekako bijesno srdjenje onako 'uopće' protiv nečesa novoga, nečesa, što se naslućuje da dolazi i da će možda prodrijeti kao bujica medju trošne ograde, kojima se ogradili nekoji, gdje misle mirno počivati i uživati, a da se ne trebaju više mučiti, novomu učiti i usavršivati, kao ljudi, koji misle, da su oni rekli zadnju riječ u napretku naroda i više ništa novo nije potrebno.“ V. „Anarhija u hrvatskoj književnosti i umjetnosti“, Nova nada, III, 1, 29.
} 
„književnički rat“ pomogao i podizanju interesa javnosti za književnost, pa i prodaju samih knjiga. ${ }^{1050}$ Zbog toga sugeriraju đacima da prate ova događanja i da kupuju knjige jer će ona imati upliva na razvoj hrvatske književnosti kako god završila. Prema ocjeni Nove nade, mladi su se u ovoj debati postavili mnogo mirnije i ozbiljnije, o čemu svjedoči Pilarova Secesija. Oni su također pozdravili i Frankovu obranu hrvatskih umjetnika, iako su mu spočitnuli da niti sam nije najbolje razumio postavke secesije i da mu nazori u određenim segmentima pripadaju staroj školi. ${ }^{1051}$

Najvažniji prikaz stavova đačke skupine mladih o secesiji i polemici oko nje dao je Cihlar u svojem prikazu Hrvatskog salona. Pokret mladih za njega je primarno reakcija na žalosne hrvatske književne prilike, i u tom je smislu on više socijalni nego književni pokret. Nepremostivi jaz koji se stvorio jest onaj među „konzervativnim i radikalnim elementom, medju ljudima sadašnjosti i ljudima prošlosti.“ Program koji je Mladost istaknula protiv tih književnih prilika bio je ,program slabosti“ i njega se niti sama Mladost nije mogla držati. Nasuprot tome ona je iznijela jednu mnogo važniju ideju, a to je ideja slobode za pisca. Kako god sudili o njoj, Mladost je pokrenula lavinu koja je dovela do toga da su mladi danas u većini, čemu je pripomogao i utjecaj Gjalskoga. Jednako kao što je i u književnosti pokret mladih nastao više kao društveni pokret protiv književnih prilika, tako je i u slikarstvu secesija mnogo više nastup protiv diktata umjetnosti, nego pravi program umjetničkog secesionizma. Nehajev pozdravlja ovo okretanje organiziranih književnika i umjetnika od pasivna i pomodna ponavljanja izvana preuzetih fraza prema aktivnu radu na poboljšavanju konkretnih društvenih uvjeta književnosti i umjetnosti. To najbolje ilustrira Dežmanovo odustajanje od programa koji je iznio u Mladosti i pomak prema mnogo „krjepčem“ programu Hrvatskog salona. Cihlar ipak zaključuje da će od ove borbe biti mnogo koristi jer će njome mnogi od mlađih izoštriti svoje nazore. Ona će uništiti brojne fraze, kojima su se hranili, uz uvjet da ne postavi nove. Ona će možda prisiliti kritičare da dublje pogledaju u piščevu dušu, a piscima će stvoriti novi svijet pogleda i razmišljanja. ${ }^{1052}$

I za Marjanovića je sukob mladih i starih više od prolazne zadjevice. Pišući o modernoj u hrvatskoj umjetnosti za slovenski Ljubljanski zvon, on je ovaj spor prikazao kao mehanizam vjekovnog procesa napretka: „Spor među starima i djecom star je kao i svijet. Taj spor je uslov napretka, tog spora ne možemo ukloniti. Idilički mir znači samo stagnaciju;

\footnotetext{
1050 J. Grgačev, „Prodja knjiga i djaci““, Isto, 2, 61

1051 V., „U obranu hrvatskih umjetnika“, Isto, 70.

1052 H., „Hrvatski salon“, Isto, 4-5, 165-167.
} 
sličan je bari u kojoj se legu žabe. “1053 U trenutku nastanka ovoga teksta, Marjanović je ocijenio da su stari privremeno uspjeli nadjačati mlade, koji trenutno nemaju svoj forum. Međutim, to je bio samo završetak jedne faze i početak druge, u kojemu polemiku riječima treba zamijeniti polemika djelima. Moderni je potreban forum u kojemu bi bi se mogla provoditi teorijska kritika kulturnog stanja, a u praksi proizvoditi djela koja će svojom kvalitetom privlačiti šire čitateljstvo, otvarati nove vidike i preživjeti svoje vrijeme. Moderna mora biti zora novog života, i to ne samo umjetničkoga, nego i socijalnoga, moralnoga, intelektualnoga i političkoga, ukratko, preporod cjelokupna bića. ${ }^{1054}$

Nova i finalna faza polemike mladih i starih nastupila je u trenutku kada su mladi inicirali pokretanje upravo takve modernističke revije, koja je trebala u djelo pretočiti proklamirane ideale moderne - Života. Tada su na čelo kritike starih izbili krugovi oko Vienca i Obzora. Jedan je od razloga tomu bio i taj što su neki dotadašnji polemičari - kao npr. Tresić Pavičić, Jakša Čedomil i Iso Kršnjavi - na ovaj ili onaj način ostvarili suradnju sa Životom. ${ }^{1055}$ Osim toga, samom svojom pojavom Život je nužno predstavljao konkurenciju Viencu kao središnjem organu hrvatske književnosti.

Jedan od najžeščih i najžučljivijih napada na mlade, odnosno točnije na onaj dio mladih koji se okupljao oko Društva hrvatskih umjetnika i Kluba hrvatskih književnika, došao je ni više ni manje nego iz pera Ante Radića, koji se po svojoj ulozi i sudjelovanjima na sastancima i u organizaciji raznih projekata mladih mogao čak smatrati njihovim dijelom. Radić je 1899. godine objavio pamflet „Život“ $t$. j. smrt hrvatskog preporoda? u kojem žestoko napada mlade - koje naziva „djecom“ i „literatima od dva redka“ - kao manipulatore koji rade protiv hrvatskog nacionalnog pokreta: „Ja sam do tada s nepouzdanjem gledao na mladost - medju kojom je bilo i ljudi tek nješto mladjih od mene - samo zato, što sam u njoj vidio pojavu, koju ne znam drugačije okrstiti, nego njekom vrsti cretinstva, koje ću poslije bliže označiti. Sad sam vidio, da se je u cretinstvu rodio komplot, koliko smiešan, toliko

\footnotetext{
1053 Milan Marjanović, „'Moderna' u hrvatskoj umjetnosti“, u: Krtalić, nav. dj., 601.

1054 Isto, 604.

1055 Društvo umjetnosti priskočilo je u pomoć Društvu hrvatskih umjetnika kao izdavaču Života s 2000 kruna, a Kršnjavi je jednoglasno izabran u redakcijski odbor lista. Kršnjavi, „Pogled“, 231. Jakša Čedomil je već 1898. u korespondenciji s Dežmanom. Tada mu pruža podršku i poticaj za daljnji rad jer u Hrvatskoj nedostaje kritičara. Oko 1900. njegov je ton nešto oštriji i neslaganja su očitija, ali ističe da se on ne priklanja ni starima ni mladima nego želi ostati neutralan. Pisma Dežmanu 19. 5. 1898. i 14. 11. 1900., u: Tomislav Sabljak (ur.), Korespondencija hrvatskih pisaca, Zagreb, 2002, 69-70. Ante Tresić Pavičić 1898. godine u jeku polemika s Kuhačem piše Franu Folnegoviću s odobravanjem što nije slijedio put Josipa Franka u obrani anarhije na polju umjetnosti, koja će "procvasti na najveću korist švapske nadrikulture.” Pismo F. Folnegoviću, 22. 9. 1898., HRDAST-178 Tresić-Pavičić, Ante, k. 1. Nekoliko godina kasnije, pak, Tresić razvija obilnu korespondenciju s Dežmanom kao novim urednikom Vienca, pa ga čak na neki način ucjenjuje da će pokrenuti svoj konkurentski list Hrvatska vila, ako Vienac ne pristane na njegove uvjete. Pismo Dežmanu, 22. 12. 1902., u: Sabljak, isto. Usp. također HR-DAST-178 Tresić-Pavičić, Ante, k. 2 za korespondenciju Tresića Pavičića i Dežmana.
} 
Žalostan, komplot protiv tradicijâ hrvatske književnosti. “ ${ }^{1056}$ Mladi su izmanipulirali Trnskoga i iskoristili Gjalskoga i Markovića da bi njihovim autoritetom nametnuli svoju agendu. Radiću je bilo vrlo važno naglasiti da iako gotovo da pripadaju istoj generaciji, on po svojem habitusu spada više među stare nego mlade. ${ }^{1057} \mathrm{~S}$ obzirom na optužbe koje će protiv njih iznijeti, nije čudno da se htio u potpunosti distancirati od mladih. On piše kako se u prostorijama Društva hrvatskih umjetnika govorilo njemačkim (što je navodno ljutilo Bukovca, moguće zato što nije govorio njemački), kako su te prostorije bile namještene čudnim i smiješnim namještajem te da su se tamo odvijale raskalašene i nedolične zabave. Sve ovo trebalo je prikazati moderniste kao amoralne, odnarođene agente protiv hrvatske kulture i tradicije. Radić ipak pravi razliku između mlade političke i mlade umjetničke generacije. Za razliku od ove druge, koja je organizirala komplot jer su o svojim stvarnim namjerama samo šaputali, a javno ih nisu nikad iznijeli, mlada politička generacija nastupila je otvoreno što je za pohvalu, pa makar se i ne slagali s njihovim idejama. ${ }^{1058}$ Zavjera mlade umjetničke generacije sastoji se u „trojnom savezu“ modernista, režimlija i frankovaca protiv tradicije hrvatskog pokreta, preporodnih ideja i njezinih nositelja iz redova hrvatske opozicije. ${ }^{1059}$ Radić si je itekako dao oduška u svojim napadima; on mlade časti opisima poput „generacija bez ideje“, čiji se „moždjanski titraji cretinstva jedva koliko razlikuju od čiste senzacije koje školjke“ ili koja se „secesionirala i od čitave vrsti Homo sapiens“ itd. ${ }^{1060}$ Naposljetku poziva sve „hrvatske književnike koji i dalje u tišini čuvaju tradicije idealnoga hrvatskoga preporoda“ da „svladaju ovu nakaznu alijancu književnoga cretinstva s grobarima“. ${ }^{1061}$

Neposredni kontekst i povod za ovakav istup Ante Radića bila su ranije opisana previranja oko osnivanja Društva hrvatskih književnika i većine koja će to društvo kontrolirati. To je ujedno bio signal da će prvenstvo u polemici s mladima sada preuzeti krug starih oko Obzora i Vienca koji nisu bili zadovoljni raspletom događaja oko Društva hrvatskih književnika i Života u kojima su mladi zadržali kontrolu u savezu s drugim starijim akterima koji su nerijetko bili njihovi raniji žestoki protivnici (kao npr. Tresić Pavičić ili Kršnjavi). Vienac je isprva bio otvoren za suradnju mladih: 1896. i 1897. za vrijeme uredništva Bartola Inhofa u njemu sudjeluju brojni mlađi autori, od Dežmana, Jelovšeka i

\footnotetext{
${ }^{1056}$ Antun Radić, ,„,Život“ t. j. smrt hrvatskoga preporoda?“, u: Antun Radić, Sabrana djela XIV, Zagreb, 1938, 18.

1059 „Tako je nastao trojni savez, koji je ovih dana jasno izašao na vidjelo. Intelektualni su vodje - koliko tu može biti govora o intelektu - bezidejni senzualisti, financirat će stvar naši grobari, a ostatci će našega nazoviradikalizma zbunjavati vojsku.“ Isto, 29.

${ }^{1060}$ Isto, 30 .

${ }^{1061}$ Isto.
} 
Livadića, pa sve do Nazora, Vidrića i Nikolića. ${ }^{1062}$ Kada se 1898. godine rasplamsao modernistički pokret u sferi književnosti i umjetnosti, Vienac je i dalje otvoren za mlade, čak i više nego ranije. U njemu Pilar objavljuje svoju studiju o secesiji, a i cijeli jedan broj bio je stavljen na raspolaganje mladima. ${ }^{1063}$ Promjena je nastupila 1899. godine kada na mjesto urednika Vienca umjesto Inhofa dolazi Jovan Hranilović. ${ }^{1064}$ Iako je već ranije - povodom polemike Markovića i Gjalskog - izrazio svoje neslaganje s modernističkim idejama, Hranilović snažnije usmjerava Vienac protiv mladih nakon najave izadavanja Života, a ujedno ih optužuje za širenje glasina o prestanku izlaženja Vienca. ${ }^{1065}$ Vrhunac sukoba Vienca s mladima bio je 1900. godine u vidu polemika između Vienca i Života. U tom smislu promjenu nije dovela ni smjena u uredništvu Vienca: s 27. brojem uredništvo je preuzeo Gjuro Arnold, a vlasništvo lista zbog prevelikih dugova od Dioničke tiskare preuzela je Matica hrvatska. ${ }^{1066}$ Hranilović je i dalje nastavio pisati polemičke tekstove protiv mladih, a obrušio se i na pojavu Glasa. ${ }^{1067}$ On iznosi gotovo čitavu polemiku Vienca sa Životom i mladima. Osim njega, u polemiku se uključuje još i Jakša Čedomil koji ponovno nastupa mnogo umjerenije od ostatka starih.

Gotovo je identična dinamika bila s Obzorom. I on isprva na pokret mladih gleda suzdržano; prijateljski, ali patronizirajuće. Praškim listovima prigovara samo u onom dijelu u kojem se oni kritički osvrću na rad pojedinih kulturnih radnika, napose pisaca i pjesnika. Tek kada se pokret rasplamsao i na kulturnom polju Obzor počinje snažnije napadati mlade, modernu i secesiju. ${ }^{1068}$ I ovdje je glavnu riječ vodio Jovan Hranilović kao član redakcije. Stav Obzora i Vienca je stoga u velikoj mjeri komplementaran, samo što je Obzor kao politički dnevnik nešto suzdržaniji u polemici, a i u političkom smislu obzoraši se nadaju privući i utjecati na mlade. ${ }^{1069}$ Vienac s druge strane kao književno-kulturni list predvodi bitku protiv modernizma u kulturi. S prestankom izlaženja Života prestaju i napadi Obzora na modernu i modernizam, a sve više mladih počinje sudjelovati u njegovu radu. ${ }^{1070}$

\footnotetext{
1062 Ujević, nav. dj., 156-157.

1063 Isto, 158.

${ }^{1064}$ Miroslav Šicel, Povijest hrvatske književnosti XIX. stoljeća, knj. III: moderna, Zagreb, 2005, 54.

1065 Ujević, nav. dj., 162.

1066 Isto, 165.

1067 Isto, 168.

1068 Isto, 228-229.

1069 Josip Pasarić je tako kao protivnik modernizma u kulturi otkazao suradnju u Obzoru Dežmanu koji je bio kazališni referent, a koji potom počinje pisati u Agramer Tagblatt. To je učinio u odsutnosti Šime Mazzure koji se s time nije slagao i koji je očito u političkom smislu simpatizirao s Dežmanom. „Šs. Mazzura - Dežmanu, b. d.“, HR-AHAZU-KN-44 Dežman, Milivoj, k. 11.

${ }^{1070}$ Ujević, nav. dj., 232.
} 
Zanimljivo je primijetiti da je stajalište režimskih Narodnih novina bilo upravo suprotno. One su bile hladne i rezervirane prema političkom dijelu mladih, a srdačno su pozdravljale modernistički pokret na polju kulture. ${ }^{1071}$ Dobro honorirani feljton Narodnih novina bio je otvoren za mlade, a Janko Ibler stao je na njihovu stranu protiv Kuhača. ${ }^{1072} \mathrm{U}$ vrijeme najžešćih polemika 1899. i 1900. Narodne novine prvo se nešto aktivnije uključuju na strani starih, da bi potom rezervirano pratile događaje, s ponekim simpatijama za mlade. ${ }^{1073}$ Sukob starih i mladih bio je dakle prvenstveno generacijski sukob unutar hrvatske građanske opozicije u politici i kulturi, dok su režimske snage mogle lavirati između suzdržane podrške jednima i drugima s obzirom na dane okolnosti i koristi koje su iz toga proizlazile.

Valja još napomenuti da je dodatnu dinamiku borbama starih i mladih dao Prvi hrvatski katolički kongres 1900. godine koji se dotaknuo socijalno-političkih, ali i književnokulturnih pitanja kojima su se bavili mladi. ${ }^{1074}$ Moderne se u svojem izlaganju o književnosti dotaknuo Jakov Čuka (Jakša Čedomil), koju je optužio da u ime uključivanja hrvatske književnosti u tokove suvremenih kretanja gazi najsvetije ideale i kreposti. Prema njemu, zadaća je književnosti da moralno, a to ujedno znači i vjerski uzdiže pojedinca i narod. Ocjenjujući postojeće stanje hrvatske književnosti kao zadovoljavajuće, kongres je u svojoj rezoluciji pozvao sve pisce, novinare i izdavače da promiču samo dobru knjigu, odnosno, da ne tiskaju ona djela koja bi se protivila katoličkom vjerskom osjećaju i moralu. ${ }^{1075}$ Nije stoga čudno da se nakon Prvog katoličkog kongresa kod mladih sve više pojavljuje deviza borbe protiv klerikalizma. Međutim, ta će borba biti značajnija kasnije, kada se u većoj mjeri i politički i kulturno oblikuje i organizira politički katolicizam.

S početkom jenjavanja samog pokreta mladih 1901. jenjavaju i polemike između mladih i starih. Budući da s prestankom Života mladi više nemaju svoj literarni list, nestao je i poticaj za snažnijim polemiziranjem. Paralelno s time započeo je proces približavanja i suradnje određenog, napose starijeg dijela mladih i starih, kako na kulturnom, tako i na političkom polju. To je dovelo do raslojavanja i polemika unutar samog pokreta mladih, pa su stari onda mogli povremeno nastaviti polemiku $\mathrm{s}$ radikalnijim dijelom mladih, $\mathrm{tj}$. $\mathrm{s}$ najmlađima. Kao ni za sam pokret mladih, ni za polemike mladih i starih ne može se odrediti jasna točka početka i kraja. Baš kao što će se pokret mladih pretvoriti u svojevrsni simbolički

\footnotetext{
${ }^{1071}$ Isto, 242-243.

1072 Isto, 244.

1073 Isto, 246-247.

1074 Isto, 204.

1075 Mario Strecha, Katoličko hrvatstvo: počeci političkog katolicizma u banskoj Hrvatskoj (1897.-1904.), Zagreb, 1997, 149-150; Za zapisnik Prvog hrvatskog katoličkog kongresa vidi: Strecha, „Mi smo Hrvati $i$ katolici... “: Prvi hrvatski katolički kongres 1900, Zagreb, 2008.
} 
kapital koji će se kasnije u različitim kontekstima ponovno oživljavati, ali u novim oblicima, isto će se tako ponovno rasplamsavati i polemike koje će imati generacijske konture. ${ }^{1076}$ Međutim, specifični polemički koloplet koji smo ovdje razmatrali, a koji je usko vezan uz fenomen pojave i razvoja modernističkog pokreta mladih na prijelomu stoljeća, može se u bitnom smislu smatrati iscrpljenim oko 1901./1902. godine, a kasnije će se ponovno pojavljivati kao borba za ocjenu same polemike i modernističkog pokreta u cjelini.

${ }^{1076}$ Tako npr. Antun Barac piše u svojim „Bilješkama o 'mladima' i 'starima'“ iz 1935. godine: „Tragovi tih borba osjećaju se u neku ruku još i danas, jer se njihovi reprezentanti još i danas od zgode do zgode sukobe, a osjećaju se ti tragovi i u literarnim i kulturnim udruženjima. Ta je borba bila veoma komplicirana, jer nije bila samo književna nego su u njoj bili odlučni i nacionalni, i politički i religiozni, i moralni pogledi pojedinaca." Prema: Damir Barbarić, „Izazov moderne: Matica hrvatska u „sukobu starih i mladih““”, Damir Barbarić, Stjepan Damjanović (ur.), Skrb za duh nacije. Prilozi za povijest nakladništva Matice hrvatske, Zagreb, 2019, 278. 


\section{JENJAVANJE I TRANSFORMACIJA POKRETA}

Ako je bilo problematično utvrditi jednu točku početka modernističkog pokreta mladih, još je teže odrediti točku njegova završetka. Prema Milanu Marjanoviću pokret je mladih nastupao u valovima. On je započeo na društveno-političkom polju, da bi se zatim prelio na kulturno-umjetničko polje. Zbog toga Marjanović predlaže općenito razlikovanje pojma modernizma od moderne, kojom obilježava pokret mladih na polju kulture. ${ }^{1077}$ Pokret moderne u hrvatskoj kulturi bukti od 1897. do 1901. godine, da bi potom počeo jenjavati: „Borba starih i mladih se ublažavala. Moderna kao grupa i pokret se je rasplinjavala, modernizam je od općih internacionalnih problema i interesovanja prilazio sve više domaćim, hrvatskim narodnim, društvenim i kulturnim problemima i interesima." ${ }^{1078}$ Ono što je dakle obilježje finalnih faza pokreta mladih jest okretanje od aproprijacija stranih kretanja prema primjeni tih aproprijacija na hrvatske društvene, političke i kulturne prilike. U toj koncentraciji na praksu događa se ponovno okupljanje mladih pod općim, zajedničkim vrijednostima, ali i jenjavanje pokreta kao pokreta. U prelasku s ideja i proklamacija na konkretnu političku, društvenu i kulturnu praksu pojedinci i grupacije pokreta mladih institucionaliziraju se ili ulaze u već postojeće institucije i organizacije, te od pripadnika jednog pokreta postaju pripadnici hrvatske političke i kulturne elite.

\section{1. Od pokreta mladih do Hrvatske napredne omladine}

Godina 1901. u mnogočemu je označavala prekretnicu što se tiče tijeka pokreta mladih. Na to su u velikoj mjeri utjecale generacijske promjene unutar samog pokreta. Dobar dio njegove pokretačke jezgre iz 1897. godine već je završio ili završavao studije te je tražio svoje prvo zaposlenje. S druge strane oni najmlađi redom su napuštali srednjoškolske klupe i stupali u studentske redove. To je dovelo do raslojavanja unutar pokreta kao što je opisano u prethodnom poglavlju, ali je istovremeno vodilo prema novoj koncetraciji pokreta u njegovoj finalnoj fazi, u Zagrebu kao centru hrvatskog kulturnog i političkog života, onog života u koji su mladi trebali stupiti s namjerom da ga promijene. Ta je promjena u strukturnom položaju mladih nužno utjecala i na njihovu percepciju politike i konkretne prakse. Nikola Fugger tako

\footnotetext{
1077 Marjanović, Hrvatska moderna I, 53.

1078 Marjanović, Hrvatska moderna II, 14.
} 
piše početkom 1901.: „Naši svi bacili su se na to, da si egzistencu osiguraju, da onda pod novim životom prouče što i kako se ima raditi. Djačka politika vidjeli smo da je odviše teoretična i hazardna.“" ${ }^{1079}$ Došlo je vrijeme da se đačka politika zamijeni pravom politikom.

Tri ključna događaja obilježila su 1901. godinu i samim time dinamiku razvoja pokreta mladih. Iznenadivši opoziciju, grof Khuen raspisao je krajem 1901. parlamentarne izbore na kojima je Koalirana opozicija doživjela težak poraz. Za razliku od izbora 1897. kada su osvojili 26 mandata, spali su na njih svega 12, što je bio rezultat koji je bio usporediv s katastrofalnim rezultatom iz 1892. godine. ${ }^{1080}$ Iako su prvaci opozicije slab rezultat pripisivali iznenadnu raspisu izbora i vladinu političkom nasilju, činjenica je da je on predstavljao njihov potop i konačni krah političke prakse koju su predstavljali. S druge strane, mladi su ostvarili svoj prvi značajni izborni uspjeh. Nakon kraha opozicije na izborima, napredna omladina dobro se organizirala te je po prvi puta uspjela pobijediti na izborima za Hrvatsko akademsko potporno društvo protiv kandidata frankovaca i Koalirane opozicije i time definitivno prekinuti dominaciju pravaštva u okviru studentskog pokreta u Hrvatskoj. ${ }^{1081}$ Godinu je 1901. u Hrvatskoj naposljetku obilježila još i obljetnica Marulićeve Judite kao proslava 400 godina hrvatske književnosti. O pripremama za tu proslavu i o njezinoj organizaciji mnogo se raspravljalo u javnosti. Mladi su pogotovo inzistirali da ta proslava ne bude jedna u nizu besplodnih ceremonija obilježenih govorancijama i plesovima, nego da se iskoristi prilika kako bi se u svim dijelovima Hrvatske radilo na širenju interesa za domaću književnost, i to u svim slojevima stanovništva. ${ }^{1082}$ Za njih je to, dakle, bila prilika da se u praksi demonstriraju načela i ideje o književnosti koje su zagovarali u svojim tekstovima i u polemici sa starima.

Reflektirajući o ovim događajima - napose o izbornom porazu opozicije i jalovoj proslavi obljetnice hrvatske književnosti - kao o dva ključna mjesta rada mladih (politika i književnost), oni su kristalizirali svoj program u novim okolnostima okupljanja i premještanja središta pokreta u Zagreb te početka konkretna rada u postojećim institucijama i opozicijskim strankama hrvatske građanske elite. Početkom 1902. godine mladi pod imenom Hrvatska napredna omladina objavljuju brošuru Poraz $i$ slavlje u kojoj se kao nova, distinktivna skupina postavljaju prema trenutnoj političkoj i društvenoj situaciji u Hrvatskoj. Brošura je tiskana u Rijeci, a finalno su je redigirali Marjanović i Cihlar. ${ }^{1083}$ „Poraz“ i „slavlje“ iz

\footnotetext{
1079 „N. Fugger - F. Hlaváčeku, Zemun 22.XI.1901.“, u: Agičić, Dragi Franta!, 51.

1080 Lovrenčić, nav. dj., 80-81.

1081 Gross, „Studentski pokret“", 461.

1082 „Proslava 400-godišnjice hrvatske književnosti“, Život II, 30; f., „Proslava četiristogodišnjice hrvatske književnosti“, Isto, 101, Ivanov, „Proslava četiristogodišnjice hrvatske književnosti“, Život III, 54.

${ }^{1083}$ Marjanović, Hrvatska moderna II, 16. Dakako, jedan od najvažnijih uzora za Hrvatsku naprednu omladinu u procesu formuliranja njihova programa bila je Češka realistička, odnosno napredna stranka (Česká strana
} 
naslova ove brošure ne referiraju se jednoznačno na izborni poraz opozicije i na proslavu obljetnice hrvatske književnosti. S jedne strane, napredna omladina kritizira opoziciju zato što je od poraza pokušala napraviti slavlje, proglašavajući moralnu pobjedu uslijed izbornih manipulacija Khuenova režima. $\mathrm{S}$ druge pak strane, proslava je za njih ujedno bila i poraz jer je jasno pokazala sve negativne strane hrvatskog javnog života. Na taj način oba ova „slavlja“ zapravo su kao fasada prikrivala poraze hrvatske politike i kulture.

Prenoseći atmosferu poraza iz redakcije opozicijskih novina, napredna omladina ističe potpuni raspad politike vodstva hrvatske opozicije: „Očevi stranke šeću dvoranom, očajno, šuteći“, a mladima „kroz zube“ poručuju ,'Eto, sad možete vi mlađi najbolje vidjeti, kako vam ne valja raditi."“1084 Ton mladih nije likujući; oni s tugom konstatiraju ovakvo stanje stvari, ali ističu kako osjećaju „potrebu nečega novoga i krepčijega“, jasno dajući do znanja da je vrijeme da stari otvore svoja vrata njima kao svježim snagama s novim idejama. ${ }^{1085}$ Uzrok ovakva stanja stvari leži u tome što opozicija u praksi nije promijenila baš ništa. Ona je nastavila svoju politiku „diplomatizovanja na sve strane“, „očijukanja i oslona na vanjske faktore“, „,igranja visoke politike“, pri čemu je najgori razvoj njezin najnoviji oslon na Vatikan i politički klerikalizam. ${ }^{1086}$ Sve je to uzrokovalo da narod, ostavljen sam sebi, potiskivan od tuđinske najezde, izrabljivan od domaćih parazita, politički neodgojen i gospodarski neorijentiran, polagano gubi vjeru u svoje vođe, a nažalost i u njihove ideale. Promjena stoga postaje imperativ i pitanje samog nacionalnog opstanka.

$\mathrm{Na}$ isti je način i proslava 400-godišnjice hrvatske književnosti demonstrirala porazno stanje u hrvatskoj kulturi. Organizator je bilo Društvo hrvatskih književnika, a program je obuhvaćao tri dana (12., 13. i 14. studeni 1901.) različitih događanja: koncert i izvedba Porina V. Lisinskog i Zlatarovog zlata u Dežmanovoj adaptaciji u Hrvatskom narodnom kazalištu, posjeti umjetničkim atelijerima i grobovima iliraca, svečana sjednica u Kolu s govorima itd. O programu proslave Hrvatska napredna omladina izrazila se vrlo kritično, signalizirajući ujedno nezadovoljstvo stanjem u Društvu hrvatskih književnika kao kompromisnom tijelu mladih i starih:

„Štampaju se pozivi na najfinijem papiru, program obuhvaća puna tri dana pohoda, sjednica i komersa. Na papiru. U praksi: svečana sjednica s frakovima; kazališna predstava $\mathrm{s}$ prologom, svečanom igrom i pjevanjem; izvanredno sijelo društva književnika, na kojem je

pokroková), osnovana 1900. godine. Njezin je program cirkulirao među mladima te su se oni opsežno osvrtali na njega i uspoređivali ga sa situacijom u Hrvatskoj. Vidi npr. „Ž. Bertić - F. Hlaváčeku, Osijek 17.VII.[1900.]“, „M. Heimrl - F. Hlaváčeku, Mosti 27.II.1900“, u: Agičić, nav. dj., 27-29, 71-74.

1084 „Poraz i slavlje“, u: Marjanović, Hrvatska moderna II, 235-236.

1085 Isto, 236.

${ }^{1086}$ Isto, 239. 
sve tako udešeno, da ne urodi nikakvim praktičkim rezultatom; skupi službeni komers sa zdravicama bez snažnije misli, bez dubljega osjećaja. Obziri prema gore, nemar prema dolje. Prvo kulturno slavlje, a Zagreb spava i miruje. Svaka deseta kuća ima po jednu zastavu; a građanin, a trgovac, a radnik gotovo i ne zna za slavu. Pa šta ga i veže za tih predesetak ljudi u frakovima, koji su inscenirali slavu, jer je „baš morala“ biti, i od kulturnog slavlja čitavog naroda učinili prazni sastanak nekolicine književnika, na kojem si iz svakog lica vidio dosadu i nehaj. “1087

Na papiru narodna politika i kultura, a u praksi politika i kultura elitna, bez ikakva doticaja s narodom - to je sukus kritike mladih upućen na račun starih u povodu ova dva događaja. Kao odgovor u posljednjim se godinama formirao „napredniji, realniji pokret“ među mladima, ali opet ne kao nova stranka, s ciljem korjenite promjene praksi u hrvatskoj kulturi i politici. Iako je taj pokret heterogen (čak se govori i o „mladim pokretima“ u množini), on svejedno sadrži određene točke i poglede koji su zajednički gotovo svim mladima, a koji se ovdje iznose kao programatska podloga Hrvatske napredne omladine. ${ }^{1088}$

Na prvome mjestu ona iznosi svoj stav prema Nagodbi kao ustavnom okviru hrvatskog političkog života. Dakako da ona ne može biti program hrvatskog naroda, međutim njezino je načelno nepriznavanje politički jalovo kada se ona može iskoristiti u pozitivne političke svrhe. Demonstrirajući svoj politički realizam, omladina zaključuje da Nagodba može biti važno oružje političkog rada: „No priznavati je, zahtijevati, da se vrši, da se promijeni, da se po vremenu drugim zamijeni, prvi je zahtjev našeg realnog političkog rada.“1089

Kao svoju drugu zajedničku programsku točku napredna omladina ističe odbacivanje nepriznavanja srpskoga imena. Međutim, zanimljivo je da se ujedno kritički osvrću na ,jednostavnu formulu o jedinstvu ili jugoslavenstvu“, udaljavajući se tako od formulacija koje su dominirale u ranijim publikacijama, napose u Narodnoj misli. Nasuprot tome, mladi se zalažu za „ozbiljno, realno međusobno upoznavanje“ i za „malo političkog razuma“ na temelju kojega bi bila „moguća složna i uspješna akcija protiv zajedničke nevolje“. ${ }^{1090}$ Usvajanje političkog realizma i u ovome je pogledu dakle utjecalo na pragmatično ublažavanje pojedinih ranijih formulacija, od Radićeva rezolutna odbacivanja koncepta sloge Srba i Hrvata jer podrazumijeva njihovo narodnosno razlikovanje politika se mladih vraća upravo na taj koncept sloge. On se od politike starih razlikuje u tome što ne ostaje u domeni

\footnotetext{
1087 Isto, 238.

1088 Isto, 242.

1089 Isto.

${ }^{1090}$ Isto.
} 
retorike, nego se treba oživotvoriti kroz realni, napose gospodarski rad među hrvatskim i srpskim stanovništvom.

$\mathrm{Na}$ trećem mjestu napredna omladina navodi još jedan negativni element svojeg programa, a to je opozicija političkom katolicizmu. Za njih je neprihvatljivo da se interesi hrvatskog naroda identificiraju s ,interesima jednog staleža“ koji se ,počelo smatrati nekom „državom u državi“, nekom organizacijom nad narodom i izvan njega. Zalažući se za slobodu misli i uvjerenja, oni im pridodaju i slobodu iskrenog vjerskog osjećaja, a pitanje napretka naroda i općih interesa mora biti uvijek iznad interesa bilo koje grupe. ${ }^{1091}$

Četvrta točka programa napredne omladine odnosi se na pitanje hrvatske financijske samostalnosti. Iako se ona pozitivno odnosi prema ovom zahtjevu, smatra da on pretpostavlja određene uvjete koji se u političkoj raspravi zanemaruju. Ključni uvjet za ostvarenje financijske samostalnosti je ekonomska snaga naroda. ${ }^{1092}$ Zbog toga nije dovoljno ovo pitanje pretvoriti samo u politički zahtjev, nego u općeniti interes i rad na narodnogospodarskom polju. Drugim riječima, ne smije se dogoditi da i ovaj zahtjev ostane mrtvo slovo na papiru i alibi za nerad političkih elita, nego on mora biti shvaćen kao cilj koji podrazumijeva rad odozdo i sitnim koracima. Osim toga, ovo pitanje ima još jednu dimenziju. S obzirom na to da se i u Hrvatskoj događaju društveno-ekonomske transformacije koje jačaju klasno-socijalne sukobe, ovakvim pristupom koji predlažu mladi spriječit će se akutnost socijalnog sukoba, koji se javio svugdje na zapadu, pa će se javiti i ovdje. Realistički program s kojim mladi izlaze pred hrvatsku političku javnost, napose pred opozicijsku, ujedno služi i kao sredstvo da se socijalno pitanje integrira u nacionalnu politiku te tako spriječi posljedična fragmentacija nacionalnog pokreta na temelju klasno-socijalnih razlika i interesa.

Naposljetku, kao svoju posljednju programsku točku napredna omladina ističe načelno zalaganje za ljubav i shvaćanje života cijeloga naroda, za pravu prosvjetu koja podrazumijeva svestrano obrazovanje i duboko uvjerenje, a ne kopiranje tuđih misli. Jedino na toj osnovi mogu nastati snage buduće zdrave i snažne nacionalne inteligencije, koja će povesti „snažnu sveopću organizaciju naše narodne snage.“1093

Posljednju fazu pokreta mladih karakterizira tako njegova preobrazba u Hrvatsku naprednu omladinu, kao prvi korak u daljnoj institucionalizaciji koja će naposljetku kulminirati osnivanjem Hrvatske napredne stranke 1904. godine. U Hrvatskoj naprednoj omladini okuplja se glavnina ključnih aktera pokreta. Osim revitalizacije pokreta, svrha je

\footnotetext{
${ }^{1091}$ Isto, 243.

1092 Isto, 244.

${ }^{1093}$ Isto, 245.
} 
ovoga okupljanja ujedinjeni nastup mladih prema starima. On, međutim, više nema prvenstveno kritički i negativni predznak, nego se ističe pozitivni program i konstruktivni pristup. Ta se promjena u pristupu zrcali u promjeni imena, u kojem više nije naglašen generacijski raskorak, nego ideološko i programsko određenje nove, mlade skupine na političkoj sceni. U tom je smislu to bio prvi korak prema pregovorima i suradnji mladih i starih.

\section{2. Suradnja starih i mladih}

Nenadani izborni poraz krajem 1901. godine definitivno je natjerao dvije stožerne stranke hrvatske opozicije - Neodvisnu narodnu stranku i Stranku prava - na dugo potrebne promjene. Već 15. siječnja 1902. godine održana je skupština na kojoj je odlučeno da se ove dvije stranke spajaju u jedinstvenu stranku pod provizornim imenom Hrvatska opozicija. Za program nove stranke prihvaćen je sporazumni program hrvatske opozicije iz 1894. godine, a o njezinu konačnom nazivu trebala je odlučiti izvanredna skupština koja će biti sazvana tijekom godine. Već je u zaključcima ove skupštine vidljivo da su stari usvojili određene zahtjeve mladih. U četvrtoj točki navodi se da će zastupnici Hrvatske opozicije u Saboru „,voditi što odrešitiju borbu, da se provede reforma postojećega političkoga izbornoga prava u pravcu što širega $\mathrm{i}$ neposrednoga učestvovanja naroda $\mathrm{u}$ izboru narodnih zastupnika $\mathrm{i}$ stvaranja garancija za slobodu biranja, naročito proti nepovlastnoj ingerenciji oblastnih organa, zatim da se donesu zakoni: o slobodi štampe, o zaštiti lične slobode, domaćega praga, listovne tajne, o družtvima, o uredjenju i zaštiti seljačkoga posjeda. “1094

Povezivanje mladih i starih u domeni politike nije, međutim, ostalo na razini idejnih utjecaja. Milivoj Dežman već je u ožujku 1901. godine bio imenovan za člana egzekutivnog odbora Kluba Neodvisne narodne stranke, a ušao je i u egzekutivni odbor nove stranke. ${ }^{1095}$ Lav Mazzura (sin obzoraškog prvaka Šime Mazzure), Dežman i Radić sudjelovali su na samoj skupštini u ime „saveza napredne omladine“ te su tamo istaknuli svoj realistički pravac. ${ }^{1096}$ Stjepan Radić tijekom 1902. godine dolazi u Zagreb i postaje glavnim tajnikom Hrvatske opozicije, Milan Krištof postao je nadzornikom zadruga, a Svetimir Korporić direktorom nove Hrvatske poljodjelske banke koja je bila projekt hrvatske građanske

1094 „Zaključci skupštine neodvisne narodne stranke i stranke prava obdržavane dne 15. siječnja 1902. u Zagrebu“, HR-AHAZU-KN-44 Dežman, Milivoj, k. 11.

1095 „Š. Mazzura - M. Dežmanu, 20. 3. 1901.“Isto.

${ }^{1096}$ Ujević, nav. dj., 252. 
opozicije. ${ }^{1097} \mathrm{Na}$ taj su način mladi započeli svoj ulazak u političke strukture hrvatske građanske opozicije.

Iako su podržali i sudjelovali u fuziji dviju stožernih stranaka hrvatske opozicije, mladi se nisu utopili u novoj stranci nego su nastupili kao distinktivna skupina koja u radu Hrvatske opozicije sudjeluje putem određenih svojih članova, a zapravo postoji kao zasebna organizacija pod nazivom napredna omladina. Kako bi dodatno naglasili svoj autonomni status, oni paralelno s procesom ujedinjenja hrvatske opozicije pokreću izdavanje svojeg lista, koji je dobio simbolično ime Hrvatska misao, baš kao njihov prvi praški list. U pozivu na pretplatu, koji je odaslan 3. siječnja 1902. godine, mladi naglašavaju kako žele zbiljski sudjelovati u radu na narodnom napretku. Upravo s tim ciljem na umu oni su se bacili na proučavanje svih društvenih i književnih pokreta. Iako je ovdje jasno naglašena sveobuhvatnost modernističkog pokreta mladih, oni ujedno priznaju da su aproprijacije raznolikih stranih uzora dovele i do diferencijacija, pa i neslaganja unutar samih mladih, „poglavito pak u dijeljenju književnosti od ostalog našeg života“. Ipak, imajući pred očima zajedničke ciljeve, najnoviji događaji uvjerili su ih u potrebu ujedinjenja i zajednička konkretnog rada. Izraz je toga ujedinjenja i zajedničkog rada svih grupacija mladih novi list s kojim oni izlaze pred hrvatsku javnost, s nadom da ,ne će uroditi nepouzdanjem i prigovorima prije reda.“1098

Prvi broj zagrebačke Hrvatske misli: smotre za narodno gospodarstvo, književnost $i$ politiku izlazi 16. siječnja 1902. godine, samo dan nakon sastanka opozicijskih stranaka na kojem je dogovorena njihova fuzija uz sudjelovanje napredne omladine. Odgovorni urednik lista bio je Lav Mazzura, a kao izdavači su navedeni „Stjepan Radić i drugovi“. Stjepan Radić nije međutim izravno sudjelovao u pokretanju lista jer tada nije bio u Zagrebu. Redakciju su činili Dežman, Korporić, Heimrl, Mazzura, Cihlar i Marjanović. ${ }^{1099}$ Po tada već ustanovljenoj tradiciji pokreta, prvi dvobroj donosi programatski uvodnik lista. Ovoga puta Radić nije bio isključivi autor programatskog teksta, što se lako može utvrditi usporedi li se sa sačuvanim konceptom koji je bio pisan njegovom rukom. ${ }^{1100}$ On je ovoga puta samo formulirao tekst na temelju zaključaka sa sastanka uredništva na kojem nije prisustvovao. ${ }^{1101}$ Uvodnik definira Hrvatsku misao kao glasilo „onoga narodnog i naprednog pokreta, koji se već desetak godina opaža u Hrvatskoj i koji danas nije živ samo u hrvatskoj mladeži srednjih i visokih škola,

\footnotetext{
${ }^{1097}$ Lovrenčić, nav. dj., 86.

1098 Prema Marjanović, Hrvatska moderna II, 17.

${ }^{1099}$ Isto, 18-19.

${ }^{1100}$ Krizman, Korsepondencija I, 375.

1101 „Živan Bertić - Stjepanu Radiću, Zagreb, 31. XII. 1901.“, u: Krizman, nav. dj., 375.
} 
nego i u znatnom dijelu mladje generacije, što je za posljednjih pet godina svršila svoje nauke i stupila u život.“ Osim što uvodi opis „narodno i napredno“, koji će postati ključna programska odrednica ovoga lista i grupe okupljene oko njega, ovaj uvodnik također jasno pokazuje pomak pokreta mladih u smjeru napuštanja okvira sveučilišta i srednjih škola i prelaska na šire političko i društveno polje. Međutim, mladi se odmah jasno ograđuju od toga da bi Hrvatska misao bila list neke političke stranke, društvenog smjera ili književne i umjetničke škole. To ne znači da oni ne zagovaraju određene zajedničke ideale i konkretne promjene. Drugi pomak koji se dogodio kada je riječ o njihovu pokretu odnosi se upravo na iskorak od radikalna, negativna i nesustavna pristupa prema kristalizaciji misli i ideja. Paralelno s procesom sazrijevanja mladih tekao je i proces tijekom kojeg su stari pod pritiskom političke krize postajali skloni suradnji. Iako je došlo do shvaćanja zajedničkog cilja mladih i starih, a to je ,ujedinjenje i sloboda hrvatskoga naroda“, s time i dalje ,još nijesu riješena pitanja najbližeg konkretnog rada na političkom, gospodarskom i kulturnom polju“, zbog čega Hrvatska misao ima za cilj da odgovori na ta i takva pitanja.

Upravo zbog toga na prvo mjesto u nazivu lista dolazi narodno gospodarstvo, a tek na posljednje politika. Mladi žele napraviti jasno razlikovanje između svoje realističke politike i idealističke politike starih. Ponavljajući argumentaciju iz brošure Poraz $i$ slavlje, oni ističu kako ni politička autonomija, pa ni sama državna samostalnost ne bi bile od pomoći Hrvatskoj „ako Hrvati kao narod ostanu tudje sluge u poljodjelstvu, u obrtu i u trgovini.“ Zbog toga se nije dovoljno zadovoljiti tek zahtjevom za financijsku samostalnost, nego treba ,u prvom redu buditi smisao za općenitu gospodarsku samostalnost hrvatskoga naroda, jer bez te samostalnosti naše bi financije bile samo zlatan ključ k praznoj blagajni.“

Isti realistički princip primjenjuje se i na polju politike: od redefinicije pitanja priznavanja ili nepriznavanja Nagodbe prema pitanju njezine koristi, preko ustavne promjene pozitivnih zakona „prema zahtjevima narodnih interesa i naprednoga duha“, do sporazuma $\mathrm{i}$ sloge Hrvata i Srba kao „državljana jedne hrvatske države“. U tom smislu napredna omladina se definira kao „pokret za narodnu obranu“ koji smjera stvaranju zdravog i iznutra izgrađenog „organizma“ koji će biti sposoban „odolijevati navalama izvana“. Što se pak tiče sukoba između liberalizma i klerikalizma, mladi ga žele izbjeći, i to tako da se utvrdi da samo sloboda znanosti i savjesti može biti uvjet naprednom razvoju, pa da upravo ta sloboda najbolje štiti slobodu iskrenoga vjerskoga osjećaja. Mladi tako sumiraju svoj društvenopolitički program na sljedeći način:

„Dosadašnje geslo: 'Prosvjetom k slobodi' popunjujemo načelom: narodnim blagostanjem k prosvjeti; dosadašnji teoretski radikalizam protiv svega i svačega 
zamijenjujemo radikalizmom u praksi protiv svih, koji gaze temelje ustavne slobode i prava; mjesto krilatih riječi o liberalizmu i klerikalizmu hoćemo savjestan rad u znanosti i književnosti.“

Što se tiče književnosti, njoj je u programatskom tekstu ponovno pripalo najmanje prostora. Nastavljajući se na tvrdnju da neće zastupati niti jedan određeni smjer, mladi navode da će se zalagati za književnost koja će odgovarati duševnom razvoju svakog domaćeg čovjeka, od seljaka do akademski obrazovane inteligencije, koja će biti istinito ogledalo stvarnih prilika i koja će dostizati suvremeni stupanj općenite ljudske prosvjete. U tom smislu oni će kao ,temelj književnog napretka tražiti $i$ čuvati slobodu mišljenja i slobodno isticanje svakog iskrenog osjećaja“, dok će „pitanje o koristi ili štetnosti bilo koje struje književne“ riješiti praksa, a ne teorija. Zanimljivo je primijetiti da se doista radi o svojevrsnoj sintezi praških, dežmanovskih i đačko-modernističkih pogleda na književnost, pri čemu je najmanje zastupljen radikalno-modernistički stav koji se u okviru pokreta mladih ionako očitovao samo u Dežmanovu uvodniku za Mladost i u ponekim istupima najmlađih. Naposljetku, mladi u uvodniku ističu kako su spremni na sudjelovanje u bilo kakvoj organizaciji koja će raditi u smjeru narodnog napretka, ali da će raditi i samostalno „da učvrstimo naš pokret, da pripravimo široko polje svojoj i općoj narodnoj akciji“, što savršeno opisuje njihov odnos prema Hrvatskoj opoziciji. ${ }^{1102}$

U zagrebačkoj Hrvatskoj misli ekonomske, socijalne i gospodarske teme doista su zastupljenije nego ikada do tad u listovima mladih. Posebno su u tom pogledu zaslužni Milan Heimrl i Svetimir Korporić koji je, kako je već rečeno, postao direktor novoosnovane Hrvatske poljodjelske banke. ${ }^{103}$ Važna tema postaje i iseljavanje domaćeg stanovništva u Ameriku, a mnogo se piše i o radničkom pitanju, na čemu surađuje i socijalistički prvak Ivan Ancel. ${ }^{1104}$

Da književnost nije ostala samo u nazivu lista kao što je to često bio slučaj s časopisima praške skupine mladih pobrinuo se trojac Marjanović, Cihlar i Dežman. Prva dvojica formulirala su teorijsko stajalište lista i pokreta o književnosti, dok je Dežman najviše pisao o stanju i potrebi reforme Matice hrvatske. Ključni teorijski tekst u kojem su formulirana stajališta lista o književnosti bio je „Moderno i narodno“ Milutina Cihlara iz prvog dvobroja. Nakon završetka akutne faze polemikâ između mladih i starih, on se osvrće na njih pokušajem formuliranja nove, zasebne pozicije na temelju raščišćavanja pojmova koji

\footnotetext{
1102 Svi navodi su iz: „Hrvatska misao“, Hrvatska misao (1902), I, 1-2, 1-6.

1103 Milan Heimrl, „Naša gospodarska kriza“, Isto, 18-21, 98-103; Svetimir Korporić, „Hrvatska poljodjelska banka“, 129-133.

${ }^{1104}$ Mid., „Iseljivanje u Ameriku“, Isto, 169-174; Ivan Ancel, „Osiguranje radnika“, Isto, 234-240.
} 
su se prema njemu rabili neprecizno i pogrešno. Ne razumijevajući s jedne strane uistinu pojam modernog, a prisvajajući $\mathrm{s}$ druge pojam narodnog za zatvoren krug ljudi $\mathrm{i}$ tradicionalnih literarnih ideja, stvoren je idejni kaos koji je doveo do toga da se čini kako su ova dva pojma u međusobnoj opreci. Cihlar međutim nadilazi polemičke tabore i gradi svoj pristup upravo na pretpostavci da su ova dva pojma itekako međusobno spojiva. Njihovo povezivanje on postiže upotrebljavajući taineovski koncept prirodnog razvoja i napretka narodne kulture: „Sve ono, što se rodi kao naravni produkat razvitka naroda, narodno je.“ Kulturni razvoj naroda slijedi određene zakonitosti, a manifestira se u književnosti koja je najočitija povijest narodne duše. Zbog toga, jedini kriterij književnosti može biti iskrenost; ako je književnost iskrena, onda je ona odraz narodne duše u određenoj fazi njezina razvoja. U tom smislu ne postoji zadana forma, stil pa niti sadržaj književnosti koji bi ju činio narodnom ili nenarodnom. Kozmopolitistička književnost u pravom smislu te riječi zapravo ne postoji jer je ona uvijek rezultat povijesnog i prirodnog razvoja narodne kulture. Stoga i dekadentizam može itekako biti narodan, samo ako je iskren: „U književnosti ne može biti kozmopolitizma: otresti sa sebe dojmove čitavog svog života, svog odgoja, svojih prilika ne može nitko. No s druge strane, rodi li se u jednom narodu književnost iskrena, pa makar i dekadentska, makar i ne znam kakva, ona će uvijek biti narodna, dok je iskren i istiniti odraz duševne dispozicije umjetnikove." Isto vrijedi i obratno: iskrenost mora biti kriterij i za to da se nešto proglasi modernim. Nije dovoljno imitirati moderni habitus, nego je potrebno zbilja duboko osjećati moderne probleme i pitanja, oni moraju umjetnika mučiti i siliti ga da traži odgovore na njih. Ako se razumije i shvaća iskreno i duboko, „modernost nije nikakvo strašilo, nikakva opreka pojmu narodnoga: ona je pače najviši njegov stupanj.“ Najbolji primjer za to je suvremeni razvoj ruske i skandinavske kulture i književnosti. U tom smislu najvažniji faktor za razvoj književnosti postaje sloboda stvaranja. Tek u okruženju slobode, u izostanku fabriciranih i propisanih uzusa i obzira - pri čemu je jasna implikacija da je ono što se forsiralo kao narodno zapravo u svojoj srži bilo nenarodno - moguće je stvoriti „,izradjene, snažne tipove u književnosti“. ${ }^{1105}$

U ovom se tekstu najbolje oprimjeruje sinteza različitih modernističkih grupacija i njihovih ideja koja se odvija oko zagrebačke Hrvatske misli. Temeljna ideja bečke skupine, hrvatske moderne i secesije - sloboda stvaranja - ovdje se povezuje s jednom od osnovnih ideja đačkog modernističkog pokreta - čvrstim umjetničkim karakterom koji se stvara u iskrenoj konfrontaciji s problemima modernog društva - i ključnim stajalištem praške skupine

${ }^{1105}$ M. Nehajev, „Moderno i narodno“, Isto, 22-24. 
o nužnosti uske veze književnosti i naroda, odnosno nacionalne uloge književnosti. Povezivanje mladih koje se odvija 1901. i 1902. godine nije stoga bila mehanička fuzija, nego ispreplitanje misli i ideja u novu kvalitativnu cjelinu. To je ujedno znak da se stubokom promijenio i sam karakter pokreta. Njegovu institucionalizaciju slijedila je i homogenizacija ideološkog sustava. Od heterogenih i neformalnih grupacija i strujanja koje su u bitnom smislu obilježavale ono što pratimo kao modernistički pokret mladih formira se jedan institucionalizirani i homogeni pokret napredne omladine iz kojega će naposljetku proizići i različite političke stranke, kao i vodstva književno-umjetničkih udruga i organizacija. Upravo zbog toga ovu transformaciju iz modernističkog pokreta mladih u pokret napredne omladine možemo smatrati njegovom završnom fazom jenjavanja i kraja.

Milan Marjanović osnažio je Cihlarov teorijski okvir pozivom na prelazak na konkretan rad, kako kritičarski tako i umjetnički. Baš kao i u domeni politike, apstraktni negativitet treba zamijeniti pozitivitet konkretnoga: „Iz analize treba preći u sintezu, iz negacije na pozitivnost, iz fragmenata stvoriti cjeline, unutarnju punoću srediti i projicirati ju van, stupiti opet u život, od njega nešto tražiti i u njemu nešto htjeti.“ Tek konkretnim radom, realnim radom na polju književnosti prestat će potreba za borbu oko uvjeta tog rada. ${ }^{1106}$ Hrvatska misao doduše nije napravila pretjerani iskorak što se tiče književne produkcije. Marjanović i Cihlar svakako su u listu i kvantitetom i kvalitetom značajno ojačali domenu književne kritike, ali sama književna produkcija ostala je oskudna. Osim Gjalskijeve alegorične crtice „Priča hrvatska“ o kući u plamenu, zapravo je sa svojim književnim djelima zastupljen jedino Živan Bertić. U prvoj godini izlaženja Hrvatske misli objavljene su njegove priče „Pita i Poldika“, „Narod“ i „Sremac“. Njegovo je književno djelo, međutim, mnogo bliže radićevskom, odnosno šarićevskom idealu tendenciozne nacionalno-pučke književnosti iz praške Hrvatske misli nego što bi odgovaralo vrhunskoj modernoj književnosti kakvu zagovaraju Marjanović i Cihlar. ${ }^{1107}$

Jedan od razloga zašto je Hrvatska misao podbacila u domeni književne produkcije - a to i sami urednici naglašavaju na kraju prvog godišta lista - jest taj što je pozornost većine ključnih aktera na području književnosti bila usmjerena na događanja oko Matice hrvatske. ${ }^{1108}$ Milivoj Dežman u Hrvatskoj misli kao i ranije u Životu nastavlja ekstenzivno pisati o stanju i potrebi promjena u Matici. ${ }^{1109}$ Jedan od gorućih problema bio je opstanak Vienca koji je

\footnotetext{
${ }^{1106}$ M. Marjanović, „Naša moderna beletristika“, Isto, 183.

1107 Ivo Frangeš (ur.), Iso Kršnjavi, Iso Velikanović, Živko Bertić, Joza Ivakić: izabrana djela, Pet stoljeća hrvatske književnosti, Zagreb, 1980, 423.

1108 „Našim prijateljima“, Hrvatska misao (1902), I, 23-24, 754.

${ }^{1109}$ M. Dežman Ivanov, „Glavna skupština Matice hrvatske“, Isto, 83-86; „Matica Hrvatska“, Isto, 276-278 itd.
} 
generirao sve veće gubitke te je postao teret i za Dioničku tiskaru i za Maticu. ${ }^{1110}$ Iako su s njime vodili žestoke polemike, mladi su sada bili voljni, napose nakon kompromisa sa starima na političkom polju, raditi na očuvanju ovog simbola hrvatske književnosti. Oni stoga nakon prestanka izlaženja Života ne pokreću novi modernistički list, nego Dežman i Gjalski pristaju preuzeti uredništvo Vienca u pokušaju njegova spašavanja. Već sama ova činjenica dovoljno govori o procesima smirivanja sukoba starih i mladih te o ulasku mladih u ključne insititucije hrvatske građanske elite.

Vienac 1903. godine pod uredništvom Gjalskog i Dežmana oživotvoruje dugogodišnju njihovu maksimu o nužnosti slobode stvaranja. U njemu pišu i stari i mladi različitih struja i uvjerenja. Stišavanju književnih borbi svakako je pridonijelo i to što je te godine fokus javnosti bio na burnim političkim događajima i društvenim nemirima. S druge pak strane, očito je bilo i ublažavanje kritičke oštrice mladih. U pozivu na pretplatu Vienca Gjalski i Dežman ističu kako će u njihovu radu prva zadaća biti da idu istim patriotskim stazama. ${ }^{1111}$ To međutim nije bila kapitulacija moderne, nego svojevrsno izbjegavanje trijumfalizma i kompromisni stav u pobjedi. Dežman će tako u jednom svojem tekstu u Viencu te godine ustvrditi kako je uspjeh modernista očigledan: „Ta kritika, često bezobzirna, nije prestala naglašavati i nuždu reforme, i evo mi svi vidimo, da su reforme na svim linijama u punom jeku, da je glavni cilj pokretača - osigurati slobodu stvaranja književnicima i umjetnicima polučen.“ Vrijeme je, zaključuje Dežman, za drugu fazu, „sad je hora, da u pozitivnom radu opravdaju borbu. “1112

Jednako kao što Marjanović i drugi najmlađi nisu bili zadovoljni kompromisnim stavovima Dežmana za vrijeme pokretanja i izlaženja Života, tako su se tada javljali glasovi novih najmlađih koji nisu bili zadovoljni $\mathrm{s}$ istim tim kompromisnim stavovima koje je u okviru pokreta napredne omladine usvojio sam Marjanović i drugi bivši pripadnici najmlađe skupine pokreta. U travnju 1902. godine u Zagrebu skupina je mladih pod vodstvom Branka Drechslera počela izdavati list Mlada Hrvatska: slobodan časopis za književnost, umjetnost $i$ socijalni život. U njemu sudjeluje niz imena koja su ranije bila povezana s krugom oko Svjetla: Zofka Kveder, Andrija Milčinović i Vladimir Jelovšek, te neka druga značajna imena kao što su Antun Gustav Matoš i Jurislav Janušić. Iako Marjanović navodi da su postojale određene političke konotacije ovoga projekta jer je Mlada Hrvatska štampana i kreditirana u tiskari Josipa Franka, krug okupljen oko ovog lista nastupa kao kritičar Hrvatske misli i

\footnotetext{
${ }^{1110}$ Vinko Brešić, Praksa i teorija književnih časopisa, Zagreb, 2014, 65.

${ }^{1111}$ Ujević, nav. dj., 259.

1112 Ivanov, „Milan Marjanović: 'Fragmenti'“, u: Marjanović, Hrvatska moderna II, 277.
} 
napredne omladine i u tom smislu kao nastavljač tradicije neovisna djelovanja mladih. ${ }^{1113}$ Naime, njihov je prigovor bio taj da su mladi ulazeći u listove i stranke starih na neki način izdali vlastita načela i načela modernističkog pokreta. U jednom od svojih tekstova Drechsler opisuje specifični karakter hrvatske moderne kao rezultat abnormalna razvoja hrvatske književnosti. Umjesto da se kritički odnosi prema realizmu i naturalizmu, ona je tek dala kritičare koji su uspjeli valorizirati glavne predstavnike tih stilskih strujanja, a u programatskom se smislu morala boriti za opće načelo slobode stvaranja i dostizanja europskih kretanja. U svemu tome ona nije proizvela nešto doista umjetnički veliko: „Jadno bi bilo, da doista ostane rezultatom onih bojeva za veliku ideju slobode stvaranja i za shvaćanje moderne knjige tek nemoć Gjalskoga, historičke drame Ivanovljeve i feljtoni Nehajevljevi. Uvjeta sad već ima, jer smo u kontaktu s mislima cijele Evrope, a lijepo je uskršnje vrijeme: treba da se iščahurimo!‘1114

Dakako da ovakav izazov nije mogao proći bez odgovora. Polemičku palicu preuzima Marjanović, koji je u poziciji da kao bivši pripadnik najmlađe skupine pokreta nastupa prema novim najmlađima. Suvremeni svijet, tvrdi Marjanović, dovodi do sve veće društvene fragmentacije i atomizacije, tako da i generacijske podjele postaju sve suptilnije. On tako uočava da se generacija iz 1895. koja je djelovala u raznim grupacijama okupila u jedan pokret oko Hrvatske misli, a da se javljaju novi najmlađi na tragu đačkog modernističkog pokreta, referirajući se prvenstveno na đačke listove Nova zvijezda i Jednakost. Marjanović je prema njima, međutim, izrazito kritičan, mnogo kritičniji nego što su mladi ikad bili prema krugu oko Nove nade. On ih optužuje za imitatorstvo i epigonstvo starije generacije, a uzrok tome pronalazi u vrlo ograničenoj i površnoj naobrazbi i u pomanjkanju prave duševne kulture. ${ }^{1115}$ Ironično, Marjanović se koristi istim onim patronizirajućim argumentima koje su stari bili iznijeli prilikom prve pojave mladih: đaci su još premladi i trebaju vremena da sazriju. Naravno da je stoga bilo teško za očekivati da će Marjanović biti blag prema krugu oko Mlade Hrvatske. Ispravno shvativši Drechslerovu kritiku da je vrijeme da modernisti počnu konzekvetno provoditi pravi modernistički program, on kritikom sadržaja prvoga broja tog lista ustanovljuje da niti oni sami nisu baš konzekventni u provođenju te svoje osnovne ideje. U tom smislu, opet pomalo patronizirajuće, Marjanović zaključuje kako bi volio u budućim brojevima vidjeti više ozbiljnosti, izrazitosti, svestranosti, pa i modernosti, hrabrosti

\footnotetext{
1113 Marjanović, Hrvatska moderna II, 24.

1114 Branko Drechsler, ,Abnormalni momenat u razvitku hrvatske knjige“, Isto, 261.

1115 M. Marjanović, „Najmladji“, Hrvatska misao (1902), I, 1-2, 57.
} 
i radikalnosti. ${ }^{1116}$ I time je na neki način zatvoren krug razvoja pokreta od mladih izazivača dominantnih kulturnih i političkih praksi do statusne pozicije moći u odnosu prema novim mladim izazivačima.

S druge pak strane, niti odnosi između mladih i starih nisu bili pretjerano idilični. Nakon katastrofalna poraza na izborima krajem 1901. godine, prvaci hrvatskih opozicijskih stranaka bili su praktički primorani otvoriti svoja vrata mladima kako bi obnovili i očuvali svoje organizacije. Međutim, nije bila riječ samo o strankama. Kao što je već rečeno, mladi ulaze i u gospodarske institucije i u listove starih. Osim već spomenutog Vienca, dobivaju važne angažmane i u Obzoru i u Novome listu. Stari su na neki način počeli ovisiti o energiji i inicijativi mladih. Oni organiziraju i održavaju skupštine preko kojih agitiraju za program i ideje Hrvatske opozicije, a kojima su pokušali ponovno oživjeti skupštinski pokret iz 1899. godine i potaknuti Hrvatsku opoziciju na aktivan terenski rad. ${ }^{117}$ Dobar primjer organizacijske uloge mladih u okviru Hrvatske opozicije bilo je pokretanje opozicijskog lista Narodna obrana u Osijeku. Za taj su zadatak bili zaduženi Većeslav Wilder i Ivan Lorković, koji je preuzeo i glavno uredništvo. U tu svrhu u Osijeku je osnovana Prva hrvatska dioničarska tiskara koja je trebala poslužiti kao infrastrukturna osnova za izdavanje novog lista. ${ }^{118}$ Prvi broj lista izašao je 16. studenog 1902. godine, a u uvodniku se izlažu njegove osnovne ideje koje se naravno podudaraju s općim programskim načelima Hrvatske opozicije: od poštivanja hrvatske autonomije na temelju Nagodbe, preko zahtjeva za financijskom samostalnošću, pa sve do cilja političkog ujedinjenja hrvatskih zemalja u okviru Monarhije. ${ }^{1119}$ Hrvatska misao je dakako pozdravila novi osječki politički dnevnik u čijem su pisanju vidjeli znatan dio svojih tendencija i odmak od besplodne stare opozicijske politike, koja je i dovela do nužde hitne obrane nacionalnog karaktera Osijeka implicirane u naslovu lista. ${ }^{1120} \mathrm{U}$ tom se argumentu zrcali tendencija nacionalne singularizacije i homogenizacije urbanih prostora koji su ranije funkcionirali kao multikulturni, a koja poseban zamah dobiva krajem 19. stoljeća. Ona se politički operacionalizira širenjem moralne panike, što se u ovom

\footnotetext{
1116 M. Marjanović, „'Mlada Hrvatska'“, Isto, 253. Nakon ovih početnih udaraca u rukavicama polemika je krenula u poprilično žučljivu smjeru. Dok je s jedne strane Drechsler napadao mlade oko Hrvatske misli da su se radi materijalnih interesa odrekli svojih načela i postali stari, oni su mu uzvratili da je on svoje nepokolebljive ideale demonstrirao u ,panegiriku“ Kršnjavome koji je napisao za Narodne novine. Vidi: „Teorija i praksa“, Isto, 508-510.

${ }^{1117}$ Za pregled rada mladih u 1902. godini vidi njihov izvještaj „Jedna godina dana“, Isto, 720-729. Lovrenčić, nav. dj., 149.

1118 Proces osnivanja tiskare i pokretanja lista pomno su pratile gradske vlasti. Vidi HR-DAOS-6 Poglavarstvo slobodnog i kraljevskog grada Osijeka, 5758, spis br. 32 od 14.7.1902., br. 58 od 30.8.1902., br. 102 od 27.10.1902 i dr.

1119 „Narodna obrana!“”, Narodna obrana, I, 1, 16. 11. 1902.

1120 „'Narodna obrana'““, Hrvatska misao (1902), I, 22, 696.
} 
periodu postiže ukazivanjem na njemački Drang, mađarsku kolonizaciju i gubitak „domaćeg“ stanovništva zbog emigracije kao na prijetnje nacionalnom opstanku. Mladi su stoga itekako posezali za tim sredstvima političke agitacije, što je razvidno i u njihovu radu oko osječke Narodne obrane.

Međutim, usprkos uspjesima i organizacijskoj energiji mladih, staro nepovjerenje nije bilo jednostavno zaboraviti. Već sama činjenica da se mladi nisu stopili s ostatkom opozicije, nego su u nju ušli kao zasebna organizacija s vlastitim listom budila je nepovjerenje i govorila o opreznu odnosu mladih prema projektu ujedinjenja. Hrvatska opozicija bila je provizorna organizacija koja je trebala postojati dok se ne provede konačna fuzija u jedinstvenu stranku. U tom smislu, usprkos tome što su svi priznavali nužnost ujedinjenja i složna rada, ona je postala poprište za stare trzavice i zakulisne borbe za što bolje pozicioniranje aktera ususret nadolazećoj fuziji. Domovinaši su htjeli zadobiti primat u novoj stranci simboličkim zahtjevom da ona nosi ime stranke prava, čime bi ujedno izbjegli da Frank prisvoji cjelokupnu pravašku tradiciju. Budući da su mladi bili bliži obzorašima, i budući još uvijek nisu zaboravili držanje domovinaša oko demonstracije 1895. godine (napose Folnegovića), kao i njihovo koketiranje s klerikalizmom, posebne trzavice razvile su se na ovoj relaciji. Mladi stoga koriste Hrvatsku misao i kao instrument polemika unutar Hrvatske opozicije. Oni tako odgovaraju na optužbe da su „nagodbenjaci“ zbog svoje politike iskorištavanja ustavnih mogućnosti koje Nagodba pruža, što dakako podrazumijeva odbacivanje pitanja njezina (ne)priznavanja, a koje su potencirali upravo pravaši. Pritom otvoreno ističu želju da se iz pokreta razvije politički faktor u pravom smislu te da zauzme dolično mjesto u jedinstvenoj hrvatskoj opoziciji. ${ }^{1121}$ Mladi su više puta iznova pojašnjavali svoju poziciju unutar Hrvatske opozicije:

„Mi nismo stupili u sjedinjenu oporbu ni stopili se s njom, jer smo znali, da mi nismo s njom jedni ni po mišljenju ni po taktici. Mi smo tek pristupili na zajednički rad s hrv. opozicijom, a ostali smo izvan nje baš s toga razloga, da nam riječ ne ostane vezana $\mathrm{i}$ mišljenje ne bude zaustavljeno. Hoćemo u radu za našu narodnu obranu da budemo s njom jedni, ali nismo jedni i ne ćemo ni da se prikazujemo kao jedni i u svojim simpatijama i u svojem sudjenju. "1122

U tom je pogledu posebno bio osjetljiv položaj Stjepana Radića koji je zauzeo važnu organizacijsku funkciju u okviru Hrvatske opozicije, a opet je - dijelom i zbog svojeg karaktera - lako i često ulazio u sukobe s drugim opozicijskim prvacima, napose onima iz

1121 Baćuška [Radić], „Zašto nismo nagodbenjaci?“, Isto, 128.

1122 „Da se razumijemo“, Isto, 221. 
redova domovinaša. Obzoraški prvaci s kojima je bio blizak - posebice Šime Mazzura - stoga su ga više puta upozoravali na nužnost taktičnosti te su mu prigovarali što je određene stvari radio na svoju ruku bez znanja stranačkog vodstva. ${ }^{1123}$ Radićeva impulzivnost i sklonost soliranju dovela je i do napetosti unutar samog pokreta napredne omladine. Očito ne želeći da se Radićevo ime previše ističe i da se tako stvara dojam da cijeli pokret stoji pod njegovim vodstvom, Milivoj Dežman je na jednom sastanku u proljeće 1902. predložio da se iz Hrvatske misli izbaci formulacija da ju izdaju „Stjepan Radić i drugovi“. Nakon što je taj prijedlog usvojen, Radić je prekinuo suradnju s Hrvatskom misli, pa ju je čak i javno kritizirao. ${ }^{1124}$ To je bio početak razlaza Radića s naprednjacima i hrvatskom opozicijom općenito, a tijekom 1902. kod njega se već jasno kristaliziraju ideje o osnivanju seljačke stranke.

Budući da se bližio trenutak fuzije hrvatske opozicije, napredna omladina morala je odlučiti o svojoj budućnosti. Nakon neuspješnih pokušaja vlasti da ju pridobije na svoju stranu i razbije homogenost opozicije, pritisak na nju postajao je sve veći. ${ }^{1125}$ Iako je napredna omladina (uz iznimku Stjepana Radića koji je tad već djelomično išao svojim putem), baš kao i ostatak Hrvatske opozicije, ostala zatečena rujanskim događajima, odnosno protusrpskim demonstracijama 1902. godine ${ }^{1126}$ te nije u tome trenutku reagirala, kasniji tekstovi u Hrvatskoj misli na ovu temu poslužili su vlastima kao povod za sve učestalije zapljenjivanje i cenzuru lista. Od 17. broja 10. rujna 1902. godine gotovo su svi brojevi do kraja godine bili cenzurirani, a ta se praksa nastavila i tijekom sljedeće godine, posebice nakon što su započeli nemiri 1903. godine kada je list bio i obustavljen. S druge pak strane mladi su se našli pod pritiskom opozicijskih krugova te su bili sve snažnije uvučeni u vrtlog unutarstranačke politike i poslova. Sve to doprinijelo je, kako zaključuje Marjanović, nužnoj decentralizaciji rada mladih, usprkos trudu da se takve tendencije obuzdaju okupljanjem oko jednog lista i u jedan pokret. ${ }^{1127}$ Rezultat svega toga bio je taj da je zaseban nastup napredne omladine u

\footnotetext{
${ }^{1123}$ Usp. npr. „ک̌. Bresztyenszky - Stjepanu Radiću, Pleso 28. III. 1902.“, „Stjepan Radić - Šimi Mazzuri, Zagreb, 14. I. 1903.“, u: Krizman, nav. dj., 382-382, 393-395

${ }^{1124}$ Lovrenčić, nav. dj., 85; „Živan Bertić i Nikola Fugger - Stjepanu Radiću, [1899.]“, Krizman, nav. dj., 352353. Krizman je pogrešno procijenio pismo na 1899. godinu. Iz sadržaja je izgledno da je riječ o 1902. godini.

${ }_{1125}$ Usp. Milan Marjanović, Hrvatski pokret: opažanja i misli na pragu narodnoga preporoda g. 1903, sv. 2, Dubrovnik, 1904 49-50.

${ }^{1126}$ Demonstracije su potaknute objavom provokativnog članka „Srbi i Hrvati“ iz Srpskog književnog glasnika u samostalskom Srbobranu, odnosno žustrom reakcijom hrvatske opozicije koja je pozvala na bojkot srpskih trgovaca u Zagrebu jer su navodno financirali Srbobran. Umjesto bojkota, međutim, dogodili su se izgredi i napadi na srpske trgovce, obrtnike i ekonomske ustanove, a glavnu su ulogu u njima igrali frankovci koji su imali snažno uporište među sitnim hrvatskim trgovcima i obrtnicima. Pozadina je „rujanskih događaja“ tako bila i ekonomske prirode. Izgredi su trajali četiri dana te su prekinuti intervencijom vojske i uvođenjem prijekog suda. Lovrenčić, nav. dj., 144-148.

${ }_{1127}$ Marjanović, Hrvatski pokret II, 47.
} 
okviru Hrvatske opozicije samo na godinu dana odgodio njezino formalno stapanje s ostatkom hrvatske opozicijske elite.

Prije glavne skupštine hrvatskih opozicijskih stranaka 29. siječnja 1903., na kojoj je trebalo biti odlučeno o konačnom obliku fuzije $\mathrm{u}$ jednu stranku, mladi su intenzivno raspravljali o svojem stajalištu po tom pitanju i o svojoj budućnosti. Marjanović opisuje atmosferu prije glavne skupštine. Odbor je omladine svakoga dana držao po jedan, a zadnjih i više sastanaka na kojima je trebalo defnitivno utvrditi stav mladih. Situacija se mijenjala iz sata u sat, tako da je sve do pred samu skupštinu sve bilo u kaosu. Svatko je vukao na svoju stranu, svaki čas je bio novi preokret i nova situacija. ${ }^{1128}$ Prvotna ideja mladih bila je da napredna omladina ostane zasebna skupina unutar nove stranke kao što je bila i dotad u okviru Hrvatske opozicije. Iskustvo je međutim pokazalo da je takav položaj neodrživ. Iskristalizirale su se stoga dvije struje, odnosno dva moguća smjera kretanja: ili će napredna omladina osnovati vlastitu stranku i krenuti svojim putem, ili će se stopiti s ostatkom opozicije u novoj Hrvatskoj stranci prava. O prvoj opciji se tada već ozbiljno razmišljalo, pa se čak govorilo i o potencijalnom karakteru te nove stranke - moderna demokratska ili seljačka stranka međutim ipak se na kraju zaključilo da je takva odluka preriskantna te da za nju trenutačno ne postoje svi nužni preduvjeti. Osim toga, postojala je opasnost da ta nova stranka ostane potpuno izolirana, da izgubi komunikacijske i organizacijske kanale, napose prema provinciji, koje im je nudila već ipak donekle izgrađena stranačka infrastruktura Hrvatske opozicije te da tako postane lak plijen za udar režima. ${ }^{1129}$ Odlučeno je stoga da se ide u fuziju s ostalim opozicijskim strankama koje su bile uključene u taj proces.

Hrvatska napredna omladina stupila je tako na skupštini 29. siječnja 1903. u novoosnovanu Hrvatsku stranku prava s izjavom u kojoj je naglasila da je „skupina mladje hrvatske generacije, koja smjera za reformom i preporodom čitavoga našeg narodnog života, u smislu demokratskom, koja hoće promjenu metode narodne borbe, a nipošto ciljeva njezinih $[\ldots]$ “ Hrvatsku stranku prava ne smatra nastavkom neke stare stranke, nego novom strankom u kojoj se koncentriraju sve narodne sile, i od koje očekuju da im pruži „široko polje za realan rad oko narodne obrane i narodnih potreba u svom dosadašnjem pravcu.“1130

Posve se analogan proces odvijao sa srpskim dijelom pokreta mladih. Nakon prestanka izlaženja Glasa 1900. godine kao zajedničkog projekta praških i zagrebačih mladih, ove se dvije skupine nisu razišle i nastavile svojim putevima, nego se dogodila diferencijacija

\footnotetext{
${ }^{1128}$ Isto, 57.

1129 Isto, 57.

${ }^{1130}$ Kopija izjave, s naglascima u originalu, nalazi se u: HR-AHAZU-KN-133 Marjanović, Milan, k. 86.
} 
pokreta po nacionalnom ključu. $\mathrm{U}$ jednu ruku bio je to rezultat određenih ideoloških i političkih neslaganja. Bertić tako piše Hlaváčeku da je sa Srbima „dioba neukloniva“, a Fugger govori o ,nebuloznim zahtjevima naših Srba i njihovih zastupnika medj nama [...]“1131 S druge pak strane, na odvajanje putanja hrvatskog i srpskog dijela pokreta mladih utjecali su i strukturni razlozi. Budući da su se mladi počeli okretati suradnji i ulaženju u organizacije i institucije starih, to je nužno podrazumijevalo i razdvajanje po nacionalnim linijama s obzirom na činjenicu da su postojeće stranke i organizacije bile nacionalno definirane. Srpski dio pokreta, predvođen Pribićevićem i Banjaninom, okreće se tako Srpskoj narodnoj samostalnoj stranci kao ključnoj srpskoj građanskoj opozicijskoj organizaciji u Hrvatskoj. Prvi su pokušaji bili neuspješni, što nije čudno s obzirom na ranije kritike mladih upućene srpskoj opoziciji u Hrvatskoj. Krajem 1901. godine Srpska samostalna stranka odbila je u svoje redove primiti Pribićevića i Banjanina. ${ }^{1132}$ Ipak, nakon katastrofalnih zagrebačkih protusrpskih izgreda u rujnu 1902. godine, i srpski opozicijski prvaci bili su primorani promijeniti kurs i prihvatiti mlade u svoje redove. S obzirom na to da je izdavanje Srbobrana bilo zabranjeno, on se ponovno pokreće u prosincu iste godine kao Novi Srbobran, a na njegovu čelu tada se nalazi Jovan Banjanin. Osim toga, Svetozar Pribićević postao je novi tajnik Srpske samostalne stranke. ${ }^{133}$ Svetimir Korporić stoga zaključuje: „Danas izlazi I. broj „Novog Srbobrana“, komu će odgovornim urednikom biti Banjanin a pravim chefredacteurom Pribićević. Dakle opet koliko toliko naši ljudi.“"1134

Ako je demonstracijom 1895. godine put pokreta mladih simbolično započeo činom kritike i odjeljivanja od hrvatske opozicije, mogli bismo reći da njihov povratak u krilo hrvatske (i srpske) građanske opozicije predstavlja njegov simbolički kraj. Kao što je već više puta bilo naglašeno, naravno da nije moguće povući jasne granice, napose zbog same naravi predmeta koji se promatra. Kao simboličnu točku kraja jednako bi se tako moglo uzeti i kasnije odvajanje mladih iz Hrvatske stranke prava i osnivanje vlastitih stranaka: naprednjačke i seljačke. Zbog toga ne govorimo o kraju pokreta, nego o njegovu jenjavanju i transformaciji. Od 1901. godine on jenjava, napose na polju kulture i u pogledu brojnosti različitih grupacija i njihovih projekata, da bi se krajem te godine transformirao iz heterogena i raspršena modernističkog pokreta mladih u homogeniji i koncentriraniji pokret napredne omladine te svoje djelovanje usmjerio prvenstveno na polje politike odakle je sve i započelo.

\footnotetext{
1131 „Ž. Bertić - F. Hlaváčeku, Osijek 17.VII.[1900.], „N. Fugger - F. Hlaváčeku, Zemun 11.I.1900.“, u: Agičić, nav. dj., 29, 42.

1132 Nicholas J. Miller, Between Nation and State: Serbian Politics in Croatia Before the First World War, Pittsburgh, 1997, 57.

${ }^{1133}$ Isto, 59.

1134 „S. Korporić - F. Hlaváčeku, Zagreb 30.XII.1902.“, u: Agičić, nav. dj., 126.
} 
Ono što je međutim indikativno jest to da se već tijekom 1902. počinju nazirati konture stvaranja narativa samih aktera o pokretu unutar samoga pokreta. U tom smislu to je još jedan od jasnih signala da dolazi do dubinskih promjena koje omogućuju da se modernistički pokret mladih konceptualizira kao zaseban i jedinstven fenomen, što nije bilo moguće u trenutku njegova akutnog trajanja. Naposljetku, simbolički kapital pokreta mladih opstat će u hrvatskom javnom prostoru kroz dulje vrijeme nakon njegova jenjavanja te će borbe mladih $\mathrm{i}$ starih, mladih i najmladih i mladih unutar sebe zamijeniti borbe za prisvajanje tog simboličkog kapitala i za uspostavljanje hegemonijskog narativa o povijesti pokreta i njegovoj ulozi u hrvatskoj povijesti.

\section{3. Stvaranje narativa o pokretu mladih}

Okupljanje mladih oko zagrebačke Hrvatske misli pratio je fenomen početaka izgradnje narativa o samome pokretu. Kao što smo već vidjeli ranije, određeni elementi autoidentifikacije i autoprezentacije pokreta bili su prisutni od samoga početka, ali su oni bili nestalni te su varirali ovisno o dinamici njegova razvoja i promjenama situacija u kojima je funkcionirao. Ključnu ulogu u izgradnji koherentna narativa o pokretu mladih u njegovoj je završnoj fazi imao Milan Marjanović. On je zapravo oblikovao osnovne crte razumijevanja pokreta mladih na prijelomu stoljeća koje će se zadržati i onda kada on postane predmet znanstvenog proučavanja. U tom pogledu, kao važan fenomen posljednje faze pokreta mladih potrebno je razmotriti ovaj narativ koji su sami akteri pokreta gradili o njemu.

Jedan od najranijih prikaza razvoja pokreta iz pera samih sudionika bio je članak Stjepana Radića, „Trojí hnutí v Chrovátsku“ („Tri pokreta u Hrvatskoj“) objavljen 1900. godine u praškom listu Slovanský přehled. On opisuje diferencijaciju pokreta koji je inicijalno nastupio kao reakcija nezadovoljne studentske mladeži i od kojega se mogao očekivati cjeloviti i jedinstveni razvoj. Karakteristično za njega, uzroke toj diferencijaciji Radić pronalazi u socijalnom sastavu mladih. Prema njemu, oni koji su bili porijeklom sa sela i iz provincije interesirali su se za političke i gospodarske probleme života naroda te su postali nacionalisti, dok su oni porijeklom iz grada, napose Zagreba, postali kozmopoliti usredotočeni na pitanja umjetnosti i kulture. On tako i unutar samog pokreta mladih implicitno provlači distinkciju između (nacionalno osviještenog) puka i (odnarođene) gospode. Međutim, njegova ocjena pokreta hrvatske moderne, koju temelji na analizi časopisa Život, za razliku od one njegova brata nije pretjerano negativna. Iako ne smatra da ima neki poseban modernistički 
program, on je kao kompromisni projekt mladih i starih ipak korak naprijed u hrvatskoj literaturi. Uz ovaj literarni, druga dva od tri pokreta koja su nastala diferencijacijom nastupa mladih djeluju na političkom polju. Pod utjecajem tadašnjih događanja, Radić opisuje pokret oko časopisa Glas, koji se pod utjecajem socijalne demokracije i liberalnog kozmopolitizma odijelio u zasebnu, prijelaznu skupinu, što bi impliciralo da je originalni politički program pokreta sadržan u trećoj struji, a to je ona oko lista Dom koji je 1899. pokrenuo njegov brat Antun. Ovo je zanimljivo jer predstavlja jedini slučaj u kojemu je Dom uključen u narativ o pokretu mladih. Radić dakle ponovno koristi istu taktiku te implicitno optužuje krug oko Glasa da se odnarodio, pokušavajući prisvojiti tradiciju pokreta za svog brata i sebe. Ovaj se moment, međutim, nije zadržao u kasnijim narativima o pokretu te je ostao ograničen na razdoblje napetih odnosa između braće Radić i ostatka pokreta mladih te je njime uvelike kontekstualno uvjetovan. ${ }^{1135}$

Ujedinjavanje aktera pokreta koji su ranije djelovali u različitim grupacijama mladih oko zagrebačke Hrvatske misli poslužilo je kao fokalna točka za kasniju izgradnju svojevrsna teleološkog narativa o razvoju pokreta mladih. Na samome kraju prvog godišta Hrvatske misli po prvi je puta predstavljen nacrt povijesti pokreta koja započinje demonstracijom 1895. godine, prolazi kroz faze heterogenih strujanja raznih grupacija koje se potom ujedinjuju i čije se misli kristaliziraju u programu napredne omladine u brošuri Poraz i slavlje te u Hrvatskoj misli. ${ }^{1136}$ Drugi važan element narativa o pokretu koji ovdje nastaje jest njegovo pozicioniranje u liniji kontinuiteta hrvatskog nacionalnog pokreta. Kritika koju su „djeca“ upućivala „ocima“ bila je interna, a njihov pokret dio je šireg procesa razvoja hrvatske nacije i nacionalnog pokreta. Zbog toga je bilo važno već na samome početku naglasiti kako pokret mladih u svojoj srži nije rezultat stranih utjecaja i aproprijacija, nego je on „logičan rezultat razvoja našeg narodnog života“. ${ }^{1137}$ Već iz same ove formulacije jasan je snažan naglasak na organskoj naravi pokreta mladih koji izrasta iz domaćih prilika, na koje odgovara kao svojevrsni unutarnji korektiv razvoja hrvatske kulture i politike.

Sve ove elemente koji su u svojim osnovnim oblicima prisutni već u Hrvatskoj misli 1902. godine detaljno je razradio Milan Marjanović u nizu svojih publikacija objavljenih nakon 1903. godine. U prvom dijelu knjižice Hrvatski pokret: opažanja i misli na pragu novoga narodnoga preporoda g. 1903. objavljene na jesen 1903. godine on razvija skicu

\footnotetext{
1135 Ova je analiza nastala na temelju prikaza teksta Ljerke Racko, koja je i prevela njegove dijelove. Racko, „Pokret hrvatske moderne“, 1-3. Za cjeloviti tekst na češkom vidi: Krtalić, Nekrolog hrvatskoj modernoj, 262271.

1136 „Jedna godina dana“, Hrvatska misao (1902), I, 23-24, 720-723.

1137 „Naš pokret“, Isto, 66.
} 
hrvatske političke povijesti u 19. stoljeću u okviru koje jasno pozicionira i pokret mladih. Devedesete godine 19. stoljeća, u kojima se razvija i javlja pokret, označene su kao „doba obrata“" nakon duge i teške krize u hrvatskom javnom i političkom životu. Kako bi se kriza riješila „,trebalo je dakle naš život produbiti, demokratizovati, spustiti mu korijenje megju puk, megju seljaštvo, koje sačinjava u Banovini gotovo $88 \%$ pučanstva, ili je trebalo svu onu političku tradiciju, sav onaj talog uništiti, ili napokon otvoriti naš narodni život neprestanoj fluktuaciji sviju modernih ideja, otvoriti sve brane, kao što učiniše to Danci i ostali narodi Skandinavije.“1138 To je dakako bio povijesni zadatak i uloga mladih. Marjanović direktno povezuje 1895. i 1903. godinu. ${ }^{1139} \mathrm{U}$ tom razdoblju, plamen koji je omladina zapalila razbuktao se i zahvatio sve slojeve hrvatskog naroda, vodeći naposljetku do narodnog pokreta 1903.

Između te dvije prijelomnice djeluju tri osnovne skupine mladih - praška, bečka i novonadaška - koje su se međusobno nadopunjavale i koje su predstavljale tri tipa mogućeg rješenja krize opisana ranije: praška skupina demokratizam i približavanje narodu, bečka skupina fluktuaciju svjetskih ideja, a novonadaška konfrontaciju s talogom političke i intelektualne tradicije. Njihova prevelika jednostranost, nedovoljna zrelost i rascjepkanost sputavala ih je u radu te ih je - uz žestoku polemiku sa starima - iscrpila i oslabila. Uvidjevši to, „bolji elementi“ iz svih grupa odlučili su se stoga ujediniti oko pozitivnog programa, što se dogodilo sa zagrebačkom Hrvatskom misli: „Tad se baciše poglavito na društveni i politički rad i postaše važnim faktorom u narodnom životu.“" ${ }^{\text {"1140 }}$ Pred dilemom između riskantnog revolucionarnog nasrtaja na sve staro i kompromisnog evolucionističkog i reformističkog pristupa, oni su izabrali potonji: „Danas reprezentira ova omladina ove misli: nacijonalizam na demokratskoj, pučkoj bazi, naprednost u smjeru i mišljenju, koncentracija sve narodne snage u svrhu narodne obrane, $\mathrm{u}$ istu svrhu oslon na misao Slavensku i složna obrana sa Srbima, ozdravljenje našega društva, politika realna i socijalna, organizacija i ojačanje gospodarsko te popularizavanje prosvjete.“1141 Kao „prelazna generacija“ koja je iznikla iz „opće narodne krize“, mladi možda neće uspjeti provesti, odnosno dovršiti narodni preporod, ali njihova je misija da stvore uvjete i temelje za izvršenje ovoga povijesnog zadatka, odnosno

\footnotetext{
${ }^{1138}$ Marjanović, Hrvatski pokret I, 109.

1139 Još maštovitije, s brojnim paralelama i analogijama to čini u drugom dijelu Hrvatskog pokreta iz proljeća 1904. godine. Vidi: Marjanović, Hrvatski pokret II, 10-11.

${ }^{1140}$ Marjanović, Hrvatski pokret I, 112.

${ }^{1141}$ Isto.
} 
za dovršenje ,procesa stvaranja modernoga hrvatskoga naroda na novom širokom demokratskom osnovu. “1142

Par godina kasnije, Marjanović je nastavio razvijati svoj historijski narativ o pokretu mladih. Dok je u Hrvatskom pokretu njegov fokus društveno-politički, u knjizi Iza Šenoe: četvrt vijeka hrvatske književnosti on se bavi problematikom kulture, napose književnosti, s posebnim fokusom na ulogu pokreta mladih u njezinu razvoju. Osnovna struktura narativa je zapravo ista: i hrvatsku kulturu u ovome razdoblju karakterizira stanje krize koje se najviše manifestira izolacijom i zaostajanjem za širim europskim kretanjima. Stoga se devedesete godine 19. stoljeća kao „doba obrata“ u kojem nastupaju mladi pojavljuju kao „put k savremenosti“: „Bilo kako bilo, mi smo bili počeli da pristupamo k stolu europske savremene kulture. I ako smo došli tek na poslastice — ipak smo došli. Bili smo počeli dostizavati ostale. Išli smo sa valom a ne proti njemu. “1143 Priča o pokretu mladih je uklopljena u mnogo širi narativ o europeizaciji hrvatske kulture. I ovdje se, međutim, uspostavlja linija kontinuiteta s ranijom tradicijom, napose s ilirskim pokretom. Pokret mladih tako se i na području kulture pozicionira kao prirodni proizvod krize, odgovor nacionalnog organizma na stanje u kojem se našao. Marjanovićeva je perspektiva 1906. godine doduše nešto manje optimistična nego par godina ranije. Potencijalne konstruktivne, sintetičke aproprijacije koje bi proizvele istinski originalnu književnost bile su osujećene neravnomjernim razvojem i uplitanjem izvanumjetničkih tendencija starih koji su nastupali iz sebičnih i političkih razloga. Rezultat je klonuće modernističkog pokreta u kulturi uslijed umora od besplodne borbe koja se vodila s nejasnim pojmovima i na krivim temeljima. Međutim, iako je za Marjanovića bilanca ovdje nešto negativnija nego na području politike, on i dalje mladima pridaje istu povijesnu ulogu i misiju, a to je stvaranje uvjeta za budući kvalitetni rad. Oni su se više borili za slobodu stvaranja nego uistinu stvarali, više su bili ogorčeni na domaće prilike nego zainteresirani za ideal nove umjetnosti, zadovoljavali su se intimnijim krugom čitatelja, a ne širokom javnosti. Usprkos tome, priširio se idejni vidokrug domaće književnosti te je njezina opća naobrazba postala produbljenija. Hrvatska je kultura postala modernija i europskija te se uspostavio življi kontakt sa stranim svijetom, što je stvorilo povoljan teren za razvoj nove umjetnosti. ${ }^{1144}$

Ako usporedimo ključne elemente Marjanovićeva narativa s pristupom radova o kojima je bilo riječi u uvodnom pregledu dosadašnjih istraživanja o pokretu mladih, lako ćemo uvidjeti da je njegov utjecaj na formiranje osnovnih kontura samoga fenomena bio od

\footnotetext{
1142 Isto, 114.

1143 Milan Marjanović, Iza Šenoe: četvrt vijeka hrvatske književnosti, Zadar, 1906, 105.

${ }^{1144}$ Isto, 193-194.
} 
presudne važnosti: od kronoloških odrednica, preko identificiranja skupina koje su sačinjavale pokret i njihovih karakterizacija, pa sve do povijesne uloge pokreta (demokratizacija nacionalne politike i europeizacija nacionalne kulture). Upravo nam je zbog toga za konačnu ocjenu i interpretaciju cjeline pokreta bilo važno osvijestiti dimenziju autoidentifikacije i autoprezentacije aktera pokreta kao karakteristiku završne faze njegova djelovanja u kojem se iz akutnog fenomena sve više pretvara u simbol i predmet borbe za hegemonijsku interpretaciju i ocjenu.

\section{4. Pokret mladih u transnacionalnoj i dijakronijskoj perspektivi}

Europski fin de siècle razdoblje je dinamična intelektualnog i kulturnog života. On je u velikoj mjeri potaknut intenzivnim društvenim promjenama, koje zahvaćaju sve segmente života i slojeve stanovništva. Intelektualni život reflektira odnos različitih aktera prema tim društvenim promjenama. S obzirom na to da je taj odnos mogao varirati od utopijskih projekcija novog čovjeka i svijetle budućnosti do apokaliptičnih vizija skorog kraja svijeta ili civilizacije, intelektualni i kulturni život na prijelomu stoljeća karakterizira iznimna eklektičnost i ambivalentnost. To je na neki način sadržano u samom nazivu fin de siècle, koji ovisno o perspektivi može označavati pozitivan ili negativan odnos spram završetka jednog doba. Nije stoga čudno da je jedno od ključnih obilježja intelektualnog i kulturnog života na prijelomu stoljeća debata i polemika, iz kojih su proizašli brojni pristupi i smjerovi suočavanja s transformacijama društvene zbilje. ${ }^{1145}$

Hrvatski fin de siècle pokazuje brojne karakteristike koje su podudarne sa širim europskim kretanjima, ali i specifičnosti koje proizlaze iz lokalnog političkog, društvenog, intelektualnog i kulturnog konteksta. Njega je u velikoj mjeri obilježio upravo modernistički pokret mladih. Iako ne isključivi, on se u svakom slučaju može smatrati glavnim mehanizmom transfera i aproprijacija europskih intelektualnih strujanja. Zbog toga nije čudno da se u njegovu okviru javljaju slične eklektične i ambivalentne tendencije, koje su obilježile i europski intelektualni život na prijelomu stoljeća. Međutim, akteri su modernističkog pokreta mladih svjesni da intenzitet promjena u hrvatskom društvu nije na istoj razini kao u europskoj jezgri. Svijest o divergenciji modernizacijskih procesa ponovno se manifestirala kao refleksija

\footnotetext{
1145 Marshall (ur.), The Cambridge Companion, 1-5.
} 
o zaostajanju za europskim uzorima. ${ }^{1146}$ Iako se, dakle, gotovo sve teme europskog fin de sièclea javljaju i u hrvatskom kulturnom i intelektualnom životu, neke se od njih pojavljuju na margini, na način imitacija stranih uzora i bez pretjerana odjeka, a neke zauzimaju središnje mjesto u raspravama kao pitanja koja se dotiču ključnih točaka razvoja hrvatskog društva i kulture. Tako su, primjerice, teme moderne psihologije, dekadentizma i esteticizma, seksualnog identiteta, socijalizma i anarhizma, koje su zauzimale jedno od središnjih mjesta u širim europskim raspravama, u hrvatskom slučaju tek otvorene sporadičnim tekstovima, bez značajnije šire recepcije. S druge strane, u hrvatskom su kontekstu primat zadobile teme aproprijacija moderne masovne politike u sklopu građanske nacionalne politike, društvene, političke i nacionalne uloge književnosti, reforme nacionalne kulture i kulturnih institucija, stvaranja nove nacionalne inteligencije itd. Pa ipak, i protivnici i zagovornici modernizma posezali su za širim, europskim rezervoarom ideja kako bi ih iskoristili u svojim lokalnim sukobima i polemikama. Tako su hrvatski protivnici modernizma sudjelovali u općim mjestima europskog antimodernizma, kao što je zgražanje nad nemoralom naturalizma, optužbi o stranom uvoženju modernističkih strujanja nasuprot autohtonim umjetničkim tradicijama i kvarenju mladeži, napose one ženske, neprimjerenim prikazima seksualnosti. ${ }^{1147}$ Dakako, ovi su transnacionalni fenomeni dobivali nacionalni okvir. Strano je uvoženje modernističih ideja tako postalo otrov njemačkih imperijalističkih agenata koji žele zatrovati hrvatsku kulturu i mladež, a europska građanska idealistička sinteza romantizma i realizma i umjetnički akademizam pretvoreni su u navodno autohton izraz hrvatske narodne kulture (šenoinski kulturni program).

Iako je jedna od ključnih ideja modernista bila odlazak na europski izvor suvremenih ideja, aproprijacije pokreta mladih nisu mogle zaobići ukorijenjena srednjoeuropska posredovanja. Kao središnji referentni okvir pokreta stoga se nameće onaj austrijski i češki, preciznije Beč i Prag. Odnos mladih prema Beču kao mjestu posredovanja kulturnih i intelektualnih kretanja izrazito je ambivalentan, i u tome ne odstupa od tradicionalnog razumijevanja tog odnosa koji je obilježio hrvatsku povijest 19. stoljeća. Beč je kao središte Monarhije uvijek figurirao i kao model i kao prijetnja. Tijekom 19. stoljeća situacija se dodatno komplicira razvojem nacionalnih pokreta, koji tradicionalnoj napetosti između monarhističkog centralizma i staleškog otpora dodaju dimenziju međunacionalnih odnosa. Odnos prema Beču počinje tako karakterizirati konflacija imperijalnog i nacionalnog, koja

1146 Usp. Diana Mishkova, Roumen Daskalov, „'Forms Without Substance': Debates on the Transfer of Western Models to the Balkans“, u: Daskalov, Mishkova (ur.), Entangled Histories of the Balkans, Volume Two: Transfers of Political Ideologies and Institutions, Leiden i Boston, 2014, 1-97.

${ }^{1147}$ Usp. Marshall, nav. dj., 171-176. 
postaje sve izraženija krajem stoljeća. ${ }^{148}$ On se ponekad javlja kao odnarođeni, kozmopolitski grad, suprotstavljen duhu nacionalnosti uopće (a slavenskih napose), ponekad pak kao središte njemačkog imperijalističkog prodora na jugoistok. I hrvatski modernisti i antimodernisti prema Beču se odnose na izrazito ambivalentan način. I za mlade i za stare on je mjesto koje treba izbjegavati: mladima predstavlja prijetnju odnarođenja za novu, mladu nacionalnu inteligenciju, a starima pak njegova modernistička strujanja prikrivaju njemački nacionalni projekt. S druge strane, i za jedne i za druge Beč je bio važno formativno mjesto, centar sveučilišnog obrazovanja i intelektualnih posredovanja. U tom smislu, modernistički zahtjev za mimoilaženjem Beča kao tradicionalnog mjesta posredovanja ne treba uzeti zdravo za gotovo. Kao što smo mogli vidjeti, bečka je moderna jedno od ključnih izvora aproprijacija za hrvatski modernistički pokret. Uz već spomenute aproprijacije H. Bahra, bečke secesije (Ver sacrum), kulture kavana, filozofije E. Macha, ali i socijaldemokratskih kretanja, možemo dodati i nastojanje M. Dežmana da u hrvatsku književnost uvede „,crtičarsku“ umjetnost po uzoru na Petera Altenberga i ključnu posredničku ulogu bečkog kazališta u cirkulaciji dramskih tekstova. ${ }^{1149}$ Kako ističe Viktor Žmegač, za razliku od europskih intelektualnih centara, napose Pariza, koji su u imaginariju hrvatske moderne funkcionirali kao prostori čežnje, Beč je i dalje bio prostor neposrednog iskustva. ${ }^{150}$

Od samoga početka, mladi ističu Prag kao ključno mjesto aproprijacija suvremenih političkih i kulturnih kretanja. Razlog je prvenstveno političke prirode. Položaj Čeha u okviru Monarhije smatrali su analognim hrvatskoj situaciji, pa su u političkim i kulturnim kretanjima u češkim zemljama vidjeli recept za primjenu u domaćim okolnostima. Zbog toga treba biti oprezan s odvajanjem političkih aproprijacija iz Praga i kulturno-umjetničkih iz Beča. Iako je praška skupina mladih doista svjesno pokušavala ignorirati Beč, pa čak i derogirati njegovu ulogu u hrvatskom kulturnom i intelektualnom životu, bečka skupina pokreta u svojim se aproprijacijama nije ograničavala na Beč. Za hrvatski modernistički pokret na polju kulture

\footnotetext{
1148 O posredničkoj ulozi Beča i odnosu prema kulturi na njemačkom jeziku vidi: Daniel Barić, Proziran $i$ prezren: njemački jezik u hrvatskom društvu u prvoj polovici 19. stoljeća, Zagreb, 2015; Marijan Bobinac, „Nostalgische Rückblicke, von Unbehangen begleitet: Reflexionen kroatischer Intellektueller zur Lage der deutschen Sprache und Kultur in Kroatien um 1900“, u: Bobinac, Wolfgang Müller-Funk, Jelena Spreicer (ur.), Mehrsprachigkeit in Imperien/Multilingualism in Empires, Zagreb, 2019, 145-162; Kristian Novak, Višejezičnost i kolektivni identiteti iliraca: jezične biografije Dragojle Jarnević, Ljudevita Gaja i Ivana Kukuljevića Sakcinskoga, Zagreb, 2012; Mario Strecha, „O pitanju utjecaja bečkog središta na kulturni identitet Zagreba u 19. stoljeću“", Radovi Zavoda za hrvatsku povijest, 26, 1993, 79-88.

1149 Žmegač, Bečka moderna, 169; Boris Senker, „Razmjena dramskih tekstova između bečkoga i zagrebačkoga književnog kruga na mijeni stoljeća“, u: Barbarić (ur.), Fin de siècle, 153-154.

${ }_{1150}$ Viktor Žmegač, „Europski kontekst hrvatske moderne“, u: Josip Bratulić, Josip Vončina, Antun Dubravko Jelčić, Hrvatska i Europa: kultura, znanost i umjetnost, sv. 4, Zagreb, 2009, 411.
} 
Prag je igrao barem jednako važnu ulogu. ${ }^{1151}$ Kao što smo mogli vidjeti iz ranije analize, manifest češke moderne bio je jedno od ključnih vrela za pokret mladih i na polju politike i na polju književnosti. Osim toga, bečka se Mladost može jednako tako komparirati s praškom Moderní revue, kao što se intuitivno prvo povezuje s bečkim Ver sacrum. Potpisnici manifesta češke moderne nisu bili homogena skupina te kasnije idu svojim putem, nerijetko ulazeći u međusobne polemike. ${ }^{1152}$ Njih razlikuje odnos prema društvu i stvarnosti, pa se tako Šaldin sintetizam sukobljava s dekadentizmom, koji je u češkoj književnosti bio mnogo snažniji nego u hrvatskoj. ${ }^{1153}$ Ipak, ključno pitanje češke književnosti u ovome razdoblju ujedno je i temeljno pitanje koje si postavljaju mladi: može li se na malom nacionalnom jeziku stvarati svjetska književnost? Ovo je pitanje dakako mnogo pripadnije češkom i hrvatskom, nego bečkom kulturnom i intelektualnom kontekstu.

Najizravnije su aproprijacije svakako bile usmjerene prema češkom političkom životu. Neuspjesi i deradikalizacija mladočeške stranke, kao i usložnjavanje društvene i političke strukture, doveli su do krize koncepta nacionalne stranke (ili pokreta) kao jedinstvena predstavnika nacije. ${ }^{1154} \mathrm{U}$ tome je važnu ulogu imao razvoj socijaldemokracije, koja je marginalizirala nacionalno pitanje, ali i radikalna kritika predvođena Masarykom, oko kojega se počela okupljati naprednjačka češka omladina. Hrvatski mladi nisu samo crpili od Masaryka kao vanjski promatrači, oni su se zapravo smatrali masarykovcima u punom smislu te riječi. On je pripadao krugu moralističkih mislioca koji su uzrok dekadencije suvremenog društva vidjeli u dominaciji modernog materijalizma (posebice u Češkom pitanju iz 1894. godine). U središtu se njegova mišljenja tako našao pojedinac, koji je kroz obrazovanje i introspekciju trebao pronaći svoj istinski identitet. ${ }^{1155}$ On je pak usko povezan s idejom nacije, koja je kod Masaryka esencijalizirana i nastavlja romantičarsku koncepciju da svaki narod ima svoj autentični, nepromjenjivi identitet i povijesnu misiju. Moralni je preporod pojedinca stoga preduvjet za preporod nacije. Masaryk se pritom oslanjao na platonističku ideju da vladar treba biti filozof, odnosno, preneseno u suvremeni kontekst, da naciju treba voditi obrazovana elita. Ova je ideja postala fundamentalna za ideologiju mladih gotovo u svim aspektima njihova djelovanja, a primarno se očitovala kao temelj za ideju obrazovanja nove nacionalne inteligencije, pri čemu su dakako sebe vidjeli kao začetak te nove nacionalne elite.

\footnotetext{
${ }^{1151}$ Usp. primjerice studiju „Vladimir Jelovšek i praški mostovi hrvatske dekadencije“, u: Marijan Šabić, Hrvatsko-češke književne veze: XIX. i početak XX. stoljeća, Zagreb, 2013, 175-200.

${ }^{1152}$ Wittlich, Prague, 13. Za književna kretanja u Češkoj na prijelomu stoljeća v. Katica Ivanković, „U obranu dekadencije. Češka književna previranja na kraju 19. stoljeća“, Književna smotra 34, 2002, 3-11.

${ }^{1153}$ Wittlich, nav. dj., 16-17.

${ }^{1154}$ Isto, 11 .

${ }^{1155}$ Isto, 12.
} 
Osim toga, i druge su Masarykove ideje izravno inkorporirane u ideologiju mladih, kao što je odbacivanje revolucije i zagovaranje sitnoga rada na ekonomskom, prosvjetnom i kulturnom planu, zalaganje za otvaranje socijalnog pitanja (koje je za njega prije svega moralno, a ne materijalno), antiklerikalizam i otvaranje ženskog pitanja (ali i dalje tradicionalnim pristupom). ${ }^{156}$ Analogije su sa češkom situacijom, međutim, imale svoja ograničenja. Najvažnije se odnosilo na različitu ekonomsku strukturu hrvatskog i češkog društva. Dok je češko već bilo izrazito industrijalizirano, u Hrvatskoj su ti procesi tek započinjali, pa je ekonomska struktura bila dominantno agrarna. Socijalno se pitanje stoga u hrvatskom kontekstu nije moglo artikulirati kao primarno radničko, nego kao seljačko pitanje, što je sa sobom povlačilo i sasvim drugačiju narav razumijevanja potreba razvoja nove nacionalne elite i njezina odnosa prema nacionalnoj društvenoj bazi. Ova se napetost jasno manifestirala u okviru same praške skupine mladih, da bi se naposljetku pretvorila u glavnu točku razlaza između Radića i njemu bliskih članova pokreta, koji su smatrali da samo seljačka stranka može adekvatno odgovoriti na potrebe rješavanja nacionalnih političkih pitanja, i ostatka naprednjaka koji su se pak zalagali za građansko-demokratsku opciju mnogo bližu češkim uzorima.

S obzirom na to da su smatrali da je položaj Čeha u austrijskom dijelu Monarhije bio analogan položaju Banske Hrvatske u ugarskom dijelu, iznenađujuće je da je situacija u (užoj) Ugarskoj ostala na samoj margini interesa mladih. I Ugarska je, napose, Budimpešta, itekako sudjelovala u modernističkim kretanjima na prijelazu 19. i 20. stoljeća. Iako je oko 1900. godine, za razliku od Zagreba, Budimpešta već bila europski velegrad s razvijenom srednjom i radničkom klasom, određeni aspekti njezina razvoja analogni su procesima koji se odvijaju u Zagrebu. Prije svega, ubrzano širenje grada očitovalo se u supostojanju provincijalizma i kozmopolitizma, koji su se manifestirali s jedne strane u nacionalizaciji grada, a s druge u uklapanju nacionalne kulture u šire europske tokove. ${ }^{1157}$ Modernistički pokret imao je u tome važnu ulogu, baš kao i u hrvatskom slučaju. Opadanje moći zemiljšnog plemstva i diverzifikacija društvene strukture značila je i krizu nacionalnog romantizma kao dominantne umjetničke paradigme te traženje novih puteva. ${ }^{158} \mathrm{U}$ drugim je pak segmentima situacija $\mathrm{u}$ Budimpešti bila mnogo sličnija onoj u Beču, nego u Zagrebu, primjerice u snažnu razvoju antiliberalnog nacionalizma, posebice među mladima, s izraženim antisemitskim tendencijama i paralelnom procvatu kulturnog i intelektualnog života, čiji su se akteri -

\footnotetext{
1156 Usp. H. Gordon Skilling, T. G. Masaryk: Against the Current, 1882-1914, London, 1994, 19-37.

1157 Lukacs, Budapest 1900, xiv.

1158 Péter Hanák (ur.), Povijest Mađarske, Zagreb, 1995, 174.
} 
uglavnom iz građanskih, nerijetko židovskih krugova - povukli iz političkog života, što bi odgovaralo Schorskeovoj paradigmi. ${ }^{159}$ Pa ipak, ta je „generacija 1900.“, kako ju naziva Lukacs, mogla itekako poslužiti kao izvor inspiracija za hrvatski modernistički pokret jer je u svojoj heterogenosti iskazivala šarolike interese koji su se poklapali s onima mladih u Hrvatskoj. Iako je znatan dio te generacije gajio urbanu, kozmopolitsku kulturu (primjerice dramski pisac Ferenc Molnár), neki su od njih posezali za pučkom kulturom kao vrelom za modernu kulturu (Béla Bartók) ili su pronalazili originalne nove načine kako pisati o lokalnoj situaciji, bez imitiacija stranih uzora (Gyula Krúdy). ${ }^{1160}$ Jedan od najvažnijih projekata te generacije bio je modernistički časopis Nyugat (Zapad), čiji je idejni pokretač bio pjesnik Endre Ady. Oko njega se okupljala radikalna demokratska inteligencija, a sam je Ady bio važan za formuliranje novih nacionalnih ideja tog reformističkog naraštaja. ${ }^{1161}$ Sva su ova kretanja ostala gotovo u potpunosti izvan vidokruga modernističkog pokreta mladih. Kao što smo mogli vidjeti, jedina iznimka bio je krug oko Mladosti, koji je bio otvoren za modernistička strujanja u mađarskoj književnosti. Razlog je tog ignoriranja dvojak. S jedne strane on je zasigurno političke naravi. Khuenova vlada u Hrvatskoj iz vizure je mladih bila produžena ruka mađarske opresivne vlasti nad svim nemađarskim narodima u ugarskom dijelu Monarhije. Usprkos pokušajima da diferenciraju između službene ugarske politike i mađarskog naroda u cjelini, politički se resantiman manifestirao u svjesnu ignoriranju, pa i omalovažavanju mađarskih kulturnih i političkih kretanja. S druge strane, ne treba isključiti niti čimbenik različita formativnog okruženja mladih, s čime je zasigurno povezano i slabije poznavanje mađarskog jezika. Niti jedan pripadnik pokreta mladih nije se obrazovao u Budimpešti, pa tamošnja intelektualna i kulturna strujanja nisu mogli iskusiti iz prve ruke, za razliku od Praga i Beča. Neovisno o tome, međutim, odnos prema mađarskoj kulturi dosta otkriva o političkim stavovima mladih, napose kada je riječ o odnosu socijalne i nacionalne komponentne, pri čemu se nacionalna jasno nadaje kao dominantna.

Za razumijevanje strukturnog položaja pokreta mladih u širem kontekstu najvažnija je usporedba sa slovenskim i srpskim slučajem jer je riječ o prostorima sličnog stupnja razvoja, međusobno isprepletenima i kulturno i politički, a opet s vlastitim osobitostima koje su utjecale na specifičnost intelektualnih kretanja. Intenzivne hrvatsko-slovenske kulturne veze, koje postoje još od razdoblja ilirskog pokreta, nastavljene su i u okviru pokreta mladih. Kao što smo mogli vidjeti, udio je slovenskih aktera u hrvatskom modernističkom pokretu znatan,

\footnotetext{
${ }^{1159}$ Usp. Lukacs, nav. dj., 131-136.

${ }^{1160}$ Isto, 138-139.

${ }^{1161}$ Hanak, nav. dj., 194-195.
} 
a hrvatski su akteri pokreta s druge strane pisali za slovenske listove i revije. Ova suradnja nije samo rezultat dugotrajnih kulturnih i političkih veza, nego i slične strukturne pozicije, koja se manifestirala u preokupacijama zajedničkim temama. Slovenski su pisci moderne također bili suprotstavljeni tradicionalizmu, nastojeći prevladati tekovine razdoblja romantizma i realizma i zagovarajući individualizam i slobodu stvaranja. ${ }^{1162} \mathrm{U}$ političkom smislu, sukob se odvijao na relaciji između klerikalizma i liberalizma, u pozadini čega je bila borba između tradicionalne svećeničke elite i svjetovne inteligencije oko primata u vođenju nacionalne politike. ${ }^{1163}$ Modernistički slovenski autori, primjerice Ivan Cankar, Dragotin Kette i Josip Murn, baš kao i hrvatski traže načine da aproprijacije suvremenih literarnih strujanja uklope u lokalni kulturni kontekst s ciljem stvaranja originalne moderne nacionalne književnosti. ${ }^{1164}$ Politički se oni - napose Cankar, zatim Oton Župančič i Etbin Kristan odvajaju od klasičnog građanskog liberalizma i ulaze u sukob s predstavnicima te tradicije, koju je u književnosti utjelovljivao Anton Aškerc. Pokušaj modernizacije građanske liberalne tradicije predvode slovenski masarykovci, koji se zalažu za snažniju integraciju socijalne i kulturne dimenzije u političko djelovanje. Oni, međutim, nisu uspjeli prodrijeti do vrhova liberalne stranke. Specifična je posljedica toga razvoja da su slovenski masarykovci stoga prišli socijaldemokratskoj stranci u nadi da će se kroz nju moći provesti modernizacija slovenskog političkog života. ${ }^{1165}$ Međusobna suradnja, zajednička formativna iskustva i intelektualno-kulturni kontekst smještaju tako pokret mladih i slovensku modernu, uz određene specifičnosti, u okvir isprepletenih povijesnih fenomena. I jedni i drugi djeluju u okviru Habsburške Monarhije, upućeni su na Prag i Beč kao obrazovne i intelektualne centre te su povezani dugogodišnjom tradicijom političke i kulturne suradnje. Ono što se, međutim, može primijetiti jest da su u slučaju slovenske moderne aproprijacije modernističkih fin de siècle strujanja mnogo jasnije i odlučnije nego u slučaju hrvatskog modernističkog pokreta. ${ }^{166} \mathrm{U}$ izostanku političke autonomije, u austrijskom političkom kontekstu koji je ipak različit od onog ugarskog, integracija se slovenske nacije snažno vezala uz polje kulture, napose književnosti. Zato se i modernizam na prijelomu 19. i 20. stoljeća u slovenskom slučaju najjasnije i najsnažnije manifestirao na polju kulture, dakako s političkim

\footnotetext{
${ }^{1162} \mathrm{Na}$ jesen 1896. godine mladi su slovenski književnici - Fran Govekar, Ivan Cankar, Oton Župančič, Fran Eller, Fran Vidic, Anton Majaron, Ferdo Jančar, Fran Goestl i Ivan Škrjanec - u Beču osnovali svoj literarni klub pod nazivom Slovenska moderna. Ovaj se naziv stoga u slovenskoj literaturi od samoga početka učvrstio kao oznaka za modernistički pokret i razdoblje oko 1900. godine. France Bernik, „Pojem 'moderna' v slovenski literarni vedi“, Primerjalna književnost 14, 1, 1991, 16.

1163 Janko Kos, Duhovna povijest Slovenaca, Zagreb, 2004, 121.

${ }^{1164}$ Danijela Marot, „Hrvatsko-slovenske književne veze u doba moderne“, Fluminensia 18, 1, 2006, 113-114.

${ }^{1165} \mathrm{Kos}$, nav. dj., 123.

${ }^{1166}$ Isto, 125-135.
} 
implikacijama. S druge strane, u hrvatskom je slučaju politička dimenzija pokreta mladih bila dominatna te je obilježila i njegov početak i završetak, dominirajući također logikom aproprijacija i sukoba na polju kulture.

Srpski pak slučaj nudi drugačiju sliku. Za razliku od istraživanja hrvatske i slovenske moderne, ona u Srbiji obilježena su kulturno-književnom perspektivom. Pojmovi koji se koriste ponajprije su stilski impostirani. Najčešće se tako susreće odrednica simbolizma, a ujedno se preferira pojam modernizma nad onim moderne. Razlog je taj što se moderna kao pojam ponajviše veže uz srednjoeuropski kulturni krug, dok su modernistička kretanja u Srbiji na prijelomu stoljeća pod snažnim utjecajem aproprijacija francuskih strujanja. ${ }^{1167}$ Politička je dimenzija modernizma u Srbiji na prijelomu 19. i 20. stoljeća tako u sjeni književno-kulturne. Razdoblje se od 1892. do 1918. godine u povijesti srpske književnosti često naziva „zlatnim dobom“, vrhuncem razvoja moderne srpske književnosti. ${ }^{1168}$ Vrhunac se modernističkih tendencija u Srbiji, međutim, smješta u drugi dio ovog razdoblja te se u historiografiji povezuje s dolaskom na vlast dinastije Karađorđevića i promjenom politike koja je uslijedila. ${ }^{1169}$ Najvažnijim časopisom ovog razdoblja smatra se Srpski književni glasnik, a najutjecajniji su modernistički kritičari Bogdan Popović i Jovan Skerlić. Političko usmjerenje prema Zapadu oslabilo je posredničku ulogu Rusije i Habsburške Monarhije, a povoljne unutrašnjo-političke prilike dovele su do toga da modernističke aproprijacije nisu uzrokovale generacijski sukob kao u slovenskom i hrvatskom slučaju. U ovome se razdoblju u Srbiji tek stvaraju moderne kulturne i umjetničke institucije, kao i građanska kultura općenito, tako da mlada generacija nije morala napadati etablirane položaje starije generacije, kao što je to bio slučaj u Hrvatskoj. Kao što smo mogli vidjeti, veze između hrvatskog modernističkog pokreta i srpskih modernista bile su iznimno slabe. U okviru pokreta mladih sudjeluju hrvatski Srbi, napose kao dio Ujedinjene hrvatske $i$ srpske akademske omladine, kao i neki srpski studenti u Pragu i Beču. Te su veze, dakle, bile snažno uvjetovane zajedničkim političkim kontekstom. Veze prema Srbiji uglavnom su postojale preko srpskih članova pokreta te su bile primarno političke naravi, primjerice radikalsko financiranje projekta Narodne misli ili podrška beogradske omladine naporima zagrebačke Ujedinjene omladine. Srpski je udio u pokretu mladih tako uglavnom ograničen na doprinos srpske omladine u Hrvatskoj, i to napose na polju politike, s ograničenim modernističkim aproprijacijama na polju kulture.

1167 Aleksandar Flaker, „Proučavanje početaka moderne u hrvatskoj, srpskoj i slovenskoj književnosti (19701989)“, Wiener Slavistisches Jahrbuch 39, 1993, 9-10.

1168 Predrag Palavestra, Istorija moderne srpske književnosti: zlatno doba, 1892-1918, Beograd, 2013, 5-16.

${ }^{1169}$ Isto, 18. 
Zanimljivo je stoga promotriti strukturni položaj modernističkog pokreta mladih u južnoslavenskom kontekstu, točnije u usporedbi sa slovenskim i srpskim slučajevima. U hrvatskom je slučaju politička dimenzija mnogo izraženija te se snažnije očituje i na polju kulture, napose u sukobu starih i mladih. Mogli bismo reći da su u slučaju slovenske moderne i srpskog modernizma aproprijacije suvremenih književno-kulturnih kretanja mnogo izravnije te se jasnije uklapaju u tipološke okvire europskog fin de siècle modernizma. Razlog predominacije političkog u okviru hrvatskog modernističkog pokreta leži u specifičnom kolopletu političkog i kulturno-intelektualnog konteksta, koji spaja ugarski politički okvir s praško-bečkim intelektualno-kulturnim aproprijacijama, lokalne političke i kulturne tradicije s pokušajima implementacije suvremenih kretanja masovne politike i modernističke kulture, što je rezultiralo originalnim translacijama koje su očitovale heterogenost, eklektičnost, pa ponekad čak i nekoherentnost. Fluidni i izrazito pluralni karakter hrvatskog modernističkog pokreta omogućio mu je stoga da u jugoslavenskom kontekstu pokuša zauzeti središnju i posredničku ulogu okupljanja nove, modernističke, ali jugoslavenski orijentirane mlade generacije.

Dijakronijska perspektiva otkriva koliko je pokret mladih u toj ulozi bio uspješan, te ujedno osnažuje početnu tezu o pokretu kao sredstvu smjene generacija u okviru hrvatske građanske elite. ${ }^{1170}$ Ako pogledamo kasniju karijeru glavnih predstavnika praške skupine mladih, možemo utvrditi da je znatan dio obnašao važne političke i gospodarske funkcije. Uz dakako najpoznatijega Stjepana Radića, o kojemu ne treba previše govoriti, više ili manje uspješne političke karijere ostvarili su Živan Bertić, Milan Heimrl, Svetimir Korporić i Franjo Poljak. U razdoblju prije Prvog svjetskog rata svi su, uz manje fluktuacije i uz iznimku Radića, koji već 1904. godine s bratom osniva Hrvatsku pučku seljačku stranku, pripadali naprednjačkoj stranci i Hrvatsko-srpskoj koaliciji, ali se kasnije njihove političke putanje pod utjecajem novih okolnosti razilaze. Živan Bertić (1875-1938) bio je član Središnjeg odbora Narodnog vijeća SHS i Privremenog narodnog predstavništva 1919.-1920. godine, nakon čega se povlači iz političkog života. U zadnjem je periodu političkog djelovanja bio blizak Hrvatskoj zajednici. Milan Heimrl (1877-1917) se povukao iz politike već oko 1910. godine, nakon niza neuspješnih pokušaja ulaska u Hrvatski sabor. Prije toga je bio član Izvršnog odbora Hrvatske stranke prava, urednik Obzora i glavni urednik Pokreta, glasila naprednjačke stranke. Iako je bio jedan od osnivača HPSS, Svetimir Korporić (1875-1921) također se vrlo brzo razišao s Radićem te se vratio u okrilje naprednjaka. Njegova je karijera uglavnom

\footnotetext{
${ }^{1170}$ Kratka biografska analiza koja slijedi uglavnom se temelji na podacima iz Hrvatskog biografskog leksikona.
} 
vezana uz gospodarske institucije. Osim što je bio prvi ravnatelj Hrvatske poljodjelske banke od 1901. do 1904. godine, kasnije je radio kao pravni savjetnik Gospodarskog društva u Zagrebu. Također je bio član Izvršnog odbora Hrvatske stranke prava, ali od otprilike 1907. pa do 1918. nije politički aktivan, da bi 1919. bio član izaslanstva SHS na Pariškoj mirovnoj konferenciji. Najuspješniju političku karijeru među pripadnicima praške skupine, uz Radića, imao je Franjo Poljak (1877-1939). Prije rata bio je na čelu Hrvatsko-slavonskog gospodarskog društva, organizator seljačkog zadrugarstva u Hrvatskoj, urednik Gospodarskog lista i Seoskog gospodara te zastupnik u Hrvatskom saboru. Nakon 1918. približava se Davidovićevoj Demokratskoj stranci te postaje ministar agrarne reforme u Kraljevstvu SHS u vladama Stojana Protića i Ljubomira Davidovića. Možemo dakle vidjeti da je, uz iznimku raskola s Radićem, politički put praške skupine prije raspada Monarhije bio poprilično jedinstven, da bi potom počeo divergirati s uspostavom jugoslavenske države. Iako su je kao jugoslavenski orijentirani političari i članovi Hrvatsko-srspke koalicije podržavali, oni su se u početnim godinama njezina postojanja ipak razišli po pitanju poželjna ustroja nove države. Neki su tako, poput Bertića, bili bliži federalizmu, dok je Poljak prišao centralističkoj Demokratskoj stranci.

Ostali članovi praške skupine mladih nisu imali tako bogate političke karijere, nego su bili vezaniji uz svoju primarnu struku, koja je gotovo svima bila pravo. Nikola Fugger (18771942) cijeli je radni vijek bio senator i viši gradski savjetnik u Zemunu, gdje se bavio upravnim pravom i općinskom samoupravom. Živan Bertić je također nakon povlačenja iz politike radio kao odvjetnik, baš kao i Heimrl. Dragan Šašel (1876-1918) je proveo životni vijek kao sudski službenik i školski nadzornik u Karlovcu, a poznat je i kao organizator borbe protiv alkoholizma i urednik glasila apstinenata Novi život. Najmanje je poznato o Milanu Šariću (1875-1913), autoru programatskog teksta praške skupine na polju književnosti, koji je 1901. objavio prijevod romana M. Gorskog Foma Gordjejev, da bi prerano preminuo od tuberkuloze 1913. godine. Živan Bertić, kao jedini književnik praške skupine, prestao je s književnim radom oko 1905. godine, ali je nastavio plodan publicistički rad. Praška je skupina tako očekivano dala uspješne političare i gospodarstvenike, ali ne i značajnije umjetnike i kulturne radnike.

Politika je dominirala životom i zagrebačke skupine mladih - Ujedinjene hrvatske $i$ srpske akademske omladine. Njezin je srpski dio uglavnom bio vezan uz Srpsku samostalnu stranku. Predvodnik je dakako bio Svetozar Pribićević, čija je politička karijera jednako poznata kao Radićeva. Jedan od njegovih najbližih suradnika još od studentskih dana bio je Jovan Banjanin (1874-1960), koji je kao član Hrvatsko-srpske koalicije iz redova samostalaca 
bio zastupnik u Hrvatskom saboru, a za vrijeme Prvog svjetskog rata djelovao je u sklopu Jugoslavenskog odbora u inozemstvu. Poslije rata bio je član Demokratske stranke, ali je ubrzo iz nje istupio te je nastavio djelovati kao nezavisni zastupnik u Privremenom narodnom predstavništvu. Banjaninova je politička karijera u prvoj jugoslavenskoj državi izrazito složena. Pripadao je skupini intelektualaca koja je zastupala jugoslavensku ideju (M. Marjanović, R. Giunio i dr.) te se okupljala oko novoga zagrebačkog lista Slobodna tribuna, 1922. godine pokušao je osnovati hrvatsko-srpsku građansku stranku (s J. Smodlakom, M. Kostrenčićem i dr.), a 1923. bio je član Nezavisne narodne organizacije, koja je 1924. pristupila Demokratskoj stranci Lj. Davidovića. U tridesetima je bio zagrebački gradski senator i zamjenik namjesnika, a u to je vrijeme član Jugoslavenske nacionalne stranke. Neposredno prije početka Drugog svjetskog rata bio je izabran u vladu generala Dušana Simovića te s njom odlazi u emigraciju, gdje je bio ministar u više emigrantskih vlada. Poslije rata ostaje u emigraciji. Danilo Dimović (1875-1951) je pak prije Prvog svjetskog rata bio vezan uz Bosnu i Hercegovinu, gdje je osnovao Srpsku narodnu stranku i bio potpredsjednik Bosanskog sabora, da bi nakon prestanka njegova rada bio zastupnik u Hrvatskom saboru ispred Hrvatsko-srpske koalicije. Politički je bio blizak Svetozaru Pribićeviću te je djelovao kao njegov pouzdanik. Nakon rata član je Narodne vlade BiH i Privremenoga narodnog predstavništva Kraljevine SHS u Beogradu. Bio je sudionik jedne od tadašnjih najvećih korupcijskih afera vezane uz primanje velikih novčanih iznosa pri skidanju sekvestra nad imanjima Thurn-Taxis. Kasnije se povlači iz političkog života i u Zagrebu živi i radi kao javni bilježnik.

Hrvatski je dio Ujedinjene omladine, baš kao i praška skupina, bio vezan uz naprednjake. Ivan Lorković (1876-1926) bio je urednik Pokreta i zastupnik u Hrvatskom saboru, prvak hrvatskog dijela Hrvatsko-srpske koalicije. U srpnju 1918. napušta Hrvatskosrpsku koaliciju te ulazi u Jugoslavensku demokratsku ligu. Bio je član plenuma i središnjeg odbora te jedan od tajnika predsjedništva Narodnog vijeća SHS. Godine 1919. bio je osnivač i predsjednik Hrvatske zajednice, a u Privremenom narodnom predstavništvu jedan je od potpredsjednika Narodnoga kluba. Politički se približava hrvatskoj opoziciji, napose Radiću te podupire ulazak Hrvatske zajednice u Hrvatski blok s HRSS i HSP. Na skupštinskim izborima 1925. izabran na listi HRSS, zatim je bio potpredsjednik Hrvatskoga seljačkoga kluba, ali je zbog sporazuma HRSS i radikala napustio Radića i osnovao Hrvatsku federalističku seljačku stranku kojoj je bio predsjednik do smrti. Lav Mazzura (1876-1930) je također prije rata bio zastupnik Hrvatsko-srpske koalicije u Hrvatskom saboru, a od 1919. radi kao državni ovdjetnik za grad Zagreb. Dušan Manđer (1870-1940) bio je jedini istaknutiji 
pripadnik zagrebačke skupine mladih koji se nije upustio u političku karijeru. Nakon što je završio studij fizike i kemije, razvio je bogatu prosvjetnu i kulturnu djelatnost u Splitu, gdje je osnovao i bio ravnatelj Gradske knjižnice i Državne ženske gimnazije.

Uzveši u obzir njihovu djelatnost za vrijeme trajanja pokreta mladih, ne čudi da su životni putevi pripadnika bečke skupine bili najdivergentniji. Milivoj Dežman (1873-1940) imao je bogatu liječničku, publicističku i političku karijeru. Kao liječnik bio je jedan od osnivača i upravitelj lječilišta za tuberkulozne bolesti Brestovac te pionir borbe protiv tuberkuloze u Hrvatskoj. Godine 1906. uglavnom prestaje s književnim radom te se posvećuje uređivanju Obzora, a 1918. sudjeluje u radu Narodnog vijeća SHS, da bi nakon rata politički bio blizak Lorkoviću i Hrvatskoj zajednici. Bio je odjelni predstojnik za socijalnu politiku u Pokrajinskoj vladi, načelnik Ministarstva socijalne politike, a od 1926. do 1934. ravnatelj grafičko-nakladnog zavoda Tipografija. Također je bio predsjednik Jugoslavenskoga novinarskog udruženja i Društva hrvatskih književnika. Drugi istaknuti akter bečke skupine mladih, Dušan Plavšić (1875-1965), izgradio je pak uspješnu bankarsku karijeru. Nakon završetka studija, zajedno s Ivom Pilarom, radi u Privilegiranoj zemaljskoj banci za Bosnu i Hercegovinu u Sarajevu, postavši naposljetku tajnik uprave. U Zagreb se vraća 1906. godine, gdje radi u Prvoj hrvatskoj štedionici i Hrvatskoj zemaljskoj banci. Bio je ravnatelj zagrebačke podružnice osječke Zemaljske hrvatske-slavonske banke, koja 1920. seli u Zagreb i mijenja ime u Jugoslavensku banku, kao i direktor Balkanske banke. Godine 1922. postao je pomoćnik ministra finacija, a 1927. predsjednik burzovnog vijeća Zagrebačke burze. Ivo Pilar (1874-1933), s druge strane, bio je jedan od rijetkih pripadnika pokreta mladih koji nisu zagovarali jugoslavensku ideju. Njegov je razlaz s naprednjacima nastupio zbog razlike pogleda u vezi položaja Bosne i Hercegovine, gdje je živio i radio prvo u bankarstvu, a zatim kao odvjetnik u Tuzli. Pilar 1907. godine sudjeluje u osnivanju Hrvatske narodne zajednice za $\mathrm{BiH}$, a politički se veže uz nadbiskupa Josipa Stadlera. Nakon 1918. uglavnom prestaje s političkim, ali nastavlja s publicističkim i znanstvenim radom, ne napuštajući pritom antijugoslavensko stajalište. Guido Jeny (1875-1952) se nakon pokreta mladih nije odlučio za političku, nego za prosvjetnu i umjetničku karijeru. Nakon što je na Visokoj tehničkoj školi u Beču završio matematiku, nacrtnu geometriju i građevinarstvo, cijeli život radi kao gimnazijski profesor u Osijeku, Srijemskoj Mitrovici i Bjelovaru, te kao prosvjetni inspektor u Zagrebu. Također nastavlja pisati likovne i kazališne kritike te slikati, ponajviše osječke krajolike u neoimpresionističkom stilu. Politički ostaje blizak socijaldemokraciji, ali bez izražene političke djelatnosti. 
Najmlađa, đačka skupina mladih dala je jednog od najvažnijih književnika hrvatske moderne - Milutina Cihlara Nehajeva (1880-1931). Iako je završio studij kemije u Beču, njegov je životni put uglavnom vezan uz novinarstvo i književnost. Uređuje listove Lovor, Obzor i tršćanski Balkan, a od 1911. živi i radi u Zagrebu kao književnik i novinar Obzora i Jutarnjeg lista. Mada je najpoznatiji kao autor Bijega, jednog od najboljih romana hrvatske moderne, razvio je svestranu književnu djelatnost koja je uključivala dramu, crtice, novele, eseje i memoaristiku. I drugi su se pripadnici đačke skupine mladih bavili književnošću, ali manje uspješno. Vladimir Jelovšek (1879-1934) objavio je dvije zbirke pjesama Simfonije i Simfonije II za vrijeme trajanja pokreta, a kasnije nastavlja plodan publicistički rad. Međutim, nakon povratka u Zagreb sa studija medicine uglavnom se posvećuje liječničkom pozivu te radi kao oftalmolog u Zagrebu i Karlovcu. Od 1912. godine bio je dugovječni urednik Liječničkog vijesnika, a bio je i član odbora Zbora liječnika Hrvatske. Treći član đačkoga „trijumvirata“, Milan Marjanović (1879-1955), imao je najburniji život. Karijerno je također bio primarno vezan uz novinarstvo. Radio je kao urednik Obzora, Crvene Hrvatske, Novog lista, Pokreta i splitske Slobode. Politički je dakako dio naprednjaka, a u Splitu se približava krugovima jugoslavenske nacionalističke omladine. Nakon atentata na Slavka Cuvaja, s čime je navodno bio povezan, živi u Beogradu i radi u tamošnjem Presbirou. Za vrijeme Prvog svjetskog rata član je Jugoslavenskog odbora, u sklopu kojega je iznimno aktivan među američkom emigrantskom zajednicom. Po povratku u novu jugoslavensku državu, nakon kratkog razdoblja političkih pokušaja vezanih uz pokret Jugoslavenske narodne obnove i Slobodnu tribunu, razvija bogatu kulturnu djelatnost. Od 1923. ponovo putuje u SAD, gdje organizira izložbe Ivana Meštrovića i sudjeluje u radu Jugoslavenskoga prosvjetnoga kola. U New Yorku završava tečaj fotografske i filmske tehnike i režije, pa u Zagrebu 1927. sudjeluje u pokretanju filmske proizvodnje Škole narodnog zdravlja. Od 1929. do umirovljenja u Beogradu vodi Centralni presbiro. Kao promicatelj filma, ondje osniva poduzeće Jugoslavenski prosvjetni film i Državnu filmsku centralu.

Ako usporedimo biografije ovih dvadesetak najvažnijih aktera pokreta mladih, lako ćemo uočiti da su njihovi životni putevi uglavnom bili vezani uz ona dva područja na kojima je pokret razvio svoju primarnu djelatnost - politiku i kulturu, napose književnost i novinarstvo, uz značajnu prisutnost gospodarstva, dakako povezanog s politikom. Politički je put generacije mladih u razdoblju prije 1918. bio poprilično uniforman. Hrvatski je dio - uz iznimku Radića i kasnije Pilara - bio gotovo isključivo vezan uz Hrvatsku naprednu stranku, a srpski uz Srpsku samostalnu stranku. Mladi su na taj način tvorili važnu jezgru Hrvatskosrpske koalicije, a time i hrvatske predratne političke elite. Njihovi politički putevi počinju 
divergirati s uspostavom nove jugoslavenske države, što je odražavalo specifičan položaj Hrvatske u njezinu okviru. Iako su svi prvaci mladih povezani s naprednjaštvom i Hrvatskosrpskom koalicijom bili jugoslavenski orijentirani, nisu se slagali oko konkretnih pitanja političkog ustroja nove države. Neki su od njih stoga izabrali put koji je bio bliži režimskoj politici, dok su drugi u novoj državi postali oporbeni pristaše i prvaci. Iako su i dalje zadržali status političke elite, u cjelini se ipak može reći da je njihov utjecaj u novim okolnostima bio manji nego u predratnom kontekstu, dakako ako izuzmemo Radića i Pribićevića, koji su odigrali ključne uloge međuratne jugoslavenske političke povijesti. Jedan od važnih razloga, dakako, leži u tome što je težište političke moći pomaknuto u Beograd, pa je tamošnja politička elita od samoga početka imala primat u donošenju političkih odluka.

U domeni kulture, s druge strane, nije bilo previše turbulencija. Nakon ulaska mladih u institucije starih, nakon osnivanja vlastitih organizacija i listova, kao i jenjavanja polemika, modernističke ideje koje su mladi zagovarali sve više postaju dio glavne struje elitne kulture, ali se zato javljaju novi, još mlađi izazivači koji će propitkivati dosljednost generacije mladih te zahtijevati radikalnije promjene na društvenom i kulturnom polju. To, međutim, ne mijenja činjenicu da je znatan dio mladih postao dio hrvatske kulturne elite. Modernistički okvir njihovih formativnih dana nije se nužno jednoznačno prelijevao u specifično stilsko ili idejno usmjerenje daljnjega rada, što ne čudi s obzirom na pluralnost, heterogenost i eklektičnost modernističkih strujanja na prijelomu 19. i 20. stoljeća. Najveća se konzistentnost kasnije kulturne djelatnosti mladih očitovala u činjenici da je veliki broj njih izgradio karijere $\mathrm{u}$ novinarstvu i publicistici. Izdavanje i uređivanje brojnih publikacija pokreta mladih poslužila im je stoga kao vrijedno vrelo iskustva za daljnji kulturni rad, a nekima i kao temelj buduće karijere.

Ova kratka i sumarna dijakronijska biografska analiza aktera pokreta potvđuje tako početnu istraživačku tezu da je pokret mladih funkcionirao kao sredstvo smjene generacija u okviru hrvatske političke i kulturne elite na početku 20. stoljeća. Mladi nisu bili napadači hrvatske građanske tradicije u politici i kulturi izvana, nego njezini izazivači iznutra. Oni su bili imanentni kritičari koji su se služili alatima koje su posudili izvana, ne s ciljem da razbiju, nego da reformiraju postojeće koncepcije i prakse. U srazu lokalnih okolnosti i iz inozemstva posuđenih alata, u načinu njihove primjene, očitovao se specifični karakter hrvatskog modernističkog pokreta, koji obilježava dominacija političkoga, fokus na ideji nove nacionalne inteligencije u liniji kontinuiteta od ilirskog pokreta, heterogenost, eklektičnost i ponekad ograničenost modernističkih impulsa te izrazita pluralnost grupacija s međusobno različitim i u određenoj mjeri kontradiktornim razmišljanjima. Koloplet ovih obilježja 
sačinjava specifični karakter hrvatskog modernističkog pokreta mladih, koji ipak ne dovodi u pitanje njegov status lokalne iteracije globalnog, transnacionalnog fenomena. 


\section{ZAKLJUČAK}

U uvodnom dijelu ovoga rada postavili smo tri početne istraživačke hipoteze, kao i konceptualni okvir koji se sastoji od dvije tematske osi - horizontalne, odnosno sinkronijske, s fokusom na načine aproprijacija i strategije upotrebe ideja, koncepata i praksi; i vertikalne, odnosno dijakronijske, koja se prvenstveno bavi pitanjem kontinuiteta i diskontinuiteta modernističkog pokreta mladih s obzirom na tradiciju hrvatske građanske politike i kulture. Sada je trenutak da se vratimo na te početne pretpostavke i da ih razmotrimo uzimajući u obzir provedenu raspravu i navedeni konceptualni okvir.

Prva hipoteza odnosila se na samu narav pokreta. Kao što je već više puta istaknuto, modernistički pokret mladih nije bio pokret u formalnom smislu te riječi. On nije imao čvrstu organizacijsku strukturu, oficijelnu ideologiju niti jasno zacrtane ciljeve i zahtjeve. Pa ipak, određena organizacija je postojala, jednako kao i ideološka matrica (koliko god ona bila heterogena) te brojni i promjenjivi zahtjevi i ciljevi. Najviše od svega, međutim, postojala je svijest samih aktera o tome da su dio jednoga pokreta. U različitim trenucima i u različitim krugovima narav toga pokreta shvaćena je drugačije: tko ga čini, kako se zove, koji su njegovi temeljni ciljevi te što i kako bi trebalo raditi da ih se ostvari - sve je to bilo podložno raspravi i promjeni ovisno o danim okolnostima. Ali osnovna svijest o postojanju i pripadnosti nekom distinktivnom gibanju među mladima koje ima karakter pokreta, kako god on bio shvaćen, nije nikad bila dovedena u pitanje, čak niti od njegovih najžešćih kritičara. Zbog toga, kada govorimo o modernističkom pokretu mladih, potrebno je pristupiti sa sviješću o njegovoj heterogenosti, neformalnosti i nestalnosti i na tome graditi daljnji narativ.

Temeljna organizacijska jedinica pokreta bile su skupine mladih - prvenstveno srednjoškolaca i studenata - koje su se okupljale oko poduhvata izdavanja različitih listova i prigodnih publikacija. Ove su skupine mogle biti više ili manje međusobno povezane, mogle su biti u savezničkim ili konkurentskim odnosima te su se sukladno tome mogle ili nisu morale smatrati dijelom istog pokreta. Njihova međusobna dinamika odražava tako dinamiku razvoja pokreta u cjelini. Prvo spominjanje nekog novog pokreta među mladima - tada se on naziva „novi smjer“, a njegovi zagovaratelji „novosmjeraši“ - javlja se tijekom 1896. godine u korespondenciji studenata relegiranih sa zagrebačkog sveučilišta nakon demonstracije paljenja mađarske zastave 1895. godine. Inicijalni je nositelj pokreta stoga praška skupina studenata povezana s različitim pojedincima na drugim mjestima, da bi se potom razvile $\mathrm{i}$ druge skupine koje su na ovaj ili onaj način polagale pravo na opći nazivnik pokreta mladih: 
zagrebačka skupina oko Narodne misli (,mišljaši“), bečka skupina oko časopisa Mladost, koja će se kasnije proširiti i povezati s drugim akterima u okviru hrvatske moderne i secesije te đačka skupina koja je predvodila (novo)nadaški pokret. Većina se ovih grupacija oformila tijekom 1896. i 1897. godine, u fazi oblikovanja i širenja pokreta. Iznimka je đački nadaški pokret koji je imao svoju raniju povijest, a koji se u ovome razdoblju zapravo pridružuje pokretu mladih kroz vlastitu, specifičnu aproprijaciju modernističkih ideja. Na vrhuncu pokreta, otprilike od 1898. do 1900. godine, može se reći da postoji općenita svijest o pripadnosti svih ovih skupina jednom zajedničkom omladinskom strujanju, usprkos nesuglasica $\mathrm{i}$ neslaganja po pitanju temeljnih načela, ciljeva i metoda rada. Tek u fazi jenjavanja pokreta, koju možemo pratiti od 1901. godine, odvija se proces njegove homogenizacije i institucionalizacije, sada pod imenom Hrvatske napredne omladine. Kraj našega narativa o pokretu mladih stoga je zapravo priča o njegovoj transformaciji iz neformalnih i heterogenih idejnih, političkih i kulturnih strujanja, koja se mogu labavo supsumirati pod općim nazivom fin de siècle modernizma, u jedinstveni, formalizirani pokret Hrvatske napredne omladine kao podloge za skoro osnivanje političkih stranaka i drugih organizacija.

Druga hipoteza koju smo iznijeli na početku rada izravno je vezana uz sinkronijsku konceptualnu os istraživanja, odnosno uz pitanje načina aproprijacija i strategija primjene i upotrebe stranih ideja, koncepata i praksi u specifičnim lokalnim uvjetima i okolnostima. Možemo slobodno reći da bez ove dimenzije priče uopće ne bi bilo moguće govoriti o modernističkom pokretu mladih u Hrvatskoj na prijelomu 19. i 20. stoljeća. Iako su sami osjećali probleme društva koje ih okružuje, te iako su imali određeni lokalni korpus ideja i djela koja su promišljala te probleme, gotovo cjelokupni konceptualni aparat pomoću kojega su oblikovali svoj pokret - uključujući i samu ideju pokreta - mladi su preuzeli izvana. To govori dvije stvari o samome pokretu. S jedne nas strane ta činjenica upućuje na fundamentalnu važnost procesa aproprijacija suvremenih ideja i kretanja, a s druge pak služi kao upozorenje da se taj proces ne smije apsolutizirati. Vanjske aproprijacije i lokalni kontekst čine nerazmrsivo klupko kada je riječ o razumijevanju geneze, razvoja i uloge modernističkog pokreta mladih. Povijesni akteri koje smo pratili bili su itekako svjesni onoga što rade te su tu svoju svijest jasno artikulirali u svojim tekstovima i korespondenciji. Od samoga početka oni problemu pristupaju imajući pred očima nužnost prilagodbe svojih aproprijacija suvremenih globalnih kretanja lokalnom, hrvatskom kontekstu. Zbog toga je rijetko kada bio slučaj da se kod tih aproprijacija radilo o imitacijama. Mladi su gotovo uvijek baratali s analogijama, imajući u vidu da one podrazumijevaju strukturne, ali ne nužno i 
sadržajne sličnosti. Ovisno o tome koja je ključna analogija bila upotrebljena, fokus aproprijacija bio je usmjeren ka zemlji u pitanju. Tako je u slučaju aproprijacija političkih koncepata ključna bila analogija između češke i hrvatske situacije, dok je u domeni kulturnih aproprijacija situacija bila nešto složenija, ali su često kao model iskakale skandinavske zemlje, dakako uz neizostavnu Rusiju. Beč je naravno i dalje zadržao prominentno mjesto kao točka posredovanja globalnih kretanja, ali se sada uz uvijek postojeće aproprijacije bečkih modernističkih strujanja ujedno javlja i svijest o nužnosti uklanjanja bilo kakvog posredovanja i o potrebi „odlaska na izvor“ određenih intelektualnih i kulturnih strujanja. Ipak se treba postaviti pitanje koliko je to u praksi doista bio slučaj, a koliko su i dalje tradicionalni centri hrvatske intelektualne emigracije igrali ključnu ulogu posredovanja širih kretanja.

I onda kada se kod tih aproprijacija radilo o imitacijama, one su imale određenu društvenu ili političku funkciju. Najčešće je bila riječ o prisvajanju habitusa modernog, fin de siècle intelektualca ili umjetnika, odnosno simboličkog kapitala koji je s njime dolazio, a koji je pojedincima omogućavao da se pozicioniraju u nastajućem polju fin de siècle kavanskog, boemskog i intelektualnog života. Sve ove aproprijacije nisu nužno morale biti međusobno kompatibilne. Ponekad su se kod istih osoba mogle očitovati u prisvajanju posve kontradiktornih ideja i strujanja. Najbolji primjer za to bio je Milivoj Dežman, osoba koja je gotovo $\mathrm{u}$ isto vrijeme među prvima otvorila pitanje reforme nacionalnog književnog života $\mathrm{s}$ ciljem njegova uzdizanja na višu razinu kvalitete, a ujedno pisala program hrvatskog dekadentizma u kojem se zagovarao bijeg od problema života. Upravo mu je ta ambivalentnost omogućavala široki manevarski prostor kako među mladima, tako i među starima. Zbog toga je on funkcionirao kao ključni posrednik cjelokupna pokreta: između različitih grupacija mladih i između mladih i starih. S druge pak strane, iako je nedvojbeno bio jedan od najvažnijih intelektualnih i političkih predvodnika pokreta, svojevrsna krutost u pogledima i neprijemčivost za društveno pozicioniranje onemogućili su da tu istu ulogu odigra Stjepan Radić, koji je pak završavao u učestalim konfliktima i s mladima i sa starima, da bi naposljetku posvema raskinuo i s jednima i s drugima. Razina ideja, njihovih aproprijacija, upotreba, međusobne kompatibilnosti i koherentnosti nije stoga u praksi bila jedina relevantna. Ideje su prenosili i upotrebljavali ljudi, a oni su se nalazili u kompleksnim mrežama odnosa koje su neizostavno utjecale na strategije njihove upotrebe, pa stoga i na sam tijek i razvoj pokreta u cjelini.

Treća i posljednja istraživačka hipoteza ovoga rada odnosila se na pitanje kontinuiteta i diskontinuiteta ideja i praksi pokreta mladih s onima hrvatske (i srpske) građanske politike i elite općenito. Iako su bili žestoki protivnici i kritičari Khuenova režima u Hrvatskoj, posve je 
nedvojebno da je pogled mladih prvenstveno usmjeren prema hrvatskoj opoziciji, prije svega obzorašima i domovinašima, kao i njihovim ključnim kulturnim institucijama - Matici hrvatskoj i Viencu. Jedan od glavnih razloga za studentsku demonstraciju 1895. godine bilo je nezadovoljstvo mladih radom hrvatske opozicije, koje dakle seže dalje u prošlost od vremenskog okvira trajanja pokreta. Ono što se s pokretom odvija jest kanaliziranje i oblikovanje tog nezadovoljstva posredstvom aproprijacija, koje su pružile konceptualni aparat za to. Od samoga je početka, dakle, samopercepcija mladih bila usko povezana uz njihov odnos prema starima. To se očitovalo i na najosnovnijoj razini - onoj naziva: od novog smjera, preko mladih, pa sve do secesije, svi su se oni na ovaj ili onaj način vezivali uz odnos spram dominantnih ideja i praksi. Stoga nije iznenađujuće da upravo u trenutku kada žele ograničiti utjecaj i povezanost sa starima, odnosno kada su u situaciji smanjivanja njihove međusobne distance ipak htjeli zadržati svoj distinktivni karakter, mladi biraju naziv koji se više ne gradi na njihovu odnosu spram tradicije, nego na njihovu pozitivnom programu: Hrvatska napredna omladina.

Iskustvo mladih vani u susretu s novim, suvremenim kretanjima samo je ojačalo njihovo nezadovoljstvo stanjem u Hrvatskoj, ali im je ujedno omogućilo da formuliraju prijedloge i programe za njegovu promjenu. Temeljni koncept na kojem su bazirali svoju kritiku bio je već odavno poznat u hrvatskoj javnosti - onaj „kašnjenja“, odnosno diskrepancije između postojećih društvenih kretanja i potreba i dominantne političke i kulturne prakse. Stari nisu bili zlotvori kao što je to bio režim i njegovi pomagači, nego su bili izgubljeni u novom vremenu, relikt prošlosti koji nije bio sposoban iznijeti nužne promjene. U tom smislu jasno je da su aproprijacije suvremenih kretanja bile neodvojive od ove dimenzije odnosa spram tradicije. Odnosno, drugim riječima, sinkronijska i dijakronijska perspektiva isprepletene su u samoj svijesti povijesnih aktera: sinkronijske intervencije (aproprijacije) trebale su na neki način sinkronizirati hrvatsku političku i kulturnu tradiciju sa zahtjevima vremena; ili, postavljeno obratno: dijakronijska svijest o desinkronizaciji hrvatske političke i kulturne tradicije s novim društvenim potrebama nagnala je mlade na put promjena.

Ako pogledamo sadržaj programa i zahtjeva mladih, jasno je da je prije svega riječ o prihvaćanju i uvođenju koncepata i praksi moderne masovne politike u hrvatski javni prostor. Oni kritiziraju stare zbog njihove pasivnosti, ignoriranja aktivna terenskog rada, oslonca na historijsko državno pravo, zanemarivanja društvene i ekonomske problematike, posebice kada je riječ o životnim uvjetima širih slojeva itd. Mladi se stoga zalažu za prihvaćanje realističke političke koncepcije, za aktivan, konkretan „sitni rad“ na terenu, za princip narodnog prava, za osnivanje institucija koje počivaju na ideji „ekonomskog nacionalizma“, ukratko za 
„socijalizaciju politike“. Ova je posljednja točka iznimno važna. Iako su se često vezivali uz demokraciju i liberalizam, taj je odnos zapravo vrlo nategnut. Ako bi se pitalo same aktere pokreta, liberalizam sigurno ne bi bila odrednica kojom bi označili svoje stajalište. U to doba, liberalizam se vezivao upravo uz neuspješnu paradigmu starih i uz sve ono što je bilo predmet kritike: od eksploatacije seljaštva i radništva, preko ekskluzije naroda iz političkog života, pa sve do zatiranja principa nacionalnosti. U tom smislu on je bio izrazito nepopularna politička etiketa, iako je nedvojbeno da su u sadržajnom smislu određeni njegovi elementi prisutni i kod njegovih navodnih kritičara. Što se pak tiče demokracije, situacija je obrnuta. Iako je ona bila poželjna politička etiketa, njezin sadržaj bio je samo djelomično prihvatljiv. Naime, iako mladi svakako zagovaraju veću inkluziju naroda u politički život, ona se prema njima mora odvijati strogo strukturirano: kroz nacionalni pokret i posredstvom nacionalne inteligencije. Bez te strukture, koja dakle uključuje i svojevrsnu hijerarhiju, inkluzija naroda u politiku značila bi rođenje mase, a ona je negacija i građanskog individiualizma i principa nacije, koji su fundamentalni za ideologiju mladih. Zbog toga oni ne govore o demokratizaciji, nego o socijalizaciji politike, i to je doista najpreciznije određenje njihove pozicije, uz dodatak: nacionalne politike. Riječ je dakle o tome da se tada već ugasli nacionalni pokret revitalizira, dovede u novu fazu, da se proširi i da dobije široku društvenu bazu. Zato je diskurs mladih prožet referencama na ilirski pokret i na potrebu njegova dovršenja. Oni se stoga svjesno stavljaju u liniju kontinuiteta $\mathrm{s}$ tom političkom tradicijom. A u onoj mjeri u kojoj je ona ujedno i građanska politička tradicija, jasno je da mladi pristaju i uz to određenje. O tome pregnantno svjedoči njihov odnos prema socijalizmu, odnosno socijaldemokraciji: iako podržavaju određene njegove društvene zahtjeve, odbacuju njegov klasni karakter. Mladi se stoga pojavljuju kao reformistička struja unutar hrvatske građanske politike, baš kao i unutar šireg koncepta hrvatskog nacionalnog pokreta.

Vrlo je slična situacija kada je riječ o kulturnom programu mladih. Usprkos povremenim izletima u esteticizam, dekadentizam i slična književno-umjetnička strujanja, glavnina se njihovih preokupacija ticala pitanja uloge i svrhe nacionalne književnosti, odnosno umjetnosti u cjelini. Razlika u pristupu grupacija mladih nije stoga bila u strogoj podjeli interesa na politiku i kulturu ili u nacionalnoj nasuprot kozmopolitskoj koncepciji kulture, nego u razumijevanju uloge i poželjnog sadržaja nacionalne kulture. Za prašku i zagrebačku skupinu, nacionalna umjetnost samo je jedan u nizu sredstava nacionalne politike. Kako bi bila uspješno sredstvo, ona mora počivati na tradicijama i tekovinama narodne kulture, koje su prijemčive za šire slojeve kao ključnu ciljanu publiku. S druge strane, dežmanovski koncept nacionalne kulture, koji je postao dominantan u okviru bečke skupine $\mathrm{i}$ 
kasnije većine projekata mladih na polju kulture, počivao je na ideji da samo vrhunska umjetnost kao sinteza univerzalnog i partikularnog, odnosno europskog i nacionalnog, može uistinu ispunjavati svoju pravu nacionalnu zadaću, a to je da bude predvodnica nacionalnog kulturnog razvoja. Njegov pristup ovom problemu možemo nazvati laissez-faire. Umjetnosti treba ukinuti sva ograničenja, a publika i vrijeme će odlučiti što je poželjno i što treba opstati, a što zaslužuje otići u ropotarnicu povijesti. Naravno da su stari vrlo jasno shvatili koliku prijetnju ovakav pristup predstavlja za njihov monopolistički položaj u kulturi. I naravno da su mladi bili svjesni izazova koji su uputili. Polemika starih i mladih koja se rasplamsala bila je stoga borba argumentima (ponekad i uvredama), koja je u podtekstu bila zapravo politička borba dvije generacije. U tome se jasno manifestiralo specifično obilježje hrvatskog modernističkog pokreta, a to je predominacija logike političkog na svim poljima djelatnosti. Ako bismo njihovo utemeljivanje politike u konceptu zamišljene narodne kulture mogli opisati sintagmom politika kao kultura, onda bismo nastojanje mladih na polju kulture mogli nazvati kulturom kao politikom.

Da je u sukobu mladih i starih primarno bila riječ o generacijskoj političkoj borbi za pristup institucijama i pozicijama društvene i političke moći svjedoči i to kako je taj sukob brzo splasnuo te se pretvorio u suradnju. Mogao je splasnuti jer ekstremnost prozivki, napose onih koje su stari upućivali mladima, nije odgovarala stvarnim razmjerima idejnog razmimoilaženja, što se jasno vidjelo već u prvim dogovorima oko ustroja Društva hrvatskih književnika. A pretvorio se u suradnju u trenutku kada je postalo jasno da su stari politički potrošeni i da im je potreban novi impuls kako ne bi potpuno nestali s povijesne pozornice. Političko približavanje starih i mladih podrazumijevalo je stoga i kompromis na polju kulture, što je pak uzrokovalo indignaciju i nezadovoljstvo određenog, napose mlađeg dijela mladih jer je postalo jasno da je sukob modernizma i antimodernizma, sekularizma i klerikalizma, novoga i staroga zapravo u velikoj mjeri sublimirao bazičnu borbu oko podjele moći. Iz vizure radikalnijeg dijela pokreta to je bila izdaja njegovih načela, dok je umjereniji krug kompromis vidio kao jedino sredstvo promjene u društvu u kojemu još nisu bili sazreli uvjeti za dublje transformacije.

Činjenica da je pokretom mladih dominirala politička logika, da je imao elitni generacijski karakter i da je u podlozi njegova sukoba sa starima bila borba za političku moć ni na koji način ne umanjuje njegovu zaslugu za otvaranje tema koje su obilježile europski fin de siècle u hrvatskoj javnosti. Dosezi obrade tih tema često nisu bili na razini uzora, čemu je djelomično uzrok u to doba još nedovoljno razvijena društvena struktura Hrvatske. Iako su otvorene gotovo sve teme europskog fin de sièclea, mogle su se primiti samo one koje su u 
danom trenutku zahvaćale stvarne društvene, političke i kulturne probleme. Pa ipak, otvaranje suvremenim intelektualnim strujanjima, osuvremenjivanje hrvatske kulturne i intelektualne javnosti, usprkos svim ograničenjima, omogućilo je idućim generacijama da se formiraju u novom, modernijem intelektualnom kontekstu i da potom sva ova pitanja otvore na produbljeniji i radikalniji način. Iako je bio izrazito kritičan prema mladima, pitanje je koliko Krleža i njegova generacija zapravo duguju Dežmanovim „nervoznim drhtajima“ ili Marjanovićevim kvazi-ničeanskim vizijama mesijanskog poslanja umjetnika. ${ }^{1171}$ Nije stoga čudno, pa niti neopravdano, da su u hrvatskoj historiografiji mladi zauzeli rijetko mjesto važne povijesne generacije, čiji su formativni dani u sklopu modernističkoga pokreta, pa i kasnija politička i kulturna djelatnost, dali značajan doprinos - i pozitivan i negativan hrvatskoj političkoj i kulturnoj povijesti na prijelomu 19. i 20. stoljeća.

1171 Usp. „Jedan dio hrvatskog naprednijeg građanskog sloja (čitave generacije devedesetih godina sve do balkanskih ratova i pokreta jugoslavenske omladine) psihološki-moralno je prevladao učmalost i kvijetizam sitnih i zaostalih prilika austro-hrvatskih, i ponijet tempom vlastitog vremena osjetio je potrebu da se oslobodi legitimističkog baroknog balasta. Pokoljenja praških đaka i starijih, iskusnijih pravaša, macharovaca i masarykovaca, prevladala su u svojoj političkoj svijesti banski, šljivarski i velikožupanski mentalitet grada Agrama i, osjetivši potrebu suvremenijih političkih formula, otputovala su preko parole Narodnog Jedinstva i Srpske Iredente do kajmakčalanske formule Ujedinjenja i do neounionističke karijere u sjenci dvorskog kapidžika. Mjesto da otpočnu normalnu i logičnu političku rabotu obrađivanja msaovne volje na vlastitom, hrvatskom terenu, ta su se gospoda rasplinula u ovom manežu kao fantomi, a seljačke su mase ostale prepuštene utjecaju političkih naivčina.“ Miroslav Krleža, „Stjepan Radić u Beogradu“, u: Deset krvavih godina: eseji $i$ članci IV, Sarajevo, 1979, 257-258. 


\section{POPIS IZVORA I LITERATURE}

\section{IZVORI}

\section{Arhivski fondovi}

Arhiv Odsjeka za povijest hrvatske književnosti Zavoda za povijest hrvatske književnosti, kazališta i glazbe Hrvatske akademije znanosti i umjetnosti

HR-AHAZU-KN-44 Dežman, Milivoj

HR-AHAZU-KN-80 Jeny, Guido st.

HR-AHAZU-KN-133 Marjanović, Milan

Državni arhiv u Osijeku

HR-DAOS-6 Poglavarstvo slobodnog i kraljevskog grada Osijeka

Državni arhiv u Splitu

HR-DAST-178 Tresić-Pavičić, Ante

$\underline{\text { Hrvatski državni arhiv }}$

HR-HDA-757 Obitelj Plavšić

HR-HDA-790 Benko Grado, Artur

Nacionalna i sveučilišna knjižnica u Zagrebu

Plavšić, Dušan R7133, R7228

Uredništvo časopisa Mladost R7134

Hrvatsko književničko društvo R7338

\section{Objavljeni izvori}

Damir AGIČIĆ, Dragi Franta! Hrvatska korespondencija Františeka Hlaváčeka (1896. 1904.), Zagreb, 2003.

Hermann BAHR, „Die Moderne“, Moderne Dichtung. Monatsschrift für Literatur und Kritik I, 1, 1890, 13-15.

Vida FLAKER, "Deset neobjavljenih pisama Stjepana Radića”, Kronika Zavoda za književnost i teatrologiju JAZU I, br. 2, 1975, str. 95-97.

Hrvatski djaci pred sudom: stenografski izvještaj o glavnoj razpravi proti hrvatskim 
sveučilištnim djacima obdržanoj pred kr. sudbenim stolom u Zagrebu dne 11 - 16. studenoga 1895., Zagreb, 1895.

Iskra IVELJIĆ, „Od uza Sudbenog stola do turneje po Rusiji, Nepoznata pisma Josipa Henneberga iz 1894.-1897.“, Časopis za suvremenu povijest XL, 2, 2008, 587- 623.

Bogdan KRIZMAN, Korespondencija Stjepana Radića, 1885.-1918., Zagreb, 1972.

Ivan KRTALIĆ (ur.), Anarhija u hrvatskoj književnosti i umjetnosti, Polemike u hrvatskoj književnosti sv. 7, Zagreb, 1983.

Ivan KRTALIĆ (ur.), Nekrolog hrvatskoj modernoj, Polemike u hrvatskoj književnosti sv. 8, Zagreb, 1983.

Milan MARJANOVIĆ, Hrvatska moderna: Izbor književne kritike, knj. I i II, Zagreb, 1951.

Stjepan MATKOVIĆ, „Ivo Pilar: Pisma Dušanu Plavšiću (1897.-1898.)“, u: Srećko Lipovčan, Zlatko Matijević, Prinosi za proučavanje života i djela dra Ive Pilara, sv. 2, Zagreb, 2002, str. 159-167.

Stjepan MATKOVIĆ, „Iz rane Pilarove korespondencije: pisma Milivoju Dežmanu“, Pilar: časopis za društvene i humanističke studije X, br. 19-20, 2015, str. 161-175.

Tomislav SABLJAK (ur.), Korespondencija hrvatskih pisaca, Zagreb, 2002.

Krsto ŠPOLJAR (ur.), Hrvatska moderna: kritika i književna povijest, Zagreb, 1975.

„The Czech modern“, u: Ahmet Ersoy, Maciej Górny, Vangelis Kechriotis (ur.), Modernism: Representations of National Culture: Discourses of Collective Identity in Central and Southeast Europe 1770-1945: Texts and Commentaries, volume III/2, Budimpešta, 2010, 260-265.

\section{Časopisi, novine i almanasi}

Glas ujedinjene hrvatske, srpske i slovenačke omladine za književnost, politička i socijalna pitanja, Beč, 1899-1900.

Hrvatska misao. List za književnost, politiku i pitanja socijalna, Prag, 1897.

Hrvatska misao. Smotra za narodno gospodarstvo, književnost i politiku, Zagreb, 1902.

Hrvatski salon, Zagreb, 1898-1899. 
Mladost. Smotra za modernu književnost i umjetnost, Beč, 1898.

Narodna misao, Zagreb, 1897.

Narodna misao, Zagreb, 1898.

Nada. Belestrički (!) list, Zagreb, 1897.

Narodna obrana, Osijek, 1902.

Nezavisnost, Split, 1898.

Nova nada. Zbornik zabave i pouke, Zagreb, 1897-1899.

Nova zvijezda. Zbornik zabave i pouke, Zagreb, 1901.

Novo doba. List sjedinjene hrvatske, srpske i slovenačke omladine za politička, socijalna $i$ književna pitanja, Prag, 1898.

Obzor, Zagreb, 1896, 1898.

Svjetlo, Karlovac, 1895, 1900.

Vienac zabavi i pouci, Zagreb, 1897, 1900.

Zajednica hrvatskoga đačtva, Karlovac, 1896.

Zora. Književno glasilo, Karlovac, 1902.

Život. Mjesečna smotra za književnost i umjetnost, Zagreb, 1900-1901.

\section{Brošure, pamfleti i publicistika}

Josip FRANK, U obranu hrvatskih umjetnika: odgovor na poslanicu Fr. Š. Kuhača "Anarkija u hrvatskoj književnosti i umjetnosti”, Zagreb, 1898.

Iso KRŠNJAVI, Kritična razmatranja, Zagreb, 1899.

Franjo Ksaver KUHAČ, Anarkija u hrvatskoj književnosti i umjetnosti: poslanica umjetničkim secesionistima i književnim dekadentima, Zagreb, 1898. 
Franjo Ksaver KUHAČ, O secesiji: odgovor gosp. J. Pilaru, Zagreb, 1898.

Milan MARJANOVIĆ, Hrvatski pokret: opažanja i misli na pragu narodnoga preporoda g. 1903, 2 sv., Dubrovnik, 1903. i 1904.

Milan MARJANOVIĆ, Iza Šenoe: četvrt vijeka hrvatske književnosti, Zadar, 1906.

Ivo PILAR, Secesija: studija o modernoj umjetnosti, Zagreb, 1898.

Antun RADIĆ, ,„,Život“" t. j. smrt hrvatskoga preporoda?“, u: Antun Radić, Sabrana djela XIV, Zagreb, 1938, 13-31.

\section{Književna djela}

Ksaver Šandor GJALSKI, Radmilović, Zagreb, 1932.

Ksaver Šandor GJALSKI, „U noći“, u: Tihomir Tonković (ur.), Ksaver Šandor Gjalski: sabrana djela, knjiga III, Zagreb, 2016, 11-239.

Milutin CIHLAR NEHAJEV, "Veliki grad”, u: Krešimir Nemec (ur.), Antologija hrvatske novele, Zagreb, 1997, 234-258.

\section{Memoari i autobiografije}

Iso KRŠNJAVI, „Autobiografija“, u: Ivo Frangeš (ur.), Iso Kršnjavi, Iso Velikanović, Živko Bertić, Joza Ivakić: izabrana djela, Pet stoljeća hrvatske književnosti, Zagreb, 1980, str. 242-254.

Iso KR ̌̌NJAVI, „Pogled na razvoj hrvatske umjetnosti u moje doba“, Hrvatsko kolo, knj. 1, Zagreb, 1905, str. 215-307.

Mihovil NIKOLIĆ, „Fragmenti iz moga života“, u: Vinko Brešić (ur.), Autobiografije hrvatskih pisaca, Zagreb, 1997, str. 561-567.

Ivan PERŠIĆ, Kroničarski spisi, priredio Stjepan Matković, Zagreb, 2002.

Stefan ZWEIG, Jučerašnji svijet, prevela Mary Melichar, Zagreb, 1999.

Vilma VUKELIĆ, Tragovi prošlosti, prir. Vlado Obad, 2. izdanje, Zagreb, 2003. 


\section{LITERATURA}

Damir AGIČIĆ, Hrvatsko-češki odnosi na prijelazu iz XIX. u XX. stoljeće, Zagreb, 2000.

Mato ARTUKOVIĆ, Ideologija srpsko-hrvatskih sporova (Srbobran 1884-1902), Zagreb, 1991.

Damir BARBARIĆ (ur.), Fin de siècle Zagreb-Beč, Zagreb, 1997.

Damir BARBARIĆ, „Izazov moderne: Matica hrvatska u ,sukobu starih i mladih“““, Damir Barbarić, Stjepan Damjanović (ur.), Skrb za duh nacije. Prilozi za povijest nakladništva Matice hrvatske, Zagreb, 2019, 277-292.

Daniel BARIĆ, Proziran i prezren: njemački jezik u hrvatskom društvu u prvoj polovici 19. stoljeća, Zagreb, 2015.

Nikola BATUŠIĆ, Zoran KRAVAR, Viktor ŽMEGAČ, Književni protusvjetovi: Poglavlja iz hrvatske moderne, Zagreb, 2001.

Steven BELLER (ur.), Rethinking Vienna 1900, New York, Oxford, 2001.

France BERNIK, „Pojem 'moderna' v slovenski literarni vedi“, Primerjalna književnost 14, 1, 1991, 13-20.

Mark BIONDICH, Stjepan Radić, the Croat Peasant Party, and the Politics of Mass Mobilization, 1904-1928, Toronto, Buffalo, London, 2000.

Philip BLOM, Vrtoglave godine: Europa, 1900.-1914., Zagreb, 2015.

Marijan BOBINAC, „The Habsburg Legacy from a Postcolonial and Postimperial Perspective“, Umjetnost riječi LIX, 3-4, 2015, 239-260.

Marijan BOBINAC, „Nostalgische Rückblicke, von Unbehangen begleitet: Reflexionen kroatischer Intellektueller zur Lage der deutschen Sprache und Kultur in Kroatien um 1900“, u: Bobinac, Wolfgang Müller-Funk, Jelena Spreicer (ur.), Mehrsprachigkeit in Imperien/Multilingualism in Empires, Zagreb, 2019, 145-162.

Vaso BOGDANOV, Historija političkih stranaka u Hrvatskoj: od prvih stranačkih grupiranja do 1918., Zagreb, 1958.

Josip BOGNER, „Polemika oko hrvatske moderne“, Književnik III, 3, 1930, 114-120, prema: Ivan Krtalić (ur.), Anarhija u hrvatskoj književnosti i umjetnosti, Polemike u hrvatskoj književnosti sv. 7, Zagreb, 1983, 7-14. 
Antonija BOGNER ŠABAN, „Uspjeh gospodina Crownenshielda (Mr. Crownenshield's Success)“, Dani Hvarskoga kazališta 32, 1, 2006, 281-296.

John W. BOYER, Political Radicalism in Late Imperial Vienna: Origins of the Christian Social Movement, 1848-1897, Chicago, London, 1981.

Marina BREGOVAC PISK, Kristian GOTIĆ (ur.), Iso Kršnjavi-veliki utemeljitelj, Zagreb, 2012.

Vinko BREŠIĆ, Praksa i teorija književnih časopisa, Zagreb, 2014.

Vinko BREŠIĆ (ur.), Bibliografija hrvatskih književnih časopisa 19. stoljeća, sv. 4, Zagreb, 2006.

Vinko BREŠIĆ, Časopisi Milana Marjanovića, Zagreb, 1990.

Jeffrey D. BURSON, „Entangled History and the Scholarly Concept of Enlightenment“, Contributions to the History of Concepts 8, 2, 2013, 1-24.

Gary B. COHEN, „Fin-de-siècle Vienna and the Larger Central Europe 1900: The Experience of Prague's Intellectuals“,

URL:https://static1.squarespace.com/static/521b937ee4b036e9c34fe712/t/581b421f9d

e4bbcf7336b51d/1478181408151/Cohen_PragueIntellectuals.pdf (pristup: 15. 7. 2020.)

Marcel CORNIS-POPE i John NEUBAUER (ur.), History of the Literary Cultures of East-

Central Europe: Junctures and Disjunctures in the 19th and 20th Centuries, 2. sv., Amsterdam i Philadelphia, 2006.

Moritz CSÁKY, Das Gedachtnis Der Stadte: Kulturelle Verflechtungen - Wien Und Die Urbanen Milieus in Zentraleuropa, Beč, 2010.

Dunja DETONI DUJMIĆ, Ljepša polovica književnosti, Zagreb, 1998.

Branimir DONAT, „Viktor Tausk, Sigmund Freud i hrvatska moderna okupljena oko zagrebačko-bečkoga časopisa Mladost“, Književna republika V, 3-4, 2007, 68-90.

Geoff ELEY, Forging Democracy: The History of the Left in Europe, 1850-2000, Oxford, 2002.

Johannes FEICHTINGER, Ursula PRUTSCH i Moritz CSÁKY (ur.), Habsburg postcolonial: Machstrukturen und kollektives Gedächtnis, Innsbruck, Wien, München, Bozen, 2003.

Aleksandar FLAKER, „O pravaškom radikalizmu 80-ih godina XIX. stoljeća“, Historijski 
zbornik 7, 1954, 85-101.

Aleksandar FLAKER, „Proučavanje početaka moderne u hrvatskoj, srpskoj i slovenskoj književnosti (1970-1989)“, Wiener Slavistisches Jahrbuch 39, 1993, 7-12.

Vida FLAKER, Časopisi hrvatskoga modernističkog pokreta, Zagreb, 1977.

Vida FLAKER, „Vladimir Nazor i evropska moderna“, u: Aleksandar Flaker i Krunoslav Pranjić (ur.), Hrvatska književnost u evropskom kontekstu, Zagreb, 1978, 451-459.

Mark FRANCIS (ur.), The Viennese Enlightenment, New York, 1985.

Ivo FRANGEŠ, „Realizam“, u: Slavko Goldstein et al., Povijest hrvatske književnosti, knj. 4, Zagreb, 1975, 219-488.

Peter FRITZSCHE, Reading Berlin 1900, Cambridge, London, 1998.

Anđelka GALIĆ, Miroslav GAŠPAROVIĆ (ur.), Secesija u Hrvatskoj, Zagreb, 2003.

Grgo GAMULIN, Hrvatsko slikarstvo XIX. stoljeća, sv. 2: Hrvatsko slikarstvo na prijelazu iz XIX. u XX. stoljeće, Zagreb, 1995.

Ljiljana Ina GJURGJAN, Mit, nacija i književnost „,kraja stoljeća“: Vladimir Nazor $i$ W. B. Yeats, Zagreb, 1995.

Ljiljana Ina GJURGJAN, „Estetska načela moderne u djelima Vladimira Nazora“, Mogućnosti 4/6, 2005, 131-148.

Idesbald GODDEERIS, „The Limits of the Transnational“, Revue belge de philologie et d'histoire 89, 3-4, 2011, 1237-1248.

Mirjana GROSS, „Nacionalne ideje studentske omladine u Hrvatskoj uoči I svjetskog rata“, Historijski zbornik XXI-XXII, 1968-1969, 75-143.

Mirjana GROSS, „Studentski pokret 1875-1914“, u: Jaroslav Šidak (ur.), Spomenica u povodu proslave 300-godišnjice Sveučilišta u Zagrebu, knj. I, Zagreb, 1969, 451-477.

Mirjana GROSS, „O integraciji hrvatske nacije“, u: Mirjana Gross (ur.), Društveni razvoj u Hrvatskoj (od 16. stoljeća do početka 20. stoljeća, Zagreb, 1981, 175-190.

Mirjana GROSS, „Nacionalno-integracijske ideologije u Hrvata od kraja ilirizma do stvaranja Jugoslavije“, u: Mirjana Gross (ur.), Društveni razvoj u Hrvatskoj (od 16. stoljeća do početka 20. stoljeća, Zagreb, 1981, 283-306. 
Mirjana GROSS, Agneza SZABO, Prema hrvatskome građanskom društvu: društveni razvoj u civilnoj Hrvatskoj i Slavoniji šezdesetih i sedamdesetih godina 19. stoljeća, Zagreb, 1992.

Serge GRUZINSKI, "Les mondes mêlés de la Monarchie catholique et autres 'connected histories'“, Annales. Histoire, Sciences Sociales 56, 1, 2001, 85-117.

Péter HANÁK (ur.), Povijest Mađarske, Zagreb, 1995.

Ivo HERGEŠIĆ, „Mladi u hrvatskoj književnosti 1897.-1907.“, u: Milivoj Dežman i Rudolf Maixner, Obzor: spomen knjiga 1860-1935, Zagreb, 1936, 126-130.

Josip HORVAT, „Izmjena generacija: ideje i ljudi kroz četvrt vijeka hrvatske politike (1895.1905.)“, u: Milivoj Dežman i Rudolf Maixner, Obzor: spomen knjiga 1860-1935, Zagreb, 1936, 15-27.

Josip HORVAT, Hrvatski panoptikum, Zagreb, 1965.

Josip HORVAT, Politička povijest Hrvatske, dio 1, Zagreb, 1990.

Miroslav HROCH, Društveni preduvjeti nacionalnih preporoda u Europi: Komparativna analiza društvenog sastava patriotrskih grupa malih europskih nacija, Zagreb, 2006.

Akira IRIYE i Pierre-Yves SAUNIER, The Palgrave Dictionary of Transnational History, London, 2009.

Katica IVANKOVIĆ, „U obranu dekadencije. Češka književna previranja na kraju 19. stoljeća“, Književna smotra 34, 2002, 3-11.

Iskra IVELJIĆ, „Prevlast unionista. Hrvatske zemlje od 1883. do 1903. godine“, u: Mislav Ježić et al. (ur.), Hrvatska i Europa. Kultura, znanost i umjetnost, sv. 4: moderna hrvatska kultura od preporoda do moderne (XIX. stoljeće), Zagreb, 2009, 93-102.

Iskra IVELJIĆ, „Prosvjeta Banske Hrvatske u 19. stoljeću - europski uzori i hrvatske posebnosti“،, u: Iveljić (ur.), Zbornik Nikše Stančića, Zagreb, 2011, 125-139.

Iskra IVELJIĆ (ur.), The Entangled Histories of Vienna, Zagreb and Budapest (18th - 20th Century), Zagreb, 2015.

Iskra IVELJIĆ, „Kulturna politika u Banskoj Hrvatskoj 19. stoljeća“, Historijski zbornik LXIX, 2, 2016, 335-370.

Bosiljka JANJATOVIĆ, „Sudski proces zagrebačkim studentima u studenome 1895.“, Historijski zbornik 50, 1997, 91-108. 
Bosiljka JANJATOVIĆ, Stjepan Radić: progoni, zatvori, suđenja, ubojstvo: 1889.-1928., Zagreb, 2003.

Peter JELAVICH, Munich and Theatrical Modernism: Politics, Playwriting, and Performance, 1890-1914, Cambridge, London, 1996.

William M. JOHNSTON, Austrijski duh: intelektualna i društvena povijest od 1848. do 1938., preveo Janko Paravić, Zagreb, 1993.

Pieter M. JUDSON, The Habsburg Empire: A New History, Cambridge, 2016.

Donald R. KELLEY, The Descent of Ideas: The History of Intellectual History, New York, 2017.

Sarah KENT, „State Ritual and Ritual Parody: Croatian Student Protest and the Limits of Loyalty at the End of the Nineteenth Century“،, u: Laurence Cole i Daniel Unowsky (ur.), The Limits of Loyalty: Imperial Symbolism, Popular Allegiances, and State Patriotism in the Late Habsburg Monarchy“, New York, 2009, 162-177

László KONTLER, Povijest Mađarske: tisuću godina u Srednjoj Europi, Zagreb, 2007

Janko KOS, Duhovna povijest Slovenaca, Zagreb, 2004.

Nevenka KOŠUTIĆ-BROZOVIĆ, „Evropski okviri hrvatske Moderne“, u: Aleksandar Flaker i Krunoslav Pranjić (ur.), Hrvatska književnost prema evropskim književnostima, Zagreb, 1970, 345-363.

Nevenka KOŠUTIĆ-BROZOVIĆ, „Ženski udio u književnom životu hrvatske moderne“, Dani Hvarskoga kazališta 27, 1, 2001, 104-111.

Irena KRAŠEVAC, Petra VUGRINEC (ur.), Izazov moderne: Zagreb i Beč oko 1900. Slikarstvo, kiparstvo i arhitektura zagrebačke i bečke secesije, Zagreb, 2017.

Zoran KRAVAR, Svjetonazorski separei: antimodernističke tendencije u hrvatskoj književnosti ranoga 20. stoljeća, Zagreb, 2005.

Miroslav KRLEŽA, „Stjepan Radić u Beogradu“, u: Deset krvavih godina: eseji i članci IV, Sarajevo, 1979, 241-237.

Ishay LANDA, Fašizam i mase: pobuna protiv posljednjih ljudi, 1848. - 1945., Zagreb, 2019.

Rene LOVRENČIĆ, Geneza politike „,novog kursa“, Zagreb, 1972. 
Tihana LUETIĆ, Studenti Sveučilišta u Zagrebu 1874.-1914.: svakodnevica i društveni život (doktorska disertacija), Zagreb, 2011.

Tihana LUETIĆ, „Hrvatsko akademsko potporno društvo (1894.-1914.)“, Zbornik Odsjeka za povijesne znanosti Zavoda za povijesne i društvene znanosti Hrvatske akademije znanosti i umjetnosti 29, 2011, 311-332.

John LUKACS, Budapest 1900: A Historical Portrait of a City and Its Culture, New York, 1988.

Stanislav MARIJANOVIĆ, Fin de siècle hrvatske moderne (Generacije „,mladih “ $i$ časopis „Mladost"), Osijek, 1990.

Stanislav MARIJANOVIĆ, „Guido Jeny o počecima Ivana Meštrovića“, Croatica XXII, 35/36, 1991, 197-226.

Stanislav MARIJANOVIĆ, „U fin de siècleu hrvatske moderne: Najmlađi mladi i europska književnost“", Dani Hvarskoga kazališta 27, 1, 2001, 55-66.

Stanislav MARIJANOVIĆ, „Europska književnost i umjetnost u časopisu Mladost (iz vidokruga »bečkog kruga«)“, Dani Hvarskoga kazališta 28, 1, 2002, 247-257.

Milan MARJANOVIĆ, Savremena Hrvatska, Beograd, 1913.

Danijela MAROT, „Hrvatsko-slovenske književne veze u doba moderne“, Fluminensia 18, 1, 2006, 105-122.

Gail MARSHALL (ur.), The Cambridge Companion to the Fin de Siècle, Cambridge, 2007.

Julijo MARTINČIĆ, Dubravka HACKENBERGER (ur.), Secesija u Hrvatskoj: zbornik radova znanstvenog skupa, Zagreb i Osijek, 1999.

Olga MARUŠEVSKI, Iso Kršnjavi: kultura i politika na zidovima palače u Opatičkoj 10, Zagreb, 2002.

Olga MARUŠEVSKI, Iso Kršnjavi kao graditelj, Zagreb, 2009.

Stjepan MATKOVIĆ, „Izbori za Hrvatski sabor 1897. godine: afirmacija Khuenove autokracije“, Časopis za suvremenu povijest 29, 3, 1997., 469-488.

Stjepan MATKOVIĆ, Čista stranka prava: 1895.-1903., Zagreb, 2001.

Stjepan MATKOVIĆ, „Ivo Pilar i naprednjaštvo“, Pilar VIII, 15-16, 2013, 69-112. 
Stjepan MATKOVIĆ, „Naprednjački prijepori o jugoslavenstvu: primjer neodržane sarajevske izložbe“, u: Damir Agičić, Drago Roksandić, Tvrtko Jakovina (ur.), Spomenica Renea Lovrenčića, Zagreb, 2016, 231-243.

Darrin M. MCMAHON, Samuel MOYN (ur.), Rethinking Modern European Intellectual History, New York, 2014.

Igor MEDIĆ, Esteticizam Oscara Wildea i književnost hrvatske moderne, doktorski rad, Zagreb, 2021.

Željka METESI DERONJIĆ, ,Polemika o secesiji u Hrvatskoj: Franjo Ksaver Kuhač i Ivo Pilar", Cris XI, 1, 2009, 229-237.

Cvjetko MILANJA, Jakša Čedomil, Zagreb, 1985.

Silvestar MILETA, „Preteča komunističkog pokreta: socijalna demokracija u Hrvatskoj i Slavoniji 1890.-1914. i njena veza s građanskim opcijama napredne omladine i Hrvatske napredne stranke“, Pro tempore 10/11, 2016, 440-461.

Nicholas J. MILLER, Between Nation and State: Serbian Politics in Croatia Before the First World War, Pittsburgh, 1997.

Diana MISHKOVA, Roumen DASKALOV, „'Forms Without Substance': Debates on the Transfer of Western Models to the Balkans“, u: Daskalov, Mishkova (ur.), Entangled Histories of the Balkans, Volume Two: Transfers of Political Ideologies and Institutions, Leiden i Boston, 2014, 1-97.

George L. MOSSE, The Nationalization of the Masses: Political Symbolism and Mass Movements in Germany from the Napoleonic Wars through the Third Reich, Ithaca i London, 1991.

Kristian NOVAK, Višejezičnost i kolektivni identiteti iliraca: jezične biografije Dragojle Jarnević, Ljudevita Gaja i Ivana Kukuljevića Sakcinskoga, Zagreb, 2012.

Vlado OŠTRIĆ, „O počecima radničkog pokreta u Senju, 1874-1914.“, Senjski zbornik 7, 1, 1979, 5-38.

Predrag PALAVESTRA, Istorija moderne srpske književnosti: zlatno doba, 1892-1918, Beograd, 2013.

Kiran Klaus PATEL, “Transnational History,” European History Online (EGO), 2010, URL: http://www.ieg-ego.eu/patelk-2010-en. Pristup: 8. 7. 2020.

Antun PAVEŠKOVIĆ, “Moderna i tradicija”, Dani Hvarskoga kazališta 27, 1, 2001, 37-46. 
Pavao PAVLIČIĆ, „Što je danas hrvatska moderna?“, Dani Hvarskoga kazališta 28, 1, 2002, 5-16.

Ivo PERIĆ, Stjepan Radić 1871. - 1928., Zagreb, 2003.

Branka PRIBIĆ, „Idejna strujanja u hrvatskoj kulturi od 1895. do 1903.“, Časopis za suvremenu povijest IV, 1, 1972, 87-127.

Dragutin PROHASKA, „Utjecaj T. G. Masaryka na modernu jugoslavensku kulturu“, u: Prohaska (ur.), T. G. Masarik: zbornik, Beograd i Prag, 1927, 102-168.

Marina PROTRKA, Stvaranje književne nacije: Oblikovanje kanona u hrvatskoj književnoj periodici 19. stoljeća, Zagreb, 2008.

Marina PROTRKA ŠTIMEC, „Pokret Mladih i paradigme moderniteta“ (radna verzija članka), URL:

https://uol.de/f/3/inst/slavistik/Oldenburger Beitraege zum 16. Internationalen Slavisten kongress in Belgrad/Stimec2018 Pokret Mladih i paradigme moderniteta..pdf; pristup: 26.8.2020.

Robert B. PYNSENT, “The Decadent Nation: The Politics of Arnošt Procházka and Jiří Karásek ze Lvovic", u: László Peter, Robert B. Pynsent, Intellectuals and the Future in the Habsburg Monarchy 1890-1914, London, 1988, 63-92.

Ljerka RACKO, „Janko Koharić (prilog poznavanju njegova znanstvenog i publicističkog rada)“ Historijski zbornik 31-32, 1978-1979, 253-269.

Ljerka RACKO, „Pokret hrvatske moderne u historiografiji“, Historijski zbornik XXXVI, 1, 1983, 1-31.

Ljerka RACKO, „Spaljivanje mađarske zastave 1895. god. u Zagrebu“, Radovi Zavoda za hrvatsku povijest Filozofskog fakulteta u Zagrebu XXIII, 1990, 233-245.

Rachel, ROSSNER, ,"The secessionists are the Croats. They've been given their own pavilion. . .": Vlaho Bukovac's Battle for Croatian Autonomy at the 1896 Millennial Exhibition in Budapest", Nineteenth-Century Art Worldwide 6, 1, 2007. URL: http://www.19thc-artworldwide.org/spring07/141-qthe-secessionists-are-the-croatstheyve-been-given-their-own-pavilion-q-vlaho-bukovacs-battle-for-croatianautonomy-at-the-1896-millennial-exhibition-in-budapest. Pristup: 20. 2. 2021.

Helena SABLIĆ TOMIĆ, „Izazov korespondencije Zofke Kveder“, Dani Hvarskoga kazališta 33, 1, 2007., 420-431. 
Ines SABOTIČ, Stare zagrebačke kavane i krčme s kraja 19. i početka 20. stoljeća, prevela Vesna Lisičić, Zagreb, 2007.

Gisèle SAPIRO, „Comparativism, Transfers, Entangled History: Sociological Perspectives on Literature", u: Ali Behdad, Dominic Thomas (ur.), A Companion to Comparative Literature, Blackwell, 2011, 225-236.

Wolfgang SCHMALE, “Cultural Transfer," European History Online (EGO), 2012, URL: http://www.ieg-ego.eu/schmalew-2012-en. Pristup: 8. 7. 2020.

Katharina SCHERKE, „Kultursoziologie und Kulturtransfer“, u: S. Moebius et al. (ur.), Handbuch Kultursoziologie, Wiesbaden, 2018.

Carl E. SCHORSKE, Beč krajem stoljeća: Politika i kultura, preveo Nikica Petrak, Zagreb, 1997.

Max-Stephan SCHULZE, Nikolaus WOLF, „Economic nationalism and economic integration: the Austro-Hungarian Empire in the late nineteenth century", The Economic History Review LXV, 2, 2012, 652-673.

H. Gordon SKILLING, T. G. Masaryk: Against the Current, 1882-1914, London, 1994.

Stefanie STOCKHORST, Cultural Transfer through Translation: The Circulation of Enlightened Thought in Europe by Means of Translation, Amsterdam i New York, 2010 .

Mario STRECHA, „O pitanju utjecaja bečkog središta na kulturni identitet Zagreba u 19. stoljeću“, Radovi Zavoda za hrvatsku povijest, 26, 1993, 79-88.

Mario STRECHA, Katoličko hrvatstvo: počeci političkog katolicizma u banskoj Hrvatskoj (1897.-1904.), Zagreb, 1997.

Mario STRECHA, "Mi smo Hrvati i katolici...": Prvi hrvatski katolički kongres u Zagrebu 1900., Zagreb, 2008.

Sanjay SUBRAHMANYAM, "Connected Histories: Notes towards a Reconfiguration of Early Modern Eurasia“, Modern Asian Studies 31, 3, 1997, 735-762.

Marijan ŠABIĆ, Hrvatsko-češke književne veze: XIX. i početak XX. stoljeća, Zagreb, 2013.

Ivan ŠAJKOVIĆ, Nekoliko momenata iz omladinskoga pokreta (1893-1903), Subotica, 1929.

Dragovan ŠEPIĆ, „Jugoslavenski pokret i Milan Marjanović 1901 - 1919“, Zbornik Odsjeka 
za povijesne znanosti Zavoda za povijesne i društvene znanosti Hrvatske akademije znanosti i umjetnosti III, 1960, 531-561.

Miroslav ŠICEL, Stvaraoci i razdoblja u novijoj hrvatskoj književnosti: analize i sinteze, Zagreb, 1971.

Miroslav ŠICEL (ur.), Hrvatska moderna: kritika i književna povijest, Zagreb, 1975.

Miroslav ŠICEL, Književnost moderne, Povijest hrvatske književnosti, knj. 5, Zagreb, 1978.

Miroslav ŠICEL, „Programi i manifesti hrvatske moderne“, Croatica XXII, 35/36, 1991, 21 33.

Miroslav ŠICEL, Povijest hrvatske književnosti XIX. stoljeća, knj. III: moderna, Zagreb, 2005.

Jaroslav ŠIDAK, Mirjana GROSS, Igor KARAMAN, Dragovan ŠEPIĆ, Povijest hrvatskog naroda g. 1860-1914., Zagreb, 1968.

Jaroslav ŠIDAK, Studije iz hrvatske povijesti 19. stoljeća, Zagreb, 1973.

Filip S̆IMETIN ŠEGVIĆ, Patriotizam i bunt: Franjo Josip I. u Zagrebu 1895. godine, Zagreb, 2014.

Filip ŠIMETIN ŠEGVIĆ, „Fin de siècle Beč i Beč 1900. kao historiografski problem: pristupi, paradigme, rasprave“, Radovi Zavoda za hrvatsku povijest 52, 2, 2020, 81128.

Ferdo ŠIŠIĆ, Pregled povijesti hrvatskoga naroda, Zagreb, 1962.

Allan John Percival TAYLOR, Habsburška monarhija: 1809.-1918, preveo Omer Lakomica, Zagreb, 1990.

Nikola TOMAŠEGOVIĆ, ,Jedinstvom protiv (ne)sloge: nacionalna koncepcija napredne omladine“", Tragovi - časopis za srpske i hrvatske teme 1, 1, 2018, 166-190.

Nikola TOMAŠEGOVIĆ, „Prema intelektualnoj historiji hrvatskog modernističkog pokreta na prijelomu 19. i 20. stoljeća: stanje istraživanja i istraživački problemi“", Radovi Zavoda za hrvatsku povijest 51, 2, 2019, 217-232.

Nikola TOMAŠEGOVIĆ, „Moderna europska intelektualna historija: teorijski problemi i suvremene tendencije“, Historijski zbornik LXXII, br. 1, 2019, 189-203.

Nikola TOMAŠEGOVIĆ, “Transnational Approaches and fin de siècle Modernisms: The 
Case of the Croatian Modernist Movement", Radovi Zavoda za hrvatsku povijest 52, 1 2020, 173-188.

Stanislav TUKSAR, „Franz Xaver Koch vs. Franjo Ksaver Kuhač. Kuhačevi glazbeni i drugi identiteti: skica za psihogram“, Arti musices 43, 2, 2012, 205-211.

Mate UJEVIĆ, Prilozi za povijest pokreta hrvatske omladine koncem XIX i početkom XX stoljeća, s osobitim osvrtom na borbu starih i mladih, Zagreb, 2015.

Lea UKRAINČIK (ur.), Hrvatski salon, Zagreb 1898.: 100 godina Umjetničkog paviljona, Zagreb, 1999.

Božena VRANJEŠŠŚLJAN, Stanovništvo gradova Banske Hrvatske na prijelazu stoljeća, Zagreb, 1991.

Michael WERNER, Bénédicte ZIMMERMAN, „Vergleich, Transfer, Verflechtung. Der Ansatz der Histoire croisée und die Herausforderung des Transnationalen“, Geschichte und Gesellschaft 28, 4, 2002, 607-636.

Michael WERNER, Bénédicte ZIMMERMAN, „Penser l'histoire croisée: entre empirie et réflexivité", Annales. Histoire, Sciences Sociales 58, 1, 2003, 7-36.

Michael WERNER, Bénédicte ZIMMERMAN, „Beyond Comparison: Histoire croisée and the Challenge of Reflexivity“, History and Theory 45, 2006, 30-50.

Richard WHATMORE, Brian YOUNG (ur.), Palgrave Advances in Intellectual History, Basingstoke, New York, 2006.

Richard WHATMORE, Brian YOUNG (ur.), A Companion to Intellectual History, Oxford, 2016.

Petr WITTLICH, Prague: Fin de Siècle, Pariz, 1992.

Ivo ŽANIĆ, „The Symbolic Identity of Croatia in the Triangle Crossroads-Bulwark-Bridge“, u: Pål Kolstø (ur.), Myths and Boundaries in South-Eastern Europe, London, 2005, $35-77$.

Viktor ŽMEGAČ, Duh impresionizma i secesije: studije o književnosti hrvatske moderne, 2. prošireno izdanje, Zagreb, 1997.

Viktor ŽMEGAČ, „Europski kontekst hrvatske moderne“, u: Josip Bratulić, Josip Vončina, Antun Dubravko Jelčić, Hrvatska i Europa: kultura, znanost $i$ umjetnost, sv. 4, Zagreb, 2009, 411-416. 
Viktor ŽMEGAČ, Bečka moderna: portret jedne kulture, 2. prošireno izdanje, Zagreb, 2012. 


\section{Životopis autora s popisom objavljenih djela}

Nikola Tomašegović rođen je 1991. godine u Zagrebu, gdje pohađa osnovnu školu i I. gimnaziju. Na Filozofskom fakultetu u Zagrebu 2016. godine završava studij povijesti i filozofije obranivši diplomske radove: „Guvermentalna funkcija razvoja statistike u Banskoj Hrvatskoj tijekom druge polovice 19. stoljeća“ i „Kantova filozofija povijesti u kontekstu njemačkih prosvjetiteljskih rasprava“. Dobitnik je nagrade za izvrsnost na preddiplomskom studiju povijesti, kao i stipendije grada Zagreba. Ak. god. 2016./2017. upisuje poslijediplomski doktorski studij moderne i suvremene hrvatske povijesti u europskom i svjetskom kontekstu. Od 2017. do 2020. član je projekta Hrvatske zaklade za znanost „Tranzicija hrvatskih elita iz Habsburške Monarhije u jugoslavensku državu“ voditeljice prof. dr. sc. Iskre Iveljić. Od 2018. godine zaposlen kao asistent na Katedri za hrvatsku povijest Odsjeka za povijest, gdje drži nastavu u sklopu obaveznih predmeta Hrvatska povijest 19. stoljeća, Hrvatsko društvo i kultura u 19. stoljeću te izbornih predmeta Problemi hrvatske moderne, Historiografija i nacionalizam i Historiografija o hrvatskoj povijesti 19. stoljeća.

\section{$\underline{\text { Izbor radova }}$}

„Transnational Approaches and fin de siècle Modernisms: The Case of the Croatian Modernist Movement“, Radovi Zavoda za hrvatsku povijest 52, 1, 2020, 173-188.

„Prema intelektualnoj historiji hrvatskog modernističkog pokreta na prijelomu 19. i 20. stoljeća: stanje istraživanja i istraživački problemi“, Radovi Zavoda za hrvatsku povijest 51, 2, 2019, 217-232.

„Međunarodni statistički kongres (1853-1876) i suvremene recepcije u Hrvatskoj“, Anali Zavoda za povijesne znanosti HAZU u Dubrovniku 57, 2019, 199-220.

„Moderna europska intelektualna historija: teorijski problemi i suvremene tendencije“, Historijski zbornik 72, 1, 2019, 189-203.

„Jedinstvom protiv (ne)sloge: nacionalna koncepcija napredne omladine“, Tragovi-časopis za srpske i hrvatske teme 1, 1, 2018, 166-190.

„Revolucija ili reforma - ili još jednom o pitanju: 'Što je prosvjetiteljstvo?"', Borislav Mikulić, Mislav Žitko (ur.), Filozofije revolucija i ideje novih svjetova - Radovi trećeg

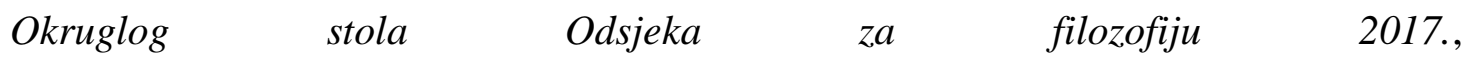
Zagreb, 2018, 50-78. 
„Modernizacija i nacionalna politika u djelima pionira statistike u Banskoj Hrvatskoj, Historijski zbornik 70, 1, 2017, 35-60.

„Polemika o željezničkom pitanju do 1862. godine u Pozoru i Narodnim novinama“, Povijest u nastavi 12, 1, 2014, 35-54. 